\title{
Mineral and Energy Resources of the Roswell Resource Area,
}

East-Central New Mexico

\section{U.S. GEOLOGICAL SURVEY BULLETIN 2063}

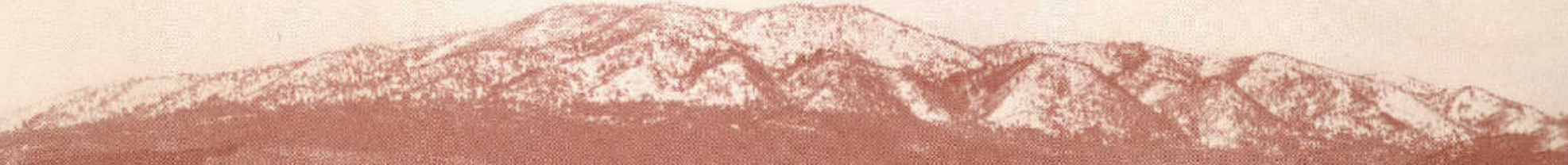

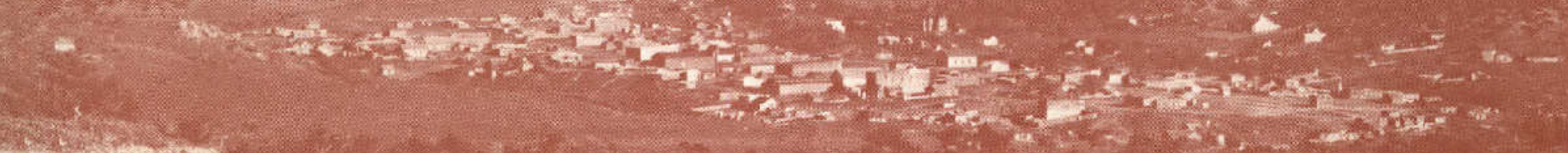


Cover: Town of White Oaks about 1905, center of the booming White Oaks gold district, Lincoln County, N. Mex. Gold was probably the first metallic commodity to be commercially mined in the Lincoln County porphyry belt and has the highest production value of metallic deposits. The gold occurs in lode Tertiary veins and associated alkalic intrusive rocks, in Cretaceous shale in contact with the intrusives, and in placer deposits. Veins commonly occur where alkaline igneous rocks have intruded through disrupted Precambrian basement into overlying sedimentary or volcanic rocks of Paleozoic or Mesozoic age. At White Oaks, a breccia pipe hosts the precious metal. A total of $152,373 \mathrm{oz}$ of gold was produced from White Oaks lodes between about 1879 and 1930. Photograph taken by L.C. Graton. (Photo number 99, U.S. Geological Survey Photo Library, Denver, Colo.) 


\section{Mineral and Energy Resources of the Roswell Resource Area, East-Central New Mexico}

By SUSAN BARTSCH-WINKLER and ALESSANDRO J. DONATICH, Editors

U.S. GEOLOGICAL SURVEY BULLETIN 2063

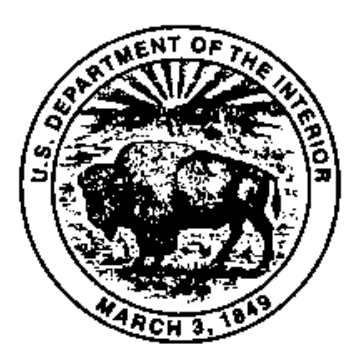

UNITED STATES GOVERNMENT PRINTING OFFICE, WASHINGTON : 1995 


\title{
U.S. DEPARTMENT OF THE INTERIOR BRUCE BABBITT, Secretary
}

\author{
U.S. GEOLOGICAL SURVEY \\ Gordon P. Eaton, Director
}

For sale by U.S. Geological Survey, Information Services

Box 25286, Federal Center

Denver, CO 80225

\begin{abstract}
Any use of trade, product, or firm names in this publication is for descriptive purposes only and does not imply endorsement by the U.S. Government
\end{abstract}

Library of Congress Cataloging-ip-Pubtication Data

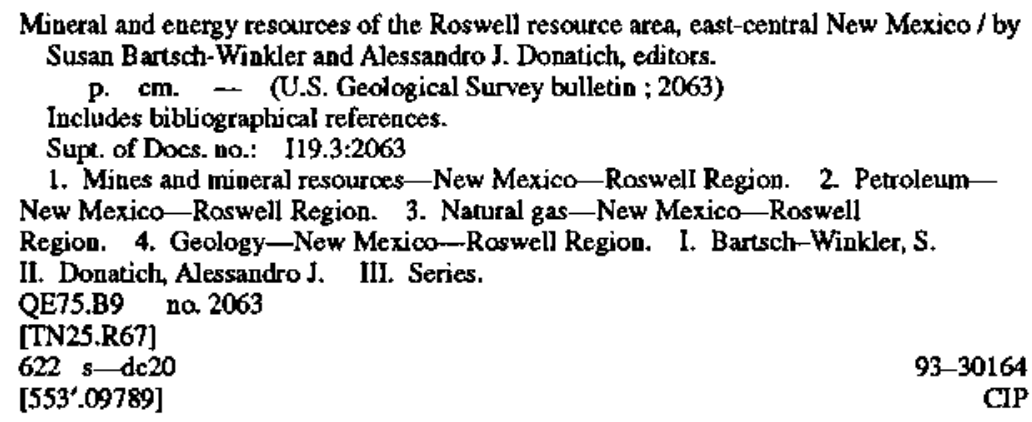




\section{CONTENTS}

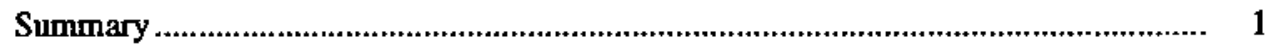

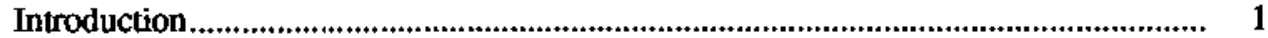

Location and Geography of Study Area .......................................................... 1

Purpose and Methodology ................................................................................... 3

Acknowledgments................................................................................. 4

References Cited .............................................................................................. 4

Geology of East-Central New Mexico, by Susan Bartsch-Winkler, with a section on

Tertiary Intrusive and Extrusive Alkaline Rocks of the Lincoln County

Porphyry Belt, by Theodore J. Armbrustmacher ................................................... 5

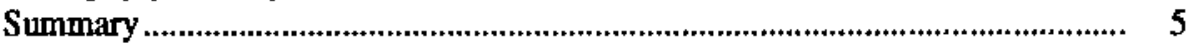

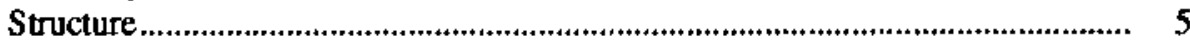

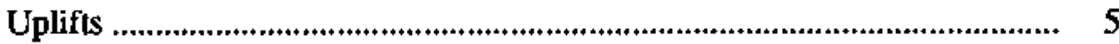

Sacramento Uplift, Pecos Slope, and Capitan Mountains ........................ 5

Carrizozo Anticline ........................................................................... 8

Pedernal Uplift ................................................................................ 8

Matador Uplift, Roosevelt Positive, and Bravo Dome …...................... 8

San Jon High .............................................................................. 9

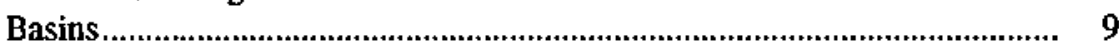

Sierra Blanca Basin......................................................................... 9

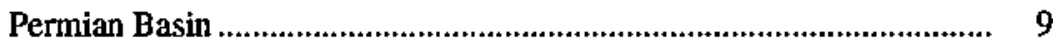

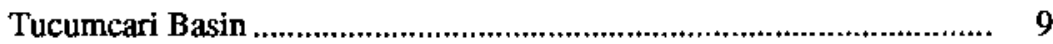

Faults and Folds

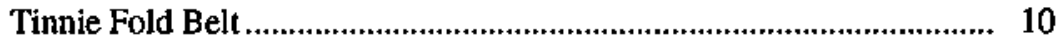

Folds in Incompetent Strata ............................................................ 10

Vaughn Trend .............................................................................. 10

Buckles and Northeast-trending Faults ................................................ 10

Roosevelt County Fault..................................................................... 11

Alamosa Creek Fault............................................................................... 11

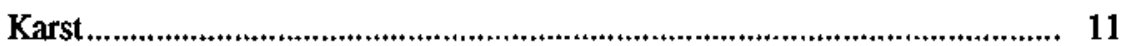

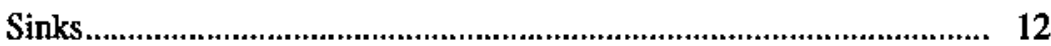

Contortion Features...................................................................... 12

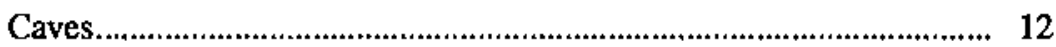

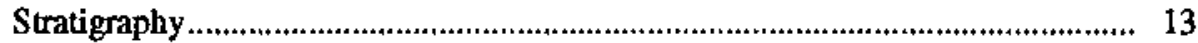

Precambrian Basement Rocks................................................................. 13

Pre-Permian Paleozoic Rocks ............................................................ 13

Pre-Permian Paleozoic Rocks of Lincoln County ................................. 13

Pre-Permian Paleozoic Rocks of the Northwestern Shelf of the Permian Basin ............................................................................ 13

Pre-Permian Paleozoic Rocks of Tucumcari Basin ................................ 14

Lower Permian Rocks ................................................................................. 14

Bursum(?) Formation ............................................................................ 14

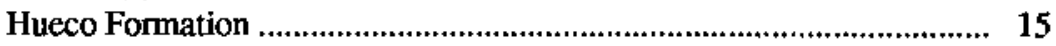

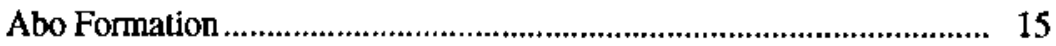

Yeso Formation.............................................................................. 15

Glorieta Sandstone and San Andres Formation ................................... 16

Rio Bonito Member ................................................................ 17

Bonney Canyon Member ........................................................... 17

Fourmile Draw Member .............................................................. 17

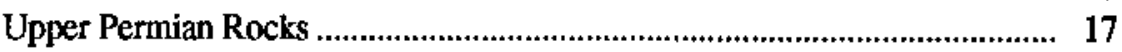

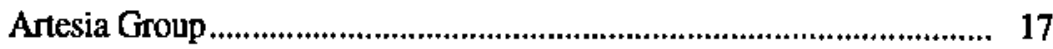

Grayburg Formation................................................................ 18 
Queen Formation...................................................................... 18

Seven Rivers Formation............................................................ 19

Yates Formation ................................................................... 20

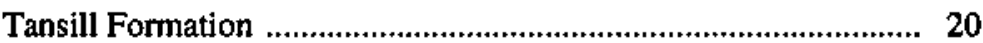

Castile, Salado, and Rustler Formations and Dewey Lake Redbeds ...... 20

Salado Formation ................................................................... 20

Rustler Formation ................................................................ 20

Dewey Lake Redbeds................................................................ 21

Upper Triassic Rocks ............................................................................ 21

Santa Rosa Sandstone of the Dockum Group ....................................... 21

Chinle Formation of the Dockum Group ........................................... 21

Redonda Formation......................................................................... 22

Middle and Upper Jurassic Rocks....................................................... 22

Exeter Sandstone ........................................................................... 22

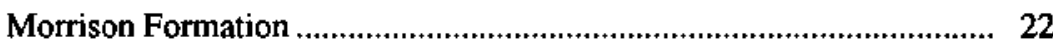

Lower and Upper Cretaceous Rocks........................................................ 22

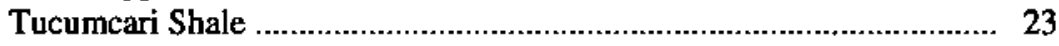

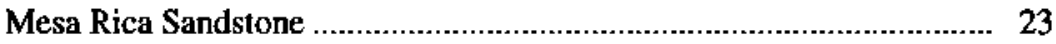

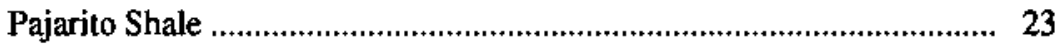

Dakota(?) Sandstone ....................................................................... 23

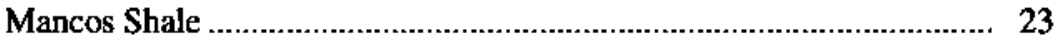

Mesaverde Formation .............................................................. 23

Cretaceous and Tertiary Rocks ....................................................... 24

Cub Mountain Formation........................................................... 24

Upper Tertiary Rocks ........................................................................ 24

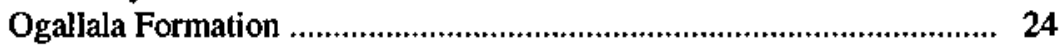

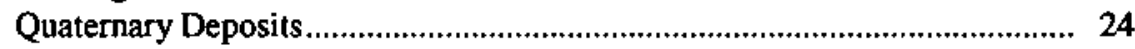

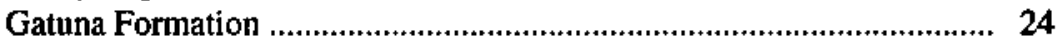

Other Unconsolidated Deposits ............................................................ 25

Pediment Deposits.................................................................... 26

Terrace Deposits ..................................................................... 26

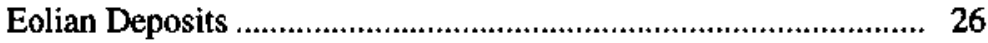

Lake Deposits...................................................................... 26

Alluvium and Colluvium Deposits ......................................... 26

Basalt Flows ........................................................................... 26

Tertiary Intrusive and Extrusive Alkaline Rocks of the Lincoln County

Porphyry Belt, by Theodore J. Armbrustmacher ..................................... 26

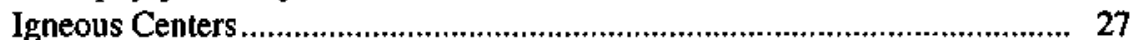

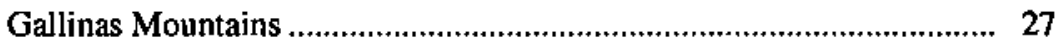

Tecolote Peak ............................................................................ 28

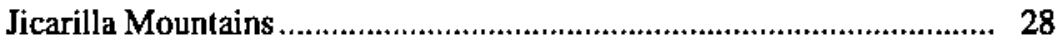

Lone and Baxter Mountains .......................................................... 28

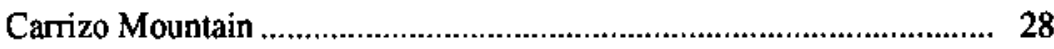

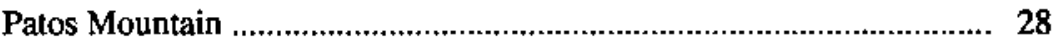

Capitan Mountains ....................................................................... 29

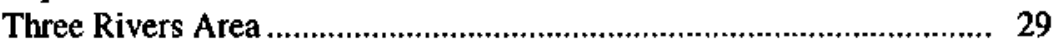

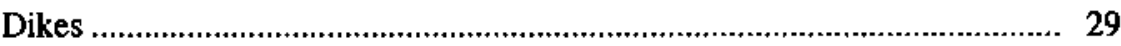

References Cited ....................................................................................... 30

Geochemistry of Sediments, and Uranium in Groundwater, by James A. Erdman,

Ronald R. Tidball, and Richard B. Tripp ................................................... 35

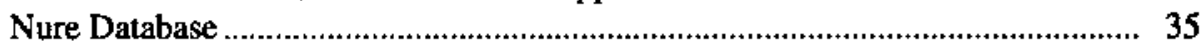

Anomaly Definition and Data Presentation .................................................. 36

Special Handling of Selected Sediment Samples .................................................. 36

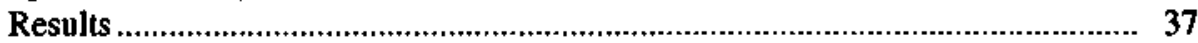




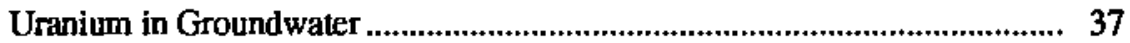

Implications for Mineral Potential ......................................................... 37

Implications for Human Health ..................................................... 37

Uranium in Sediments................................................................................ 38

Lithium in Sediments....................................................................... 38

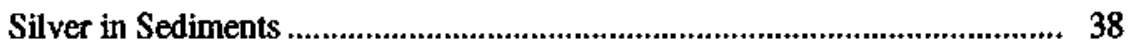

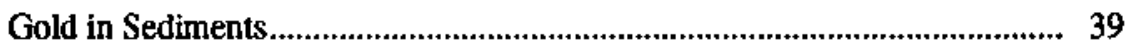

Molybdenum in Sediments .................................................................. 39

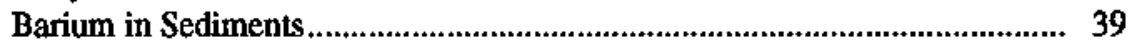

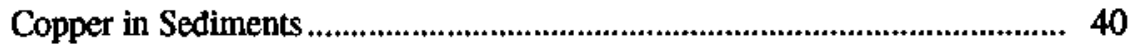

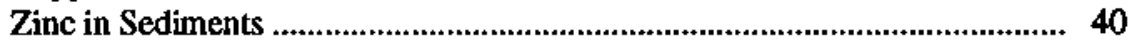

Thorium in Sediments............................................................................. 41

Cerium in Sediments....................................................................................... 41

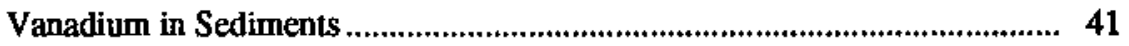

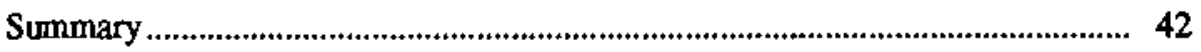

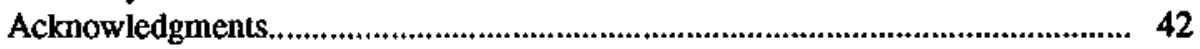

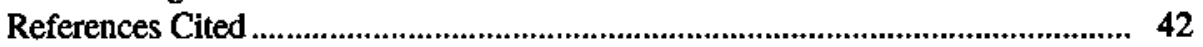

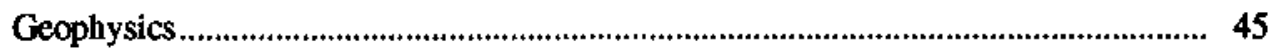

Aeromagnetic and Gravity Data, by Dolores M. Kulik ........................................ 45

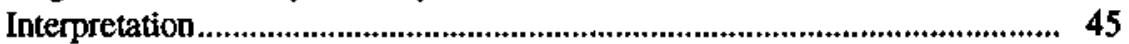

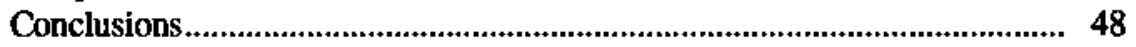

Aerial Gamma-ray Data, by Joseph S. Duval ..................................................... 48

References Cited ........................................................................................ 53

Mineral Resources of the Roswell Resource Area ................................................. 54

Industrial Mineral Resources, by Susan Bartsch-Winkler, with sections on Potash and Iodine and Bromine in Saline Brines and Brine Deposits, by Sherilyn Williams-Stroud, and Sulfur, by Charles S. Spirakis ............ 54

Evaporite Deposits ............................................................................. 54

Potash, by Sherilyn Williams-Stroud................................................. 54

Carlsbad Potash District................................................................ 54

Potash Deposits in the Study Area............................................. 56

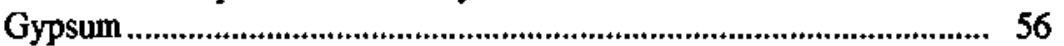

Descriptions of Selected Gypsum Deposits in the

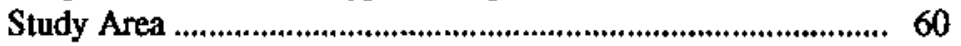

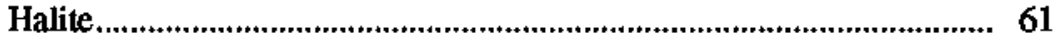

Iodine and Bromine in Saline Brines and Brine Deposits,

by Sherilyn Williams-Stroud ..................................................... 61

Sulfur, by Charles S. Spirakis ……………................................................ 62

Texas Deposits ...................................................................................... 62

Origins and Assessment of Sulfur Resources ................................... 62

Aggregate and Construction Material ....................................................... 65

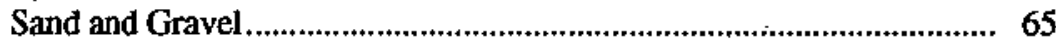

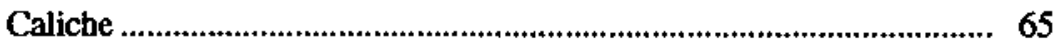

Dike Rock and Scoria ........................................................................... 68

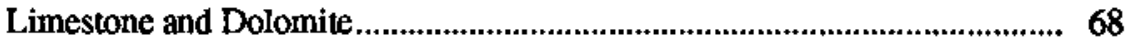

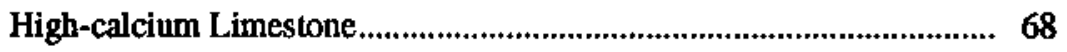

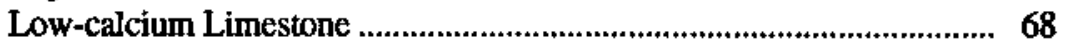

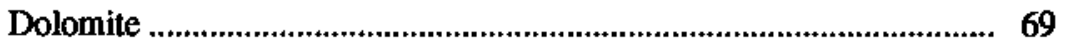

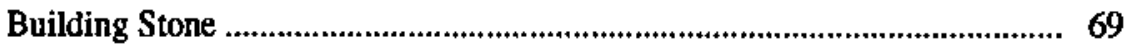

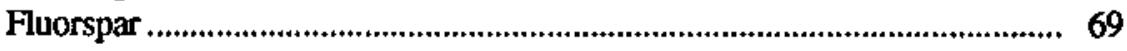

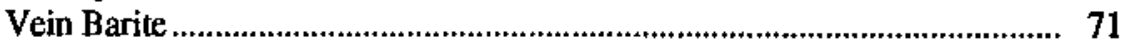

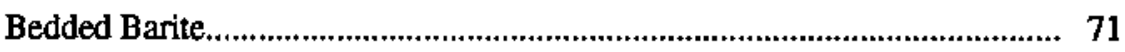

Clay and Adobe Brick......................................................................... 71

Semiprecious Gemstones and Collectible Specimens ................................... 72 
Smoky Quartz and Fluorite ............................................................ 72

"Pecos Diamonds" ............................................................................ 73

Petrified Wood and Bone ….............................................................. 74

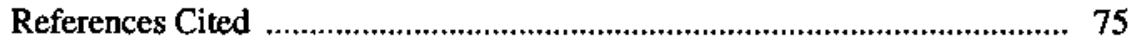

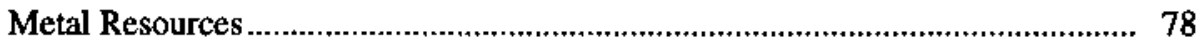

Mining History and Production, by David M. Sutphin and

Theodore J. Armbrustmacher ...................................................... 78

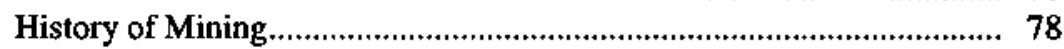

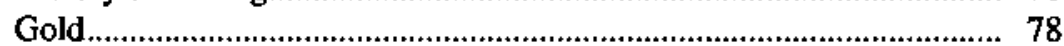

White Oaks District ................................................................... 78

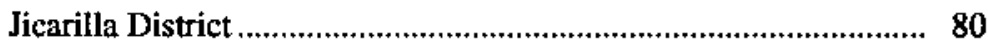

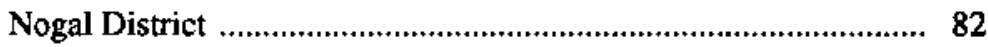

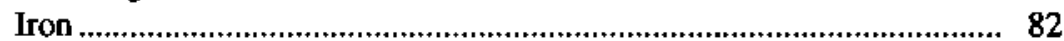

Capitan Iron Deposit ............................................................... 83

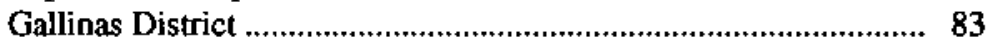

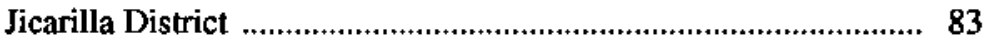

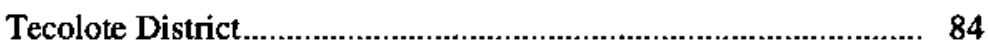

White Oaks District ................................................................ 84

Base Metals, Silver, Fluorspar, and Rare-earth Elements ..................... 84

Gallinas District ................................................................... 84

Nogal District ....................................................................... 85

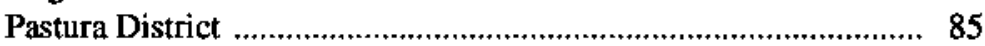

Oscura District …................................................................. 85

Quay County ................................................................. 85

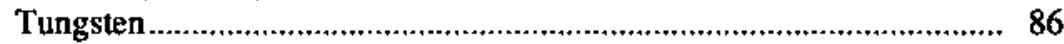

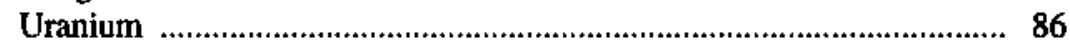

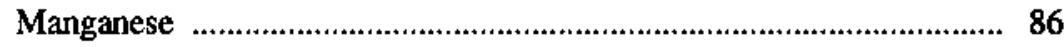

Descriptions of Metal Deposits, by David M. Sutphin and

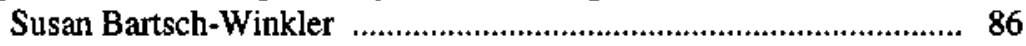

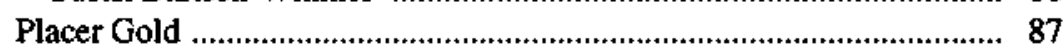

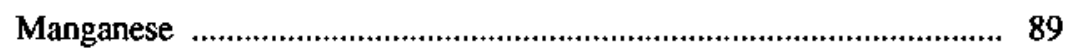

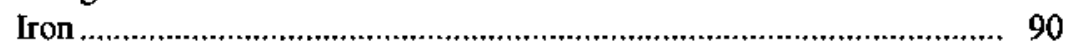

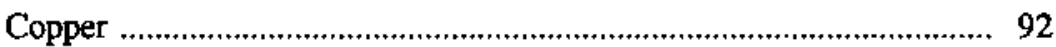

Porphyry Molybdenum Deposits ....................................................... 93

Base and Precious Metals in Veins ................................................. 96

Polymetallic Veins in the Nogal District .................................. 96

Polymetallic Veins in the Gallinas District ................................. 96

Gold and Silver in Tellurium-bearing Veins ............................. 97

Thorium-Rare-earth-element Veins ........................................ 98

Mississippi-Valley-Type Deposits ................................................. 99

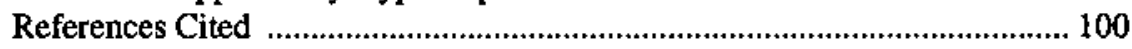

Estimate of Undiscovered Mineral Resources Using the Mark-3 Simulator

Computer Program, by David M. Sutphin .............................................. 103

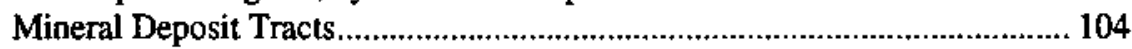

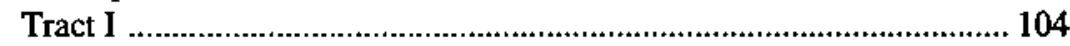

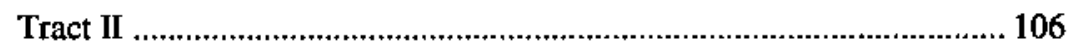

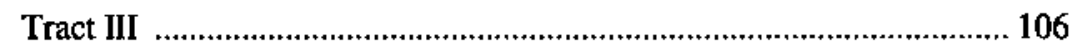

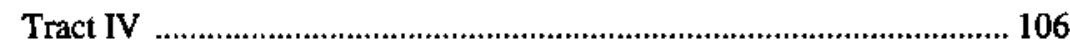

Estimates of Tonnages of Metallic Commodities and Gypsum in

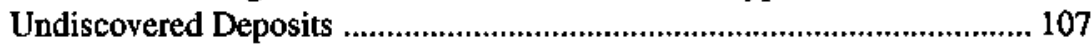

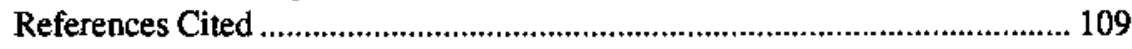

Uranium and Vanadium .............................................................................. 110

Uranium Deposits and Occurrences, by Warren I. Finch, James K. Otton, and Charles T. Pierson ........................................................................... 110 
Sandstone Uranium Deposits ........................................................... 110

Uranium in Veins in Tertiary Igneous Rocks .................................... 111

Undiscovered Uranium Resources.......................................................... 111

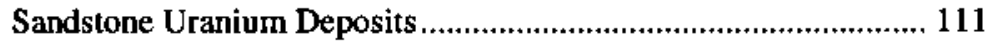

Permian and Upper Pennsylvanian Rocks .............................. 111

Dockum Group..................................................................... 112

Surficial Uranium Deposits......................................................... 114

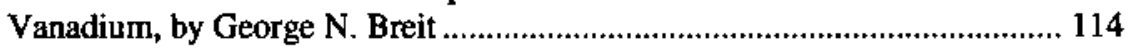

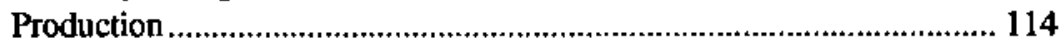

Undiscovered Vanadium Resources .................................................... 116

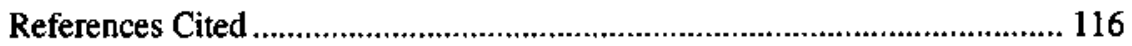

Energy Resources of the Roswell Resource Area...................................................... 118

Petroleum Geology, by Mahlon M. Ball, Gordon L. Dolton,

Richard F. Mast, Ronald R. Charpentier, Mitchell E. Henry,

Keith Robinson, Craig J. Wandrey, Robert A. Crovelli,

Charles W. Spencer, and William C. Butler ............................................. 118

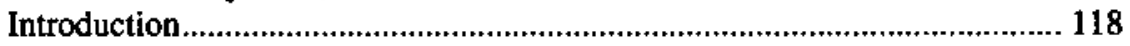

Structural Controls of Hydrocarbon Traps ................................................. 118

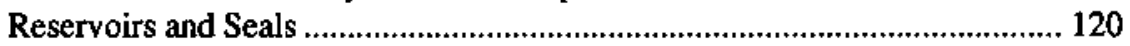

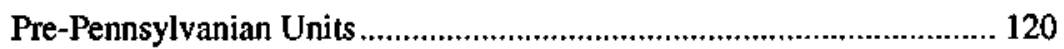

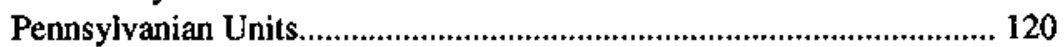

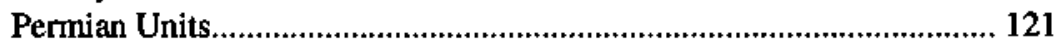

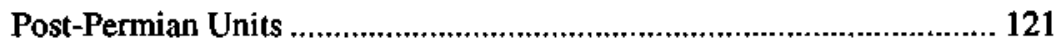

Hydrocarbon Source, Maturation, and Migration.......................................... 121

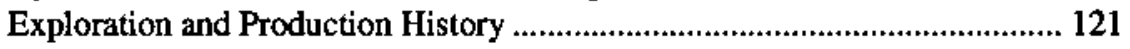

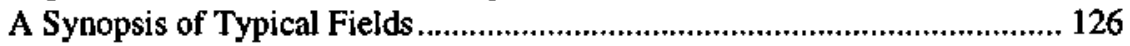

Peterson and Peterson South Fields ........................................................ 126

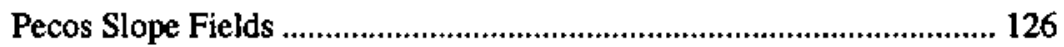

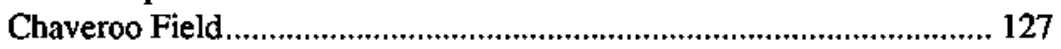

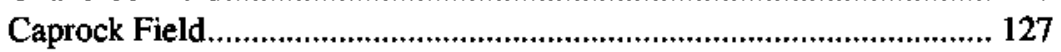

Play Analysis and Hydrocarbon Assessment............................................... 127

Northwestern Shelf of the Permian Basin, Pennsylvanian and Permian Play .................................................................... 128

Northwestern Shelf of the Permian Basin, Pre-Pennsylvanian Play....... 129

Small Field Plays .................................................................................. 130

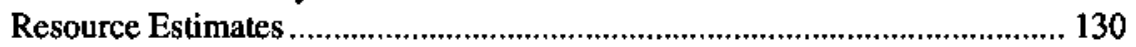

Roswell Resource Area ................................................................... 130

Tucumcari Basin ............................................................................. 130

Other Resources Associated with Conventional Oil and Gas........................ 131

Tar Sand at Santa Rosa ................................................................... 131

Heavy Oil at Newkirk .................................................................. 132

Nonhydrocarbon Gas, by Susan Bartsch-Winkler and Mahlon M. Ball............... 132

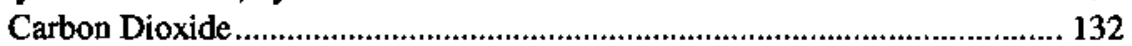

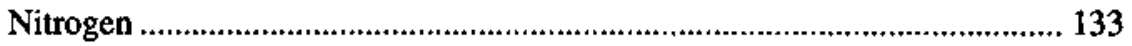

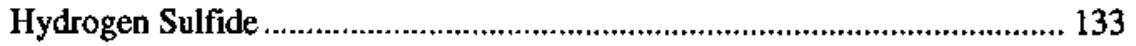

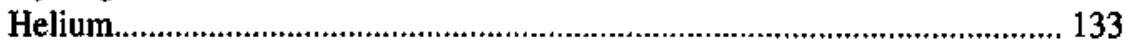

Coal Production and Estimated Resources, by Gary D. Stricker......................... 133

References Cited ............................................................................................ 134

Appendix. Geologic and Mineral Resources Information for the Roswell

Resource Area, New Mexico, by David M. Sutphin ............................................ 137 


\section{PLATES}

[Plates are in box]

1. Geologic map of the Roswell Resource Area, New Mexico

2. Geologic and lithologic cross sections, and correlation chart showing rock sequences and associated deposits and prospects, Roswell Resource Area, New Mexico

3. Map showing tectonic features of the Roswell Resource Area and vicinity, New Mexico

4. Maps showing distribution of uranium in groundwater and of selected elements in sediments, Roswell Resource Area, New Mexico

5. Composite residual total intensity aeromagnetic map of the Roswell Resource Area and vicinity, New Mexico

6. Complete Bouguer gravity anomaly map of the Roswell Resource Area and vicinity, New Mexico

7. Color representation of complete Bouguer gravity anomaly map of the Roswell Resource Area and vicinity, New Mexico

8. Digital topographic map of an area encompassing the Roswell Resource Area

9. Isostatic residual gravity map of an area encompassing the Roswell Resource Area

10. Map showing apparent surface concentrations of potassium, Roswell Resource Area, New Mexico

11. Map showing apparent surface concentrations of equivalent uranium, Roswell Resource Area, New Mexico

12. Map showing apparent surface concentrations of equivalent thorium, Roswell Resource Area, New Mexico

13. Map showing locations and mineral deposit types of mines, deposits, and prospects in the Roswell Resource Area, New Mexico

14. Map showing mineral resource tracts of undiscovered commodities in the Roswell Resource Area, New Mexico

15. Map showing drilled areas, field names, and hydrocarbon play boundaries in the Roswell Resource Area and vicinity, New Mexico

\section{FIGURES}

1. Index map of the Roswell Resource Area, New Mexico, showing locations and physiographic features mentioned in text

2. Photomosaic of Landsat 2 and Landsat 3 satellite images of the Roswell Resource Area and vicinity,

New Mexico

3. Map showing reference locations for figure 2

4-8. Photographs of:

4. The Capitan Mountains in the Lincoln County porphyry belt, New Mexico

5. The Border buckle, east-central New Mexico

6. Nonresistant gypsiferous marine evaporite beds of the Artesia Group exposed in the bottom of Pintada

Canyon west of Santa Rosa, N. Mex., where they are overlain by the cliff-forming Upper Triassic Santa Rosa Sandstone

7. Exposure of layered dolomite and limestone beds of the Seven Rivers Formation of the Artesia Group in the walls of a sinkhole, Bottomless Lakes State Park, N. Mex.

8. Basal conglomerate of upper Tertiary Ogallala Formation resting unconformably on weathered sandstone of the Upper Triassic Redonda Formation near Ragland, Quay County, N. Mex.

9. Index map to analysts of supplemental analyses (analyses of samples for elements other than uranium),

Roswell Resource Area, New Mexico.

10. Index map to $1^{\circ} \times 2^{\circ}$ quadrangles showing locations of U.S. Department of Energy aerial gamma-ray surveys used in this study of the Roswell Resource Area, New Mexico.

11-13. Diagrams showing:

11. Average concentrations of uranium versus potassium for selected map units of geologic map of Roswell Resource Area, New Mexico.

12. Average concentrations of thorium versus potassium for selected map units of geologic map of Roswell Resource Area, New Mexico.

13. Average concentrations of thorium versus uranium for selected map units of geologic map of Roswell Resource Area, New Mexico 
14. Map showing distribution of halite-bearing and potassium-bearing saline deposits in the Roswell Resource Area and vicinity, New Mexico.

15. Isopach map of salt in the Salado Formation in southwestern New Mexico and western Texas...

16. Photograph of gypsum outcrops in the Lower Pernian San Andres Formation and Upper Permian Artesia Group at Ancho, N. Mex.

17. Map showing distribution of gypsum deposits in the Roswell Resource Area, New Mexico....

18. Photograph of blocks of native sulfur and stalactites of gypsum in the Ghost Town deposit, approximately $820 \mathrm{ft}$ below the surface in Lechuguilla Cave, N. Mex.

19-21. Maps showing:

19. Distribution of areas favorable for sulfur in the subsurface of the Roswell Resource Area, New Mexico.

20. Locations of aggregate pits in the Roswell Resource Area, New Mexico

21. Distribution of caliche, Mesozoic limestone, and Paleozoic limestone and dolomite in the Roswell

Resource Area and vicinity, New Mexico

22. Diagrammatic profile of typical caliche section, showing multiple caliche layers on the plains near Fort Sumner, N. Mex.

23. Geologic map showing locations of mines or prospects for fluorspar and other metals, Gallinas Mountains, N. Mex.

24. Photograph of modern adobe cottage, "Casita Bonita," built from stabilized adobe between 1983 and 1986, Lincoln, N. Mex.

25. Map showing distribution of adobe-material sources in the Roswell Resource Area and vicinity, New Mexico

26. Photograph of "Pecos diamonds," and map showing distribution of surface deposits containing "Pecos diamonds" in the Roswell Resource Area and vicinity, New Mexico

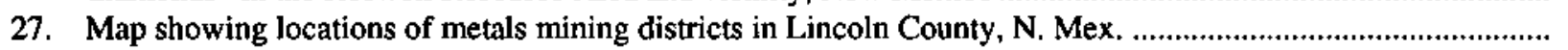
79

28-30. Photographs of:

28. Town of White Oaks, N. Mex.

29. Old Abe mine and mill, White Oaks district, New Mexico.

30. Iron ore being extracted from the Smokey mine and pulverized for use as road metal, Capitan Mountains district, New Mexico.

31. Geologic map of the Jicarilla Mountains, N. Mex., showing locations of surface mine workings, placer gold workings, and placer gold deposits

32. Diagram showing estimates of gold grade and placer volume for placer gold deposits in the Jicarilla district, New Mexico, in comparison with grade and volume model for world-wide placer gold deposits.

33. Diagram showing gold grade for 65 world-wide placer gold deposits of Orris and Bliss (1986) and placer tonnage for placer gold deposits in Ancho Gulch and Rico and Little Nugget Gulches, N. Mex., in comparison with tonnage model for 65 world-wide placer gold deposits

34. Photographs of iron ore at the Smokey mine in the Capitan Mountains district, New Mexico, showing bedding concentrations of the iron ore and brecciated and replaced host rock.

35. Diagram showing iron grade and tonnage of iron skam deposits in the Roswell Resource Area, New Mexico, in comparison with grade and tonnage model for 168 world-wide iron skarn deposits

36. Diagram showing copper grade and tonnage and silver grade at the Pintada and Stauber mines, New Mexico, in comparison with grade and tonnage model for 57 world-wide sediment-hosted copper deposits .....

37. Map showing mineralization zones of the low-fluorine porphyry molybdenum deposit at the Rialto, Three Rivers, and Bonito Lake stocks, New Mexico, and locations of surface workings in and near the deposit.........

38-40. Diagrams showing:

38. Molybdenum grade and tonnage of the low-fluorine porphyry molybdenum deposit at the Rialto stock, New Mexico, in comparison with the grade and tonnage model for 33 world-wide low-fluorine porphyry molybdenum deposits.

39. Gold grade and tonnage of alkaline-hosted telluride-bearing veins in the White Oaks district, New Mexico, in comparison with the grade and tonnage model for 20 world-wide telluride-bearing veins

40. Thorium oxide grade and tonnage of a thorium-rare-earth-element vein deposit in the Capitan Mountains, N. Mex., in comparison with the grade and tonnage model for 32 world-wide thorium-rare-earth-element vein deposits. 
41. Photographs of uraniferous calcrete exposed in a trench on the Beam Ranch along Sulphur Springs Draw north of Midland, Texas, and uranium concentrated along fractures in calcrete at Beam Ranch.

42-44. Maps showing:

42. Residual Bouguer gravity anomaly of eastern New Mexico and West Texas

43. Plan distribution of Pennsylvanian and Permian oil and gas fields of the Roswell Resource Area and vicinity, New Mexico-Texas

44. Regional oil and gas provinces of southeastem New Mexico and West Texas

\section{TABLES}

1. Susceptibility measurements of rock samples from the Lincoln County porphyry belt, New Mexico.

2. Estimated average concentrations of potassium (K), equivalent uranium (eU), and equivalent thorium (eTh) for different geologic units within the Roswell Resource Area, New Mexico

3. Mineral constituents of the gypsite deposits at Ancho, N. Mex.

4. Chemical analyses of gypsum from three selected deposits within the Roswell Resource Area, New Mexico... 58

5. Total reported past production for selected commodities in the Roswell Resource Area, New Mexico.............. 78

6. Production of iron ore from metals mining districts in Lincoln County, N. Mex., having iron ore production ... 82

7. Reported identified mineral resources and estimated gross in-place value of commodities in the Roswell Resource Area, New Mexico.

8. Mineral deposit types known or expected to occur in the Roswell Resource Area, New Mexico

9. Estimated number of undiscovered deposits for each of the $\mathbf{1 2}$ deposit types in tracts I-IV of the Roswell Resource Area, New Mexico

10. Estimated pre-mining tonnages of commodities contained in undiscovered deposits in tracts I-IV of the Roswell Resource Area, New Mexico

11. Estimated mean number of undiscovered deposits and pre-mining tonnages of commodities contained in undiscovered deposits in tracts I-IV, listed by deposit type, of the Roswell Resource Area, New Mexico

12. Estimated pre-mining tonnages of commodities contained in undiscovered deposits in tracts I-IV of the Roswell Resource Area, New Mexico

13. National Uranium Resource Evaluation program estimates of unconditional mean uranium endowment of formations in the Roswell Resource Area, New Mexico.

14. Estimated grade distribution and size-frequency distribution for uranium in the Dockum Group and Ogallala Formation, Roswell Resource Area, New Mexico.

15. Probability distribution of estimated uranium endowment in the Dockum Group, tracts $\mathrm{Va}$ and $\mathrm{Vb}$, Roswell Resource Area, New Mexico

16. Probability distribution of estimated uranium endowment in the Ogallala Formation in tract VI, Roswell Resource Area, New Mexico

17. Vanadium production from deposits within the Roswell Resource Area, New Mexico.

18. Geologic, engineering, and production parameters of oil fields exceeding cumulative production of 1 million barrels of oil equivalency through 1988, in the Roswell Resource Area, New Mexico

19. Geologic, engineering, and production parameters of gas fields exceeding cumulative production of 1 million barrels of oil equivalency through 1988, in the Roswell Resource Area, New Mexico

20. Quantitative estimates of undiscovered, conventionally recoverable oil and gas in the Roswell Resource Area, New Mexico, and for Federal lands therein

21. Analyses of coals in the Sierra Blanca field, Lincoln County, N. Mex. 


\section{METRIC CONVERSION FACTORS}

\begin{tabular}{lll}
\hline U.S. Customary unit & & Metric equivalent \\
\hline I inch & $=$ & 2.54 centimeters \\
1 foot & $=$ & 0.3048 meter \\
1 mile & $=$ & 1.609 kilometers \\
1 acre & $=$ & 4,047 square meters \\
1 cubic foot & $=$ & 0.028 cubic meter \\
1 cubic yard & $=$ & 0.765 cubic meter \\
1 gallon & $=$ & 3.785 liters \\
1 ounce & $=$ & 28.350 grams \\
1 pound & $=$ & 453.592 grams \\
1 short ton & $=$ & 0.907 metric ton \\
1 long ton & $=$ & 1.016 metric tons \\
\hline
\end{tabular}





\title{
MINERAL AND ENERGY RESOURCES OF THE ROSWELL RESOURCE AREA, EAST-CENTRAL NEW MEXICO
}

\author{
By Susan Bartsch-Winkler and Alessandro J. Donatich, Editors
}

\section{SUMMARY}

The sedimentary formations of the Roswell Resource Area have significant mineral and energy resources. Some of the pre-Pennsylvanian sequences in the Northwestern Shelf of the Permian Basin are oil and gas reservoirs, and Pennsylvanian rocks in Tucumcari Basin are reservoirs of oil and gas as well as source rocks for oil and gas in Triassic rocks. PrePermian rocks also contain minor deposits of uranium and vanadium, limestone, and gases. Hydrocarbon reservoirs in Permian rocks include associated gases such as carbon dioxide, helium, and nitrogen. Permian rocks are mineralized adjacent to the Lincoln County porphyry belt, and include deposits of copper, uranium, manganese, iron, polymetallic veins, and Mississippi-Valley-type lead-zinc. Industrial minerals in Permian rocks include fluorite, barite, potash, halite, polyhalite, gypsum, anhydrite, sulfur, limestone, dolomite, brine deposits (iodine and bromine), aggregate (sand), and dimension stone. Doubly terminated quartz crystals, called "Pecos diamonds" and collected as mineral specimens, occur in Permian rocks along the Pecos River. Mesozoic sedimentary rocks are hosts for copper, uranium, and small quantities of gold-silver-tellurium veins, as well as significant deposits of oil and gas, carbon dioxide, asphalt, coal, and dimension stone. Mesozoic rocks contain limited amounts of limestone, gypsum, petrified wood, and clay. Tertiary rocks host ore deposits commonly associated with intrusive rocks, including platinum-group elements, iron skams, manganese, uranium and vanadium, molybdenum, polymetallic vein deposits, gold-silver-tellurium veins, and thorium-rare-earth veins. Museum-quality quartz crystals are associated with Tertiary intrusive rocks. Industrial minerals in Tertiary rocks include fluorite, vein- and beddedbarite, caliche, limestone, and aggregate. Tertiary and Quaternary sediments host important placer deposits of gold and titanium, and occurrences of silver and uranium. Important industrial commodities include caliche, limestone and dolomite, and aggregate. Quaternary basalt contains sub-oregrade uranium, scoria, and clay deposits.

\section{INTRODUCTION}

\section{LOCATION AND GEOGRAPHY OF STUDY AREA}

The Roswell Resource Area (the "study area" of this report) is located in east-central New Mexico, approximately between latitudes $33^{\circ}-35^{\circ} \mathrm{N}$, and longitudes $103^{\circ}-106^{\circ} \mathrm{W}$. (fig. 1). The study area encompasses $14,014,720$ acres (about 21,890 $\mathrm{mi}^{2}$ ) and all of Guadalupe, Quay, De Baca, Curry, Roosevelt, and Lincoln Counties, and most of Chaves County. Of this total acreage, the U.S. Bureau of Land Management (BLM) manages only about 1.5 million surface acres (about 2,320 mi2) and 3.9 million subsurface (mineral rights) acres (about $6,075 \mathrm{mi}^{2}$ ).

Cities and towns within the Roswell Resource Area include Carrizozo (western part of study area), Santa Rosa (northwest), Fort Sumner (north-central), Tucumcari (northeast), Clovis and Portales (east), and Hagerman and Roswell (south). Federal and State lands included within the study area are Lincoln National Forest, the southem part of Cibola National Forest, White Mountain Wilderness Area, Salt Creek Wilderness Area, Sumner Lake State Park, Ute Lake State Park, Valley of Fires Recreation Area, Bottomless Lakes State Park, Bitter Lake National Wildlife Refuge, Grulla National Wildlife Refuge, Cannon Air Force Base, and the Melrose Bombing Range. Reserved lands within or adjacent to the study area are the Mescalero Apache Indian Reservation on the southwest and the White Sands Missile Range on the west. The Texas-New Mexico State line is the eastern boundary of the study area.

Prominent physiographic features of the Roswell Resource Area include the southern part of the Gallinas Mountains, the Jicarilla Mountains, the northem part of the Sacramento Mountains, the Capitan Mountains, the Pecos Slope, the Mescalero pediment, and the Llano Estacado. Major drainages include the Pecos River, which drains into the Rio Grande, and the Canadian River, which drains into the Red River. The Capitan and Gallinas Mountains rise to 


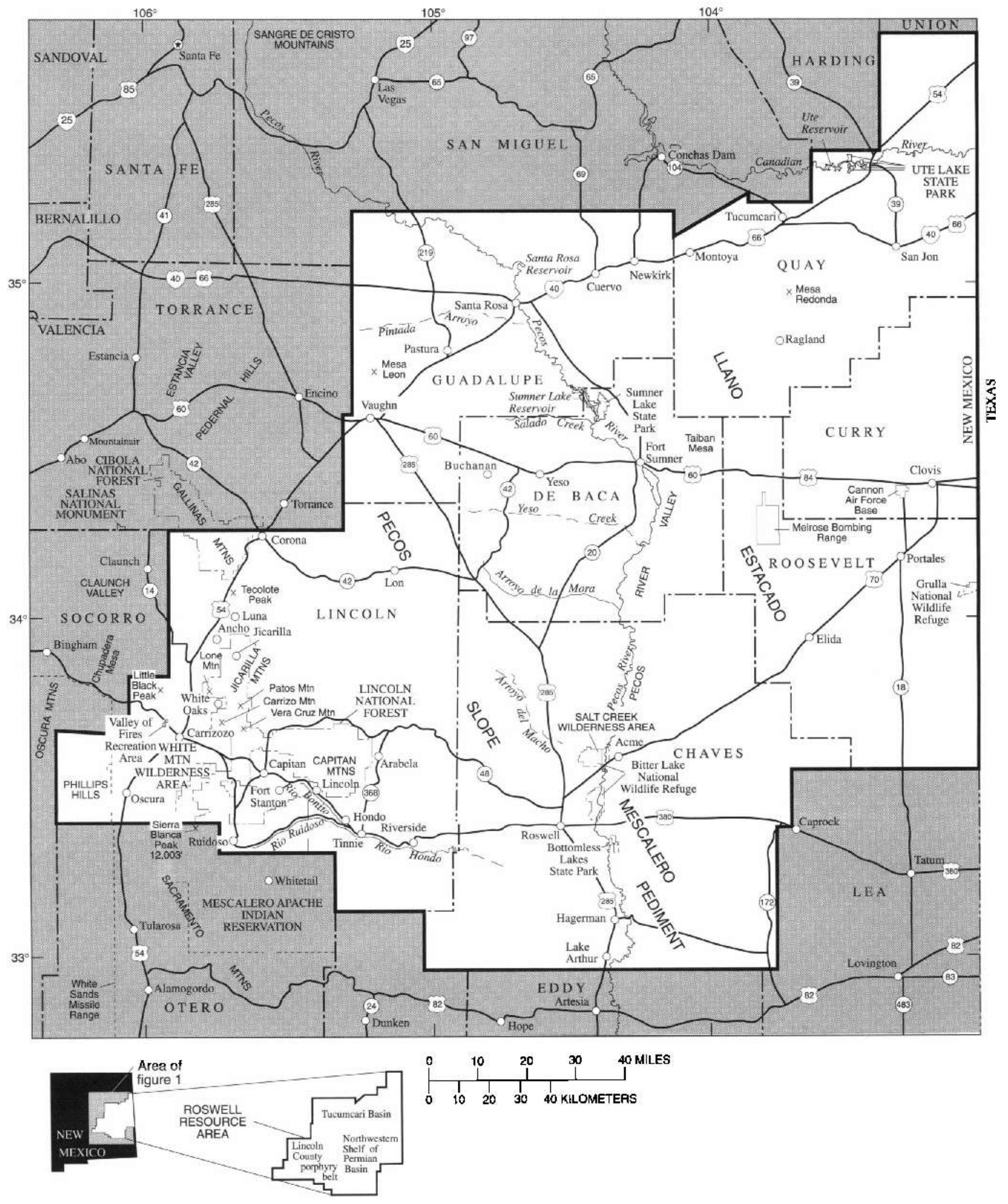

Figure 1. Index map of the Roswell Resource Area (unshaded), New Mexico, showing locations and physiographic features mentioned in text. 
about $10,200 \mathrm{ft}$ and $8,600 \mathrm{ft}$, respectively; Sierra Blanca Peak in the northern Sacramento Mountains reaches 12,003 $\mathrm{ft}$ at the southwestern border of Lincoln County. The western escarpment of Sierra Blanca Peak has the highest relief in New Mexico (nearly 7,800 ft). The Sacramento Mountains, Jicarilla Mountains, and Gallinas Mountains form a northsouth-trending mountain chain; the Capitan Mountains and smaller associated intrusives trend east-west. These mountain ranges slope to the Pecos River valley, about $80 \mathrm{mi}$ to the east.

The arid, undulating, eastward-sloping area that extends east of the mountains to the Pecos River is referred to as the Pecos Slope; the slope ranges in altitude eastward from about $10,000 \mathrm{ft}$ to about $3,000 \mathrm{ft}$, and is locally interrupted by small mesas. In the Roswell Resource Area, the Pecos Slope is drained by several east-flowing ephemeral and perennial rivers, including the Rio Hondo, Arroyo del Macho, Arroyo de la Mora, Yeso Creek, Salado Creek, and Pintada Arroyo; each of these major streams has its own tributary system. Numerous large subsurface drainage systems extend eastward from the mountains into the Pecos drainage system, which is greatly modified and locally entrapped by karst activity. The Pecos River has been dammed to form two major reservoirs, the Sumner Lake and Santa Rosa Reservoirs, both near Santa Rosa. The eastward-flowing Canadian River, located in the northeastern part of the study area, is also dammed along its course to form the Ute Reservoir. Two additional drainage basins are northwest of the study area: Estancia Valley, which is an interior basin west of the PedemaI Hills, and Claunch Valley, which drains into the Sierra Blanca Basin northwest of Carrizozo. Two interior drainage basins, the Encino and Vaughn, are located north of the Capitan Mountains and south of Pintada Arroyo; these drain into the subsurface karst and eventually into the Pecos River system.

The Mescalero pediment extends southeast from Roswell to the Mexican border, and between the Pecos River and the Llano Estacado (the Staked Plains or Caprock). The Llano Estacado makes up the largest part of the study area to the east of the Pecos River, extending from the Canadian River to the southeast comer of New Mexico and from the Mescalero pediment to beyond the Texas-New Mexico State boundary. It is crossed by large, mostly ephemeral stream systems with low gradients, which drain westward and southwestward into the Pecos River.

\section{PURPOSE AND METHODOLOGY}

This report assesses the potential for mineral and energy resources on the surface and in the subsurface within the Roswell Resource Area, an area managed by the U.S. Bureau of Land Management (BLM) that contains many important commodities in a variety of geologic settings. Resource potential is the likelihood for the occurrence of undiscovered concentrations of metals and nonmetals, industrial rocks and minerals, and energy resources. This report includes a description of the stratigraphy and tectonic setting of the study area, the geochemical and geophysical evidence used in the mineral and energy resource assessment, a description of the mineral occurrences and the hydrocarbon fields, an historical account of mineral and energy resource exploration and production, and a description and analysis of the mineral resource tracts and hydrocarbon plays.

The MARK-3 computer program for mineral resource simulation (Drew and others, 1986; Root and Scott, 1988; Root and others, 1992) is a statistical method that is used herein to estimate potential gross in-place tonnages for unknown resource commodities. This mineral resource assessment of the Roswell Resource Area relies upon previous work of the U.S. Geological Survey, the Canadian Geological Survey, and others who have developed mineral deposit models. Uranium and vanadium commodities, for which no models are currently available, are assessed by another similar statistical method, the deposit-sizefrequency method (Finch and McCammon, 1987). The resource potential of industrial commodities other than gypsum are discussed, but no quantitative assessments were made due to a lack of models, grade-and-tonnage curves, subsurface information, or knowledge of production. Two hydrocarbon plays are described from the national assessment of 1988 (U.S. Geological Survey and Minerals Management Service, 1988; Mast and others, 1989).

Limited field investigations of the Roswell Resource Area were independently conducted in 1990 and 1991 by Theodore J. Armbrustmacher, Susan Bartsch-Winkler, James A. Erdman, Dolores M. Kulik, Samuel L. Moore, Charles S. Spirakis, and David M. Sutphin. A summary of all available previously published geologic reports and maps on surface and subsurface geology and mineral occurrences was prepared by Bartsch-Winkler and Sutphin. Data from the Anaconda Collection (University of Wyoming, Laramie, Wyo.), the New Mexico Bureau of Mines and Mineral Resources (Socorro and Albuquerque, N. Mex.), and the BLM (Roswell, N. Mex.) were compiled by Mahlon M. Ball (oil and gas occurrences), Bartsch-Winkler (industrial mineral occurrences), Erdman (water geochemistry), Spirakis (sulfur occurrences), and Sutphin (metallic mineral occurrences). Information on the geology of the alkaline rocks was compiled by Armbnustmacher. Geologic map information was compiled and modified by Moore from the New Mexico Highway Map (New Mexico Geological Society, 1982). Edward J. LaRock transferred the geologic data onto a mylar base, and digitized, edited, and transferred the geology into ARC/NFO (Larock and Moore, 1992). Erdman and Ronald $R$. Tidball compiled and interpreted geochemical information from the National Uranium Resource Evaluation (NURE) surveys and transferred the geochemical data into ARC/INFO (Tidball and Erdman, 1992). Geophysical 
information was interpreted by Kulik. Joseph S. Duval studied and interpreted the NURE aerial gamma ray information for the study area. Data on various commodities were gathered by George N. Breit (vanadium), Warren I. Finch (uranium), James K. Otton (uranium), Spirakis (sulfur), Gary D. Stricker (coal), and Sherilyn Williams-Stroud (potash and brines). Various members of the study team identified models and evaluated the potential for deposits of certain commodities, and Sutphin, Richard B. McCammon, and Finch conducted statistical analyses of pertinent data for the mineral resource assessment. Ball and others assessed the petroleum potential and outlined the oil and gas plays.

\section{ACKNOWLEDGMENTS}

We thank the U.S. Bureau of Land Management Roswell Resource Area staff, Roswell, N. Mex., and particularly Jerry T. Dutchover, Jr., and Roger C. Maynard, for helpful assistance in the course of the work. We are especially grateful to Virginia T. McLemore, James M. Barker, and George S. Austin, New Mexico Bureau of Mines and Mineral Resources, Socorro, N. Mex., for access to State files on various assessed commodities, for help in obtaining materials for the report, and for reviewing the report. Ronald F. Broadhead, New Mexico Bureau of Mines and Mineral Resources, Socorro, N. Mex., was especially helpful in providing information pertinent to the assessment of hydrocarbons and associated resources. Discussions with Richard F. Kness and Stanley L. Korzeb, U.S. Bureau of Mines, Denver, Colo., provided helpful information on known resources and logistics. Kim Ong, Water Resources Division, U.S. Geological Survey, Albuquerque, N. Mex., provided information on water quality from samples taken in the Pecos River valley and reviewed the discussions of water quality in this report. This manuscript benefitted from technical review by David A. Lindsey and discussions on the stratigraphy with Marjorie E. MacLachlan, both of the U.S. Geological Survey, Denver, Colo.

\section{REFERENCES CITED}

Drew, L.J., Bliss, J.D., Bowen, R.W., Bridges, N.J., Cox, D.P., DeYoung, J.H., Jr., Houghton, J.C., Ludington, S., Menzie, W.D., Page, N.J., Root, D.H., and Singer, D.A., 1986, Quantitative estimation of undiscovered mineral resonrces-A case study of U.S. Forest Service wilderness tracts in the Pacific Mountain System: Economic Geology, v. 81, no. 1, p. 80-88.

Finch, W.I., and McCammon, R.B., 1987, Uranium resource assessment by the Geological Survey-Methodology and plan to update the national resource base: U.S. Geological Survey Circular 994, 31 p.

LaRock, E.J., and Moore, S.L., 1992, Digital geologic map of the Roswell Resource Area, New Mexico: U.S. Geological Survey Open-File Report 92-328-A-C, 4 p., 2 diskettes.

Mast, R.F., Dolton, G.L., Crovelli, R.A., Root, D.H., Attanasi, E.D., Martin, P.E., Cooke, L.W., Carpenter, G.B., Pecora, W.C., and Rose, M.B., 1989, Estimates of undiscovered conventional oil and gas resources in the United States-A part of the Nation's energy endowment: U.S. Geological Survey and Minerals Management Service Special Publication, 44 p.

New Mexico Geological Society, 1982, New Mexico highway geologic map: New Mexico Geological Society, scale $1: 1,000,000$.

Root, D.H., Menzie, W.D., and Scott, W.A., 1992, Computer Monte Carlo simulation in quantitative resource estimation: Nonrenewable resources, v. 1, no. 2, p. 125-138.

Root, D.H., and Scott. W.A., 1988, User manual for mineral simulation program: U.S. Geological Survey Open-File Report $88-15,64 \mathrm{p}$.

Tidball, R.R., and Erdman, J.A., 1992, NURE data for groundwater and stream sediments, BLM Roswell Resource Management Area, east-central New Mexico: U.S. Geological Survey OpenFile Report 92-365-A-B, 9 p., 1 diskette.

U.S. Geological Survey and Minerals Management Service, 1988, Working papers-National assessment of undiscovered conventional oil and gas resources [revised July 1989]: U.S. Geological Survey Open-File Report 88-373, 511 p. 


\title{
GEOLOGY OF EAST-CENTRAL NEW MEXICO
}

\author{
By Susan Bartsch-Winkler \\ With a section on \\ Tertiary Intrusive and Extrusive Alkaline Rocks \\ of the Lincoln County Porphyry Belt \\ By Theodore J. Armbrustmacher
}

\section{SUMMARY}

Surface and subsurface geologic units within the Roswell Resource Area span Precambrian to Holocene time, yet the surface units are mostly Permian, Mesozoic, Tertiary, and Quatemary (pls.1 and 2). The Roswell Resource Area contains three major terranes: the Tucumcari Basin, the Northwestern Shelf of the Permian Basin, and the Lincoln County porphyry belt (fig. 1). Uplifted sequences of sedimentary rock dip gently eastward along the Pecos Slope into the Northwestem Shelf of the Permian Basin. Exposed formations are composed mainly of clastic, carbonate, and evaporite successions above the warped and faulted Precambrian basement (pl. 2). Features of the Northwestern Shelf, as well as northward extremeties of the Permian Basin which include the Tucumcari Basin, Bravo dome, and Roosevelt positive, were probably formed in Paleozoic time (Budnik, 1989) (pl. 3). Laccoliths and stocks of late Laramide (Tertiary) age, known as the Lincoln County porphyry belt, intrude the older sedimentary sequences of the Pecos Slope in the western part of the study area; this belt generally includes the north-trending mountain chain composed of the Sacramento, Jicarilla, and Gallinas Mountains, the easttrending Capitan Mountains, and the smaller Carrizo, Patos, Vera Cruz, and Lone-Baxter Mountains (pl. 3). The rock units of the Pecos Slope display superimposed small-scale tectonic features that were reactivated at various times (pl. 3; figs. 2 and 3). Uplift and subsidence events, in association with the Pecos River drainage system, resulted in evaporite dissolution and eventual development of karst terrane (especially in Permian rocks). The Pecos River and its tributaries deposited Pleistocene and Holocene alluvium and terrace gravel; this fluvial system continues to dissolve evaporite and form karst.

\section{STRUCTURE}

\section{UPLIFTS}

\section{SACRAMENTO UPLIFT, PECOS SLOPE, AND CAPITAN MOUNTAINS}

Uplift was initiated by intrusive activity in Tertiary time in the Sacramento, Jicarilla, Gallinas, and Capitan
Mountains and adjacent ranges (the highest points in the study area). High-angle, westward-dipping normal faults and pre-Tertiary(?) thrust faults near the base of mainly Paleozoic and Mesozoic strata, which manifest themselves as scarps, fans, and step faults, are exposed southwest of the study area in the Sacramento uplift (pl. 3). The steep west front of the Sacramento uplift, which marks the eastward extent of the Rio Grande rift (Pray, 1961; Chapin, 1971), is at least $7,000 \mathrm{ft}$ higher than the adjacent Tularosa Basin (Kelley and Thompson, 1964) (pl. 2).

The east side of the Sacramento uplift is an eastwardly inclined surface called the Pecos Slope. The western boundary of the Pecos Slope in Lincoln County is defined by the distribution of intrusive and extrusive rocks in the mountainous area referred to as the Lincoln County porphyry belt, and by the Dunken uplift (south of the study area) and the Tinnie fold belt (Kelley, 1971) (pl. 3). On the Pecos Slope, anticlines, synclines, basins, monoclines, and circular domes occur; some of the folds are overtumed.

The Capitan Mountains, probably a laccolith, is one of the largest Tertiary intrusions in New Mexico (McLemore and Phillips, 1991) (fig. 4). The aplite roof and granite core of the pluton are exposed by erosion (Allen, 1988; Allen and McLemore, 1991). Sedimentary strata that crop out on the western and overlying parts (the roof) of the intrusive dip to the west; the eastern part (the core) of the intrusive is in contact with near-vertical strata (Kelley, 1971; McLemore and Phillips, 1991). The intrusion is probably a basement-related feature because it lies within the east-west-trending Capitan Mountains lineament, which extends westward from the Matador uplift in West Texas to Socorro in central New Mexico (Griswold, 1959; Kelley, 1971) (inset, pl. 3). The junction of the north-northeast-trending structural zones of the Sacramento, Jicarilla, and Gallinas Mountains and the east-west-trending structural zone of the Capitan Mountains occurs in the vicinity of several other smaller intrusions, including those of the Carrizo, Patos, Vera Cruz, and Lone Mountains (pls. 1 and 3) (Griswold, 1959). According to Kelley (1971), the apparent left-lateral offset of the northsouth-trending Pedernal uplift (Mescalero arch) is concealed by intrusive rocks of the Capitan Mountains; the mountains themselves are apparently locally offset by north- or northeast-trending faults. 


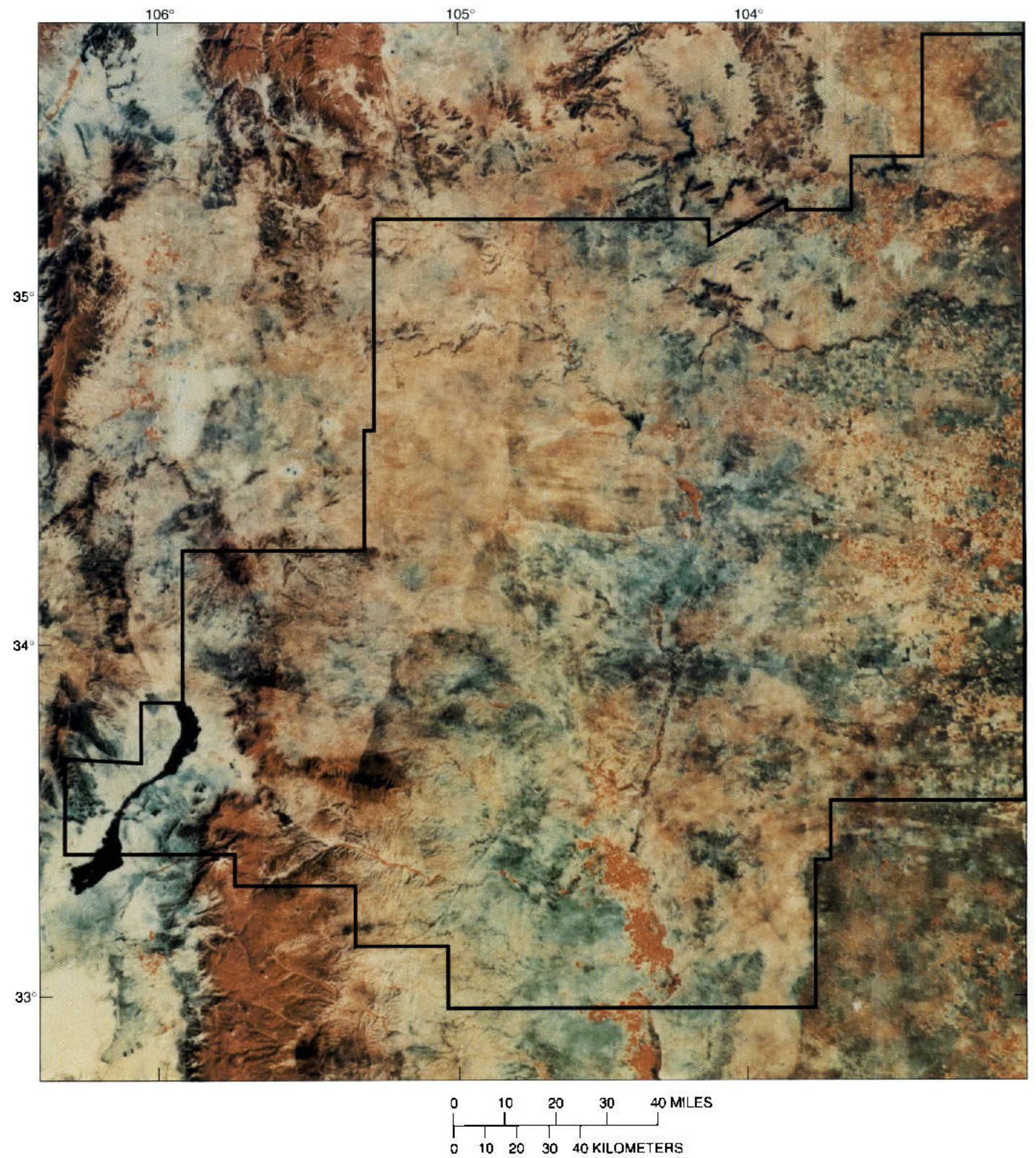

Figure 2 (ception continued on facing page). Photomosaic of Landsat 2 and Landsat 3 satellite images of the Roswell Resaurce Area (heavy line) and vicinity, New Mexico (see fig. 3 for reference locations). Images [using bands 4 (natural), 5 (visible red), and 7 (near infrared)] were taken at an altitude of about $560 \mathrm{mi}$ during the late 1970 's. Live vegetation emits radiation detectible in the near-infrared spectrum, shown in shades of red. It is especially noticeable in irrigated patches adjacent to the south-flowing Pecos River, near Portales and Clovis, and east of Tucumcari, and in forested mountainous areas such as the Capitan, Sacramento. Jicarilla, and Gallinas Mountains; Sierra Blanca Peak is above timberline. Rivers and deep parts of reservoirs are shown in black, and shallow turbid water is blue. Karst-related features of the Pecos River valley in the southem part of the study area appear as pale-blue to black ovoid patches. Extensive lineaments are discemible, 


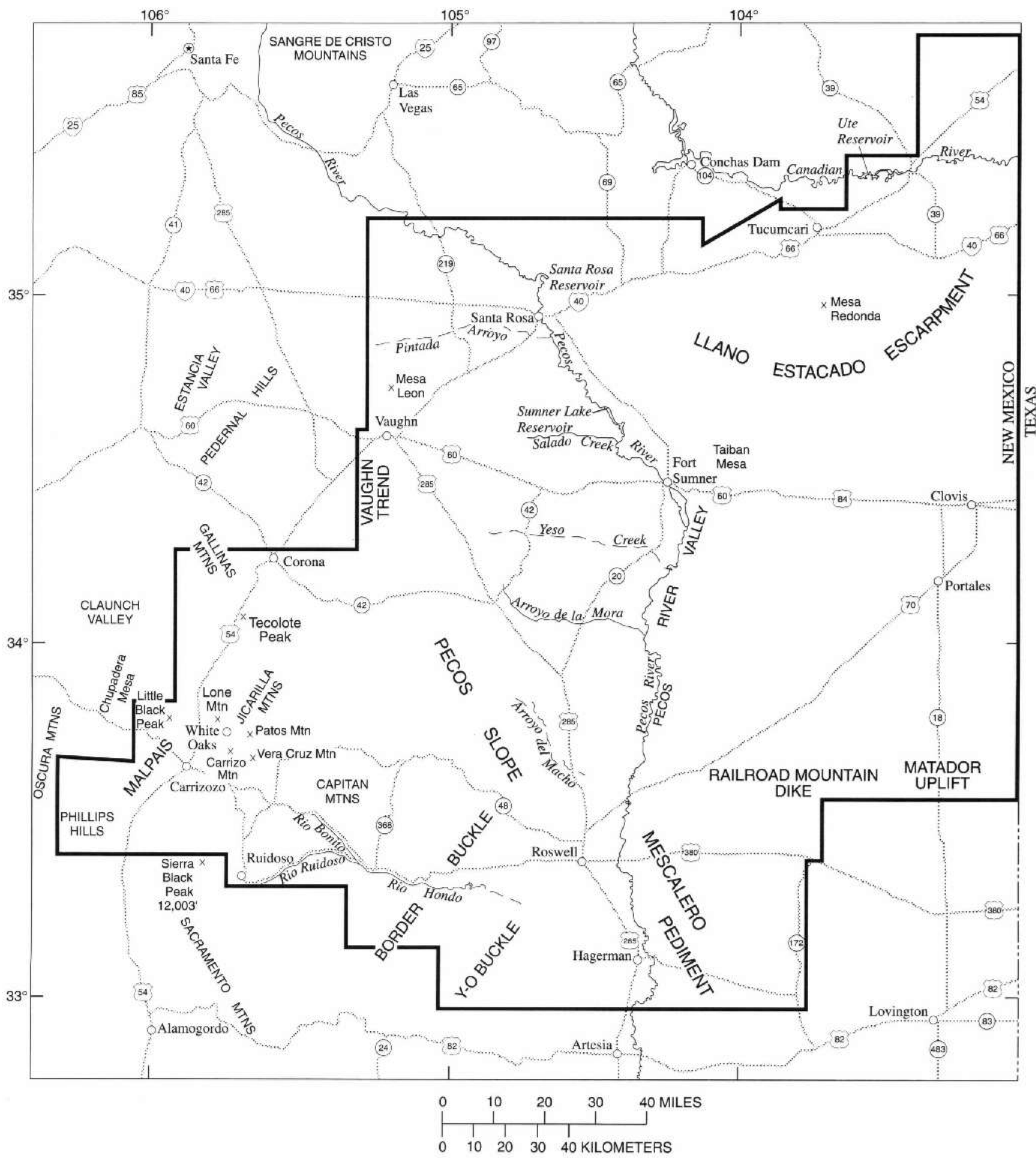

Figure 3. Reference locations for figure 2.

such as the northeast-trending Border and $\mathrm{Y}-\mathrm{O}$ buckle zones near Roswell; traces of features associated with the north-south-trending Vaughn trend are faint, as are the east-west-trending lineaments related to the Matador uplift, Railroad Mountain dike, and Capitan Mountains. Other recognizable features are the malpais (black basalt flows) west of Carrizozo and the curved escarpment of the Llano Estacado south of Tucumcari, upon which are situated (near Clovis and Portales) light-colored Pleistocene sand dunes. Gypsum dunes of White Sands National Monument are evident. [Excerpted from a photomosaic of New Mexico that is available from the U.S. Agricultural Stabilization and Conservation Service, Aerial Photography Field Office, Box 30010, Salt Lake City, Utah 84125.] 


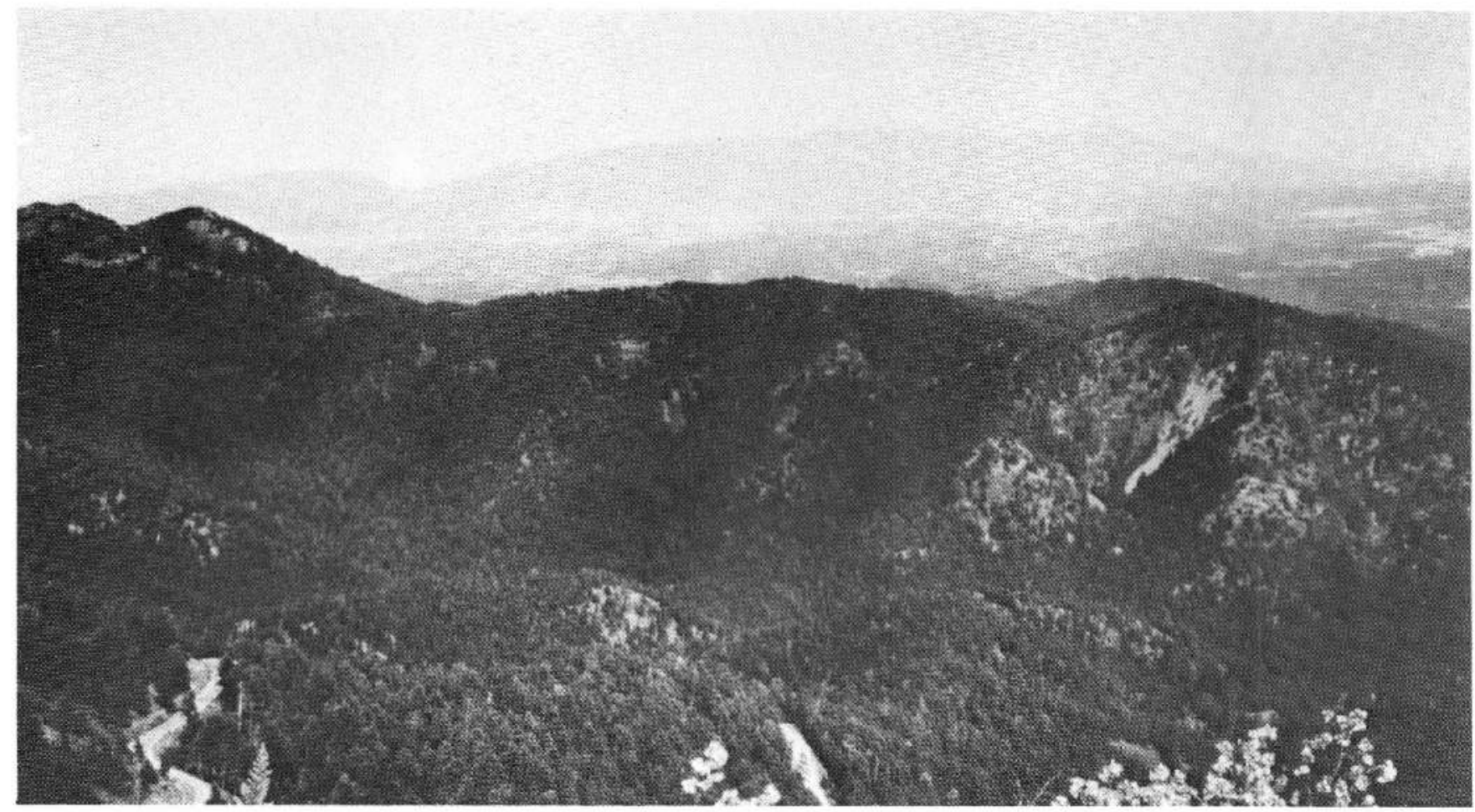

Figure 4. The Capitan Mountains in the Lincoln County porphyry belt, New Mexico. View is to the north from Sierra Blanca Pcak. Photograph taken by Gary R. Winkler (U.S. Geological Survey).

\section{CARRIZOZO ANTICLINE}

The Carrizozo anticline is a broad, elliptical-shaped, northeast-trending, doubly plunging, slightly asymmetric fold that extends from the Sierra Blanca Basin on the east to the southem end of Chupadera Mesa on the west (outside the study area) (pl. 3). It crosses the north-south structural trend that extends from the Tularosa Basin to the Claunch sag (Kelley and Thompson, 1964).

\section{PEDERNAL UPLIFT}

The buried Paleozoic Pedemal uplift (southem part of the Ancestral Rocky Mountains and Sierra Grande uplift) extends from the northern edge of the study area at Vaughn to east of the southern Sacramento Mountains (south of the study area) (pl. 3). The Mescalero arch of Kelley and Thompson (1964), a broad structural divide that is offset by the Capitan Mountains, generally coincides with the Pedernal uplift (Kelley, 1971). The rise of the Pedemal uplift, which is cored by Precambrian basement rocks, probably was initiated in Middle Pennsylvanian (early Atokan) time, with major uplift recurring in Pernian time (pl. 2). No coarse clastic material from this Precambrian-age landmass is found in pre-Pennsylvanian rocks (Lloyd, 1949); however, Precambrian clastics are found in lower Atokan and Lower Permian sedimentary rock sequences. In late Paleozoic time, the Pedernal uplift caused various overlying Paleozoic for- mations to be truncated along its flanks (Pray, 1949, 1954, 1961; Kottlowski, 1963; Perhac, 1964; Kottlowski and Stewart, 1970; Broadhead and King, 1988).

\section{MATADOR UPI.JFT, ROOSEVELT POSITIVE, AND BRAVO DOME}

The pre-Permian Matador uplift is a prominent subsurface Precambrian basement feature that trends east-west in southern Roosevelt County (pl. 3). It is marked by a series of en-echelon fault-bounded blocks that range in size from 5 $\mathrm{mi}^{2}$ to $50 \mathrm{mi}^{2}$, with as much as $4,000 \mathrm{ft}$ of basement relief (Budnik, 1989). Oil wells drilled in the area encountered Pennsylvanian and Permian sequences that overlie Precambrian basement rocks; each block along the trend contains oil reservoirs of Mississippian to middle Permian age (Budnik, 1989). Only small amounts of Precambrian detritus were eroded from the Matador uplift, indicating that the Matador uplift was a relatively low, positive feature during Pennsylvanian and Permian time (Lloyd, 1949). Pre-Mississippian strata are missing on the uplift. Multiple unconformities in strata overlying the fault blocks of the Matador uplift indicate a complex history (Budnik, 1989).

The Roosevelt positive, an aligned series of small domes in the subsurface, lies at the southwest extremity of the Matador uplift ( $\mathrm{pl}$. 3). The positive was reactivated episodically in early to middle Paleozoic time and uplift took place until at least middle Permian time (Budnik, 1989). 
The Bravo dome is parallel and similar to the Matador uplift in being a faulted (reactivated) subsurface Precambrian basement high that extends from eastern New Mexico to northwestern Texas (Budnik, 1989) (inset, pl. 3). The Bravo dome separates the Tucumcari Basin to the southwest from the Dalhart Basin to the northeast. The Bravo dome apparently formed in Middle Pennsylvanian time and deformation continued into Miocene time. The uplift influenced deposition of sedimentary rocks throughout Permian time; basement rocks of the dome are onlapped by Pennsylvanian strata and the Lower Permian Glorieta Sandstone.

\section{SAN JON HIGH}

The San Jon high (also referred to as the Frio uplift) is a broad Precambrian basement positive in the subsurface that separates the Palo Duro and Tucumcari Basins (pl. 3); Budnik (1989) described the San Jon high as being composed of two small highs. It is bounded on the west by the Bonita fault; a high-angle, northeast-trending normal basement fault occurs within the high on the southeast. Subsurface data indicate that Pennsylvanian and Permian sedimentary strata thin over the San Jon high.

\section{BASINS}

\section{SIERRA BLANCA BASIN}

The Sierra Blanca volcanic pile rests on a $750-\mathrm{mi}^{2}$ structural basin delimited by Cretaceous deposits [mainly Dakota(?) Sandstone] that crop out along its perimeter (Griswold, 1959; Kelley and Thompson, 1964) (pls. 1 and 3). This basin, the Sierra Blanca Basin, is about $40 \mathrm{mi}$ long and $20 \mathrm{mi}$ wide and trends north-northeast (Thompson, 1966). The basin lies west of the Pedernal uplift or Mescalero arch, east of the Carrizozo anticline, and northeast of the Tularosa Basin; the northem part of the Sierra Blanca Basin has been altered by the White Oaks and Capitan faults and by intrusions, including those of Lone Mountain (Kelley and Thompson, 1964). The eastern edge of the basin slopes into a fault zone near Ruidoso, which has as much as $1,400 \mathrm{ft}$ of vertical offset (Kelley and Thompson, 1964). Folds and faults on the eastern edge of the basin near Sierra Blanca Peak (including the Tinnie fold belt) (Kelley, 1971) trend east-northeast, nearly paralleling the buckle faults discussed below. The Sierra Blanca Basin is Laramide in age, and is filled by Eocene and later volcanogenic and plutonic units (Thompson, 1972; Lucas and others, 1989; Cather, 1991; Moore and others, 1991).

\section{PERMIAN BASIN}

The Permian Basin extends in the subsurface from southeastern New Mexico and West Texas into southern Kansas and western Oklahoma (Budnik, 1989) (inset, pl.
3). The Northwestern Shelf is that part of the Permian Basin that lies north of the Permian Capitan Reef and extends into the study area; features of the Northwestern Shelf include Tucumcari Basin, Bravo dome, Roosevelt positive, and the western part of the Palo Duro Basin. Important features of the Permian Basin in New Mexico, but outside the study area boundary, include the Delaware Basin (south of the Capitan Reef) and the northwestern part of the Central Basin Platform (east of the Delaware Basin). At the western extremity of the Permian Basin, especially in the central and northern parts of the study area, prePennsylvanian rocks generally are shelf deposits that have been truncated and (or) eroded.

\section{TUCUMCARI BASIN}

The Tucumcari Basin, in the subsurface in the northeastern part of the study area, is a Pennsylvanian-age, asymmetric structural basin bounded by ancestral uplifts of the Rocky Mountains (Paleozoic Sierra Grande uplift on the north and Pedernal uplift on the south and west), the Bravo dome on the northeast, and a subsurface horst block of Middle Pennsylvanian to Early Permian (Wolfcampian) age on the southeast (Broadhead, 1989) (pl, 3). The deepest part of Tucumcari Basin is composed of down-faulted block structures (grabens) in basement rocks; it is as much as $9,000 \mathrm{ft}$ deep west of Newkirk, N. Mex. (Broadhead and King, 1988; Broadhead, 1989). The basin is underlain by Precambrian basement and sedimentary units of Mississippian, Pennsylvanian, Permian, Triassic, Jurassic, Cretaceous, Tertiary, and Quaternary ages (Dobrovolny and others, 1946); Mississippian rocks were deposited before development of Tucumcari Basin (Broadhead, 1989). Pre-Mississippian strata are not present (Broadhead and King, 1988).

According to Broadhead and King (1988), gentle surface structures are not indicative of the large-scale subsurface structures in Tucumcari Basin. The norhern, western, and eastern parts of the basin are complexly faulted, but major structural movement in the basin and surrounding uplifts was apparently limited to Middle Pennsylvanian through Early Permian time (Broadhead and King, 1988) because basin faults (rooted in Precambrian basement) cut these strata and control their thickness and facies distribution (Broadhead, 1989). Upper Permian units have few faults and are draped over deeper fault blocks (Broadhead, 1989). During the Laramide orogeny, some of the older structures in Tucumcari Basin were reactivated. The Bonita fault, an isolated structural feature in southeastern Tucumcari Basin, displaces beds as young as Cretaceous in age and may have offset strata as young as Quatemary in age; dissolution of Permian units complicates the analysis of fault movement (Budnik, 1989). The Bonita fault trends N. $40^{\circ} \mathrm{E}$. and dips $60^{\circ} \mathrm{W}$.; it has as much as $700 \mathrm{ft}$ of normal displacement (Stearns, 1972). 


\section{FAULTS AND FOLDS}

\section{TINNIE FOLD BELT}

The north-trending Tinnie fold belt, in the southwest comer of the study area, is about $20 \mathrm{mi}$ long and about 3-5 mi wide (Kelley, 1971) (pl. 3). The belt consists of narrow anticlines and synclines whose moderately steep limbs overlie a narrow north-trending basement block (Bowsher, 1991). In the northern part of the belt where the basement block has structural relief of about $6,000 \mathrm{ft}$ (Burt, 1991), as many as 12 folds occur in a width of $3 \mathrm{mi}$. Near Hondo Canyon, as many as nine folds occur in a width of $2 \mathrm{mi}$ (Kelley, 1971); structural relief on these folds is as much as $1,000 \mathrm{ft}$ (Kelley, 1971). Folding and faulting in the Tinnie fold belt probably took place during Tertiary time. The folds may be related to tectonic reactivation of Precambrian basement that underlies them (Craddock, 1964; Yuras, 1976; Burt, 1988).

\section{FOLDS IN INCOMPETENT STRATA}

In Rio Bonito Canyon northwest of the Tinnie fold belt (pl. 3), the Yeso Formation and the overlying Glorieta Sandstone and San Andres Formation are folded into a series of north-trending folds named the Lincoln fold belt by Craddock (1960); overlying strata are not folded (Griswold, 1959). The Lincoln fold belt apparently formed in Tertiary time independently from, and unrelated to, basement activity. Folds occur in Yeso strata south and east of Corona (Fischer and Hackman, 1964), in the Claunch sag, on Chupadera Mesa, and on the flanks of the Capitan Mountains (Kelley and Thompson, 1964). Because of their occurtence in (but not restriction to) the Yeso Formation, which is composed predominantly of gypsum and is highly susceptible to slumping, the folds are thought to be related to incompetency in bedrock, and were probably caused by collapse, intrusion, solution, slumping, and (or) compressive or gravity tectonics, or by combinations of these factors (Kelley and Thompson, 1964; Craddock, 1964; Foley, 1964).

\section{VAUGHN TREND}

The Vaughn trend is a fold belt of minor deformation that extends through Vaughn, N. Mex., on a north-south trend, aligning with the Tinnie fold belt (Kelley, 1972a, b) (pl. 3). At its southern end, the trend is composed of staggered anticlines; to the west it is composed of a narrow fault zone that has, in part, right-lateral strike-slip movement (the Nalda shear zone) and which passes farther north into a gentle flexure (the Derramadura monocline). Three miles east of the Nalda shear zone is the 25-mi-long Vaughn fault, which, farther to the north, becomes a 13-mi-long buckle or westfacing monocline (Leon monocline) that extends into Pintada Arroyo. According to Kelley (1972a, b), deep-seated extension in the Ancestral Rocky Mountains may be manifest in the Vaughn sag, which is located between the Leon
monocline-Vaughn fault on the east and the Derramadura monocline on the west.

\section{BUCKLES AND NORTHEAST-TRENDING FAULTS}

A series of northeast-trending faults and associated folds, some termed buckles in the literature, occur on the southern Pecos Slope west of Roswell, N. Mex., (Merritt, 1920) (pl. 3). In general, these features are straight, exposed for $35-80 \mathrm{mi}$, and spaced at $8-$ to $20-\mathrm{mi}$ intervals. Many of the buckles may be right-lateral wrench faults, as evidenced by their great length and small amount of throw, associated drag folding, left-branching folds and short faults, and long left-diagonal folds in the blocks between the buckles (Kelley, 1971). Most of these structural features plunge northeastward and diagonal to regional dip. These faults, folds, and buckles are named the Bonito fault, White Tail buckle, Serrano buckle, Border buckle, Sixmile buckle, Y-O buckle, and the K-M fault; many form structural traps related to gas accumulations. Additional, smaller, right-lateral offset faults and buckles not shown on plate 3 include the Ruidoso, Little Creek, Airstrip, and Champ faults and the Purcella buckle (Kelley, 1971).

The Bonito fault trends N. $55^{\circ}$ E. for about $36 \mathrm{mi}$ from Sierra Blanca Peak to near Lincoln, N. Mex., north of the Capitan Mountains (Kelley, 1971). Offset faults, folds, and a sill indicate right-lateral movement.

The White Tail buckle trends N. $50^{\circ}-60^{\circ}$ E. for about 21 mi near Hondo, N. Mex. (Kelley, 1971). The fault is downthrown on the southeast side, except at the southwest end where it is downthrown to the northwest; it probably has experienced some right-lateral movement, although no drag folds are apparent (Kelley, 1971).

The Serrano buckle is about $26 \mathrm{mi}$ long and trends about N. $35^{\circ} \mathrm{E}$, extending northward from the Tinnie fold belt (Kelley, 1971). Relative movement varies along its length. The buckle zone has a width of less than $300 \mathrm{ft}$ (Kelley, 1971). Local drag folds and faults indicate rightlateral movement, with locally as much as $500 \mathrm{ft}$ of lateral offset (Kelley, 1971).

The Border buckle is about $60 \mathrm{mi}$ long and trends $\mathrm{N}$. $35^{\circ}-55^{\circ} \mathrm{E}$. (Kelley, 1971). This buckle is the most strongly deformed of all these structural features; the zone of deformation ranges in width from $1,600 \mathrm{ft}$ to less than $500 \mathrm{ft}$ (Kelley, 1971). Localized brecciated intervals indicate faulting, but the sense of lateral offset changes repeatedly along the length of the buckle (Kelley, 1971) (fig. 5).

The Sixmile buckle is as much as $80 \mathrm{mi}$ long and trends about $\mathrm{N} .40^{\circ} \mathrm{E}$. The upper beds in the Sixmile buckle are vertically offset, but the lower beds indicate possible rightlateral strike-slip movement (Kelley, 1971).

The Y.O buckle is at least $72 \mathrm{mi}$ long and trends about N. $40^{\circ}$ E., as inferred from surface and subsurface evidence. The buckle apparently follows a preexisting line of deformation; the most deformed part of the fold is about 


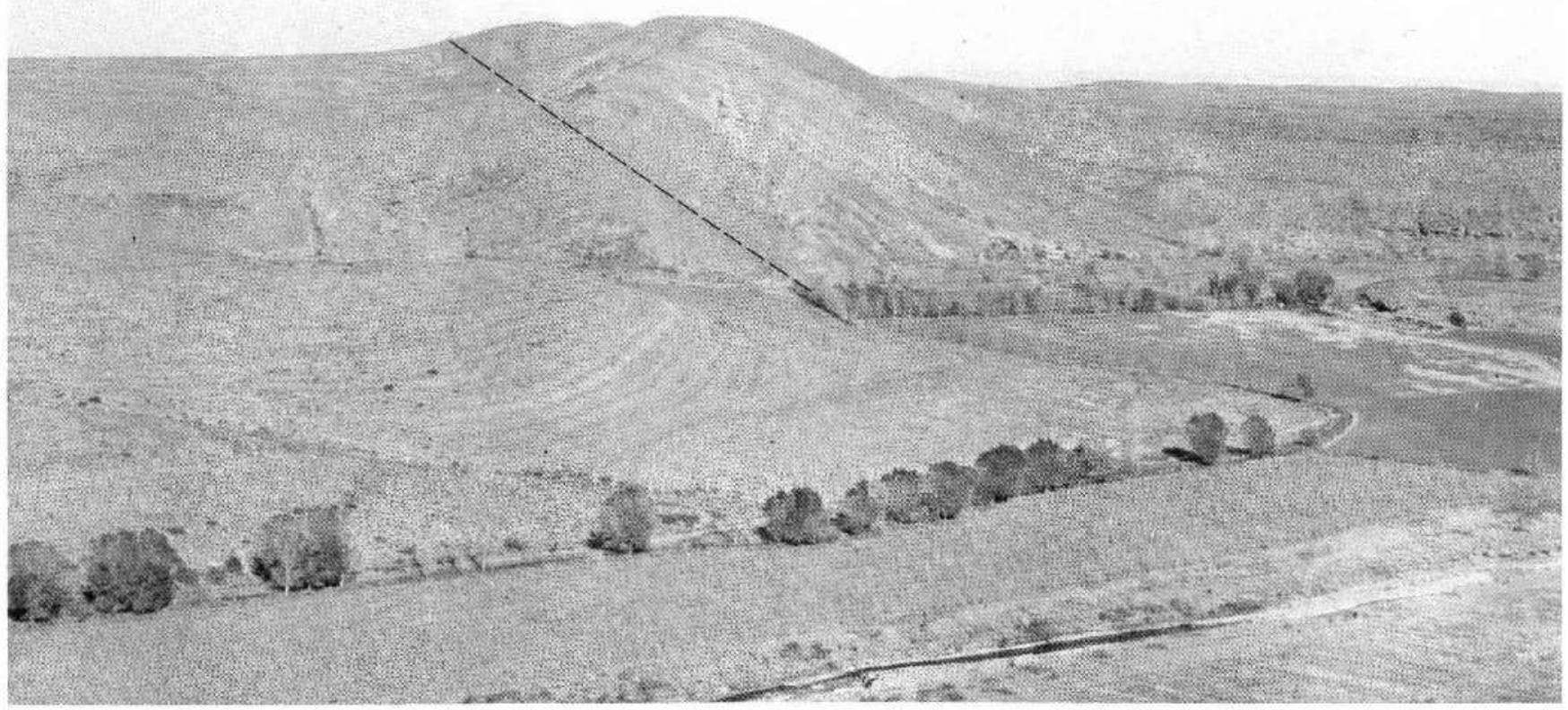

Figure 5. The Border buckle, east-central New Mexico (approximate location shown by dashed line). Photograph by S.S. Nye in December 1927, from the south side of Rio Hondo looking northeast (photograph number 25, on file at the U.S. Geological Survey Photo Library, Denver, Colo.).

$500-800 \mathrm{ft}$ wide (Kelley, 1971). Drag folds adjacent to the buckle indicate right-lateral movement estimated to be as much as $1,800 \mathrm{ft}$.

The K-M fault extends in the subsurface from Artesia, N. Mex., to about Lake Arthur, N. Mex., near the southem border of the study area (Kelley, 1971). It is apparently about $30 \mathrm{mi}$ long, and its southeast side is downdropped as much as $200 \mathrm{ft}$ (Kelley, 1971).

\section{ROOSEVELT COUNTY FAULT}

The Roosevelt County fault, a subsurface fault about 43 mi long, is a normal fault that bounds the westem margin of the Matador uplift (pl. 3). Flawn (1956) suggested that as much as $15 \mathrm{mi}$ of right-lateral offset has occurred on the fault on the basis of offsets in Precambrian strata. The fault was reactivated in as late as middle Permian time, as evidenced by the occurrence of as much as $250 \mathrm{ft}$ of relief in San Andres Formation strata across the fault (Ramondetta, 1982; Budnik, 1989).

\section{ALAMOSA CREEK FAULT}

The Alamosa Creek fault in northern Roosevelt and western Curry Counties, N. Mex., is manifest as a 6-mi-long, northeast-trending surface graben that contains rocks of Cretaceous to late Tertiary age (Budnik, 1989) (pl. 3). As much as $200 \mathrm{ft}$ of Cretaceous rocks and $150 \mathrm{ft}$ of Tertiary and Quaternary caliche deposits are preserved within the graben. The fault was active in middle Permian time and was reactivated twice in Cretaceous time, but the nature of fault movement is controversial because of the lack of subsurface information and because of known dissolution of evaporitic Permian units. Strike-slip movement is suggested, however, by the lack of vertical offsets in underlying units of the surface graben, and the fault may be related to other northeast-trending strike-slip faults and buckles of the region.

\section{KARST}

Postdepositional jointing of lithified deposits occurred during regional uplift in the study area as stress was released by erosion of overburden. Regionally, joint sets in bedrock allow percolation by surface water and groundwater, resulting in dissolution of water-soluble components in the rock, especially evaporite, limestone, and dolomite. Ultimately, caverns and vadose zones form and become holding areas for surface runoff. Subsurface drainage channels also form. Finally, the cavemous terrane is modified by collapse, forming breccia pipes filled with insoluble residue and destroying all evidence of previously formed features. Such features may be, in part, the result of upward-flowing subsurface water under hydrostatic pressure (an artesian system). This 
combination of features is typical of karst. Karst features, which form important aquifers in southeastern New Mexico, are described in detail by Bachman (1987). Karst has probably been forming in the study area since Triassic time (Bachman, 1987).

\section{SINKS}

The Santa Rosa collapse basin, in the northwestern part of the study area (pl. 3), is perbaps the most notable karst feature in the study area. It is a large circular sinkhole, about 6 $\mathrm{mi}$ in diameter and as much as $400 \mathrm{ft}$ deep, that is infilled with sand, mud, and gravel to a depth of as much as $200 \mathrm{ft}$ (Kelley, 1972b). The collapse resulted from dissolution of underlying salt, gypsum, or limestone deposits of Permian age (Sweeting, 1972). The boundary of the sink is marked by faults and monoclinal flexures arranged in concave-inward segments. Sink holes have formed along the flexures and adjacent uplands, but are especially prevalent along the west and north sides of the Santa Rosa collapse basin where the Pecos River and Pintada Arroyo enter the basin and have eroded into the basin fill. Near the town of Santa Rosa, $\mathrm{N}$. Mex., many smaller sinkholes (not shown on pl. 3) include the locally renowned Blue Hole. It is $60 \mathrm{ft}$ in diameter, more than $81 \mathrm{ft}$ deep, and has an artesian flow of 3,000 gallons per minute.

In southeastern Chaves County and western Lea County, N. Mex., sinks are aligned along joints that trend $\mathrm{N}$. $60^{\circ} \mathrm{W}$. (Reeves, 1972). East of Artesia, numerous small sinks and domes are present. The structures are noted by the presence of slumping, flexing, and apparent doming of bedrock caused by dissolution of evaporite and movement of salt; they are localized at the wedge edge of the Upper Permian Salado Formation in the shallow subsurface (Kelley, 1971; Bachman, 1987).

\section{CONTORTION FEATURES}

Contortion is notable in exposures of the evaporitebearing Lower Permian Yeso Formation along the Rio Bonito canyon and on the Pecos Slope. The incompetent folds associated with the Yeso have axes that are randomly oriented, highly curved in some places, and generally not continuous for more than $1,000 \mathrm{ft}$ (Kelley, 1971). Such features may result from faulting, but they are more likely caused by surficial collapse, evaporite intrusion, volume change accompanying hydration, and regional tilting (Kelley, 1971). In the subsurface, dissolution can be recognized as zones of abrupt thinning, especially in layers containing salt deposits; overlying strata may be warped or folded. In areas where groundwater movement is facilitated along faults, dissolved layers may be more common. Tectonic and nontectonic origins for folding in these layers may be difficult to distinguish.

\section{CAVES}

East-central New Mexico contains numerous gypsum and limestone caves. Gypsum caves are developed in the Upper Permian Artesia Group in and near the study area, especially near Lake McMillan east of Artesia, along the Pecos River, and in the vicinity of Roswell (Peerman and Belski, 1991). Tres Niños Cave, a privately owned gypsum cave west of Carrizozo, extends under a Quatemary basalt flow (National Speleological Society, 1986). Millrace Cave, adjacent to the east entrance to Valley of Fires Recreation Area, is a gypsum cave that extends to a depth of $360 \mathrm{ft}$ beneath a Quatemary basalt flow (one of the deepest gypsum caves in the United States) (National Speleological Society, 1986). Fort Stanton Cave (near Fort Stanton), developed in limestone of the San Andres Formation, is the third longest (after Lechuguilla Cave and Carlsbad Caverns) and the earliest discovered limestone cave in New Mexico; additional limestone caves are near Fort Stanton Cave (National Speleological Society, 1986). South of the study area but in the same geologic setting, Carlsbad Caverns and Lechuguilla Cave occur in the Upper Permian Capitan Limestone in the Guadalupe Mountains (north and west of Carlsbad) (pl. 2; inset, pl. 3). Caves, including these exceptional examples, occur mainly along flanks or crests of anticlinal folds and other positive structures, and (or) at the intersections of joints and fractures in Permian carbonate rocks.

The genesis of caves in eastern New Mexico and Texas is poorly understood and numerous recent theories on their origin have been proposed (Bachman, 1987; Hill, 1987, 1989). One hypothesis is that in late Tertiary to early Quaternary time, uplift caused relative lowering of the water table, which may have allowed caverns to develop, especially in the limestone- and evaporite-bearing Lower Permian San Andres Formation and Upper Permian Artesia Group in the southern and southeastern parts of New Mexico (Bachman, 1987). During this time, rainfall and runoff may have increased and drainages may have existed above the water table. Cavern and breccia-pipe development took place during dissolution of evaporite beds by downward-percolating water, especially at the joint intersections. Karst development probably was accelerated by climate change and uplift.

Davis (1980), using the replacement-solution hypothesis of Egemeier (1973), suggested that cavern development is the result of the (1) interaction of groundwater carrying hydrogen sulfide gas (from petroleum deposits) with air to form sulfuric acid, (2) sulfuric acid dissolution of limestone and conversion of limestone in the cave to gypsum, and (3) buildup and collapse of gypsum in the cave and dissolution and removal by cave streams. Isotopic studies by Hill (1987, 1990) support the theory of sulfuric acid dissolution of certain limestone beds, and Hill proposed a possible connection between hydrocarbons and sulfuric acid generation (although the migration path and source of such hydrogensulfide-producing hydrocarbons is unknown), leading to 
formation of certain types of caves that contain gypsum blocks and rinds, native sulfur, and endellite clay deposits (Hill, 1990) (see fig. 18 and "Sulfur" section, this report).

\section{STRATIGRAPHY}

\section{PRECAMBRIAN BASEMENT ROCKS}

Precambrian rocks are best exposed in the Pedemal Hills in Torrance County, but also crop out in the Gallinas Mountains west of Corona, N. Mex., and in the Oscura Mountains in the western part of the study area (Griswold, 1959). Only the exposure in the Oscura Mountains is shown on plate 1 (unit pCu). Exposed rocks are predominantly pink granite gneiss and minor schist, quartzite, greenstone, and granite (Griswold, 1959). Southwest of the study area near Whitetail, N. Mex., Precambrian rocks make up the core of the Pajarito Mountain dome (Kelley, 1971) (pl. 3). These rocks are hornblende syenite, hornblende syenite gneiss, and diabase, and are intruded by leucocratic syenite and hornblende syenite pegmatite; a well-developed paleosol occurs locally at the top of these Precambrian rocks (Kelley, 1971).

In the subsurface, similar Precambrian lithologies are encountered. West of Lon, N. Mex., Precambrian pink biotite granite was encountered in a drill hole at a depth of $1 ; 990 \mathrm{ft}$ (Standard Oil Company of Texas Morrow No. 1 Franks; sec. 23, T. 2 S., R. 15 E.); northwest of Carrizozo, N. Mex., near the Little Black Peak lava flow, Precambrian diorite was encountered at a depth of $8,739 \mathrm{ft}$ (Standard Oil Company of Texas Heard No. 1 well; sec. 33, T. 6 S., R. 9 E.) (Griswold, 1959, p. 6). Precambrian rocks form the unexposed core of the pre-Permian Matador uplift (Lloyd, 1949). In Tucumcari Basin, buried Precambrian igneous and metasedimentary basement rocks include granite, quartz diorite, monzonite, gabbro, and thyolite (Broadhead and King, 1988). Precambrian basement rocks make up the ancient Pedemal uplift that lies buried under younger strata in the western part of the study area (pls. 2 and 3). The uplift was exposed during late Paleozoic time, shedding sediments into adjacent basins (Gonzalez and Woodward, 1972).

\section{PRE-PERMIAN PALEOZOIC ROCKS}

Pre-Permian Paleozoic formations were eroded during Pennsylvanian and Permian uplift events. The disconformities that were formed are important traps for hydrocarbon accumulations.

\section{PRE-PERMIAN PALEOZOIC ROCKS OF LINCOLN COUNTY}

In Lincoln County, the pre-Permian sequences were erosionally truncated during and subsequent to the Pedemal uplift (Griswold, 1959). Pre-Permian Paleozoic rocks are exposed in the westem escarpment of the Sacramento Mountains south of the study area, possibly in one exposure in northern Lincoln County, and in the Oscura Mountains of western Lincoln County. Only the exposures in the Oscura Mountains are shown on plate 1 (units $\mathrm{M} \hat{u}$ and $P_{\mathfrak{u}}$ ). In the Sacramento Mountains escarpment south of the study area, Precambrian quartzite and metasedimentary rocks are unconformably overlain by the Upper Cambrian to Lower Ordovician Bliss Sandstone and younger carbonate, sandstone, and shale formations ranging in age from Early Ordovician to Late Pennsylvanian (pl. 2). In the northern Sacramento Mountains, however, only the Bliss(?) Sandstone (Darton, 1928), the Upper Devonian Percha(?) Shale (Darton, 1928), and Pennsylvanian rocks (described below) may be exposed (Griswold, 1959).

Exposed Pennsylvanian rocks in the southern Sacramento Mountains (in Otero County south of the study area) are thicker than the total underlying Paleozoic sequence; they record continuous deposition throughout most of the Pennsylvanian (pl, 2). Pennsylvanian rocks were mostly eroded during rise of the Pedernal uplift, which accounts for their meagre exposure in the study area (Griswold, 1959). Where exposed in the southwestern part of Lincoln County, Pennsylvanian rocks are predominantly limestone sequences that attain a thickness of 3,000 ft, but on the surface and in the subsurface in western Lincoln County, Pennsylvanian rocks are only as thick as $1,500 \mathrm{ft}$ (Grant and Foster, 1989) (unit $\mathrm{Pu}, \mathrm{pl} . \mathrm{1}$ ) and have been completely eroded from the Pedernal highland near the Gallinas Mountains. In southeastern New Mexico (see "Pre-Permian Paleozoic rocks of the Northwestern Shelf of the Permian Basin" section), subsurface formations of pre-Permian age have not been correlated to the rocks that crop out in the southern Sacramento Mountains escarpment, although they may be partly equivalent (Grant and Foster, 1989).

\section{PRE-PERMIAN PALEOZOIC ROCKS OF THE NORTHWESTERN SHELF OF THE PERMIAN BASIN}

Sequences of pre-Permian Paleozoic rocks are thickest in the subsurface in the southern part of the Northwestern Shelf of the Permian Basin in the southern part of Chaves and Roosevelt Counties; these sequences are successively bevelled from the rest of the Northwestern Shelf nearer to the Pedemal uplift and Central Basin Platform (pl. 2) (Grant and Foster, 1989).

Cambrian and Lower Ordovician rocks only occur beneath Chaves County, where they are as much as $250 \mathrm{ft}$ thick. Middle to Upper Ordovician rocks occur beneath eastern Chaves and southwestern Roosevelt Counties where the Upper Ordovician Montoya Dolomite is as thick as $300 \mathrm{ft}$ (Grant and Foster, 1989) (pl. 2). Silurian beds are $500 \mathrm{ft}$ thick beneath the southeastem tip of Chaves County (Grant and Foster, 1989). Devonian rocks are less than $100 \mathrm{ft}$ thick in the subsurface beneath southeastem Chaves County and southwestern Lincoln County (Grant and Foster, 1989). In some areas, Silurian and Devonian rocks (which may also 
change facies) are truncated up-dip and sealed by overlying Permian rocks. Mississippian rocks thin to the northwest and do not occur east of Roswell, north of Hagerman, in western and southwestern Roosevelt County, and in southeastern De Baca County. Beneath southeastem Chaves County, Mississippian rocks are as thick as $1,000 \mathrm{ft}$.

Pennsylvanian strata are absent from beneath southeastem Torrance County, southwestem Guadalupe County, southwestem De Baca County, and most of westem Chaves County, as well as eastern Lincoln County (Grant and Foster, 1989). In the subsurface in the southem part of the study area, Pennsylvanian units unconformably overlie eroded Precambrian basement rocks, the source of detritus for Lower Pennsylvanian clastic sequences (pl. 2). Oil wells penetrate as much as $2,750 \mathrm{ft}$ of Pennsylvanian strata in the Northwestern Shelf and as much as 3,000 ft of strata in the Delaware Basin near the Permian Capitan Reef (Grant and Foster, 1989).

\section{PRE-PERMIAN PALEOZOIC ROCKS OF TUCUMCARI BASIN}

In the subsurface of Tucumcari Basin, eroded remnants of the Lower and Upper Mississippian Arroyo Peñasco Group as much as $200 \mathrm{ft}$ thick unconformably overlie Precambrian basement rocks and are unconformably overlain by as much as $2,000 \mathrm{ft}$ of Pennsylvanian rocks (Broadhead and King, 1988; Grant and Foster, 1989) (pl. 2). Pennsylvanian rocks include the Middle to Upper Pennsylvanian Magdalena Group, equivalents of the Middle Pennsylvanian Atoka Formation and Strawn Group, and the Upper Pennsylvanian Canyon Group of the Delaware Basin (pl. 2); an uppermost sequence (Upper Pennsylvanian Cisco Group, which overlies the Canyon Group in the Delaware Basin) occurs in the adjacent Palo Duro Basin in Texas, but is removed from Tucumcari Basin (Broadhead and King, 1988).

In the northern part of Tucumcari Basin, rocks equivalent to the basal Strawn rocks are truncated by younger units; in the central and southern parts of the basin these rocks are conformably overlain by equivalent Canyon rocks. The source for equivalent Strawn sediment is the Precambrian Pedernal uplift, which was emergent during Pennsylvanian time. Facies of Strawn-equivalent rocks change from coarse-grained proximal marine limestone and sandstone in the northern part of the basin to marine limestone only locally containing sandstone in the south (pl. 2). In the northem part of the basin, the sandstone beds indicate a high-energy-, marginal-, or shallow-marine environment of deposition; the units intercalate with fossiliferous and silicic marine mudstone units. In the southern part of the basin, marine limestone facies rocks are interbedded limestone and mudstone and contain minor, generally nonporous sandstone; the limestone is locally fossiliferous, bioclastic wackestone and packstone having poor porosity.
Locally, however, the marine limestone facies in the southem part of the basin contain oolites and areas that have undergone solution of limestone during probable subaerial exposure, creating improved porosity.

Canyon Group-equivalent rocks thin to the north onto uplifts, and may have been locally faulted and repeated by tight folding, possibly during deposition, resulting in increased apparent thickness. The facies distribution of these rocks is similar to the distribution of Strawn Group-equivalent rocks-proximal, coarser, fluvial sandstone facies and marine limestone in the north grade southward into marine limestone facies (pl. 2). The sandstone has poor primary and secondary porosity. The marine limestone is nonporous and impermeable because it is interbedded with mudstone.

The upper $80 \mathrm{ft}$ of strata equivalent to the Canyon Group thin eastward and southward, probably due to erosional truncation and syndepositional faulting near the San Jon high and the Northwestern Shelf of the Permian Basin. Sedimentary rocks equivalent to Canyon Group rocks grade from coarse sandstone, limestone, and dolomite in the north to limestone in the south. The northern sandstone beds are porous, and the dolomite beds have minor porosity formed by dissolution and microfracturing. Throughout Tucumcari Basin, limestone beds are interbedded with nonporous marine mudstone and carbonate beds.

\section{LOWER PERMIAN ROCKS}

The Lower Permian sequences within the study area include, from bottom to top, the Bursum(?) Formation (in Lincoln County), Hueco Formation, Abo Formation, and Yeso Formation (unit Pu, pl. 1), and the San Andres Formation and Glorieta Sandstone (unit Psg, pl. 1). These rocks are important reservoirs and potential hosts for hydrocarbons, potash, and sulfur in the study area.

\section{BURSUM(?) FORMATION}

Exposures of the Bursum(?) Formation within the study area are limited to the southwestern part of Lincoln County. Rocks there are similar to surface exposures of the Bursum Formation from the northern Sacramento Mountains described by Pray (1961) as drab calcareous shale, thin argillaceous limestone, guartz sandstone, limestone conglomerate, minor red beds, and thin fusulinid-bearing limestone layers. In the subsurface west of Lon (No. 1 Heard well), about $230 \mathrm{ft}$ of Bursum(?) is composed of marine limestone interbedded with dark-red mudstone and arkosic conglomerate (Griswold, 1959). Some workers consider the Bursum(?) to be a northern marine facies of the Hueco Formation, which occurs in the subsurface of the Tucumcari Basin (Broadhead, 1984b) (pl. 2). The Bursum(?) is overlain by the Abo Formation; the contact is typically conformable (Kottlowski, 1963; Kottlowski and Stewart, 1970; Broadhead, 1984a). 


\section{HUECO FORMATION}

The Hueco Formation, which occurs in the subsurface in the central and eastern parts of the study area, is probably time equivalent to the lower part of the Abo Formation (pl. 2). The lower part of the Abo overlies the flanks of the Pedernal uplift, but the Hueco conformably underlies the middle mudstone-rich unit of the middle part of the Abo east of the flanks of the uplift (Broadhead, 1984a, b). The Hueco is flat lying and is generally composed of interbedded limestone and mudstone, and minor sandstone and conglomerate near the base (Broadhead, 1984a, b). In the subsurface, the Hueco has been subdivided into upper and lower parts (Broadhead and King, 1988).

The lower part of the Hueco Formation is $0-1,847 \mathrm{ft}$ thick, attaining maximum thickness in the northern part of the Tucumcari Basin (Broadhead, 1989). The lower part of the Hueco is nonmarine and contains coarser clastics in the northem part of the basin and marginal marine rocks (fewer coarse clastics) in the southem part. A mixed marine facies of limestone, porous dolomite, and mudstone occurs on the San Jon high and in the Palo Duro Basin in New Mexico. To the north and west of the Tucumcari Basin on the Pedemal uplift, the Hueco unconformably overlies Atokan Series and Precambrian rocks and the Pennsylvanian Canyon Group; in the central and southern parts of the basin, it unconformably overlies the Canyon rocks. The lower part of the Hueco is unconformably overlain by both the upper part of the Hueco and the Abo Formation in the westernmost occurrences; elsewhere it typically conformably underlies the upper part of the Hueco. Broadhead and King (1988) considered strata of the lower part of the Hueco to be potential source rocks for oil and gas in Triassic rocks.

The upper part of the Hueco Formation is $310-520 \mathrm{ft}$ thick and includes a coarse sand in the northem part of Tucumcari Basin, muddy sediments in the northwestern part of the basin, limestone containing minor coarse-grained sandstone in the central and western parts of the basin and on the San Jon high, and limestone in the southem part of the basin. The coarse sandstone units are porous, but locally the interstices are filled with red mud, lowering reservoir potential. The limestone units that are composed of interbedded limestone, mudstone, and minor fine-grained sandstone are "tight" (nonporous); however, the fine-grained sandstone has poor oil-reservoir characteristics and limited "tight"-gas potential (reservoirs are fracture dependent). Limestone of the upper part of the Hueco in the Northwestern Shelf of the Permian Basin and in the Delaware Basin contains abundant chert, minor red and gray shale, and some dolomite, and is a reservoir for oil and gas in stratigraphic and structural traps (Grant and Foster, 1989).

\section{ABO FORMATION}

The Abo Formation crops out in the Oscura Mountains and the southern Sacramento Mountains (Otero County) outside of the study area (Lloyd, 1949; Pray, 1961); small exposures of the Abo are found on the Pecos Slope in Lincoln (including the Gallinas Mountains), Chaves, and De Baca Counties but are not shown on plate 1 (Griswold, 1959; Kelley, 1972a, b). In much of the study area, the Abo occurs in the subsurface (Broadhead, 1984b). In Lincoln County, the Abo increases in limestone content eastward (Kelley, 1972a); in the subsurface east of the Pedernal uplift, clastics from the Abo are correlated with interbedded limestone and clastic units of the Hueco Formation (Broadhead, 1984b).

The Abo Formation is composed mainly of reddishbrown mudstone and very fine grained to very coarse grained arkosic sandstone and conglomerate that contain crossbeds, ripple marks, fossils, desiccation cracks, and halite crystal casts. Arkosic sandstone, more common in the lower part of the formation, contains pink orthoclase and microcline clasts (Pray, 1961). Sandstone beds are well sorted, and porosity is variable and dependent on the nature of the interstices (some sandstone beds have clay matrices or calcite or dolomite cements and others are porous). Strata of the Abo are generally darker red than those of the overlying Yeso Formation, but are difficult to discern from those of the underlying Bursum(?) Formation.

The Abo Formation is variable in thickness. Outside of the western boundary of the study area in Torrance County, well information indicates about $1,000 \mathrm{ft}$ of $\mathrm{Abo}$ in a northtrending band; in Lincoln and De Baca Counties, the Abo is 250-500 ft thick (Kelley, 1972a, b). The Abo is as thick as $2,372 \mathrm{ft}$ in the northem part of Tucumcari Basin (Broadhead and King, 1988).

The contact between the Abo Formation and the overlying Yeso Formation is gently folded and abruptly gradational where it is exposed in the southern Sacramento Mountains (Pray, 1961), but sharp and disconformable in the subsurface in the eastern part of the study area (Broadhead, 1984a; Broadhead and King, 1988). The Abo locally unconformably overlies the Bursum(?) Formation (Kottlowski, 1963; Bachman, 1968; Kottlowski and Stewart, 1970) (pl. 2). In the Gallinas Mountains, the Abo overlies Precambrian basement rocks (Lloyd, 1949). The Abo was probably deposited in a nonmarine environment in the northem part of the study area, but farther south the Abo is probably partly marine where it intertongues with the marine Hueco Formation (Broadhead, 1984a, b).

\section{YESO FORMATION}

The evaporite-bearing Yeso Formation crops out outside of the study area along the escarpment and crest of the southern Sacramento Mountains, west of the Pedernal Hills, and north of the Gallinas Mountains, and within the study area in the Oscura Mountains, the Jicarilla Mountains, and along the dip slopes of the Pecos Slope predominantly between long $105^{\circ} \mathrm{W}$. and $107^{\circ} \mathrm{W}$. (Budding, 1964; Kelley, 1972c). It occurs in the subsurface of most of the eastern part 
of the study area. There, the basal sandstone of the Yeso both overlies and lies to the west of Precambrian rocks of the Pedernal uplift, which affected the spatial distribution and thickness of the Yeso. According to Wasiolek (1991), the Yeso is the principal aquifer of the westem Pecos Slope.

The Yeso Formation is commonly contorted or collapsed; it consists of shale, siltstone, sandstone, limestone, dolomite, gypsum, interbedded anhydrite, and minor halite (Pray, 1961; Broadhead, 1984a). The Yeso generally contains more gypsum and clastics in the north and more carbonates in the south (Lloyd, 1949). The formation grades eastward into bedded limestone, dolomite, anhydrite, sandstone, and mudstone (Broadhead, 1984a).

The Yeso Formation is extremely variable in thickness, due, in part, to dissolution of evaporite beds and to discordant folding, and to thinning over the Precambrian basement uplift and thickening on the flanks (Kottlowski and others, 1956; Pray, 1961; Kelley, 1971). Near Ruidoso in Rio Ruidoso, nearly $1,000 \mathrm{ft}$ of Yeso crop out, but the base of the formation is concealed (Kelley, 1971). In the subsurface near Ruidoso, the lower part of the formation contains numerous beds of anhydrite and gypsum, the middle part is composed of fine clastic sedimentary rock, and the upper part is mostly sandstone (Wasiolek, 1991). In the eastern part of the Mescalero Apache Indian Reservation (upper Rio Hondo drainage), the Yeso ranges from a few feet to 1,700 ft thick. In the Gallinas Mountains, as much as 1,000 ft of Yeso crops out. In the subsurface, the Morrow No. 1 Franks well encountered as much as $1,380 \mathrm{ft}$ of Yeso strata. South of Riverside and west of Roswell, as much as $1,830 \mathrm{ft}$ of Yeso occurs in the Stanolind No. 1 Picacho well (sec. 10, T. 12 S., R. 18 E.). It is 2,000 ft thick in south-central Roosevelt County, southeast Chaves County, and west of Hagerman (Grant and Foster, 1989). In Tucumcari Basin, the Yeso is $400-2,000 \mathrm{ft}$ thick (thickest in Curry County) (Foster and others, 1972; Broadhead, 1989). In the southern part of the study area, the Yeso apparently grades upward into the Rio Bonito Member of the San Andres Formation and the Glorieta Sandstone (Pray, 1961; Kelley, 1971; Milner, 1978) (pl. 2). Sharp contacts are locally present. Springs are common markers of the San Andres-Yeso contact (Pray, 1961).

\section{GLORIETA SANDSTONE AND SAN ANDRES FORMATION}

The Glorieta Sandstone and the Rio Bonito Member of the San Andres Formation are intertonguing units; in the northem part of the study area, the Glorieta is thickest and is interbedded with the Rio Bonito Member, but it thins to the south and is included as part of the San Andres (Kelley, 1971). The undifferentiated Glorieta Sandstone and San Andres Formation (unit Psg, pl. 1) is approximately $700 \mathrm{ft}$ thick near Capitan, according to Allen (1951); to the south and east, the San Andres thickens whereas the Glorieta thins (Allen, 1951; Griswold, 1959). Unit Psg is as much as 1,200 $\mathrm{ft}$ thick in the subsurface in Tucumcari Basin and east of the
Pecos River north of the Delaware Basin (Foster and others, 1972; Bachman, 1987; Broadhead, 1989).

The distinctive Glorieta Sandstone is composed of rounded to subrounded, frosted, fine- to medium-grained, well-sorted orthoquartzite (Pray, 1961; Kelley, 1972c). Locally the sandstone is hematitic and contains iron concretions, ironstone, or brown chert (Kelley, 1972c). The Glorieta is permeable, locally oil stained, and potentially a good oil and gas reservoir (Broadhead and King, 1988), but it has not produced oil or gas in New Mexico (Milner, 1978). It is an aquifer in Chaves County (Borton, 1972).

The Glorieta is thickest in the north-central part of New Mexico (Milner, 1978; Pitt and Scott, 1981). In northem Lincoln County, resistant exposures of the Glorieta are as much as $245 \mathrm{ft}$ thick (Milner, 1978); they are $120 \mathrm{ft}$ thick northeast of Luna (Budding, 1964) and $225 \mathrm{ft}$ thick near Corona (Kelley, 1971). In the Gallinas Mountains, where it is the youngest exposed rock unit, the Glorieta is as much as $250 \mathrm{ft}$ thick (Kelley, 1949; Perhac, 1964). The Glorieta is poorly exposed in the southeastem part of the Jicarilla Mountains and in the eastern and northern parts of the Capitan Mountains (Griswold, 1959; Kelley, 1971). There, individual sandstone beds are as much as $60 \mathrm{ft}$ thick, typically about 2-3 ft thick, parallel bedded to crossbedded, and lenticular (Pray, 1961; Kelley, 1972c). The Glorieta becomes thinner and finer grained to the south where it intertongues with beds of the Rio Bonito Member (Kelley, 1971). Near Rio Hondo south of the Capitan Mountains, sandstone beds thought to be Glorieta are as much as $150 \mathrm{ft}$ above the base of the San Andres Formation where, typically, $40-70 \mathrm{ft}$ of dolomite of the San Andres is present below the first sandstone bed of the Glorieta (Kelley, 1971). In the subsurface in the study area in northwestem Tucumcari Basin, the Glorieta ranges in thickness from 0 to as much as $300 \mathrm{ft}$ (Broadhead, 1989). It is apparently thickest in the Morrow No. 1 Franks well, where it is as thick as $340 \mathrm{ft}$.

In Tucumcari Basin, the San Andres Formation is of variable thickness (as much as $1,200 \mathrm{ft}$ near Clovis; Foster and others, 1972) and consists primarily of anhydrite, dolomite, limestone, and salt (Broadhead and King, 1988). Resistant beds (predominantly dolomite) of the San Andres form much of the crest of the Sacramento and Jicarilla Mountains, and most of the eastern slope and present erosion surface on the Pecos Slope (Pray, 1961). According to Bachman (1987), as much as $600 \mathrm{ft}$ of evaporite beds have been dissolved in the subsurface from the upper part of the San Andres along the Pecos River near Roswell; dissolved beds are recognized as solution breccia (Welder, 1983). Marine fossils are present as well as oolite, indicating near-subaerial shelf affinities and a back-reef environment. The San Andres is the principal petroleum producer in the region, but both the San Andres and the Glorieta are primary targets for oil and gas wells on the Northwestem Shelf of the Permian Basin; both units are also potential source rocks for later Triassic accumulations (Grant and Foster, 1989). The San 
Andres Formation is subdivided from base to top into the Rio Bonito, Bonney Canyon, and Fourmile Draw Members (Kelley, 1971) (pl. 2).

\section{RIO BONITO MEMBER}

The Rio Bonito Member, the thicker-bedded bottom part of the San Andres Formation, is composed predominantly of lenticular beds of carbonate rock in the study area (Kelley, 1971, 1972c; Milner, 1978). The Rio Bonito typically consists of beds that are $2-6 \mathrm{ft}$ thick, locally as much as $30 \mathrm{ft}$ thick. The Rio Bonito is locally crossbedded, oolitic, and fossiliferous, with rare occurrences of bioherms and algal stromatolites (Milner, 1978). The carbonate is mostly dolomite and limestone with rare chert lenses, and is typically banded in shades of dark and light gray with brown tinting (Kelley, 1971). Wackestone and mudstone are common (Milner, 1978). The Rio Bonito, which is approximately $300 \mathrm{ft}$ thick (including sandstone tongues of the Glorieta Sandstone) near Picacho, grades upward into the Bonney Canyon Member of the San Andres Formation (Kelley, 1971).

\section{BONNEY CANYON MEMBER}

The Bonney Canyon Member, the middle part of the San Andres Formation, is best exposed on the Pecos Slope west of Roswell and Artesia (Kelley, 1971), but it crops out from northeast of the Capitan Mountains to as far south as the Capitan Reef (Guadalupe Mountains) (Kelley, 1971). It is thin- to medium-bedded, locally laminated, porous, very fine grained to fine-grained, indurated, dark-grayish-brown to medium- and light-gray dolomite and limestone, containing marine fossils and numerous pale-yellow silty and sandy carbonate beds. In places, chert-bearing and oolitic beds are present. The beds typically are disturbed in the upper $50 \mathrm{ft}$, probably due to the localized removal of gypsum and anhydrite beds (Kelley, 1971).

The Bonney Canyon Member ranges from 60 to $300 \mathrm{ft}$ thick, thinning northward (Kelley, 1971). The LlevelandSlaughter zone of porosity, widely recognized in the subsurface near Roswell and the zone of oil-producing dolomite in West Texas, is equivalent to the Bonney Canyon, although in places it may also include the lower part of the overlying Fourmile Draw Member (Kelley, 1971). The Bonney Canyon grades upward into the Fourmile Draw Member (Kelley, 1971).

\section{FOURMILE DRAW MEMBER}

The Fourmile Draw Member is the upper part of the San Andres Formation and is characterized by evaporite, karst, and surficial caliche. It is well exposed west and northwest of Roswell, with good exposures extending north and west of the Capitan Mountains to Tecolote and Ancho. Measured surface thickness of the Fourmile Draw ranges from 342 to $387 \mathrm{ft}$ (Kelley, 1971). In the subsurface in De Baca County about $6 \mathrm{mi}$ southwest of Fort Sumner, N. Mex., drill holes have encountered as much as $625 \mathrm{ft}$ of the Fourmile Draw Member (Mourant and Shomaker, 1970; Kelley, 1972c). It is composed of thin beds of predominantly dolomite, gypsum, and red mudstone. Thin-bedded sandstone, locally cherty, occurs at the top of the unit, as well as red, pink, or yellow mudstone and red siltstone. White sandstone as much as 30 $\mathrm{ft}$ thick is present west of Roswell, and white sandstone has been described as an upper ledge-forming unit of the San Andres near Ancho, N. Mex. (northwest of the Jicarilla Mountains) (Kelley, 1971).

Gypsum is abundant in the Fourmile Draw Member within the study area, and intervals $50-100 \mathrm{ft}$ thick are not uncommon (Kelley, 1971). To the north and west in the study area, the member becomes more evaporitic, and near Ancho, an exceptional thickness of about $800 \mathrm{ft}$ of gypsum and minor dolomite and sandstone has been reported from the San Andres Formation (Kelley, 1971). In much of the area, sinkholes produced by dissolution of gypsum and other evaporite beds are common features.

\section{UPPER PERMLAN ROCKS}

\section{ARTESIA GROUP}

The Artesia Group crops out on the Delaware Basin (fore-reef area) of the Permian Basin, the massive Capitan Reef area, and the Northwestern Shelf (back-reef area) of the Permian Basin, extending as far west as the Lincoln County porphyry belt; it occurs in the subsurface in Tucumcari Basin. Each of these areas has different stratigraphic nomenclature for rocks of this stratigraphic position, reflecting the different lithofacies of time-synchronous parts of the deposit (pl. 2). On the correlation chart (pl. 2), the back-reef area is designated by columns headed "Northwestern Shelf of Permian Basin," "Tucumcari Basin," and "Lincoln County." The Capitan Reef is shown by the column headed "Carlsbad," and the Delaware Basin fore-reef area is designated "Delaware Basin."

The Artesia Group changes character northward from the Capitan Reef complex, from structureless and massive close to the Capitan Reef to bedded in the backreef area (Kelley, 1971). Equivalents of the Artesia in the study area include back-reef units from the top of the San Andres Formation. The Artesia is divided into, in ascending order, the Grayburg, Queen, Seven Rivers, Yates, and Tansill Formations (pl. 2), although these units are not everywhere distinguishable and may be mapped as undifferentiated in published reports (for example, unit $\mathrm{Pa}$ of $\mathrm{pl}$. 1; Kelley, 1971).

The thickness of the Artesia Group is extremely variable due to dissolution of evaporite beds. In Tucumcari Basin, the Artesia in the subsurface is $134-918 \mathrm{ft}$ thick 


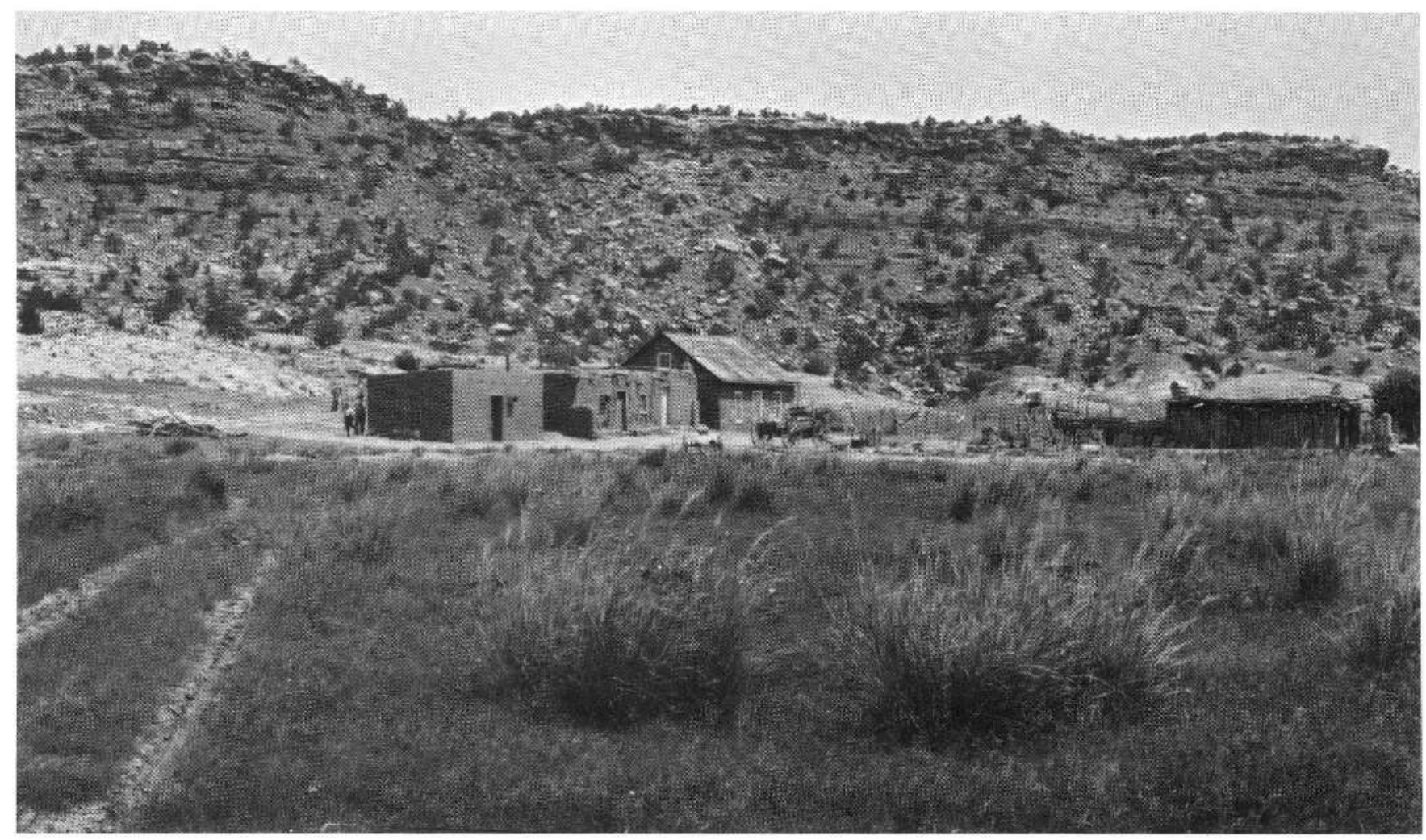

Figure 6. Nonresistant gypsiferous marine evaporite beds of the Artesia Group exposed in the boltom of Pintada Canyon west of Santa Rosa, N. Mex., where they arc overlain by the cliff-forming Upper Triassic Santa Rosa Sandstone. Note the house built of adobe. Photograph taken by N.H. Darton about 1913-1915 (photograph number 1653, on file at the U.S. Geological Survey Photo Library, Denver, Colo.).

(Broadhead, 1984a) and is thickest in Quay, Curry, and northeastem De Baca Counties (Broadhead, 1989). The Artesia thins to the north and west onto the Pedernal and Sierra Grande uplifts and the Bravo dome, partly due to erosional truncation (Broadhead and King, 1988; Broadhead, 1989). Karst features typify the Artesia where it is exposed in the southern part of the study area. Evaporite beds of the Artesia are primarily gypsum on the surface; anhydrite and salt are the predominant evaporite deposits in the subsurface (Bachman, 1987) (fig. 6).

\section{GRAYBURG FORMATION}

The Grayburg Formation is typically tan to brown, medium- to fine-grained sandstone and contains thin-bedded mudstone and minor cherty gray dolomite near the top; it is as thick as $500 \mathrm{ft}$. Bedding thickness, carbonate content, and sandstone content in the lower part of the formation increase southward with proximity to the Capitan Reef (Kelley, 1971). Gypsum is common, and beds as thick as several tens of feet occur near Hope, N. Mex., about $20 \mathrm{mi}$ west of Artesia. Near Arroyo del Macho in the central part of the study area about $30 \mathrm{mi}$ north of Roswell, the Grayburg and Queen Formations are undifferentiated because they are both composed predominantly of red mudstone and muddy gypsum; thin dolomite beds are present in the lower part of the sequence (Kelley, 1971, 1972a b). The Grayburg is the most important oil and gas reservoir rock in the Artesia Group.

In some of the western exposures (Capitan Mountains to Ruidoso), the Grayburg Formation unconformably overlies the Bonney Canyon Member of the San Andres Formation (Kelley, 1971), but north of the Capitan Mountains the contact is nearly conformable with the Fourmile Draw Member of the San Andres Formation (Kelley, 1971). In most places, the lower contact of the Grayburg is irregular, in part due to solution of the evaporitic sequences and karst development within the Fourmile Draw Member; locally the Fourmile Draw Member is missing or is represented by collapse breccia (Kelley, 1971).

\section{QUEEN FORMATION}

The Queen Formation is a widely recognized unit in the subsurface. Surface exposures are more difficult to recognize due to dissolution of some units, and the formation is commonly undifferentiated from the Grayburg Formation north of Roswell (Kelley, 1971). The Queen, which contains beds of anhydrite, dolomite, and salt, is lithologically similar to the Grayburg near Capitan Reef, where it contains more 


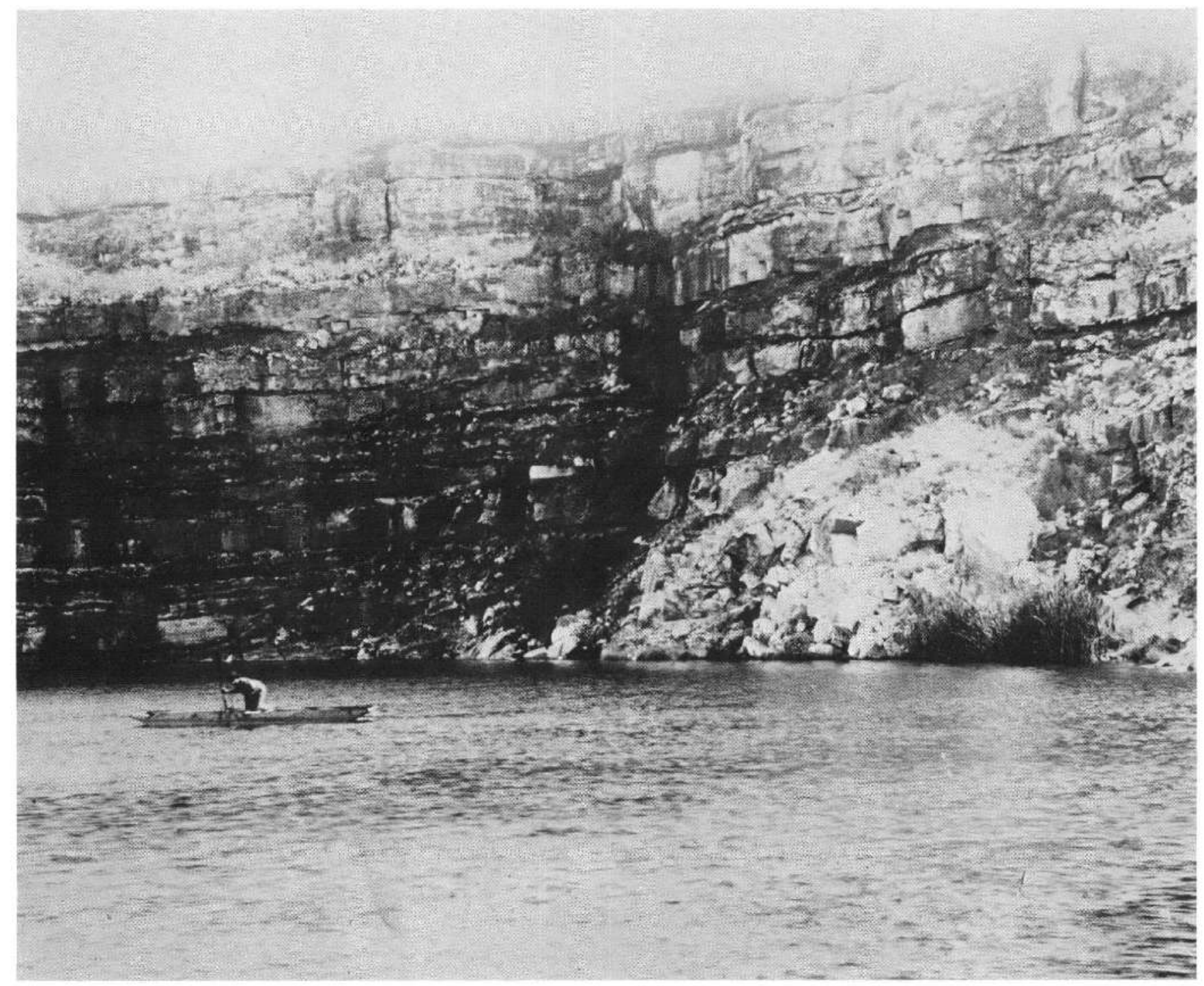

Figure 7. Exposure of layered dolomite and limestonc beds of the Seven Rivers Formation of the Artesia Group in the walls of a sinkhole, Bottomless Lakes State Park, N. Mex. Photograph taken by C.A. Fisher between 1904 and 1907, during an early-day hydrologic survey (photograph number 32, on file at the U.S. Gcological Survey Photo Library, Denver, Colo.).

clastic material. Progressively northward away from the reef in the back-reef area, the Queen contains thin-bedded red sandstone and mudstone and minor dolomite; near Roswell, gypsum and minor thin magenta and gray dolomite predominate in the upper part of the Queen (Kelley, 1971). Total thickness of the unit is unknown (Kelley, 1971), but it is as much as $300 \mathrm{ft}$ thick in the subsurface in southem De Baca and Roosevelt Counties.

The Queen Formation is the aquitard between the shallow and the artesian aquifers in the Roswell artesian basin (Havenor, 1968). The Grayburg and Queen strata are generally too fine grained to be good reservoirs of oil and gas in the study area, except east of Roswell and east of Hagemnan (Broadhead, 1989; Grant and Foster, 1989).

\section{SEVEN RIVERS FORMATION}

The Seven Rivers Formation is recognized both on the surface (in the southern part of the study area) and in the subsurface as a distinct formation in the carbonate part of the shelf (back-reef) margin. Upper and lower contacts of the Seven Rivers are well defined due to the prevalence of intrastratal gypsum (Kelley, 1971, 1972c). Exposures of the Seven Rivers are prominent east of Roswell in the Bottomless Lakes area (fig. 7). The unit is mostly anhydrite and thin-bedded (a few inches thick) dolomite in the north, but is more massively bedded (as thick as $10 \mathrm{ft}$ ) and limestone and dolomite rich in the south near the reef (Kelley, 1971; Grant and Foster, 1989). Total thickness of the unit is unknown due to dissolution, but is as much as $460 \mathrm{ft}$ thick about $2 \mathrm{mi}$ north 
of the Capitan Reef near Carlsbad (about $30 \mathrm{mi}$ south of the study area) (Kelley, 1971) and about $360 \mathrm{ft}$ thick in De Baca and Roosevelt Counties (Grant and Foster, 1989).

"Pecos diamonds," in the upper part of the Seven Rivers Formation and the lower part of the Yates Formation (Kelley, 1971), may be used as stratigraphic indicators (fig. 26). They occur in 100 - to 200 -ft-thick beds in a belt that extends from about $5 \mathrm{mi}$ south of Artesia to $65 \mathrm{mi}$ north of Roswell (south of Yeso), and locally in Guadalupe County (Albright and Kruckow, 1958).

\section{YATES FORMATION}

The Yates Formation crops out in the south-central part of the study area. From Lake McMillan (about $12 \mathrm{mi}$ south of Artesia) to Roswell, it is predominantly gypsum and only minor 1- to 2-ft-thick beds of dolomite (Kelley, 1971). In the southern part of the study area, extending to about $10 \mathrm{mi}$ north of Roswell, greenish-gray to olive-drab siltstone and fine-grained thin sandstone characterize the lower part of the Yates, and gypsum and red mudstone characterize the upper part; limonite ironstone concretions are abundant. In the north near Fort Sumner, the Yates and Tansill Formations are undifferentiated (Kelley, 1972a).

Near Lake McMillan, the unit is as much as $405 \mathrm{ft}$ thick, as measured in outcrop near the shelf margin adjacent to the Capitan Reef. Southwest of Portales near Elida, the formation in the subsurface is about $130 \mathrm{ft}$ thick (Kelley, 1971). Thickness variations in the Yates Formation, as measured in surface and subsurface exposures, indicate possible syndepositional tectonic activity along the Artesia-Vacuum arch just south of the study area (Kelley, 1971), but dissolution is a large factor in thickness variability.

\section{TANSILL FORMATION}

A thin (less than 100-ft-thick) north-south-trending belt of evaporitic rocks of the Tansill Formation crops out in the southern part of the study area east of Hagerman (Kelley, 1971). North of Hagerman, the Tansill is covered by pediment gravel (Pleistocene Gatuna Fornation) and troncated by Triassic rocks. South of the study area, the Tansill Formation is the uppermost shelf unit adjacent to the Capitan Reef and consists primarily of dolomite; there it is unconformably overlain by the Upper Permian Salado Formation (Deford and Riggs, 1941; Garber and others, 1989) (pl. 2). In the subsurface, some salt and minor anhydrite are found in the Tansill south of the study area.

\section{CASTILE, SALADO, AND RUSTLER FORMATIONS AND DEWEY LAKE REDBEDS}

The remainder of the Upper Permian rocks in the Permian Basin are composed of, from bottom to top, the Castile, Salado, and Rustler Formations and the Dewey Lake Redbeds. The Castile does not occur north of the Capitan Reef on the Northwestem Shelf of the Permian Basin and, thus, does not occur in the study area and is not described in this report. The Salado, Rustler, and Dewey Lake occur in the back-reef area in southeastern New Mexico and pinch out just north of the study area boundary (unit Pds, pl. 1). The Salado and Rustler are important sources of potassium salts as well as halite, polyhalite, and anhydrite; the Castile and Salado host world-class sulfur deposits south of the Capitan Reef in Culberson County. Texas.

\section{SALADO FORMATION}

The Salado Formation of post-Capitan age is found shoreward as well as basinward of the Capitan Reef, and disconformably overlies the Tansill Formation from Carlsbad to Hagerman (Keiley, 1971) (pl. 2). North of Hagerman, the Salado is covered by Cenozoic deposits. The Salado is the oldest formation to have transgressed northward across the reef into the back-reef area of the Northwestern Shelf of the Permian Basin, and represents deposition by a shallowing Permian sea.

In southeastem New Mexico, broad areas have subsided by solution collapse of the Salado Formation. In the study area, the formation ranges from 0 to $300 \mathrm{ft}$ thick, pinching out northward onto higher parts of the shelf. In the subsurface in Eddy County south of the study area, the Salado ranges from 1,200 to 2,300 ft thick, with extreme thickness variation due to salt dissolution (Kelley, 1971; Cheeseman, 1978; Bachman, 1984). The Salado is composed mostly of beds of halite and commercial amounts of potash, with thin beds of anhydrite and sulfur (Jones, 1954, 1978; Bachman, 1987; Smith, 1980).

\section{RUSTLER FORMATION}

The Rustler Formation, like the underlying Salado Formation, occurs shoreward of the Capitan Reef, and was deposited by a shallow Permian sea. Vine (1963) and Bachman (1987) described five members in the Rustler east of the Pecos River: a basal 120-ft-thick siltstone, gypsum, anhydrite, and sandstone unit (unnamed); a 30-ft-thick vuggy dolomite (Culebra Dolomite Member); a 180-ft-thick gypsum and minor halite and anhydrite unit (Tamarisk Member); a 30-ft-thick dolomite and anhydrite unit (Magenta Dolomite Member); and an upper 25-ft-thick gypsum, anhydrite, siltstone, and halite unit (Forty-niner Member). Carbonate content increases, and evaporite content decreases, southward (Grant and Foster, 1989). Only the basal part of the Rustler is exposed east of Artesia along the southem border of the study area; here, the Rustler rests unconformably on the Tansill Formation (Kelley, 1971). The Rustler commonly shows evidence of dissolution and collapse into the underlying Salado Formation (Kelley, 1971), and according to Bachman (1984), complete sections are present only in some areas of the subsurface. The Rustler conformably underlies the Dewey Lake Redbeds (Bachman, 1987) (pl. 2). 
South of the study area, the Rustler Formation is as much as $550 \mathrm{ft}$ thick in southwestern Lea County (Bachman, 1984), and as much as $500 \mathrm{ft}$ thick near the Pecos River in Eddy County (Grant and Foster, 1989). It thins to the north, and is only about $100 \mathrm{ft}$ thick on the Northwestem Shelf of the Permian Basin (Grant and Foster, 1989). It may only be tens of feet thick over limited parts of the study area.

\section{DEWEY LAKE REDBEDS}

The Dewey Lake Redbeds were deposited at the end of Permian time and represent retreat of the Permian sea and deposition in a shallow saline lake. The Dewey Lake is composed of thin red siltstone and fine-grained, rippled, and small-scale-crossbedded sandstone. The unit is cemented by anhydrite, selenite, clay, and carbonate, and is typically mottled to greenish gray. The Dewey Lake thins westward and is unconformably overlain by Triassic strata (pl. 2).

In the subsurface in Eddy and Lea Counties south of the study area, the Dewey Lake is as much as $560 \mathrm{ft}$ thick (Bachman, 1984). In the study area, however, only thin, discontinuous red beds that are possible Dewey Lake strata are exposed along the southern border of the study area.

\section{UPPER TRIASSIC ROCKS}

Upper Triassic continental rocks crop out over parts of Lincoln County, the eastern half of De Baca and Chaves Counties, and most of Guadalupe, Quay, Curry, and Roosevelt Counties (Grant and Foster, 1989, fig. 13). In the southeastern part of the study area, Triassic rocks are as much as 2,000 ft thick; in the Tucumcari Basin, they are $1,500 \mathrm{ft}$ thick. Typically, Triassic rocks unconformably overlie Upper Permian strata and were deposited as a result of Late Permian movement of the Pedernal uplift.

In the study area, the Upper Triassic units are the Dockum Group (also Middle Triasic, locally) (Finch, 1988) and the overlying Redonda Formation, which is included with the Chinle Formation on plate 1 . The Dockum comprises the Santa Rosa Sandstone (unit Ks, pl. 1) and the Chinle Formation (unit Kc, pl. 1) (Grant and Foster, 1989); in places on plate 1, the Santa Rosa and Chinle are mapped together as unit Kcs. In the Jicarilla Mountains, the Dockum combined with the Redonda is about $560 \mathrm{ft}$ thick (Budding, 1964); near Capitan, it is $480 \mathrm{ft}$ thick (Griswold, 1959). The Dockum combined with the Redonda, in the vicinity of the Pecos River near Roswell, is reportedly brecciated and occurs in isolated collapse structures or sinks, indicating solution of underlying Permian rocks (Bachman, 1987).

\section{SANTA ROSA SANDSTONE OF THE DOCKUM GROUP}

The continental sandstone beds of the Santa Rosa Sandstone are typically thick, grayish and reddish brown, generally parallel bedded, lenticular, and channel crossbedded; the unit is conglomeratic, especially near its base. Thin beds of red, brown, and variegated mudstone are intercalated with the sandstone. Vertebrate remains have been reported from the upper shaly part of the formation (Lucas and others, 1985a).

The Santa Rosa Sandstone occurs at depths of less than 2,000 ft over most of northeast New Mexico (Broadhead, 1984a). The Santa Rosa is best exposed along the Pecos River and its western tributaries, especially in the northcentral part of the study area near Santa Rosa (fig. 6). Near Capitan, the Santa Rosa is $300 \mathrm{ft}$ thick (Griswold, 1959). In the subsurface and on the surface in Tucumcari Basin, the Santa Rosa is $67-350 \mathrm{ft}$ thick and is subdivided into a lower sandstone, middle mudstone, and upper sandstone. Near the town of Santa Rosa, the Santa Rosa is $225 \mathrm{ft}$ thick and is composed of a lower sandstone member, a middle sandstone member, a mudstone member, and an upper sandstone member (Finch, 1988). As shown in isopach maps of the area, the thickest sequences occur in paleovalleys that were eroded into the underlying Artesia Group during Triassic time (Broadhead, 1989). The Santa Rosa intertongues with the younger Chinle Formation and unconformably overlies the Artesia Group (pl. 2).

\section{CHINLE FORMATION OF THE DOCKUM GROUP}

Continental rocks of the Chinle Formation crop out mostly east of the Pecos River in the northern part of the study area and occur in the subsurface in the eastern part of the study area where they are generally covered by younger strata (Kelley, $1972 \mathrm{a}, \mathrm{b}$ ). Thin outliers of the Chinle occur west of the Pecos River as far as Lincoln County. The Chinle is typically reddish-brown mudstone interbedded with clayrich sandstone. The upper part of the Chinle is variegated in shades of reddish purple and grayish green. The Cuervo Sandstone Member is a clastic middle member of the Chinle in Tucumcari Basin that bas a distinctive signature on geophysical logs.

The Chinle Formation and Santa Rosa Sandstone are intertonguing units of variable thicknesses; the Chinle increases in thickness northward in the study area (Kelley, 1971). The Chinle is $180 \mathrm{ft}$ thick near Capitan (Griswold, 1959 ), and as thick as $1,230 \mathrm{ft}$ in Quay County (Berkstresser and Mourant, 1966). It is over $1,300 \mathrm{ft}$ thick in the subsurface in Tucumcari Basin (Broadhead and King, 1988), where the Cuervo Sandstone Member is as much as $1,516 \mathrm{ft}$ thick (Broadhead, 1989). An incomplete exposed section in the Santa Rosa area is $20 \mathrm{ft}$ thick (Finch, 1988).

The Chinle may unconformably overlie older rock units in the study area, including the Permian sequences (Kelley, 1971, 1972a, b). The Chinle grades upward into the Redonda Formation in Tucumcari Basin, but is unconformably overlain by the Upper Cretaceous Dakota(?) Sandstone in Lincoln County (Kelley, 1971; 1972a, b) (pl. 2). 


\section{REDONDA FORMATION}

The Redonda Formation occurs in the northern part of the study area near Tucumcari, where it is overlain by the Middle Jurassic Exeter Sandstone (Dobrovolny and others, 1946; Kelley, 1972a, b) and is gradational with the underlying Chinle Formation (pl. 2). It is locally overlain unconformably by the upper Tertiary Ogallala Formation (fig. 8). The Redonda is lithologically similar to, and has been tentatively correlated with, the predominantly eolian Jurassic Wingate Sandstone of the Colorado Plateau (Griggs and Read, 1959; Kelley, 1972a, b). The Redonda is an evenly bedded, reddish-orange, vertebrate-bearing sandstone that is as much as $450 \mathrm{ft}$ thick (Dobrovolny and others, 1946; Lucas and others, 1985b).

\section{MIDDLE AND UPPER JURASSIC ROCKS}

Jurassic sediments were never deposited in southeastern New Mexico (Bachman, 1984, 1987). In the western and northwestern parts of the study area (especially in Lincoln County), the Jurassic and Early Cretaceous were times of erosion (Budding, 1964). Thus, Jurassic rocks are present only in the northern part of the study area near Tucumcari, where they include the Middle Jurassic Exeter Sandstone (unit Je, pl. 1) and the overlying Upper Jurassic Morrison Formation (unit Jm, pl. 1); in places on plate 1, the Morrison and Exeter are mapped together as unit Jme.

Deposition was apparently continuous throughout Middle and Late Jurassic time and there are no regional disconformities within the Jurassic sequences, although Jurassic rocks unconformably overlie Triassic sedimentary rocks and are unconformably overlain by Cretaceous strata. Jurassic rocks in the region, including the Exeter Sandstone and the Morrison Formation, are continental eolian and stream deposits whose sediment source is thought to be the Ancestral Rocky Mountains (Mankin, 1972). In the study area, Jurassic rocks are as much as $300 \mathrm{ft}$ thick, but are as thick as $500 \mathrm{ft}$ near Bueyeros in southeastern Harding County (Foster and others, 1972). The Exeter is predominantly an eolian deposit that grades upward into a predominantly playa-lake deposit (possibly reflecting increased rainfall) (Mankin, 1972). The Morrison Formation, a fluvial or deltaic sequence, was deposited in a more humid (possibly subtropical) environment. Volcanic activity increased during deposition of the Morrison Formation, as evidenced by volcanic ash found within the unit in the study area.

\section{EXETER SANDSTONE}

The Exeter Sandstone (Exeter Member of Entrada Sandstone of Lucas and others, 1985b) crops out along the Canadian River escarpment, along the north-facing escarpment of the Llano Estacado south of the Canadian River, and in isolated buttes and mesas in northern Guadalupe and Quay Counties (Mankin, 1972). The Exeter that rims Tucumcari
Basin is white to pale-brown, fine-grained, massive to crossbedded, very well sorted to well-sorted quartz sandstone that is slightly cemented. In the Tucumcari region, the beds are large-scale crossbedded in the lower part of the formation and more massively bedded and contain smaller-scale crossbeds in the upper part. The Exeter is as much as $228 \mathrm{ft}$ thick in the subsurface of Tucumcari Basin (Trauger and Bushman, 1964). It unconformably overlies the Upper Triassic Redonda Formation and is conformably overlain by the Morrison Formation (pl. 2).

\section{MORRISON FORMATION}

In the Tucumcari region along the Canadian River, the Morrison Formation consists of a lower variegated shale, a middle mudstone and lenticular sandstone, and an upper shale intercalated with silica-cemented sandstone (Mankin, 1972). These units are not continuous, however, and their relations vary within the study area. Typically, the Morrison is a fine-grained, well-sorted to poorly sorted sandstone containing rare coarse to pebbly layers. In the lower shale, there is a thin, continuous, widespread red chert unit (jasper). The Morrison also contains 1- to 3-ft-thick beds of gypsum, impure limestone, volcanic ash, rare bentonite in beds as thick as $1 \mathrm{ft}$, and nodular chert. It contains sparse fossils and is locally anomalously radioactive. The Morrison is thought to have originated in fluvial and lacustrine environments, and its clastic material was derived from the south or southwest (Wanek, 1962).

The Morrison Formation is $100-500 \mathrm{ft}$ thick, and is slumped in most locations. Thickness variations may be due to contemporaneous subsidence (F.D. Trauger, in Mankin, 1972). Oil wells north of the study area encountered as much as $400 \mathrm{ft}$ of the Morrison. The Morrison conformably overlies the Middle Jurassic Exeter Sandstone and is unconformably overlain by the Lower Cretaceous Tucumcari Shale (pl. 2).

\section{LOWER AND UPPER CRETACEOUS ROCKS}

Cretaceous units that crop out in the western part of the study area include the Lower Cretaceous Tucumcari Shale, Mesa Rica Sandstone, and Pajarito Shale mostly in the Tucumcari region (Brand and Mattox, 1972), and the Upper Cretaceous Dakota(?) Sandstone, Mancos Shale, and Mesaverde Formation in Lincoln County (Griswold, 1959). The Tucumcari, Mesa Rica, and Pajarito are undivided and mapped within unit $\mathrm{KK} u$ on plate 1 ; the Dakota(?), Mancos, and Mesaverde are undivided and mapped as unit Kmmd on plate 1 . Surface and subsurface relations suggest that the Cretaceous rocks rest unconformably on the Upper Triassic Chinle and Redonda Formations and are unconfornably overlain by the Miocene Ogallala Fornation in the Tucumcari region and by the Upper Cretaceous and Tertiary Cub Mountain Formation in Lincoln County (pl. 2). Cretaceous rocks were probably eroded from the area to the south, where 
only remnants of Cretaceous strata are preserved in sinks and isolated outcrops near Carlsbad (Bachman, 1984, 1987). South of lat $33^{\circ} \mathrm{N}$., only sporadic occurrences of Cretaceous rocks are present in the subsurface. Cretaceous strata are thickest in the northeastem part of Lea County, thinning northwestward to about long $103^{\circ} 30^{\prime} \mathrm{W}$.

\section{TUCUMCARI SHALE}

Within the study area, the Lower Cretaceous Tucumcari Shale is $0-200 \mathrm{ft}$ thick in the subsurface and $50-100 \mathrm{ft}$ thick on the surface. On the surface and in the subsurface in Tucumcari Basin, the Tucumcari is composed of fossiliferous, bedded, fissile, dark-gray shale overlain by lighter gray fossiliferous shale and yellow-brown clay (Brand and Mattox, 1972). Minor limestone occurs throughout the unit. The uppermost beds contain thin sandstone beds that lithologically are similar to those of the overlying Mesa Rica Sandstone, which unconformably overlies the Tucumcari (pl. 2). In Tucumcari Basin, the Tucumcari is as much as $80 \mathrm{ft}$ thick (Kelley, 1972a, b). The Tucumcari(?) Shale crops out and occurs in the subsurface in Lea County just outside the southem border of the study area (Ash and Clebsch, 1961). The Tucumcari is probably marine south and east of Tucumcari, but interfingers north and west into continental sequences.

\section{MESA RICA SANDSTONE}

The Lower Cretaceous Mesa Rica Sandstone crops out in bluffs in the Tucumcari area and in the Canadian River escarpment north of Tucumcari (Brand and Mattox, 1972). The Mesa Rica may be correlative to the Dakota(?) Sandstone, although the stratigraphic relation between the two units and the overlying Pajarito Shale is unclear (Kilmer, 1987). The Mesa Rica is composed of medium-brown to light-gray crossbedded sandstone intercalated with gray shale and clay of deltaic origin. The basal part is a conglomerate that contains broken fossil pieces and which scours into the underlying Lower Cretaceous Tucumcari Shale. The uppermost part contains thin shale beds similar to those of the overlying Lower Cretaceous Pajarito Shale, which it conformably underlies (pl. 2). Combined, the Mesa Rica and Pajarito are as thick as $60 \mathrm{ft}$.

\section{PAJARITO SHALE}

The Lower Cretaceous Pajarito Shale occurs only locally in the Tucumcari area; it occurs in the downthrown block of the Bonita fault, on Mesa Rica in northwestern Quay County, and in the escarpment south of San Jon in eastern Quay County (Brand and Mattox, 1972). The Pajarito is predominantly a delta-plain lacustrine light-gray shale interbedded with sandstone. The shale contains bentonitic and limonitic layers and iron concretions, and is locally fossiliferous. A thick, medium-yellowish-brown to white sandstone occurs locally at the top of the unit and has been correlated with the Dakota(?) Sandstone outside the study area in northeastern New Mexico and southeastem Colorado (Kilmer, 1987). Near San Jon, the Pajarito and underlying Mesa Rica interfinger. The Pajarito is unconformably overlain by the upper Tertiary Ogallala Formation and by Quaternary deposits (pl. 2).

\section{DAKOTA(?) SANDSTONE}

The Upper Cretaceous Dakota(?) Sandstone, which crops out in the westem part of the study area in the Sierra Blanca Basin, is a transitional sequence of massive to locally crossbedded, coarse- to medium-grained, brown to red sandstone. The upper part grades upward into thin- to mediumbedded shale and sandstone that are transitional into the overlying Mancos Shale (Kelley, 1971). The Dakota(?) unconformably overlies older units, including the Chinle Formation, Santa Rosa Sandstone, Grayburg Formation of the Artesia Group, and Bonney Canyon Member of the San Andres Formation (Kelley, 1971) (pl. 2).

The Dakota(?) Sandstone is typically from 100 to $150 \mathrm{ft}$ thick (Griswold, 1959; Kelley, 1971), but in the Jicarilla Mountains it varies from 120 to $200 \mathrm{ft}$ thick.

\section{MANCOS SHALE}

The Upper Cretaceous Mancos Shale is typically a marine black shale interbedded with gray siltstone and minor thin dark-gray limestone beds and lenses. It crops out in the western part of the study area in the Sierra Blanca Basin (Griswold, 1959; Kelley, 1971) and underlies much of the Jicarilla Mountains region (Budding, 1964). The Mancos is easily eroded and poorly exposed, and fills valley bottoms.

The Mancos Shale is variable in thickness, but near Capitan it is as thick as $389 \mathrm{ft}$ (Allen and Jones, 1951). It is estimated to be $410 \mathrm{ft}$ thick in the Jicarilla Mountains, where it conformably overlies the Dakota(?) Sandstone (Budding, 1964) (pl. 2).

\section{MESAVERDE FORMATION}

The Upper Cretaceous Mesaverde Formation is well exposed in the Sierra Blanca Basin near White Oaks, Carrizozo, Capitan, and Ruidoso, where it contains coal (Kelley, 1971). In the Capitan coal field in the southwestem part of the study area, the Mesaverde is composed of a lower sandstone ( $150 \mathrm{ft}$ thick), a middle shale and coal (about $200 \mathrm{ft}$ thick), and an upper sandstone (100-150 ft thick) (Kelley, 1971). The upper and lower sandstones are both typically fossiliferous, massive to medium bedded (thick bedded in some areas), white, buff, or brown in color, and fine to 
medium grained (Kelley, 1971). The shale is light gray to black and may contain some siltstone and coal (Kelley, 1971). The Mesaverde is commonly faulted, intruded by dikes, and poorly exposed (Kelley, 1971).

In the Jicarilla Mountains, the Mesaverde Formation is as much as $415 \mathrm{ft}$ thick (Budding, 1964). Coal beds in the Sierra Blanca Basin range from less than 1 to $4.5 \mathrm{ft}$ thick.

In the Sacramento and Capitan Mountains, the Mesaverde is probably unconformably overlain by the Upper Cretaceous and Tertiary Cub Mountain Formation, although Weber (1964) suggested a local conformable contact. In the Jicarilla Mountains, it is unconformably overlain locally by as much as $50 \mathrm{ft}$ of the upper Tertiary Ogallala Formation (Budding, 1964) (pl. 2).

\section{CRETACEOUS AND TERTIARY ROCKS}

\section{CUB MOUNTAIN FORMATION}

The Upper Cretaceous and Tertiary Cub Mountain Formation is exposed in the western part of the study area near the Lincoln County porphyry belt (unit TKc, plate 1). According to Weber (1964), the Cub Mountain crops out southward from Cub Mountain (west of the White Mountain Wilderness Area) into the Three Rivers drainage area west of Sierra Blanca Peak. The unit is faulted and intruded by dikes and is as much as $600 \mathrm{ft}$ thick (Kelley, 1971). The Cub Mountain is generally a poorly sorted, channel-crossbedded, continental deposit. It is composed of interbedded purple and red mudstone, arkosic white to buff friable sandstone, lenticular conglomerate, and montmorillonitic claystone, mudstone, siltstone, and fine-grained sandstone that typically contain fine veinlets and seams of gypsum (Griswold, 1959; Weber, 1964; Kelley, 1971). It unconformably overlies both the Mancos Shale and Mesaverde Formation near Ruidoso and Capitan, and is intruded and overlain by Tertiary intrusive and volcanic rocks (pl. 2).

\section{UPPER TERTIARY ROCKS}

\section{OGALLALA FORMATION}

The Miocene Ogallala Formation is exposed throughout the study area, occurring as outliers as far west as the Lincoln County porphyry belt (unit To, pl. 1; also locally included in unit QTg). The Ogallala, named by Darton (1899), is extensively exposed in the Great Plains of the United States, extending from South Dakota to Texas, and is a major groundwater aquifer for this region. The High Plains of eastern New Mexico is covered by the most resistant upper part of the Ogallala (Leonard and Frye, 1975).

Large parts of the study area east of long $104^{\circ} \mathrm{W}$. and the Pecos River are either capped or shallowly underlain by the Ogallala. The Ogallala thins westward from the area in Texas east of the Pecos River (the Llano Estacado) to its source in the southern Rocky Mountains and adjacent uplands north of the study area (Leonard and Frye, 1975). West of the Pecos River, it commonly forms small, discontinuous terraces below higher upland surfaces developed on older rocks. It crops out in high, northeast-trending, dendritic, pediment-covered, segmented mesas between Capitan and Ruidoso; these remnants may be fault-controlled valley fill (Kelley, 1971; Frye and others, 1982).

The Ogallala Formation is composed of alluvial and minor eolian deposits that were derived from the western uplands; some clasts are Precambrian (Kelley, 1972a; Leonard and Frye, 1975). The composition of the Ogallala is variable throughout the study area depending on the source rock. In the north, channel deposits (gravel) are more common in the lower part of the formation (fig. 8). The more easterly exposures of the Ogallala contain gravel deposits that occur stratigraphically higher in the Ogallala. The more southerly exposures contain only rare coarse gravel deposits, and in many of the southem locations gravel is absent (Leonard and Frye, 1975). In uneroded areas, calcium carbonate caliche as much as $50 \mathrm{ft}$ thick is present at the top of the formation and minor silt- and clay-bearing sandstone is predominant (Leonard and Frye, 1975).

During deposition of the Ogallala, the climate of the region became increasingly arid. Alluvial deposition diminished, and thick, hard caliche (referred to as the "Ogallala climax soil") formed at the top of the Ogallala. This soil covered earlier formed Pleistocene stream valleys, causing streams to shift laterally on the relatively impermeable alluvial plain, without regard to earlier valley positions (Frye and Leonard, 1959; Leonard and Frye, 1975). North of Roswell, the Ogallala was deposited by streams flowing generally east-southeast (Leonard and Frye, 1975); south of Roswell, however, the course of streamflow is not clear (Bachman, 1987). The thickness of the Ogallala is variable, ranging from 0 to $200 \mathrm{ft}$, and reflects the depth of the underlying erosional unconformity (Frye, 1971; Leonard and Frye, 1975). Local thickness variability of the Ogallala can be attributed to evaporite dissolution and karst collapse at the surface.

Eastward tilting and warping of the High Plains continued after deposition of the Ogallala, lasting from latest Tertiary to the middle Pleistocene (Frye and others, 1982). Downwarping apparently took place along the present Pecos River valley, and upwarping occurred on the eastern and western flanks of the valley. The distribution of the Ogallala delineates stream capture caused by downwarping, collapse, or subsidence (Frye and others, 1982).

\section{QUATERNARY DEPOSITS}

\section{GATUNA FORMATION}

The Gatuna Formation is a fine-grained, valley-filling formation of uncertain age that is lithologically similar to, but younger than, the Ogallala Formation. It is exposed intermittently in the Pecos River valley near Artesia, Hagerman, 


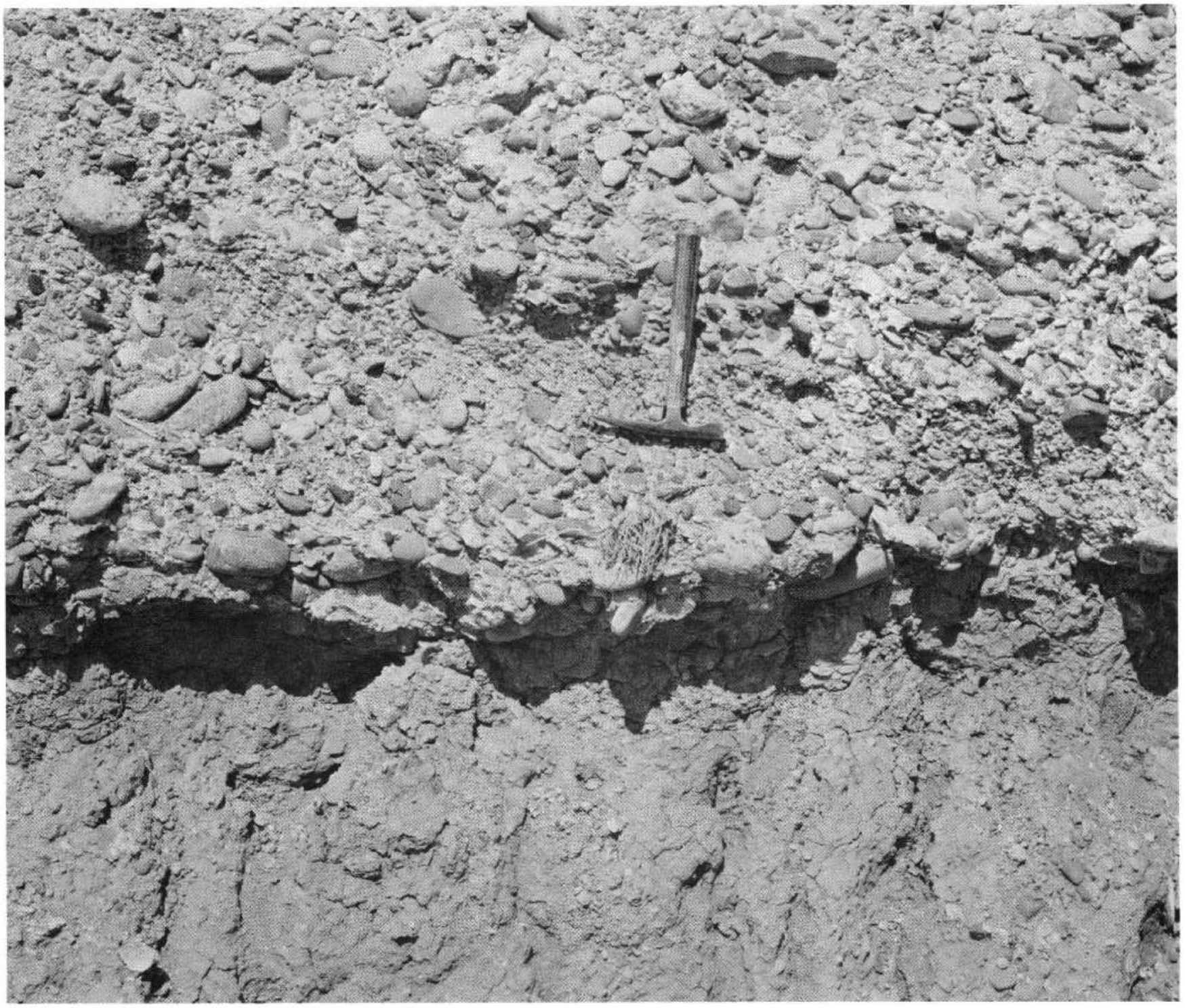

Figure 8. Basal conglomerate of upper Tertiary Ogallala Formation resting unconformably on weathered sandstone of the Upper Triassic Redonda Formation near Ragland, Quay County, N. Mex. Hammer (13 in. long) for scale. Photograph taken by R.L. Griggs about 1957 (photograph number 28, on file at the U.S. Geological Survey Photo Library. Denver, Colo.)

and Roswell, and possibly as far north as Santa Rosa (unit Qt, pl. 1). It is a predominantly orange-red (also gray, yellow, or purple), friable sandstone containing minor amounts of conglomerate, clayey mudstone, siltstone, limestone, or gypsum, derived from the Dockum Group, Tertiary igneous rocks, and the Ogallala caprock (Kelley, 1971; Bachman, 1987). The Gatuna is fossiliferous in places, containing fresh-water gastropod remains. It also contains at least one 620,000-yr-old Pleistocene (upper part of Yellowstone Group) ash bed south of the study area in Nash Draw about $20 \mathrm{mi}$ east of Carlsbad (Kelley, 1971; Izett and Wilcox, 1982; Bachman, 1984).

The Gatuna Formation is consolidated in places, but is locally intermixed with underlying units due to slumping and collapse and it unconformably overlies older sequences (Kelley, 1971). The Gatuna Formation is as thick as $300 \mathrm{ft}$, although the thickness is highly variable (Kelley, 1971).

\section{OTHER UNCONSOLIDATED DEPOSITS}

Quatemary sediments include pediment, terrace, eolian, alluvial, and colluvial deposits that are widespread in the study area (units Qt and Qal, pl. 1). Small rock glaciers occur in the western Capitan Mountains (Blagbrough, 1991). The sediments are mostly unconsolidated, but locally they may be cemented by caliche. In some areas, the Quaternary deposits are mixed due to slumping, landsliding, and collapse. 


\section{PEDIMENT DEPOSITS}

The Mescalero pediment east of long $104^{\circ} \mathrm{W}$. slopes gently eastward and is a poorly drained pediment approximately $350 \mathrm{ft}$ above the Pecos River from about $25 \mathrm{mi}$ north of Roswell to the southern boundary of the study area (Kelley, 1971). Long Valley cuts southward between Roswell and Hagerman across the sink-dotted plain. Mesas form on the Mescalero pediment in resistant calichecemented gravel and sand deposits that are as much as $10 \mathrm{ft}$ thick. A similar surface that is covered with sand, caliche caprock, and local gravel deposits (Diamond A Plain) is present west of the Pecos River at about the same latitude. Lag gravel deposits are widespread on both of these surfaces, but it is slightly coarser on the Diamond A Plain.

\section{TERRACE DEPOSITS}

In the study area, a low terrace is present within the Pecos River valley from about $15 \mathrm{mi}$ north of Roswell to the southem border of the study area. Three named terraces (in ascending order, the Lakewood, Orchard Park, and Blackdom) are present (Fiedler and Nye, 1933). The Lakewood terrace is the alluvial bottom of the Pecos River and its tributaries; the Orchard Park is about 5-25 ft above the lower terrace; the Blackdom is as much as $100 \mathrm{ft}$ above the Orchard Park. The Blackdom terrace contains caliche deposits as thick as $\mathbf{4} \mathbf{f t}$. All three terraces are visible north of Roswell where the Pecos River is crossed by U.S. Highway 70 . Thick (300 ft) deposits of pediment gravel cover the Blackdom terrace in this area (Kelley, 1971).

\section{EOLIAN DEPOSITS}

The Mescalero pediment is covered by impure tan to brown eolian sand containing minor soil and caliche (the "Mescalero sands" of Darton, 1928). The sand deposits are covered with mesquite, cactus, or buffalo grass, and are most extensive northeast and east of Carlsbad south of the study area. Extensive dune fields are present between and west of Clovis and Portales along the Curry County-Roosevelt County line and in Chaves County on the Llano Estacado east of Roswell (Reeves, 1972). They are thought to be remnants of postglacial fluvial systems.

\section{LAKE DEPOSITS}

Karst sinkholes and sags may be filled with playa deposits in areas where carbonate-evaporite deposits are exposed. According to Kelley (1971), the largest of these playa lakes had persistent Pleistocene lake stands above present-day valley floors.

\section{ALLUVIUM AND COLLUVIUM DEPOSITS}

Significant alluvial and colluvial deposits are present along many ephemeral streams in the study area, especially where less competent bedrock or fault zones crop out adjacent to stream channels (Kelley, 1971). Disturbed gravel pediment deposits are north of Roswell on the Pecos Slope, where they are underlain by gypsum and karst. Alluvial deposits as much as $600 \mathrm{ft}$ thick have been reported in the Tucumcari area (Trauger and Bushman, 1964).

\section{BASALT FLOWS}

Vesicular basalt flows located west of Carrizozo (the Little Black Peak and Carrizozo lava flows of the Valley of Fires Recreation Area) are termed malpais ("badlands") (unit Qb, pl. 1). These flows extend for $\mathbf{4 4} \mathrm{mi}$ and are as wide as $5 \mathrm{mi}$; they encompass about $1 \mathrm{mi}^{3}$ of basalt (Allen and Jones, 1951; Weber, 1964). The flows represent probable recent (approximately 5,000-yr-old) outflow from nearby cinder cones that lie along the east-west Capitan Mountains lineament (Weber, 1964, 1979; Salyards, 1991). Lava flowed southwestward over strata that include the Dakota(?) Sandstone (Weber, 1979). The lava field is typical of pahoehoe flows, containing ropy surfaces, pressure ridges, and collapse features. A basal flow located about $2 \mathrm{mi}$ south of U.S. Highway 380 consists of fine-grained massive subalkaline olivine basalt as much as $60 \mathrm{ft}$ thick (Weber, 1964). Much of the basalt in the flow is vesicular and contains phenocrysts of olivine in a fine matrix of andesine-labradorite, augite, olivine, and glass.

\section{TERTIARY INTRUSIVE AND EXTRUSIVE ALKALINE ROCKS OF THE LINCOLN COUNTY PORPHYRY BELT}

\author{
By Theodore J. Armbrusumacher
}

Alkaline igneous rocks in the Roswell Resource Area are found in all but the southernmost part of the Lincoln County porphyry belt (Kelley and Thompson, 1964). These rocks of Tertiary age form at least 9 (Kelley and Thompson, 1964), 12 (Allen and Foord, 1991a), or 14 (Kelley, 1971) intrusive and extrusive centers that lie between Corona on the north and Ruidoso on the south in the southwestern part of the study area (units Tis and Tv, pl. 1). Allen and Foord (1991a) compiled age determinations of the igneous rocks and concluded that there were three episodes of Cenozoic igneous activity in the study area: (1) $38.2-36.5 \mathrm{Ma}$ for intrusive rocks from the Jicarilla Mountains, volcanic flows and intrusions from Sierra Blanca Peak and Black Mountain, and perhaps compositionally similar rocks from the Gallinas Mountains and the hills near Tecolote Peak; (2) 30-26 Ma for late syenite and granite of Sierra Blanca Peak, several dikes along the Capitan Mountains lineament, and perhaps compositionally similar plutons at Carrizo Mountain, Lone Mountain, and Patos Mountain; and (3) Quaternary basalt flows of the malpais. Kelley and Thompson (1964) listed the 
principal rock types for the nine igneous centers: Gallinas Mountains, rhyolite laccolith in the north, trachyte laccolith in the south; hills near Tecolote Peak, syenite-diorite laccolith; Jicarilla Mountains, monzonite(?) laccolith and stock; Lone and Baxter Mountains, syenite(?) stock and laccolith; Carrizo Mountain, microgranite(?) laccolith; Patos Mountain, monzonite(?) laccolith; Capitan Mountains, microgranite stock and laccolith; Three Rivers area, monzonite to granite stocks (pl. 3). Allen and Foord (1991a) grouped the igneous rocks into (1) "younger" Tertiary granitic plutons, including the intrusions at Capitan Mountains, Carrizo Mountain, Patos Mountain, and Lone Mountain; (2) "younger" Tertiary dikes, including the Railroad Mountain dike; (3) and "older" Tertiary alkalic complexes, including Black Mountain, Sierra Blanca Peak, Baxter MountainWhite Oaks district, the hills near Tecolote Peak, Jicarilla Mountains, and Gallinas Mountains.

According to Allen and Foord (1991a), igneous activity in the study area was localized along two major structural features during two distinct episodes within the porphyry belt. Magmas of alkali gabbroic to syenitic composition, or volcanic equivalents at Sierra Blanca Peak, were emplaced during an earlier episode (38-30 Ma) along the north-southtrending Pedernal uplift during the transition from Laramide compression to extension. Along this trend, alkaline magmas were intruded along subordinate northeast-trending faults during the transition of Laramide compression to extension. A later episode (28-26.5 Ma) of alkali gabbroic to granitic composition occurs along the east-west Capitan Mountains lineament and within the Sierra Blanca volcanic pile coincident with early rifting along the Rio Grande rift zone (Allen and Foord, 1991b). Rare-earth-element data and rubidium/ strontium ( $\mathrm{Rb} / \mathrm{Sr})$ and neodymium/samarium $(\mathrm{Nd} / \mathrm{Sm})$ isotopic data presented by Allen and Foord (1991a) suggest that mafic alkaline magmas during the earlier episode were derived from metasomatized mantle, whereas granitic magmas during the later episode were derived from the lower crust. Just east of the Sierra Blanca Basin is the north-southtrending Pedernal uplift (Mescalero arch), which appears to be offset to the west near Capitan Peak. Many of the igneous centers appear to be associated with these structures (Kelley and Thompson, 1964). The Sierra Blanca Basin filled with at least $3,340 \mathrm{ft}$ of volcanic rocks during Oligocene time (Thompson, 1972). The volcanic rocks, which consist of andesitic to trachytic flow breccias, flows, and tuffs, were then intruded by magmas that crystallized into the leucocratic to mesocratic rocks of the Three Rivers and Bonito Lake stocks.

The alkaline rocks of the study area share a common igneous heritage with lithologically similar rocks of the Rocky Mountain front from West Texas to Montana, including those at Cripple Creek, Colo., and north-central Montana (Judith Mountains, Moccasin Mountains, Bearpaw Mountains, and so forth). The tectonic setting appears to be subduction related (Allen and Foord, 1991a), or back-arc extension related (Thompson, 1991c). Limited isotopic data suggest that the saturated to undersaturated alkaline magmas originated in the mantle and (or) lower crust.

\section{IGNEOUS CENTERS}

\section{GALIINAS MOUNTAINS}

The Gallinas Mountains comprise at least two domal uplifts underlain by Precambrian granitic rocks that are in turn covered by almost 2,000 ft of Lower Permian Abo Formation, Yeso Formation, and Glorieta Sandstone (Perhac, 1964, 1970). In fact, outcrops of foliated Precambrian granite exposed within the mountains represent one of only a few occurrences of basement rocks in the study area. In Tertiary time, leucocratic magmas intruded the Permian sedimentary rocks as laccoliths and possibly as stocks. The intrusive contacts are mostly concordant with the bedding of the overlying sedimentary rocks when they are observed in outcrop. Flow banding is parallel to sedimentary rock bedding whenever it is observed.

Porphyritic latite occurs at Cougar Mountain, northeast of the main Gallinas Mountains (pl, 3). Nearby Yeso Formation is flat lying, suggesting that the porphyritic latite is a stock (Perhac, 1970). Major rock-forming minerals are orthoclase, sodic plagioclase, and homblende, and accessory quartz, magnetite, apatite, zircon, and titanite. Plagioclase and hornblende occur as phenocrysts, and the other minerals constitute the groundmass.

The southern part of the Gallinas Mountains is underlain by a laccolith of porphyritic trachyte and associated syenite. The porphyritic trachyte contains orthoclase and sodic plagioclase phenocrysts, minor hornblende and (or) aegirine-augite, and groundmass consisting of altered feldspar and accessory quartz, magnetite, apatite, zircon, rutile, titanite, and ilmenite. The texture of the groundmass is trachytic. The syenite phase contains essentially the same minerals as the porphyritic trachyte, but the texture is equigranular. Acmite and biotite are minor constituents of some specimens.

The north-northwestern part of the mountains is underlain by a laccolith of porphyritic rhyolite that is more than $500 \mathrm{ft}$ thick at Gallinas Peak and thins away from this center. This rock contains feldspar phenocrysts set in a fine-grained groundmass of minerals nearly identical to those of the other rocks in the area. Small circular to elliptical bodies of trachyte breccia occur west of Rough Mountain. Fragments include porphyritic trachyte, shale, sandstone, limestone, and granite set in a trachyte matrix.

Nearly all the rocks have been hydrothermally altered, resulting in replacement of original feldspar and mafic minerals by clay minerals, ferric iron oxide, and other secondary minerals. Sedimentary rocks at the contacts with the igneous rocks show almost no evidence of contact metasomatic effects. Minor silicification of limestone and 
sandstone, and local development of skam minerals are sometimes observed. The laccoliths are emplaced chiefly into the Yeso Formation and most of the mineral deposits occur in that formation.

\section{TECOLOTE PEAK}

Subsilicic rocks including syenite, monzonite porphyry, and diorite occur in laccoliths with maximum thickness of $400 \mathrm{ft}$ in the hills near Tecolote Peak (Rawson, 1957). Allen and Foord (1991a) briefly described compositions ranging from syenogabbro to syenite, and they suggested that the diorite of Rawson is biotite-augitehornblende pyroxenite. The Lower Permian Yeso Formation and the Upper Permian Glorieta Sandstone are hosts for the laccoliths. The laccoliths appear to be an extension of the larger igneous bodies that occur in the Gallinas Mountains to the northwest (Griswold, 1959). A laccolith of monzonite porphyry underlies Tecolote Peak to a thickness of near 400 $\mathrm{ft}$ and thins to about $200 \mathrm{ft}$ toward the east and south (Rawson, 1957). Reconnaissance mapping revealed that $10 \mathrm{ft}$ of sandstone [Glorieta Sandstone(?)] overlies the laccolith at the top of Tecolote Peak. The monzonite porphyry laccolith overlies and is locally intrusive into a smaller diorite laccolith. Small syenite lenses occur within the diorite laccolith. Contact metasomatic alteration of limestone beds at the base of the diorite laccolith are observed locally.

\section{JICARILLA MOUNTAINS}

The main igneous centers in the Jicarilla Mountains are represented by two intrusions, one consisting of latite porphyry near the village of Jicarilla in the southern part of the mountains, and the other consisting of monzonite to diorite underlying Jacks Peak in the northeastern part of the mountains (Ryberg, 1968). Allen and Foord (1991a) found that the rocks consist of an alkaline sequence of biotite syenogabbro to syenite and a calc-alkalic monzonite and tonalite. The intrusions have caused the pre-Tertiary sedimentary rocks to be domed. The coarse-grained rocks have potassium-argon (K-Ar) ages on biotite of 38.2 and $37.3 \mathrm{Ma}$ (Allen and Foord, 1991a; Thompson, 1991a). The intrusion at Jacks Peak is in contact with the Lower Permian San Andres Formation; smaller sill- or laccolith-like bodies occur away from the main intrusions, chiefly within the San Andres Formation. Small dikes of basaltic composition intersect the intrusion at Jicarilla and some of the surrounding sedimentary rocks.

\section{LONE AND BAXTER MOUNTAINS}

Lone and Baxter Mountains are the dominant physiographic features of the White Oaks area, southwest of the Jicarilla Mountains (Griswold, 1959). According to Smith
(1964), intrusive rocks of this area are of two major typesquartz rich and quartz poor; the Lone Mountain intrusive consists of quartz-poor rocks. Monzonite and syenite underlie Lone Mountain, where probable laccolithic intrusion has domed the surrounding San Andres Formation (Griswold, 1959; Smith and Budding, 1959). Lone Mountain rocks are uniform, containing sparse plagioclase and less than 10 percent quartz (Smith, 1964). Schnake (1977) indicated that the rocks in the Lone Mountain intrusion were zoned-a peripheral felsic zone surrounds a more mafic core. Allen and Foord (1991a) observed that the core consists of quartz syenite and the marginal zone consists of alkali-feldspar granite. Small intrusions extend southward from Lone Mountain through the White Oaks area to Baxter Mountain. Compositions of rocks underlying Baxter Mountain range from syenogabbro to syenite and lamprophyre. These rocks (and the sedimentary rocks in contact with them) are the hosts for ore deposits in the White Oaks district. Rocks from the Lone and Baxter Mountains have a K-Ar age on biotite of 35.2-29.8 Ma (Thompson, 1991a).

\section{CARRIZO MOUNTAIN}

Contacts between the igneous rocks underlying Carrizo Mountain and the surrounding Upper Cretaceous Mesaverde Formation are obscured by alluvial fans and landslides. According to Elston and Snider (1964), the igneous rocks form a steep-sided laccolith or stock that has domed the Mesaverde rocks. Patton (1951) characterized the rocks as alaskites, but Weber (1964) described the presence of homblende- and biotite-bearing quartz syenite locally showing trachytic texture. Elston and Snider (1964) concluded that Carrizo Mountain is underlain by a differentiated body, ranging from fine-grained spherulitic thyolite having vertical flow banding at the contact to porphyritic granite containing phenocrysts of intermediate plagioclase rimmed by orthoclase. Biotite and opaque minerals constitute over 10 percent of the rock. Pertl (1984) and Pertl and Cepeda (1991) described the Carrizo Mountain stock as a steeply dipping rhyolite body having a central zone of quartz monzonite. Data from Allen and Foord (1991a) indicate that the rocks range in composition from quartz syenite to alkali-feldspar granite.

\section{PATOS MOUNTAIN}

The close spatial association of the Patos Mountain intrusive rocks with those of Carrizo Mountain and Lone Mountain suggests a similarity in origin. The Patos Mountain intrusion appears to be a laccolith, but the lower part is concealed by alluvial and colluvial deposits. The Patos Mountain body is a texturally and compositionally zoned thyolite, having a slightly more mafic, porphyritic center and a more siliceous, fine-grained margin (Haines, 1968). 


\section{CAPITAN MOUNTAINS}

The intrusive body underlying the Capitan Mountains, emplaced at 26.5 $\pm 1.2 \mathrm{Ma}$ (Allen, 1988), is the largest in the Lincoln County porphyry belt and one of the largest Tertiary intrusions exposed in New Mexico (Allen, 1988; Allen and McLemore, 1991). It is elongate in an east-west direction due to alignment along the westem part of the Capitan lineament (herein referred to as the Capitan Mountains lineament) along lat $34^{\circ} \mathrm{N}$. (Moore and Foord, 1986; Allen, 1988). On the west, the intrusion is in contact with the San Andres Formation, and on the east, with the Yeso Formation; elsewhere, the contact is covered by surficial deposits. Carbonate rocks in contact with the intrusion are locally altered to calc-silicate skarns and replacement iron deposits. Although Kelley (1971) stated that the composition and texture of the rocks in the intrusion are remarkably uniform, Allen and McLemore (1991) indicated that the intrusion is zoned-a high-silica, miarolitic, granophyric aplite in the roof zone at the west end, and a lower silica, fine-grained, alkali-feldspar granite porphyry core at the east end. Rocks from the west end tend to contain higher amounts of quartz and no mafic minerals other than iron oxides, whereas the rocks of the east end contain lesser amounts of quartz, feldspar phenocrysts, and biotite and amphibole as mafic minerals (Allen and McLemore, 1991). Allen and McLemore (1991) defined three major textural types (granophyre, aplite, and porphyry) having geochemical differences. Granophyric types occur in the westem part of the intrusion and grade into equigranular-textured aplite toward the east; rocks from the eastern half of the intrusion are porphyritic. Isotopic and rare-earth-element data suggest that the rocks of the Capitan Mountains intrusion are derived from a lower crustal source.

\section{THREE RIVERS AREA}

The Three Rivers area lies at the southern end of the Lincoln County porphyry belt and constitutes part of the Sierra Blanca Igneous Complex (Thompson, 1966, 1972). The complex consists of a thick pile of volcanic rocks that overlie with angular unconformity the Upper Cretaceous and Tertiary Cub Mountain Formation and the Upper Cretaceous Mesaverde Formation (pl. 2). Rocks of the volcanic sequence comprise four units-Walker Andesite Breccia, Nogal Peak Trachyte, Church Mountain Latite, and Godfrey Hills Trachyte--and consist chiefly of andesitic to trachytic flow breccia, flows, and tuffs (Thompson, 1972). The volcanic pile is in turn intruded by four stocks-Three Rivers, Rialto, Chaves Mountain, and Bonito Lake (pl. 3). These stocks appear to be comagmatic with their volcanic precursors.

According to Giles and Thompson (1972), the Three Rivers stock is a molybdenum-related, hypabyssal complex that consists of three major intrusive phases: (1) an early, passively emplaced shell of syenite porphyry, (2) quartz syenite intruded along the northeastern margin of the stock, and (3) late, equigranular quartz syenite to alkali granite forcibly injected along a northeastem trend into the syenite porphyry. Each phase has a different texture, but similar geochemistry and mineralogy (Thompson, 1972). The southern part of the stock that underlies Sierra Blanca Peak comprises five separate units ranging from syenite to alkali granite (Moore and Foord, 1986). The alkali granite has been dated at 26.8 $\pm 0.09 \mathrm{Ma}$ (Moore and Foord, 1986).

The Rialto stock consists of hornblende-bjotite monzonite cut by small bodies of comagmatic biotite monzonite (Thompson, 1968, 1972). Orthoclase and sodic plagioclase constitute nearly 90 percent of the hornblende-biotite monzonite. Biotite and magnetite partially replace homblende, and quartz, apatite, rutile, and titanite occur as accessory minerals. The Rialto stock contains brecciated zones that have localized deposits of gold.

The syenite stock at Chavez Mountain intrudes rocks of the Cub Mountain Formation (Thompson, 1972). Rocks of the stock contain anorthoclase phenocrysts in a groundmass of sodic plagioclase, homblende, and biotite. The texture is trachytic.

The predominant rock type in the Bonito Lake stock is homblende-biotite syenite although the rocks become monzonitic toward the western margin (Thompson, 1972, 1973). Orthoclase and sodic plagioclase are more abundant than microperthite. Corroded remnants of clinopyroxene are partly replaced by hornblende and magnetite, which in turn are replaced by biotite. Hydrothermal alteration of the syenite occurs along the northem contact of the syenite and along fracture zones. Pyrite, molybdenite, and chalcopyrite have been added to the syenite that has been argillized and silicified.

\section{DIKES}

A generally northeast trending composite dike swarm (unit Td, pl. 1; pl. 3), probably related to regional extension, occurs from Sierra Blanca Peak to the Jicarilla Mountains (Griswold, 1959; Kelley and Thompson, 1964). The dikes are composed of seven different rock types, including labradorite-olivine diabase porphyry, olivine diabase porphyry, diabase, hornblende-biotite diabase, rhyolite, latite grading into trachyte, and phonolite (Elston and Snider, 1964). The dikes in this belt generally form a radial pattern outward from the central part of the Sierra Blanca Basin. [Some dikes are concentric with the basin in the Three Rivers area (Kelley and Thompson, 1964).] The dikes are younger than the Upper Cretaceous and Tertiary Cub Mountain Formation and cut all units including some intrusives, stocks, and sedimentary and volcanic rocks. Dikes in the Ruidoso area are postulated to have been related to considerable regional extension, totalling at least $1 \mathrm{mi}$ in the Mesaverde Formation outcrop belt near Capitan (Jones, 1951; Kelley and Thompson, 1964). 
A diabase dike complex occurs in the subsurface in Tucumcari Basin in Quay County; the dikes are probably of Tertiary age and may have been intruded along preexisting faults on the northern edge of Tucumcari Basin (Broadhead and King, 1988). Railroad Mountain dike, Camino del Diablo dike, and other small stocks, flexures, and numerous sills occur in the south-central part of the study area (unit Td, pl. 1; pl. 3). Railroad Mountain dike, about $31 \mathrm{mi}$ long and $100 \mathrm{ft}$ wide, has positive topographic expression and cuts the Upper Triassic Santa Rosa Sandstone. It consists of mediumgrained olivine gabbro (Kelley, 1971). Camino del Diablo dike, $25 \mathrm{mi}$ long and $50 \mathrm{ft}$ wide, has negative topographic expression. It is composed of surficially altered andesitic to basaltic diabase (Kelley, 1971).

\section{REFERENCES CITED}

Albright, J.L., and Kruckow, Th., 1958, Schwebend gebildete quartzkristalle in New Mexico, USA: Der Aufschlus 5, (9) S. 98-101.

Allen, J.E, and Jones, S.M., 1951, Preliminary map of the Capitan quadrangle, New Mexico, in Guidebook, Field trip No. 5, Capitan-Carrizozo-Chupadera Mesa region, Lincoln and Socorro Counties, New Mexico, Nov. 30 and Dec. 1, 1951: Roswell, N. Mex., Roswell Geological Society, scale 1:63,360.

Allen, M.S., 1988, The Capitan pluton, New Mexico-An example of a zoned granite chamber: Geological Society of America Abstracts with Programs, v. 20, p. A313.

Allen, M.S., and Foord, E.E., 1991a, Geological, geochemical, and isotopic characteristics of the Lincoln County porphyry belt, New Mexico-Implications for regional tectonics and mineral deposits, in Barker, J.M., and others, eds., Geology of the Sierra Blanca, Sacramento, and Capitan Ranges, New Mexico: New Mexico Geological Society, 42nd Annual Field Conference Guidebook, p. 97-113.

- 19916, The igneous rocks of the Lincoln County porphyry belt, New Mexico-Constraints on magma sources and implications: Geological Society of America Abstracts with Programs, v. 23, no. 4, p. 2.

Allen, M.S., and McLemore, V.T., 1991, The geological petrogenesis of the Capitan pluton, New Mexico, in Barker, J.M., and others, eds., Geology of the Sierra Blanca, Sacramento, and Capitan Ranges, New Mexico: New Mexico Geological Society, 42nd Annual Field Conference Guidebook, p. 115-127.

American Association of Petroleum Geologists, 1983, Southwest/ southwest mid-continent region; Correlation of stratigraphic units of North America (COSUNA) project: Tulsa, Okla., AAPG Bookstore, 1 sheet.

Ash, S.R., and Clebsch, Alfred, Jr., 1961, Cretaceous rocks in Lea County, New Mexico, in Geological Survey Rescarch 1961: U.S. Geological Survey Professional Paper 424-D, p. D139-D142.

Bachman, G.O., 1953, Geology of a part of northwestern Mora County, New Mexico: U.S. Geological Survey Oil and Gas Investigations Map OM-137, scale 1:148,000.
1968, Geology of the Mockinghird Gap quadrangle, Lincoln and Socorro Counties, New Mexico: U.S. Geological Survey Professional Paper 594-J, 43 p.

1984, Regional geology of Ochoan evaporites, northem part of Delaware Basin: New Mexico Bureau of Mines and Mineral Resources Circular 184, 22 p.

1987, Karst in evaporites in southeast New Mexico: Contractor Report SAND 86-7078, prepared by Sandia National Laboratories, Albuquerque, N. Mex., and Livermore, Calif., for the U.S. Department of Energy (Contract DE-AC04-76DP00789), microfiche, 74 p.

Berkstresser, C.F., Jr., and Mourant, W.A., 1966, Ground-water resources and geology of Quay County, New Mexico: New Mexico Bureau of Mines and Mineral Resources Ground-Water Report 9, 115 p.

Blagbrough, J.W., 1991, Late Pleistocene rock glaciers in the westem part of the Capitan Mountains, Lincoln County, New Mexico-Description, age, and climatic significance, in Barker, J.M., and others, eds., Geology of the Sierra Blanca, Sacramento, and Capitan Ranges, New Mexico: New Mexico Geological Society, 42nd Annual Field Conference Guidebook, p. 333-338.

Borton, R.L., 1972, Structure of Glorieta Sandstone in northwest Chaves County, New Mexico: New Mexico Bureau of Mines and Mineral Resources Circular 122, 23 p.

Bowsher, A.L., 1991, Some effects of Precambrian basement on the development of the Sacramento Mountains, in Barker, J.M., and others, eds., Geology of the Sierra Blanca, Sacramento, and Capitan Ranges, New Mexico: New Mexico Geological Society, 42nd Annual Field Conference Guidebook, p. 81-89.

Brand, J.P., and Mattox, R.B., 1972, Pre-Dakota Cretaceous formations of northwestem Texas and northeastem New Mexico, in Kelley, V.C., and Trauger, F.D., eds., Guidebook of east-central New Mexico: New Mexico Geological Society, Twentythird Field Conference, p. 98-104.

Broadhead, R.F., 1984a, Subsurface petroleum geology of Santa Rosa Sandstone (Triassic), northeast New Mexico: New Mexico Bureat of Mines and Mineral Resources Circular 193, 22 p. 1984b, Stratigraphically controlled gas production from Abo red beds (Permian), east-central New Mexico: New Mexico Bureau of Mines and Mineral Resources Circular 183, 35 p.

1989. Petroleum potential of Tucumcari Basin, east-central New Mexico, in Grant, P.R., Jr., and Foster, R.W., Future petroleum provinces in New Mexico--Discovering new reserves: New Mexico Bureau of Mines and Mineral Resources Atlas, p. $39-48$.

Broadhead, R.F., and King, W.E., 1988, Petroleum geology of Pennsylvanian and Lower Permian strata, Tucumcari Basin, east-central New Mexico: New Mexico Bureau of Mines and Mineral Resources Bulletin 119, 51 p.

Budding, A.J., 1964, Geologic outline of the Jicarilla Mountains, Lincoln County, New Mexico, in Ash, S.R., and Davis, L.V., eds., Guidebook to the Ruidoso Country: New Mexico Geological Society, Fifteenth Field Conference Guidebook, p. 82-86.

Budnik, R.T., 1989, Tectonic structures of the Palo Duro Basin, Texas Panhandle: Austin, Texas, Bureay of Economic Geology, University of Texas Report of Investigations No. 187, 43 p.

Burt, D.M., 1988, Structural and geophysical evaluation of the northern Tinnie fold belt, southeastem Lincoln County, New 
Mexico: Long Beach, Calif., Califomia State University Master's thesis, $111 \mathrm{p}$.

1991 , Evaluation of basement control on the formation of the northem Tinnie fold belt, southeastern Lincoln County, New Mexico, in Barker, J.M., and others, eds., Geology of the Sierra Blanca, Sacramento, and Capitan Ranges, New Mexico: New Mexico Geological Society, 42nd Annual Field Conference Guidebook, p. 33-35.

Cather, S.M., 1991, Stratigraphy and provenance of Upper Cretaceous and Paleogene strata of the westem Sierra Blanca basin, New Mexico, in Barker, J.M., and others, eds., Geology of the Sierra Blanca, Sacramento, and Capitan Ranges, New Mexico: New Mexico Geological Society, 42nd Annual Field Conference Guidebook, p. 265-274.

Chapin, C.E., 1971, The Rio Grande Rift, Part I-Modifications and additions, in San Luis Basin: New Mexico Geological Society, Guidebook 22, p. 101-201.

Cheeseman, R.J., 1978, Geology and oil/potash resources of Delaware Basin, Eddy and Lea Counties, New Mexico, in Austin, G.S., compiler, Geology and mineral deposits of Ochoan rocks in Delaware Basin and adjacent areas: New Mexico Bureau of Mines and Mineral Resources Circular 159, p. 7-14.

Craddock, Campbell, 1960, The origin of the Lincoln fold system, southeastern New Mexico: International Geological Congress, 21st, Copenhagen 1960, Report, Part 18, p. 34-44.

1964, The Lincoln fold system, in Ash, S.R., and Davis, L.V., eds., Guidebook of the Ruidoso Country: New Mexico Geological Society, Fifteenth Field Conference Guidebook, p. $122-133$.

Darton, N.H., 1899, Preliminary report on the geology and water resources of Nebraska west of the one hundred and third meridian: U.S. Geological Survey, 19th Annual Report, p. 721-785.

- 1928, "Red beds" and associated formations in New Mexico with an outline of the geology of the State: U.S. Geological Survey Bulletin 794, 372 p.

Davis, D.G., 1980, Cavern development in the Guadalupe Mountains-A critical review of recent hypotheses: National Speleological Society Bulletin, v. 42, p. 42-48.

Deford, R.K., and Riggs, G.D., 1941, Tansill Formation, West Texas and southeastem New Mexico: American Association of Petroleum Geologists Bulletin, v. 25, p. 1713-1728.

Dobrovolny, Ernest, Summerson, C.H., and Bates, R.L., 1946, Geology of northwestern Quay County, New Mexico: U.S. Geological Survey Oil and Gas Investigations Map OM-62, scale $1: 62,500$.

Egemeier, S.J., 1973, Cavem development by thermal waters with a possible bearing on ore deposition: Palo Alto, Calif., Stanford University $\mathrm{Ph}$. D. dissertation, $88 \mathrm{p}$.

Elston, W.E., and Snider, H.I., 1964, Differentiation and alkali metasomatism in dike swarm complex and related igneous rocks near Capitan, Lincoln County, New Mexico, in Ash, S.R., and Davis, L.V., eds., Guidebook of the Ruidoso Country: New Mexico Geological Society, Fifteenth Field Conference Guidebook, p. 140-147.

Fiedler, A.G., and Nye, S.S., 1933, Geology and ground-water resources of the Roswell artesian basin, New Mexico: U.S. Geological Survey Water-Supply Paper 639, 372 p.
Finch, W.I., 1988, Principal reference section for the Santa Rosa Formation of Middle and Late Triassic age, Guadalupe County, New Mexico: U.S. Geological Survey Bulletin 1804, 27 p.

Fischer, W.A., and Hackman, R.J., 1964, Geologic map and sections of the Torrance Station 4 NE quadrangle, Lincoln County, New Mexico: U.S. Geological Survey Miscellaneous Geologic Investigations Map I-400, scale 1:24,000.

Flawn, P.T., 1956, Basement rocks of Texas and southeast New Mexico: Austin, Texas, Bureau of Economic Geology, University of Texas Publication No. 5605, 261 p.

Foley, E.J., 1964, The Lincoln folds, Lincoln, New Mexico, in Ash, S.R., and Davis, L.V., eds., Guidebook of the Ruidoso Country: New Mexico Geological Society, Fifteenth Field Conference Guidebook, p. 134-139.

Foster, R.W., Frentress, R.M., and Riese, W.C., 1972, Subsurface geology of east-central New Mexico: New Mexico Geological Society Special Publication No. 4, 22 p.

Frye. J.C., 1971, The Ogallala Formation-A review, in Ogallala Aquifer Symposium: Texas Technical University Special Report No. 39, p. 5-14.

Frye, J.C., and Leonard, A.B., 1959, Correlation of the Ogallala Formation (Neogene) in western Texas, with type localities in Nebraska: Austin, Texas, Bureau of Economic Geology, University of Texas Report of Investigations No. 39, 46 p.

Frye, J.C., Leonard, A.B., and Glass, H.D., 1982, Westem extent of Ogallala Formation in New Mexico: New Mexico Bureau of Mines and Mineral Resources Circular 175, $41 \mathrm{p}$.

Garber, R.A., Grover, G.A., and Harris, P.M., 1989. Geology of the Capitan shelf margin-Subsurface data from the northern Delaware Basin, in Harris, P.M., and Grover, G.A., eds., Subsurface and outcrop examination of the Capitan Shelf margin, northem Delaware Basin: Society of Economic Paleontologists and Mineralogists Core Workshop No. 13, San Antonio, Texas, p. 3-269.

Giles, D.L., and Thompson. T.B., 1972, Petrology and mineralization of a molybdenum-bearing alkalic stock, Sierra Blanca, New Mexico: Geological Society of America Bulletin, v. 83, no. 7 , p. $2129-2148$.

Gonzalez, R.A., and Woodward, L.A., 1972, Petrology and structure of Precambrian rocks of the Pedernal Hills, New Mexico, in Kelley, V.C., and Trauger, F.D., eds., Guidebook of eastcentral New Mexico: New Mexico Geological Society, Twenty-third Field Conference Guidebook, p. 144-147.

Grant, P.R., Jr., and Foster, R.W., 1989, Future petroleum provinces in New Mexico-Discovering new reserves: Socorro, N. Mex., Atlas prepared for the New Mexico Research and Development Institute by the New Mexico Bureau of Mines and Mineral Resources, 94 p.

Griggs, R.L., and Read, C.B., 1959, Revisions in stratigraphic nomenclature in Tucumcari-Sabinoso area, northeastem New Mexico: American Association of Petroleum Geologists Bulletin, v. 43, p. 2003-2007.

Griswold, G.B., 1959, Mineral deposits of Lincoln County, New Mexico: New Mexico Bureau of Mines and Mineral Resources Bulletin $67,117 \mathrm{p}$.

Haines, R.A., 1968, The geology of the White Oaks-Patos Mountain area, Lincoln County, New Mexico: Albuquerque, N. Mex, University of New Mexico Master's thesis, $63 \mathrm{p}$.

Havenor, K.C., 1968, Structure, stratigraphy, and hydrogeology of the northern Roswell artesian basin, Chaves County, New 
Mexico: New Mexico Bureau of Mines and Mineral Resources Circular 93, 30 p.

Hill, C.A., 1987, Geology of Carlsbad Caverns and other caves in the Guadalupe Mountains, New Mexico and Texas: New Mexico Bureau of Mines and Mineral Resources Bulletin 117, $150 \mathrm{p}$.

-1989, The evolution of the Delaware Basin-Preliminary results, in Harris, P.M., and Grover, G.A., eds., Subsurface and outcrop examination of the Capitan shelf margin, northem Delaware Basin: Society of Economic Paleontologists and Mineralogists Cone Workshop No. 13, San Antonio, Texas, p. $467-473$.

1990, Sulfuric acid speleogenesis of Carlsbad Cavern and its relationship to hydrocarbons, Delaware Basin, New Mexico and Texas: American Association of Petroleum Geologists Bulletin, v. 74, no. 11, p. 1685-1694.

Izett, G.A., and Wilcox, R.E., 1982, Map showing localities and inferred distributions of the Huckleberty Ridge, Mesa Falls, and Lava Creek ash beds (Pearlette family ash beds) of Pliocene and Pleistocene age in the Westem United States and southern Canada: U.S. Geological Survey Miscellaneous Investigations Series Map I-1325, scale 1:4,000,000.

Jones, C.L., 1954, The occurrence and distribution of potassium minerals in southeastem New Mexico, in Guidebook of southeastern New Mexico: New Mexico Geological Society, Fifth Annual Field Conference, p. 107-112.

1978, Test drilling for potash resources; Waste Isolation Pilot Plant site, Eddy County, New Mexico: U.S. Geological Survey Open-File Report 78-592, 441 p.

Jones, S.M., 1951, Regional tectonics of the Lincoln-White Oaks, Chupadera Mesa area, in Guidebook, Field trip No. 5, Capitan-Carrizozo-Chupadera Mesa region, Lincoln and Socorro Counties, New Mexico, Nov. 30 and Dec. 1, 1951; Roswell, N. Mex., Roswell Geological Society, p. 12.

Kelley, V.C., 1949, Geology and economics of New Mexico ironore deposits: University of New Mexico Publications in Geology No. 2, 246 p.

1971, Geology of the Pecos Country, southeastern New Mexico: New Mexico Bureau of Mines and Mineral Resources Memoir 24, 72 p.

1972a, Geology of the Fort Sumner Sheet, New Mexico: New Mexico Bureau of Mines and Mineral Resources Bulletin $98,51 \mathrm{p}$.

1972b, Geology of the Santa Rosa area, in Kelley, V.C., and Trauger, F.D., eds., Guidebook of east-central New Mexico: New Mexico Geological Society, Twenty-third Field Conference Guidebook, p. 218-220.

1972c, Outcropping Permian shelf formations of eastem New Mexico, in Kelley, V.C., and Trauger, F.D., eds., Guidebook of east-central New Mexico: New Mexico Geological Society, Twenty-third Field Conference Guidebook, p. 72-78.

Kelley, V.C., and Thompson, T.B., 1964, Tectonics and general geology of the Ruidoso-Carrizozo region, central New Mexico, in Ash, S.R., and Davis, L.V., eds., Guidebook of the Ruidoso Country: New Mexico Geological Society, Fifteenth Field Conference Guidebook, p. 110-121.

Kilmer, L.C., 1987, Water-bearing characteristics of geologic formations in northeastem New Mexico-southeastem Colorado, in Lucas, S.G., and Hunt, A.P., eds., Northeastern New Mexi- co: New Mexico Geological Society. Thirty-eighth Field Conference Guidebook, p. 275-279.

Kottlowski, F.E., 1963. Paleozoic and Mesozoic strata of southwestern and south-central New Mexico: New Mexico Bureau of Mines and Mineral Resources Bulletin 79, $100 \mathrm{p}$.

Kottlowski, F.E., Flower, R.H., Thompson, M.L., and Foster, R.W., 1956, Stratigraphic studies of the San Andres Mountains, New Mexico: New Mexico Bureau of Mines and Mineral Resources Memoir 1, 132 p.

Kottlowski, F.E., and Stewart, W.J., 1970, The Wolfcampian Joyita uplift in central New Mexico: New Mexico Bureau of Mines and Mineral Resources Memoir 23, pt. I, p. 1-31.

Leonard, S.B., and Frye, J.C., 1975, Pliocene and Pleistocene deposits and molluscan faunas, east-central New Mexico: New Mexico Bureau of Mines and Mineral Resources Memoir 30, 44 p.

Lloyd, E.R., 1949, Pre-San Andres stratigraphy and oil-producing zones in southeastem New Mexico: New Mexico Bureau of Mines and Mineral Resources Bulletin 29, $87 \mathrm{p}$.

Lucas, S.G., Cather, S.M., Sealey, P., and Hutchison, J.H., 1989, Stratigraphy, paleontology, and depositional systems of the Eocene Cub Mountain Formation, Lincoln County, New Mexico-A preliminary report: New Mexico Geology, v. 11, p. 11-17.

Lucas, S.G., Hunt, A.P., and Bennett, S.C., 1985a, Triassic vertebrates from east-central New Mexico in the Yale Peabody Museum, in Lucas, S.G., ed., Santa Rosa-Tucumcari region: New Mexico Geological Society, Thirty-sixth Field Conference Guidebook, p. 199-203.

Lucas, S.G., Keitzke, K.K., and Hunt, A.P., 1985b, The Jurassic System in east-central New Mexico, in Lucas, S.G., ed., Santa Rosa-Tucumcari region: New Mexico Geological Society, Thirty-sixth Field Conference Guidebook, p. 213-242.

Mankin, C.J., 1972, Jurassic strata in northeastern New Mexico, in Kelley, V.C., and Trauger, F.D., eds., Guidebook of east-central New Mexico: New Mexico Geological Society, Twentythird Field Conference Guidebook, p. 91-97.

McLemore, V.T., and Phillips, R.S., 1991, Geology of mineralization and associated alteration in the Capitan Mountains, Lincoln County, New Mexico, in Barker, J.M., and others, eds., Geology of the Sierra Blanca, Sacramento, and Capitan Ranges, New Mexico: New Mexico Geological Society, 42nd Annual Field Conference Guidebook, p. 291-298.

Merritt, J.W., 1920, Structures of western Chaves County, New Mexico: American Association of Petroleum Geologists Bulletin, v. 4, no. 1, p. 53-57.

Milner, Sam, 1978, Genesis, provenance, and petrography of the Glorieta Sandstone of eastem New Mexico: New Mexico Bureau of Mines and Mineral Resources Circular 165, 25 p.

Moore, S.L., and Foord, E.E., 1986, Roadlog from Inn of the Mountain Gods to the Ruidoso ski run on Sierra Blanca Peak, in Ahlen, J.L., and Hanson, M.E., eds., Southwest section of American Association of Petroleum Geologists; transactions and guidebook of 1986 convention: New Mexico Bureau of Mines and Mineral Resources, p. 29-36.

Moore, S.L., Thompson, T.B., and Foord, E.E., 1991, Structure and igneous rocks of the Ruidoso region, New Mexico, in Barker, J.M., and others, eds., Geology of the Sierra Blanca, Sacramento, and Capitan Ranges, New Mexico: New Mexico Geological 
Society, 42nd Annual Field Conference Guidebook, p. 137-145.

Mourant, W.A., 1963, Water resources and geology of Rio Hondo drainage basin, Chaves, Lincoln, and Otero Counties, New Mexico: New Mexico State Engineering Technical Report 28, unpaginated.

Mourant, W.A., and Shomaker, J.W., 1970, Reconnaissance of water resources of De Baca County, New Mexico: New Mexico Bureau of Mines and Mineral Resources Ground-Water Report $10,87 \mathrm{p}$.

National Speleological Society, 1986, 1986 National Speleological Society Convention guidebook: Tularosa, N. Mex., p. 19-53.

New Mexico Geological Society, 1982, New Mexico highway geologic map: New Mexico Geological Society, scale $1: 1,000,000$.

Patton, L.T., 1951, Igneous rocks of the Capitan quadrangle, New Mexico and vicinity: American Mineralogist, v. 36, p. 713-716.

Peerman, Steve, and Belski, Dave, 1991, GYPKAP_-Another New Mexico caving project: NSS (National Speleological Society) News, v. 49 , no. 2, p. 57-63.

Perhac, R.M., 1964, Resume of the geology of the Gallinas Mountains, in Ash, S.R., and Davis, L.V., eds., Guidebook of the Ruidoso Country: New Mexico Geological Society, Fifteenth Field Conference Guidebook, p. 87-91.

1970 , Geology and mineral deposits of the Gallinas Mountains, Lincoln and Torrance Counties, New Mexico: New Mexico Bureau of Mines and Mineral Resources Bulletin 95, $51 \mathrm{p}$.

Pertl, D.J., 1984, Geology of the Carrizo Mountains, Lincoln County, New Mexico: Canyon, Texas, West Texas State University Master's thesis, $129 \mathrm{p}$.

Pertl, D.J., and Cepeda, J.C., 1991, The Carrizo Mountain stock and associated intrusions, Lincoln County, New Mexico, in Barker, J.M., and others, eds., Geology of the Sierra Blanca, Sacramento, and Capitan Ranges, New Mexico: New Mexico Geological Society, 42nd Annual Field Conference Guidebook, p. $147-152$.

Pitt, W.D., and Scott. G.L., 1981, Porosity zones of lower part of San Andres Formation, east-central New Mexico: New Mexico Bureau of Mines and Mineral Resources Circular 179, $20 \mathrm{p}$.

Pray, L.C., 1949, Pre-Abo deformation in the Sacramento Mountains, New Mexico [abs.]: Geological Society of America Bulletin, v. 60, p. 1914-1915.

-1954, Outline of the stratigraphy and structure of the Sacramento Mountains escarpment: New Mexico Geological Society, 5th Field Conference Guidebook, p. 92-107.

1961, Geology of the Sacramento Mountains escarpment, Otero County, New Mexico: New Mexico Bureau of Mines and Mineral Resources Bulletin 35, 144 p.

Ramondetta, P.J., 1982, Facies and stratigraphy of the San Andres Formation, northem and northwestem shelves of the Midland Basin, Texas and New Mexico: Austin, Texas, Bureau of Economic Geology, University of Texas Report of Investigations No. $128,56 \mathrm{p}$.

Rawson, D.E., 1957, The geology of the Tecolote Hills area, Lincoln County, New Mexico: Albuquerque, N. Mex., University of New Mexico Master's thesis, $77 \mathrm{p}$.

Reeves, C.C., Jr., 1972, Tertiary-Quatemary stratigraphy and geomorphology of West Texas and southeastern New Mexico, in Kelley, V.C., and Trauger, F.D., eds., Guidebook of east-cen- tral New Mexico: New Mexico Geological Society, Twentythird Field Conference Guidebook, p. 108-117.

Roswell Geological Society, Stratigraphic Studies Commission, 1953, North-south correlation section, western flank of Permian basin, southeastem New Mexico, in Oil and gas fields of southeastern New Mexico: Roswell, N. Mex., Roswell Geological Society Symposium Supplement, 376 p.

1956, West-east correlation section, San Andres Mountains to New Mexico-Texas line, southeastern New Mexico, in Oil and gas fields of southeastern New Mexico: Roswell, N. Mex., Roswell Geological Society Symposium Supplement, 376 p.

Ryberg. G.E., 1968, The geology of the Jicarilla Mountains, Lincoln County, New Mexico: Albuquerque, N. Mex., University of New Mexico Master's thesis, 95 p.

Salyards, S.L., 1991, A possible mid-Holocene age of the Carrizozo malpais from paleomagnetics using secular variation magnetostratigraphy, in Barker, J.M., and others, eds., Geology of the Sierra Blanca, Sacramento, and Capitan Ranges, New Mexico: New Mexico Geological Society, 42nd Annual Field Conference Guidebook, p. 153-157.

Schnake, D.W., 1977, Conditions of formation of the iron-bearing skarns at Lone Mountain, Lincoln County, New Mexico: Socorro, N. Mex., New Mexico Institute of Mining and Technology Master's thesis, $88 \mathrm{p}$.

Smith, A.R., 1980, Sulfur deposits in Ochoan rocks of the Gypsum Plain, southeast New Mexico and west Texas, in Dickerson, P.W., and Hoffer, J.M., eds., Trans-Pecos region, southeast New Mexico and west Texas: New Mexico Geological Society. Thirty-first Field Conference Guidebook, p. 277-283.

Smith, C.T., 1964, Geology of the Little Black Peak quadrangle, Socorro and Lincoln Counties, New Mexico, in Ash, S.R., and Davis, L.V., eds., Guidebook of the Ruidoso Country: New Mexico Geological Society, Fifteenth Field Conference Guidebook, p. 92-99.

Smith, C.T., and Budding, A.J., 1959, Reconnaissance geologic map of Litule Black Peak 15' quadrangle, east half, New Mexico: New Mexico Bureau of Mines and Mineral Resources Geologic Map 11, scale 1:62,500.

Steams, D.W., 1972, Structural interpretation of the fractures associated with the Bonita Fault, in Kelley, V.C., and Trauger, F.D., eds., Guidebook of east-central New Mexico: New Mexico Geological Society, Twenty-third Field Conference Guidebook, p. 161-164.

Sweeting, M.M., 1972, Karst and solution phenomena in the Santa Rosa area, New Mexico, in Kelley, V.C., and Trauger, F.D., eds., Guidebook of east-central New Mexico: New Mexico Geological Society, Twenty-third Field Conference Guidebook, p. 168-170.

Thompson, T.B., 1966, Geology of the Sierra Blanca, Lincoln and Otero Counties, New Mexico: Albuquerque, N. Mex., University of New Mexico Ph. D. dissertation, 146 p.

1968. Hydrothermal alteration and mineralization of the Rialto stock, Lincoln County, New Mexico: Economic Geology, v. 63 , p. $943-949$.

1972, Sierra Blanca igneous complex, New Mexico: Geological Society of America Bulletin, v. 83, no. 8, p. 2341-2356.

1973, Mineral deposits of Nogal and Bonito mining districts. New Mexico: New Mexico Bureau of Mines and Mineral Resources Circular 123, 24 p. 
1991a, The Bonito-Nogal district, Lincoln County, New Mexico: Geological Society of America Abstracts with Programs, v. 23, no. 4, p. 99.

199lb, Genesis of gold associated with alkaline igneous rocks: Geological Society of America Abstracts with Programs, v. 23, no. 4, p. 99-100.

Trauger, F.D., and Bushman, F.X., 1964, Geology and ground water in the vicinity of Tucumcari in Quay County, New Mexico: New Mexico State Engineer, Technical Report 30, 178 p.

Vine, J.D., 1963, Surface geology of the Nash Draw quadrangle, Eddy County, New Mexico: U.S. Geological Survey Bulletin 1141-B, p. B1-B46.

Wanek, A.A., 1962, Reconnaissance geologic map of parts of Harding, San Miguel, and Mora Counties, New Mexico: U.S. Geological Survey Oil and Gas Investigation Map OM-208, scale 1:96,000.

Wasiolek, Maryann, 1991, The hydrogeology of the Permian Yeso Formation within the upper Rio Hondo basin and the eastem
Mescalero Apache Indian Reservation, Lincoln and Otero Counties, New Mexico, in Barker, J.M., and others, eds., Geology of the Sierra Blanca, Sacramento, and Capitan Ranges, New Mexico: New Mexico Geological Society, 42nd Annual Field Conference Guidebook, p. 343-351.

Weber, R.H., 1964, Geology of the Carrizozo quadrangle, New Mexico, in Ash, S.R., and Davis, L.V., eds., Guidebook of the Ruidoso Country: New Mexico Geological Society, Fifteenth Field Conference Guidebook, p. 100-109.

1979, Valley of Fires: New Mexico Geology, v. 1, p. 22-28.

Welder, G.E., 1983, Geohydrologic framework of the Roswell groundwater basin, Chaves and Eddy Counties, New Mexico: New Mexico State Engineer, Technical Report 42, unpaginated.

Yuras, W., 1976, The origin of the Lincoln fold belt, Lincoln County, New Mexico: Socorro, N. Mex, New Mexico Institute of Mining and Technology Master's thesis, $97 \mathrm{p}$.

\section{ERRATUM}

On plate 2, geologic and lithologic cross sections $A-A^{\prime}$ and $B-B^{\prime}$ were modified from Roswell Geological Society $(1953,1956)$. 


\title{
GEOCHEMISTRY OF SEDIMENTS, AND URANIUM IN GROUNDWATER
}

\author{
By James A. Erdman, Ronald R. Tidball, and Richard B. Tripp
}

Two large geochemical databases were available for this part of the mineral resource assessment of the Roswell Resource Area. These databases are from the National Uranium Resource Evaluation (NURE) program of $1^{\circ} \times 2^{\circ}$ quadrangles and from 819 stream-sediment samples from National Forest lands in and near the White Mountain Wilderness Area. The NURE database was selected because its sample sites are fairly evenly distributed throughout the study area. The White Mountain Wilderness Area database covers too small an area for the present study; it was used to assess the mineral potential of the wildemess area (Segerstrom and others, 1979; Segerstrom and Stotelmeyer, 1984).

The NURE Hydrogeochemical and Stream Sediment Reconnaissance Program (HSSR) consisted of sampling surface water, groundwater, and stream, pond, and lake sediments throughout the United States to identify favorable areas for detailed uranium exploration. Los Alamos National Laboratory (LANL), Los Alamos, N. Mex., was responsible for conducting the HSSR program in New Mexico, as well as several other Rocky Mountain States and Alaska, and for analyzing all the samples for uranium. Field-sampling techniques are detailed in Sharp and Aamodt (1978).

Supplemental analyses - that is, analyses of samples for elements other than uranium-were conducted for most of the samples from the study area by the Oak Ridge National Laboratory (ORNL), Oak Ridge, Tenn., and the remainder by LANL (fig. 9). This contribution by two laboratories created difficulties in the data presentation, as described in the following section.

\section{NURE DATABASE}

U.S. Geological Survey $1^{\circ} \times 2^{\circ}$ quadrangles were used as base maps to plot results of the NURE hydrogeochemical and stream-sediment surveys. The study area encompasses parts of nine such quadrangles; the Roswell and Fort Sumner quadrangles are most represented. The NURE data are available for each of these quadrangles in 12 separate reports (Broxton, 1978; LaDelfe, 1981; Los Alamos National Laboratory, 1980, 1981, 1982; Oak Ridge National Laboratory, 1981a-f; Warren and Nunes, 1978). All the NURE databases for all of the $1^{\circ} \times 2^{\circ}$ quadrangles in New Mexico have

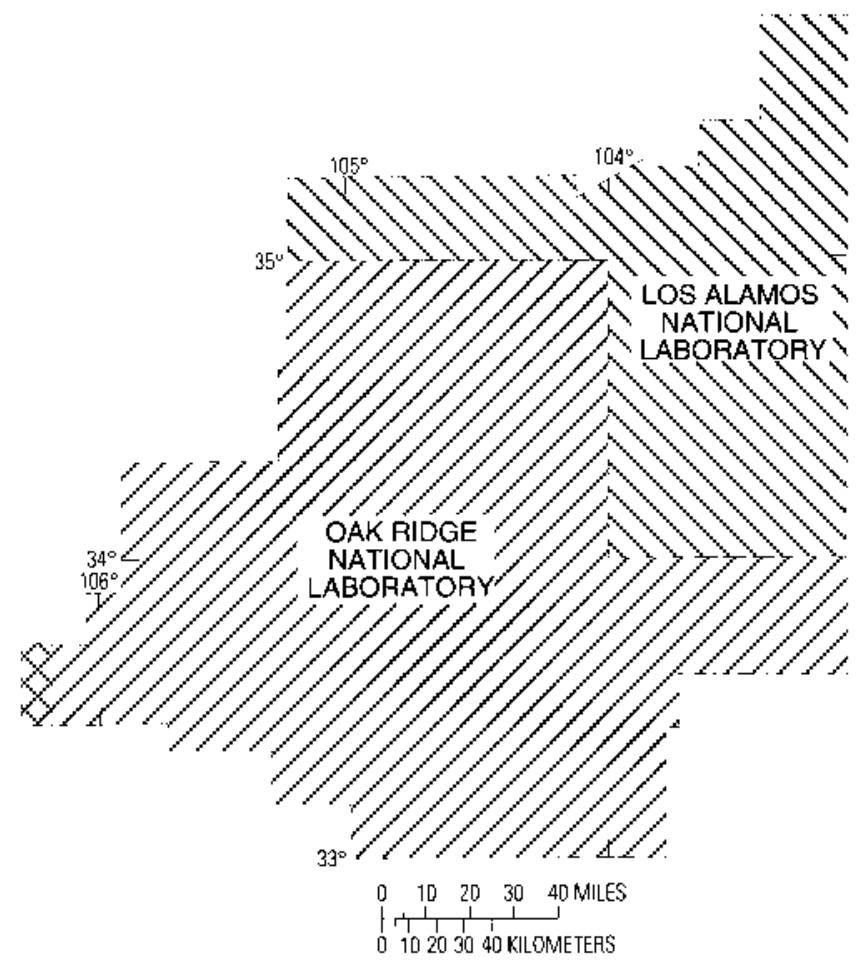

Figure 9. Index to analysts of supplemental analyses (analyses of samples for elements other than uranium), Roswell Resource Area, New Mexico.

recently been made available by the New Mexico Bureau of Mines and Mineral Resources (McLemore and Chamberlin, 1986).

Analyses for 5,872 samples were retrieved from the NURE digital tapes, about one-half were water samples and one-half sediment samples. The 3,059 water samples consisted of five types in two general categories: 165 surfacewater samples (stream, natural pond, and artificial pond), and 2,894 groundwater samples (wells and springs). All water samples were filtered through a 0.45 -micron membrane filter and acidified to the same $\mathrm{pH}$. Because the number of surface-water samples is small and the areal coverage is not uniform, we have not used the surface-water data in this report. Extensive sinkhole (karst) topography in much of the study area limits clearly defined drainage systems. 
Only 84 of the groundwater samples were from springs; these were included with the 2,810 well-water samples.

The 2,813 sediment samples consisted of eight types: dry and wet stream sediments, dry and wet natural-pond sediments, dry and wet artificial-pond sediments, and dry and wet spring sediments. Most of these samples $(1,938)$ were dry stream sediments. All sediment samples were dried at the same temperature and sieved to minus 100 mesh $(0.15$ $\mathrm{mm}$ ); therefore, we combined all eight types into the same database.

The numbers of analyses of the groundwater and sediment actually available were reduced from the above totals because of missing data, and (as in the case of zinc data on sediments analyzed by LANL) because of varying lower limits of determination. Also, groundwater samples are missing from large tracts within the Roswell and Fort Sumner quadrangles in the west-central part of the study area.

All uranium analyses were conducted at LANL. Water samples were initially analyzed for uranium by fluorometry (Hues and others, 1977). Those samples that contained more than 40 parts per billion (ppb) - the upper limit of determination without recalibration-were reanalyzed either by (1) a modification of the basic fluorometric method that not only increased the upper limit of determination but reduced the lower limit of determination in natural waters from 0.50 to $0.02 \mathrm{ppb}$, (2) delayed-neutron counting (DNC), or (3) mass spectrometry-isotope dilution. All sediment samples were analyzed by DNC.

The greatest difficulty in comparing the NURE sediment data arose from the use of different analytical methods for supplemental elements by the two laboratories. LANL used neutron activation analysis, energy dispersive $X$-ray fluorescence (Hansel and Martell, 1977), and arc-source emission spectrography-all total analysis techniques. ORNL, however, used plasma source emission spectrometry as part of a partial-extraction method described by Cagle (1977) and Arendt and others (1979). For this reason, the supplemental databases from the two laboratories had to be statistically analyzed and interpreted separately.

\section{ANOMALY DEFINITION AND DATA PRESENTATION}

We used an empirical rather than statistical approach to define anomalous element concentrations. Except for the groundwater uranium data, lognormal probability plots were constructed for selected elements to show the general distribution and range of the data. Thresholds (Sinclair, 1991) for anomalous element concentrations and potentially different populations in the data were usually chosen from these plots where gaps or breaks-in-slope occurred. For uranium in groundwater, the 90th percentile of the frequency distribution was chosen as the anomalous threshold because no threshold was evident on the probability plot below a clear gap that segregated a few outlying samples from the rest of the population.

Elements whose distribution patterns appear to reflect mineralization or seem to relate to underlying tectonic structures were selected for display in single-element maps. Except for uranium, separate probability plots were generated for each laboratory because different analytical methods were used for sediments analyzed by LANL and by ORNL. As explained above, the methods used by LANL measured total element concentrations whereas the acid-leach method used by ORNL measured only partial concentrations. This difference in analytical methods resulted in consistently lower medians from the latter laboratory. In addition, the same suite of elements was not analyzed by both laboratories because they used different analytical procedures. For example, molybdenum data are only available for sediments analyzed by ORNL, and bismuth data are only available for sediments analyzed by LANL. All uranium analyses were performed at LANL, so the uranium map for sediment samples is based on a single probability plot.

Baseline averages given in the explanations that accompany each sediment map are either geometric means for samples of soils and other surficial materials from the Western United States (Shacklette and Boerngen, 1984) or soil averages cited by Levinson (1980).

Usable data sets consisted of 2,507 uranium analyses of groundwater samples; 2,391 uranium analyses of sediment samples; 2,004 sediment samples analyzed by ORNL for supplemental elements; and 387 sediment samples analyzed by LANL for supplemental elements. The data set for zinc in sediments analyzed by LANL was adjusted to 345 samples because lower limits of determination were highly variable (A.T. Miesch, U.S. Geological Survey, unpublished computer program GXFIXX, 1984). The supplemental data for the groundwater samples were not studied in detail for this report.

\section{SPECIAL HANDLING OF SELECTED SEDIMENT SAMPLES}

Twelve sediment samples were retrieved from the NURE sample archives to help interpret several of the geochemical anomalies shown in the maps described below. These unground, minus 100-mesh samples were split; one split was returned to storage and the other was panned to remove the clay fraction. Residual light minerals that remained in these cleaned sediments were removed by heavy liquid flotation (bromoform, specific gravity 2.8 ). The resultant heavy-mineral concentrate was separated into three fractions using a modified Frantz Isodynamic Separator. The most magnetic material, primarily magnetite, was not analyzed, nor was the slightly magnetic fraction, which contains largely ferromagnesian silicates and iron oxides. The nonmagnetic fraction-the third fraction-which generally 
concentrates ore and ore-related minerals (zircon, sphene, barite, and so forth) was saved for mineralogical analysis. All 12 samples were optically scanned for ore-related minerals, and 4 of the 12 were further studied using the scanningelectron microscope.

\section{RESULTS}

\section{URANIUM IN GROUNDWATER}

\section{IMPLICATIONS FOR MINERAL POTENTIAL}

Levels of uranium in groundwater greater than $98 \mathrm{ppb}$, with one exception, follow a broad north-south zone that lies just east of the Pecos River (pl. 4, map A). These especially anomalous concentrations tend to occur in four clusters, as follows: (1) around San Jon in Quay County; (2) southeast of Cuervo in Guadalupe County; (3) around Urton Lake in De Baca County; and (4) east of Hagerman in Chaves County. The sample that contained the maximum groundwater concentration of $3,078 \mathrm{ppb}$ was taken from a well near the town of Cuervo just south of extensive bluffs of the Upper Triassic Chinle Formation (pl. 4, map $A$ ). The remarkably tight Urton Lake cluster might represent groundwater dispersion of uranium from a nearby deposit in the Chinle Formation at Cibolo Creek (Finch, 1972) and subsequent concentration in the closed depression that drains into the lake. This uraniumladen groundwater most likely originates from outcrops of the Chinle in the area. These red beds are the main source rocks for uranium in the study area and elsewhere in the central Great Plains (Landis, 1960).

Nichols and others (1977) reported that well water was the most reliable sample medium for outlining uranium deposits and, at wider spacing, potential uranium districts in northwest Texas. Their geochemical samples were collected from outcrop areas that included rocks equivalent to the Upper Triassic Dockum Group. In the study area, rocks equivalent to this unit are divisible into the Santa Rosa Sandstone and the Chinle Formation.

Miller and others (1984) agreed that groundwater uranium is often used as a direct indicator for uranium exploration; but they caution: "The presence of groundwater with high concentrations of $U$ is not necessarily an indication of the most favorable site for exploration drilling." Both Nichols and others (1977) and Miller and others (1984) described the geochemical complexity of groundwaters associated with uranium mineralization and stated that uranium enrichment in groundwater simply indicates oxidizing conditions where uranium has been mobilized, not deposited. Favorable sites for stable uranium deposits lie, instead, slightly down the hydrologic gradient from the zone where groundwater changes from oxidizing to reducing conditions. Roll-type deposits may form in a narrow zone where this change occurs.
Multiple groundwater flow systems exist in the study area even within the same formation (Douglas McAda, U.S. Geological Survey, oral commun., 1991). Studies on the groundwater head distribution in the Pecos River Basin show that groundwater flows updip, downdip, and across lithologic or stratigraphic boundaries (Summers, 1981). The effects of these flow systems on the groundwater uranium distribution are beyond the scope of this basically descriptive report.

The important aquifers, however, differ spatially across the study area. According to Dinwiddie and Clebsch (1973), the main aquifers in Guadalupe County are in the consolidated sedimentary rocks of the Yeso Formation, Glorieta Sandstone, San Andres Formation, Bernal(?) Formation, Santa Rosa Sandstone, and Chinle Formation; the San Andres is most likely to yield water to wells in quantities sufficient for municipal supply or for irrigation use. Mourant and Shomaker (1970), on the other hand, reported that in De Baca County to the south, the Santa Rosa, not the San Andres, yields large amounts of water to wells for municipal and irrigation purposes. In Quay County, Quaternary alluvial deposits, the Tertiary Ogallala Formation, and the Jurassic Exeter Sandstone are the only units that yield large amounts of water to wells (Berkstresser and Mourant, 1966). In southeastern New Mexico, the Ogallala aquifer is the sole source of potable groundwater (Stephens and Spalding, 1984). Because the Ogallala Formation contains lowgrade uranium deposits, all of these aquifers could serve as conduits for the mobilized uranium, especially east of the Pecos River where the groundwater tends to become more alkaline and saline-conditions under which uranium is extremely mobile (Wanty and Schoen, 1991, p. 186-188).

\section{IMPLICATIONS FOR HUMAN HEALTH}

The maximum uranium concentration measured in the NURE groundwater samples in the study area is $3,078 \mathrm{ppb}$. Most natural waters contain uranium at concentrations between 0.1 and $10 \mathrm{ppb}$. Levels of more than $1,000 \mathrm{ppb}$ can occur in water associated with uranium-ore deposits (Hem, 1985, p. 148). The human health standard for dissolved uranium in groundwater adopted by the state of New Mexico is 5,000 ppb (New Mexico Water Quality Control Commission, 1988). However, recent recommendations by a U.S. Environmental Protection Agency (EPA) committee set a 100-ppb limit in groundwater; this limit was based on the heavy-metal toxicity of natural uranium to the kidneys (Wrenn and others, 1985, 1987). This recommended limit approximates the 99th percentile of the groundwater uranium abundant in the study area.

Interim guidelines released by the EPA in June 1991 (U.S. Environmental Protection Agency, 1991) are even more stringent. As a result of the proposed maximum contaminant level (MCL) of $20 \mathrm{ppb}$ uranium, about 1 in 10 of the groundwater samples in the Roswell Resource Area, 
especially those from the Pecos River valley region, exceed the primary drinking water standard. [MCL is a level (concentration) of contaminant that might cause adverse human health effects if exceeded, and is enforceable for public drinking-water supplies.] All of these anomalous samples probably reflect uranium that resides in the Chinle Formation.

\section{URANIUM IN SEDIMENTS}

Wrenn and others (1987) reported that soils in the United States typically contain from 1 to $4 \mathrm{ppm}$ uranium. The upper limit of that range approximates the background threshold (90th percentile) of $3.3 \mathrm{ppm}$ for uranium in sediments from the study area.

Most sediments containing anomalous uranium concentrations occur at sites that parallel outcrops of the Capitan Mountains intrusive or Precambrian crystalline rocks exposed in the Oscura Mountains (pl. 4, map B). An array of uraniferous sediments around the Capitan Mountains intrusion may represent, in part, detritus shed from thoriumuranium-rare-earth veins and uranium-iron veins that cut Tertiary alaskite (McLemore and Chenoweth, 1989), although the distribution seems to indicate fairly uniform concentrations throughout the stock. Minor uranium anomalies occur in sediments at the headwaters of Rio Bonito, around White Oaks, and south of Gallinas Peak. Consistently high uranium concentrations are found in sediments along the northwest-trending, thin outcrop belt of Precambrian rocks along the west flank of the Oscura Mountains.

Many anomalous levels of uranium also occur in sediments that were probably derived from extensive outcrops of the Chinle Formation north of Santa Rosa. A widely spaced dispersion train of enriched sediments follows the floodplain of the Pecos River.

The most puzzling anomaly consists of a roughly linear suite of samples-five of which contain very high concentrations of uranium-in the southeastern corner of the study area. This apparent feature extends from Long Arroyo northeastward to Little Salt Lake and Salt Lake on the New Mexico-Texas border (pl. 4, map B). It lies on the north side of the projected strike of the K-M fault, a structure that penetrates basement rocks. According to D.M. Kulik (oral commun., July 1991), relatively steep and linear gravity gradients indicate that this fault probably extends northeastward to a northwest-trending gradient that marks the Roosevelt County fault.

The K-M fault may serve as a conduit for the migration of uranium-enriched brines produced from underlying Pennsylvanian and Permian formations. The sedimentary section in and around the Delaware Basin to the south contains vast quantities of hydrocarbons. In a study on the relationship between uranium and the diagenesis of rocks of the Lower Pennsylvanian Morrowan Series, which produce a hydrocarbon reservoir in southeastem New Mexico, Denham and others (1989) stated: "In general, rocks rich in organic matter-potential hydrocarbon source rocks-are enriched in uranium and thorium. During thermal maturation of hydrocarbon source rocks, uranium is released to migrate with pore fluids prior to and during hydrocarbon migration.*** Thorium remains essentially immobile."

Even though uranium should be extremely mobile in the alkaline and saline aqueous systems common to the area, it may adsorb to clays in surficial sediments after migrating in pore fluids along the $\mathrm{K}-\mathrm{M}$ fault.

\section{LITHIUM IN SEDIMENTS}

The most lithium-enriched sediments occur along a northeast-trending zone (pl. 4, map $C$ ) along the possible extension of the K-M fault, similar to the pattern reported for uranium in sediments. Their distribution supports the possibility that deep-seated brines associated with hydrocarbon reservoirs are leaking to the surface through the K-M fault. Supplemental data for groundwater samples are only available for most of the area covered by ORNL (see fig. 9); nevertheless, lithium concentrations in well-water samples in the southeastern part of the study area and east of the Pecos River are almost consistently high. Thus, the surface lithium anomalies are supported by groundwater lithium anomalies for approximately the same area.

Oil-field brines are among several hydrologic environments cited by Mertz and others (1974) that concentrate lithium. Vine (1980) suggested that the exploration for lithium brines may be warranted in Permian basins of the United States where the sequence of evaporite beds is known to include potash minerals. Potash is mined and processed in Eddy and Lea Counties in the Permian Delaware Basin just south of the study area, and numerous oil and gas fields occur in the southeast corner of the study area.

The source of the lithium and of the possibly associated uranium anomalies in sediments from this area is equivocal pending more detailed studies of the underlying structures.

\section{SIL VER IN SEDIMENTS}

Few of the sediment samples from the study area contain detectable silver ( $\mathrm{pl}, 4$, map $D$ ) because of the relatively poor sensitivity of the analytical methods used by LANL and ORNL. Therefore, any measurable silver is anomalous.

The silver anomalies can be attributed to the following sources: (1) lode or placer gold occurrences, (2) polymetallic veins, (3) porphyry molybdenum deposits, (4) veins in Precambrian rocks in the Oscura Mountains, or (5) sedimentary red beds of Triassic age; the first three of these sources are related to Tertiary stocks in the Nogal mining district. A 4ppm silver anomaly occurs in sediment from the Nogal district, which lies at the headwaters of Rio Bonito between the Capitan Mountains and the White Mountain Wilderness Area. Although the Nogal district is primarily a lode gold district, four molybdenum anomalies (pl. 4, map $E$ ) centered 
along the South Fork of Rio Bonito were described by Segerstrom and others (1979). Molybdenum deposits can also carry silver, but small polymetallic deposits found in the district are characterized by lead-zinc-silver minerals in simple fissure veins (Griswold, 1959).

The sediment sample that contains the highest silver value ( $9 \mathrm{ppm})$ was collected from the south flank of the Capitan Mountains below Capitan Peak. A lead concentration of $442 \mathrm{ppm}$, well above a norm of $17 \mathrm{ppm}$ for soils from the Western United States, was also reported in this sample. The source of this extreme silver-lead anomaly might be either polymetallic veins or contamination from lead shot. A scan by electron microscopy of the heavy-mineral concentrates prepared from this sample found no lead mineral, but barite was present.

East of the Pecos River, sedimentary rocks are the probable source of the silver anomalies shown in plate 4 , map $D$. Lindgren (1932) reported that copper ores, which often carry high assays of silver, are widely distributed in the red beds of the southwestem United States.

The adjacent 4-ppm silver anomalies in sediment samples near Sumner Lake Reservoir in the north-central part of the study area as well as the 3-ppm and associated unposted anomalies east of Red Lake in Chaves County (pl. 4, map D) probably reflect mineralized outcrops of the Upper Triassic Chinle Formation. McLemore and North (1985) listed silver as a commodity commonly associated with widespread uranium occurrences in the Chinle Formation of east-central New Mexico. An optical microscopic scan of the heavymineral concentrates prepared from the two sediments containing $4 \mathrm{ppm}$ silver failed to identify any heavy minerals that might account for the silver anomaly.

\section{GOLD IN SEDIMENTS}

Gold was determined only in those sediments that were analyzed by LANL; coverage for this important element therefore is limited. The varying lower detection limits of $20-150 \mathrm{ppb}$ by neutron activation analysis were well above the 1-ppb concentration normally found in soils. However, highly anomalous gold was found in three samples from Quay County (pl. 4, map D). The highest value $(720 \mathrm{ppb})$ came from a wet-spring sediment in a tributary to Ute Reservoir on the Canadian River, on the western edge of the Logan mining district as shown in North and McLemore (1986). Although no precious-metal production was reported for the district, gold occurs with pyrite in shale beds of stratabound sedimentary-copper deposits of the Upper Triassic Chinle Formation (North and McLemore, 1986). A dry-stream sediment near the head of Barranca Creek northeast of Ragland yielded $270 \mathrm{ppb}$ gold and anomalous barium $(1,660 \mathrm{ppm})$, and a natural wet-pond sediment from a tributary of Barranca Creek east of Mesa Redonda contained $200 \mathrm{ppb}$ gold. These latter two samples were collected about 5 and $12 \mathrm{mi}$ west and southwest, respectively, from the Red Peak mining district, where argentiferous chalcocite nodules and stratabound sedimentary-copper deposits occur in middle and upper units of the Chinle Formation (North and McLemore, 1986). All three sites occur where the Chinle Formation crops out.

\section{MOLYBDENUM IN SEDIMENTS}

Molybdenum was not determined in samples analyzed at LANL. However, because of its importance (particularly in the porphyry belt of Lincoln County) and its association with silver, we have included a map that locates samples with detectable (anomalous) molybdenum in samples analyzed by ORNL (pl. 4, map E). Locations of anomalous molybdenum levels in sediments generally correspond with those shown on the silver map (pl. 4, map $D$ ), however, no molybdenum anomalies were found in the Oscura Mountains.

The molybdenum-enriched sediments at the headwaters of Rio Bonito in the southwestern part of the study area (5-9 ppm, pl. 4, map E) probably were shed from the Three Rivers stock. This stock contains four of the five significant molybdenum anomalies described by Segerstrom and others (1979, p. 18-19, pl. 2) for the White Mountain Wilderness area. Although no molybdenum has been mined, its widespread occurrence in the syenitic rocks led these authors to conclude that molybdenum is by far the most likely mineral resource to be found in the wildemess area and vicinity.

The pair of unposted anomalous samples east of Sumner Lake Reservoir also contained anomalous concentrations of silver, and most likely derive from mineralized red beds of the Chinle Formation that form limited or extensive outcrops locally. No molybdenum minerals were identified in the heavy-mineral concentrates prepared from the sediments, however.

The largest molybdenum anomalies found in the NURE survey make up the cluster that lies along the east-central edge of Chaves County east of Red Lake where the concentrations range from 5 to $17 \mathrm{ppm}$. The molybdenum content of surface waters from this area also tends to be anomalous (maximum, $274 \mathrm{ppb}$ ) compared to surface waters sampled elsewhere. An additional cluster of anomalous sediments occurs in the southeastern corner of Chaves County east of Hagerman. Extensive exposures of the Chinle crop out at Red Lake and along the Mescalero Ridge to the south, and the NURE results suggest that these exposed rocks are mineralized.

\section{BARIUM IN SEDIMENTS}

Sediment samples that contain elevated levels of barium are numerous and extensive in the study area (pl. 4, map $F$ ). Nevertheless, focus is drawn to several parts of the map, and especially to the porphyry belt and associated Tertiary stocks of Lincoln County. The source of the three-site cluster of posted values that lies east of White Oaks may be vein 
barite from the Fox Lode prospect or related barite occurrences (see "Vein barite" section, this report). Abundant barite was identified in a heavy-mineral concentrate prepared from a split of the sediment that contained $1,486 \mathrm{ppm}$ barium. In the Nogal district to the south where high concentrations of barium in sediments are also found, barite occurs as an accessory mineral in polymetallic veins. Another cluster of barium-enriched sediments lies to the north in the Pajaro Canyon area near the Gallinas district. The barium source may be barite gangue found with fluorite and the rare-earth mineral, bastnaesite, in the nearby Gallinas Mountains.

Several clusters of anomalous barium lie east of the Pecos River. From south to north, these clusters center on (1) the Red Lake area, east of Palma Mesa in Chaves County, which contains silver, molybdenum, lithium, and uranium anomalies, (2) the Hemandez Draw and Sixmile Draw area, and (3) the Taiban Mesa area east of Fort Sumner in De Baca County.

The Chinle Formation or, possibly, the underlying Santa Rosa Sandstone appears to be the source of these barium anomalies east of the Pecos River. Small amounts of barite frequently occur in mineralized Triassic red beds (Lindgren, 1932). However, barite commonly forms a cement in sandstone beds of this age and may be unrelated to any significant mineral occurrences (W.I. Finch, oral commun., 1991).

\section{COPPER IN SEDIMENTS}

Anomalous concentrations of copper occur in sediments that are, for the most part, widely scattered. Some conspicuous multiple-point anomalies appear only in the extensively mineralized Lincoln County (pl. 4, map $G$ ). The weak cluster of anomalies located in the extreme southeastern comer of Roosevelt County remains unexplained. Although the source of the copper anomalies in Lincoln and Roosevelt Counties (and associated zinc anomalies shown in pl. 4, map $H$ ) is highly uncertain, it may relate to oil and, to a lesser extent, gas production.

Major producing oil and gas fields in the region occur in the San Andres Formation (Grant and Foster, 1989). Copper sulfides are reported to have been found in drill core from related oil and gas wells; thus, the copper anomalies in surface sediments reported here could indicate leakage from hydrocarbon reservoirs. Very limited evidence of this possibility comes from a well-water sample a few miles northwest of the posted anomaly of $129 \mathrm{ppm}$ in the southeastem part of the study area. The water sample had a highly anomalous copper concentration of $261 \mathrm{ppb}$, the sixteenth highest sample in a suite of 1,308 samples.

An alternative explanation for these copper and zinc anomalies may be leakage from possible underlying Mississippi-Valley-type lead-zinc deposits. Two deposits in New Mexico that may be oxidized Mississippi-Valley-type deposits (North and McLemore, 1986) occur just south of the study area near Artesia and Carlsbad adjacent to the Permian Basin. The deposits are restricted to collapse breccias in Permian dolomite and clastic sedimentary rocks. The Red Lake deposit east of Artesia consists of secondary copper, lead, and zinc in the Permian Rustler Formation. However, as North and McLemore (1986) explained, these two known deposits are small.

Copper is commonly found with uranium in clastic red beds throughout New Mexico (McLemore and North, 1985). This appears to be the source of the two anomalous samples (47 and 66 ppm) between Tucumcari and San Jon in Quay County, an area mapped as Chinle Formation. Two other copper anomalies (134 and $143 \mathrm{ppm}$ ) were found in sediments collected from the Minneosa Creek drainage in the northeastern part of Quay County. These occur downstream from small outcrops of the Jurassic Morrison Formation.

An outlier copper anomaly (981 ppm) comes from Salado Creek west of Sumner Lake Reservoir. From 1915 to 1957, 13 million pounds of copper were mined from the lower member of the Santa Rosa Sandstone in the Pastura district about $25 \mathrm{mi}$ to the northwest. Most of the production came from one deposit, the Stauber mine. Some copper, however, was also hosted in the Queen Formation (Artesia Group) at the Pintada mine. The Santa Rosa Sandstone crops out in the Salado Creek drainage and thus may host local copper deposits. Barite was identified in the heavy-mineral concentrate prepared from the sediment, but no copper sulfides were found, suggesting that the copper resides as chalcocite, an oxide mineral commonly found in copper-bearing red beds (Lindgren, 1932).

\section{ZINC IN SEDIMENTS}

Zinc anomalies in sediments (pl. 4, map $H$ ) are even more sparse than are those for copper in the study area (pl. 4, map $G$ ). The following descriptions are limited to a few of the more interesting anomalies.

A cluster of three anomalous samples occurs in Quay County in the northeast comer of the study area (pl. 4, map $H$ ). Two prospects among the many deposits listed for the county by McLemore and North (1985) reported uranium and (or) copper production. The Chinle Formation crops out where two of the sediments containing 1,290 and $178 \mathrm{ppm}$ were sampled, and Quatemary pediment gravel that thinly covers the Chinle is mapped where the third sample was collected. Zinc occurs locally in some red-bed sedimentary copper-uranium deposits (McLemore and North, 1985).

In De Baca County just south of Salado Creek, a highly organic-rich sediment contained 1,637 ppm zinc, the second highest zinc concentration. The zinc may have formed a chemical complex with the organic material. On the other hand, the proximity of this sample to the extreme copper anomaly in sediment from Salado Creek (pl. 4, map $G$ ) may indicate a local mineralized source that could be an offshoot of the Pastura district. 
Lastly, the strong multiple-point, posted anomaly in the southeastern corner of Roosevelt County overprints the copper anomaly from the same area. High terrace gravels cover an almost featureless terrain. Numerous oil fields lie just to the south, and ephemeral ponds abound to the north. As with the associated copper anomalies, these zinc anomalies have no clear explanation, but suggest migration from a deepseated source such as underlying Permian red beds.

\section{THORIUM IN SEDIMENTS}

Notably few anomalous concentrations of thorium were found in the sediments from the study area (pl. 4, map $I$ ). A single-point anomaly (19 ppm) on the north side of the Capitan Mountains coincides with small thorium-rare-earth veins known to occur in this Tertiary pluton (Phillips and others, 1990). The anomalous site lies near the Bonito fault, a major northeast-trending fault that bisects the intrusive. A heavy-mineral concentrate prepared from the sediment sample did contain an unidentified thorium-rich mineral, as well as barite, and the rare-earth minerals, allanite and monazite.

A major cluster of thorium-rich sediments follows the west flank of the Oscura Mountains along one exposure of Precambrian rocks in the study area. Felsic igneous rocks characteristically contain thorium and rare-earth minerals.

We have no reasonable explanation for the source of the thorium anomalies associated with red beds of the Chinle Formation near Taiban Mesa east of Fort Sumner. Heavymineral concentrates prepared from the anomalous sediments from the Taiban Mesa area were scanned by optical and electron microscopy. Barite was identified, but no thorium mineral. The multiple-element anomalies in sediments around Taiban Mesa may be a surface expression of mineralized rocks at the juncture of deeply penetrating northeastand northwest-trending faults. Taiban Mesa lies approximately on strike with projections of the Bonita fault, Roosevelt County fault, and Border buckle. Interpretation of the gravity data for this report has extended the buckles northeastward across much of the study area.

\section{CERIUM IN SEDIMENTS}

The distribution of high concentrations of cerium in sediments coincides with the outcrop of both Precambrian and Tertiary igneous rocks in the study area (pl, $4, \operatorname{map} J$ ). A plot of another light-rare-earth element, lanthanum, produced an identical pattern.

Rare-earth-rich sediments are derived from very pure felsic rocks, possibly granite or rhyolite. Precambrian rocks, predominantly pink granite gneiss, are best exposed outside of the study area in the Pedernal Hills west of Vaughn, but small exposures (not shown on plate 1) crop out on the west flank of the Oscura Mountains and north of Gallinas in Lincoln County. The closely spaced pair of unposted cerium anomalies located west of Gallinas may represent contamination from the mining of the rare-earth mineral, bastnaesite, in the Red Cloud copper and fluorite mines upstream.

The most obvious cluster of cerium anomalies derives from sediments east of the Bonito fault, which bisects the Capitan Mountains intrusive (pl. 1); a dispersion train trails eastward from the intrusive to the Pecos Slope. Sources of this rare-earth element are probably the rare-earth minerals, allanite and monazite, identified in the concentrate prepared from the only thorium-rich sediment from the Capitan Mountains described in the preceding section. Allanite has been mentioned as occurring in thorium-uranium-rareearth-element quartz-fluorite veins of the pluton (McLemore, 1983; Willis and others, 1989; Phillips and others, 1990). A cluster of highly enriched potassium sediments is associated with the Capitan Mountains; anomalous values follow the same pattem east of the fault as that found for cerium and lanthanum.

These higher concentrations of cerium and lanthanum in sediments toward the eastern end of the Capitan Mountains are probably derived from thorium-uranium-rareearth-element quartz-fluorite veins of the Capitan Mountains intrusive (Phillips and others, 1990). The distinct geochemical difference between sediments on either side of the Bonito fault may be related to the deeper level of exposure of the eastern part of the Capitan Mountains intrusive and to erosion and concentration of elements from the rare-earth-bearing veins that once occurred on the periphery of the eastern side of the pluton. These geochemical differences may be important in assessment of the rare-earth-element potential of the Capitan intrusive.

\section{VANADIUM IN SEDIMENTS}

Vanadium is part of a suite of elements (vanadium, arsenic, selenium, and molybdenum) in groundwater that can serve as pathfinders for uranium occurrences (Nichols and others, 1977). Some vanadium was produced along with uranium from the Little Rattler and Good Luck mines near San Jon, Quay County (McLemore and North, 1985, table 3; Breit, "Vanadium" section, this report), but nowhere else in the study area. Several clusters of vanadium-rich sediments from the study area, therefore, may represent vanadiferous uranium occurrences. These clusters are located where the Chinle Formation is exposed, and include the Taiban Mesa area, the area around Sixmile and Hernandez Draws, and the Red Lake-Long Arroyo area to the south (pl. 4, map $K$ ). Vanadium-rich sediments are relatively insoluble in the clay fraction of sediments and therefore do not necessarily correlate with uranium-rich sediments.

Larger vanadium anomalies are found in the southern part of the porphyry belt and near the Oscura Mountains in Lincoln County. Here, the more likely source may be either magnetite from the numerous iron deposits in the county (Griswold, 1959) or vanadiferous ilmenite, a titanium-iron oxide mineral. The focal points of the vanadium-enriched 
sediments tend to be (1) near faults in the Oscura Mountain region and (2) Tertiary volcanic flows just west of the White Mountain Wilderness Area. The pattern of anomalous titanium concentrations in sediments closely matches that of anomalous vanadium in Lincoln County and in the area around Sixmile and Hernandez Draws in Chaves County.

\section{SUMMARY}

The NURE geochemical data have identified distribution patterns of ore-related elements on a fairly broad regional scale. The data have also been useful in identifying (1) locally anomalous areas that may relate to mineralization and (2) possibly underlying structures that served as conduits for metal-rich fluids. At least some of the local anomalies identified herein, such as the Taiban Mesa and the Red Lake areas, should be studied in more detail and evaluated for possible new mineral occurrences.

A significant aspect of the groundwater uranium results is related to potential hazards to human health rather than mineral resource assessment. The maximum contaminant level of $20 \mathrm{ppb}$ proposed by the U.S. Environmental Protection Agency in June 1991 could impact a number of public drinking-water supplies that might exceed the standard.

\section{ACKNOWLEDGMENTS}

We thank U.S. Geological Survey colleagues G.A. Nowlan for the initial data retreival, D.E. Owen for providing timely references on groundwater uranium standards, J.M. Nishi for conducting the scans of selected heavymineral concentrates by electron microscopy, and Douglas McAda and Scott Anderholm for providing helpful advice on groundwater flow systems and geochemistry. John Boxton, Los Alamos National Laboratory, Los Alamos, N. Mex., clarified analytical and operational procedures used during the NURE program. Richard Chamberlin, New Mexico Bureau of Mines and Mineral Resources, Socorro, N. Mex., contributed some helpful advice in interpreting anomalies in the southeastern part of the study area.

\section{REFERENCES CITED}

Arendt, J.W., Butz, T.R., Cagle, G.W., Kane, V.E., and Nichols, C.E., 1979, Hydrogeochemical and stream sediment reconnaissance procedures of the National Uranium Resource Evaluation Project: Oak Ridge, Tenn., Union Carbide Corporation, Nuclear Division, Oak Ridge Gaseous Diffusion Plant, Report No. GBX-32(80), 56 p.

Berkstresser, C.F., Jr., and Mourant, W.A., 1966, Ground-water resources and geology of Quay County, New Mexico: New Mexico Bureau of Mines and Mineral Resources Ground-Water Report 9,115 p.
Broxton, D.E., 1978, Uranium hydrogeochemical and stream sediment reconnaissance of the Tularosa NTMS quadrangle, New Mexico: U.S. Department of Energy Report No. GJBX-104(78), 85 p. [Available from U.S. Geological Survey Books and Open-File Reports Section, P.O. Box 25425, Denver, CO 80225.]

Cagle, G.W., 1977, The Oak Ridge analytical program, in Symposium on hydrogeochemical and stream sediment reconnaissance for uranium in the United States, March 16 and 17, 1977: Grand Junction, Colo., U.S. Energy Research and Development Administration, Report No. GJBX-77(77), p. 133-156. [Available from U.S. Geological Survey Books and Open-File Reports Section, P.O. Box 25425, Denver, CO 80225.]

Denham, M.E., Niemann. M.H., and Tieh, T.T., 1989, The occurrence of uranium as related to the diagenesis of the Morrow Sandstone, Empire South Field, Eddy County, New Mexico, in Flis, J.E., Price, R.C., and Sarg, J.F., eds., Search for the subtle trap, Hydrocarbon exploration in mature basins: West Texas Geological Society Publication No. 89-85, p. 243-254.

Dinwiddie, G.A., and Clebsch, Alfred, Jr., 1973, Water resources of Guadalupe County, New Mexico: New Mexico Bureau of Mines and Mineral Resources Hydrologic Report 3, 43 p.

Ellinger, S.T., and Cepeda, J.C., 1991, A geochemical survey of ferrous and selected base metals in the eastern half of the Capitan Mountains, Lincoln County, New Mexico, in Barker, J.M., and others, eds., Geology of the Sierra Blanca, Sacramento, and Capitan Ranges, New Mexico: New Mexico Geological Society, 42nd Annual Field Conference Guidebook, p. 299-304.

Finch, W.I., 1972, Uranium in eastem New Mexico, in Kelley, V.C., and Trauger, F.D., eds., Guidebook of east-central New Mexico: New Mexico Geological Society, Twenty-third Field Conference, p. 171-175.

Grant, P.R., Jr., and Foster, R.W., 1989, Future petroleum provinces in New Mexico-Discovering new reserves: Socorro, $\mathbf{N}$. Mex., Altas prepared for the New Mexico Research and Development Institute by the New Mexico Bureau of Mines and Mineral Resources, $94 \mathrm{p}$.

Griswold, G.B., 1959, Mineral deposits of Lincoln County, New Mexico: New Mexico Bureau of Mines and Mineral Resources Bulletin 67, $117 \mathrm{p}$.

Hansel, J.M., and Martell, C.J., 1977, Automated energy-dispersive $\mathrm{X}$-ray determination of trace elements in streams: U.S. Department of Energy Report No. GJBX-52(77), 8 p. [Available from U.S. Geological Survey Books and Open-File Reports Section, P.O. Box 25425, Denver, CO 80225.]

Hem, J.D., 1985, Study and interpretation of the chemical characteristics of natural water: U.S. Geological Survey WaterSupply Paper 2254, 263 p.

Hues, A.D., Henicksman, A.L., Ashley, W.H., and Romero, D., 1977. The fluorometric determination of uranium in natural waters: U.S. Department of Energy Report No. GJBX-24(77), 11 p. [Available from U.S. Geological Survey Books and Open-File Reports Scction, P.O. Box 25425, Denver, CO 80225.]

LaDelfe, C.M., 1981, Detailed geochemical survey data release for the San Andres-Oscura Mountains special study area, New Mexico: U.S. Department of Energy Report No. GJBX-215(81), 91 p. [Available from U.S. Geological Survey 
Books and Open-File Reports Section, P.O. Box 25425, Denver, CO 80225.]

Landis, E.R., 1960, Uranium content of ground and surface waters in a part of the central Great Plains: U.S. Geological Survey Bulletin 1087-G, p. 223-258.

Levinson, A.A., 1980, Introduction to exploration geochemistry, second edition: Wilmette, Ill., Applied Publishing Ltd., 924 p.

Lindgren, Waldemar, 1932, Mineral deposits, fourth edition: New York, McGraw-Hill Book Co., Inc., 930 p.

Los Alamos National Laboratory, 1980, Uranium hydrogeochemical and stream sediment reconnaissance data release for the Santa Fe NTMS quadrangle, New Mexico: U.S. Department of Energy Report No. GJBX-197(80), 135 p. [Available from U.S. Geological Survey Books and Open-File Reports Section, P.O. Box 25425, Denver, CO 80225.]

- 1981 , Uranium hydrogechemical and stream sediment reconnaissance of the Tucumcari NTMS quadrangle, New Mexico/Texas: U.S. Department of Energy Report No. GJBX-183(81), 79 p. [Available from U.S. Geological Survey Books and Open-File Reports Section, P.O. Box 25425, Denver, $\mathrm{CO} 80225$.]

- 1982, Uranium hydrogeochemical and stream sediment reconnaissance of the Clovis NTMS quadrangle, New Mexico: U.S. Department of Energy Report No. GJBX-184(82), 92 p. [Available from U.S. Geological Survey Books and Open-File Reports Section, P.O. Box 25425, Denver, CO 80225.]

McLemore, V.T., 1983, Uranium and thorium occurrences in New Mexico-Distribution, geology, production, and resources, with selected bibliography: New Mexico Bureat of Mines and Mineral Resources Open-file Report 183, 174 p.

McLemore, V.T., and Chamberlin, R.M., 1986, National Uranium Resource Evaluation (NURE) data: Socorro, N. Mex., New Mexico Bureau of Mines and Mineral Resources, $10 \mathrm{p}$.

McLemore, V.T., and Chenoweth, W.L., 1989, Uranium resources in New Mexico: New Mexico Bureau of Mines and Mineral Resources Resource Map 18, scale 1:1,000,000,36 p.

McLemore, V.T., and North, R.M., 1985, Copper and uranium mineralization in east-central New Mexico, in Lucas, S.G., ed., Santa Rosa-Tucumcari region: New Mexico Geological Society, 36th Field Conference Guidebook, p. 289-299.

Mertz, Walter, Angino, E.E., Cannon, H.L., Hambidge, K.M., and Voors, A.W., 1974, Lithium, in Geochemistry and the environment, v. 1, The relation of selected trace elements to health and disease: Washington, D.C., National Academy of Sciences, p. 36-42.

Miller, W.R., Wanty, R.B., and McHugh, J.B., 1984, Application of mineral-solution equilibria to geochemical exploration for sandstone-hosted uranium deposits in two basins in west central Utah: Economic Geology, v. 79, p. 266-283.

Mourant, W.A., and Shomaker, J.W., 1970, Reconnaissance of water resources of De Baca County, New Mexico: New Mexico Bureau of Mines and Mineral Resources Ground-Water Report $10,87 \mathrm{p}$.

New Mexico Water Quality Control Commission, 1988, New Mexico Water Quality Control Commission regulations, as amended through November 25, 1988: Santa Fe, N. Mex., Water Quality Control Commission 82-1, Amendment No. 4, p. 21.

Nichols, C.E., Kane, V.E., and Cagle, G.W., 1977, National Uranium Resource Evaluation Program; Regional geochemical model for groundwater associated with uranium mineralization in northwest Texas: Oak Ridge, Tenn., Union Carbide Corporation, Nuclear Division, Oak Ridge Gaseous Diffusion Plant, Report No. GJBX-93(77), 26 p.

North, R.M., and McLemore, V.T., 1986, Silver and gold occurrences in New Mexico: New Mexico Bureau of Mines and Mineral Resources Resource Map 15, scale 1:1,000,000, 32 p.

Oak Ridge National Laboratory, 1981a, Hydrogeochemical and stream sediment reconnaissance basic data for Brownfield quadrangle, New Mexico, Texas: U.S. Department of Energy Report No. GJBX-319(81), 81 p. [Available from U.S. Geological Survey Books and Open-File Reports Section, P.O. Box 25425, Denver, CO 80225.]

$198 \mathrm{lb}$, Hydrogeochemical and stream sediment reconnaissance basic data for Carlsbad quadrangle, New Mexico: U.S. Department of Energy Report No. GJBX-415(81), 191 p. [Available from U.S. Geological Survey Books and Open-File Reports Section, P.O. Box 25425, Denver, CO 80225.]

1981c, Hydrogeochemical and stream sediment reconnaissance basic data for Fort Sumner quadrangle, New Mexico: U.S. Department of Energy Report No. GJBX-395(81), 161 p. [Available from U.S. Geological Survey Books and Open-File Reports Section, P.O. Box 25425, Denver, CO 80225.]

-1981d, Hydrogeochemical and stream sediment reconnaissance basic data for Hobbs quadrangle, New Mexico: U.S. Department of Energy Report No. GJBX-288(81), 91 p. [Available from U.S. Geological Survey Books and Open-File Reports Section, P.O. Box 25425, Denver, CO 80225.]

1981e, Hydrogeochemical and stream sediment reconnaissance basic data for Roswell quadrangle, New Mexico: U.S. Department of Energy Report No. GJBX-397(81), 185 p. [Available from U.S. Geological Survey Books and Open-File Reports Section, P.O. Box 25425, Denver, CO 80225.]

1981f, Hydrogeochernical and stream sediment reconnais. sance basic data for Tularosa quadrangle, New Mexico: U.S. Department of Energy Report No. GJBX-326(81), 183 p. [Available from U.S. Geological Survey Books and Open-File Reports Section, P.O. Box 25425, Denver, CO 80225.]

Phillips, R.S., Campbell, A.R., and McLemore, V.T., 1990 , Geochemistry of magmatic REE-Th-U quartz/fluorite veins from the Capitan pluton, Capitan Mountains, south-central New Mexico: Geological Society of America Abstracts with Programs, v. 23, p. A159.

Segerstrom, Kenneth, and Stotelmeyer, R.B., 1984, White Mountain Wildemess, New Mexico, in Marsh, S.P., Kropschot, S.J., and Dickinson, R.G., eds., Wilderness mineral potential, assessment of mineral-resource potential in U.S. Forest Service lands studied 1964-1984: U.S. Geological Survey Professional Paper 1300, v. 2, p. 836-838.

Segerstrom, Kenneth, Stotelmeyer, R.B., and Williams, F.E., 1979 , Mineral resources of the White Mountain Wildemess and adjacent areas, Lincoln County, New Mexico: U.S. Geological Survey Bulletin 1453, $135 \mathrm{p}$.

Shacklette, H.T., and Boemgen, J.G., 1984, Element concentrations in soils and other surficial materials of the conterminous United States: U.S. Geological Survey Professional Paper 1270,105 p.

Sharp, R.R., Jr., and Aamodt, P.L., 1978, Field procedures for the uranium hydrogeochemical and stream sediment reconnaissance by the Los Alamos Scientific Laboratory: U.S. Department of Energy Report No. GJBX-68(78), 64 p. [Available 
from U.S. Geological Survey Books and Open-File Reports Section, P.O. Box 25425, Denver, CO 80225.]

Sinclair, A.J., 1991, A fundamental approach to threshold estimation in exploration geochemistry-Probability plots revisited: Joumal of Geochemical Exploration, v. 41, p. 1-22.

Stephens, D.B., and Spalding, C.P., 1984, Oil-field brine contamination-A case study, Lea County, N. Mex., in Stone, W.J., compiler, Selected papers on water quality and pollution in New Mexico: New Mexico Bureau of Mines and Mineral Resources Hydrologic Report 7, p. 194-203.

Summers, W.K., 1981, Ground-water head distribution in the third dimension of the Pecos River basin, New Mexico: New Mexico Geology, v. 3, no. 1, p. 6-10, 12.

U.S. Environmental Protection Agency, 1991, National primary drinking water regulations for radionuclides, proposed rule, June, 1991; Radionuclides in drinking water fact sheet: Washington, D.C., Office of Ground Water and Drinking Water, U.S. Environmental Protection Agency, 12 p.

Vine, J.D., 1980, Where on Earth is all the lithium?, with a section on Uranium isotope studies, Fish Lake Valley, Nevada, by J.R. Dooley, Jr.: U.S. Geological Survey Open-File Report 80-1234, 114 p.
Wanty, R.B., and Schoen, Robert, 1991, A review of the chemical processes affecting the mobility of radionuclides in natural waters, with applications, in Gundersen, L.C.S., and Wanty, R.B., eds., Field studies of radon in rocks, soils, and water: U.S. Geological Survey Bulletin 1971, p. 183-194.

Warren, R.G., and Nunes, H.P., 1978, Uranium hydrogeochemical and stream sediment reconnaissance data release for the New Mexico portions of the Hobbs and Brownfield NTMS quadrangles, New Mexico/Texas: U.S. Department of Energy Report No. GJBX-103(78), 61 p. [Available from U.S. Geological Survey Books and Open-File Reports Section, P.O. Box 25425, Denver, CO 80225.]

Willis, M.A., Campbell, A., and Phillips, R.S., 1989, High salinity fluids associated with allanite mineralization, Capitan Moun. tains, New Mexico: Geological Society of America Abstracts with Programs, v. 21, p. A287.

Wrenn, M.E., Durbin, P.W., Howard, Blaine, Lipsztein, Joyce, Rundo, John, Still, E.T., and Willis, D.L., 1985, Metabolism of ingested U and Ra: Health Physics, v. 48, p. 60I-633.

Wrenn, M.E., Durbin, P.W., Willis, D.L., and Singh, N.P., 1987, The potential toxicity of uranium in water: American Water Works Association Joumal, v. 79, p. 177-184. 


\section{GEOPHYSICS}

\section{AEROMAGNETIC AND GRAVITY DATA}

\author{
By Dolores M. Kulik
}

Aeromagnetic and gravity data were evaluated in conjunction with geological, geochemical, and aerial gammaray data in determining the mineral resource potential of the Roswell Resource Area. The aeromagnetic and gravity data provide information on the subsurface distribution of rock masses and the structural framework. The data are reconnaissance in nature and are, in most cases, adequate only to define regional features.

Aeromagnetic data are from the composite residual total intensity aeromagnetic map of New Mexico (Cordell, 1983) and are shown on plate 5. Most of the aeromagnetic data in the study area are from surveys flown for the U.S. Department of Energy National Uranium Resource Evaluation (NURE) program. These surveys were flown at $400 \mathrm{ft}$ above ground level and at flight-line spacings of 3-6 mi. An index of data sources and methods of combining the surveys are included on the original map by Cordell.

Gravity data were provided by the University of Texas at El Paso, Texas. Bouguer gravity values were computed for this study using the 1967 gravity formula (International Association of Geodesy, 1967) and a reduction density of $2.67 \mathrm{~g} / \mathrm{cm}^{3}$ (grams per cubic centimeter). Mathematical formulas are given in Cordell and others (1982). Terrain corrections were made by computer for a distance of $104 \mathrm{mi}$ from each station using the method of Plouff (1977). The complete Bouguer gravity data are shown on plate 6 at a contour interval of $5 \mathrm{mGal}$ (milligals); the same data without station locations are shown in color on plate 7 at a contour interval of $10 \mathrm{mGal}$. A digital topographic map of an area encompassing the study area is shown on plate 8 at a contour interval of $500 \mathrm{ft}$. The digital topographic data were obtained from the National Oceanic and Atmospheric Administration (NOAA) Data Center. An isostatic residual gravity map of an area encompassing the study area is shown on plate 9 at a contour interval of $5 \mathrm{mGal}$. These data were taken from digital files produced for the isostatic residual gravity map of the conterminous United States by Simpson and others (1986). The geologic map (pl. 1) and tectonic map (pl. 3) include place names and identify structural features that will be referred to in the following discussion.

\section{INTERPRETATION}

Gravity anomalies reflect differences in density distribution of igneous, sedimentary, and metamorphic rocks, whereas magnetic anomalies usually reflect differences in magnetic susceptibility (relative magnetite content) only of igneous rocks. The magnetic anomalies may be caused by differences in magnetite content or by differences in depth to crystalline basement rocks. Sedimentary rocks may usually be considered to be nonmagnetic.

Three broad magnetic highs (1-3, pl. 5) occur along the eastern edge of the study area. Gravity anomalies A, B, and, to a lesser extent, C (pls. 6 and 7) generally coincide with these magnetic anomalies, although the apex of the magnetic anomaly is offset to the south of the apex of the associated gravity anomaly because of the inclined polarization of the Earth's magnetic field. The breadth and moderate gradient of both the magnetic and gravity anomalies indicate that the sources of the anomalies lie within the basement. Keller and others $(1980,1989)$ determined that the gravity relief between the Delaware Basin gravity low and the Central Basin Platform gravity high (which lie south of the area of pls. 6 and 7) cannot be explained by differences in thickness of sedimentary rocks overlying the basement. Only density contrasts in the basement can explain the anomaly.

Broad, low-amplitude magnetic anomalies occur in the eastern half of plate 5 and are caused by differences in lithology of the rocks of the Delaware Basin shelf and differences in depth to basement beneath these sedimentary rocks. Basalt flows of Quaternary age in the western part of the study area, which frequently have associated magnetic anomalies, have no characteristic associated anomalies in the study area, suggesting that these flows are thin.

The Lincoln County porphyry belt in the westemmost part of the study area, where Tertiary intrusive rocks crop out, is characterized by short-wavelength magnetic anomalies (4, pl. 5) having magnitudes of as much as 1,000 nanoteslas (nT). Similar anomalies extend to the northeast from the porphyry belt (area indicated by dashed line on pl. 5), where only Permian sedimentary rocks are exposed. The magnetic anomalies suggest that intrusive rocks similar to those of the porphyry belt are present at shallow depth. Magnetic anomalies of 1,660-2,000 nT ( 5 and 6, pl. 5) extend to the southeast of the porphyry belt. These are attributed to uplifted Precambrian crystalline rocks of the Pajarito 
Mountain area, which crop out southeast of Ruidoso near the edge of aeromagnetic anomaly 6.

A T-shaped gravity anomaly (D, pls. 6 and 7 ) indicates that relatively high-density rocks underlie (1) the Lincoln County porphyry belt, (2) most of the northeast extension of the belt as interpreted from magnetic data, (3) the area just northwest of the exposed intrusive rocks where similar rocks are probably also present in the subsurface, and (4) the area of Precambrian rocks southeast of the porphyry belt at Pajarito Mountain. The T-shaped gravity anomaly appears to be caused by a composite source including both Tertiary intrusive and Precambrian rocks. The shape of the anomaly suggests that the Tertiary rocks were emplaced in a northeast-trending zone, orthogonal to the north-northwest trend of the Precambrian Pedernal uplift in this area. The northwest trend of the part of the anomaly attributed to Precambrian rocks is deflected to the northeast (E, pls. 6 and 7) near Tertiary rocks that crop out west of Hondo.

Magnetic data in the region of the Lincoln County porphyry belt indicate that there is no consistent correlation of intrusive rocks with either magnetic highs or lows, and some of the larger intrusions are spatially associated with both high and low anomalies. The lack of any consistent correlation indicates that the intrusive rock is widely variable in magnetite content.

Hand samples from outcrops in the porphyry belt were measured for magnetic susceptibility using a portable susceptibility meter. The results show high variability (table 1). Outcrop samples yielding measured magnetic susceptibility values greater than $1,000 \times 10^{-5}$ SI (Systeme Internationale) units are associated with relatively high magnetic anomalies, whereas those with lower measured values are associated with magnetic lows or gradients between anomalies.

Magnetic lows in the Gallinas Peak and Rough Mountain areas are caused by hydrothermal alteration of the intrusive rocks, as reported by Armbrustmacher (this report). Magnetic lows in the hills near Tecolote Peak suggest that those rocks are altered as well. The two intrusive bodies of the Jicarilla Mountains are represented by separate magnetic highs. Values of samples 13,14 , and 15 range from 1,400 to $3,400 \times 10^{-5}$ SI units, and are associated with one of the closed highs. The value of sample $16\left(17,000 \times 10^{-5}\right.$ SI units) from near Jacks Peak is an order of magnitude higher (table 1). The sample site is on the west flank of another closed high having greater amplitude than that to the south. The location of the Jacks Peak anomaly suggests that the source body extends and is centered east and southeast of Jacks Peak in the subsurface. Monzonite and syenite of Lone Mountain have no associated magnetic anomaly. A magnetic high is associated with the syenite and syenogabbro of Baxter Mountain, which are hosts for the White Oaks ore deposits. The magnetic anomaly indicates that a large body of similar composition extends to the southeast and includes the west flank of Carrizo Mountain. A magnetic low is associated with the east half of Carrizo Mountain, and extends north to Patos Mountain and east for another 5-7 mi. Lower magnetic values continue around the northeast side of the Baxter Mountain high to Lone Mountain, supporting the suggestion of a similar origin for the Patos, Carrizo, and Lone Mountain stocks. A magnetic low is associated with the high-silica rocks of the west end of the Capitan Mountains; magnetic values are variable to the east, are not clearly associated with the Capitan Mountains intrusive body, and may have a basement source. Magnetic values associated with the Sierra Blanca Igneous Complex are varied, and more study is required to determine the relations of individual anomalies to mapped stocks and possible subsurface intrusive bodies.

Whereas the general area of the porphyry belt is associated with a gravity high (pls. 6 and 7), the intrusive rocks and associated volcanic flows at Sierra Blanca Peak and the western end of the Capitan Mountains body are associated with gravity lows, further indicating the varied composition of igneous rocks within the belt. The complex relationship of lithology, age, mineralization, and geophysical character of the Lincoln County porphyry belt cannot be resolved with currently available data.

Gravity lows are associated with thick sequences of sedimentary rock in the Claunch sag (F, G, pls. 6 and 7 ) and on the flanks of the Delaware Basin (H, I, J, pls. 6 and 7). Low anomalies that might be expected to occur over thick sedimentary rocks in the southeastern part of the map area are overwhelmed by the high values from basement sources, including the uplifted Central Basin Platform and probable mafic bodies within it.

In the south-central part of the study area, strong northeast-trending gravity gradients parallel wrench faults, termed buckles (pl. 3), that have normal, reverse, and strikeslip components. The continuity of the gravity gradients suggests that the buckles extend to the northeast beyond mapped exposures for many miles in the subsurface (to approximately lat $34^{\circ} 30^{\prime} \mathrm{N}$.). The Bonita fault and the parallel unnamed fault to the southeast may be surface expressions of these features. Beyond these faults, northeasttrending gradients terminate against a northwest-trending gradient. Similar strong northeast-northwest-trending gradients extend in a zigzag fashion across northeastern New Mexico and southeastern Colorado, and may represent a crustal transition and (or) change in basement character from the Rocky Mountains to the High Plains and interior craton.

An isostatic residual gravity map of an area encompassing the study area (pl. 9) was extracted from the data used to prepare the map of the conterminous United States (Simpson and others, 1986) in order to display regional features and to compare with the Bouguer gravity data (pls. 6 and 7). Longwavelength Bouguer gravity anomalies commonly show an inverse correlation with topography. Isostasy, as defined by Airy (1855) and Dutton (1889), uses the principle that the load of topographic features is compensated or supported at depth by mass deficiencies or "roots," as though the Earth's 
Table 1. Susceptibility measurements of rock samples from the Lincoln County porphyry belt, New Mexico

[Sample locations shown on plate 5. Susceptibility values have been multiplied by a correction factor of 2 ]

\begin{tabular}{|c|c|c|c|}
\hline $\begin{array}{l}\text { Sample } \\
\text { Nos. }\end{array}$ & Lat $(N$.$) flong (W)$ & $\begin{array}{c}\text { Susceptibility } \\
\left.\text { (in SI units } \times 10^{-5}\right)\end{array}$ & Rock type or location \\
\hline 1 & $33^{\circ} 21^{\prime} 14^{\prime \prime} / 105^{\circ} 24^{\prime} 25^{\prime \prime}$ & & Limestone, sandstone. \\
\hline a & & 0 & \\
\hline$b$ & & 0 & \\
\hline c & & 0 & \\
\hline$d$ & & 0 & \\
\hline $2 \mathrm{E}$ & $33^{\circ} 37^{\prime} 10^{\prime \prime} / 105^{\circ} 27^{\prime} 40^{\prime \prime}$ & & Eastern Capitan Mountains. \\
\hline a & & 6 & \\
\hline$b$ & & 6 & \\
\hline $\mathrm{c}$ & & 10 & \\
\hline $\begin{array}{l}d \\
e\end{array}$ & & $\begin{array}{l}6 \\
8\end{array}$ & \\
\hline e & & 8 & \\
\hline $\begin{array}{r}2 W \\
a\end{array}$ & 330371671052813 & 65 & western Laplan iviountans. \\
\hline$b$ & & $\begin{array}{l}65 \\
25\end{array}$ & \\
\hline c & & 6 & \\
\hline$d$ & & 60 & \\
\hline e & & 6 & \\
\hline$f$ & & 10 & \\
\hline 3 & $33^{\circ} 23^{\prime} 28^{\prime \prime} / 105^{\circ} 45^{\prime} 31^{\prime}$ & 20 & Sierra Blanca Peak stock. \\
\hline 4 & $33^{\circ} 24^{\prime} 20^{\prime \prime} / 105^{\circ} 45^{\prime} 16^{\prime \prime}$ & 20 & Sierra Blanca Peak stock. \\
\hline 5 & $33^{\circ} 23^{\prime} 23^{\prime \prime} / 105^{\circ} 44^{\prime} 14^{\prime \prime}$ & 25 & Porphyry, Sierra Blanca Peak. \\
\hline 6 & $33^{\circ} 23^{\prime} 23^{\prime \prime} / 105^{\circ} 44^{\prime} 14^{\prime \prime}$ & 4,000 & Sierra Blanca lgneous Complex. \\
\hline 7 & $33^{\circ} 27^{\prime} 15^{\prime \prime} / 105^{\circ} 43^{\prime} 30^{\prime \prime}$ & & Sierra Blanca Peak stock at \\
\hline a & & 7,000 & Bonito Lake. \\
\hline $8^{b}$ & & 6.600 & \\
\hline $\begin{array}{l}8 \\
a\end{array}$ & $33^{\circ} 29^{\prime} 11^{\prime \prime} / 105^{\circ} 47^{\prime} 03^{\prime \prime}$ & 6 & $\begin{array}{l}\text { Sierra Blanca Peak stock, } \\
\text { Parsons mine. }\end{array}$ \\
\hline b & & 0 & \\
\hline 9 & $33^{\circ} 30^{\prime} 05^{\prime} / 105^{\circ} 46^{\prime} 19^{\prime \prime}$ & 7.600 & $\begin{array}{l}\text { Sierra Blanca Peak stock, } \\
\text { Nogal Creek. }\end{array}$ \\
\hline 10 & $33^{\circ} 30^{\circ} 02^{\prime} / 105^{\circ} 46^{\prime} 10^{\prime \prime}$ & 16,000 & Andesite. Sierra Blanca Peak. \\
\hline 11 & $33^{\circ} 42^{\prime 1} 11^{\prime} / 105^{\circ} 41^{\prime} 00^{\prime \prime}$ & 10 & Carrizo Mountain stock. \\
\hline 12 & $33^{\circ} 42^{\prime} 04^{\prime \prime} / 105^{\circ} 41^{\prime} 31^{\prime \prime}$ & & Carrizo Mountain stock. \\
\hline a & & 500 & \\
\hline b & & 500 & \\
\hline 13 & $33^{\circ} 50^{\prime} 17^{\prime \prime} / 105^{\circ} 40^{\prime} 28^{\prime}$ & 2,500 & Southern Jicarilla Mountains. \\
\hline 14 & $33^{\circ} 50^{\prime} 20^{\prime \prime} / 105^{\circ} 40^{\prime} 32^{\prime}$ & 1,400 & Southern Jicarilla Mountains. \\
\hline 15 & $33^{\circ} 51^{\prime} 02 " / 105^{\circ} 40^{\prime} 23^{\prime}$ & 3,400 & Southern Jicarilla Mountains. \\
\hline 16 & $33^{\circ} 54^{\prime} 10^{\prime \prime} / 105^{\circ} 38^{\prime} 00^{\prime \prime}$ & 17,000 & Jacks Peak. \\
\hline 17 & $34^{\circ} 11^{\prime} 11^{\prime \prime} / 105^{\circ} 44^{\prime} 12^{\prime \prime}$ & & Rhyolite, Conquistador mine. \\
\hline a & & 0 & \\
\hline b & & 0 & \\
\hline 18 & $34^{\circ} 13^{\prime} 00^{\prime \prime} / 105^{\circ} 45^{\prime} 23^{\prime \prime}$ & 0 & Rihyolite. \\
\hline 19 & $34^{\circ} 13^{\prime} 18^{\prime \prime} / 105^{\circ} 45^{\prime} 16^{\prime \prime}$ & 0 & Rhyolite. \\
\hline 20 & $34^{\circ} 14^{\prime} 30^{\prime \prime} / 105^{\circ} 47^{\prime} 10^{\prime \prime}$ & 8 & Rhyolite, Gallinas Peak. \\
\hline 21 & $33^{\circ} 37^{\prime} 22^{\prime \prime} / 105^{\circ} 33^{\prime} 25^{\prime \prime}$ & $>200,000$ & $\begin{array}{l}\text { Magnetite mine, Capitan } \\
\text { Mountains. }\end{array}$ \\
\hline
\end{tabular}

crust were floating on a denser layer. The Bouguer correction commonly applied to gravity data (as in pls. 6 and 7) removes the attraction of topographic features down to sea level. Supporting or compensating masses, if beneath those features, then produce broad gravity lows. The isostatic correction attempts to remove the attraction of the compensating masses and, thus, isolate the gravity anomalies that arise from sources within the shallow crust. An in-depth discussion of isostatic principles applied to gravity data and methods used in preparing the isostatic residual map of the United States is found in Simpson and others (1986).
If it is assumed that isostatic balance is everywhere effective, high anomalies remaining on the isostatic residual map (pl. 9) imply relatively more mafic bodies within the crust, and low anomalies imply sedimentary basins or felsic bodies. The inverse correlation between Bouguer gravity and topography is not clearly expressed in the study area (compare pls. 6 and 7 with pl. 8), suggesting that the anomalies on the Bouguer anomaly map are not caused by compensating masses, but arise from sources within the upper crust. Both the Bouguer and isostatic residual maps have similar anomaly patterns and clearly display crustal density 
anomalies related to these features, which are identified by the numbers 1-7 on plate $9: 1$, intrusive rocks of the Lincoln County porphyry belt (A, pls. 6 and 7 ); 2, uplifted, relatively dense Precambrian rocks of the Pajarito Mountain area (B, pls. 6 and 7); 3, other Laramide uplifts of the Rocky Mountains; 4, the Sierra Grande uplift; 5, the high-standing Central Basin Platform and intrabasement mafic intrusives $(E$, pls. 6 and 7); 6, the Delaware Basin and its flanks (H, I, J, pls. 6 and 7); and 7, the Midland Basin.

\section{CONCLUSIONS}

Gravity data define the presence and location of dense and (or) shallow basement rocks beneath sedimentary rocks of the study area, and indicate the greater subsurface extent of buckles mapped at the surface. Magnetic data and, to a lesser degree, gravity data define the subsurface extent and location of intrusive rocks of the Lincoln County porphyry belt. The magnetic data suggest that similar intrusive rocks extend in the subsurface beyond the mapped exposures. Good correlation exists between measured susceptibility values of exposed rocks and their associated magnetic anomalies, and varying lithologies may be correlated with individual magnetic anomalies in the northern part of the Lincoln County porphyry belt. Variability of susceptibility within intrusions in the Sierra Blanca Igneous Complex in the southern part of the belt prevents their correlation with individual magnetic anomalies. The lack of an inverse correlation between topography and Bouguer gravity values and the similarity of features on the Bouguer and isostatic gravity maps suggest that isostatic compensation has not been achieved in the study area.

\section{AERIAL GAMMA-RAY DATA}

\section{By Joseph S. Duval}

Aerial gamma-ray data used in this study were originally acquired as part of the NURE program of the U.S. Department of Energy (fig. 10). These surveys were flown at a nominal altitude of $400 \mathrm{ft}$ above the ground at a flightline spacing of about $3 \mathrm{mi}$. The data acquisition equipment included about 50 liters of sodium-iodide detectors.

Because the gamma-ray data acquired as part of the NURE Program were found to be an inconsistent data base with regard to a constant datum among the various surveys, the data were reprocessed and appropriate corrections were applied to achieve a consistent data base. The procedures and corrections applied to the data are described by Duval and others $(1989,1990)$. The reprocessed NURE data were gridded using a minimum curvature algorithm (Briggs, 1974; Webring, 1981) and an initial grid interval of $1.5 \mathrm{mi}$. For this

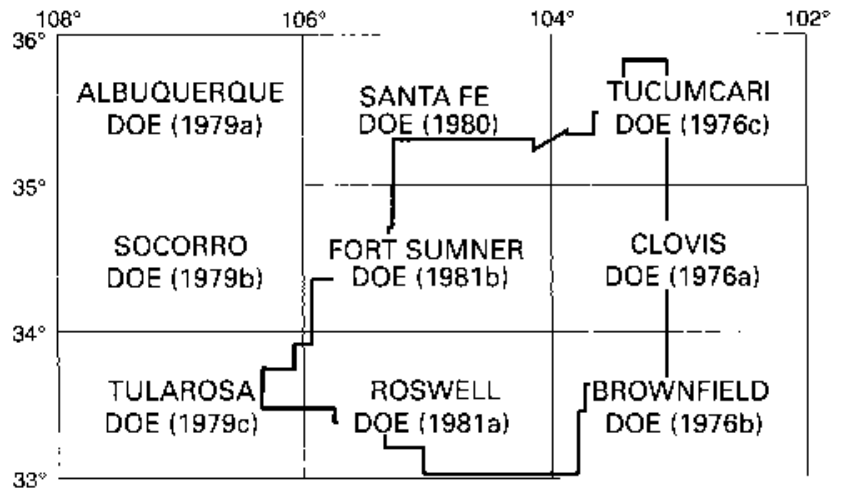

Figure 10. Index to $1^{\circ} \times 2^{\circ}$ quadrangles showing locations of U.S. Department of Energy (DOE) aerial gamma-ray surveys used in this study of the Roswell Resource Area (outlined), New Mexico.

particular study, the initial grid was regridded to an interval of $0.8 \mathrm{mi}$ using a two-dimensional spline. The initial grid interval was chosen on the basis of the initial flight-line spacing of $3 \mathrm{mi}$, and the data were regridded to facilitate comparison to the geology and to simplify computer processing associated with the preparation of maps at the desired scale of $1: 500,000$.

The NURE aerial gamma-ray surveys included measurements of the gamma-ray flux produced by the radioactive decay of $\mathrm{K}^{40}$, and by members of the radioactive decay series of $U^{238}$ and $T^{232}$. The resulting measurements have been expressed as the apparent surface concentration of potassium, uranium, and thorium. The uranium and thorium concentrations are usually described as equivalent concentrations because of the possibility of radioactive disequilibrium in the uranium and thorium decay series. Plates 10,11 , and 12 show the data for the apparent surface concentrations of potassium (percent $K$ ), equivalent uranium [parts per million (ppm) eU], and equivalent thorium (ppm eTh), respectively.

The $\mathrm{K}, \mathrm{eU}$, and eTh data were imported into the Geographic Resource Analysis Support System (GRASS) (Lozar and Goran, 1987; Hastings, 1988; Lozar, 1989). Analysis algorithms within GRASS were used to analyze the data. In order to compare the gamma-ray data to the geology, a digitized version of the geologic map was also imported into the GRASS system and then converted to a grid using the same grid interval as the gamma-ray data $(0.78 \mathrm{mi})$. Because of the limited resolution defined by the grid cell size, some of the smaller geologic units (less than about 0.77 $\mathrm{mi}^{2}$ ) were not represented in the grid version of the geologic map. Table 2 and figures 11-13 show estimated average concentrations of $\mathrm{K}, \mathrm{eU}$, and $\mathrm{eTh}$ for the different geologic units within the study area. These average values were obtained by identifying the grid cells associated with each geologic unit and calculating the average values for those grid cells. Table 2 includes columns that contain calculated values for the standard deviation of the concentrations. Because of the 
Table 2. Estimated average concentrations of potassium $(\mathrm{K})$, cquivalent uranium (eU), and equivalent thorium (eTh) for different geologic units within the Roswell Resource Area, New Mexico

[Astcrisks (*) mark calculated standard deviations that are greater than the average value of the calculated standard deviations?

\begin{tabular}{|c|c|c|c|c|c|c|c|}
\hline $\begin{array}{l}\text { Map-unit } \\
\text { symbol } \\
\text { (plate 1) }\end{array}$ & $\begin{array}{l}K \\
|\%|\end{array}$ & $\begin{array}{l}\text { Standard } \\
\text { deviation }\end{array}$ & $\begin{array}{c}\mathrm{eU} \\
\text { (ppm) }\end{array}$ & $\begin{array}{l}\text { Standard } \\
\text { deviation }\end{array}$ & $\begin{array}{c}\text { eTh } \\
\text { (ppm) }\end{array}$ & $\begin{array}{l}\text { Standard } \\
\text { deviation }\end{array}$ & $\begin{array}{l}\text { No. of } \\
\text { ceils }\end{array}$ \\
\hline $\mathrm{Ob}$ & 1.37 & 0.21 & 1.58 & 0.22 & 5.5 & 1.3 & 214 \\
\hline Oal & 1.16 & 0.29 & 1.55 & 0.42 & 5.2 & $1.8^{*}$ & 23,519 \\
\hline Qt & 1.11 & 0.23 & 1.47 & 0.28 & 4.9 & 1.4 & 6,393 \\
\hline OTg & 1.82 & $0.53^{*}$ & 2.10 & $0.41^{*}$ & 8.3 & $2.2^{*}$ & 1,233 \\
\hline To & 1.18 & 0.19 & 1.61 & 0.29 & 5.1 & 1.4 & 2,678 \\
\hline Tis & 2.09 & $0.46^{*}$ & 2.35 & 0.33 & 10.2 & $1.9^{*}$ & 545 \\
\hline Tv & 1.87 & $0.41^{*}$ & 2.16 & $0.44 *$ & 9.0 & $1.7^{*}$ & 408 \\
\hline TKc & 1.83 & $0.59^{*}$ & 2.22 & $0.51^{*}$ & 9.2 & $1.9^{*}$ & 59 \\
\hline Kmmd & 1.50 & $0.53^{*}$ & 2.12 & 0.34 & 8.1 & $2.2^{*}$ & 789 \\
\hline K下u & 1.25 & 0.16 & 2.00 & 0.18 & 6.2 & 0.9 & 61 \\
\hline $\mathrm{Jm}$ & 1.13 & 0.15 & 2.15 & 0.29 & 6.1 & 0.7 & 230 \\
\hline Je & 1.22 & 0.15 & 1.92 & 0.27 & 6.1 & 0.8 & 119 \\
\hline FC & 1.13 & 0.20 & 1.81 & 0.31 & 6.3 & 1.2 & 3,708 \\
\hline $\mathrm{ks}$ & 1.04 & 0.19 & 1.63 & 0.30 & 5.6 & 1.2 & 1,888 \\
\hline Pds & 1.01 & 0.06 & 1.37 & 0.10 & 4.3 & 0.2 & 14 \\
\hline $\mathrm{Pa}$ & 1.22 & 0.20 & 1.52 & 0.23 & 5.2 & 0.8 & 3,569 \\
\hline Psg & 1.03 & $0.34^{*}$ & 1.77 & 0.34 & 5.1 & 1.4 & 10,431 \\
\hline $\mathrm{Pu}$ & 1.11 & $0.41^{*}$ & 1.91 & 0.33 & 5.8 & $2.3^{*}$ & 464 \\
\hline Pu & 0.84 & 0.11 & 1.96 & 0.29 & 4.8 & 0.9 & 77 \\
\hline M€u & 1.16 & 0.22 & 1.76 & 0.24 & 5.0 & 1.0 & 13 \\
\hline$p \in u$ & 0.86 & 0.11 & 1.97 & 0.26 & 4.7 & 0.5 & 89 \\
\hline
\end{tabular}

processing used to obtain the data grids, the standard deviation values should not be interpreted as estimates of accuracy, but as indicators of the uniformity of the radioactivity of the mapped geologic units. Also, the concentration estimates of those geologic units for which the grids contained fewer than 100 grid cells may not be reliable.

The most radioactive rocks in the study area are Tertiary volcanic flows (Tv) and alkalic intrusions (Tis), Upper Cretaceous and Tertiary Cub Mountain Formation (TKc), Quaternary and Tertiary intermountain gravel (QTg), and undivided Cretaceous rocks (Kmmd) (figs. 11A, 12A, and $13 A$ ). The most radioactive map units are also the most variable, as shown by the calculated standard deviations shown as error bars (figs. $11 B, 12 B$, and $13 B$ ). Table 2 lists the calculated standard deviation for selected units of plate 1 ; asterisks mark the calculated standard deviations that are greater than the average values. Units $Q T g, T v$, and $T K c$ have greater variability than the averages for $K, e U$, and $e T h$. Quaternary pediment and terrace gravel (Qal) has greater than average variability for $\mathrm{eU}$ and $\mathrm{eTh}$. Units Tis, Kmmd, and $\mathrm{Pu}$ (undivided Lower Permian rocks) have greater than average variabilities for $K$ and $e T h$.

Each of the map units that have greater than average variability were examined to determine the nature of their gamma-ray characteristics. Unit QTg has two areas displaying distinct characteristics. Part of this unit has low radioactivity and concentrations of $0.6-1.4$ percent $\mathrm{K}, 1.0-2.0 \mathrm{ppm}$ $\mathrm{eU}$, and 3.4-8.0 ppm eTh, and part of it has higher radioactivity and concentrations of $1.4-3.0$ percent $K$, $2.0-3.0 \mathrm{ppm} \mathrm{eU}$, and 8.0-13.0 ppm eTh. The radioactivity of Quatemary pediments and terraces tends to be similar to that of the source rocks described above, from which the materials are derived, and could easily be subdivided based upon the gamma-ray signatures. Unit $\mathrm{Tv}$ contains localized areas yielding greater than 1.7 percent $\mathrm{K}$, greater than $2.0 \mathrm{ppm} \mathrm{eU}$, and greater than $8.0 \mathrm{ppm}$ eTh. Unit TKc crops out in three geographically separated clusters. Of these areas, the westernmost area is the most radioactive and has concentrations of 2.0-3.0 percent $\mathrm{K}, 2.4-3.0 \mathrm{ppm} \mathrm{eU}$, and $10.0-12.2 \mathrm{ppm}$ eTh. The remaining areas have concentrations of $0.9-1.8$ percent $\mathrm{K}, 1.6-2.4 \mathrm{ppm}$ eU, and 6.9-9.3 ppm eTh. Unit Kmmd crops out in the northeastern and southwestern parts of the study area. In the northeastern part, the unit has lower radioactivity and values of $0.8-1.1$ percent $\mathrm{K}, 1.6-3.0 \mathrm{ppm} \mathrm{eU}$, and 4.7-6.8 ppm eTh. In the southwestem part, it has a similar range of values, but also includes localized areas of higher radioactivity and concentrations of 1.6-2.8 percent $\mathrm{K}$, 3.0-3.5 ppm eU, and 8.4-14.0 ppm eTh. Unit Tis crops out in isolated areas in the southwestern part of the study area and includes areas of higher radioactivity with values of 1.4-3.1 percent $K, 2.1-3.1 \mathrm{ppm} \mathrm{eU}$, and 7.4-15.3 ppm eTh, and areas of lower radioactivity with $0.7-2.0$ percent $\mathrm{K}, 1.5-2.3 \mathrm{ppm}$ $\mathrm{eU}$, and 3.4-10.7 ppm eTh. The Lower Permian San Andres Formation and Glorieta Sandstone (unit Psg) have generally similar patterns for the distribution of $\mathrm{K}$ and $\mathrm{eTh}$-large areas of low radioactivity and values of $0.2-0.8$ percent $K$ and 

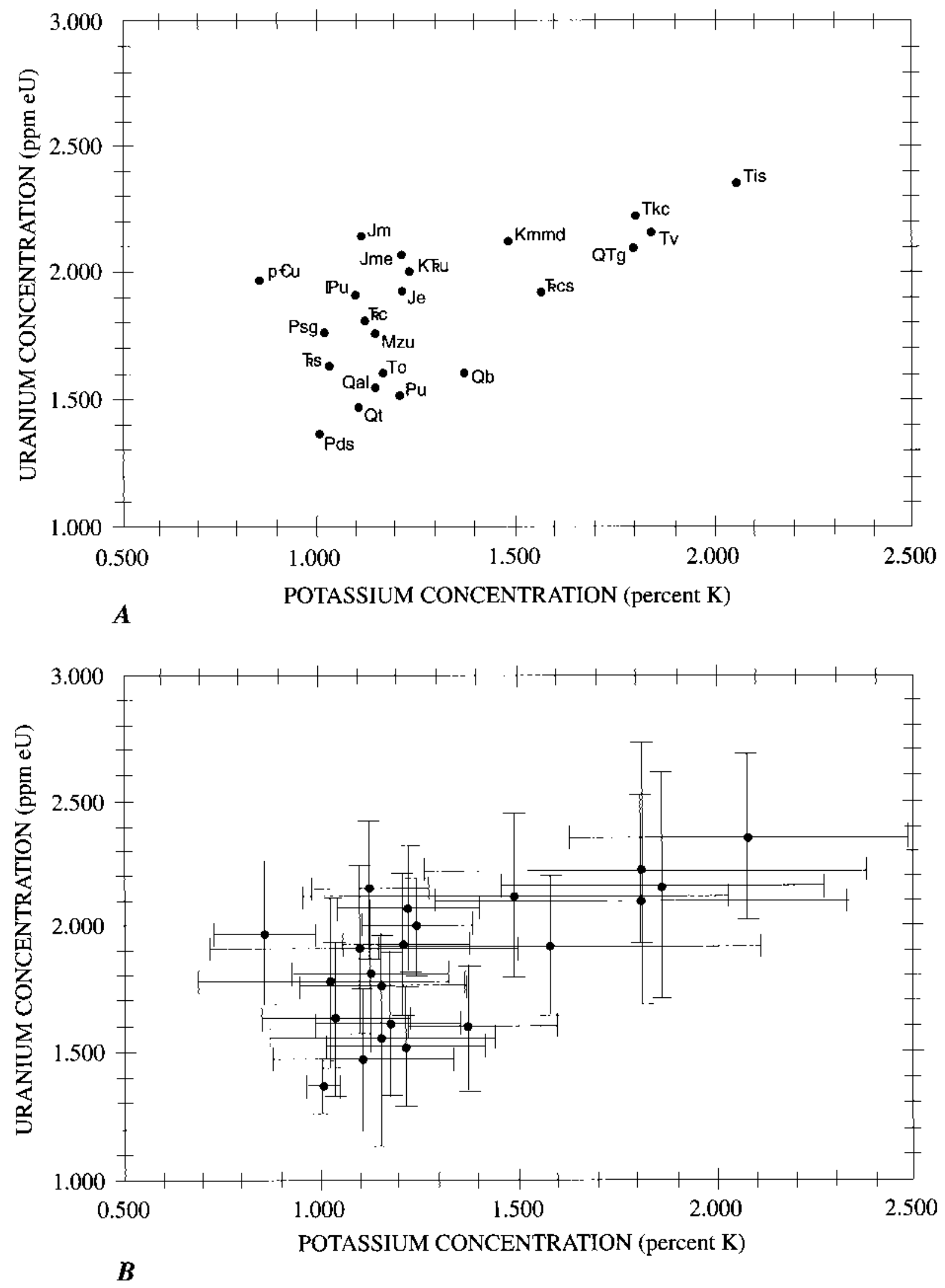

Figure 11. Average concentrations of uranium versus potassium for selected map units of geologic map of Roswell Resource Area, New Mexico (pl. 1). A, Plot of concentrations and corresponding map-unit symbols. $B$, Plot of concentrations and corresponding standard deviations (table 2); horizontal and vertical lines represent potassium and uranium, respectively. 


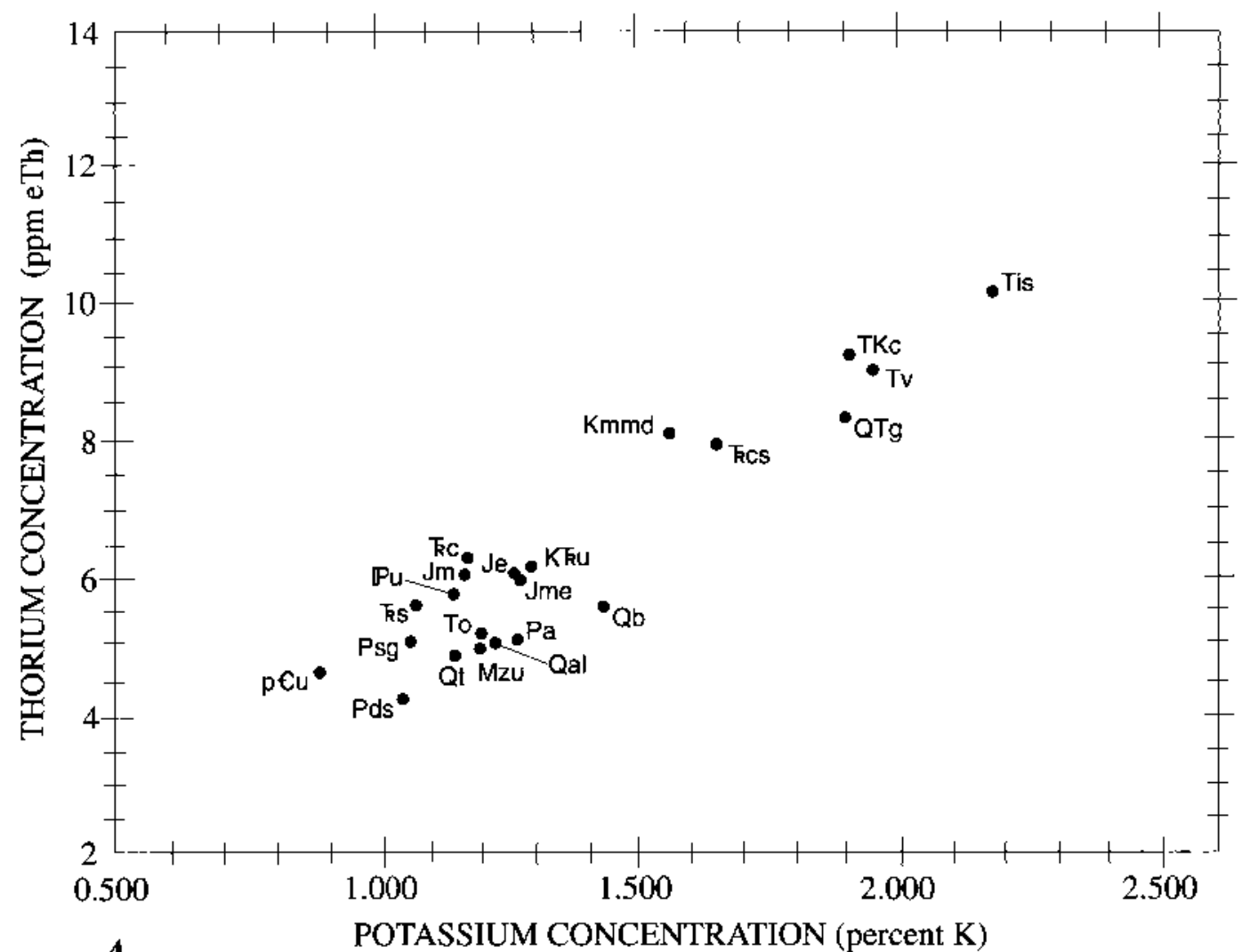

A

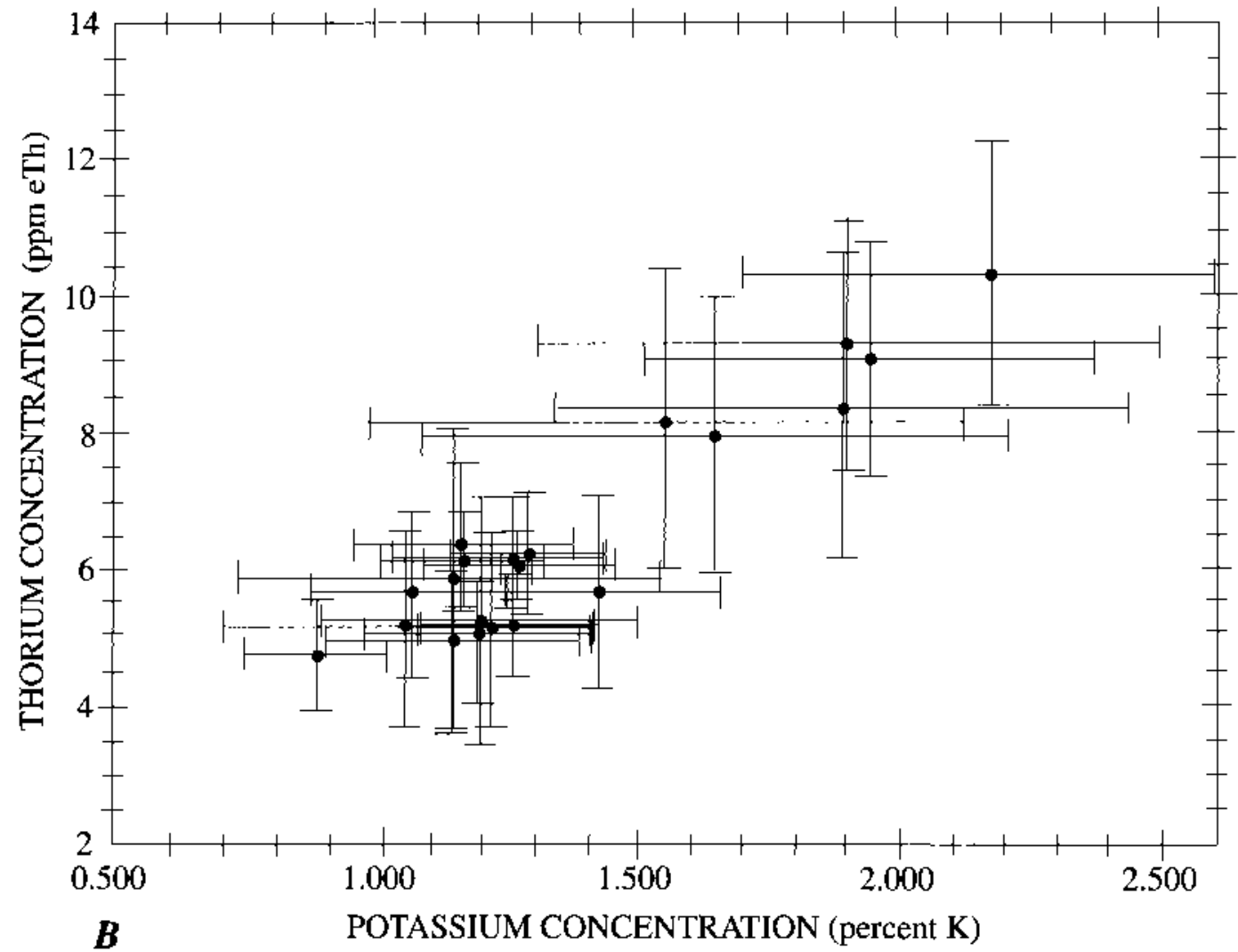

Figure 12. Average concentrations of thorium versus potassium for selected map units of geologic map of Roswell Resource Area, New Mexico (pl. 1). A, Plot of concentrations and corresponding map-unit symbols. $B$, Plot of concentrations and corresponding standard deviations (table 2); horizontal and vertical lines represent potassium and thorium, respectively. 

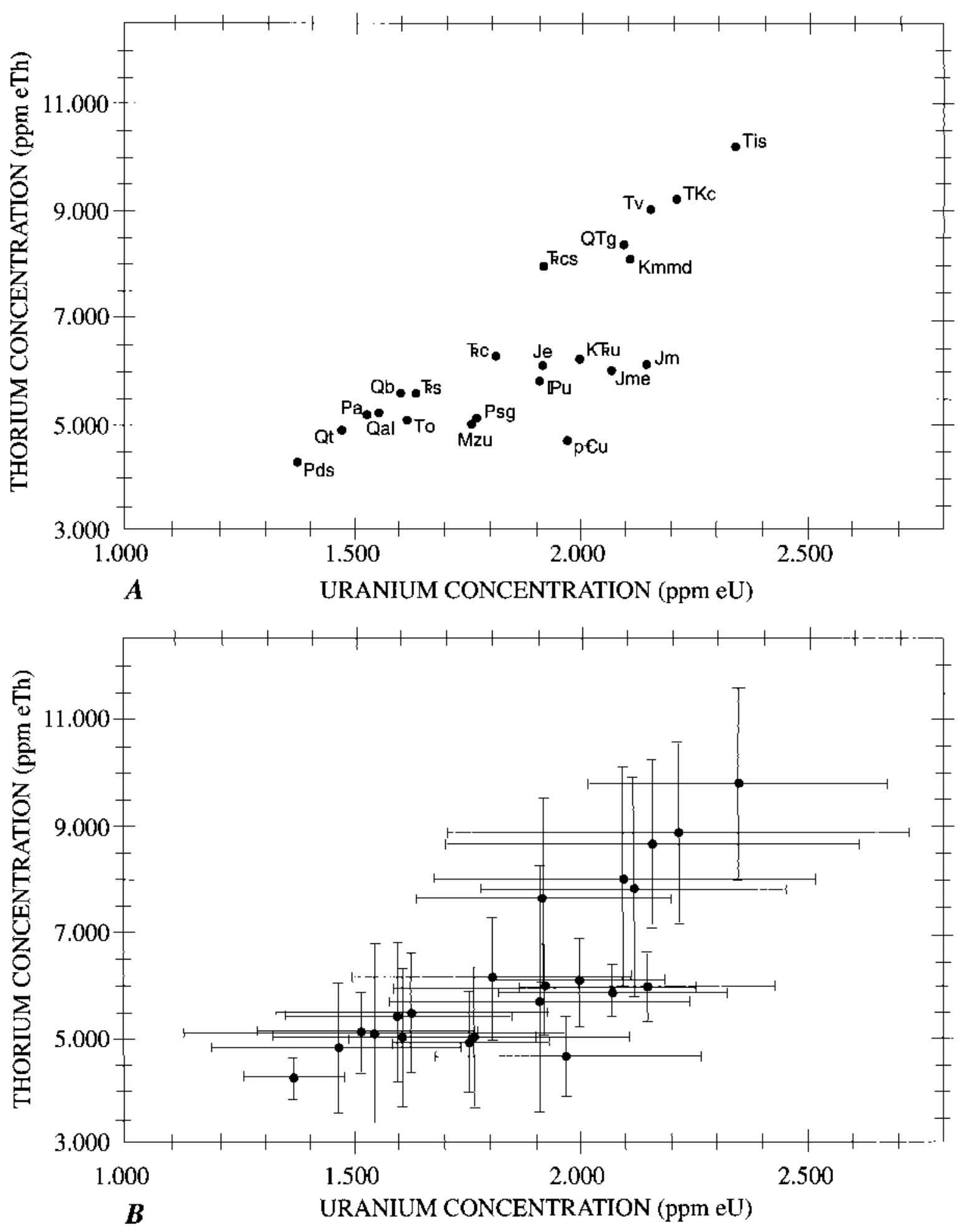

Figure 13. Average concentrations of thorium versus uranium for selected map units of geologic map of Roswell Resource Area, New Mexico (pl. 1). A, Plot of concentrations and corresponding map-unit symbols. $B$, Plot of concentrations and corresponding standard deviations (table 2); horizontal and vertical lines represent uranium and thorium, respectively. 
2.1-4.0 ppm eTh, and localized areas of higher radioactivity and values of 1.7-2.9 percent $K$ and 6.3-9.6 ppm eTh. Most of the outcrops of the San Andres have concentrations of 0.8-1.7 percent $\mathrm{K}$ and $4.0-6.3 \mathrm{ppm} \mathrm{eTh}$. The distribution of $\mathrm{eU}$ within the San Andres is distinct from the distributions of $\mathrm{K}$ and $\mathrm{eTh}$, except for some low radioactivity areas in the northern part of the study area that have $0.8-1.2 \mathrm{ppm} \mathrm{eU}$. The $\mathrm{eU}$ pattern includes large areas of higher uranium concentration (2.4-2.7 ppm eU) that do not, in general, coincide with higher concentrations of $K$ and $e T h$. This difference in the radioelement patterns suggests that the uranium has been moved by geochemical processes such as groundwater circulation. Unit Pu has generally low radioactivity and concentrations of $0.5-1.5$ percent $\mathrm{K}, 1.3-2.5 \mathrm{ppm} \mathrm{eU}$, and 2.8-7.0 $\mathrm{ppm} \mathrm{eTh}$ and localized areas of higher concentrations (1.8-2.5 percent $\mathrm{K}, 1.9-2.4 \mathrm{ppm}$ eU, and 8.2-11.5 ppmeTh). With the exception of the San Andres Formation, the variability of the radioelement concentrations noted above is probably a reflection of different lithologic materials within each map unit or, in the case of the Quaternary units, of the different source rocks. The explanation for the difference between the distributions of $\mathrm{K}$ and $\mathrm{eTh}$ and that of $\mathrm{eU}$ within the San Andres Formation is unknown.

\section{REFERENCES CITED}

Airy, G.B., 1855, On the computation of the effect of the attraction of the mountain-masses, as disturbing the apparent astronomical latitude of stations in geodetic surveys: Philosophical Transactions of the Royal Society of London, 145, p. 101-104.

Briggs, I.C., 1974, Machine contouring using minimum curvature: Geophysics, v. 39, no. 1, p. 39-48.

Cordell, Lindreth, 1983, Composite residual total intensity aeromagnetic map of New Mexico: National Geophysical Data Center, National Oceanic and Atmospheric Administration, scale 1:500,000.

Cordell, Lindreth, Keller, G.R., and Hildenbrand, T.G., 1982, Bouguer gravity map of the Rio Grande rift, Colorado, New Mexico, and Texas: U.S. Geological Survey Geophysical Investigations Series Map GP-949, scale 1:1,000,000.

Dutton, C.E., 1889, On some of the greater problems of physical geology: Washington, D.C., Philosophical Society Bulletin, v. 11, p. $51-64$.

Duval, J.S., Jones, W.J., Riggle, F.R., and Pitkin, J.A., 1989, Equivalent uranium map of conteminous United States: U.S. Geological Survey Open-File Report 89-478, 10 p., scale $1: 2,500,000$.

1990, Potassium and thorium maps of the conterminous United States: U.S. Geological Survey Open-File Report 90-338, 17 p., scale $1: 2,500,000$.

Hastings, D., 1988, New public domain GIS coming of age: Photogrammetric Engineering and Remote Sensing, v. 54, no. 1, p. 88-89.

International Association of Geodesy, 1967, Geodetic Reference System, 1967: International Association of Geodesy Special Publication 3, 116 p.
Keller, G.R., Hills, J.M., Baker, M.R., and Wallin, E.T., 1989, Geophysical and geochronological constraints on the extent and age of mafic intrusions in the basement of west Texas and eastem New Mexico: Geology, v. 17, p. 1049-1052.

Keller, G.R., Hills, J.M., and Djeddi, R., 1980, A regional geological and geophysical study of the Delaware Basin, New Mexico and West Texas, in Dickerson, P.W., Hoffer, J.M., and Callender, J.F., eds, Trans-Pecos region--Southeastem New Mexico and West Texas: New Mexico Geological Society, Field Conference Guidebook No. 31, p. 105-111.

Lozar, R.C., 1989, ed., Proceedings of the 1988 Geographical Resource Analysis Support System (GRASS) user group meeting: USACERL technical manuscript $\mathrm{N}-89 / 18$, unpaginated.

Lozar, R.C., and Goran, W.D., 1987. GRASS for military land use planning: The Military Engineer, no. 516, p. 468-469.

Plouff, D.L., 1977, Preliminary documentation for a FORTRAN program to compute gravity terrain corrections based on topography digitized on a geographic grid: U.S. Geological Survey Open-File Report 77-535, 45 p.

Simpson, R.W., Jachens, R.C., Blakely, R.J., and Saltus, R.W., 1986, A new isostatic residual gravity map of the conterminous United States with a discussion on the significance of isostatic residual anomalies: Joumal of Geophysical Research, v. 91, no. B8, p. 8348-8372.

U.S. Department of Energy, 1976a, Aerial radiometric and magnetic survey, Brownfield national topographic map, Texas and New Mexico: U.S. Department of Energy Open-File Report GJBX-339(76), v. 2, 58 p.

$1976 \mathrm{~b}$, Aerial radiometric and magnetic survey, Clovis national topographic map, Texas and New Mexico: U.S. Department of Energy Open-File Report GJBX-339(76), v. 2, 65 p.

-1976c, Aerial radiometric and magnetic survey, Tucumcari national topographic map, Texas and New Mexico: U.S. Department of Energy Open-File Report GJBX-339(76), v. 2, $61 \mathrm{p}$.

1979a, Aerial radiometric and magnetic survey, Raton Basin project-Albuquerque quadrangle, New Mexico: U.S. Department of Energy Open-File Report GJBX-116(79), v. 2, $164 \mathrm{p}$.

-1979b, Aerial radiometric and magnetic survey, Socorro national topographic map, New Mexico: U.S. Department of Energy Open-File Report GJBX-163(79), v. 2, 200 p.

$-1979 \mathrm{c}$, Aerial radiometric and magnetic survey, Tularosa national topographic map, New Mexico: U.S. Department of Energy Open-File Repon GJBX-67(79), v. 2. 55 p.

1980, Aerial gamma-ray and magnetic survey, Raton Basin project-Santa Fe quadrangle, New Mexico: U.S. Department of Energy Open-File Report GJBX-9(80), v. 2, 153 p.

1981a, NURE aerial gamma-ray and magnetic reconnaissance survey of portions of New Mexico, Arizona, and Texas-Fort Sumner quadrangle: U.S. Department of Energy Open-File Report GJBX-412(81), v. 2A, 60 p.

$1981 \mathrm{~b}$, NURE aerial gamma-ray and magnetic reconnaissance survey of portions of New Mexico, Arizona, and Texas-Fort Roswell quadrangle: U.S. Department of Energy Open-File Report GJBX-412(81), v. 2B, 64 p.

Webring, Michael, 1981, MINC-A gridding program based on minimum curvature: U.S. Geological Survey Open-File Report $81-1224,41 \mathrm{p}$. 


\section{MINERAL RESOURCES OF THE ROSWELL RESOURCE AREA}

\section{INDUSTRIAL MINERAL RESOURCES}

By Susan Bartsch-Winkler

With sections on

Potash and Iodine and Bromine in

Saline Brines and Brine Deposits

By Sherilyn Williams-Stroud and Sulfur

By Charles S. Spirakis

Industrial minerals are an important mineral endowment of the Roswell Resource Area. Gypsum, caliche, clay, limestone, building stone, aggregate, sand and gravel, and semi-precious gemstones (including "Pecos diamonds," smoky quartz, and petrified wood) are or have been produced in the study area. Potentially important sulfur and potash reserves are found within the study area, but none have been produced.

\section{EVAPORITE DEPOSITS}

Evaporite deposits of southeastem New Mexico (fig. 14) and western Texas occur in the Permian Basin back-reef environment. Concentrations of halite, polyhalite, anhydrite, gypsum, and other salts probably were precipitated from seawater or were transported into the Permian Basin during periodic salt-brine influx from evaporite deposits surrounding the basin (Adams, 1969; Williams-Stroud, 1991). Evaporite beds are deposited by trapping of sea-water brine and subsequent evaporation. Many evaporite deposits have been isolated by impermeable overlying and underlying units and, thus, are protected from groundwater dissolution (Bachman, 1987).

According to Pitt and Scott (1981) in their study of subsurface depositional cycles in the San Andres Formation in Guadalupe, De Baca, Chaves, Quay, Curry, and Roosevelt Counties, N. Mex., the evaporite deposits are transitional from halite to anhydrite; northward, halite occurs with greater frequency and anhydrite with lesser frequency. Also, anhydrite is more abundant and dolomite less abundant north of the Matador uplift (Gratton and LeMay, 1969). Evaporite beds are thick along the north-south border between Quay and Guadalupe Counties near Montoya, in Quay County south of Tucumcari, and in Curry County near Clovis. At the latter locality, subsurface evaporites consist mostly of halite. In the subsurface, evaporite deposits are as much as $130 \mathrm{ft}$ thick in western Quay County, as much as $80 \mathrm{ft}$ thick in northern Roosevelt County, and as much as $60 \mathrm{ft}$ thick in southeastem Roosevelt County (Pitt and Scott, 1981).

\section{POTASH}

By Sherilyn Williams-Stroud

Since 1931, the Carlsbad potash district (about $50 \mathrm{mi}$ south of the southem boundary of the study area) has been the largest domestic producer and contains the largest reserves of potash in the United States; it is one of the world's major potassium deposits (Cheeseman, 1978). The total capacity of present New Mexico mining operations is estimated to be 1,650 short tons of potassium oxide equivalent $\left(\mathrm{K}_{2} \mathrm{O}\right)$ per year (Searles, 1985). New Mexico contains total recoverable reserves of about 55 million short tons of 100 percent $\mathrm{K}_{2} \mathrm{O}$ equivalent, or about 57 percent of the nation's reserves (New Mexico Department of Energy, Minerals and Natural Resources, 1990); most of the reserves are located in Eddy and Lea Counties south of the study area. Potash is used primarily for fertilizer (Austin, 1980). The largest consumer of potash has been the (former) U.S.S.R.; soybean and com farmers in the Midwest have been the largest domestic users. However, due to transportation costs, only about 20 percent of New Mexico's potash is used domestically (New Mexico Department of Energy, Minerals and Natural Resources, 1990). The vast potash reserves in the Carlsbad potash district and in Utah and Canada are more likely to provide potash for domestic and world markets than any deposits beneath the study area.

\section{CARLSBAD POTASH DISTRICT}

Twelve potash ore zones are identified in the Carlsbad potash district. They typically occur, but are not confined to, the middle and upper parts of the Salado Formation (Austin, 


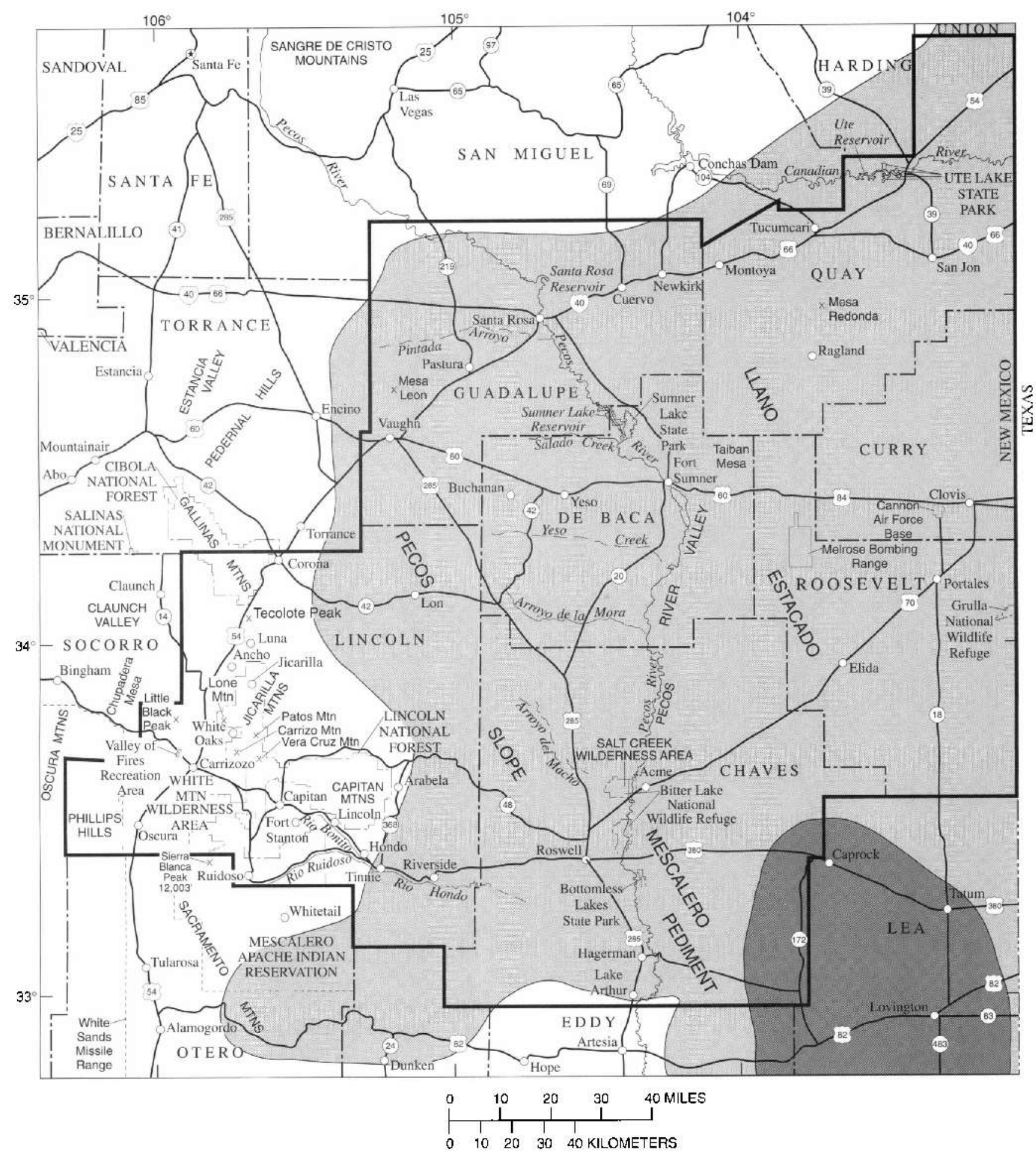

Figure 14. Distribution of halite-bearing (shaded light gray) and potassium-bearing (shaded dark gray) saline deposits in the Roswell Resource Area and vicinity, New Mexico (modified from U.S. Geological Survey, 1965).

1980). A mixture of sylvite and halite (known as sylvinite) and langbeinite have been mined (Cheeseman, 1978; Austin and Barker, 1990). Gangue minerals in the Salado of the Carlsbad district include leonite $\left(\mathrm{MgSO}_{4} \cdot \mathrm{K}_{2} \mathrm{SO}_{4} \cdot 4 \mathrm{H}_{2} \mathrm{O}\right)$, kainite $\left(\mathrm{MgSO}_{4} \cdot \mathrm{KCl} \cdot 3 \mathrm{H}_{2} \mathrm{O}\right)$, carnallite $\left(\mathrm{MgCl}_{2} \cdot \mathrm{KCl} \cdot 6 \mathrm{H}_{2} \mathrm{O}\right)$, polyhalite $\left(2 \mathrm{CaSO}_{4} \cdot \mathrm{MgSO}_{4} \cdot \mathrm{K}_{2} \mathrm{SO}_{4} \cdot 2 \mathrm{H}_{2} \mathrm{O}\right)$ kieserite $\left(\mathrm{MgSO}_{4} \cdot \mathrm{H}_{2} \mathrm{O}\right)$, bloedite $\left[\mathrm{Na}_{2} \mathrm{Mg}\left(\mathrm{SO}_{4}\right)_{2} \cdot \mathrm{MgSO}_{4} \cdot 4 \mathrm{H}_{2} \mathrm{O}\right]$, halite, and anhydrite (Cheeseman, 1978). Major accessory evaporite minerals in the district are gypsum $\left(\mathrm{CaSO}_{4} \cdot \mathrm{H}_{2} \mathrm{O}\right)$, anhydrite $\left(\mathrm{CaSO}_{4}\right)$, and halite $(\mathrm{NaCl})$. Sylvite $(\mathrm{KCl})$, 
carnallite, and langbeinite $\left(2 \mathrm{MgSO}_{4} \cdot \mathrm{K}_{2} \mathrm{SO}_{4}\right)$ are interbedded with halite. According to Cheeseman (1978), a typical mixed-ore sample from the Salado in the Carlsbad district contains 60 percent halite, 30 percent sylvite, 5 percent langbeinite, and 2 percent each of polyhalite and insolubles.

In the Carlsbad potash district, potash is mined by conventional underground techniques using drum miners to remove the sylvite ore in a room-and-pillar configuration. Because of the hardness of the ore, the mines that recover langbeinite use jumbo drills and undercutters, blasting and mucking techniques, and shuttle cars. Sylvite ore is beneficiated into muriate of potash, and langbeinite ore is beneficiated into sulfate of potash-magnesia (New Mexico Department of Energy, Minerals and Natural Resources, 1990).

\section{POTASH DEPOSITS IN THE STUDY AREA}

The potash-bearing Salado Formation extends north and east from the Carlsbad potash district to the Northwestern Shelf of the Permian Basin, the Central Basin Platform, and the Midland Basin in Texas (Cheeseman, 1978). The evaporite sequence is as much as $1,300 \mathrm{ft}$ thick and contains potassium minerals in 12 soluble potash horizons that occur over a relatively confined area of approximately $1,870 \mathrm{mi}^{2}$ of the west-central Permian Basin (fig. 15) (Adams, 1970). The Salado is as much as 2,300 $\mathrm{ft}$ thick in this part of the Permian Basin and consists of generally flat lying beds composed of halite, muddy halite, anhydrite, polyhalite, dolomite, and mudstone. Massive polyhalite beds occur in halite beds over the majority of the area of salt extent (Jones, 1972; Lowenstein, 1988) (fig. 15).

The northwestern part of the soluble potash zone of the Salado Formation falls within the study area in the southeastern corner of Chaves County (fig. 15). Due to their southeast dip, the potash-bearing beds probably are closer to the surface or probably have been dissolved to the north and west (the area of the study area). The Salado in Chaves County thins northward from 660 to $0 \mathrm{ft}$ over an area of approximately $187 \mathrm{mi}^{2}$ (from the southern boundary of the study area) (File and Northrop, 1966; Lowenstein, 1988; Austin and Barker, 1990).

Thus, although economically important potash deposits are found in the Salado Formation near Carlsbad, the part of the potash facies of the Salado that is located within Chaves County is not as thick as that found in the Carlsbad potash district, where the thickness ranges from 660 to over 1,300 ft. It is possible that the evaporite deposits in the study area are of similar economic grade to those in the Carlsbad district, although the thicknesses of the potash beds in the study area may be the factor that determines whether the resource will become economic in the near future. A very rough estimate of the volume of $\mathrm{K}_{2} \mathrm{O}$ that is currently economic in grade, based on the volume of halite in the Salado in the study area and assuming the same ore grade as in the
Carlsbad district, is approximately 0.03 trillion $\mathrm{ft}^{3}$, or the equivalent of 2 billion short tons.

The Rustler Formation, which overlies the Salado Formation within the Ochoan Series, and the Tansill and Yates Formations, which occur below the Salado, all contain evaporite deposits (pl. 2). Some occurrences of potash have been reported in these formations (Jones, 1972), but the potassium-bearing beds contain primarily polyhalite. Although polyhalite is not currently considered a potash ore mineral, recent studies suggest that finely ground polyhalite may be as effective as granular soluble potassium salts for the fertilization of acid soils (Barbarick, 1991). The total volume of polyhalite in the Salado Formation alone may approach 1.9 billion short tons.

\section{GYPSUM}

About 1900, near Ancho and in the Phillips Hills near Oscura, gypsum beds from 10 to $20 \mathrm{ft}$ thick were quarried from the Lower Permian San Andres Formation and Upper Permian Artesia Group; the gypsum was processed locally for plaster (Talmage and Wootton, 1937; Griswold, 1959; Weber and Kottlowski, 1959). In 1902, a small testing plant was in operation at Ancho, and a large mill was under construction for processing gypsite (fig. 16). In 1903, 100 short tons per day were being processed for cement, plaster of Paris, stucco, and other uses (Herrick, 1904; Jones, 1915). Near Acme northeast of Roswell, Permian (probably Artesia Group) gypsum beds of variable thickness have been quarried for plaster (Weber and Kottlowski, 1959). However, structural complications and the low purity of these gypsum beds (table 3) are inhibiting factors for commercial production (Weber and Kottlowski, 1959).

In order to be of economic value, gypsum deposits must be thick and laterally extensive, and have only thin overburden. Typical ore dimensions of minable gypsum deposits range from 33 to $164 \mathrm{ft}$ in thickness over an area of several square miles (Raup, 1991). Most gypsum is strip mined, but beds having $164 \mathrm{ft}$ or more of overburden can be mined by conventional underground methods. Marine-bedded gypsum deposits account for the major part of the world's gypsum production. Often the gypsum in these deposits is the result of near-surface hydration of anhydrite, but the economic value depends on the completeness of this process.

Gypsum and anhydrite are important construction materials, agricultural additives, and sources of chemicals. Gypsum is hydrous calcium sulfate, containing 20 percent water. This property makes it an important additive (after calcining) of quick-setting plasters, such as plaster of Paris. Most gypsum is used for the manufacture of wallboard, Portland cement, and building plaster, and gypsum is used to break up alkaline-rich soils. Anhydrite (the anhydrous form of gypsum) is also used in many applications, but to a lesser extent due to differing chemical and physical properties. Alabaster, a crystalline form of gypsum, is used for carving. 


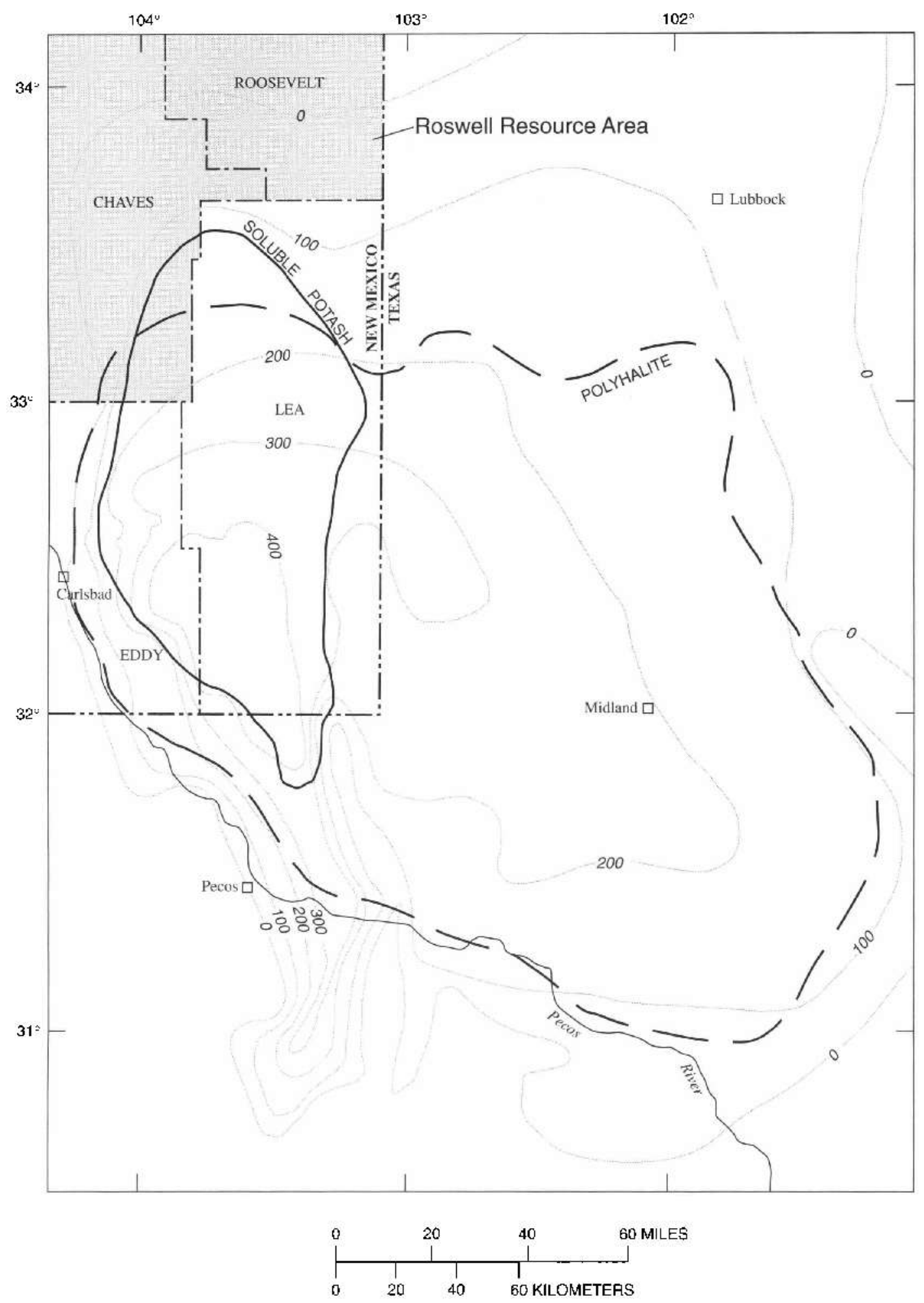

Figure 15. Isopach of salt in the Salado Formation in southwestern New Mexico and western Texas. Contour interval $100 \mathrm{~m}(328 \mathrm{ft})$. Area enclosed by solid line is extent of soluble polash salts; dashed line is extent of polyhalitc. (Modificd from Lowenstein, 1988.)

Economic gypsum deposits, however, must be relatively free of impurities. Table 4 lists the chemical compositions of various gypsum deposits in east-central New Mexico.
Large gypsum and anhydrite deposits are present from Carlsbad to Santa Rosa in the Artesia Group and San Andres Formation, where they cover an estimated $1,400 \mathrm{mi}^{2}$ (Weber 


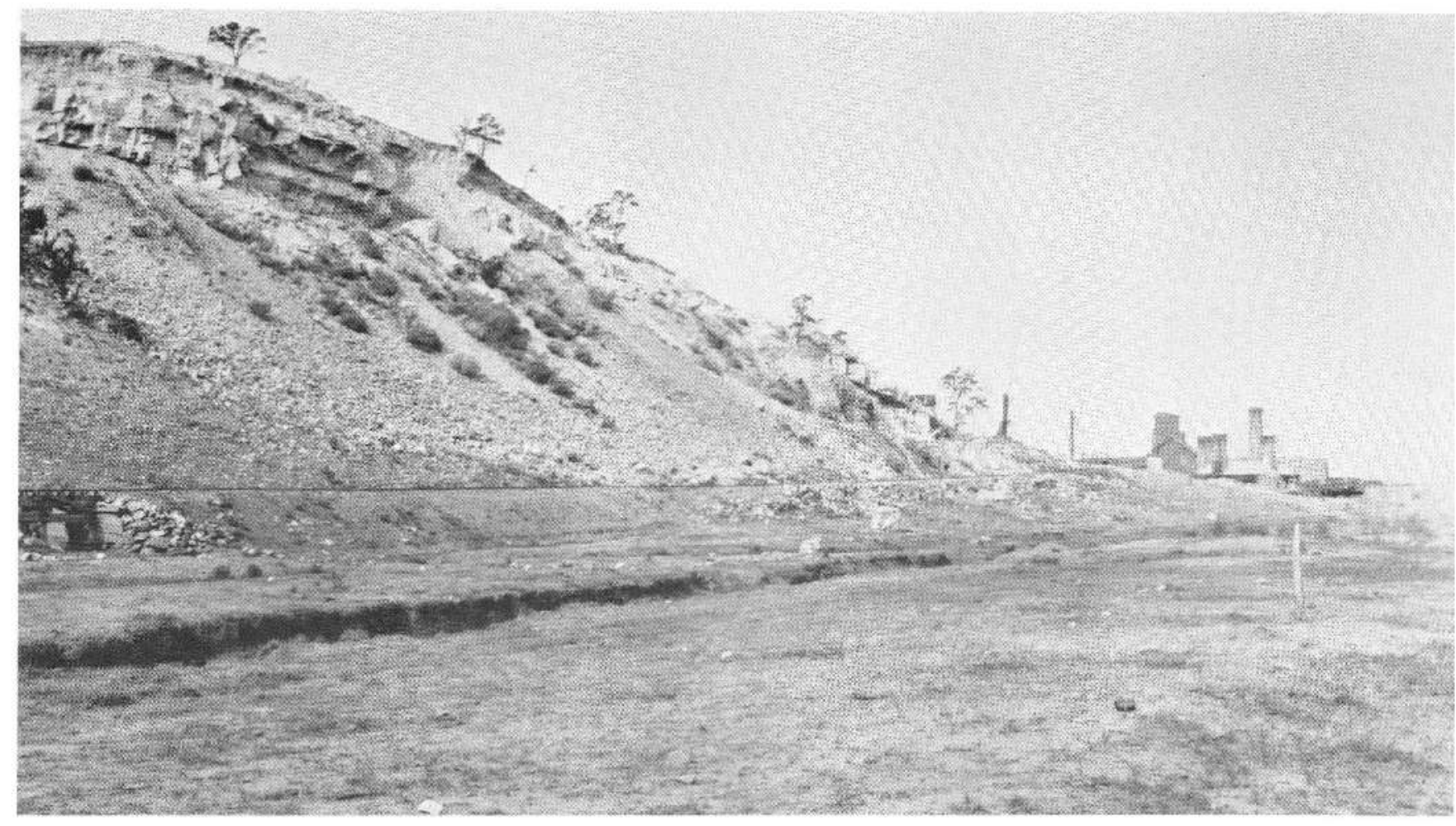

Figure 16. Gypsum outcrops in the Lower Permian San Andres Formation and Upper Permian Artesia Group at Ancho, N. Mex. Gypsum mill also shown. Photograph taken about 1/2 mi from the town of Ancho by N.H. Darton on September 30,1917 (photograph number 1603. on file at the U.S. Geological Survey Photo Library, Denver, Colo.).

Table 3. Mineral constituents of the gypsite deposits at Ancho. N. Mex. (Jones, 1915)

\begin{tabular}{lc} 
[Lcaders (-), not reported] \\
Mineral constituents & $\begin{array}{c}\text { Concentration } \\
\text { (in percent) }\end{array}$ \\
\hline Calcium sulphate (gypsum) & 63.95 \\
Calcium carbonate & 20.04 \\
Magnesium sulphate & - \\
Magnesium carbonate & - \\
Magnesium oxide & 0.89 \\
Potassium sulphate & - \\
Sodium carbonate & - \\
Sodium chloride & 0.09 \\
Silica & 3.57 \\
Iron and aluminum oxides & 2.01 \\
Moisture & 9.45 \\
$\quad$ Total & 100.00 \\
\hline
\end{tabular}

and Kottlowski, 1959; Bachman, 1987) (fig. 17). Gypsum deposits also occur on the westem Pecos Slope and adjacent to the Lincoln County porphyry belt in the Yeso and San Andres Formations and the Artesia Group (fig. 17). In the study area, gypsum deposits are estimated to cover $8,766 \mathrm{mi}^{2}$ (fig. 17; pl. 13); because they are at or near the surface, they can be mined easily.
Table 4. (hemical analyses of gypsum (in percent) from three selected deposits within the Roswell Resource Area, New Mexico (from Weber and Kottlowski, 1959, table 1)

[Compositions are considered approximate for each deposit]

\begin{tabular}{|c|c|c|c|}
\hline & 1 & 2 & 3 \\
\hline $\mathrm{CaO}$ & 33.55 & 32.04 & 32.94 \\
\hline $\mathrm{SO}_{3}$ & 45.16 & 46.10 & 45.65 \\
\hline $\mathrm{H}_{2} \mathrm{O}$ (combined) & 18.16 & 19.36 & 19.47 \\
\hline $\mathrm{Fe}_{2} \mathrm{O}_{3}$ and $\mathrm{Al}_{2} \mathrm{O}_{3}$ & 0.25 & 0.42 & 0.16 \\
\hline $\mathrm{SiO}_{2}$ (insoluble & 0.57 & 1.70 & 0.16 \\
\hline $\mathrm{MgO}$ & 0.36 & 0.20 & 0.55 \\
\hline $\mathrm{CO}_{2}$ & 2.16 & 0.66 & 0.55 \\
\hline Total & 100.21 & 100.88 & 99.02 \\
\hline $\begin{array}{l}\mathrm{CaSO}_{4} \text { (calculated from } \\
\text { available } \mathrm{SO}_{3} \text { ). }\end{array}$ & 76.9 & 78.4 & 77.6 \\
\hline $\begin{array}{l}\text { Gypsum (Anhydrite from } \\
\mathrm{CaSO}_{4} \text { plus combined } \\
\text { water, adjusted to total } \\
100 \text { percent with } \\
\text { impurities listed). }\end{array}$ & 94.8 & 96.9 & 98.1 \\
\hline
\end{tabular}

1: San Andres Formation gypsum; sec. 34, T. 5 N., R. 16 E., approximately $3 / 4$ mi northwest of Vaughn; 20-ft chip sample from old quarry face.

2: San Andres Formation gypsum; upper gypsum sequence in old plaster-mill quarry at Ancho, NE1/4 sec. 25, T. 4 S., R. $11 \mathrm{E}$; chip sample at $1-f t$ intervals.

3: Gypsum in the upper part of the Yeso Formation and the lower part of the San Andres Formation, Phillips Hills; sec. 21, T. 10 S., R. 8 E.: chip-channel sample. 

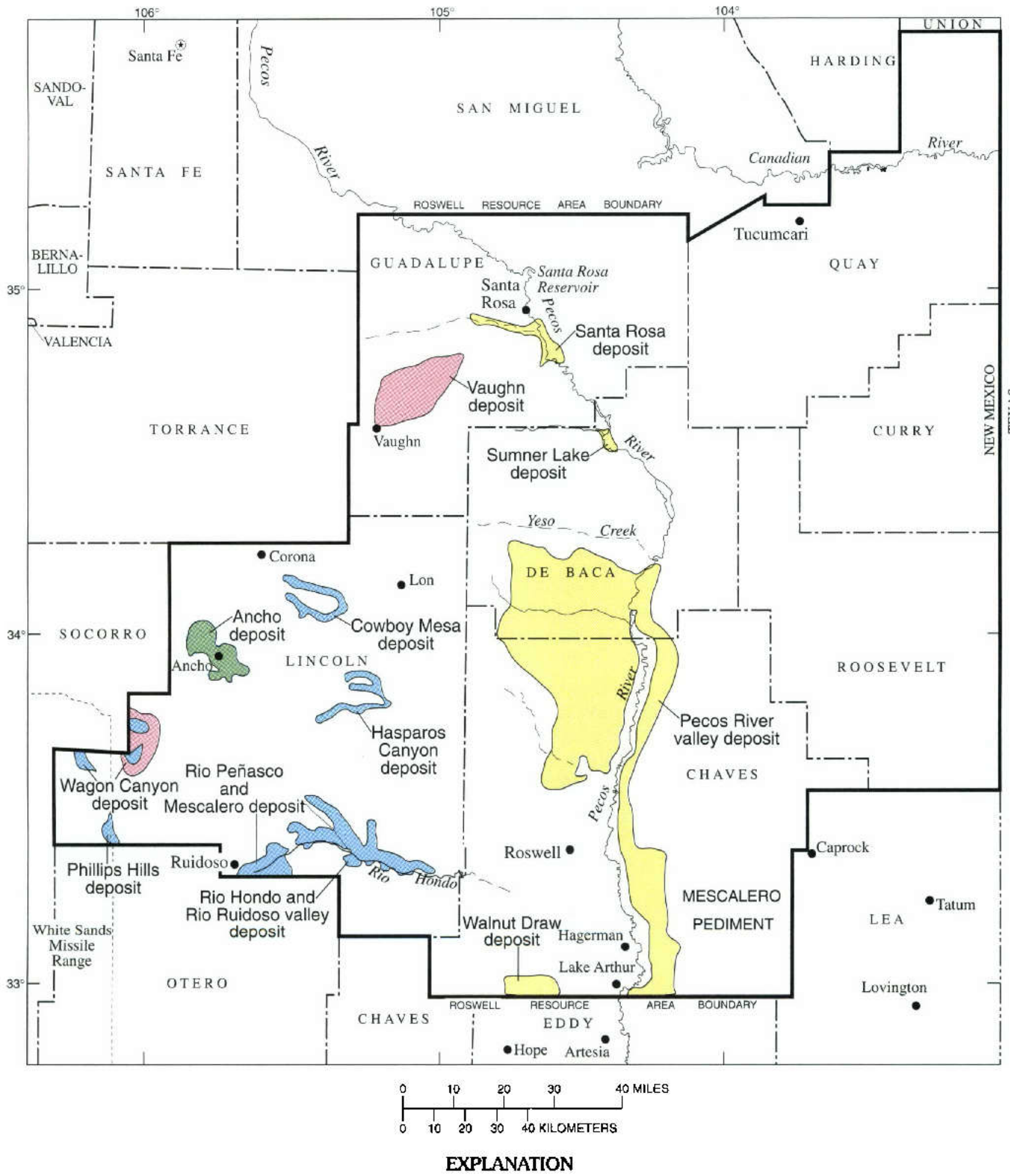

Upper Permian Artesla Group

Artesia Group and San Andres Formation, undlvided

Lower Permlan San Andres Formation

Lower Permian Yeso Formathon

Figure 17. Distribution of gypsum deposits in the Roswell Resource Area. New Mexico (modified from Weber and Kottlowski, 1959). 
The Yeso Formation hosts the most important gypsum resources in the study area, although the gypsum is typically interbedded with clastic and carbonate units, altered, and covered by thick overburden. Within the study area, the Yeso hosts the deposits of Rio Hondo and Rio Ruidoso valley, Rio Peñasco and Mescalero (at the southem border of the study area and in the Mescalero Apache Indian Reservation south of the study area), Phillips Hills, Wagon Canyon, Hasparos Canyon, and Cowboy Mesa, as well as unnamed deposits exposed in many smaller tributaries that drain the Pecos Slope east of the Sacramento Mountains. Gypsum beds in the Yeso are generally 2-10 ft thick and poorly exposed.

Gypsum occurs in the San Andres Formation within the study area in the Wagon Canyon, Ancho, and Vaughn deposits, and is a large component of the San Andres on the Pecos Slope in Lincoln and Guadalupe Counties (Weber and Kottlowski, 1959; U.S. Geological Survey, 1965). West of the study area, gypsum occurs in the San Andres on Chupadera Mesa. The continuity of gypsum in the San Andres is typically destroyed by dissolution and collapse; lenticularity of the gypsum beds may also be due to structural complications.

Gypsum occurs in the Artesia Group within the study area in the Ancho, Pecos River valley, Walnut Draw, Sumner Lake, and Santa Rosa deposits; these deposits are relatively thin and lenticular (Weber and Kottlowski, 1959).

Large deposits of gypsum occur in the Castile and Rustler Formations south of the study area. Limited quantities of gypsum occur in the Rustler in the southeastern part of New Mexico northeast of Carlsbad. Gypsum occurs only as small stringers in veins and as cement in the Dewey Lake Redbeds (Weber and Kottlowski, 1959).

\section{DESCRIPTIONS OF SELECTED GYPSUM DEPOSITS IN THE STUDY AREA}

The study area contains vast gypsum resources (Weber and Kottlowski, 1959; Austin and others, 1982). The median estimated tonnage of undiscovered deposits of gypsum in the study area is about 2 billion short tons (Sutphin, table 10, this report). However, as both Darton (1920) and Weber and Kotllowski (1959) acknowledged, structural complications, such as folding, fracturing, faulting, and igneous intrusions, are limiting factors to the economic potential of gypsum in the study area.

Gypsum is exposed extensively and at moderate depths beneath Permian limestone in the region that extends southwestward from Vaughn to beyond Corona (Darton, 1920; Weber and Kottlowski, 1959), especially in the Ancho area where the most production took place (fig. 17). This gypsum contains thin limestone laminae, is coarsely crystalline and as much as $35 \mathrm{ft}$ thick, and locally contains selenite porphyroblasts (Weber and Kottlowski, 1959). The gypsum beds and associated gypsite cap in the upper part of the deposit are
$30-35 \mathrm{ft}$ thick and consist of white, gray, and thin dark-gray gypsum beds containing sparse limestone laminations. Chip samples taken from the top to the bottom of this sequence at 1 -ft intervals contained an average of 96.9 percent gypsum (Weber and Kottlowski, 1959). Other gypsum beds in the deposit are 10-15 ft thick.

At the Vaughn deposit in Guadalupe County, Darton (1920) and Weber and Kottlowski (1959) described gypsum beds in an abandoned rock quarry and in the walls of sinkholes. In the quarry, a gypsum bed at least $20 \mathrm{ft}$ thick was observed; the total thickness is not known because the bottom of the bed was concealed by rubble. A random chip sample of the bed contained 94.8 percent gypsum. The gypsum is overlain by $10-30 \mathrm{ft}$ of limestone. Other prospect pits in the area show approximately $11 \mathrm{ft}$ of gypsum and 2-13 ft of limestone cover. Additional gypsum exposures were seen in the wall of a sinkhole southeast of the quarry. Two gypsum beds are exposed in another sinkhole where, according to Weber and Kottlowski (1959), the lower bed is a minimum of $17 \mathrm{ft}$ thick (the bottom of the bed was covered) and the upper bed is $15 \mathrm{ft}$ thick. Between the two gypsum beds is an 8 -ft-thick bed of limestone; about $20 \mathrm{ft}$ of limestone separates the upper bed from the surface. A nearby drill hole passed through gypsum interbedded with thin clay to a depth of $170 \mathrm{ft}$. These observations led Weber and Kottlowski (1959) to conclude that gypsum beds lie beneath a thin cover of limestone and alluvium over a very large area near Vaughn; further exploration would be required to assess its extent and quality.

In the region from Vaughn to Santa Rosa, surface and near-surface exposures of bedded gypsum in the San Andres Formation and Artesia Group are covered locally by a thin veneer of Tertiary and Quatemary deposits (Weber and Kottlowski, 1959). Deposits of massive gypsum are as much as $20 \mathrm{ft}$ thick. The gypsum is white, contains limestone seams, selenite porphyroblasts, and basal limestone nodules, and grades upward into thin-bedded, gray to white gypsum containing lesser amounts of limestone at the top (Weber and Kottlowski, 1959). Quarries expose good- to poor-quality gypsum as much as $17 \mathrm{ft}$ thick and the gypsum is overlain by blocky limestone (Weber and Kottlowski, 1959). A drillhole log from the area describes a thick sequence of gypsum interbedded with clay from the surface to a depth of $170 \mathrm{ft}$ (Darton, 1928; Weber and Kottlowski, 1959).

Gypsum deposits have been described from the Wagon Canyon and Phillips Hills deposits (fig. 17) in Lincoln County (Schmalz, 1955). The deposits are in numerous beds of the San Andres and Yeso Formations, are poorly exposed, and occur as interbeds in limestone. Pure white gypsum beds as much as $100 \mathrm{ft}$ thick are apparently covered by cellular gypsite and numerous interbeds of limestone and siltstone (Weber and Kottlowski, 1959). Weber and Kottlowski (1959) noted that the beds are poorly exposed beneath darkgray limestone and gypsite. A columnar section (Darton, 1920) shows beds as much as $100 \mathrm{ft}$ thick. The total 
thickness of the beds is approximately $400 \mathrm{ft}$, and the majority is described as being white and of good quality. At most places, the beds dip eastward at $5^{\circ}-16^{\circ}$, but in some places they are almost horizontal. Weber and Kottlowski (1959) reported that in some canyons several acres of gypsum underlie a thin veneer of soil and limestone. In most places, however, extensive stripping or underground mining would be required to exploit large deposits. Chip samples of a 20$\mathrm{ft}$-thick interval indicated an average of 98.1 percent gypsum (Weber and Kottlowski, 1959) (No. 3, table 4).

In the Rio Hondo and Rio Ruidoso valley deposits, thin (2-10 ft) gypsum beds are poorly exposed in the upper part of the Yeso Formation.

West of the Pecos River valley on the Pecos Slope, gypsum beds are not as well exposed as they are farther east in the Pecos River valley, but they are near the surface and amenable to strip mining (although the beds are of variable grade and thickness) (Weber and Kottlowski, 1959). The gypsum deposits are interbedded with dolomitic limestone and red beds, lenticular, and relatively thin bedded.

The Pecos River valley from Santa Rosa to Carlsbad and to the east of Artesia and Hagerman contains abundant gypsum beds in the Artesia Group, especially in the Grayburg, Seven Rivers, Yates, and Tansill Formations, which are at or near the surface (Weber and Kottlowski, 1959). Gypsum beds are also exposed near Roswell east of the Pecos River. They are 1-5 ft thick, interbedded with red beds (shale, fine-grained sandstone, and siltstone), green shale, and limestone (Weber and Kottlowski, 1959), and locally contorted, and contain lenses and thin beds of high-purity gypsum. Intervals of gypsum-bearing limestone (containing as much as 80 percent gypsum) are as thick as $20 \mathrm{ft}$. A $42-\mathrm{ft}$ thick section of the Seven Rivers Formation along the Pecos River has been estimated to contain 3.7 billion short tons of gypsum; the Yates Formation in the same area is estimated to contain 1.4 billion short tons of gypsum (Korzeb and Kness, 1992). Along the Pecos River valley, thin to thick Permian gypsum beds have potential for local agricultural and industrial use, especially near Acme (Weber and Kottlowski, 1959). At Acme, the beds are light-gray crystalline gypsum, 1-6 ft thick, interbedded with red beds, and covered by gypsite.

Beds of pink to white alabaster as much as 26 in. thick are known to occur at one locality north of Roswell, but it is unknown whether alabaster deposits occur elsewhere in the study area (George S. Austin, New Mexico Bureau of Mines and Mineral Resources, oral commun., July 1991).

\section{HALITE}

Halite-bearing strata occur throughout the Permian Basin in Kansas, Oklahoma, Texas, Colorado, and New Mexico (fig. 15) (McKee and Oriel, 1967; Budnik, 1989). Halite is most abundant in the Salado Formation near Carlsbad south of the study area. The Salado contains as much as
$1,300 \mathrm{ft}$ of halite (Lowenstein, 1988), typically pink to pale red due to the presence of hematite, silt, or clay impurities. In the western Delaware Basin, salt layers in the Rustler Formation are represented by breccia, gypsum, siltstone, and sandstone due to solution and collapse; to the north, halite beds in the Salado wedge out (U.S. Geological Survey, 1965). Halite also occurs in other Permian formations including the Yeso, San Andres, Grayburg, Queen, Seven Rivers, Yates, and Tansill Formations. Subsurface halite and anhydrite beds (but no potash) in the Yeso are as thick as $1,935 \mathrm{ft}$ in sec. 33, T. $6 \mathrm{~S}$., R. 9 E., Lincoln County (U.S. Geological Survey, 1965; Austin and others, 1982).

Within the study area, halite deposits occur beneath all of Guadalupe, Quay, Curry, De Baca, Chaves, and Roosevelt Counties and beneath the eastern half of Lincoln County (Austin and others, 1982). Known halite beds of variable thickness occur on the surface and in the subsurface over approximately $13,000 \mathrm{mi}^{2}$ of the study area. Despite these vast resources, there are no active salt mines in the study area (Austin and others, 1982).

\section{IODINE AND BROMINE IN SALINE BRINES AND BRINE DEPOSITS}

By Sherilyn Williams-Stroud

Saline brine deposits form in a karstic setting where much groundwater is introduced into an evaporite sequence and the rocks are dissolved until the liquid is saturated. Brines also occur in beds associated with evaporite deposits, which may have been original deposition brines from which salts precipitated. The salts became trapped in associated rocks of higher porosity upon expulsion from the evaporite deposits due to burial compaction. In many cases, these brines may be altered from their original composition by rock interactions. The permeability of the host rock is typically negligible, resulting in loss of circulation and stagnation of the brine (Bachman, 1987).

The presence of brine "aquifers" is important to the hydrologic regime of an area because they may contaminate groundwater. Such aquifers may be perched above impermeable layers within evaporite sequences (Bachman, 1984). It is likely that brine deposits occur beneath the study area in beds of Permian age, although their extent is unknown.

Both iodine and bromine occur in brines south of the study area in the Rustler Formation, Dewey Lake Redbeds, and Bell Canyon Formation (partly equivalent to Artesia Group south of the Capitan Reef; pl. 2); bromine is known to occur in brines at concentrations of 26-78 ppm (Steven J. Lambert, U.S. Geological Survey, written commun., 1991). In contrast to the low expected concentrations in the study area of less than $1 \mathrm{ppm}$, concentrations of iodine in brines of commercial operations in Oklahoma range from 150 to $1,200 \mathrm{ppm}$, in Michigan at concentrations of $30 \mathrm{ppm}$, and in Califomia at concentrations of 30-70 ppm (Lyday, 1985a). 
Bromine is produced commercially in Arkansas and Michigan from subsurface brines having concentrations of 5,000 ppm and 1,600 ppm, respectively (Lyday, 1985b). If brine aquifers containing iodine and bromine occur in the subsurface beneath the study area, they would probably occur at subeconomic concentrations.

\section{SULFUR}

\section{By Charles S. Spirakis}

In the United States, the largest producer of sulfur using the Frasch process (Smith, 1980), most sulfur is produced from salt dome caprock deposits beneath Texas and Louisiana. Sulfur is extracted by the Frasch process, which uses hot water and high-pressure air to melt sulfur and force the molten liquid through pipes to the surface.

In the study area, many occurrences of native sulfur in association with anhydrite have been reported (Talmage and Wootton, 1937; Hinds and Cunningham, 1970; Smith, 1978; Thomsen, 1990) and many other occurrences have been noted in drill cuttings and cores. Near the study area boundary northwest of Artesia (sec. 8, T. 16 S., R. 22 E.), a 20-ftthick sulfur bed of high purity was encountered at a depth of $940 \mathrm{ft}$ (Talmage and Wootton, 1937). Sulfur occurrences in gypsum are also reported from near White Oaks (Jones, 1915; Talmage and Wootton, 1937). Except for sulfur recovered as a byproduct of oil and gas production, no native sulfur has been produced in the study area, but exploration is continuing, especially near Artesia (south of the study area) and Santa Rosa, and in an area stretching from just east of Roswell to the southem boundary of the study area.

\section{TEXAS DEPOSITS}

Large deposits of bedded sulfur occur south of the study area in the Rustler Springs sulfur district, Culberson County, Texas. The Rustler Springs sulfur district contains one of the world's largest sulfur deposits produced using the Frasch process. Production has totaled more than $36,100,000$ long tons from 1969 to early 1990 , and the average daily production has been 6,000-7,000 long tons (Hentz, 1990). The deposits are in the Salado and Castile Formations and in the Permian reef (Hentz, 1990; Crawford, 1990). The thick Castile Formation (which does not occur in the study area) and the Salado Formation are targets in sulfur exploration in the Permian Basin, where there is evidence of both underlying petroliferous rock, intrastratal salt and clay units, and faults and (or) joints (Hentz and Henry, 1989; Hentz, 1990). Sulfur is thought to have been entrapped and (or) preserved by impermeable beds and structures (Hentz, 1990).

The Culberson sulfur mine, the largest in the Rustler Springs district, produces from an elliptical deposit in vuggy, secondary-limestone host rock. Sulfur occurs in the Castile and Salado Formations, lining both vugs and fractures in the central part of the body (Hentz, 1990). The deposit trends into a northeast-trending graben (Hentz, 1990). Shale deposits typically overlie the sulfur deposits and possibly are related to sulfur deposition. The Culberson deposit is not directly associated with oil, but minor oil and asphalt occur in surrounding strata. Barite deposits locally overlie the sulfur deposits. The Phillips Ranch deposit, west of the Culberson mine, also occurs in a northeast-trending graben, and the elongate ore body contains the thickest sulfur deposits in the central part of the graben (Hentz, 1990). The sulfur was apparently concentrated along fault zones that define the down-faulted block and that may have served as impermeable traps. Sulfur is restricted to the basal part of the Castile

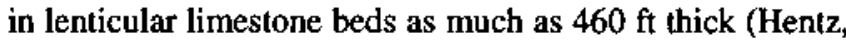
1990). The Pokorny deposit, as yet unmined, is located northwest of the Culberson mine near a fracture zone (typically the fractures provide permeability); sulfur occurs in the basal part of the Castile (Hentz, 1990). In other aspects, this deposit is similar to the Phillips Ranch deposit.

\section{ORIGINS AND ASSESSMENT OF SULFUR RESOURCES}

In assessing the potential for native sulfur deposits, it is important to consider the volume of reductant (oil or gas) needed to make a large deposit. For example, it is estimated that the volume of oil needed to form the Culberson deposit was 200 million barrels (Smith, 1978). Deposits much smaller than the Culberson might become economic; nevertheless, substantial amounts of reductant are required.

Two types of sulfur deposits that formed by similar processes might be of economic importance in the study area. In one of these deposit types, exemplified by the Culberson deposit discussed above, organic matter in the form of oil or gas migrated into anhydrite beds at the site now occupied by the sulfur deposit. Bacteria catalyzed the reduction of sulfate by organic matter to form hydrogen sulfide; hydrogen sulfide was then oxidized, either by excess sulfate or oxygen in meteoric water, to native sulfur (Feely and Kulp, 1957; Davis and Kirkland, 1970). Commonly, an impermeable cap of shale or salt overlies these deposits.

In the second type of sulfur deposit, exemplified by the native sulfur deposits in Lechuguilla Cave, Eddy County, $N$. Mex. (Spirakis and Cunningham, 1992) (fig. 18), sulfate is reduced by organic matter to hydrogen sulfide; in this example, the reduction does not occur at the site now occupied by the sulfur deposit. It is possible that the reduction process occurs deep in the basin at sufficiently high temperatures for thermochemical sulfate reduction (that is, reduction not catalyzed by bacteria) to occur. In contrast to the first type of sulfur deposit, hydrogen sulfide in these deposits migrates away from its parent sulfate before being oxidized to native sulfur. As in the first type of sulfur deposit, the sluggish kinetics of hydrogen sulfide oxidation suggests that bacteria were involved in the oxidation. 


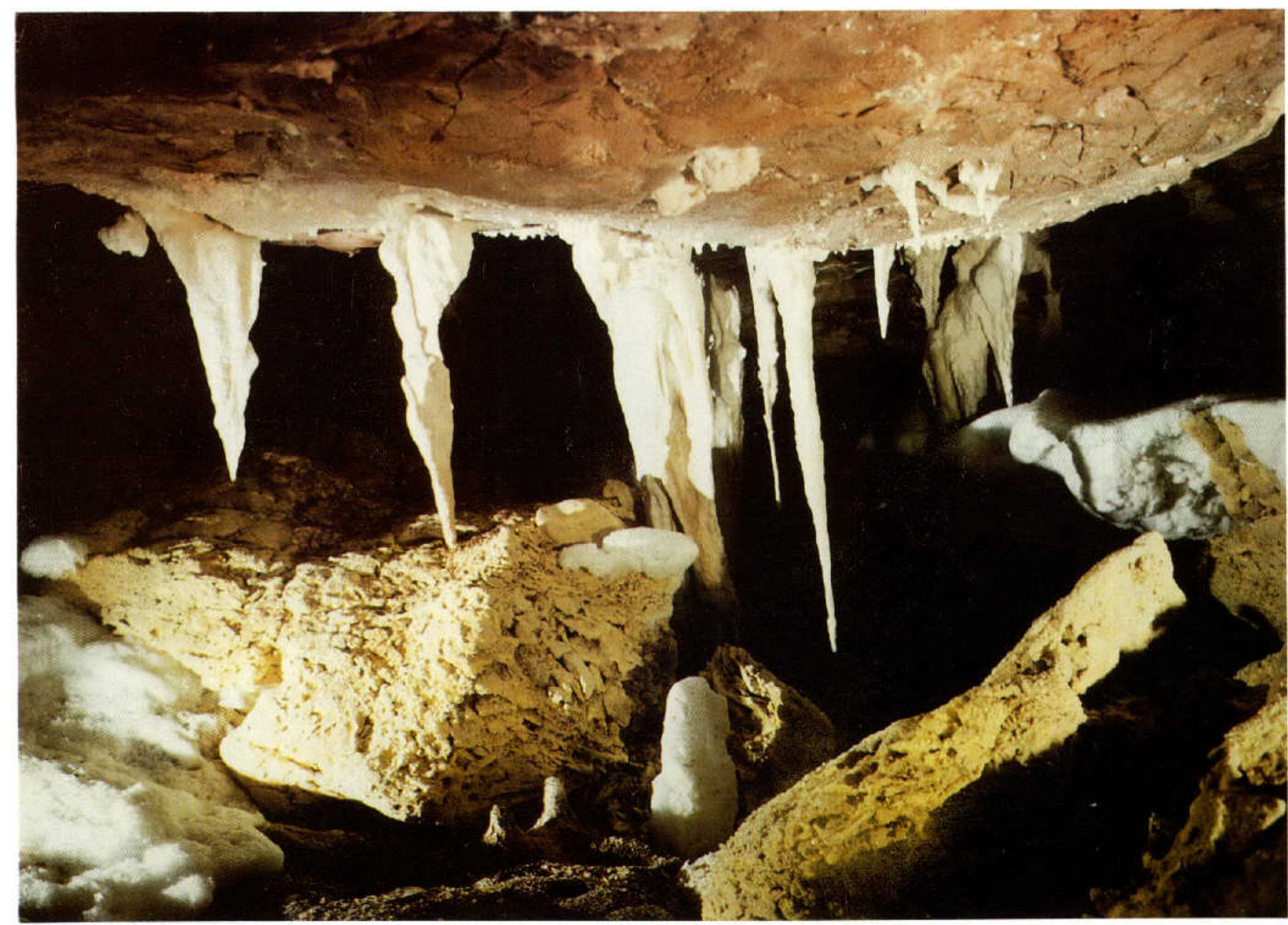

Figure 18. Blocks of native sulfur (yellow) and stalactites of gypsum (white) in the Ghost Town deposit, approximately $820 \mathrm{ft}$ below the surface in Lechuguilla Cave, N. Mex. (1 in.=l ft). Sulfur is deposited in beds as much as $3 \mathrm{ft}$ thick in the cave. The sulfur deposit formed by oxidation of hydrogen sulfide, which probably migrated several miles from its source (see text). Photograph taken by Laurent D. McLaughlin, Nederland, Colo., in June 1990.

In both of these deposit types, the critical factors in forming native sulfur are (1) sedimentary anhydrite as a source of sulfur, (2) organic matter to act as a reductant, (3) sufficient permeability to allow the organic matter to migrate to the anhydrite, (4) temperatures low enough for bacteria to survive and to catalyze the oxidation of hydrogen sulfide, and (5) presence of an oxidant. Temperatures low enough for bacteria to survive and the penetration of oxidizing groundwaters are ubiquitous in the upper few thousand feet within the study area and, hence, are not useful for outlining most favorable areas within the study area.

In the study area, regions favorable for native sulfur deposits may be outlined by superimposing the areas having potential for oil, gas, or tar sand upon the areas underlain by anhydrite deposits (fig. 19). Much of the study area is underlain by anhydrite deposits, and individual beds are more than $98 \mathrm{ft}$ thick (Johnson and others, 1989). Migrated organic matter (oil, gas, and tar sand) occurs near Artesia and Santa
Rosa. In this area, large deposits of both types described above might be found. Areas of lesser potential surround the favorable regions; they might contain sulfur deposits derived from migrated hydrogen sulfide. How far hydrogen sulfide can migrate before it encounters oxidizing conditions is not clear and, therefore, the outer limits of these regions are not well defined.

Specific exploration targets within the favorable areas might be identified by applying other criteria, including the presence of cap rocks, the presence of secondary calcite that forms as sulfate is reduced by organic matter, and the identification of faults, dissolution zones, or other permeable zones that might have provided avenues for migration of organic matter, hydrogen sulfide, or oxidizing groundwaters. Hentz and Henry (1989) suggested that grabens form migration paths and are prospecting guides for sulfur deposits in West Texas. In some cases, dissolution zones could be an indicator that sulfur-producing reactions had occurred. 


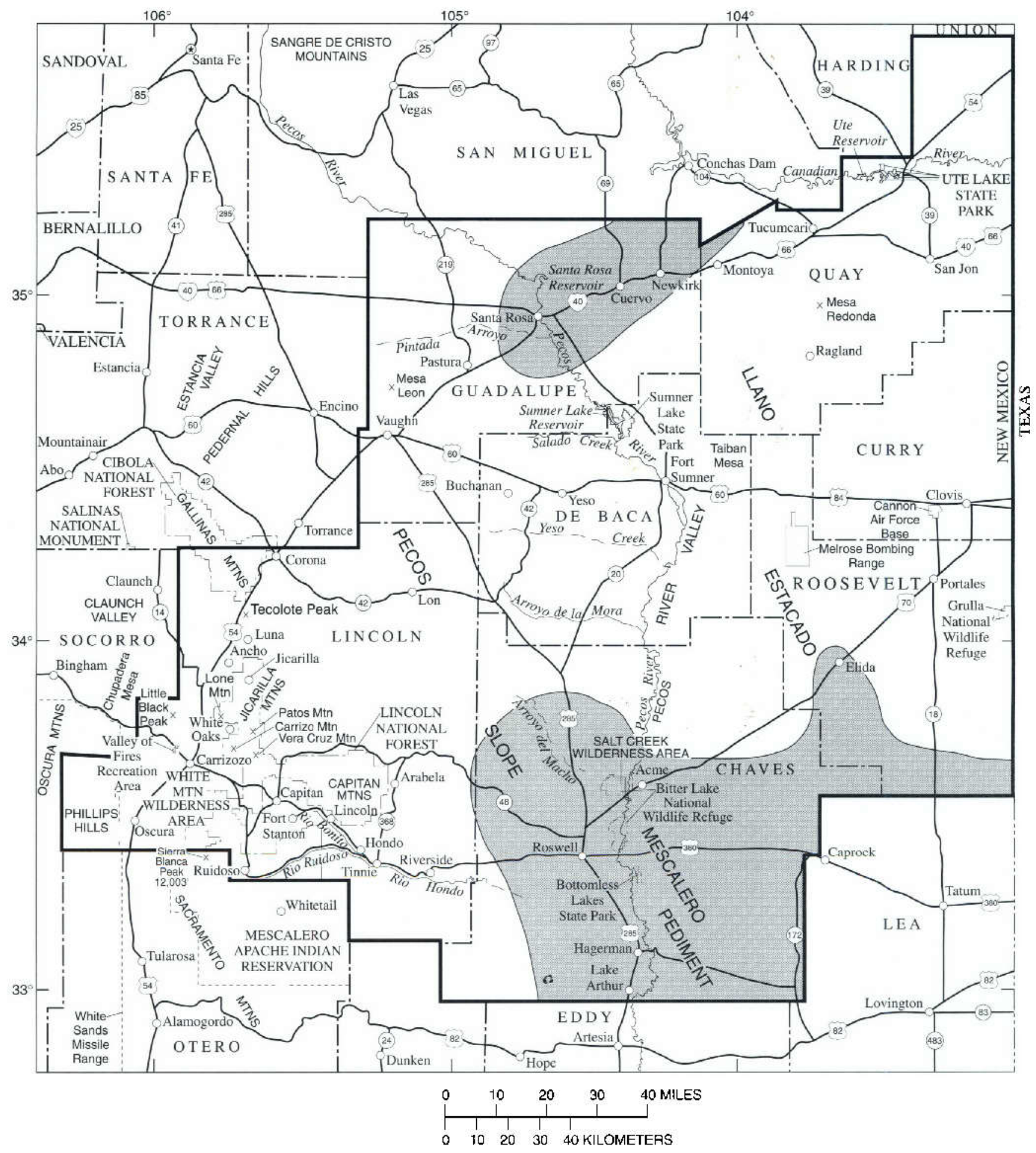

Figure 19. Distribution of areas favorable for sulfur (shaded) in the subsurface of the Roswell Resource Area, New Mexico.

Although the oxidation of hydrogen sulfide $\left(\mathrm{H}_{2} \mathrm{~S}\right)$ to (solid) native sulfur $\left(\mathrm{S}^{\circ}\right)$ does not produce acid,

$$
\mathrm{H}_{2} \mathrm{~S}+1 / 2 \mathrm{O}_{2} \rightarrow \mathrm{S}^{\circ}+\mathrm{H}_{2} \mathrm{O},
$$

the continued (or concomitant) oxidation to sulfate does,

$$
\mathrm{S}^{\circ}+3 / 4 \mathrm{O}_{2}+\mathrm{H}_{2} \mathrm{O} \rightarrow \mathrm{SO}_{4}=+2 \mathrm{H}^{+}
$$

Thus, carbonate and sulfate mineral dissolution may be a prospecting guide for sulfur deposits. Because bacteria remove sulfate from groundwater as they reduce sulfate in forming native sulfur deposits, the solubility of gypsum and 
anhydrite is locally enhanced to the point of dissolution (Davis and Kirkland, 1970).

In addition to native sulfur deposits, sulfur might also be produced in the study area as a byproduct in oil and gas processing (sulfur has been recovered from natural gas near Artesia, just south of the study area) or from sulfide mineral refining.

\section{AGGREGATE AND CONSTRUCTION MATERIAL}

Aggregate, including crushed stone, is plentiful throughout the study area, but especially in the eastern part of the study area on the Llano Estacado, Mescalero pediment, Pecos and Canadian River terraces, and parts of the Pecos Slope (fig. 20). Road-building aggregate includes sand and gravel in rivers and creeks, caliche, gravel, and sand from the Ogallala Formation, and basalt, igneous dikes, sandstone, limestone, and dolomite (New Mexico State Highway Department, 1961, 1966, 1971-72). Aggregate (exclusive of caliche) occurs in pediments, terraces, and valley alluvium throughout the Pecos Slope. The locations and descriptions of these numerous deposits are discussed by Kelley (1971). Caliche from the Ogallala Formation is commonly used as aggregate in the east-central part of the study area.

According to Lovelace (1972), the aggregate supply within the study area is locally unlimited, but large areas are aggregate poor, such as the populated region near Roswell. Concrete-quality aggregate, however, occurs only in terrace deposits of the Canadian and Pecos Rivers. Pecos River terrace gravel is most plentiful in De Baca County and Guadalupe County, but the highest quality, low-clay gravel is in De Baca County where the beds are as much as $60 \mathrm{ft}$ thick. Fairto good-quality aggregate from pediment deposits occurs near Santa Rosa and Vaughn. The basal part of the Ogallala Formation contains coarse aggregate deposits, but they are generally of poor quality and buried by younger deposits. Quaternary sand dune deposits used for aggregate are widespread from near Clovis to the Mescalero pediment.

\section{SAND AND GRAVEI}

Sand and gravel deposits have very low unit cost, but because they are required in modern construction of all types (especially in the paving and building industries), the total amount of sand and gravel produced in the United States is very large. Sand and gravel are easily the mineral commodities with the highest dollar values, outstripping the production of all metallic commodities combined. The deposits occur in a variety of geologic settings, but most typically result from fluvial, eolian, and glacial deposition. The composition of the deposits determines their use.

Deposits of sand and gravel are produced from along the valleys of the Pecos and Canadian Rivers and their tributary systems (fig. 20). They occur in Tertiary and
Quaternary deposits on the Llano Estacado, in Holocene deposits throughout the study area, and in the Glorieta Sandstone in the western part of the study area.

\section{CAI,ICHE}

Caliche is abundant in the eastern part of the study area (fig. 21), accounting for $\$ 300,000$ in sales in 1991 (Jerry T. Dutchover, Jr., U.S. Bureau of Land Management, oral commun., April 1992). In the study area, aggregate caliche occurs on Llano Estacado, Buchanan Mesa and outliers near Buchanan, Taiban Mesa, the aggraded surface southeast of Vaughn, the aggraded surface west of Santa Rosa, the mesa south of Cuervo, Mescalero pediment, and the lower erosional surfaces near the Canadian River and other drainages (Lovelace, 1972; New Mexico State Highway Department, 1971-1972). Caliche is quarried locally for road metal and for pad construction in the petroleum industry. It may also be used as a substitute for high-calicum limestone and as lime fertilizer (Talmage and Wootton, 1927). Deposits are as thick as 32-49 ft on the Llano Estacado in the eastem part of the study area (Kottlowski, 1962), the major caliche resource in the State. According to the New Mexico Department of Energy, Minerals and Natural Resources (1990), caliche production in the State increased by 431 percent between 1989 and 1990 , and increased in value by 388 percent.

Caliche is a near-surface calcium carbonate deposit that forms by leaching (weathering) of calcium carbonate at the surface and redeposition beneath the surface (Lovelace, 1972). The surficial (source) sediments are continually reworked and redeposited by storms, providing for unlimited caliche formation, but rainfall totals must be within precise limits for optimal caliche precipitation (Bachman, 1987). Groundwater helps to silicify caliche, and many caliche profiles have repeatedly been altered and recemented (New Mexico State Highway Department, 1971-1972). Caliche is formed more easily on bedrock surfaces that have a high calcium carbonate content, such as limestone, and it is not easily formed on sulfate-bearing surfaces and on surfaces protected by sand dune cover. Multiple layers of caliche occur on much of the High Plains of the United States, principally in the Ogallala Formation (fig. 22).

The best source of aggregate caliche is in the older caliche deposits, but quality is variable depending on the amount of carbonate content, amount of sand cover, elevation of the caliche deposit, type of bedrock on which the caliche forms, weather zone in which the caliche is formed, as well as other factors. The highest quality caliche is from the Llano Estacado, where it is well indurated and 3-6 ft thick. Typically the upper surface is laminated and is underlain by laminated to brecciated layers. Pisolitic structures are common. Locally, caliche on the Llano Estacado may be equivalent to high-calcium limestone, but because they are localized and discontinuous, their use may be limited to road metal (Kottlowski, 1962; Siemers, 1982). 


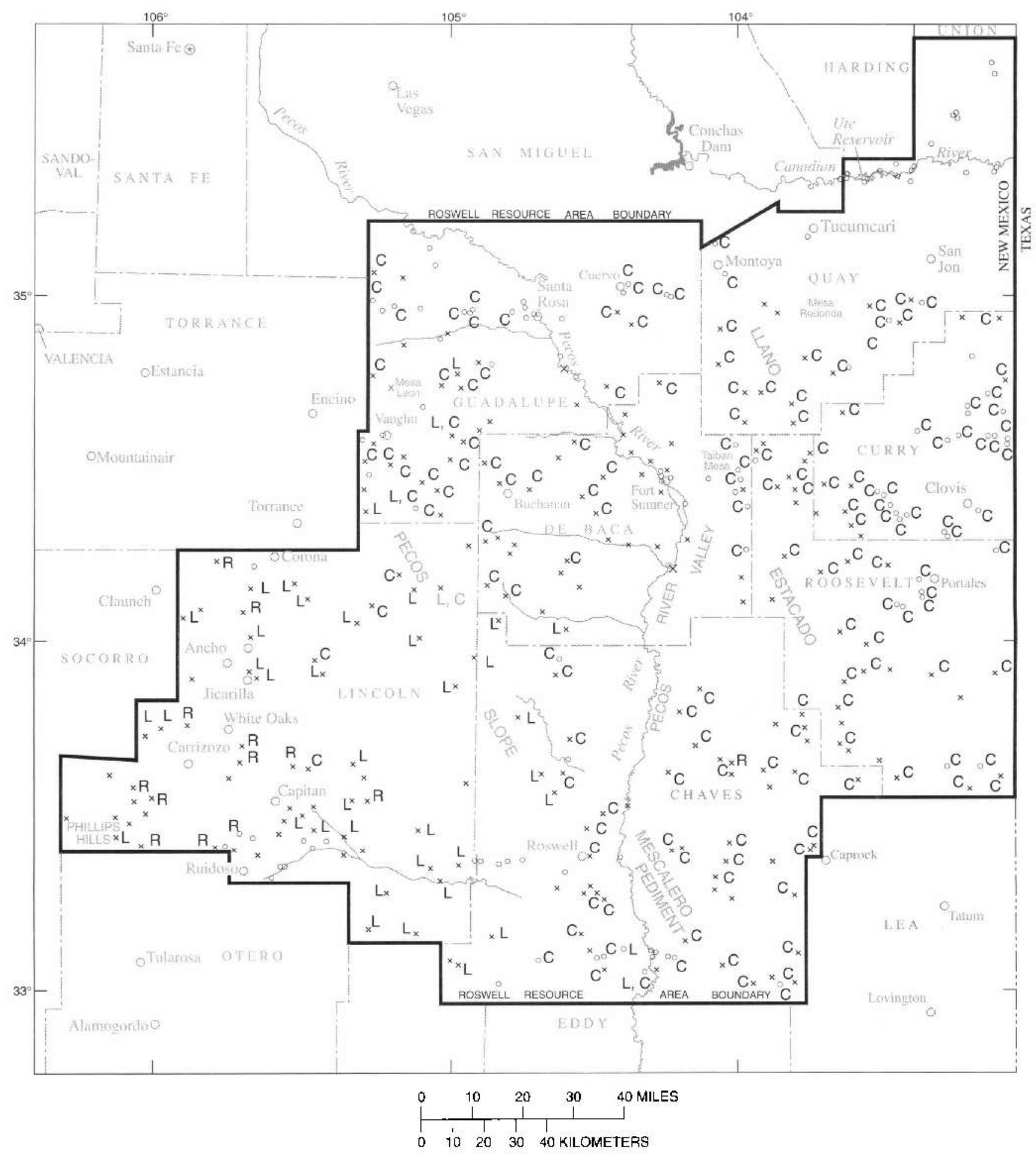

EXPLANATION

L Pit-Letter indicates type of aggregate (all or in part): C, caliche: L, limeslone and (or) dolornile; R. igneous or sedimentary rock. Pit symbol without lester indicates unconsolidated sand and (or) gravel

Developed pit

$\times$ Prospect pit

Figure 20. Locations of aggregate pits in the Roswell Resource Area. New Mexico (compiled from New Mexico State Highway Department, 1971-1972). 


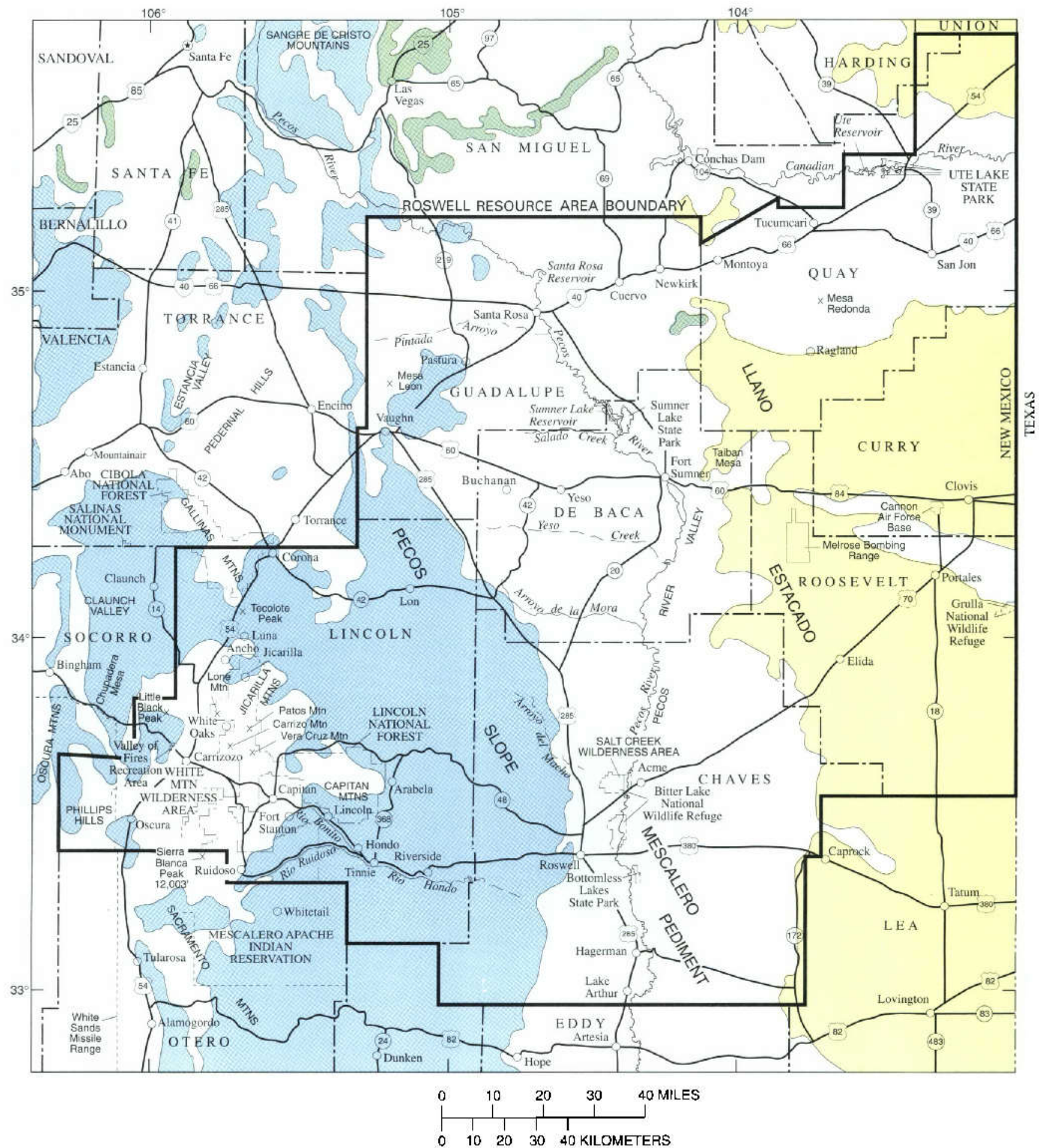

Figure 21. Distribution of caliche (yellow), Mesozoic limestone (green), and Paleozoic limestone and dolomite (blue) in the Roswell Resource Area and vicinity, New Mexico (modified from U.S. Geological Survey, 1965).

The most extensive deposits of caliche occur in Curry and Roosevelt Counties, and, except for areas covered by eolian deposits, both counties have unlimited supplies of caliche for use as aggregate (New Mexico State Highway
Department, 1971-1972). From Clovis to Tucumcari, the Ogallala Formation contains as much as $15 \mathrm{ft}$ of caliche at the top. Near Taiban Mesa, caliche is developed on limy sand and silt, and the upper caprock is 5-10 ft thick. 


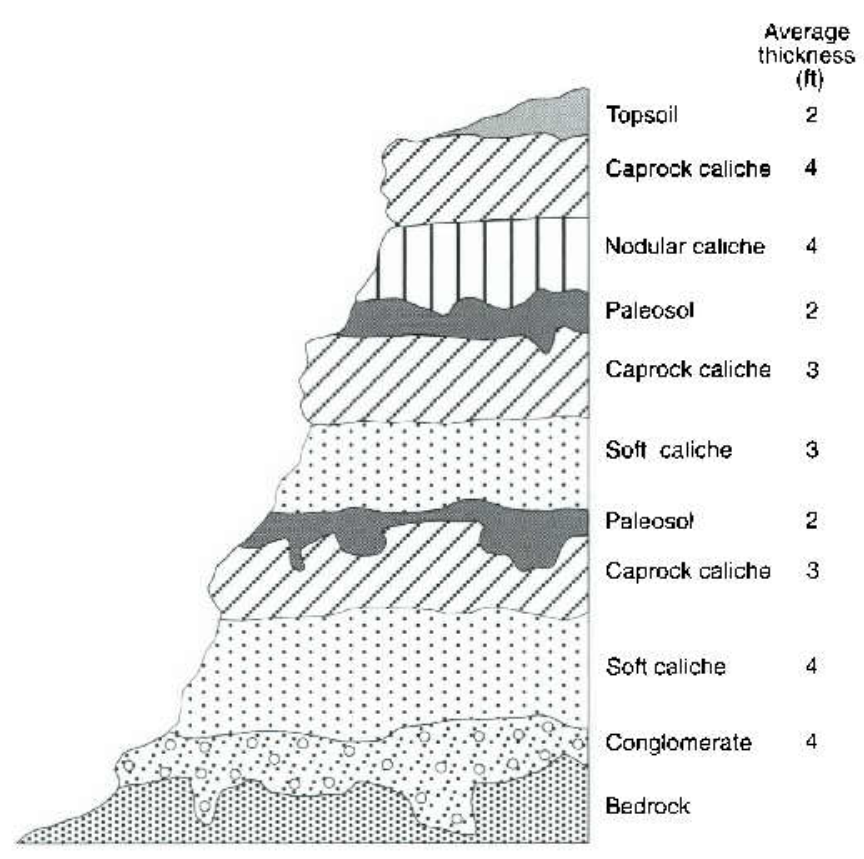

Figure 22. Diagrammatic profile of typical caliche section, showing multiple caliche layers on the plains near Fort Sumner, N. Mex. (modified from New Mexico State Highway Departnent. 1971-1972, p. 61).

Near the Roosevelt County-Chaves County line, the caliche deposits are irregular, locally reaching thicknesses of $20 \mathrm{ft}$, but averaging $5 \mathrm{ft}$ thick. East of Roswell and to the south, caliche forms thicker caprock that is higher in lime content. Bretz and Horberg (1949) reported that caprock in this area is as thick as $30 \mathrm{ft}$ and includes an underlying chalky caliche that is as thick as $15 \mathrm{ft}$ (reported in Kottlowski, 1962).

Bretz and Horberg (1949) analyzed 12 caprock caliche samples from the Llano Estacado, and reported an average of 3 percent insoluble residues. However, samples from other zones in the caliche from widely separated localities had as much as 31 percent insoluble residues, indicating variability in the caliche and the necessity of testing to determine feasibility for use (Kottlowski, 1962).

\section{DIKE ROCK AND SCORIA}

The Railroad Mountain and Camino del Diablo dikes, as well as other dikes in the study area, have been quarried for road metal (Lovelace, 1972; New Mexico State Highway Department, 1961, 1966, 1971-1972) (fig. 20). Scoria, a lighter weight aggregate than dike rock, has coarser vesicles, greater strength, and more crystalline structure than pumice, and it is used for road surfacing and railroad ballast. In the study area, abundant lava of the Little Black Peak and Carrizozo flows in western Lincoln County provide material for commercial and industrial uses, including decorative stone, road metal, landscaping, and building stone (File and
Northrop, 1966; New Mexico State Highway Department, 1971-1972; Stoeser and others, 1989).

\section{LIMESTONE AND DOLOMITE}

Limestone and dolomite occur on the western Pecos Slope and are quarried from Paleozoic and Mesozoic units on or near the surface (fig. 21). Depending on their composition, limestone and dolomite have been used in local road construction and as building stone, railroad ballast, sewage filter beds, and roofing granules. Typically, limestone composition varies laterally and vertically (Siemers, 1982).

\section{HIGH-CALCIUM LIMESTONE}

High-calcium limestone contains at least 95 percent calcium carbonate (about 53.22 percent calcium oxide) and less than 3-5 percent magnesium carbonate (Bowen, 1957; Bates, 1960). High-calcium limestone forms some of the Ogallala caliche deposits on the Llano Estacado and is extracted from some quarries (Kottlowski, 1962). It is used as a primary source of lime, and is important in the manufacturing and metallurgical industries in the production of cement, paper, glass, alkalis, and calcium carbide, and as a metallurgical flux. For industrial use, high-calcium limestone must contain limited amounts of impurities (magnesium carbonate, alumina, silica, sulfur, iron oxide, and phosphorous). The correct combinations of raw materials, including limestone and gypsum, are combined to produce cement of the correct chemical composition.

Extensive outcrops of high-calcium limestone occur in Pennsylvanian and Permian deposits of the Sacramento and Oscura Mountains (Kottlowski, 1962). High-calcium limestone is present in the Bursum(?) Formation in the northem Sacramento Mountains (Otte, 1959). Some limestone beds of the Hueco Formation are high in calcium; Permian units generally are high in calcium, except for the San Andres Formation, which is locally high in calcium (Siemers, 1982). Due to the wide occurrence of the San Andres, there are probably numerous localized occurrences of high-calcium limestone in the San Andres on the Pecos Slope. In southwestern Chaves County along Rio Peñasco (outside the study area), the lower part of the San Andres contains high-calcium limestone (97.4 percent calcium carbonate, 0.9 percent magnesium carbonate, and 1.3 percent silica) (Kottlowski, 1962). Jurassic limestone, 2-10 ft thick, was sampled near the Quay County-Guadalupe County line east of Santa Rosa; analysis of this limestone showed 94.6 percent calcium carbonate, 3.5 percent magnesium carbonate, 1.0 percent silica, and 0.07 percent sulfur (Kottlowski, 1962).

\section{LOW-CALCIUM LIMESTONE}

Low-calcium limestone is used in aggregate and as dimension stone. When mixed with certain appropriate 
additives, the deposits near White Oaks may be used in the manufacture of Portland cement (Jones, 1915; Siemers, 1982).

The Upper Pennsylvanian sequences contain the bestquality massive limestone beds most amenable to quarry mining (Kottlowski, 1962). Numerous limestone quarries are near Vaughn and Tecolote (Lovelace, 1972) (fig. 20). Samples of limestone from the Permian San Andres Formation in the Gallinas Mountains average 20.02 percent magnesium oxide, 32.20 percent lime, and 3.26 percent silica (V.C. Kelley, in Kottlowski, 1962). Samples of limestone from the San Andres collected southwest of Vaughn, along the Rio Bonito canyon east of Capitan, and in the Phillips Hills contained 3.4-7.8 percent insoluble residues, chiefly quartz silt (Kottlowski, 1962). About $4 \mathrm{mi}$ west of the Lincoln CountyChaves County line on U.S. Highway 70, the San Andres is medium bedded to massive, dark gray, and fossiliferous, and contains gypsum stringers. Spectrographic analysis showed that it contains 22.3 percent magnesium carbonate and 1.7 percent silica.

Limy beds of the Upper Cretaceous Mancos Shale north of Capitan are as much as $60 \mathrm{ft}$ thick, lenticular, impure, and interbedded with black shale. Analyses showed that these beds contain 76.8 percent calcium carbonate, 2.6 percent magnesium carbonate, 13.1 percent silica, 3.1 percent alumina, 2.2 percent iron oxide, and 0.18 percent sulfur (Kottlowski, 1962).

\section{DOLOMITE}

Dolomite products include dead-burned dolomite, refractory magnesite, basic magnesium carbonate, and magnesium metal. These products are used in industrial applications, such as in furnace linings and in the manufacture of asbestos-fiber insulation.

Limestone beds in the Yeso Formation are apparently silty and dolomitic (Kottlowski, 1962). Limestone beds in the San Andres Formation are dolomitic and contain more than 5 percent magnesium carbonate. Although dolomitic rock is abundant in the San Andres and Yeso Formations and the Artesia Group in the study area, the rocks are not highpurity dolomite (Kottlowski, 1957). Of 49 random chip limestone samples from the study area, 36 were dolomitic limestone and only 8 were high-magnesium dolomite (Korzeb and Kness, 1993).

\section{BUILDING STONE}

The Guadalupe Courthouse and other older buildings and homes in Santa Rosa are constructed of Santa Rosa Sandstone quarried within $2 \mathrm{mi}$ of the town (Talmage and Wootton, 1937). Red sandstone from the Morrison Formation or the Mesa Rica Sandstone in the Tucumcari area was used in construction in Tucumcari (Talmage and Wootton, 1937). Limestone and sandstone from surrounding areas have been used in construction in Roswell (Jones, 1915; Talmage and Wootton, 1937). Jones (1915) mentioned the occurrence of bluish-gray and light- and dark-gray marble near White Oaks and the Capitan Mountains that will take a high polish and may be useful for decorative stone.

\section{FLUORSPAR}

According to McAnulty (1978), fluorite-bearing deposits are commonly associated with areas that contain alkalirich rhyolite and granite, or syenite, nepheline syenite, and phonolite, and were probably introduced into the crust during a late hydrothermal stage by magmatic fluids that were rich in silica, soda, and potash. Fluorite deposits are found along fissures and faults in permeable rocks; the largest deposits apparently formed in near-surface (low temperature, low pressure) conditions associated with meteoric water.

In Lincoln County, fluorspar occurs in two areas: (1) the Gallinas district, where there are 19 mined fluorspar deposits [All American, Deadwood, Rio Tinto, Helen S, Conqueror No. 4, Hilltop, Eagle Nest, Bottleneck, Old Hickory, Congress, Eureka, Summit, Last Chance, Buckhorn, and Big Ben (Sky High) prospects, and two each at Red Cloud and Hoosier Girl prospects] (fig. 23); and (2) the Julia Ann prospect on Lone Mountain, where no production has been reported (Rothrock and others, 1946; Williams, 1966). The fluorspar in the Gallinas district was probably produced from gangue in earlier mined lead and copper ores (Soule, 1946).

In both areas, fluorspar occurs in brecciated zones, along contacts and faults, and as disseminations in rocks of the Yeso Formation that overlie Precambrian granite and gneiss and have been intruded by Tertiary alkalic dikes and sills (Rothrock and others, 1946). Vein deposits of fluorite are the most common type, filling fissures and interstices in the Yeso quartz sandstone. Fluorite in fractures is typically localized and irregular. Disseminated deposits, in which the fluorite is most widespread, occur in replaced dikes, sills, and sandstone. Several periods of fluorite deposition and brecciation took place, wherein fluorite gradually replaced arkosic and calcareous sedimentary rock and intrusives.

Fluorspar grade and quality are irregular and variable. Higher grade ore bodies at the All American prospect assayed $77-80$ percent $\mathrm{CaF}_{2}$ and 11 percent $\mathrm{SiO}_{2}$; composite values assayed 54.3 percent $\mathrm{CaF}_{2}, 23.2$ percent $\mathrm{SiO}_{2}, 11.5$ percent $\mathrm{BaSO}_{4}$, and 1.5 percent $\mathrm{CaO}$. The fluorite is mostly light blue to dark purple; the richest fluorspar grade is found in deeply colored ore. The deposits are mainly fluorite, barite, and siliceous and argillaceous host rock fragments; minor constituents include calcite, dolomite, and rare bastnaesite. Small amounts of galena, pyrite, chalcocite, celestite, barytocalcite, azurite, malachite, and limonite occur locally. Fluorspar production from Lincoln County totaled 1,190 long tons in 1966 (Williams, 1966). 


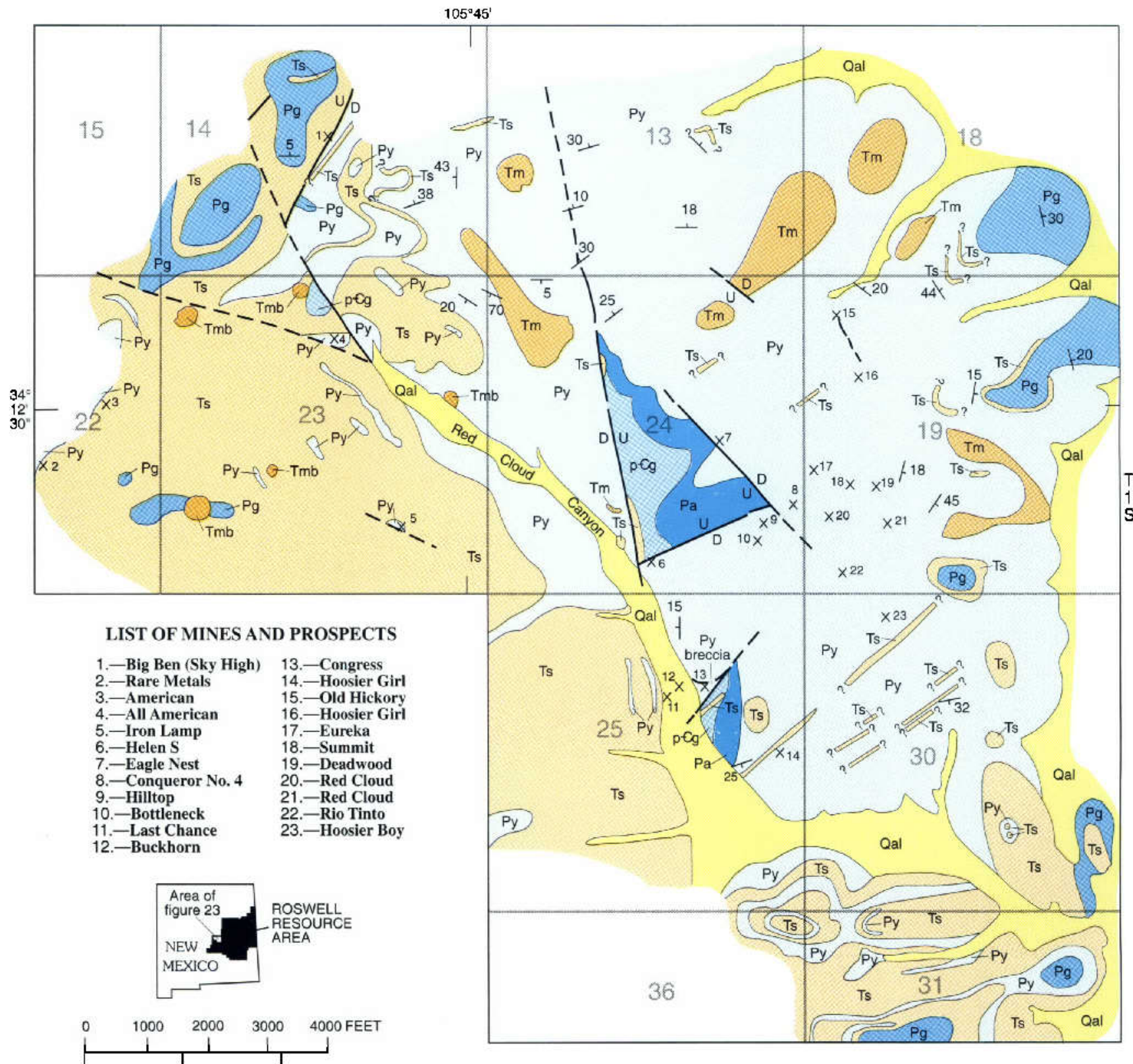

\section{EXPLANATION}

\begin{tabular}{|c|c|}
\hline Qal & $\begin{array}{l}\text { Quaternary alluvium, } \\
\text { fan, and terrace deposits } \\
\text { Tertiary monzonite breccia } \\
\text { Tmb }\end{array}$ \\
\cline { 1 - 1 } $\mathrm{Ts}$ & $\begin{array}{l}\text { Tertiary syenite porphyry } \\
\text { Tertiary monzonite }\end{array}$ \\
\cline { 1 - 2 } $\mathrm{Pg}$ & $\begin{array}{l}\text { Permian Glorieta Sandstone } \\
\text { Permian Yeso Formation }\end{array}$ \\
\hline
\end{tabular}

\begin{tabular}{|c|c|}
\hline $\mathrm{Pa}$ & Permian Abo Formation \\
\hline$p \in g$ & Precambrian aplitic granite and \\
\hline$-?$ & Contact--Queried where uncertain \\
\hline$\frac{U}{D}$ & $\begin{array}{l}\text { Fault--Dashed where concealed or inferred. } \\
\text { U, upthrown; D, downthrown }\end{array}$ \\
\hline$\perp^{15}$ & Strike and dip \\
\hline$x$ & Mine or prospect--Fluorspar and other metals \\
\hline
\end{tabular}

Figure 23. Geologic map showing locations of mines or prospects for fluorspar and other metals, Gallinas Mountains, N. Mex. (modified from V.C. Kelley, 1944, in Griswold, 1959). 


\section{VEIN BARITE}

Vein barite deposits occur in the Gallinas Mountains in Lincoln County at the Fox Lode prospect between Jicarilla and White Oaks, and at the Helen Rae mine southwest of Nogal where barite is an accessory mineral to a lead-zincsilver-bearing vein. In the Gallinas Mountains on the eastern edge of the Rio Grande rift, barite is found in several fluorite deposits that formed in association with alkalic intrusives; these include the Red Cloud, Old Hickory, Conqueror, and All American mines and the Big Ben (Sky High), Bottleneck, Eagle Nest, Eureka, and Hoosier Girl prospects (fig. 23; pl. 13) (Soule, 1946; Williams, 1966; Rothrock, 1970; Griswold, 1959). No barite has been produced commercially from these deposits (Williams and others, 1964). At Red Cloud, the largest producing mine in the Gallinas Mountains, barite occurs in brecciated and altered sandstone in a $50 \times 50 \times 100$-ft ore body (Williams, 1966) from which fluorite and bastnaesite have been produced. Two samples taken by Soule (cited in Williams and others, 1964) from the Red Cloud mine contained 17.62 percent and 28.56 percent $\mathrm{BaSO}_{4}$. Samples from other deposits in the Gallinas Mountains ranged as low as 11.72 percent $\mathrm{BaSO}_{4}$; none exceeded the Red Cloud values.

According to Williams and others (1964), relatively pure barite is found at the Fox Lode prospect northeast of White Oaks. There, a 2-ft-wide pocket of white, crystalline, fluorite- and quartz-free barite has been exposed. A composite sample yielded 89.7 percent $\mathrm{BaSO}_{4}$ and a specific gravity of 4.2 .

West of the study area in the northem Oscura Mountains, the Hansonburg mining district has been the most important barite producer in the State. In 1982, it accounted for 90 percent of all recorded production (Smith, 1982). The Hansonburg deposits are veins in fault breccias and replacement bodies in fracture zones in limestone.

\section{BEDDED BARITE}

Clark and Poole (1989) have classified bedded barite deposits into associated deposit types. Two of the types may apply to the geologic setting in the study area. In the first type, evaporite-associated, stratabound, syngeneticdiagenetic barite deposits are associated with anhydrite and celestite, having formed in fresh- to brackish-water interfaces in nearshore marine or lacustrine settings. The minerals are concentrated during later diagenesis. In the second type, carbonate-hosted stratabound epigenetic barite deposits are thought to form as a result of basinal brine or mineralized groundwater migration to sites where barite may precipitate, commonly in solution breccias or open spaces created in a karst environment (for example, MississippiValley-type lead-zinc deposits).

Bedded barite, a few tens of feet thick, occurs in the subsurface in the Rustler Springs sulfur deposit (Salado
Formation) south of the study area (Smith, 1978). A barite deposit overlies the sulfur deposit, but the relationship of the barite to the sulfur is unclear. There are numerous and extensive barium anomalies in geochemical sediment samples in the study area. Triassic beds are the inferred source; the barium is probably related to barite cement in sandstone and of no economic significance.

Although the geologic setting seems favorable for the formation of bedded barite, no barite has been produced from the study area, and no occurrences are known (Smith, 1978).

\section{CLAY AND ADOBE BRICK}

Clays and clay products are used extensively in the building, ceramics, and oil and gas industries. The type of clay determines its use. The occurrence of clay as an impermeable layer in the stratigraphic section is of utmost importance in the early phase of oil and gas exploration, and clay is important in the production phase as a constituent in drilling mud.

Small deposits of fire clay occur $1.5 \mathrm{mi}$ southeast of Ancho in west-central Lincoln County (Darton, 1928; Talmage and Wootton, 1937; Griswold, 1959; Budding, 1964). A brick plant operated at Ancho from about 1912 to about 1922. According to Budding (1964), shale for making the bricks was mined from the Dakota(?) Sandstone about $2 \mathrm{mi}$ east of Ancho. Common clay deposits have also been mined near Acrme (Talmage and Wootton, 1937).

Clay occurs as thin beds and in clay-rich zones in various formations that are at or near the surface in the study area. Rare beds of bentonite as thick as $\mathbf{1} \mathbf{f t}$ occur in the Morrison Formation. In Quay and Guadalupe Counties, thin beds of montmorillonite (smectite) occur in Triassic rocks (Northrup, 1959).

Although small deposits of clay were exploited in the past in the study area, none of the clays is of commercial grade today. Clays of the Mancos Shale and Mesaverde Formation that occur near Capitan in the Sierra Blanca Basin could be used in making bricks (G.S. Austin, New Mexico Bureau of Mines and Mineral Resources, oral commun., July 1991).

Adobe bricks are manufactured using sand, silt, and clay deposits from Holocene stream, alluvial fan, and terrace deposits as well as from older deposits, such as the Tertiary Ogallala Formation (Smith, 1982). Adobe has been used for several centuries for building construction in this region (fig. 6). Adobe bricks, to which stabilizers have been added to conform to building codes for durability, are still being used today in building construction for use in both traditional and native architecture (fig. 24).

In the study area (as of the early $1980^{\prime}$ 's), there are no adobe brick manufacturing facilities, although the region contains deposits that are suitable for adobe construction. According to Smith (1982) (fig. 25), abundant resources of 


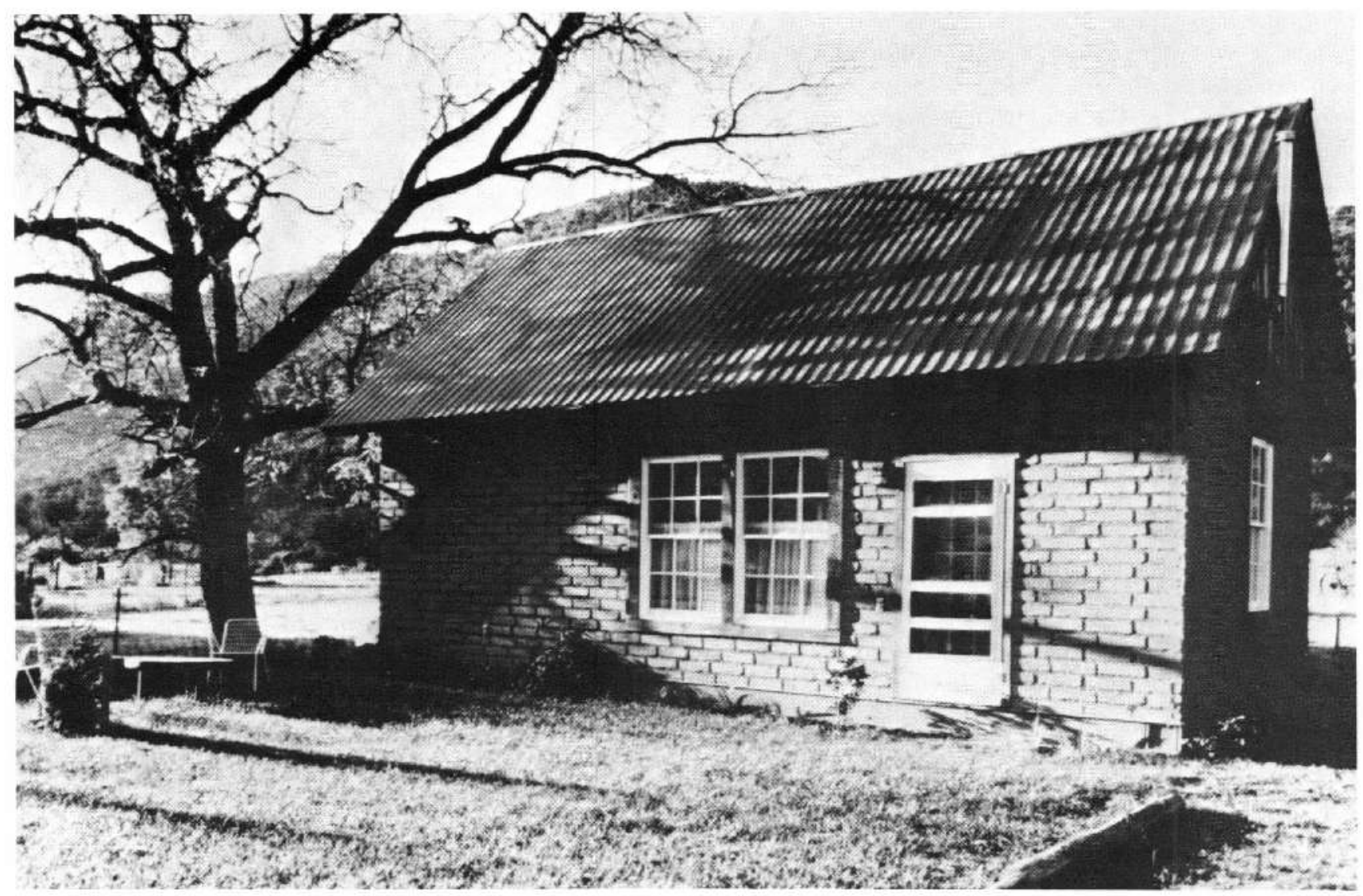

Figure 24. Modern adobe cottage, "Casita Bonita," built from stabilized adobe betwecn 1983 and 1986. The cottage is part of historic Casa de Patrón, Lincoln, N. Mex. Photograph by Jerry Jordan, owner and builder.

adobe material occur throughout the study area in lower to upper Tertiary deposits, including the Ogallala Formation in the eastem part of the study area, and in Quaternary flood-plain, arroyo, terrace, and dune deposits, especially in areas adjacent to the Pecos River. Although the deposits suitable for making adobe bricks are in large supply, they would have to be shipped to construction areas, generally near the larger towns.

\section{SEMIPRECIOUS GEMSTONES AND COLLECTIBLE SPECIMENS}

Smoky quartz and fluorite crystals are associated with intrusive rocks in the Lincoln County porphyry belt. "Pecos diamonds" are considered collectible by many and sold as local curios. Petrified wood occurs in the Chinle and Santa Rosa Formations, but its use as a gemstone is limited due to variable quality. Jasper occurs about 2 mi north of Ancho and is apparently suitable for ornamental use (Talmage and Wootton, 1937; Northrup, 1959). According to Jones (1904, p. 343; 1915, p. 75), jet occurs near Santa Rosa. A small quantity of turquoise has been reponted from the Nogal district (Northrup, 1959, p. 525).

\section{SMOKY QUARTZ AND FLUORITE}

Specimen-quality smoky quartz crystals and fluorite crystals are located within the Three Rivers stock of the Sierra Blanca Igneous Complex in the White Mountain Wilderness Area (sec. 29, T. 10 S., R. 11 E.) (Segerstrom and others, 1979; Hanson and Thompson, 1991). Quartz crystals of museum quality have also been obtained from the Mina Tiro Estrella claims in the Capitan Mountains (Hanson and Thompson, 1991; McLemore and Phillips, 1991).

Smoky quartz crystals described by Segerstrom and others (1979) have been mined from the Sierra Blanca Peak area. Quartz crystals range from 0.08 in. to 16 in. in length, averaging about $2.8 \mathrm{in}$. long (Hanson and Thompson, 1991). They are found in miarolitic cavities and open fractures, and are adjacent to a breccia pipe (Hanson and Thompson, 1991). The quartz crystals contain phantoms, including rare amethyst phantoms, which record quartz crystal growth. Rare doubly terminated specimens also were found. The crystals have commercial value to mineral collectors and have been sold to tourists. However, because the locality is now a wilderness area, the crystals are no longer available for commercial extraction. 


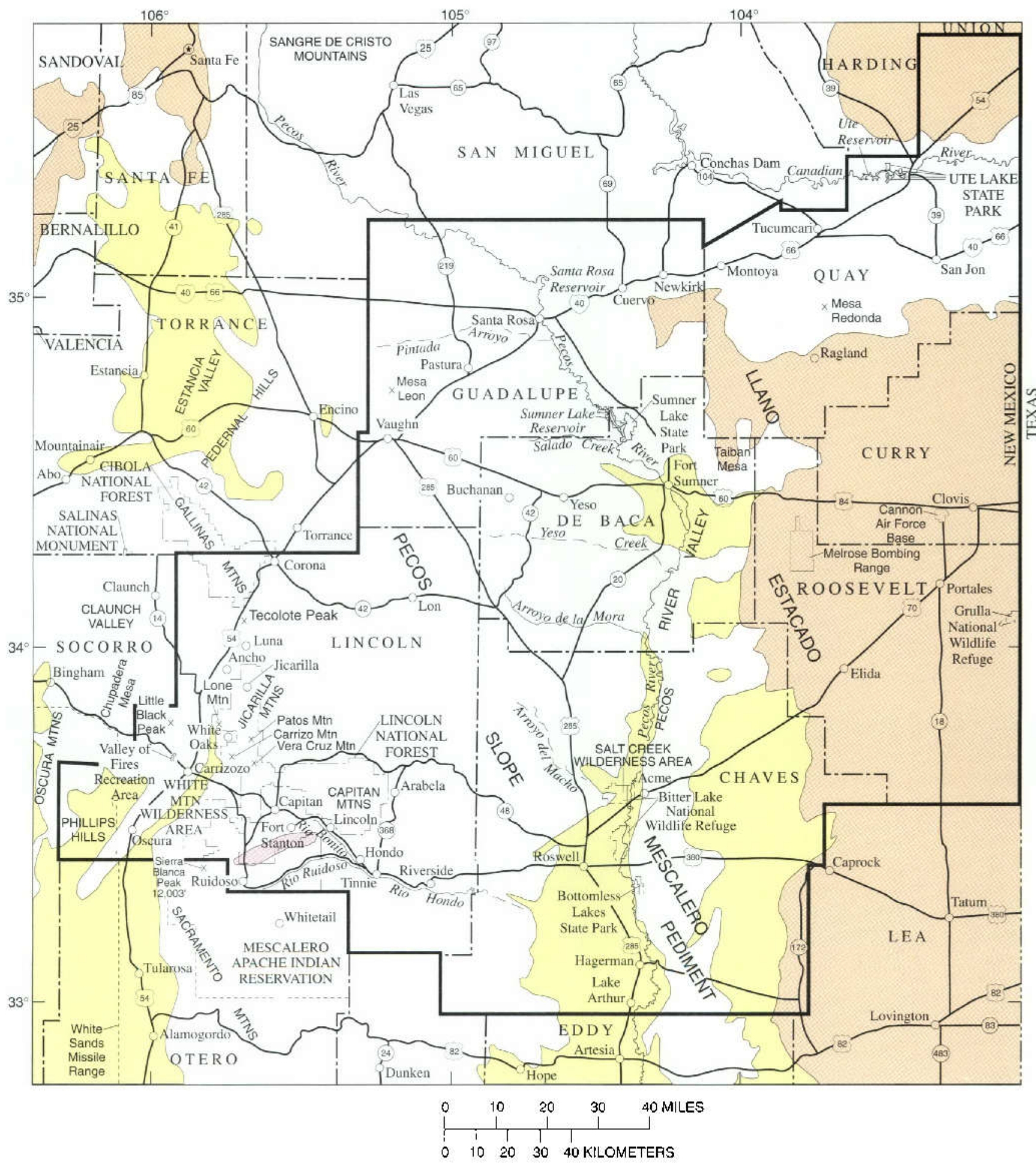

Figure 25. Distribution of adobe-material sources in the Roswell Resource Area and vicinity, New Mexico (modified from Smith, 1982 , fig. 50). Quatemary deposits in yellow; upper and middle Tertiary deposits (Ogallala Formation) in tan; lower Tertiary deposits in pink.

"PECOS DIAMONDS"

In 1583, a Spanish miner named Don Antonio de Espejo discovered the occurrence of quartz crystals in gypsum now known as "Pecos diamonds" (also known locally as
"Indian diamonds") (fig. 26A). Although no industrial use has been developed for these crystals, they are collected locally as souvenirs of the area. They may be unique to North America, and the Pecos River valley (fig. 26B). 


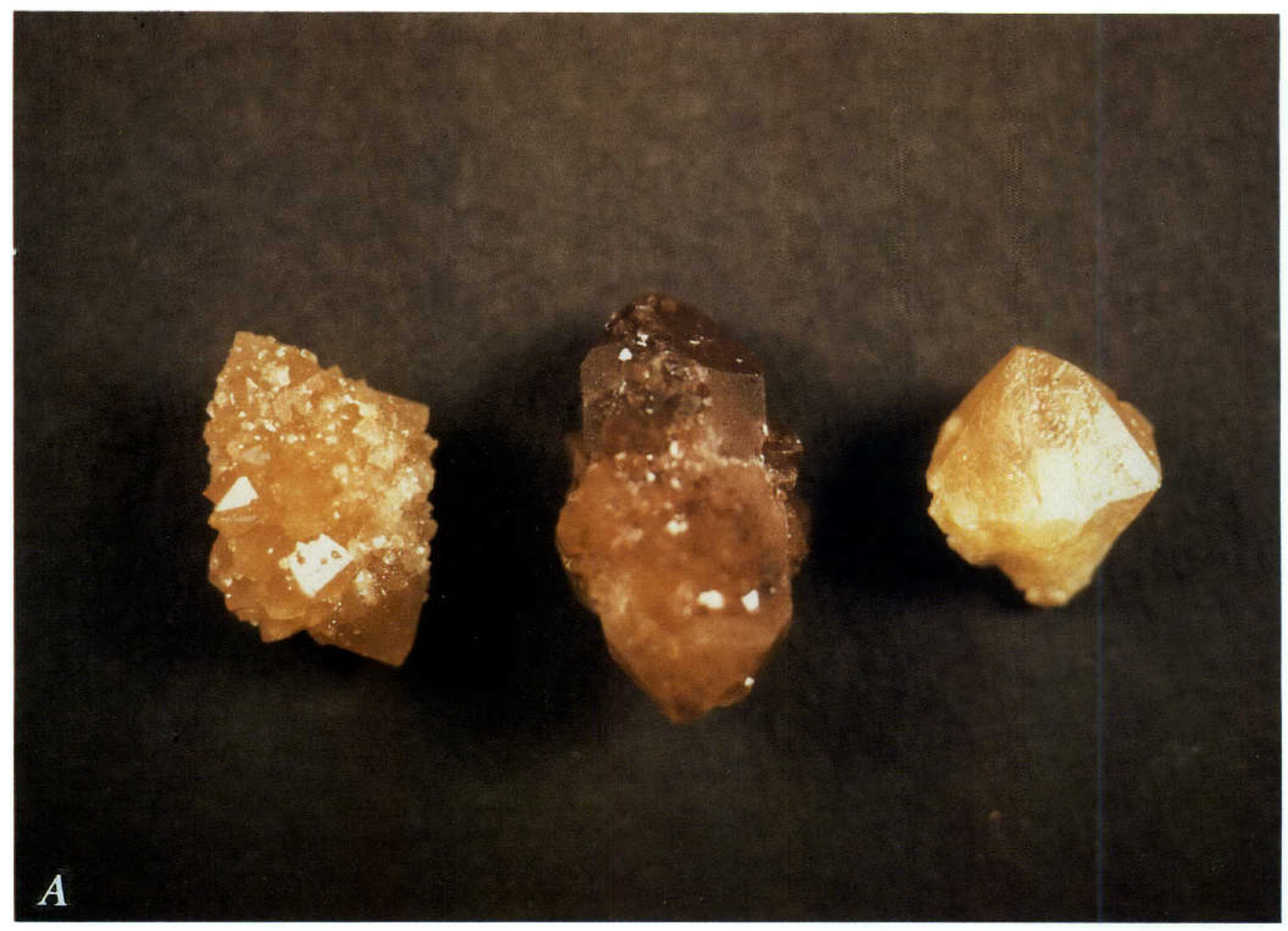

Figure 26 (above and facing page). A, Photograph of "Pccos diamonds." $B$, Distribution of surface deposits containing "Pecos diamonds" (shaded light gray) in the Roswell Resource Area and vicinity, New Mexico (from Albright and Bauer, 1955), Area shaded dark gray indicates surface deposits possibly conlaining "Pecos diamonds."

"Pecos diamonds" serve as stratigraphic markers in the lower part of the Yates Formation and the upper part of the Seven Rivers Fonnation ( $\mathrm{pl} .2$ ), especially in Chaves and De Baca Counties (Northrup, 1959). They are diagenetic quartz, dolomite, aragonite, and anhydrite crystals that are typically embedded at any angle with respect to bedding in weathered gypsum and dolomite. Prisms are doubly terminated (Tarr, 1929; Tarr and Lonsdale, 1929), and both positive and negative quartz rhombohedrons are present; locally common pseudocubic forms are also present. They range in size from microscopic to $3.5 \mathrm{in}$. long and as much as $1.5 \mathrm{in}$. in diameter. Only a few have perfect crystal shape, and these are commonly less than 1 in. long (Albright and Bauer, 1955). They are clear or variously colored yellow, pink, brown, orange, green, white, or black. The color variation is probably due to trace amounts of iron and (or) manganese oxides, organic matter, and other contaminants (Albright and Bauer, 1955). Quartz forms thin overgrowths on gypsum cores in some specimens. Relict bedding lamination occurs in some crystals.

Tarr (1929) suggested that the silica source for crystal formation is from associated sandstone and shale, and that the bedded host gypsum causes coagulation and precipitation. Albright and Bauer (1955) noted that there are no mineralized veins, fissures, or openings allowing circulation of solution-derived precipitation. Albright and Kruckow (1958) described the occurrence of crystals at a depth of $1,160 \mathrm{ft}$ in Lea County southeast of the study area, and suggested a probable diagenetic cause for their formation.

\section{PETRIFIED WOOD AND BONE}

Petrified or silicified wood is found in the Triassic Chinle and Santa Rosa Formations in other parts of the State, 


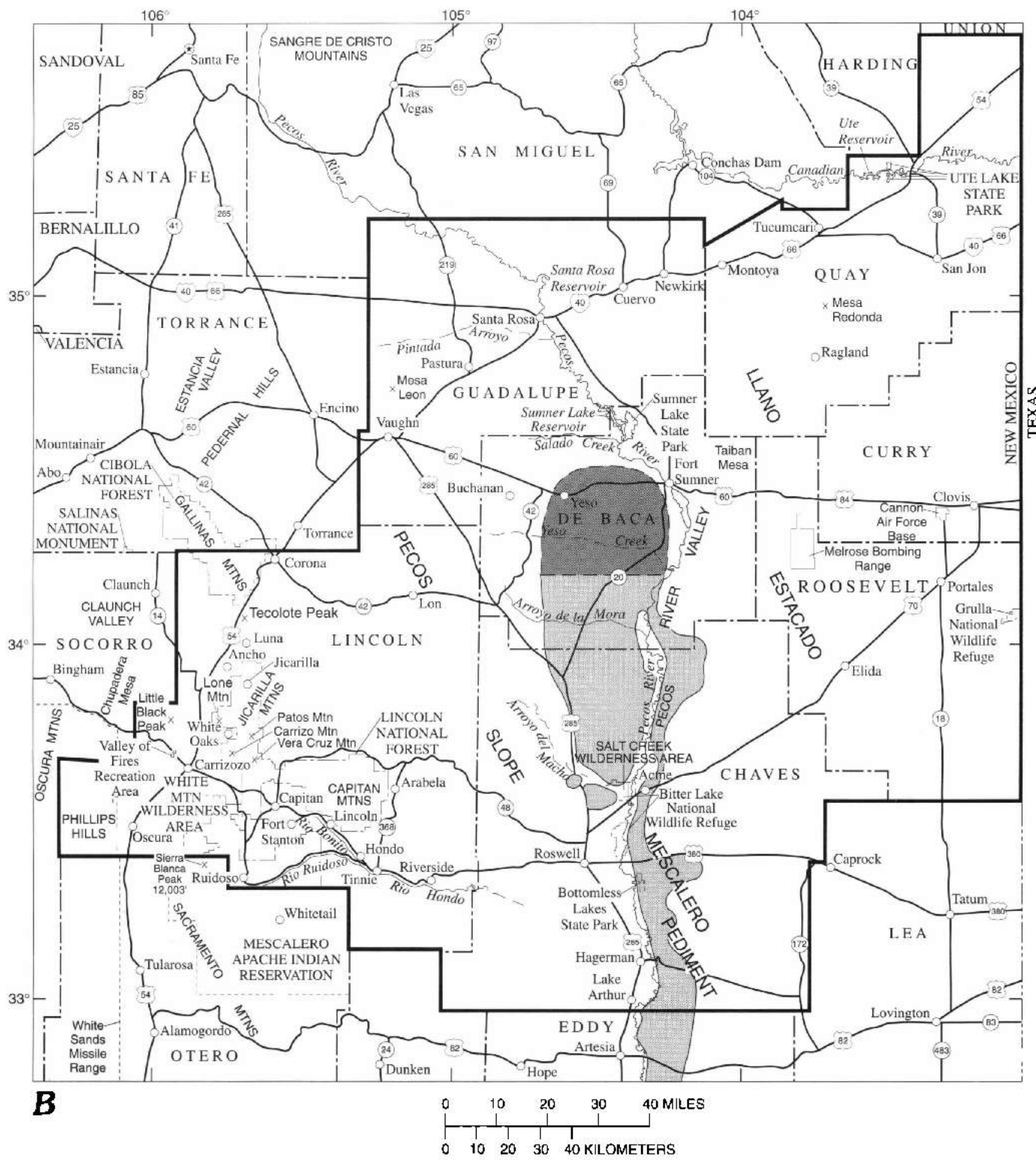

and has been reported from the study area in association with sediment-hosted copper deposits. The quality varies according to silicification and alteration. According to Northrup (1959), a few small specimens of radioactive silicified bone, probably from the Ogallala Formation, have been found in Curry County (Barnes, 1955).

\section{REFERENCES CITED}

Adams, S.S., 1969, Bromine in the Salado Formation, Carlsbad Potash District, New Mexico: New Mexico Bureau of Mines and Mineral Resources Bulletin 93, 122 p.

1970, Ore controls, Carlsbad potash district, southeast New Mexico, in Rau, J.L., and Dellwig. L.F., eds., Third symposium 
on salt, v. 1: Cleveland, Ohio, Northem Ohio Geological Society, p. 246-257.

Albright, J.L., and Bauer, R.M., Jr., 1955, Pecos Valley "diamonds": Rocks and Minerals, v. 30, no. 7-8, p. 346-350.

Albright, J.L., and Kruckow, Th., 1958, Schwebend gebildete quartzkristalle in New Mexico, USA: Der Aufschlus 5, (9) S. 98-101.

Austin, G.S., 1980, Potash in New Mexico: New Mexico Geology, v. 2, no. 1, p. 7-9.

Austin, G.S., and Barker, J.M., 1990, Economic geology of the Carlsbad Potash district, in Kyle, J.R., ed., Industrial mineral resources of the Delaware Basin, Texas and New Mexico: Society of Economic Geologists Guidebook Series, v. 8, p. 97-114.

Austin, G.S., Kottlowski, F.E., and Siemers, W.T., 1982, Industrial minerals of New Mexico in 1981, in Austin, G.S., compiler, Industrial rocks and minerals of the southwest: New Mexico Bureau of Mines and Mineral Resources Circular 182, p. 9-16.

Bachman, G.O., 1984, Regional geology of Ochoan evaporites, northem part of Delaware Basin: New Mexico Bureau of Mines and Mineral Resources Circular 184, 22 p.

1987, Karst in evaporites in southeast New Mexico: Contractor Report SAND 86-7078, prepared by Sandia National Laboratories, Albuquerque, N. Mex., and Livermore, Calif., for the U.S. Department of Energy (Contract DE-AC04-76DP00789), microfiche, 74 p.

Barbarick, K.A., 1991, Polyhalite application to sorghum-sudangrass and leaching in soil columns: Soil Science, v. 151, p. 159-166.

Barnes, F.C., 1955, Further uranium developments in New Mexico: Uranium Magazine, v. 2, no. 3, March, p. 8, 10-12. 14.

Bates, R.L.,1960, Geology of the industrial rocks and minerals: New York, Harper \& Brothers, 441 p.

Bowen, O.E., Jr., 1957, Limestone, dolomite, and lime products, in Mineral commodities of Califomia: San Francisco, Calif., Califomia Department of Natural Resources, Division of Mines, Bulletin 176, p. 293-306.

Bretz, J.H., and Horberg, L., 1949, Caliche in southeastem New Mexico: Journal of Geology, v. 57, p. 491-511.

Budding, A.J., 1964, Geologic outline of the Jicarilia Mountains, Lincoln County, New Mexico, in Ash, S.R., and Davis, L.K., eds., Guidebook of the Ruidoso Country: New Mexico Geological Society, Fifteenth Field Conference Guidebook, p. 82-86.

Budnik, R.T., 1989, Tectonic structures of the Palo Duro Basin, Texas Panhandle: University of Texas Bureau of Economic Geology Report of Investigations No. 187, 43 p.

Cheeseman, R.J., 1978, Geology and oil/potash resources of Delaware Basin, Eddy and Lea Counties, New Mexico, in Austin, G.S., compiler, Geology and mineral deposits of Ochoan rocks in Delaware Basin and adjacent areas: New Mexico Bureau of Mines and Mineral Resources Circular 159, p. 7-14.

Clark, S.H.B., and Poole, F.G., 1989, Stratabound barite ore fields of North America (excluding Arkansas), in de Brodtkorb, M.K., ed., Nonmetalliferous stratabound ore fields: New York, Van Nostrand Reinhold, p. 93-119.

Crawford, J.E., 1990, Geology and Frasch mining operations of the Culberson sulfur mine, Culberson County, west Texas, in Kyle, J.R., ed., Industrial mineral resources of the Delaware
Basin, Texas and New Mexico: Society of Economic Geologists Guidebook 8, p. 141-162.

Darton, N.H., 1920, New Mexico, in Stone, R.W., and others, Gypsum deposits of the United States: U.S. Geological Survey Bulletin 697, p. 161-186.

1928, Geologic map of New Mexico: Scale 1:500,000.

Davis, J.B., and Kirkland, D.W., 1970, Native sulfur deposition in the Castile Formation, Culberson County, Texas: Economic Geology, v. 65, p. 107-121.

Feely, H.W., and Kulp, J.L., 1957, Origin of Gulf Coast salt-dome sulfur deposits: American Association of Petroleum Geologists Bulletin, v. 41, no. 8, p. 1802-1853.

File, Lucien, and Northrop, S.A., 1966, County, township, and range locations of New Mexico's mining districts: New Mexico Bureau of Mines and Mineral Resources Circular 85, $66 \mathrm{p}$.

Gratton, P.J.F., and LeMay, W.J., 1969, San Andres oil east of the Pecos, in Summers, W.K., and Kottlowski, F.E., eds., The San Andres Limestone-A reservoir for oil and water in New Mexico: New Mexico Geological Society Special Publication 3, p. $37-43$.

Griswold, G.B., 1959. Mineral deposits of Lincoln County, New Mexico: New Mexico Bureau of Mines Bulletin 67, 117 p.

Hanson, Tim, and Thompson, Bob, 1991, The Smokey Bear quartz claims, Lincoln County, New Mexico: The Mineralogical Record, v. 22, September-October, p. 359-366.

Hentz, T.F., 1990, Native sulfur deposits in the western Delaware Basin, Trans-Pecos Texas-Origin, distribution, and exploration strategy, in Kyle, J.R., ed.. Industrial mineral resources of the Delaware Basin, Texas and New Mexico: Society of Economic Gcologists Guidebook Scries, v. 8, p. 115-140.

Hentz, T.F., and Henry, C.D., 1989. Evaporite-hosted native sulfur in Trans-Pecos Texas-Relation to late phase Basin and Range deformation: Gcology, v. 17. p. 400-403.

Herrick, H.N., 1904, Gypsum deposits in New Mexico, in Adams, G.I., and others, eds., Gypsum deposits in the United States: U.S. Geological Survey Bulletin 233, p. 89-99.

Hinds, J.J., and Cunningham, R.R., 1970, Elemental sulfur in Eddy County, New Mexico: U.S. Geological Survey Circular 628, $13 \mathrm{p}$.

Johnson, K.S., Gonzales, S., and Dean, W.A., 1989, Distribution and geologic characteristics of anhydrite deposits in the United States, in Dean, W.A., and Johnson, K.S., eds., Anhydrite deposits of the United States and characteristics of anhydrite important for storage of radioactive wastes: U.S. Geological Survey Bulletin 1794, p. 9-90.

Jones, C.L., 1972, Permian basin potash deposits, southwestern United States, in Richter-Bernburg, G., ed., Geology of saline deposits: Paris, UNESCO, Earth Sciences Series, No. 7, p. 191-201.

Jones, F.A., 1904, New Mexico mines and minerals (World's Fair Edition): Santa Fe. N. Mex., New Mexico Printing Co., 349 p. 1915, The mineral resources of New Mexico: New Mexico Mines and Mineral Resources Bulletin 1, p. 46-49.

Kelicy, V.C., 1971, Geology of the Pccos Country, southeastem New Mexico: New Mexico Bureau of Mines and Mincral Resources Memoir 24. $72 \mathrm{p}$.

Korzeb, S.L., and Kness, R.F., 1993, Mineral resource investigation of the Roswell Resource Arca, Chaves, Curry, DeBaca, Guadalupe, Lincoln, Quay, and Roosevelt Counties, New 
Mexico: U.S. Bureau of Mines Open-file Report MLA 12-92, $229 \mathrm{p}$.

KottJowski, F.E., 1957, High-purity dolomite deposits of southcentral New Mexico: New Mexico Bureau of Mines and Mineral Resources Circular 47, 43 p.

1962, Reconnaissance of commercial high-calcium limestones in New Mexico: New Mexico Bureau of Mines and Mineral Resources Circular 60, $77 \mathrm{p}$.

Lovelace, A.D., 1972, Aggregate resources in central eastem New Mexico, in Kelley, V.C., and Trauger, F.D., eds., Guidebook of east-central New Mexico: New Mexico Geological Society, Twenty-third Field Conference Guidebook, p. 187-191.

Lowenstein, T.K., 1988, Origin of depositional cycles in a Permian "saline giant"-The Salado (McNutt zone) cvaporites of New Mexico and Texas: Geological Society of America Bulletin, $v$. 100 , p. 592-608.

Lyday, P.A., 1985a, Iodine, in Mineral facts and problems, 1985 edition: U.S. Bureau of Mines Bulletin 675, p. 377-384.

$-1985 \mathrm{~b}$, Bromine, in Mineral facts and problems, $1985 \mathrm{edi}-$ tion: U.S. Bureau of Mines Bulletin 675, p. 103-110.

McAnulty, W.N., 1978, Fluorspar in New Mexico: New Mexico Bureau of Mines and Mineral Resources Memoir 34, 64 p.

McKee, E.D., and Oriel, S.S., 1967, Paleotectonic investigations of the Permian System in the United States: U.S. Geological Survey Professional Paper 515, $271 \mathrm{p}$.

McLemore, V.T., and Phillips, R.S., 1991, Geology of mineralization and associated alteration in the Capitan Mountains, Lincoln County, New Mexico, in Barker, J.M., and others, eds., Geology of the Sierra Blanca, Sacramento, and Capitan Ranges, New Mexico: New Mexico Geological Society, 42nd Annual Field Conference Guidebook, p. 291-298.

New Mexico Department of Energy, Minerals and Natural Resources, 1990, Annual Resources Report: Santa Fe, N. Mex., New Mexico Department of Energy, Minerals and Natural Resources Department, $106 \mathrm{p}$

New Mexico State Highway Department, 1961, Aggregatc resources and soils study, New Mexico Interstate Route 40: Santa Fe, N. Mex., New Mexico State Highway Department unpublished report, sections $40-1$ and $40-21$, unpaginated. [On file at the New Mexico Bureau of Mines and Mineral Resources, Socorro, N. Mex.]

-1966, Aggregate resources study, District No. 4: Santa Fe, N. Mex., New Mexico State Highway Department unpublished report, $119 \mathrm{p}$. [On file at the New Mexico Bureau of Mines and Mineral Resources, Socorro, N. Mex.]

1971-1972, Geology and aggregate resources-District II: Santa Fe, N. Mex., New Mexico State Highway Department unpublished report, 65 p. [On file at the New Mexico Bureau of Mines and Mineral Resources, Socorro, N. Mex.]

Northrup, S.A., 1959, Minerals of New Mexico (revised edition): Albuquerque, N. Mex., New Mexico University Press, 665 p.

Otte, Carel, Jr., 1959, Late Pennsylvanian and Early Permian stratigraphy of the northern Sacramento Mountains. Otero County, New Mexico: New Mexico State Bureau of Mines and Mineral Resources Bulletin 50, $111 \mathrm{p}$.

Pitt, W.D., and Scott, G.L., 1981, Porosity zones of lower part of San Andres Formation, east-central New Mexico: New Mexjco Bureau of Mines and Mineral Resources Circular 179, $20 \mathrm{p}$.
Raup, O.B., 1991, Descriptive model of bedded salt; Deposit subtype-Marine evaporite salt (model 35ac), in Orris, G.J., and Bliss, J.D., eds., Some industrial mineral deposit models-Descriptive deposit models: U.S. Geological Survey Open-File Report 91-11-A, p. 29-30.

Rothrock, H.E., 1970, Fluorspar, in Woodward, L.A, ed., Tyrone-Big Hatchet Mountains-Florida Mountains region; New Mexico Geological Society, Guidebook 21, p. 123-125.

Rothrock, H.E., Johnson, C.H., and Hahn, A.D., 1946, Fluorspar resources of New Mexico: New Mexico Bureau of Mines and Mineral Resources Bulletin 21, 245 p.

Schmalz, R.F., 1955, Preliminary report, geology of the Three Rivers-Oscura area, Lincoln and Otero Counties, New Mexico: Unpublished report on file at the New Mexico Bureau of Mines and Mineral Resources, Socorro, N. Mex., unpaginated.

Searles, J.P., 1985, Potash, in Mineral facts and problems, 1985 edition: U.S. Bureau of Mines Bulletin 675, p. 617-633.

Segerstrom, Kenneth, Stotelmeyer, R.B., and Williams, F.E., 1979 . Mineral resources of the White Mountain Wildemess and adjacent areas, Lincoln County, New Mexico: U.S. Geological Survey Bulletin 1453, $135 \mathrm{p}$.

Siemers, W.T., 1982, New Mexico limestones-Geology, uses, and economic potential of high-calcjum limestone, in Austin, G.S., compiler, Industrial rocks and minerals of the southwest: New Mexico Bureau of Mines and Mineral Resources Circular 182 , p. $39-42$.

Smith, A.R., 1978, Sulfur deposits in Ochoan rocks of southeast New Mexico and West Texas, in Austin, G.S., compiler, Geology and mineral deposits of Ochoan rocks in Delaware Basin and adjacent areas: New Mexico Bureau of Mines and Mineral Resources Circular 159, p. 71-77.

1980, Sulfur deposits in Ochoan rocks of the Gypsum Plain, southeast New Mexico and west Texas, in Dickerson, P.W, Hoffer, J.M., and Callender, J.F., eds., Trans-Pecos regionSoutheastem New Mexico and West Texas: New Mexico Geological Society, Field Conference Guidebook No. 31, p. 277-283.

Smith, E.W., 1982, Adobe bricks in New Mexico: New Mexico Bureau of Mines and Mineral Resources Circular $188.89 \mathrm{p}$.

Soule, J.H., 1946, Exploration of Gallinas fluorspar deposits, Lincoln County, New Mexico: U.S. Bureau of Mines Report of Investigations $3854,25 \mathrm{p}$.

Spirakis, C.S., and Cunningham, K.L., 1992, Sulfur deposits in Lechuguilla Cave, Eddy County, New Mexico, in Wessel G., and Wimberly, B., eds., Native sulfur-Developments in geology and exploration: American Institute of Mining Engineers Press, p. 139-145.

Stoeser, D.B., Senterfit, M.K., and Zeiten, J.E., 1989, Mineral resources of the Little Black Peak and Carrizozo Lava Flow Wilderness Study Areas, Lincoln County, New Mexico: U.S. Geological Survey Bulletin 1734-E, 17 p.

Talmage, S.B., and Wootton, T.P., 1937. The non-metallic mineral resources of New Mexico and their economic features (exclusive of fuels): New Mexico Bureau of Mines and Mineral Resources Bulletin 12, p. 152-154.

Tarr, W.A., 1929, Doubly terminated quartz crystals in gypsum from Acme, New Mexico: American Mincralogist, v. 14, p. 19-25. 
Tarr, W.A., and Lonsdale, J.T., 1929, Pseudo-cubic quartz crystals from Artesia, New Mexico: American Mineralogist, v. 14, p. $50-53$.

U.S. Geological Survey, 1965, Mineral and water resources of New Mexico: Washington, D.C., U.S. Government Printing Office, Report to the Committee on Interior and Insular Affairs, U.S. Senate, $437 \mathrm{p}$.

Weber, R.H., and Kottlowski, F.E., 1959, Gypsum resources of New Mexico: New Mexico Bureau of Mines and Mineral Resources Bulletin 68,68 p.

Williams, F.E., 1966, Fluorspar deposits in New Mexico: U.S. Bureau of Mines Information Circular $8307,143 \mathrm{p}$.

Williams, F.E., Fillo, P.V., and Bloom, P.A., 1964, Barite deposits of New Mexico: New Mexico Bureau of Mines and Mincral Resources Circular 76, 46 p.

Williams-Stroud, Sherilyn, 1991, Potash-bearing bedded salt, model 35abT, in Orris, G.J., and Bliss, J.D., eds., Some industrial mineral deposit models-Descriptive deposit models: U.S. Geological Survey Open-File Report 91-11-A, p. 26-28.

\section{METAL RESOURCES}

\section{MINING HISTORY AND PRODUCTION}

By David M. Sutphin and Theodore J. Armbrustmacher

\section{HISTORY OF MINING}

The study area has produced significant amounts of gold, iron, base metals, and silver, and smaller amounts of fluorspar, rare-earth elements, tungsten, uranium, and manganese (pl. 13; Appendix). Initially, the search for gold led prospectors into the area. Gold placers were discovered in Lincoln County, and their discovery led to exploration and discovery of other mineral deposits. World Wars I and II provided economic incentives to locate and produce muchneeded mineral commodities, including copper, iron, rareearth elements, and tungsten, from previously marginal or subeconomic resources and poorly explored mineral occurrences.

The report on water and mineral resources of New Mexico (U.S. Geological Survey, 1965) provides information on mining districts and mineral deposits in the study area. Of the seven counties that encompass the study area, Lincoln County has had the majority of the mine production and will be described in more detail than the others (pl. 13). Information sources for specific metals mining districts in that county include Perhac and Heinrich (1964) on the Gallinas district, Segerstrom and Ryberg (1974) and Segerstrom and others (1979) on the Jicarilla district, Thompson (1973) on the Nogal district, Griswold (1959) and Lasky and Wootton (1933) on the Oscura district, Anderson (1957) on the Tecolote district, and Bielack and Williams (1982) and Griswold (1959) on the White Oaks district. A map showing the metals mining districts located in Lincoln County and referred to in this report is shown on figure 27 . Table 5
Table 5. Total reported past production for selected commodities in the Roswell Resource Area, New Mexico

foz, troy ounces; st, short tons. Values modified from Griswold, 1959, p. 19-22]

\begin{tabular}{lr} 
Gold & Production \\
Silver & $194,000 \mathrm{oz}$ \\
Copper & $161,476 \mathrm{oz}$ \\
Lead & $7,092 \mathrm{st}$ \\
Zinc & $909 \mathrm{st}$ \\
& $9 \mathrm{st}$ \\
Iron & \\
Tungsten ( $\left.\mathrm{WO}_{3}\right)$ & $270,000-320,000 \mathrm{st}$ \\
Manganese & $34.07 \mathrm{st}$ \\
Rare-earth concentrates & $\mathrm{small} \mathrm{st}$ \\
Fluorite concentrates & $73 \mathrm{st}$ \\
\hline
\end{tabular}

summarizes the reported production of several commodities from the study area.

\section{GOLD}

Gold was the first metallic commodity to be mined in the study area, and has the most valued production. Mining was conducted in the days of Spanish rule by hauling water and panning gold and silver from stream gravels in ephemeral drainages. Gold placers in the White Oaks and Jicarilla districts were mined from Lincoln County in the $1850^{\prime} \mathrm{s}$ (Griswold, 1959). By the 1860's, placer gold was also being mined along Dry Gulch in the Nogal district, which eventually led, in 1868, to discovery of the lode source of gold in the Helen Rae-American vein system. In 1879 and 1880 , lode sources for placers were found in the White Oaks and Jicarilla districts, respectively.

\section{WHITE OAKS DISTRICT}

In terms of production value, the most important goldmining district in the study area is the White Oaks district (fig. 28). Here, gold occurs in veins in Tertiary monzonite and lamprophyre and Cretaceous shale, and in placer deposits (Lindgren and others, 1910; Jones, 1904). Production figures for placer operations prior to 1879 are lacking; from 1879 until 1957, the district produced at least $152,373 \mathrm{oz}$ of gold (Griswold, 1959). McLemore (1991) estimated that $163,500 \mathrm{oz}$ of gold were produced from 1850 through 1942. Total production, in ounces of gold, for major mines in the district was as follows: Old Abe 45,745; South Homestake, 30,000; North Homestake, 20,039; Little Mack, 2,579; Smuggler, 279; and placer and other mines, including Rita, Lady Godiva, Little Nell, and Hannibal, 53,731, of which about 1,000 oz was from placers (McLemore, 1991). An additional 0.25 short tons of copper, 1,044 oz of silver, and 6.1 short tons of lead were produced as byproducts of gold mining between 1933 and 1951 (McLemore, 1991).

The first lode deposit in the district was discovered in 1879, at what would become the North Homestake mine. 

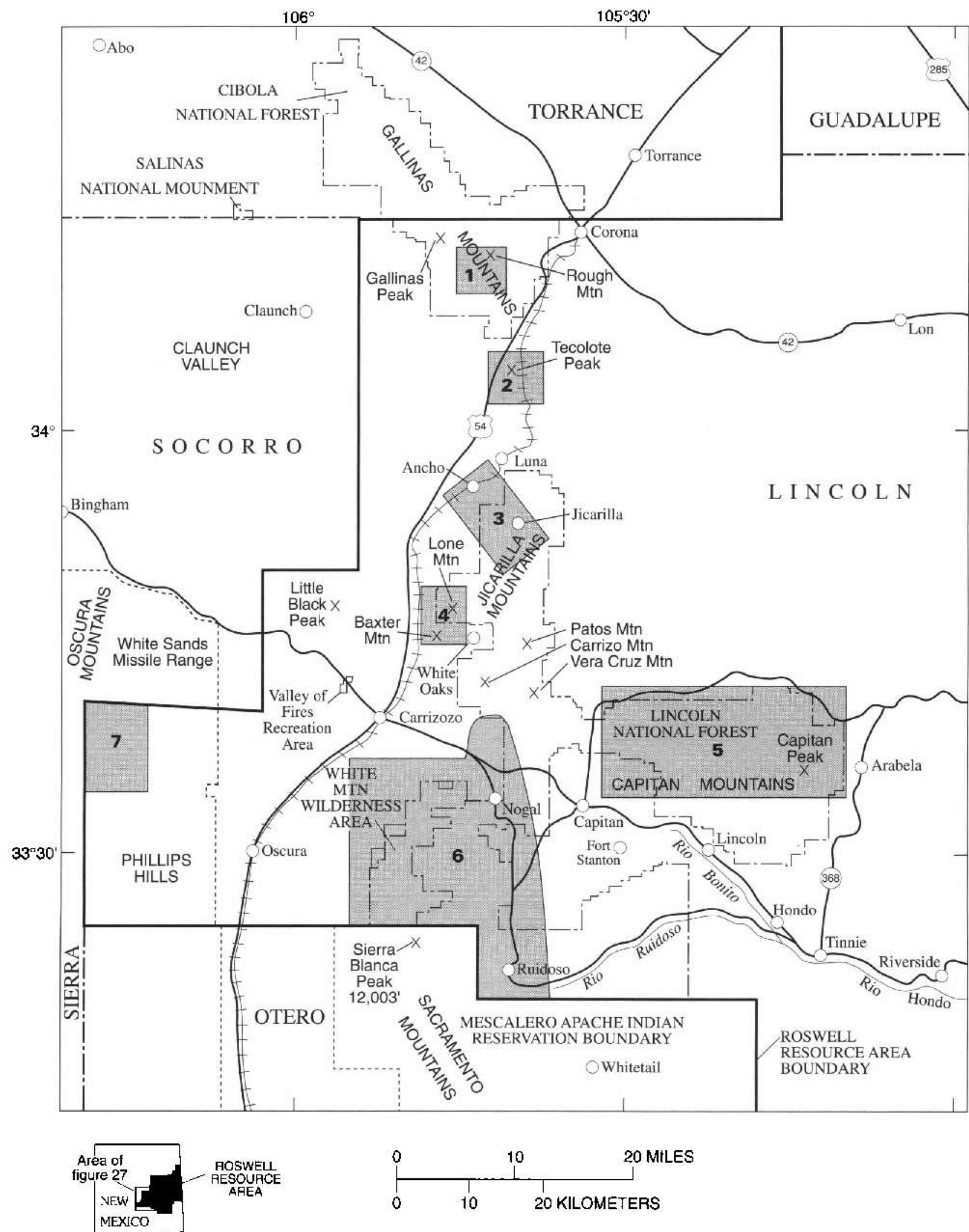

Figure 27. Locations of metals mining districts in Lincoln County, N. Mex. (modified from Griswold, 1959). 1, Gallinas district; 2 , Tecolote district; 3, Jicarilla district; 4, White Oaks district; 5, Capitan Mountains district; 6, Nogal district; 7, Oscura district. 


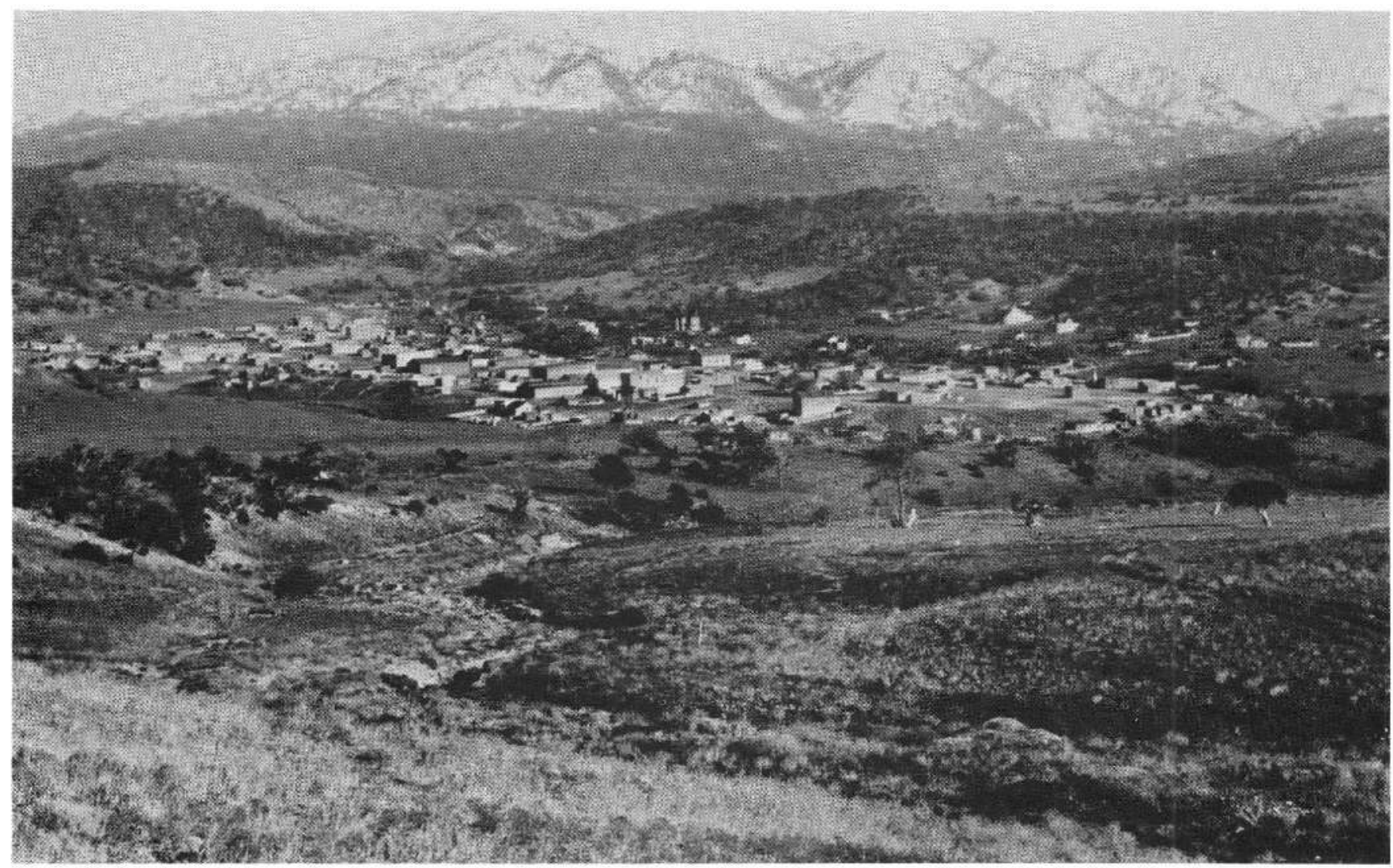

Figure 28. Town of White Oaks, N. Mex. Photograph taken by L.C. Gratton about 1905 (photograph number 99, on file at the U.S. Geological Survey Photo Library, Denver, Colo.).

Soon after, other veins were discovered, including the vein that would be exploited in Old Abe mine. A 20-stamp amalgamation plant was built there in 1893; in 1898, it was expanded to include cyanide extraction (fig. 29).

Old Abe mine, the largest producing mine in the district, was worked to a depth of $1,400 \mathrm{ft}$. Ore grade was highest in pockets and shoots near the surface. Despite the depth, significant amounts of water were not encountered, so that water for milling operations was brought to the site by truck. Ore at Old Abe contained free-milling gold in quartzlimonite veins that, through 1890 , had an average grade of about $0.44 \mathrm{oz}$ of gold per short ton. Grade dropped somewhat thereafter. The most productive period was from its discovery until 1904. Pay zones formed pockets and shoots in the veins, which ranged in width from 4 to $20 \mathrm{ft}$. Assays of individual samples ranged from 0.77 to $30.84 \mathrm{oz}$ of gold per short ton of ore. Lindgren and others (1910) reported that the Fish Pond stope was $20 \times 50 \times 60 \mathrm{ft}$ and yielded $\$ 80,000$ (about $3,870 \mathrm{oz}$ ) in gold at the 1910 price of $\$ 20.67 / \mathrm{oz}$.

The history of other mines in the district is similar to that of Old Abe. At South Homestake mine, however, the Capitan and the Devil's Kitchen stopes were mined by glory-hole methods down to the 180-ft level, where stoping began. The Smuggler and Little Mack mines were the last continuous mining operations in the district, operating until the 1930's. After World War II, North Homestake and Old Abe operated for a brief period. Since then, except for occasional exploration, the district has been a typical ghost mining camp.

\section{JICARILLA DISTRICT}

As early as 1700 , the Spanish may have mined the district's gold placers in gulches near the present-day village of Jicarilla (Smith and Dominian, 1904). But it was not until 1850 , when prospectors began panning gold from gravels using meltwater or water they hauled in, that placer mining began in eamest. Such small-scale placer mining continued in the district until it was interrupted in World War I and remained shut down through the 1920 's. During the depression in the $1930^{\circ} \mathrm{s}$, miners returned to the Jicarilla Mountains in search of gold. At that time, the district became home to about 300 miners, and in 1934 as many as 84 placer mines were operating. From 1933 to 1942 , more than $1,800 \mathrm{oz}$ of gold and 143 oz of silver were produced from placers (Segerstrom and Ryberg, 1974, p. 17). Entry of the United States into World War II ended gold mining in the district except for an occasional attempt to reinvigorate some of the placer locations. At one time or another, almost every arroyo in the 


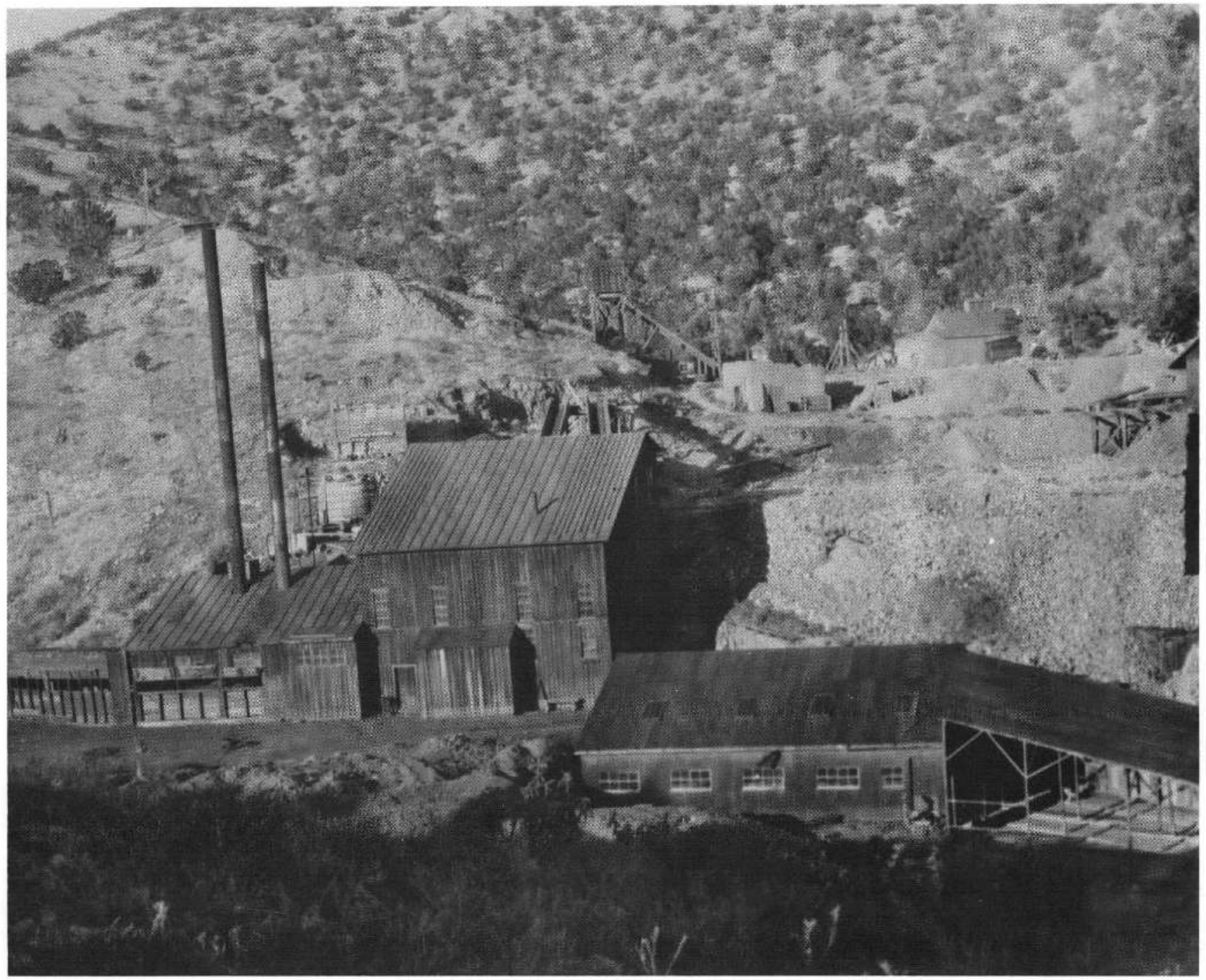

Figure 29. Old Abe mine and mill, White Oaks district. New Mexico. Photograph taken by L.C. Graton about 1905 (photograph number 100, on file at the U.S. Geological Survey Photo Library, Denver, Colo.).

district has been worked. However, the most productive were Ancho, Rico, Spring, and Wamer Gulches.

Large-scale placer mining has also been tried in the district. In 1903, a large dredgelike placer mining machine was unsuccessfully tested west of the post office in Jicarilla. In the 1930's, power shovels and other power equipment for removing overburden were used, as were special sluices for gold recovery. Johnson (1972) noted that large-scale operations have not been successful because of lack of water and the thickness of the overburden. Within the alluvium, the gold is not well concentrated in the channels, and large quantities of stream gravel must be processed to recover the gold, some of which consists of fine grains and thin foils that float by surface tension and are lost if special care is not taken. Small-scale operations in the past were successful for some miners, however.
About 1880, exploration began for lode sources of the placer gold, and small lodes have since been found. McLemore (1991) estimated that lodes produced 7,347 oz from 1912 to 1957. Segerstrom and Ryberg (1974) reported that the only year for which lode-gold production records are available was 1933, when 83 oz were produced from the Lucky Strike mine and another unnamed mine. There are many shafts and adits at the head of Ancho Gulch and near Ancho Peak; most were dug early in this century and in the 1930's. In some mines, copper and silver accompanied gold. Finlay reported that a large body in one mine contained $\$ 13.50$ of gold per short ton of ore at 1920 prices (Finlay, 1921-1922). Another mine was less rich, having sulfide ore ranging from $\$ 4.00$ to $\$ 5.20$ per short ton.

An estimated $8,000 \mathrm{oz}$ of gold (Johnson, 1972) have been produced from the district's placers. This total may be 
erroneous, however, due to reporting problems associated with early small-scale operations. McLemore (1991) reported that byproducts of gold production from 1912 to 1957 were about 2,100 short tons of copper, 37,531 oz of silver, and 1.33 short tons of lead. From time to time, new exploration has been conducted and pilot plants have been built (see Segerstrom and Ryberg, 1974, p. 19), but little gold has been produced since 1942. Although platinum-group elements have been reported in the district, little information is available and no authoritative confirmation has been made.

\section{NOGAL DISTRICT}

Most of the Nogal district is located on the eastern side of Sierra Blanca Peak. For this report, the Nogal district includes the mineralized areas in the vicinity of Sierra Blanca Peak. According to Segerstrom and others (1979), a part of the present Nogal district was the Bonito mining district, which was referred to in mining claim records as early as 1879. However, the official Nogal mining district was not established until July 1880 . Other unofficial mining district names, such as West Bonito, Tortolito, and White Mountain, have been used for part of the area.

Prospecting and mining in the Nogal district probably date back to the time of Spanish rule. More recently, placer gold deposits were found in the district in 1865 at Dry Gulch, and gold lodes were located in the district in 1868. It was not until 1882, when the region was withdrawn from the Mescalero Apache Indian Reservation, that prospecting was undertaken seriously (Anderson, 1957, p. 92). Most of the major veins in the area were discovered at that time.

Lode gold deposits were exploited sporadically in the Nogal district from the 1880's to the 1930's. Records of the earliest production in the district were not maintained. One source indicated that, until 1920, 10 mines in the district had produced $\$ 212,000$ worth of gold at the prices of the day (Thompson, 1973). From 1900 to the 1920's, the Parsons mine produced an estimated $15,000 \mathrm{oz}$ of gold from 85,000 short tons of ore. Since 1904, at least 25 lode mines and 19 placers have operated in the Nogal district. McLemore (1991) estimated that from 1858 to 1942 , the placers produced $200 \mathrm{oz}$ of gold.

There was little mining activity during 1920-1933. About 1933, the Helen Rae and American mines produced from the same vein. In 1936, a 75-short-ton mill and an amalgam plant were installed, and development work began at the Silver Plume and Bonita properties where gold was milled 1 yr later. These mines produced 30 short tons of gold ore in 1938 and 84 short tons in 1939 (Anderson, 1957). From 1937 to 1953, a total of 914 short tons of ore (Segerstrom and others, 1979) was produced. Thompson (1973) suggested that the other mines in the district had only smallscale production. Total production estimated in 1973 was on the order of $\$ 1$ million. Segerstrom and others (1979) suggested that the small size of most of the workings and the
Table 6. Production of iron ore from metals mining districts in Lincoln County, N. Mex., having iron ore production (modified from Griswold, 1959, after Kelley, 1949)

[n.r., not reported]

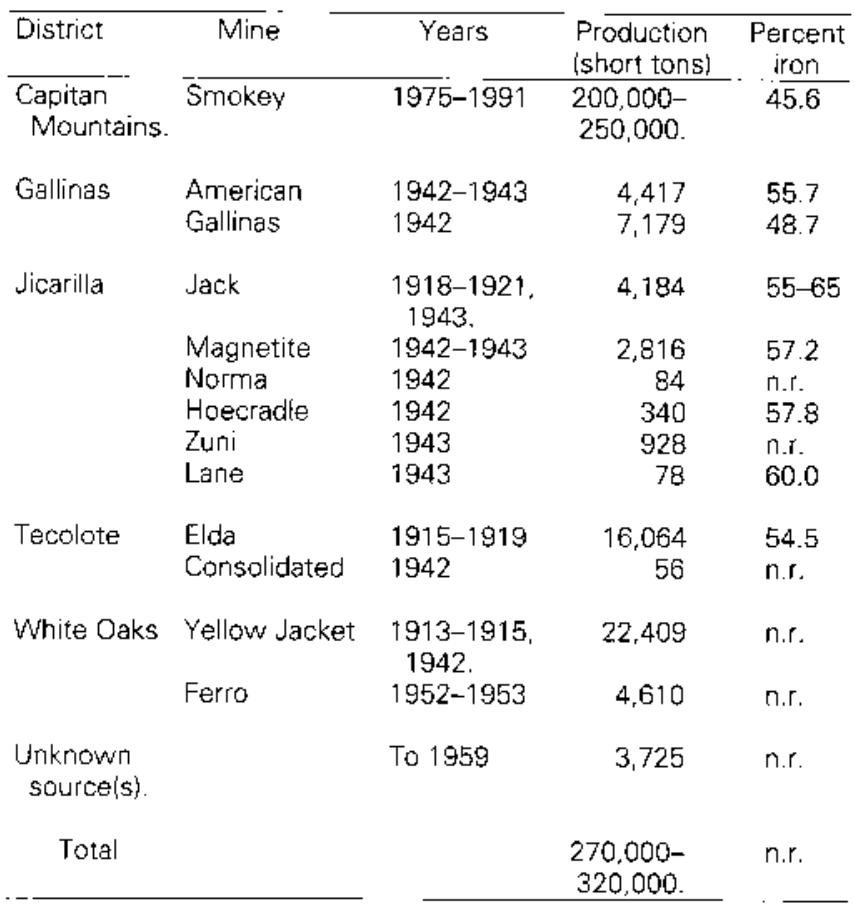

lack of evident stopes indicate limited production. The ore probably was sold locally to merchants or to larger mining companies, such as those at White Oaks.

More recently, an attempt to recover gold from iron ore led to the Cimmarron mill site in Carrizozo being designated as a Superfund site by the U.S. Environmental Protection Agency. According to Brandvold (1991), potentially hazardous concentrations of cyanide, mercury, selenium, arsenic, lead, and copper were found in groundwater, soil, and tailings. The damage was caused by alleged operating violations while attempting to improve gold recovery. Cleanup was slated for 1991-1992. Exploration in the district continues. In 1989, an epithermal breccia system estimated to contain $190,000 \mathrm{oz}$ of gold was reported at the Great Westem deposit (Dayton, 1988).

\section{IRON}

The history of iron mining in New Mexico, from its prehistoric use as a pigment to post-World War II production, is discussed by Kelley (1949), and more recent activities are summarized by Smith (1991). Of the counties within the study area, only Lincoln County has iron deposits and historical iron ore production (table 6) (pl. 13). The iron ore occurs as pyrometasomatic replacements in Permian carbonate rocks of the San Andres and Yeso Formations (U.S. Geological Survey, 1965). 
Iron ore was probably discovered by prospectors looking for other mineral commodities such as gold, silver, and copper. Iron deposits were found in such gold-producing districts as the Gallinas, Jicarilla, and White Oaks, where iron deposits are found together with gold veins. Iron deposits in the White Oaks district were well known prior to 1900 . Samples analyzed around the turn of the century from iron deposits at Lone Mountain and the Jicarilla district contained 62.2-65.52 percent iron and $0.21-0.41$ percent sulfur (Kelley, 1949). At that time, the deposits were considered to be high grade and to contain vast resources.

There are approximately 24 known iron deposits from the Gallinas Mountains to the Capitan Mountains (Griswold, 1959). Production of iron ore from these deposits probably began between 1900 and the beginning of World War I. The first recorded production was in 1913, when about 3,700 short tons of ore were shipped from the Yellow Jacket mine in the White Oaks district to the Colorado Fuel and Iron Co., in Pueblo, Colo. (Griswold, 1959). From 1913 to 1921, mines in the Jicarilla, Tecolote, and White Oaks districts produced 40,457 short tons of iron ore, which averaged 2.0 percent of New Mexico's production for that period; a high of 7.8 percent was reached in 1914 . No iron ore production was reported for Lincoln County from 1922 until 1942. About 1942, mines in the Gallinas, Jicarilla, Tecolote, and White Oaks districts were again activated, producing 13,759 short tons of iron ore or 7.3 percent of the State's iron ore output. From 1913 to 1943 , about 59,140 short tons of iron ore were produced from districts in Lincoln County, accounting for 1.2 percent of New Mexico's cumulative iron ore production for that period. In 1952 and 1953, the White Oaks district was again producing iron ore, this time from the Ferro mine, which had an output of 4,610 short tons. Total production for the study area has been about $270,000-320,000$ short tons of iron ore (table 6).

\section{CAPITAN IRON DEPOSIT}

The Capitan deposit, about $6 \mathrm{mi}$ north of Capitan in the Capitan Mountains district, was explored extensively during and after World War II by the U.S. Geological Survey and the U.S. Bureau of Mines as part of the search for iron resources to meet the nation's strategic need for steel. Soule (1947, 1949) led the exploration effort of 179 drill holes totalling $3,490 \mathrm{ft}$. Kelley (1949) mapped the deposit and described the geology using the drill-hole data. Analyses of composite samples showed the deposit to contain about $3,000,000$ short tons containing 48.1 percent iron, 0.06 percent sulfur, and 0.06 percent phosphorous (Kelley, 1949). Since 1975, when it was taken over by L.D. Larue and Sons, $200,000-250,000$ short tons of iron ore have been produced from the Smokey mine (table 6), whose pit has grown to about 1,480 $1,100 \mathrm{ft}$ (Smith, 1991). Presently, the Smokey mine, which exploits part of the Capitan deposit, intermittently produces $10,000-15,000$ short tons of iron ore per year

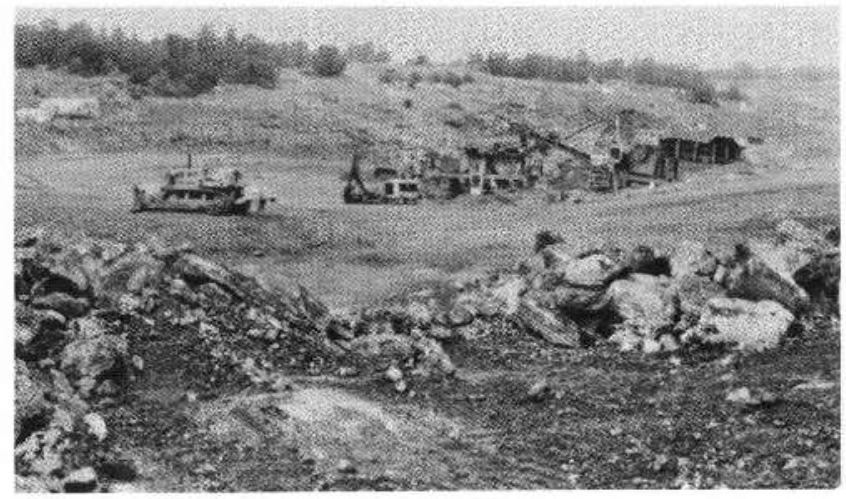

Figure 30. Iron ore being extracted from the Smokey mine and pulverized for use as road metal, Capitan Mountains district, New Mexico. Photograph taken in September 1991.

containing about 50 percent iron (Hatton and Childs, 1990) (fig. 30).

Other deposits in the Capitan Mountains district, such as the Major, Red Wing, Ajax, and Oslo deposits, were prospected during World War II. Grades ranged from 59.3 to 63.7 percent iron (Kelley, 1949; Sheridan, 1947), and resources were estimated to be about 22,000 short tons. No ore has been reported as having been produced from these deposits.

\section{GALLINAS DISTRICT}

In the Gallinas district, the American mine (along the west side of Crashed Bomber Ridge) was mined in 1942-1943 and then abandoned. The Rare Metals deposit, located about $1,500 \mathrm{ft}$ southwest of the American mine, has not been mined, but resources are estimated to be a few thousand short tons of iron ore (Kelley, 1949). The Gallinas mine produced iron ore in 1942 from an ore body exposed in a pit measuring $125 \times 100 \times 10 \mathrm{ft}$. Kelley (1949) doubted that more than a few hundred short tons of minable material remained. During 1942-1943, the district produced 11,540 short tons of iron ore (Kelley, 1949; Griswold, 1959).

\section{JICARILLA DISTRICT}

Iron deposits in the Jicarilla district are similar to iron deposits in other districts in the Lincoln County porphyry belt in that they are small iron skarns and replacements in limestone surrounding a monzonite stock. Both the Jicarilla and White Oaks districts were known for their gold deposits before iron mining began (Griswold, 1959). In the Jicarila district, iron ore mining was carried out during 1918-1921 at the deposits near Jacks Peak. At one of those deposits, Jack mine was the source of the iron in the early years of mining and Hoecradle, Jack, Lane, Magnetite, Norma, and Zuni mines produced during the latter period of mining during World War II. At Jack mine, the most productive iron mine 
in the district, magnetite and hematite occurred as replacements of limestone beds that were traced for several thousand feet. The thickness of the iron-rich beds ranged from a few inches to $10 \mathrm{ft}$. South of the village of Jicarilla along Ancho Gulch, several magnetite bodies are known in limestone, but none has reported iron production. Total iron ore production for the Jicarilla district was 8,679 short tons of iron ore averaging 12 percent iron (Kelley, 1949, p. 159; Griswold, 1959).

\section{TECOLOTE DISTRICT}

The Tecolote district has produced only iron ore from the Elda mine and the Consolidated mine. The Elda mine produced 16,064 short tons of ore in 1915-1919. At the Elda mine, the ore was soft, porous, banded magnetite, averaging $5 \mathrm{ft}$ thick. Mining was done underground using room-andpillar methods with only occasional timbering. No iron ore was produced from the Elda mine during World War II. In 1942, the Consolidated mine produced about 56 short tons of iron ore (Griswold, 1959).

Other prospects in the district, such as the Betty, Bond, and the Iron City No. 2, are located within the same deposit as the Elda mine, but neither have produced any iron ore.

\section{WHITE OAKS DISTRICT}

The White Oaks district has two principal mines, Ferro and Yellow Jacket, that account for all of the reported iron ore production in the district. The mines occur along the periphery of the Lone Mountain monzonite stock outside of the town of White Oaks. At the Ferro mine, an iron skarn deposit is localized along the contact between the San Andres Formation and the intrusion. According to Griswold (1959), the deposit consists of a steeply dipping magnetite vein $1-6 \mathrm{ft}$ wide where limestone has been replaced. Silicate minerals, such as actinolite, epidote, and hedenbergite, typical of skarn mineralization are present. A total of 4,610 short tons of iron ore was produced at the Ferro mine in 1952 and 1953 (Griswold, 1959).

At the Yellow Jacket mine, the deposit consists of hematite ore and subordinate magnetite and specularite hosted in the limestone member of the San Andres Formation, which is sandwiched between monzonite sills (Griswold, 1959). The geology is complicated by close folding of the sedimentary rocks and the intrusion of dikes and sills. Mineralization is restricted to the limbs and trough of a synclinal structure. The Yellow Jacket mine was developed shortly after 1900; iron mining began in 1913 and was suspended in 1915. Both glory-hole and underground methods were employed. Further production occurred from July to December 1942, for a total of 22,409 short tons of iron ore (Kelley, 1949; Griswold, 1959). The Yellow Jacket mine had the largest iron ore production in Lincoln County, having nearly 38 percent of the total for the years 1913-1943, until its total was exceeded by the Smokey mine in the late 1970's.

The House prospect is described by Griswold (1959) as a magnetite replacement deposit within a limestone bed of the Yeso Formation adjacent to the Lone Mountain intrusion. The prospect has been assayed and explored, but as of 1959, no iron ore had been produced (Griswold, 1959). Grade of the uranium at the House prospect, discussed in Walker and Osterwald (1956), was uneconomical.

According to Kelley (1949), the Black Knight prospect consists of irregular-shaped replacements of magnetite in limestone. Chip samples across two exposures as wide as 10 $\mathrm{ft}$ yielded readings of 43.4 and 62.1 percent iron. The deposits were prospected by small cuts and short adits and appear to have small iron resources.

\section{BASE METAIS, SILVER, FLUORSPAR, AND RARE-EARTH ELEMENTS}

Base metals (copper, lead, and zinc), silver, fluorspar, and rare-earth-element-bearing bastnaesite have been discovered and mined in several mining districts in the study area, including the Gallinas, Nogal, Pastura, and Oscura districts (pl. 13).

\section{GALLINAS DISTRICT}

In the Gallinas district, numerous small veins in the iron deposits were being worked as early as $\mathbf{1 8 8 5}$ for copper, lead, zinc, and silver. By 1904, several small mining operations in the district were shipping ore to Socorro for smelting. Records are incomplete, but from 1920 to 1922 , the Red Cloud mine (on one of the earliest claims staked in the dis(rict) shipped 2,384 short tons of lead-copper-silver ore to El Paso, Texas. From 1922 to the early $1940^{\prime}$ s, the Gallinas district was dormant. With the onset of World War II, the district was reactivated to provide iron and fluorite for the war effort. During 1942 and 1943, in order to obtain better information on the geology and resources of the district, the U.S. Geological Survey and the U.S. Bureau of Mines cartied out extensive exploratory surveys defining and describing the district's resources and ores. Despite this new work, production from the district was small. From 1922 to 1949, an estimated 4,000 short tons of copper ore were shipped (Perhac and Heinrich, 1964).

From 1943 to 1955, fluorspar concentrates were shipped from three mines. In 1953-1955, the Red Cloud and Conqueror No. 9 mines shipped less than 2,000 short tons of fluorspar concentrates valued for their content of bastnaesite, a chief source of rare-earth elements. In 1954, 60 short tons of bastnaesite concentrates were derived from 1,000 short tons of fluorspar concentrates from the Red Cloud mine.

Other mines in the Gallinas district produced small amounts of metals. The All American mine produced 129 
short tons of fluorspar ore in 1949-1951. The Conqueror mine produced about 300 short tons of iron-lead-copper ore in 1956. The Old Hickory mine was worked for lead and copper initially, and may have yielded fluorspar ore in World War II. McLemore (1991) reported that from 1909 to 1955 , the Gallinas district produced $23,723 \mathrm{oz}$ of silver, about 193 short tons of copper, 863 short tons of lead, and about 8.7 short tons of zinc.

\section{NOGAL DISTRICT}

The Nogal district has been considered chiefly a gold or molybdenum district, although lead-zinc-silver has been known in the district since the 1880's. The Helen Rae and American mines, the most extensively worked lead-coppersilver mines in the district, produced from the $1880^{\circ} \mathrm{s}$ to the early 1930's. At the Maud mine, the upper workings were active in the 1890's and later worked in 1963-1964. In this latter period, a composite sample at the Maud mine contained 7.10 percent lead, 0.39 percent zinc, 0.017 percent molybdenum, $0.32 \mathrm{oz}$ gold per short ton of ore, and $1.28 \mathrm{oz}$ silver per short ton of ore, with no detectable copper. North and McLemore (1986) estimated that the district produced about 20,000 oz of silver between 1868 and 1942 .

\section{PASTURA DISTRICT}

The only metals mining district in Guadalupe County is the Pastura district, where the Stauber and Pintada mines have been exploited for copper, silver, and lead. Total production for the Pastura district was reported in McLemore and North (1985) as 265,954 short tons of ore valued at about $\$ 2.75$ million, containing 6,879 short tons of copper, 23 short tons of lead, $8,466 \mathrm{oz}$ of silver, and $2 \mathrm{oz}$ of gold.

The Stauber deposit, north of Pastura, was discovered by a section worker on the Southern Pacific Railroad. Prior to 1915 , when it was acquired by I.J. Stauber, it produced 2.7 short tons of copper and 48 oz of silver from a single bed of Triassic Santa Rosa Sandstone. The mine was in operation from 1925 to 1930 , from 1940 until the end of World War II, and from 1949 to 1957 .

During World War I, a small amount of underground mining produced ore typically assaying at 1 percent copper; rare nodules assayed at as much as 8 percent copper (Stauber, 1930). In 1942, the Stauber mine was an important source of high-grade siliceous copper ore for smelter flux (Holmquist, 1947). From 1925 to 1942, 2,876 short tons of copper were recovered from ore having a copper content of 3.86-5.24 percent (Holmquist, 1947).

The mine was operated later as an open-pit mine. Around 1954, the overburden became too great to remove economically and the mine returned to underground operations. In 1957, production was 300 short tons of ore per day. Total production from 1915 to 1956 was over 264,000 short tons of ore containing 2.56 percent copper, $0.03 \mathrm{oz}$ of silver per short ton, and 0.0087 percent lead (Soulé, 1956). The original copper grade was slightly over 5 percent when mining began, but dropped to about 1 percent in later years.

The Pintada mine, located about $15 \mathrm{mi}$ southwest of Santa Rosa in Pintada Canyon on Rio Agua Negra, had small-scale open-pit production in 1916-1917, 1951, 1956, and 1967-1970. Shipments of 23 short tons of 5.6 percent copper ore in 1916-1917, 490 short tons of 1.7 percent copper ore in 1951, and 980 short tons of 2.4 percent ore in 1956 , were shipped to the smelter (Burleson, 1966). The ore consisted of chalcocite, mostly finely disseminated and in streaks and patches, in fine-grained well-cemented sandstone.

About 1,597 short tons of ore containing 10.75 short tons of copper and $71 \mathrm{oz}$ of silver were produced at the Pintada mine from a $49 \times 85 \times 30$ - $\mathrm{ft}$ pit (McLemore and North, 1985) from mineralized parts of the Artesia Group (Grayburg and Queen Formations) (Sandusky and Kaufman, 1972). Additional resources were located in the early 1970 's, but poor economic conditions and low grade prevented their development. As of July 1990, the mine remained abandoned. Weakly mineralized host rock at the Pintada mine that contained the greatest concentration of ore minerals was as thick as 10.5 ft (Burleson, 1966). According to Read and others (1944), other weakly mineralized occurrences are present along Pintada Canyon (sec. 14, T. 8 N., R. 19 E.).

\section{OSCURA DISTRICT}

The Oscura district, in western Lincoln County, was not exploited until about 1900 , when a few carloads of coppersilver ore were shipped. McLemore (1991) estimated that about 21.1 short tons of copper and $124 \mathrm{oz}$ of silver were produced from 234 short tons of ore. The district has remained idle since 1910. The ore is of refractory copper oxides, and its grade is variable. The district is now within the White Sands Missile Range, which would prevent further exploitation.

\section{QUAY COUNTY}

In Quay County, copper mineralization has been recognized along the base of the Canadian River escarpment for 5-6 mi and to the south near the junction of Ute Creek and the Canadian River. In the latter area, there was some mining from 1910 to 1920, according to Soule (1956). After 1920, there was no mining activity until the mid-1950's when claims were staked for uranium minerals.

Approximately $8 \mathrm{mi}$ west of Logan in Quay County, copper minerals, including malachite, azurite, and chalcocite, are reported to occur as replacements between grains and as nodular masses in a shaly sandstone of the Triassic Dockum Group (Soule, 1956). According to Soule (1956), copper grades are low and scattered, and prospecting has been limited to shallow pits. 


\section{TUNGSTEN}

In addition to gold, tungsten was produced intermittently from 1915 to 1952 in the White Oaks district (Soulé, 1956). Griswold (1959) reported (from incomplete records) a production of almost 60 short tons of material containing 56.81 percent tungsten trioxide $\left(\mathrm{WO}_{3}\right)$. The raw tungsten ore, which probably contained less than 1 percent $\mathrm{WO}_{3}$, came from the South Homestake mine. In the early days of mining in the district, tungsten minerals were not recognized as being of economic importance and were discarded. Later, tungsten production came from old waste dumps.

\section{URANIUM}

New Mexico's uranium industry has a rich history that has been well documented. McLemore (1983) briefly summarized that history and provided references for additional information. Much of the following is from that account.

In 1947, creation of the Atomic Energy Commission (AEC) (an independent civilian agency of the federal government whose functions were taken over in 1974 by the Energy Research and Development Administration and the Nuclear Regulatory Commission) fostered extensive exploration, development, and production of uranium in New Mexico and the nation. In the early 1950's, eastern New Mexico had a uranium boom of its own, because extensive exposures of the Morrison and Chinle Formations, the chief uranium-bearing rocks of the Colorado Plateaus physiographic province, were known to crop out (Finch, 1972a, b). To encourage exploration, the AEC conducted airborne radiometric surveys over eastem New Mexico from 1953 to 1955 , and detected numerous anomalies. Prospectors used this information to locate uranium claims in the 1950 's, and some of the more promising deposits were explored by pits and short adits, and a few were drilled.

Although extensive exploration led to the discovery of several prospects and occurrences in the study area, little production resulted. AEC figures (McLemore, 1983) show that between 1948 and 1970 , uranium production from the counties in the study area consisted of $1 \mathrm{lb}$ of uranium oxide mined from 3 short tons of ore that contained 0.02 percent uranium oxide from the Bear Canyon Group of prospects in Lincoln County (pl. 13), and $91 \mathrm{lb}$ of uranium oxide from 83 short tons of ore that contained 0.05 percent uranium oxide from the Good Luck No. 1, Little Rattler, and Windy No. 9 mines in Quay County. Another 30 short tons of silicified uraniferous logs were shipped from the Bel Aro mine in Quay County, but were not recorded by the AEC (Finch, 1972b).

\section{MANGANESE}

Manganese was mined at the Arabela Manganese Inc. mine in the northeastern Capitan Mountains (pl. 13) at some time between when Griswold (1959) described the deposit as
Table 7. Reported identified mineral resources and estimated gross in-place value of commodities in the Roswell Resource Area, New Mexico

|Figures have been rounded. I metric ton=l.102 short tons|

\begin{tabular}{|c|c|c|c|}
\hline Commodity & $\begin{array}{l}\text { Value per } \\
\text { metric to }{ }^{1} \\
\text { (dollars) }\end{array}$ & $\begin{array}{l}\text { Identified } \\
\text { resources } \\
\text { (metric tons) }\end{array}$ & $\begin{array}{c}\text { Gross in- } \\
\text { place value } \\
\text { (dollars) }^{2}\end{array}$ \\
\hline Gold & $12,970,250$ & 30.76 & $399,000,000$ \\
\hline Copper & 2,306 & 6,800 & $15,700,000$ \\
\hline Iron & 62.18 & $2,700,000$ & $168,000,000$ \\
\hline Fluorspar & 119 & 46,000 & $5,470,000$ \\
\hline Moly & 7,434 & 19,000 & $142,000,000$ \\
\hline arth oxides & 2,334 & 255 & 595,00 \\
\hline Thorite & 42 & 122 & 5,10 \\
\hline Total & - & 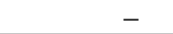 & $731,000,000$ \\
\hline
\end{tabular}

'Mostly calculated using average yearly prices for the years $1986-$ 1990 (U.S. Bureau of Mines, 1991).

2Estimates of gross in-place value do not imply that these resource would be necessarily economic to produce. Such a determination would require economic analysis of mining and concentrating of ores and metal production.

a promising prospect and 1983, when Tuftin (1984) visited the site and found a mined-out or rubble-covered trench. Griswold (1959) reported that production began in 1959 , when 1 short ton of concentrate containing 54 percent manganese was shipped. The government stockpile program was due to end that year, however, and there seemed little time to develop the property. When Tuftin visited, there were only abandoned workings. Sketches of the mine by Tuftin (1984, p. 14) show the dimensions of the trench to be approximately $170 \times 70 \times 35 \mathrm{ft}$, large enough to have yielded several thousand short tons of manganese ore.

\section{DESCRIPTTONS OF METAL DEPOSITS}

\section{By David M. Sutphin and Susan Bartsch-Winkler}

In the following sections, the metal-bearing deposits in the Roswell Resource Area are discussed by deposit type rather than by commodity because grouping by deposit type allows appropriate deposit models to be used to describe the deposits. Grades, tonnages, and volumes derived from grade and tonnage models are reported in the Metric System; U.S. Customary equivalents are given in parentheses. More than $\$ 700$ million worth of resources of gold, copper, iron, molybdenum, and other metallic commodities at the average yearly prices for the years 1986-1990 have been identified within the study area (tables 7 and 8; pl. 14; Appendix).

Most types of metal deposits found in the study area are genetically linked to igneous rocks; they commonly occur as mineralized breccia and fractures, fissure veins, and disseminated and replacement deposits (Woodward, 1991). Mineral occurrences of manganese, uranium, and minor titanium may occur in sedimentary rocks distant from intrusions, as well as in igneous terrane or nearby igneous terrane from which they were derived. 
Table 8. Mineral deposit types known or expected to occur in the Roswell Resource Area, New Mexico

[Model numbers of Cox and Singer (1986) given in parentheses following deposit type. Grade and tonnage models have been compiled for all deposit types except sandstone uranium deposits and fluorite-bastnaesite veins. Grade and tonnage models for epigenetic barite veins and marine bedded gypsum are preliminary. Grade and tonnage model for Mississippi Valley-type lead-zinc deposits contains data for both Southeast Missouri lead-zinc and Appalachian zinc deposit typesl

\begin{tabular}{|c|c|c|}
\hline Deposit type & $\begin{array}{c}\text { Roswell Resource Area } \\
\text { example }\end{array}$ & $\begin{array}{l}\text { Reference for grade and } \\
\text { tonnage model }\end{array}$ \\
\hline Thorium-rare-earth veins (11c) & Capitan Mountains deposits & Bliss (1992). \\
\hline Iron skarn (18d) & Yellow Jacket mine & Mosier and Menzie (1986). \\
\hline Replacement manganese (19b) & Arabella manganese mine & Mosier (1986). \\
\hline $\begin{array}{l}\text { Porphyry molybdenum, } \\
\text { low-fluorine (21b). }\end{array}$ & $\begin{array}{l}\text { Rialto and Three Rivers } \\
\text { stocks. }\end{array}$ & Menzie and Theodore (1986). \\
\hline $\begin{array}{l}\text { Gold-silver-tellurium veins asso- } \\
\text { ciated with alkaline rocks }(22 \mathrm{~b}) \text {. }\end{array}$ & White Oaks district & Bliss and others (1992). \\
\hline Polymetallic veins $(22 \mathrm{c})$ & Maud mine & Bliss and Cox (1986). \\
\hline Epigenetic barite veins (27e) & Fox lode prospect & $\begin{array}{l}\text { Orris, G.J. loral commun., } \\
\text { 1991). }\end{array}$ \\
\hline Marine bedded gypsum [35ae\} & Ancho deposit & $\begin{array}{l}\text { Orris, G.J. loral commun., } \\
\text { 19911. }\end{array}$ \\
\hline Sediment-hosted copper (30b\}) & Pintada and Stauber mines & Mosier and others (1986). \\
\hline Sandstone uranium $\{30 \mathrm{c}\}$ & Quay County occurrences & None. \\
\hline $\begin{array}{l}\text { Southeast Missouri lead-zinc }\{32 a\} \\
\text { and Appalachian zinc }\{32 b\} \text {. }\end{array}$ & None & Mosier and Briskey (1986). \\
\hline $\begin{array}{l}\text { Gold-platinum-group-element } \\
\text { placer (39a). }\end{array}$ & Jicarilla Mountains placers & Orris and Bliss (1986). \\
\hline Fluorite-bastnaesite veins & Gallinas Mountain deposits & None. \\
\hline
\end{tabular}

\section{PLACER GOLD}

Placer gold deposits have been an important source of gold in New Mexico. Outside of the study area, much of New Mexico's placer gold production has come from drainages below vein and skarn deposits in districts such as Elizabethtown-Baldy, Old Placers, New Placers, and Orogrande (North and McLemore, 1988; Johnson, 1972). In the study area, gold placers containing minor silver and possibly rare platinum-group elements occur in the Jicarilla, Nogal, Tecolote, and White Oaks districts in Lincoln County and in the bed of the Rio Hondo River (which drains these districts) in Chaves and Lincoln Counties (pl. 13). Although platinum-group elements have been mentioned in the literature as occurring in the Lincoln County porphyry belt, they have never been reliably documented (V.T. McLemore, New Mexico Bureau of Mines and Mineral Resources, written commun., June 1991).

The placer deposits of the Jicarilla district (fig. 31) have produced most of the placer gold in the study area and are the best known (Segerstrom and Ryberg, 1974). They occur on the north-facing mountain slopes in the Ogallala(?) Formation, a fanglomerate of Tertiary age. The fanglomerate consists of unsorted, unstratified, slightly lithified, coarse gravel or boulders (3-ft clasts), sand, silt, and minor clay derived from nearby Tertiary granodiorite and monzonite intrusives and older sedimentary rocks. Much of the gold was probably derived from small gold-pyrite veins and disseminations in intrusive monzonite porphyry (Segerstrom and Ryberg, 1974). At some sites, gold was found directly above decomposed gold-bearing rock. Quaternary placers contain reworked Ogallala(?) Formation and, thus, may contain second-cycle gold.

Gold in the placers of the Jicarilla district is very fine grained and difficult to extract. It is also erratically distributed both vertically and laterally (Segerstrom and Ryberg, 1974). The gold grains are $2.0-0.061 \mathrm{~mm}$ in size, but some grains may be as small as $0.001-0.01 \mathrm{~mm}$. Commonly, gold coats hematite grains and is floated off during washing. As a consequence, old tailings may be reprocessed and substantial amounts recovered. Some of the principal placer mines and gold-bearing gravels of the Jicarilla district are in Ancho, Rico, Spring, and Warner Gulches (fig. 31).

Segerstrom and Ryberg (1974) estimated that the placer gold deposits in the Jicarilla district cover a distance of at least $4 \mathrm{mi}$ of the gulches and an area of $5-6 \mathrm{mi}^{2}$, have an 


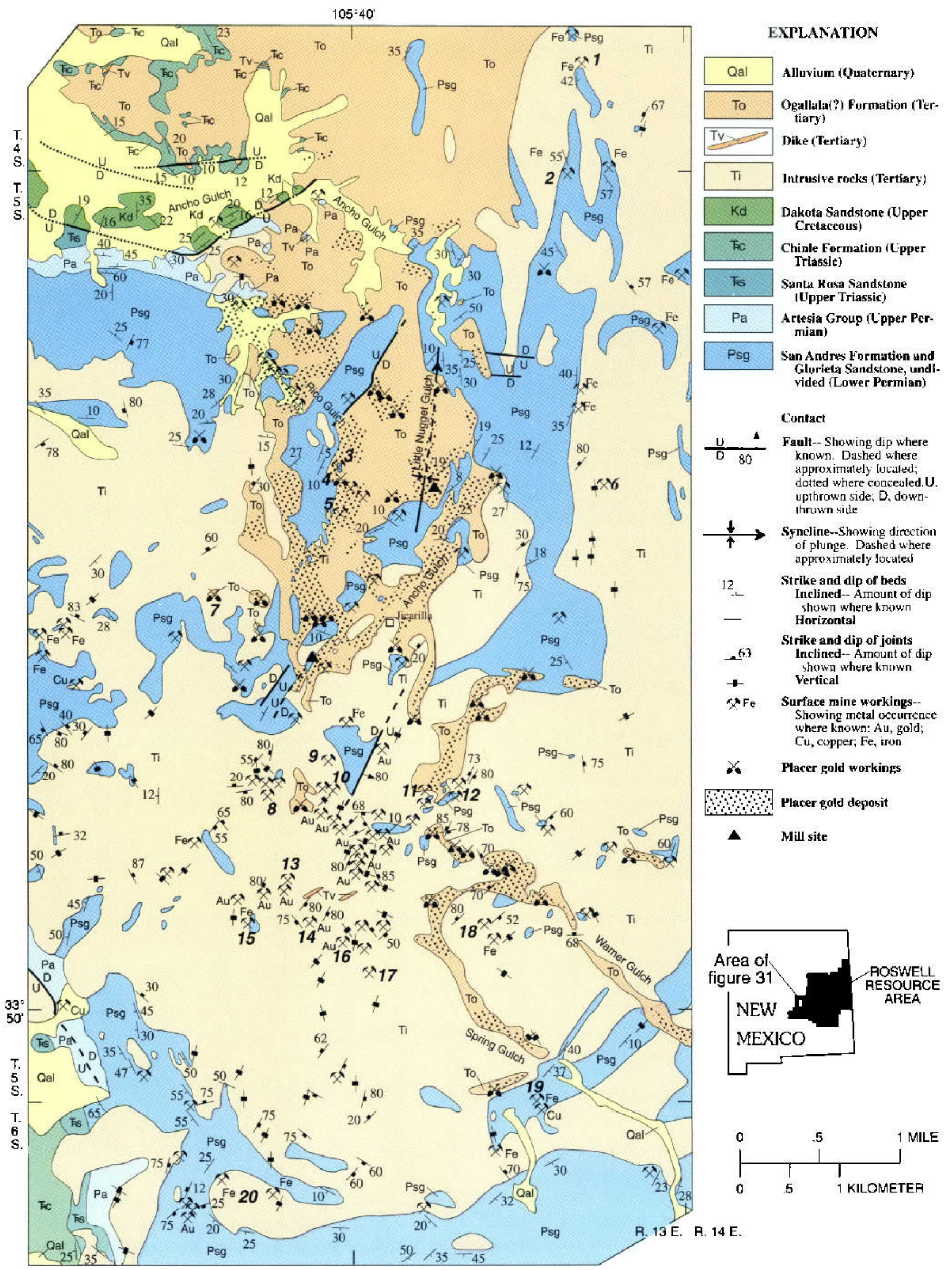


Figure 31 (facing page). Geologic map of the Jicarilla Mountains, N. Mex, showing locations of surface mine workings, placer gold workings, and placer gold deposits (modified from Segerstrom and Ryberg, 1974). Numbers represent named surface workings as follows: 1, Jack No. 1; 2, Jack No. 3; 3, Blucjay; 4, Buzzard; 5 . Scratchout; 6, Hoecradle; 7, Little Pine; 8, Blackgold; 9, Zulu; 10. Old Homestead; 11, Old Doctor; 12, Lucky Strike; 13, Goldstain or Spring; 14, Apex; 15, Ascho Rico Consolidated; 16. Sally; 17, Revenue; 18, Polly or Magnetite; 19, Norma; 20, Zuni.

average thickness of about $15 \mathrm{ft}$, and contain 18 short tons of gold. Using these estimates, the volume of the Jicarilla district reserves is about $46,000,000 \mathrm{~m}^{3}\left(60,000,000 \mathrm{yd}^{3}\right)$, at a gold grade of about $0.35 \mathrm{~g} / \mathrm{m}^{3}\left(0.009 \mathrm{oz} / \mathrm{yd}^{3}\right)$. The volume is large when compared to other large-volume placers found elsewhere (Bliss and others, 1987) (fig. 32B), but the gold grade is typical (fig. 32A). The Ancho Gulch placer gold deposit contains an estimated 1.5 million metric tons ( 1.7 million short tons) of material, which is more than about 53 percent of the 65 gold placers compared world wide by Orris and Bliss (1986) (fig. 33). The Rico Gulch and Little Nugget Gulch placer deposits (combined) may contain 8 million metric tons ( 8.8 million short tons), about 63 percent larger than other placers in the world. Placer deposits in the Jicarilla district may be the largest low-grade gold resource in the State. Segerstrom and Ryberg (1974) estimated the grades of individual deposits to range from $0.1 \mathrm{ppm}$ for lowgrade deposits to $1 \mathrm{ppm}$ for high-grade deposits, which corresponds to grades higher than 15 percent and 99 percent,

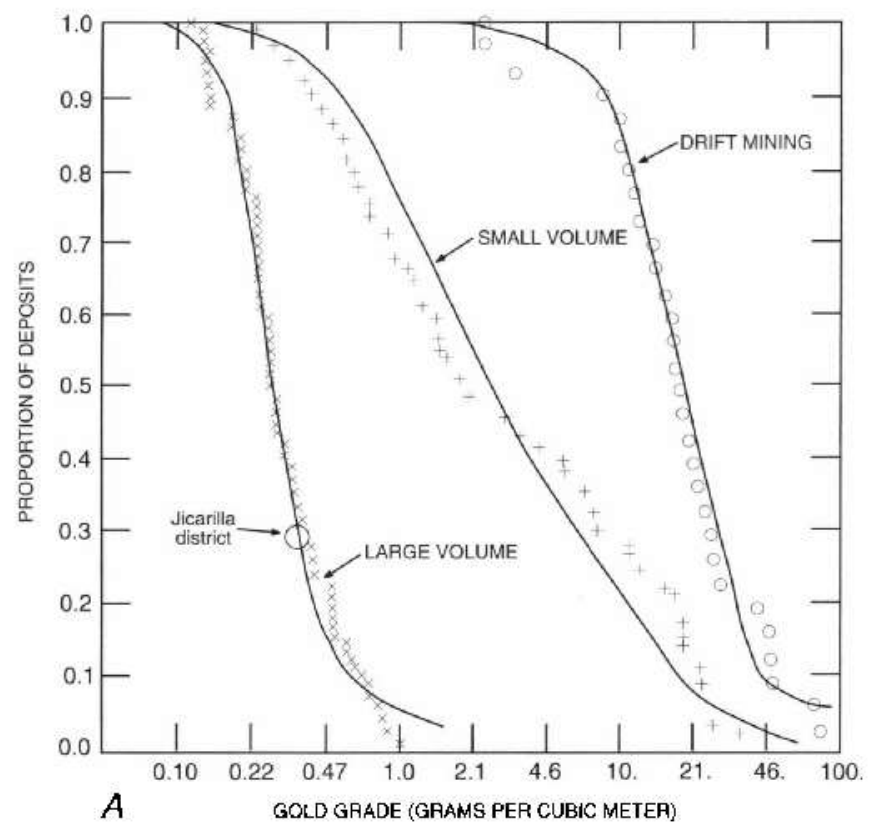

respectively, of world placers compared by Orris and Bliss (1986). Placer deposits in the Jicarilla district would offer an opportunity for placer gold production if a reliable source of water (or a process less reliant on water) could be found.

Placer gold deposits in the remaining districts in the study area are less extensive than those in the Jicarilla district. In the Nogal district (primarily a lode gold district), placers have been worked along Dry Gulch. However, they are usually near the gold-sulfide veins of the Helen Rae and American mines. In the Tecolote district, as in the Jicarilla district, platinum-group elements have been reported along with gold in heavy-mineral placers but, as of 1986, there was no positive identification (Northrup, 1959; North and McLemore, 1986). In the White Oaks district (primarily a lode-gold district), Baxter and White Oak Gulches and their small distributaries have been worked intermittently and were a source of income for miners when the lode mines were not producing. As with the other districts, placer gold at White Oaks is derived from gold-bearing pyrite veins in the Tertiary intrusive rocks. Most of the placer mining was conducted near the major lode deposits. Schrader and others (1916) reported that placer gold occurs along Rio Hondo, which drains eastward from deposits in western Lincoln County.

\section{MANGANESE}

Only one manganese mine and one nearby manganese prospect are known in the study area (Griswold, 1959) (pl.

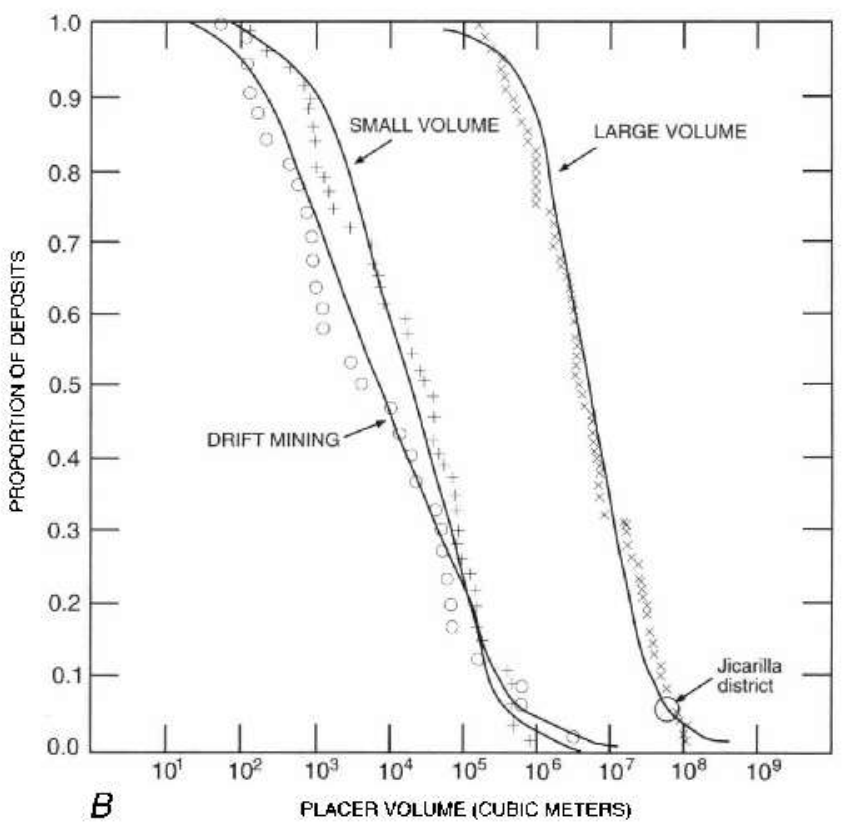

Figure 32. Estimates of $A$, gold grade and $B$, placer volume for placer gold deposits in the Jicarilla district, New Mexico, in comparison with grade and volume model for world-wide placer gold deposits (modificd from Bliss and others. 1987). Plots labeled small volume, large volume, and drift mining represent world-wide placer gold deposits. [1 gram per cubic meter=0.026 ounce per cubic yard; 1 cubic meter=1.307 cubic yards.] 


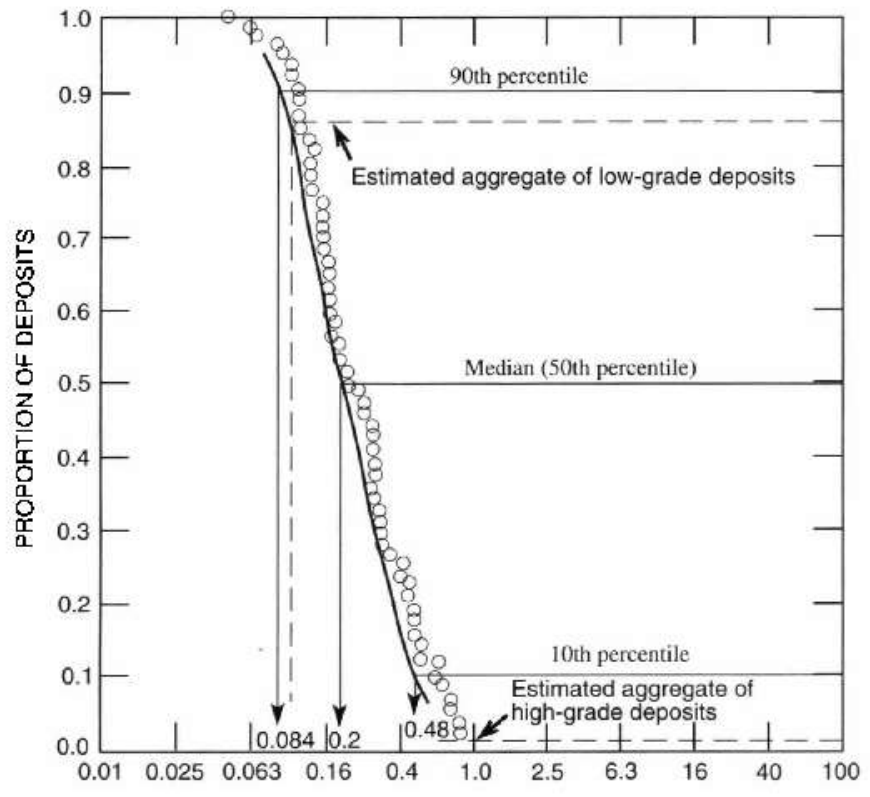

A golo grade (Grams per metric ton)

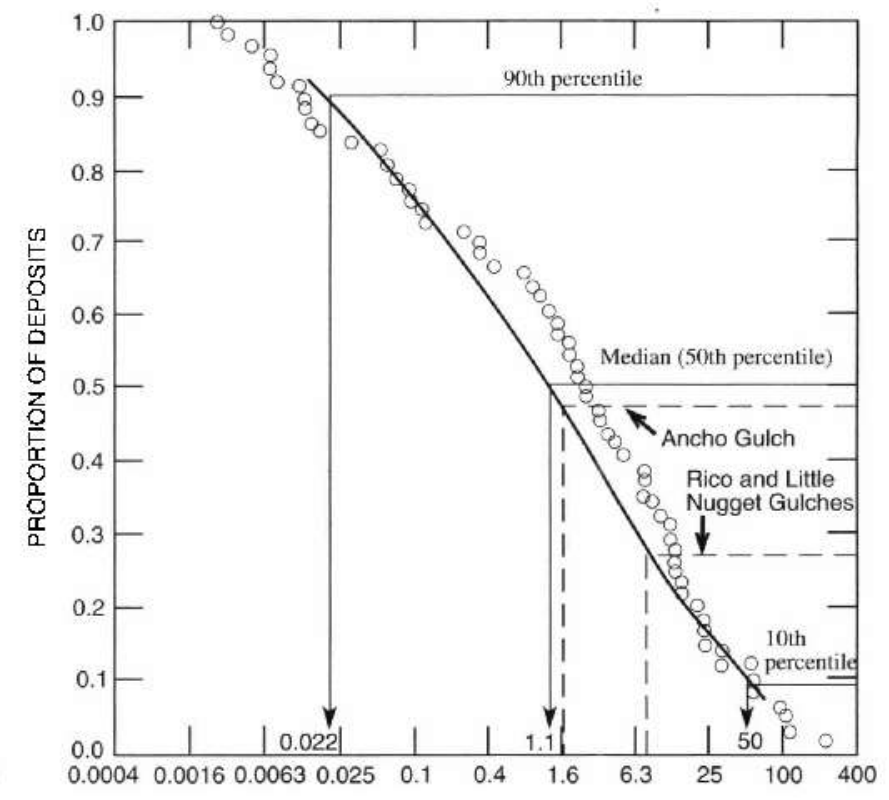

$B$ PLAGER TONNAGE (MILLION METRIC TONS)

Figure 33. A, gold grade for 65 world-wide placer gold deposits of Orris and Bliss (1986) and $B$, placer tonnage for placer gold deposits in Ancho Gulch and Rico and Little Nugget Guiches, N. Mex., in comparison with tonnage model for 65 world-wide placer gold deposits. [ 1 gram per metric ton $=0.029$ ounce per short ton; 1 metric ton=1.102 short tons.]

13). The Arabela mine is north of Capitan Peak and $5 \mathrm{mi}$ west of Arabela. There, a small replacement deposit consisted of a 2-ft-thick vein in a northwest-striking shear zone near the contact of the alaskite intrusive in the Capitan Mountains and the San Andres Formation (Griswold, 1959). The vein contained a 6-in.-thick "soft-ore" zone of ironmanganese oxide containing 15 percent manganese and a 18 in.-thick "hard-ore" zone of psilomelane fragments containing 49 percent manganese. Psilomelane nodules also extended into the footwall. Only 1 short ton of material con taining 54 percent manganese was shipped before 1959 (Griswold, 1959). Some time after 1959, the Arabela mine was expanded and the ore zone mined out or abandoned (Tuftin, 1984). Selected psilomelane nodules sampled by Tuftin (1984) contained 45 percent manganese and $0.02 \mathrm{oz}$ gold per short ton of ore. Chip samples yielded less than $1 \mathrm{oz}$ of silver per short ton of ore. The manganese-bearing zone may continue about $0.2 \mathrm{mi}$ northeast of the manganese mine (Tuftin, 1984).

\section{IRON}

The Lincoln County porphyry belt contains numerous iron deposits in skarn (Kelley, 1949); the Capitan Mountains, Gallinas, Jicarilla, Tecolote, and White Oaks districts all contain iron skarns (pl. 13). Iron skams typically occur as replacements in the San Andres and Yeso Formations adjacent to Tertiary intrusions (Griswold, 1964). The grade of the deposits is generally high (nearly 50 percent iron), but individual deposits are small and reserves are low.
In the Capitan Mountains district, the Capitan iron deposit is by far the largest and most economically important iron skarn yet identified in the study area. The deposit is located west of the Capitan Mountains and has been described in detail by Kelley (1949), Griswold (1959), Anderson (1957), and Soule (1947). The northwest quarter of the deposit is being produced at the Smokey mine (Smith, 1991). The deposit is ring shaped and about $1,300 \mathrm{ft}$ in diameter, and has an average ring width of about $100 \mathrm{ft}$ (Kelley, 1949). The thickness of the deposit is limited, as evidenced by drill holes from 200 to $400 \mathrm{ft}$ deep that bottomed in the Capitan Mountains intrusive. The center of the deposit contains low-grade magnetite-bearing rock and brecciated limestone and marble (fig. 34). Magnetite is the predominant ore mineral, and hematite is subordinate. Gangue is calcite, epidote, phlogopite, muscovite, tremolite, quartz, and fluorite. The Capitan iron deposit may have formed in a preintrusive, preore collapse structure or sinkhole in which the ore fluids collected and spread laterally into the adjacent limestone (Kelley, 1945; Smith, 1991).

In the Gallinas district, limestone of the Yeso Formation was intruded by Tertiary porphyritic trachyte and syenite. Contact metamorphism of the limestone resulted in emplacement of silicate skarn minerals and magnetite and hematite. Ore is localized by the combination of igneous contacts, limestone, and local folds (Kelley, 1949, p. 172).

The iron skams in the Jicarilla, Tecolote, and White Oaks districts formed much like those in the Gallinas district. Limestone of the San Andres Formation is intruded by 

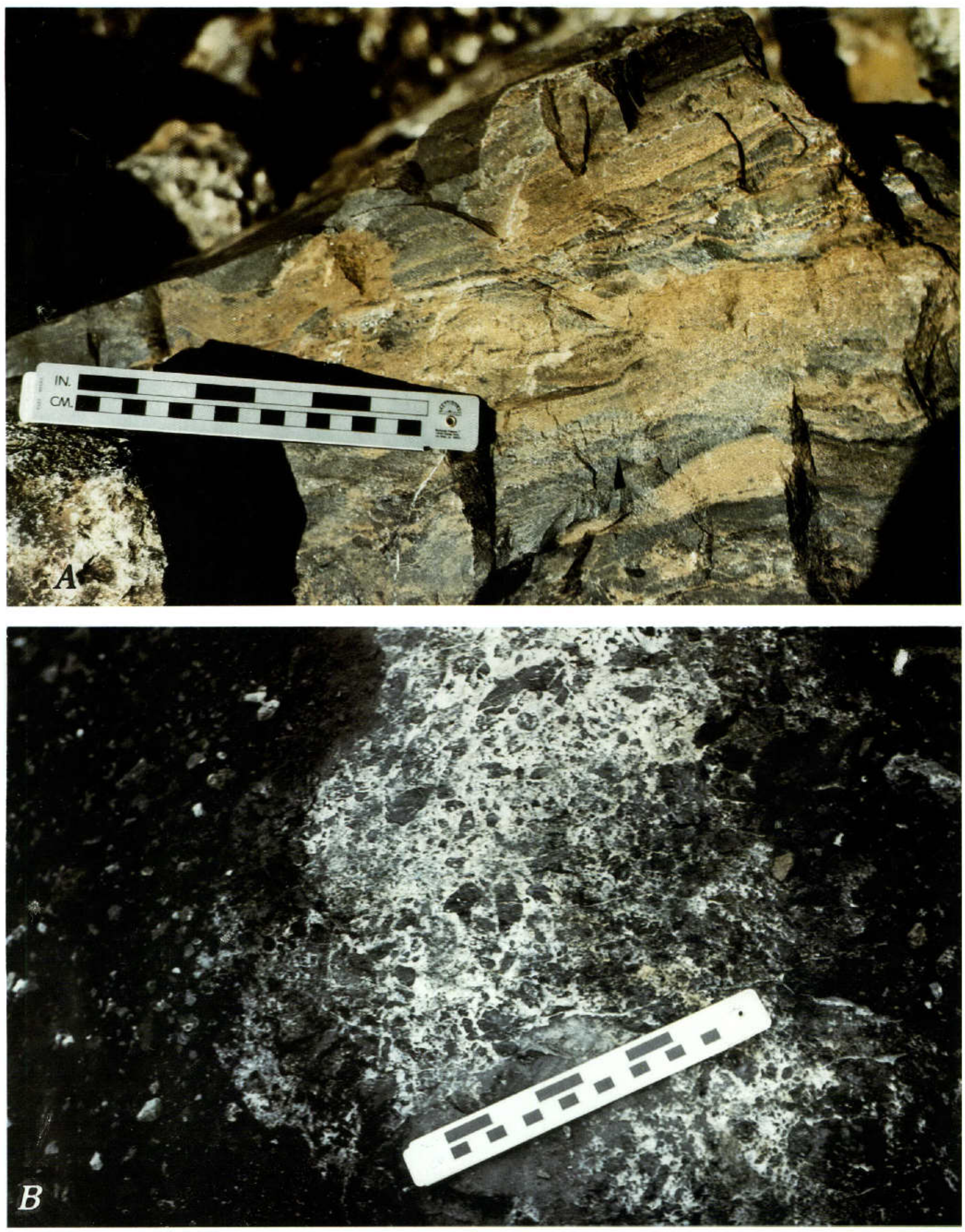

Figure 34. Iron ore at the Smokey mine in the Capitan Mountains district. New Mexico, showing $A$, bedding concentrations of the iron ore and $B$, brecciated and replaced host rock. 
Tertiary monzonite porphyry in the Jicarilla district and by syenite at Lone Mountain in White Oaks district. The Tecolote district contains several small deposits where the Yeso and San Andres Formations have been intruded by syenite.

A uranium-bearing iron deposit occurs at the Prince mine on the north side of Lone Mountain (Walker and Osterwald, 1956). The uranium minerals coat fractures, fill pore spaces, and are dispersed as finely divided grains within the magnetite-hematite ore. Uranium content averages about 0.020 percent; uranium content of iron ore elsewhere in the area is typically one or two orders of magnitude less.

Of 168 world-wide skarn deposits that range in size from 30,000 to about 5 billion metric tons $(33,000$ to about 5.5 billion short tons) and have a grade of 15-70 percent iron, the median tonnage is 7.2 million metric tons $(7.9$ million short tons) and the median grade about 50 percent iron (fig. 35) (Mosier and Menzie, 1986). Iron skarns in the study area are significantly smaller than the world-wide median. When available grades and tonnages for iron skarns in the study area are plotted on the grade and tonnage model, the Capitan iron deposit is shown to be larger than about 37 percent of the deposits in the model and the grade for the Capi$\tan$ deposit is higher than only about 33 percent of the deposits in the model (fig. 35). The Elda mine, in the Tecolote district, for which only production figures (not estimated resources) were reported, ranks in the smallest 10 percent of deposits. The small size of skam deposits in the study area may be because the intrusions with which they are associated are relatively small and scattered. The Capitan iron deposit is an exception, having over 3 million short tons that contain 45.6 percent iron (Kelley, 1949, p. 178-179).

\section{COPPER}

Three copper deposits occur within the study area at the Estey, Pintada, and Stauber mines (pl. 13). All of these deposits are of the sediment-hosted copper (red-bed) type (Cox, 1986b), and occur in oxidized sandstone interbedded with green or gray (reduced) shale, siltstone, and sandstone. Like most red-bed deposits, those in the study area contain chalcocite and secondary copper carbonate-hydroxide minerals.

The Estey mine is located in the Oscura district, which is within the White Sands Missile Range and closed to the general public. The mine is located along the western border of Lincoln County at the southeastern edge of the Oscura Mountains. According to Lasky and Wootton (1933), the copper deposit occurs in red beds of the Lower Permian Abo Formation, which is structurally repeated by faulting. Copper mineralization occurs in three horizons, the most important being an arkosic bed at the base of the red-bed sequence. Mineralized layers range in thickness from $1 \mathrm{in}$. to $3 \mathrm{ft}$. The main copper mineral is malachite, which is found in layers, fractures, and joints. Chalcocite is commonly associated with carbonaceous matter in the arkose, having replaced calcite cement in the arkose and sandstone. The mineralized material contains a small amount of gold and silver; coal and other carbonaceous matter are noted in the gangue.

The Pintada mine is located about $15 \mathrm{mi}$ southwest of Santa Rosa in Pintada Canyon and has been described by Sandusky and Kaufman (1972). The copper deposit is in sandstone of the Upper Permian Queen and Grayburg Formations of the Artesia Group, which cannot be differentiated and are described as follows. The lower $60-75 \mathrm{ft}$ of the undifferentiated unit is gypsiferous. This is overlain by a lower sandstone unit about $9 \mathrm{ft}$ thick, which is copper mineralized and contains both primary and secondary gypsum. The mineralized unit is composed of five locally crossbedded sandstone bodies that are interbedded with siltstone, mudstone, and shale. This mineralized sandstone grades upward into an upper sandstone unit that is 150-170 ft thick, interbedded with siltstone, mudstone, and shale, and unconformably overlain by the Upper Triassic Santa Rosa Sandstone. The deposit is generally flat lying, dipping about $4^{\circ}$ north-northwest, and contains folds and minor wavy bedding and gravity faults. The mineralized sandstone contains chalcocite and minor pyrite, carbonaceous material, and kaolin; it is locally stained by limonite. In addition to chalcocite, the main copper mineral, minor copper carbonate minerals are present. Copper minerals are associated with the carbonaceous material.

The Stauber mine contains disseminated copper minerals in sandstone overlain by a clay bed as much as $\mathbf{4 0} \mathrm{ft}$ thick and underlain by an iron-stained clay bed about $25-30 \mathrm{ft}$ thick (Stauber, 1930). The ore is mostly malachite, azurite, and chalcocite, as well as minor chrysocolla, bornite, and black copper oxide minerals (tenorite). Rarely, replaced mineralized logs are present that contain as much as 40 percent copper (Stauber, 1930). The ore was found to contain no detectable vanadium (Holmquist, 1947). Host for the copper minerals is the Santa Rosa Sandstone, a medium-grained gray sandstone locally stained by iron and containing interstitial cement commonly composed of silica and calcite. The ore trend is parallel to the strike of the sandstone beds and occurs in small veinlets and fissures, and as interstitial cement as well as disseminated grains. The ore content typically increases toward the base of the sandstone beds, but high-grade concentrations are found throughout the unit.

Local structures may control mineralization at both the Pintada and Stauber mines. At the Stauber mine, mineralization is related to a shallow depression that may be either the result of soft-sediment deformation of underlying clay beds, karst topography caused by dissolution of underlying Permian evaporite and carbonate beds, or gentle folding seen elsewhere in Guadalupe County (McLemore and North, 1985, p. 291-292). Mineralization control at the Pintada mine is similar to that at the Stauber mine.

Low-grade copper also occurs in association with uranium in the Upper Triassic Chinle Formation near Logan in Quay County and in the San Jon area of Quay County. There, 

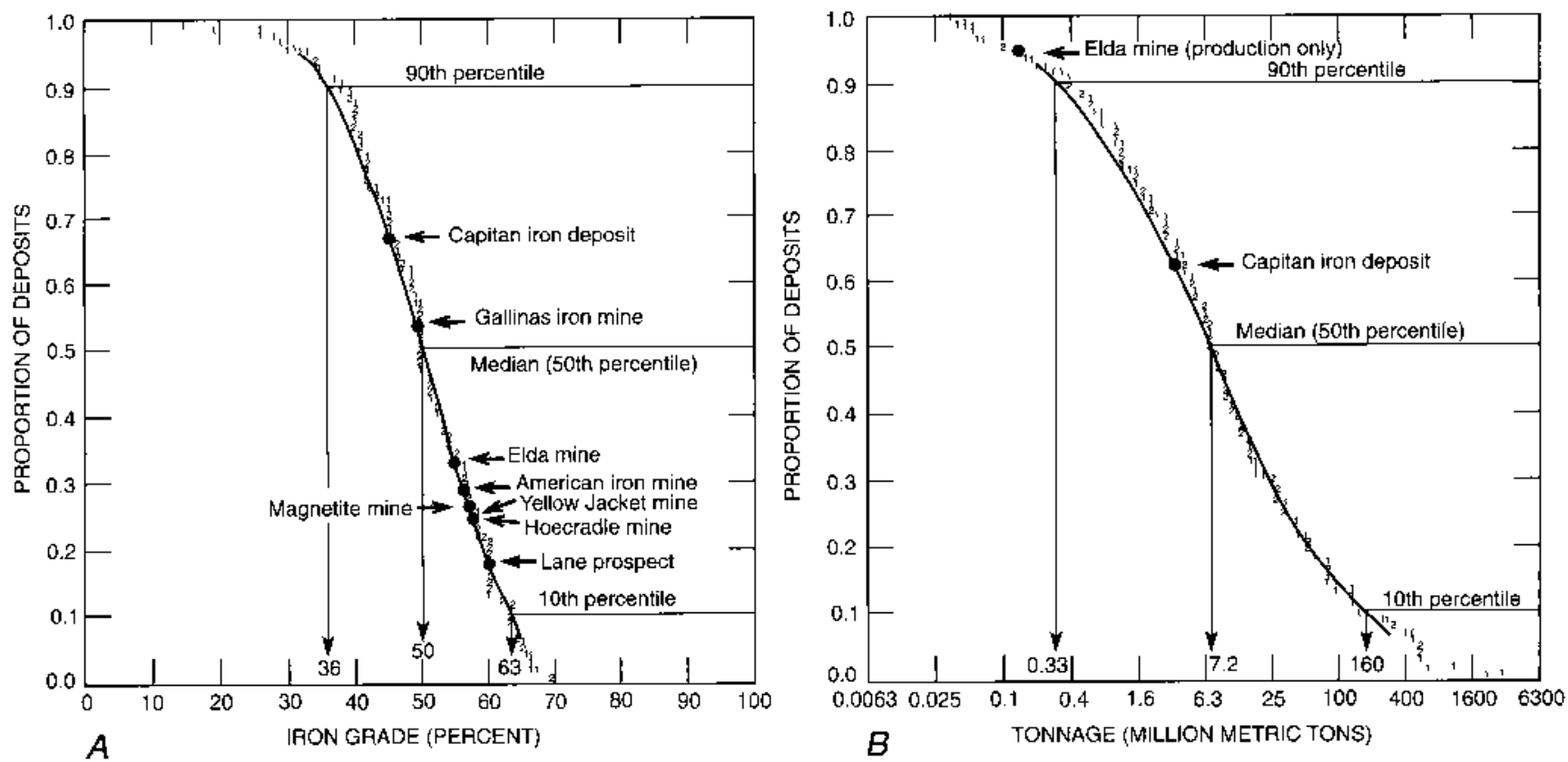

Figure 35. $A$, iron grade and $B$, tonnage of iron skarn deposits in the Roswell Resource Area, New Mexico, in comparison with grade and tonnage model for 168 world-wide iron skan deposits (modified from Mosier and Menzie, 1986). Plot intersected by percentiles represents world-wide iron skarn deposits. [1 metric ton=1.102 short tons.]

in a shale bed in the upper part of the Chinle, numerous nodules or concretions consist of cuprite, barite, malachite, fluorapatite, quartz, and minor chalcocite. Selected samples were reported to contain as much as 22.6 percent copper (McLemore and North, 1985, p. 296).

As shown on the grade and tonnage model of sedimenthosted copper deposits (Mosier and others, 1986) (fig. 36), this deposit type, of which the Stauber and Pintada mines are but two examples, ranges in size from about 150,000 metric tons ( 165,000 short tons) to about 1.6 billion metric tons ( 1.8 billion short tons), and the median is 22 million metric tons (24 million short tons). Grades range from about 0.67 percent to about 10 percent copper, with a median of 2.1 percent copper. Production of 239,821 metric tons $(264,357$ short tons) from the Stauber mine (McLemore and North, 1985) (Appendix), when plotted on the grade curve for world-wide sediment-hosted copper deposits (Cox, 1986), is small. The copper grade of 2.56 percent for the Stauber mine is higher than the grades of over 60 percent of the deposits. The reported production grade of 0.67 percent copper for the Pintada mine is at the very low end of the grade curve.

\section{PORPHYRY MOLYBDENUM DEPOSITS}

Porphyry molybdenum deposits are typically largetonnage, low-grade deposits that are closely associated with small- to medium-size bodies of alkaline to calc-alkaline intrusive rocks. Most deposits that have been mined contained tens of millions to hundreds of millions of short tons of ore, having grades of about $0.08-0.2$ percent molybdenum. The deposits are characterized by stockworks or veinlets that contain mostly quartz and molybdenite, and pyrite is commonly abundant. Copper, tungsten, or tin are byproducts in some deposits. Many of the deposits are hosted in the genetically associated intrusive, but many others are partly or entirely in the adjacent country rock, especially above subsurface plutons.

The most significant property of the country rock that makes it favorable for hosting molybdenum mineralization is brittleness--its ability to fracture so that a stockwork can form. Porphyry molybdenum deposits are believed to form when heat from a cooling and crystallizing body of magma causes circulation of large quantities of fluid that carry the dissolved components of the ore upward and outward to locations where the vein minerals are stable.

Porphyry molybdenum deposits of the low-fluorine type (Westra and Keith, 1981; Theodore, 1986) have been identified in the Three Rivers and Rialto stocks intruding the Sierra Blanca Igneous Complex in Lincoln County (pl. 13). Mineralized areas are in fine-grained, equigranular syenite, possibly near an earlier vent.

Molybdenite mineralization occurred in areas of silicic alteration in the northeastem part of the Three Rivers stock where it comes in contact with the Sierra Blanca Igneous Complex in both the nordmarkite intrusive and the andesite volcanic rocks. Molybdenum mineralization occurs in three forms: (1) molybdenite films along fractures and as finegrained disseminations in quartz veinlets, (2) molybdenite and abundant breccia zones, and (3) anomalous molybdenum in aphanitic high-silica rocks that contain no visible 

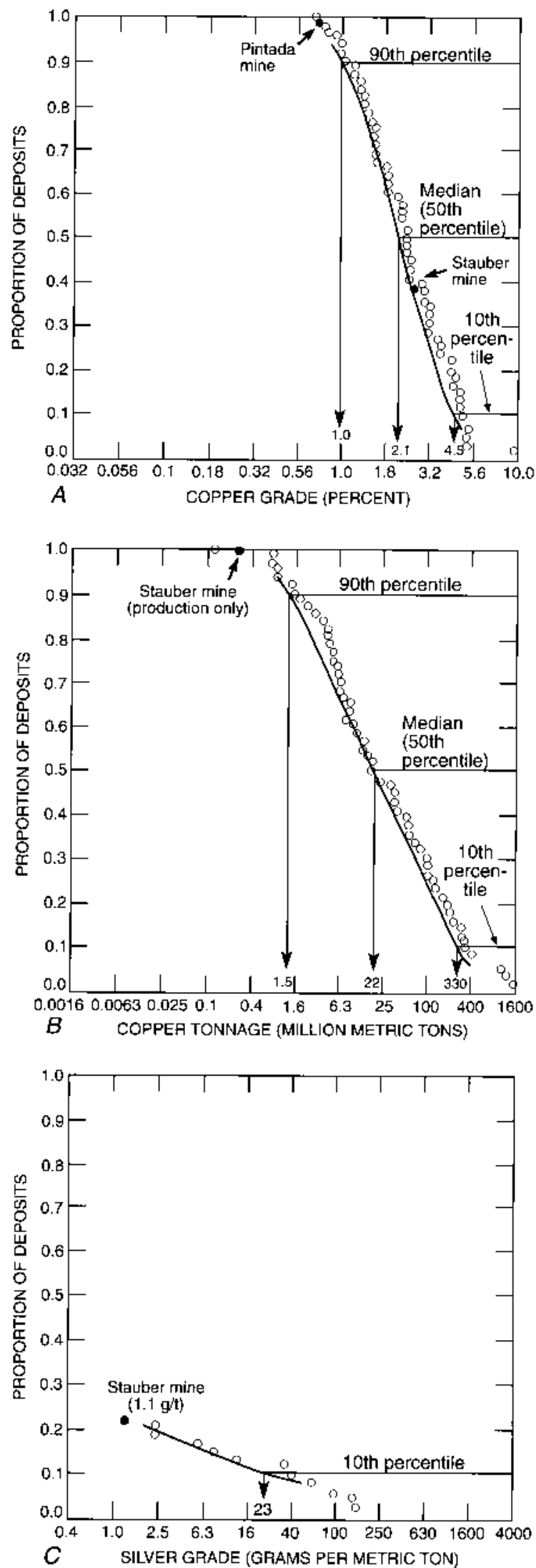

molybdenite veinlets or smears. The third type of mineralization is believed by Giles and Thompson (1972) to represent hydrothermal fluid that was little fractionatedevidence for sparse molybdenum values in the mineralized zone. That is, hydrothermal differentiation and enrichment had little time to concentrate metal and form a large, economic ore deposit. Hydrothermal alteration, including silicification, argillization, and sericitization, and secondary development of potassium feldspar, is most intense and prevalent on the northern and eastern periphery of the stock (Giles and Thompson, 1972). Sparse fluorite and 2-5 percent pyrite are found here also.

Geochemical sampling and analyses by Segerstrom and others (1979) have revealed four molybdenum anomalies associated with the Three Rivers stock. These anomalies form an area having a radius of about $2.0 \mathrm{mi}$, centered along the South Fork of Rio Bonito about $2.6 \mathrm{mi}$ north-northeast of Sierra Blanca Peak. The southwesternmost of these anomalies is located on a ridge underlain by equigranular syenite of the Three Rivers stock, and extends from about Sierra Blanca Peak to about $1.8 \mathrm{mi}$ north-northwest. Typical geochemical samples contained $100 \mathrm{ppm}$ molybdenum. One sample of float contained 1,500 ppm molybdenum; the molybdenum was found in limonite and in heavy-mineral concentrates derived from limonite. The northwestemmost anomaly is partially located in a breccia zone near the contact of nordmarkite and the Walker Andesite Breccia of the Sierra Blanca Igneous Complex at the head of Little Bear Canyon. A high value of $70 \mathrm{ppm}$ molybdenum was found in a sample from this area. The northeasternmost anomaly, between Waltsmith Canyon and Eagle Creek, had molybdenum values ranging as high as $150 \mathrm{ppm}$. The anomaly is located in equigranular syenite, nordmarkite, and Walker Andesite Breccia. The fourth anomaly, the southeasternmost anomaly on a ridge at the head of Eagle Creek, had a maximum geochemical value of $150 \mathrm{ppm}$ molybdenum. It was the object of an extensive drilling and geochemical exploration in the 1960's, but has yet to be exploited.

Four mineralized zones have been recognized in the Rialto stock and on the westem periphery of the Bonito Lake stock (fig. 37): I, an inner molybdenite zone; II, a magnetite zone that fringes the molybdenite zone to the west, north, and east; III, a copper-rich zone that truncates the southern parts of the molybdenite and magnetite zones; IV, an extensive lead-zinc zone on the eastern and southem periphery of the stock (Segerstrom and others, 1979). Pyrite is found in all four zones. Griswold and Missaghi (1964) reported

Figure 36 (facing column). A, copper grade, $B$, copper tonnage, and $C$, silver grade at the Pintada and Stauber mines, New Mexico, in comparison with grade and tonnage model for 57 world-wide sediment-hosted copper deposits (Mosier and others, 1986). Grade and tonnage are calculated from McLemore and North (1985). Plot intersected by percentiles represents world-wide sediment-hosted copper deposits. [ 1 metric ton=1.102 short tons.] 

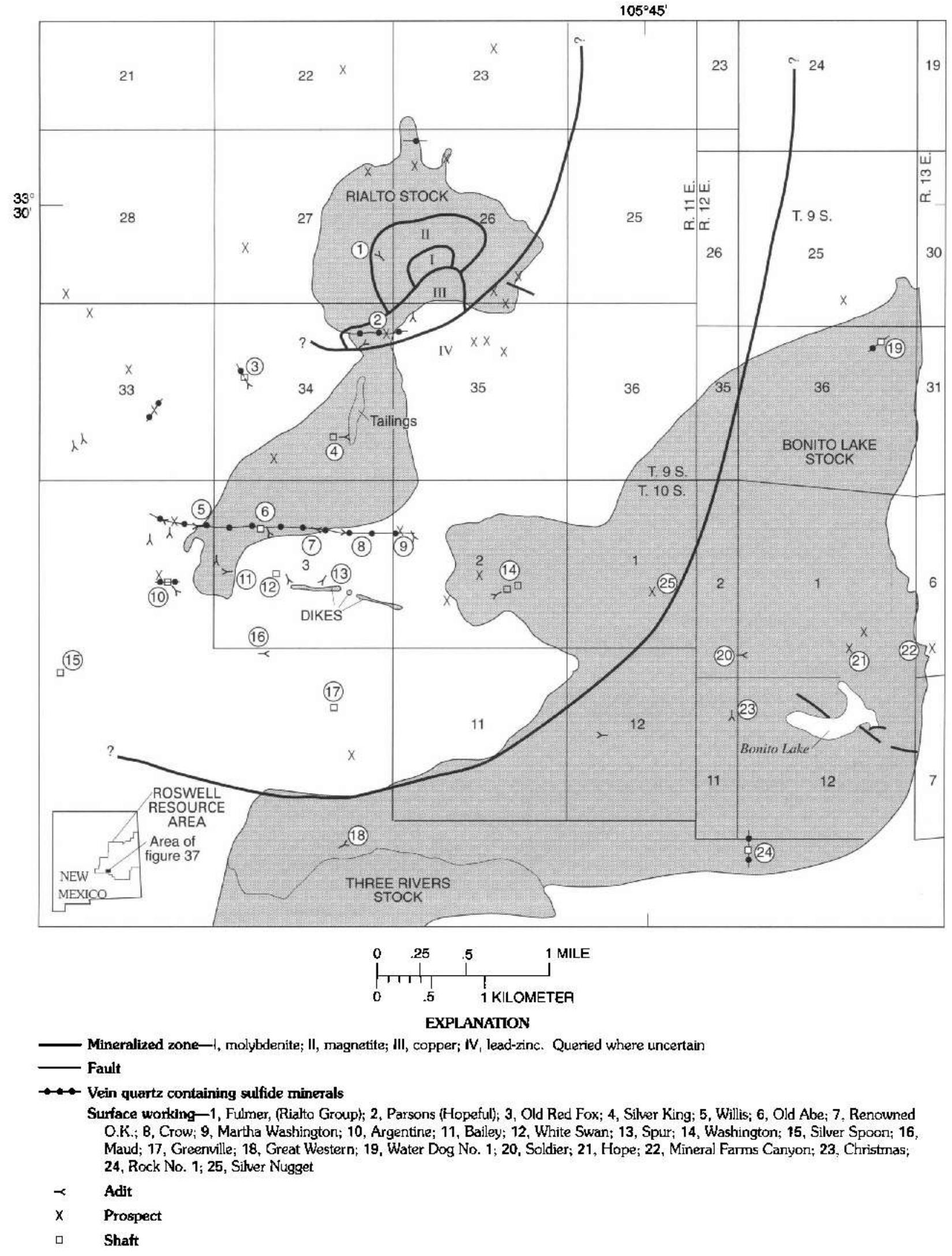

Figure 37. Mineralization zones of the low-fluorine porphyry molybdenum deposit at the Rialto, Three Rivers, and Bonito Lake stocks, New Mexico, and locations of surface workings in and near the deposit (from Thompson, 1973). 

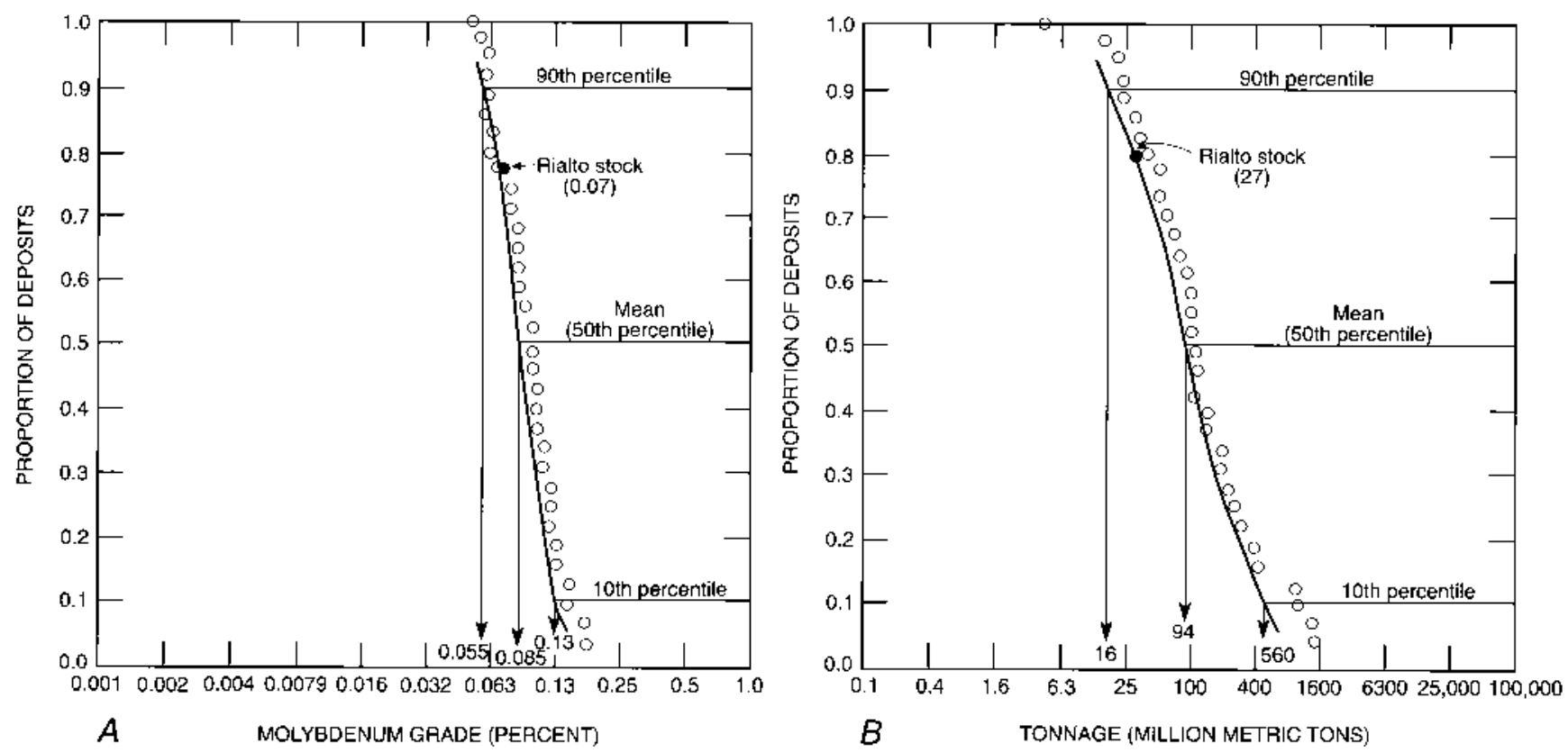

Figure 38. A, molybdenum grade and $B$, tonnage of the low-fluorine porphyry molybdenum deposit at the Rialto stock, New Mexico, in comparison with the grade and tonnage model for 33 world-wide low-fluorine porphyry molybdenum deposits (from Mosier and Theodore, 1986). Plot intersected by percentiles represents world-wide low-fluorine porphyry molybdenum deposits. [1 metric ton=1.102 short tons.]

molybdenite mineralization in areas of the Rialto stock where the monzonite was silicified, sericitized, kaolinitized, and pyritized. Several periods of hydrothermal alteration silicified, propylitized, and argillized the rocks.

Eight breccia pipes in the Rialto stock are located at the intersections of joint and fracture systems near contacts of biotite-monzonite and homblende-biotite-monzonite (Thompson, 1973). The Parsons mine exploited a highly altered, gold-bearing breccia pipe in the central part of the stock, and a nearby tunnel explored another. Many of the surface workings of this deposit are located on figure 37.

The porphyry molybdenum deposit in the Rialto stock is estimated to contain 27 million metric tons ( 30 million short tons) at a molybdenum grade of $0.05-0.18$ percent (Hollister, 1978). Thus, the deposit is smaller than the median-tonnage low-fluorine porphyry molybdenum deposit [94 million metric tons (104 million short tons); Menzie and Theodore, 1986], but may be higher in grade (fig. 38).

\section{BASE AND PRECIOUS METALS IN VEINS}

\section{POLYMETALLIC VEINS IN THE NOGAL DISTRICT}

The Nogal district contains numerous mines and prospects in polymetallic veins adjacent to the Rialto stock. The veins formed as fracture or fissure fillings within the Sierra Blanca Igneous Complex after emplacement of the Rialto stock. The Helen Rae and American mines, typical of the many mines and prospects described by Griswold (1959) and Thompson (1973) within the Nogal district, produced gold from the same carbonate-quartz vein. Gold was probably contained in sulfides such as pyrite, galena, and sphalerite, which were minor constituents of the vein. The highest grade ore occurred at the intersection of the main vein with smaller crosscutting veins. Two barite veins, the eastemmost of which contained a small amount of galena, are near the main vein. The Crow vein is host to the Renowned OK and Crow mines, located south of the center of the Rialto stock. This quartz vein contains galena, sphalerite, pyrite, and minor amounts of chalcopyrite in altered andesite. Griswold (1959) reported that the vein averaged $1 \mathrm{ft}$ in width and contained 11.3 percent lead.

The Maud mine, in the southern part of the Rialto stock, is located on a vein composed primarily of quartz, sphalerite, and galena, and lesser amounts of pyrite, chalcopyrite, and barite. Vein width in the lower workings ranged from 16 to 82 in. (Thompson, 1973). A composite sample (Thompson, 1973) from the face of the upper workings assayed at 7.10 percent lead, 0.39 percent molybdenum, $0.32 \mathrm{oz}$ of gold per short ton of ore, and $1.28 \mathrm{oz}$ of silver per short ton of ore.

\section{POLYMETALLIC VEINS IN THE GALLINAS DISTRICT}

The polymetallic veins and mineralized breccias in the Gallinas district cut unaltered sandstone and siltstone of the Yeso Formation close to two alkalic laccoliths of porphyritic trachyte and porphyritic leucorhyolite (Perhac and Heinrich, 1964). The deposits have been exploited for base-metal sulfides, fluorite, bastnaesite (source of rare-earth elements), silver, and gold. Typical hand specimens consist of a mass of 
fine-grained purple fluorite, barite, and bastnaesite in breccia; in addition, galena, chalcopyrite, sphalerite, chalcocite, malachite, azurite, and possibly wulfenite have been identified (Griswold, 1959). Calcite and quartz are major gangue constituents of the veins. Copper minerals and fluorite commonly occur together (Perhac, 1970).

Numerous small fluorite-bastnaesite-copper deposits also occur in the eastern Gallinas Mountains in the Red Cloud mine (Soule, 1946; Rothrock and others, 1946; Griswold, 1959; Perhac and Heinrich, 1964; Williams, 1966). Nearly all of the deposits fill open spaces in faults and breccia pipes at fault intersections in the Yeso Formation. The Red Cloud copper deposits contain fluorite, bastnaesite, agardite, barite, mimetite, conichalcite, wulfenite, vanadinite, mottramite, cerussite, and chrysocolla.

The Red Cloud and Old Hickory mines on both sides of Red Cloud canyon road were visited and sampled in 1990. At the Old Hickory mine, fine-grained massive purple fluorite in breccia containing calcite and quartz was observed; Griswold (1959) also reported dolomite and barite. Secondary copper minerals were common in some specimens. Massive purple fluorite having a higher percentage of base-metal minerals (especially fine-grained to massive galena) than at the Old Hickory mine was observed in breccia at the Red Cloud mine. Sixteen analyses of samples collected from the deposits by Armbrustmacher for this study range from less than 11 to $195 \mathrm{ppm}$ thorium and from 2.5 to $142 \mathrm{ppm}$ uranium.

The Conqueror No. 9 mine is located in a breccia zone composed of fragments of Yeso Formation (Griswold, 1959). The principal ore mineral was fluorite that occurs as breccia filling or matrix replacement. Fine-grained bastnaesite occurs in the ore. Soule (1946) reported that hand-picked bastnaesite grains, with some contamination, contained 74.39 percent total rare-earth oxides, including 25.61 percent cesium oxide and 48.78 percent lanthanum-didymium oxide.

About 4,000 short tons of copper ore and less than 2,000 short tons of fluorite, from which about 60 short tons of bastnaesite concentrate were extracted, were mined during 1920-1949 and 1942-1955, respectively (Perhac and Heinrich, 1964). Ore shipped during 1920-1922 contained 6 oz of silver per short ton of ore, 22.1 percent lead, 6.93 percent copper, and 1.93 percent zinc. The Gallinas district is estimated to contain about 46,000 short tons of fluorspar and 28,000 short tons of material containing 1.4 percent bastnaesite (Jackson and Christiansen, in press).

\section{GOLD AND SILVER IN TELLURIUM-BEARING VEINS}

The study area contains numerous examples of telluride-bearing veins containing gold and silver (Thompson, 1991) in the White Oaks, Gallinas, and Jicarilla districts. These veins commonly occur where alkaline igneous rocks have intruded through a disrupted Precambrian basement into younger sedimentary or volcanic rocks. Silica-undersaturated rock types, such as syenite, monzonite, and diorite, are some of the probable intrusive rocks that may host epithermal gold-silver-tellurium veins (Mutschler and others, 1985). The telluride veins may contain calaverite ( $\mathrm{AuTe}_{2}$ ), sylvanite ( $\mathrm{AuAgTe}_{4}$ ), hessite $\left(\mathrm{Ag}_{2} \mathrm{Te}\right.$ ), and coloradoite ( $\mathrm{HgTe}$ ), as well as fine-grained pyrite, galena, and sphalerite (Cox and Bagby, 1986). Accessory minerals are quartz, calcite, purple fluorite, barite, celestite, roscoelite, and adularia. Kelly and Goddard (1969) described in detail many of these minerals and their occurrence in the Boulder County, Colo., telluride belt.

The breccia deposit in the White Oaks district surrounds a 1- to 1.5-mi-diameter breccia pipe that is cut by a variety of dikes and plugs. Most rocks show evidence of at least four episodes of alteration, occurring in narrow, highgrade veins, sheeted fractures, and broad, low-grade zones of brecciation (Ronkos, 1991); gold mineralization (dated at 34 Ma on adularia) is associated with the youngest episode.

The Old Abe mine, the most important producer of precious metals in the White Oaks district, exploited a narrow vein and a wide breccia zone along the contact between a monzonite dike and Cretaceous sedimentary rocks. The breccia contains fragments of both rock types. Mineralization consisted of veins of limonite and manganese oxide and minor quartz and gypsum. Griswold (1959) reported that gold occurred as thin plates, wire, and tiny blebs in the veins. Other minerals include albite, wolframite, heubnerite, tourmaline, fluorite, and auriferous pyrite (Anderson, 1957). Telluride minerals were not reported in the literature; however, they may not have been recognized. Pyrite is present in veins at lower levels in the mine. Higher in the mine, limonite is an alteration product of pyrite and bears gold. Sericitic alteration and silicification were recognized. Other mines in the district, such as South Homestake, had similar mineralization. At the Old Abe mine, heubnerite was associated with the gold veins and was of such abundance that, once recognized, it was mined for byproduct tungsten (Griswold, 1959).

In the Nogal district, the Bonito property (formerly the site of the Great Western mine) is presently being explored for gold and silver associated with alkaline intrusive rocks. The old workings consist of several adits located in a westtrending arm of the Bonito Lake stock about $1.2 \mathrm{mi}$ southsoutheast of the Maud mine (Thompson, 1973). Pyrite and quartz were noted in the adits where low-grade ore had been removed. An epithermal breccia system consisting of several breccia zones has been identified at the site. The 143-ft-thick Main zone is estimated to contain 1.3 million short tons having $0.045 \mathrm{oz}$ of gold per short ton of ore and the 75 -ft-thick Blue Front zone is estimated at 2,305,000 short tons having $0.057 \mathrm{oz}$ of gold per short ton of ore (Dayton, 1988).

The Mudpuppy-Waterdog prospect lies about $3 \mathrm{mi}$ northeast of the Bonito property. Here, the stock is pervasively altered to propylitic, argillic, and phyllic zones that 
are concentric about the prospect area (Fulp and Woodward, 1991). The prospect lies in a zoned epithermal breccia system similar to others in the district containing gold, silver, tellurium, copper, and molybdenum, and may have the potential for a large-tonnage deposit. Geochemical analysis of rock samples has yielded values as high as $222 \mathrm{ppb}$ gold, 0.69 percent copper, and $3.2 \mathrm{ppm}$ tellurium (Fulp and Woodward, 1991). Molybdite occurs as fracture coatings, with values of as much as $0.28-0.90$ percent molybdenum.

Perhac (1970) described several fairly small (230-ftdiameter) breccia masses in the Gallinas district, composed of angular rock fragments in a trachyte matrix. The poorly exposed breccia is a potential site for mineralization because of the nearby fluorite-bastnaesite-copper mineralization in breccia zones and because of the gold mineralization in breccias in other districts.

The Vera Cruz mine, in the northern part of the Jicarilla district, occurs in a hypabyssal breccia pipe that intrudes sandstone and shale in the Upper Cretaceous Mesaverde Formation (Ryberg, 1991). The breccia pipe exploited by the mine is about $660 \mathrm{ft}$ long and $200 \mathrm{ft}$ wide at the surface and is believed to widen with increasing depth. The breccia consists of fragments of highly altered sandstone, shale, and intrusive rock that range to greater than $3 \mathrm{ft}$ in size. Argillization and sericitization of the breccia has been intense. Fine-grained gold occurs in the upper, oxidized part of the pipe. The central part of the breccia is highly silicified; Ryberg (1991) reported as much as $5.43 \mathrm{oz}$ of gold per short ton of material. The unsilicified part of the breccia yields $0.01 \mathrm{oz}$ of gold per short ton or less of material. Limonite and hematite are abundant and areas containing more abundant iron oxides contain more gold. Beneath the old workings at the Vera Cruz mine, drilling has located a sulfide zone at least $295 \mathrm{ft}$ thick having 1 percent copper, and $190 \mathrm{ft}$ of material grading 0.28 oz of gold per short ton of material (Danielson, 1991).

Dikes and sills of monzonite are abundant throughout the Jicarilla district. Mineralization occurs in fractures and in disseminations in the monzonite porphyry in the form of pyrite, quartz, arsenopyrite, and minor amounts of copper and gold. Hydrothermal alteration is minor and bleaching occurs only in mineralized parts of the monzonite (Griswold, 1959). Weathering of these rocks and constituent veins and disseminations results in formation of the area's placer deposits.

The grade and tonnage model of gold-silver-tellurium veins associated with alkaline rocks (Bliss and others, 1992) was developed for use in this study. The model includes grades and tonnages for 24 deposits consisting of goldbearing epithermal veins and breccias associated with alkaline intrusive and extrusive rocks. Two deposits are likely mesothermal veins. The breccia deposit in the White Oaks district is one of the deposits in the model. The tonnages of the deposits in the model range from 156,000 to 118 million metric tons $(172,000$ to 130 million short tons), and the median is about 4.9 million metric tons ( 5.4 million short tons) (fig. 39). The gold grades range from 0.23 to 46.7 grams per metric ton ( 0.007 to $1.36 \mathrm{oz}$ per short ton) of material, and the median grade is 4.5 grams per metric ton ( $0.13 \mathrm{oz}$ per short ton). Silver grades are reported for 15 of the 24 deposits in the model; they range from 0.75 to 84.0 grams per metric ton ( 0.02 to $2.44 \mathrm{oz}$ per short ton) of material, and the median grade is 1.1 grams per metric ton $(0.03$ oz per short ton).

Estimates show that the gold-silver-tellurium-bearing veins in the White Oaks district contain 1.5 million metric tons (1.7 million short tons) of material having a gold grade of 10.6 grams per metric ton ( $0.31 \mathrm{oz}$ per short ton). When these estimates are compared to those in the grade and tonnage model on figure 39 , the deposit is larger than about 31 percent of deposits of this type, and has a higher gold grade than about 75 percent of these deposits.

\section{THORIUM-RARE-EARTH-ELEMENT VEINS}

Thorium-rare-earth-element veins in the Capitan Mountains district are associated with an alaskite to monzonite intrusive stock or laccolith that may represent the most siliceous major intrusive in this part of Lincoln County (McLemore, 1981). The veins were discovered in the 1950's during an extensive exploratory program for radioactive deposits; radioactive anomalies had scintillometer readings of three to five times background. Fluid-inclusion microthermometry and stable isotope data presented by Phillips and others (1991) indicate that the fluids responsible for the formation of the mineralized zones were of magmatic origin and were derived from the Capitan Mountains intrusion during cooling and injected into the brecciated zones. Small and irregular-shaped thorium mineral accumulations occur within joints and as fracture fillings in intrusive rocks of the Capitan Mountains (Tuftin, 1984). Staatz (1974) reported the presence of 12 veins that are $10-150 \mathrm{ft}$ long and $0.02-8$ $\mathrm{ft}$ wide; 17 samples collected by him contained less than 0.01 to 1.12 percent thorium. The thorium-bearing vein minerals are thorite and allanite; gangue minerals include quartz, tourmaline, purple fluorite, and iron oxides (McLemore, 1983). Willis (1988) found allanite, sphene, quartz, plagioclase, chlorite, and clay minerals. The allanite also contains cerium, a light-rare-earth element. Fluid inclusions in sphene and quartz are very saline (the intrusive penetrates underlying Paleozoic evaporite deposits) and indicate a homogenization temperature of $480-580^{\circ} \mathrm{C}$ (Willis, 1988).

One of the prospects in the Capitan Mountains, the Barry prospect on the south slope, has a vertical, northwesttrending breccia vein about $1 \mathrm{ft}$ thick and possibly $330 \mathrm{ft}$ long (Griswold, 1959). Several assays indicating as much as 1.7 percent thorium were reported, but the average grade was probably less. Other prospects nearby, such as Drunzer and King, are similar to Barry, and may contain uranium along 

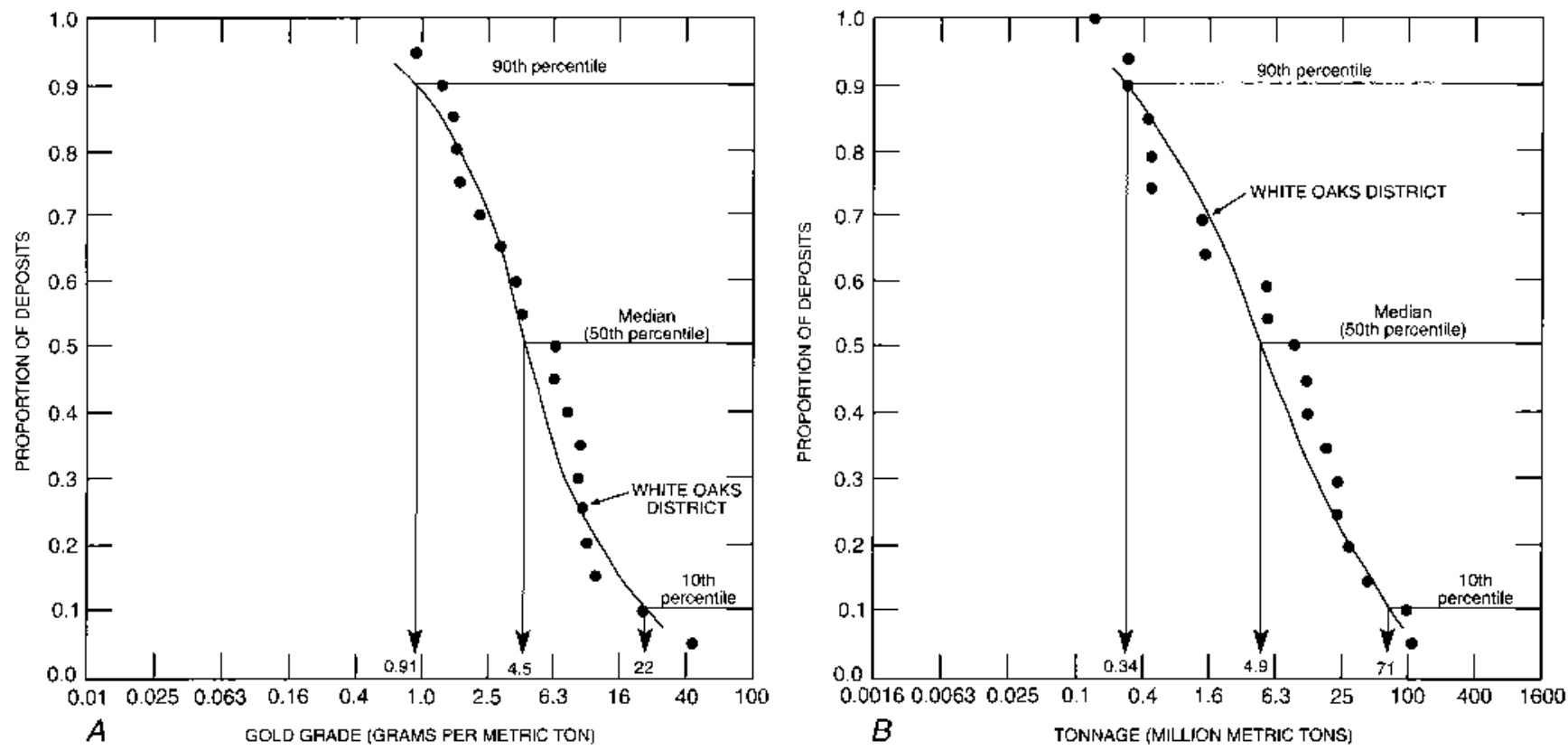

Figure 39. $A$, gold grade and $B$, tonnage of alkaline-hosted telluride-bearing veins in the White Oaks district, New Mexico, in comparison with the grade and tonnage model for 20 world-wide telluride-bearing veins (from Bliss, 1992). Plot intersected by percentiles represents world-wide telluride-bearing veins. [ 1 gram per metric ton $=0.029$ ounce per short ton; 1 metric ton $=1.102$ short tons.]

with thorium and rare-earth elements. Development of these veins in the Capitan Mountains has been limited to exploratory pits, shafts, and trenches (McLemore, 1981).

The grade and tonnage of only one deposit in the Capitan Mountains is known; it is estimated to contain 21,800 metric tons $(24,000$ short tons) of material having 0.56 percent thorium oxide $\left(\mathrm{ThO}_{2}\right)$. No rare-earth-element grade was reported for that deposit. In comparison, world-wide thorium-rare-earth-element veins (Bliss, 1992; Staatz, 1992) range in size from less than about 2,000 metric tons $(2,200$ short tons) to about $\mathbf{4 0}$ million metric tons (44 million short tons), and the median tonnage is about 180,000 metric tons (200,000 short tons) (fig. 40). Thorium oxide grades range from less than 0.1 percent to about 4 percent, and the median is 0.39 percent. Less than one-half of the world-wide deposits are reported to contain rare-earth oxides.

\section{MISSISSIPPI-VALLEY-TYPE DEPOSITS}

Mississippi-Valley-type (MVT) deposits, also referred to as southeast Missouri lead-zinc deposits, are stratabound, carbonate-hosted deposits of galena, sphalerite, chalcopyrite, pyrite, and marcasite. MVT deposits are characteristically located in ancient sedimentary reef facies on the flanks of paleotopographic highs (Briskey, 1986). No MVT deposits have been identified in the study area; however, MVT deposits may be discovered in the study area because the geologic setting of the Permian Basin may be favorable for their formation, and because MVT deposits are known nearby in the Hansonburg district in the northern Oscura Mountains in Socorro County. There, Upper Pennsylvanian limestone of the Burrego Formation, which hosts the Hansonburg deposits, extends into the study area.

The Hansonburg district formed by mineralization of a Pennsylvanian reef-facies limestone built onto a topographic high that was created by differential uplift along the Capitan Mountains lineament (Putnam and others, 1983). Lead, fluorite, and barite deposits occur along westward-facing fault scarps in cliff-forming limestone, shale, and sandstone. Premineralization karstification of bedrock created open spaces into which low-temperature, upward-flowing ore fluids migrated through faults from the adjacent basin. Ore minerals, such as galena, fluorite, barite, quartz, and minor sphalerite, pyrite, and chalcopyrite, were deposited by simple cooling of the liquid.

Sulfur isotope evidence suggests epigenetic ore formation for small lead-zinc-fluorite deposits south of the study area, which contain anomalous arsenic, barium, copper, iron, lead, molybdenum, and zinc; some of the deposits contain anomalous cadmium, gallium, antimony, silver, bismuth, scandium, uranium, vanadium, and tungsten (Hill, 1989). Hydrogen sulfide gas generated by reactions between petroleum and anhydrite deposits at the lower contact of the Castile Formation may lead to sulfuric acid generation and dissolution of evaporite beds and calcareous deposits (cave generation). The small deposits in the Guadalupe Mountains area occur in the same structural and stratigraphic position as many of the caves (for example, along the flanks and crests 

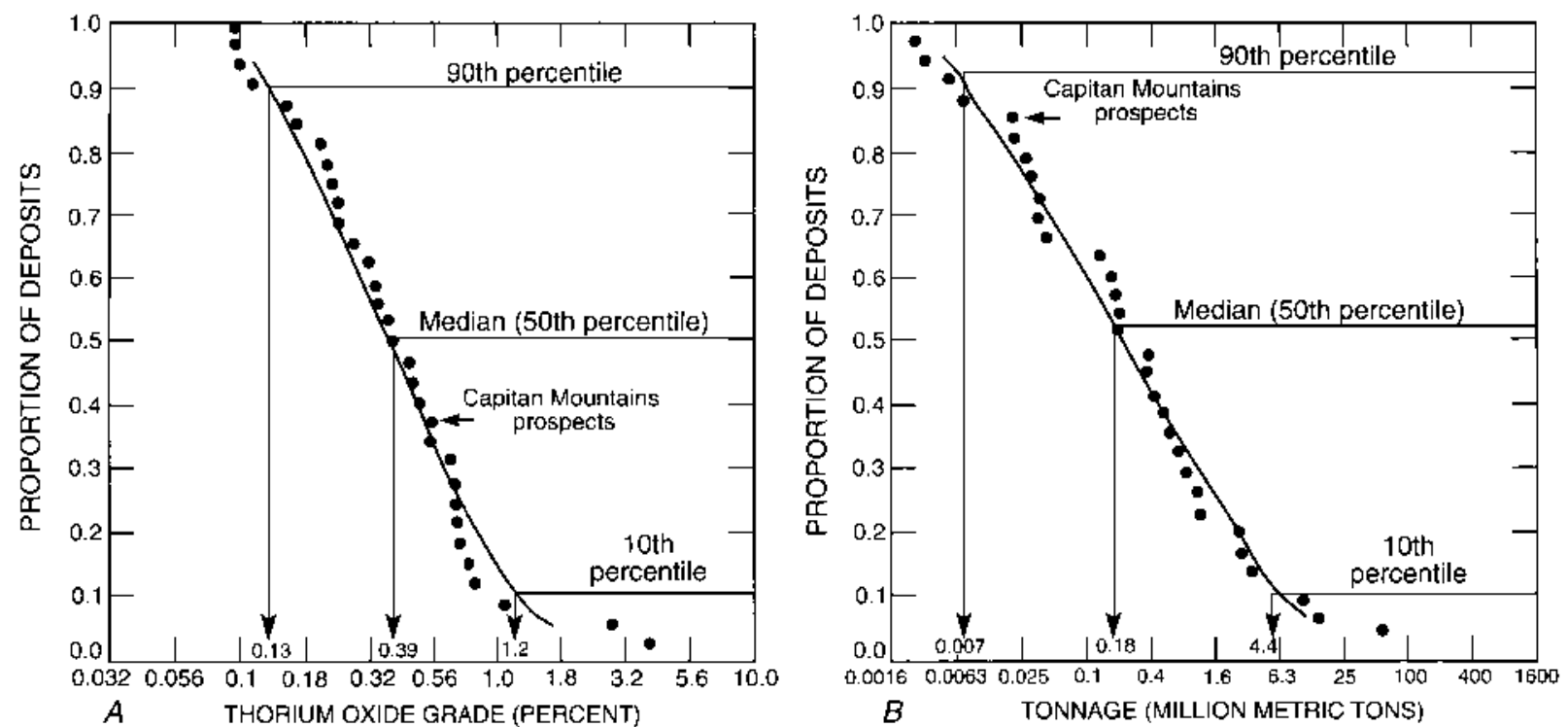

Figure 40. A, thorium oxide grade and $B$, tonnage of a thorium-rare-earth-element vein deposit in the Captain Mountains, $\mathrm{N}$. Mex., in comparison with the grade and tonnage model for 32 world-wide thorium-rare-earth-element vein deposits (from Bliss, 1992). Plot intersected by percentiles represents world-wide thorium-rare-earth-element vein deposits. [ 1 metric ton=1.102 short tons.]

of positive topographic features of the reef), and beneath impermeable siltstone layers in the Yates Formation. They may form veins and disseminated deposits in cements replacing the host rock, or occur in rocks having primary oolitic textures (Hill, 1989).

Mazzullo (1986) described MVT mineralization in the subsurface of the southem Central Basin Platform (southeast of study area; inset, pl. 3). Host dolomite represents shelf marginal facies that grade laterally and landward into inner shelf carbonate and evaporite, and seaward into basinal facies adjacent to a prominent basement fault. The minerals present include zoned sphalerite, accessory gypsum, and abundant pyrite. Mineralization probably took place in late Mesozoic to early Tertiary time; mineralizing fluids from older basinal rocks migrated along the basement fault. The basinal brine and host fluids (locally sulfur-bearing) were mixed, causing complex sulfide mineral deposition after dissolution of the host rock.

Undiscovered resources of MVT deposits outside of known metals districts in the study area include possible deposits in the carbonate rocks of eastem New Mexico (Heyl and others, 1975). The regional occurrence of similar cement sequences (Mazzullo, 1986) suggests regional migration of fluids through rocks of the Permian Basin; some of these fluids may have formed MVT deposits. Such deposits, if they exist, could represent a significant undiscovered resource in and near the study area. Median tonnage for MVT and Appalachian zinc deposits is $\mathbf{3 5}$ million metric tons ( 39 million short tons); the largest 10 percent contain greater than 540 million metric tons ( 600 million short tons) and the smallest 10 percent contain 2.2 million metric tons $(2.4$ million short tons) or less (Mosier and Briskey, 1986). Median grades are about 4.0 percent zinc, 0.87 percent lead, and 0.48 grams of silver per metric ton ( $0.014 \mathrm{oz}$ of silver per short ton) of material. A study of Canadian lead-zinc deposits (Sangster, 1986) found that 16 MVT deposits there had a median tonnage of about 3.5 million short tons; 95 percent were greater than about 103,000 short tons and 5 percent greater than almost 40 million short tons. The median amount of lead and zinc in the Canadian deposits was about 149,000 short tons.

\section{REFERENCES CITED}

Anderson, E.C., 1957, The metal resources of New Mexico and their economic features through 1954: New Mexico Bureau of Mines and Mineral Resources Bulletin 39, $183 \mathrm{p}$.

Bielack, James, and Williams, Michael, 1986, White Oaks gold district: Laramie, Wyo., University of Wyoming, Anaconda Collection, File No. 43413.01, 28 p.

Bliss, J.D., 1992, Grade and tonnage model of thorium-rare-earth veins, in Bliss, J.D., ed., Developments in mineral deposit modeling: U.S. Geological Survey Bulletin 2004, p. 16-18.

Bliss, J.D., and Cox, D.P., 1986, Grade and tonnage model of polymetallic veins, in Cox, D.P., and Singer, D.A., eds., Mineral deposit models: U.S. Geological Survey Bulletin 1693, p. $125-129$.

Bliss, J.D., Orris, G.J., and Menzie. W.D., 1987, Changes in grade, volume, and contained gold during the mining life-cycle of gold placer deposits: CIM (Canadian Mining and Metallurgical) Bulletin, v. 80, no. 903 , p. 75-80.

Bliss, J.D., Sutphin, D.M., Mosier, D.L., and Allen, M., 1992, Grade-tonnage and target-area models of All-Ag-Te veins 
associated with alkalic rocks: U.S. Geological Survey OpenFile Report 92-208, 15 p.

Brandvold, L.A., 1991, Cimarron mill, Carrizozo, New Mexico-A typical Superfund site?, in Barker, J.M., and others, eds., Geology of the Sierra Blanca, Sacramento, and Capitan Ranges, New Mexico: New Mexico Geological Society, 42nd Annual Field Conference Guidebook, p. 353-355.

Briskey, J.A., 1986, Descriptive model of southeast Missouri Pb-

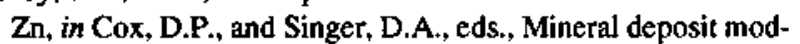
els: U.S. Geological Survey Bulletin 1693, p. 220-221.

Burleson, W.E., 1966, The Pintada Mine Bateman-Roberts partnership, San Ignacio (Pintada) mining district near Santa Rosa, New Mexico: U.S. Bureau of Mines unpublished report CEP 53, unpaginated. [On file at the New Mexico Bureau of Mines and Mineral Resources, Socorro, N. Mex.]

Clark, Sandra, and Orris, G.J., 1991, Vein barite, in Orris, G.J., and Bliss, J.D., eds., Some industrial mineral deposit models: U.S. Geological Survey Open-File Report 91-11-A, p. 19-20.

Cox, D.P., 1986a, Descriptive model of sediment-hosted $\mathrm{Cu}$, in Cox, D.P., and Singer, D.A., eds., Mineral deposit models: U.S. Geological Survey Bulletin 1693, p. 205.

$-1986 \mathrm{~b}$, Descriptive model of polymetaltic veins, in Cox, D.P., and Singer, D.A., eds., Mineral deposit models: U.S. Geological Survey Bulletin 1693, p. 125.

-1986c, Descriptive model of Fe skarn deposits, in Cox, D.P., and Singer, D.A., eds., Mineral deposit models: U.S. Geological Survey Bulletin 1693, p. 94.

Cox, D.P., and Bagby, W.C., 1986, Descriptive model of Au-AgTe veins, in Cox, D.P., and Singer, D.A., Mineral deposit models: U.S. Geological Survey Bulletin 1693, p. 124.

Cox, D.P., and Singer, D.A., eds., 1986, Mineral deposit models: U.S. Geological Survey Bulletin 1693, 379 p.

Danielson, V., 1991, Hot holes from New Mexico: The Northern Mines, v. 77, no. 10, p. 1.

Dayton, S.H., 1988, Exploration roundup_Projects: Engineering and Mining Journal, v. 189, no. 3, p. 119-131.

Finch, W.I., 1972a, Uranium in eastern New Mexico, in Kelley, V.C., and Trauger, F.D., eds., Guidebook of east-central New Mexico: New Mexico Geological Society, Twenty-third Field Conference, p. 171-175.

1972b, Uranium in eastern New Mexico: U.S. Geological Survey Open-File Report, 19 p.

Finlay, J.R., 1921-1922, Report of appraisal of mining properties of New Mexico: New Mexico State Tax Commission, $154 \mathrm{p}$.

Fulp, M.S., and Woodward, L.A., 1991, The Mudpuppy-Waterdog prospect--An alkalic copper-gold porphyry systern in the Nogal-Bonito mining district, Lincoln County, New Mexico, in Barker, J.M., and others, eds., Geology of the Sierra Blanca, Sacramento, and Capitan Ranges, New Mexico: New Mexico Geological Society, 42nd Annual Field Conference Guidebook, p. 327-328

Giles, D.L., and Thompson, T.B., 1972, Petrology and mineralization of a molybdenum-bearing alkalic stock, Sierta Blanca, New Mexico: Geological Society of America Bulletin, v. 83. no. 7, p. 2129-2148.

Griswold, G.B., 1959, Mineral deposits of Lincoln County, New Mexico: New Mexico Bureau of Mines Bulletin 67, 117 p.

Griswold, G.B., and Missaghi, Fazlollah, 1964, Geology and geochemical survey of a molybdenum deposit near Nogal
Peak, Lincoln County, New Mexico: New Mexico Bureau of Mines and Mineral Resources Circular 67,24 p.

Hatton, K.S., and Childs, M.B., compilers, 1990, Mines and mills in New Mexico: New Mexico Energy, Mineral and Natural Resources Department, in cooperation with New Mexico Bureau of Mines and Mineral Resources, $50 \mathrm{p}$.

Heyl, A.V., Bozion, C.N., and Maxwell, C.H., 1975, Silver resources of New Mexico [abs.], in Seager, W.R., Clemons, R.E., and Callender, J.F., eds., Guidebook of the Las Cruces Country: New Mexico Geological Society, Twenty-sixth Field Conference Guidebook, p. 340.

Hill, C.A., 1989, The evolution of the Delaware Basin-Preliminary results, in Harris, P.M., and Grover, G.A., eds., Subsurface and outcrop examination of the Capitan Shelf margin, northem Delaware Basin: Society of Economic Paleontologists and Mineralogists Core Workshop No. 13, San Antonio, Texas, p. 467-473.

Hollister, V.F., 1978, Porphyry molybdenum deposits, in Sutulov, Alexander, ed., Intemational molybdenum encyclopaedia 1778-1978, v. I, Resources and production: Santiago, Chile, Alexander Sutulov, Intermet Publications, p. 270-288.

Holmquist, R.J., 1947, Stauber copper mine, Guadalupe County, New Mexico: U.S. Bureau of Mines Report of Investigations 4026, 7 p.

Jackson, W.D., and Christiansen, Grey, in press, International Strategic Minerals Inventory Summary report-Rare-earth elements: U.S. Geological Survey Circular 930-N.

Johnson, M.G., 1972, Placer gold deposits of New Mexico: U.S. Geological Survey Bulletin 1348, 46 p.

Jones, F.A., 1904, New Mexico mines and minerals (World's Fair Edition): Santa Fe, N. Mex., New Mexico Printing Co., 349 p.

Kelley, V.C., 1945, Tertiary iron ore in Triassic collapse breccia [abs.]: Geological Society of America Bulletin, v. 56, p. 1171-1173.

1949, Geology and economics of New Mexico iron-ore deposits: University of New Mexico Publications in Geology No. 2, $246 \mathrm{p}$.

Kelley, V.C., and Goddard, E.M., 1969, Telluride ores of Boulder County, Colorado: Gcological Society of America Memoir $109,237 \mathrm{p}$.

Lasky, S.G., and Wootton, T.P., 1933, The metal resources of New Mexico and their economic features: New Mexico Bureau of Mines and Mineral Resources Bulletin 7, $178 \mathrm{p}$.

Lindgren, Waldemar, Graton, L.C., and Bordon, C.H., 1910, The ore deposits of New Mexico: U.S. Geological Survey Professional Paper 68, 361 p.

Longe, R.V., and others, 1978, Computer-based files on mineral deposits-Guidelines and recommended standards for data content [prepared by the Mineral Deposits Working Committee, National Advisory Committee on Research in the Geological Sciences]: Canada Geological Survey Paper 78-26, 72 p.

Mazzullo, S.J., 1986, Mississippi Valley-type sulfides in Lower Permian dolomites, Delaware Basin, Texas-Implications for basin evolution: American Association of Petroleum Geologists Bulletin, v. 70, p. 943-952.

McLemore, V.T., 1981, Radioactive occurrences in veins and igneous and metamorphic rocks of New Mexico, with annotated bibliography: New Mexico Bureau of Mines and Mineral Resources Open-file report OF-155, 267 p. 
1983, Uranium and thorium occurrences in New MexicoDistribution, geology, production, and resources, with selected bibliography: New Mexico Bureau of Mines and Mineral Resources Open-file report OF-183, $180 \mathrm{p}$.

1991, Gallinas Mountains mining district, New Mexico, in Barker, J.M., and others, eds., Geology of the Sierra Blanca, Sacramento, and Capitan Ranges, New Mexico: New Mexico Geological Society, 42nd Annual Field Conference Guidebook, p. 62-63.

McLemore, V.T., and North, R.M., 1985, Copper and uranium mineralization in east-central New Mexico, in Lucas, S.G., ed., Santa Rosa-Tucumcari region: New Mexico Geological Society, 36th Field Conference Guidebook, p. 289-299.

Menzie, W.D., and Theodore, T.G., 1986, Grade and tonnage model of porphyry Mo, low-F, in Cox, D.P., and Singer. D.A., eds., Mineral deposit models: U.S. Geological Survey Bulletin 1693, p. 120-122.

Mosier, D.L., 1986, Descriptive model of replacement Mn, in Cox, D.P., and Singer, D.A., eds., Mineral deposit models: U.S. Geological Survey Bulletin 1693, p. 105.

Mosier, D.L., and Briskey, J.A., 1986, Grade and tonnage model of southeast Missouri $\mathrm{Pb}-\mathrm{Zn}$ and Appalachian $\mathrm{Zn}$ deposits, in Cox, D.P., and Singer, D.A., eds., Mineral deposit models: U.S. Geological Survey Bulletin 1693, p. 224-226.

Mosier, D.L., and Menzie, W.D., 1986, Grade and tonnage model for Fe skarn deposits, in Cox, D.P., and Singer, D.A., eds., Mineral deposit models: U.S. Geological Survey Bulletin 1693, p. 94-97.

Mosier, D.L., Singer, D.A., and Cox, D.P., 1986, Grade and tonnage model of sediment-hosted Cu, in Cox, D.P., and Singer, D.A., eds., Mineral deposit models: U.S. Geological Survey Bulletin 1693, p. 206-208.

Mutschler, F.E., Griffin, M.E., Stevens, S.D., and Shannon, S.S., Jr., 1985, Precious-metal deposits related to alkaline rocks in the North American cordillera-An interpretive review: Transactions of the Geological Society of South Africa, v. 88, no. 2, p. 355-377.

North, R.M., and McLemore, V.T., 1986, An overview of silver and gold in New Mexico: Arizona Geological Society Digest, v. 16, p. $481-488$.

1988, A classification of the precious-metal deposits of New Mexico, in Schafer, R.W., Cooper, J.J., and Vikre, P.G., eds., Bulk minable precious-metal deposits of the western United States-Symposium proceedings: Reno, Nev., Geological Society of Nevada, p. 625-659.

Northrup, S.A., 1959, Minerals of New Mexico (revised edition): Albuquerque, N. Mex., University of New Mexico Press, 665 p.

Oris, G.J., and Bliss, J.D., 1986, Grade and tonnage model of placer Au-PGE, in Cox, D.P., and Singer, D.A., eds., Mineral deposit models: U.S. Geological Survey Bulletin 1693, p. 261-264.

Perhac, R.M., 1970, Geology and mineral deposits of the Gallinas Mountains, Lincoln and Torrance Counties, New Mexico: New Mexico Bureau of Mines and Mineral Resources Bulletin 95,51 p.

Perhac, R.M., and Heinrich, E.W., 1964, Fluorite-bastnaesite deposits of the Gallinas Mountains, New Mexico, and bastnaesite paragenesis: Economic Geology, v. 59, no. 2, p. 226-239.
Phillips, R.S., Campbell, A.R., and McLemore, V.T., 1991, Th-UREE quartz/fluorite veins, Capitan pluton, New Mexico; Evidence for a magmatic/hydrothermal origin, in Barker, J.M., and others, eds., Geology of the Sierra Blanca, Sacramento, and Capitan Ranges, New Mexico: New Mexico Geological Society, 42nd Annual Field Conference Guidebook, p. 129-136.

Putnam, B.R., Norman, D.I., and Smith, R.W., 1983, Mississippi Valley-type lead-fluorite-barite deposits of the Hansonburg mining district, in Chapin, C.E., ed., Socorro region II: New Mexico Geological Society, 34th Field Conference Guidebook, p. 253-259.

Raup, O.B., 1991, Descriptive model of bedded gypsum; descriptive subtype-Marine evaporite gypsum, in Orris, G.J., and Bliss, J.D., eds., Some industrial mineral deposit models: U.S. Geological Survey Open-File Report 91-11-A, p. 34-35.

Read, C.B., Sample, R.D., and Shelton, J.S., 1944, Sandstone copper deposits in westem Guadalupe County, New Mexico: Unpublished report on file at the New Mexico Bureau of Mines and Mineral Resources, Socorro, N. Mex., 24 p.

Ronkos, C.J., 1991, Geology, alteration, and gold mineralization in the White Oaks district, Lincoln County, New Mexico: Geological Society of America Abstracts with Programs, v. 23, no. 4, p. 88 .

Rothrock, H.E., Johnson, C.H., and Hahn, A.D., 1946, Fluorsparresources of New Mexico: New Mexico Bureau of Mines and Mineral Resources Bulletin 21, 245 p.

Ryberg, G.E., 1991, Geology of the Vera Cruz breccia pipe, Lincoln County, New Mexico: Geological Society of America Abstracts with Programs, v. 23, no. 4, p. 89.

Sandusky, C.L., and Kaufman, W.H., 1972, Geology of the Pintada Mine, in Kelley, V.C., and Trauger, F.D., eds., Guidebook of east-central New Mexico: New Mexico Geological Society, Twenty-third Field Conference Guidebook, p. 176-177.

Sangster, D.F., 1986, Classification, distribution and grade-tonnage summaries of Canadian lead-zinc deposits: Geological Survey of Canada Economic Geology Report 37, 68 p.

Schrader, F.C., Stone. R.W., and Sanford, S., 1916, Useful minerals of the United States: U.S. Geological Survey Bulletin 624, $412 \mathrm{p}$.

Segerstrom, Kenneth, and Ryberg, G.E., 1974, Geology and placergold deposits of the Jicarilla Mountains, Lincoln County, New Mexico: U.S. Gcological Survey Bulletin 1308, 25 p.

Segerstrom, Kenneth, Stotelmeyer, R.B., and Williams, F.E., 1979, Mineral resources of the White Mountain Wildemess and adjacent areas, Lincoln County, New Mexico: U.S. Geological Survey Bulletin 1453, 135 p.

Sheridan, M.J., 1947, Lincoln County iron deposits, New Mexico: U.S. Bureau of Mines Report of Investigations 3988, 19 p.

Smith, C.T., 1991, Notes on the Smokey mine, Capitan iron deposits, Lincoln County, New Mexico, in Barker, J.M., and others, eds., Geology of the Sierra Blanca, Sacramento, and Capitan Ranges, New Mexico: New Mexico Geological Society, 42nd Annual Field Conference Guidebook, p. 42-44.

Smith, E.P., and Dominian, Leon, 1904, Notes on a trip to White Oaks, New Mexico: Engineering and Mining Journal, v. 77 , p. $799-800$. 
Soulé, J.H., 1946, Exploration of Gallinas fluorspar deposits, Lincoln County, New Mexico: U.S. Bureau of Mines Report of Investigations 3854,25 p.

1947, Capitan iron deposits, Lincoln County, New Mexico: U.S. Bureau of Mines Report of Investigations 4022, 8 p. 1949. Investigations of Capitan iron deposits, Lincoln County, New Mexico: U.S. Bureau of Mines Report of Investigations $4514,5 \mathrm{p}$.

- 1956, Reconnaissance of the "red bed" copper deposits in southeastem Colorado and New Mexico: U.S. Bureau of Mines Information Circular 7740, 74 p.

Staatz, M.H., 1974, Thorium veins in the United States: Economic Geology, v. 69, p. 494-507.

1992, Descriptive model of thorium-rare-earth veins, in Bliss, J.D., ed., Developments in mineral deposit modelling: U.S. Geological Survey Bulletin 2004, p. 13-15.

Stauber, I.J., 1930, A sandstone copper deposit: The Mining Congress Journal (December, 1930), p. 928-932.

Theodore, T.G., 1986, Descriptive model of porphyry Mo, low-F, in Cox. D.P., and Singer, D.A., eds., Mineral deposit models: U.S. Geological Survey Bulletin 1693, p. 120.

Thompson, T.B., 1973, Mineral deposits of Nogal and Bonito mining districts, New Mexico: New Mexico Bureav of Mines and Mineral Resources Circular 123, 24 p.

1991, Genesis of gold assoxiated with alkaline igneous rocks: Geological Society of America Abstracts with Programs, v. 23, no. 4, p. 99-100.

Tuftin, S.E., 1984, Mineral investigation of the Capitan Mountains Wildemess Area, Lincoin County, New Mexico: U.S. Bureav of Mines Open-file report MLA 20-84, $20 \mathrm{p}$.

Turner-Peterson, C.E., and Hodges, C.A., 1986, Descriptive model of sandstone U, in Cox, D.P., and Singer, D.A., eds., Mineral deposit models: U.S. Geological Survey Bulletin 1693, p. 209-210.

U.S. Bureau of Mines, 1991, Mineral commodity summaries, 1991: Washington, D.C., Government Printing Office, 196 p.

U.S. Geological Survey, 1965, Mineral and water resources of New Mexico: Washington, D.C., U.S. Government Printing Office, Report to the Committee on Interior and Insular Affairs, U.S. Senate, $437 \mathrm{p}$.

Walker, G.W., and Osterwald, F.W., 1956, Uraniferous magnetiteilmenite deposit at the Prince mine, Lincoln County. New Mexico: Economic Geology, v. 51, p. 213-222.

Westra, Gerhard, and Keith, S.B., 1981, Classification and genesis of stockwork molybdenum deposits: Economic Geology, v. 76, no. 4, p. 844-873.

Williams, F.E., 1966, Fluorspar deposits in New Mexico: U.S. Bureau of Mines Information Circular $8307,143 \mathrm{p}$.

Willis, M., 1988, Investigation of a rare-earth element occurrence: New Mexico Geology, v. 10, no. 3, p. 68.

Woodward, L.A., 1991, Tectono-metallogenic maps of mining districts in the Lincoln County Porphyry Belt, New Mexico, in Barker, J.M., and others, eds., Geology of the Sierra Blanca, Sacramento, and Capitan Ranges, New Mexico: New Mexico Geological Society, 42nd Annual Field Conference Guidebook, p. 283-290.

Yeend, W.E., 1986, Descriptive model of placer Au-PGE, in Cox, D.P., and Singer, D.A., eds., Mineral deposit models: U.S. Geological Survey Bulletin 1693, p. 261.

\section{ESTIMATE OF UNDISCOVERED MINERAL RESOURCES USING THE MARK-3 SIMULATOR COMPUTER PROGRAM}

\author{
By David M. Sutphin
}

In the "Metal resources" section of this report, grades and tonnages of known metallic mineral deposits and occurrences in the Roswell Resource Area were described. In this section, estimates of the number of undiscovered deposits are made for each of the 12 deposit types that have grade and tonnage models (including marine bedded gypsum, but excluding sandstone uranium) and that are known to occur or are expected to occur in the study area (table 8). When combined with estimates of the number of undiscovered deposits in an area, statistical methods can be applied to grade and tonnage models to obtain estimates of the study area's undiscovered mineral resources. In this section, tonnages derived from grade and tonnage models are reported in the Metric System; U.S. Customary equivalents are given in parentheses.

The technique used here in estimating the undiscovered mineral resources is based upon the three-step assessment described by Singer and Ovenshine (1979). These steps are: 1, using known geological, geochemical, and geophysical characteristics to delineate tracts that may contain specific deposit types; 2 , estimating the probabilities that a certain number of undiscovered deposits exist in these tracts; and 3 , estimating the amount of a given commodity contained in the undiscovered deposits by means of comparison with the grades and tonnages of known deposits of a similar type. Steps 1 and 2 are conducted by a team of specialists; step 3 is a computer simulation. The assessment team that delineated the mineral resource tracts and estimated the probabilities of undiscovered deposits in the tracts consisted of specialists in economic geology, geochemistry, geophysics, and mineral resource assessment who had studied infomation on the study area and briefly visited and sampled locations in that area. T.J. Armbrustmacher, Susan BartschWinkler, G.N. Breit, J.S. Duval, J.A. Erdman, W.I. Finch, D.M. Kulik, J.K. Otton, C.S. Spirakis, D.M. Sutphin, and R.R. Tidball served on the team, but not every member of the team participated in the assessment of each tract. R.B. McCammon assisted the team with the quantitative mineral resource assessment of the tracts, and W.A. Scott executed the computer simulations.

Tracts favorable for the occurrence of undiscovered mineral resources in the study area were delineated from interpretation of the geology, geochemistry, and geophysics of the area (pl. 14). Geologic information was used initially to select areas (or tracts) of favorable rock types and to interpret the structure of the surface and subsurface. Geochemical data revealed areas of anomalous values for both metals in deposits, such as silver or copper, and pathfinder elements, such as barium. Maps showing the distribution of the 
geochemical data were used to reduce or expand the areas initially based on the geology, and to detect targets in areas that might have been overlooked initially. Geophysical maps were used to outline the distribution of rock types in the subsurface. Remote sensing and aerial radioactivity surveys enabled detection of additional anomalies on the surface. The geology, geochemistry, and geophysics of the study area were compared to the geologic environments and characteristics of deposit types until a consensus on the tract borders was agreed upon by the assessment team. A consensus on the types of deposits permissible in the tract and the number of those deposits at the $90 \mathrm{th}, 50 \mathrm{th}$, and 10 th percent probability levels was agreed upon after further discussion.

The computer program used to transform estimates of the number of undiscovered deposits into estimates of the mean number of undiscovered deposits and estimates of the contained commodities in those deposits is known in the U.S. Geological Survey as MARK-3, a computer program for mineral resource simulation (Drew and others, 1986; Root and Scott, 1988). The program requires estimates of the number of undiscovered deposits of a given type within an area. The number of deposits is stated in terms of likelihood of occurrence, resulting in a probability distribution. Computer simulations are performed by selecting simulated deposits from this probability distribution, and for each simulated deposit, selecting a grade and tonnage according to probability distributions of the grades and tonnages of known deposits of the given type. Grade and tonnage models used in this report, with a few exceptions, were taken from Cox and Singer (1986), Bliss (1992), and Orris and Bliss (1991) (table 8). The deposit model for gold-silvertellurium veins associated with alkaline rocks (Bliss and others, 1992) was developed for this study, and the models for epigenetic vein barite and marine bedded gypsum are preliminary.

The grade and tonnage of the simulated deposits are accumulated as part of the simulation process. Once the simulations are performed, the program generates the probability distribution of the contained commodities in the simulated deposits that correspond to the initial estimates of the number and types of deposits. These results are presented in an attempt to bridge the gap between a qualitative assessment of the study area's favorability for mineral deposit occurrences and a quantitative inventory of its mineral resources, and do not explicitly consider the economic processes of exploration, development, production, processing, and marketing necessary to transform a mineral resource into a material product.

\section{MINERAL DEPOSIT TRACTS}

Six mineral resource tracts (I-VI, pl. 14) were identified in which undiscovered mineral deposits can be expected in the Roswell Resource Area. Tracts I-IV were identified as possibly containing deposit types suitable for evaluation in
Table 9. Estimated number of undiscovered deposits for each of the 12 deposit types in tracts I-IV of the Roswell Resource Area, New Mexico

\begin{tabular}{|c|c|c|c|c|}
\hline \multirow[t]{2}{*}{ Deposit type } & \multirow[t]{2}{*}{$\begin{array}{l}\text { Commodity } \\
\text { modeled }\end{array}$} & \multicolumn{3}{|c|}{$\begin{array}{l}\text { Number of deposits } \\
\text { by probability } \\
\text { percentile }\end{array}$} \\
\hline & & 90th & 50 th & 10 th \\
\hline \multicolumn{5}{|l|}{ Tract I: } \\
\hline Thorium-rare-earth veins & $\begin{array}{l}\text { Thoria, rare- } \\
\text { earth oxides. }\end{array}$ & 0 & 1 & 1 \\
\hline Iron skarn & $\mathrm{Fe}$ & 2 & 4 & 5 \\
\hline Replacement manganese & $\begin{array}{l}\text { Mn, Cu, Fe. } \\
\text { phosphate. }\end{array}$ & 0 & 1 & 1 \\
\hline $\begin{array}{l}\text { Porphyry molybdenum, } \\
\text { low-fluorine. }\end{array}$ & Mo & 0 & 1 & 2 \\
\hline $\begin{array}{l}\text { Gold-silver-tellurium veins } \\
\text { associated with alkaline } \\
\text { rocks. }\end{array}$ & $\mathrm{Au}$ & 2 & 4 & 8 \\
\hline Polymetallic veins & $\begin{array}{l}\mathrm{Au}, \mathrm{Ag}, \mathrm{Cu} \\
\mathrm{Pb}, \mathrm{Zn} .\end{array}$ & 1 & 2 & 4 \\
\hline Fluorite-bastnaesite veins & Fluorspar & 0 & 0 & 1 \\
\hline Epigenetic barite veins & Barite & 1 & 1 & 2 \\
\hline $\begin{array}{l}\text { Gold-platinum-group- } \\
\text { element placer. }\end{array}$ & $\mathrm{Au}, \mathrm{Ag}$ & 1 & 2 & 4 \\
\hline \multicolumn{5}{|l|}{ Tract II: } \\
\hline Sediment-hosted copper & $\mathrm{Cu}, \mathrm{Ag}, \mathrm{Co}$ & 0 & 1 & 2 \\
\hline $\begin{array}{l}\text { Southeast Missouri lead- } \\
\text { zinc and Appalachian zinc. }\end{array}$ & $\mathrm{Ag}, \mathrm{Pb}, \mathrm{Zn}$ & 0 & 0 & 1 \\
\hline \multicolumn{5}{|l|}{ Tract III: } \\
\hline Sediment-hosted copper & $\mathrm{Cu}, \mathrm{Ag}, \mathrm{Co}$ & 0 & 0 & 1 \\
\hline $\begin{array}{l}\text { Tract IV: } \\
\text { Marine bedded gypsum }\end{array}$ & Gypsum & 2 & 3 & 4 \\
\hline
\end{tabular}

the MARK-3 program. For tracts I-IV, estimates of one or more undiscovered deposits were made at three different levels of probability - the 90th, the 50th (median), and the 10th percentile confidence levels. Table 9 lists the types of undiscovered deposits possible in tracts I-IV and the numbers of undiscovered deposits estimated at each level of confidence for those deposit types. Tracts V and VI were identified as permissible for undiscovered uranium and vanadium resources and were evaluated using a different method in the "Uranium and vanadium" section of this report by W.I Finch, G.N. Breit, and others.

\section{TRACT I}

Tract I represents the composite geophysical gravity and geomagnetic outline of the subsurface boundary of the Lincoln County porphyry belt (pl. 14). Tract I extends southward from the village of Corona and the Gallinas Mountains in the northern part of western Lincoln County to the villages of Hondo and Ruidoso and Sierra Blanca Peak. The western edge of tract I parallels the Phillips Hills in far western Lincoln County, whereas the eastern edge includes the eastern end of the Capitan Mountains. Tract I has an approximate area of 3,000 $\mathrm{mi}^{2}$ and includes the Capitan Mountains, Gallinas, Jicarilla, Nogal, Tecolote, and White Oaks mining districts, which have been the most significant past producers of metals and have the largest identified metal resources 
in the study area. Included also in tract I are broad areas north and south of the Capitan Mountains where geophysical evidence suggests that several shallow intrusions have yet to be exposed.

Tract I was selected as having rock types and geology with the potential for the occurrence of iron skams, thoriumrare-earth-element veins, gold-silver-tellurium veins associated with alkaline rocks, polymetallic veins, fluoritebastnaesite veins, gold-platinum-group-element placers, low-fluorine porphyry molybdenum deposits, epigenetic barite veins, and replacement manganese deposits.

The criteria used to determine that undiscovered iron skarns were possible in tract I were (1) recognition that a large percentage of the exposed intrusions in the Lincoln County porphyry belt, such as those in the Gallinas, Jicarilla, and White Oaks districts, contained iron skarns (surface tract Ia, pl. 14) and (2) presence of limestone host rocks in areas where shallow unexposed intrusions were detected by geophysics (subsurface tract Ib, pl. 14). Probability estimates of the number of undiscovered iron skam deposits to a depth of $0.6 \mathrm{mi}$ in tract $\mathrm{I}$ are: two or more at 90 percent probability, four or more at 50 percent probability, and five or more at 10 percent probability (table 9 ).

Tract I is considered to have potential for undiscovered thorium-rare-earth-element veins because of the identified occurrences of these veins in the Capitan Mountains, thorium geochemical anomalies in stream-sediment samples, and the presence of faults and fractures where mineralization could have occurred. A 50 percent probability is estimated that one or more thorium-rare-earth-element veins occur in tract I (table 9).

The exposed intrusions in tract I, such as those near the White Oaks district, have been well explored for gold deposits. The unexposed intrusions, however, are thought to have received little attention by modem exploration methods and are deemed permissible for alkaline-associated gold-silvertellurium deposits. It was assumed that many of the unexposed intrusions of the Lincoln County porphyry belt were of alkaline compositions like those exposed. A 90 percent probability is estimated for the occurrence of two or more alkaline-associated gold-silver-tellurium deposits in tract I (table 9). There is a 50 percent probability for four or more undiscovered deposits and a 10 percent probability for eight or more undiscovered deposits of this type in the upper half mile of tract I (table 9).

Insufficient information was available when the assessment team met to estimate the probability of occurrence of gold-platinum-group placers in the study area. Estimates are offered here after further study. Several factors were considered when estimating the number of undiscovered gold placers in tract $I$. The long mining history of placer deposits within the tract and the estimate of a large resource of placer gold in the Jicarilla district are evidence that the tract has been well explored for placer gold and that most deposits may have been discovered. (As mentioned earlier, no platinum-group minerals have been confirmed for the area and platinum-group minerals were not assessed.) Gold mineralization of the alkaline-associated gold-silver-tellurium deposit type is very fine grained and occurs in foils and other shapes that do not lend themselves easily for placer enrichment at an appreciable distance from the source. There is a 90 percent probability that tract I contains one or more undiscovered gold-platinum-group-element placer deposits, a 50 percent probability that the tract contains two or more such deposits, and a 10 percent probability that the tract contains four or more such deposits (table 9). No estimate was made of placer gold deposits between tract I and the Pecos River in the center of the study area, which may have less than 10 percent probability for undiscovered placer gold deposits.

The estimate of undiscovered low-fluorine porphyry molybdenum deposits in tract $I$ is based upon reported molybdenum anomalies (Segerstrom and others, 1979), geochemical anomalies in stream-sediment samples, the presence of possible volcanic host rocks in the southem part of Lincoln County, unexposed intrusives in the tract, and magnetic lows that may be indicative of hydrothermal alteration of host rocks. Table 9 lists the estimates of undiscovered low-fluorine porphyry molybdenum deposits in the tract.

The presence of replacement manganese deposits at the Arabela Manganese Inc. mine and another small prospect nearby, the association with intrusive rocks, and the presence of faults and fractures suitable for vein mineralization suggest a 50 percent probability that one or more deposits of this type are contained in tract I (table 9).

On the basis of the known occurrence of polymetallic veins in the Gallinas Mountains and near Sierra Blanca Peak, the presence of base-metal geochemical anomalies near Sierra Blanca Peak and elsewhere, and the occutrence of fractures and faults in areas that may be underlain by alkaline intrusives, a 90 percent probability is estimated that one undiscovered polymetallic vein deposit is contained in tract I (table 9). There is a 50 percent probability for two such undiscovered deposits there, and a 10 percent probability for four such deposits (table 9).

Fluotite-bastnaesite veins are estimated to have a 10 percent probability of one deposit occurring in tract I. A deposit model for fluorite-bastnaesite veins has yet to be developed so the total probable tonnage cannot be estimated.

The estimate of undiscovered epigenetic barite veins in tract $I$ is based on three factors that indicate that the tract is permissible for epigenetic barite mineralization. First, barite is present as an accessory mineral with fluorite in the Gallinas district and with no fluorite in the Nogal district. Barite is the primary fissure-filling mineral at the Fox lode prospect. Second, geochemical samples indicate that barium is present in stream sediments in many parts of the tract. Third, faults and fractures created by doming of brittle rocks overlying plutonic intrusions provide openings for barite veins to form. A 90 percent probability is estimated for one 
undiscovered epigenetic vein deposit in tract $I$, a 50 percent probability for one deposit, and a 10 percent probability for two deposits (table 9).

\section{TRACT II}

Tract II delineates areas having the potential for sediment-hosted copper and Mississippi Valley-type leadzinc deposits in the western panhandle of Lincoln County (pl. 14). Tract II has an approximate area of $346 \mathrm{mi}^{2}$. About three-fourths of the tract is within the White Sands Missile Range and encompasses the southern part of the Oscura Mountains. The remainder of the tract is immediately east of the missile range; a thumblike extension lies between Walnut Canyon and Valley of Fires Recreation Area in the malpais. Quail and Sixshooter Canyons are part of the tract. From west of the State park, the eastem boundary of tract II runs parallel to Route 54 southward, passing west of Oscura and east of the Phillips Hills to the southem boundary of the study area.

Tract II includes outcrops and the inferred subsurface continuations of Pennsylvanian and Permian clastic and carbonate sedimentary rocks. The Permian sedimentary rocks of the Abo Formation have potential for red-bed-type sediment-hosted copper deposits because they are permeable continental margin sandstone and host identified mineralization of this type in the Oscura district within the tract. Copper, silver, and base-metal geochemical anomalies within the tract suggest mineralization. Documentation of copper mineralization in faults in the Oscura Mountains (Bachman, 1968) both within and outside the tract is another positive indication. A 50 percent probability is estimated for one or more undiscovered sediment-hosted copper deposits in tract II and a 10 percent probability for two or more such deposits (table 9).

A 10 percent probability of one Mississippi Valley-type lead-zinc deposit is estimated for tract II (table 9). This deposit type is possible because of the extension into the tract of Pennsylvanian limestone and geologic structures associated with the Hansonburg district, a Mississippi Valley-type deposit mined outside of the study area at the northem end of the Oscura Mountains.

\section{TRACT III}

Tract III encompasses an area of $707 \mathrm{mi}^{2}$; it is a circle $30 \mathrm{mi}$ in diameter centered on the Stauber mine in Guadalupe County (pl. 14). The boundary of the tract extends from east of Santa Rosa where Route 84 and Interstate 40 (I-40) intersect, northward through the approximate center of the Perea Grant, and north of Colonias. Tract III includes about 10.5 mi of Route 84 north of where it crosses I-40 west of Santa Rosa. The border of the tract again crosses I-40 about $27 \mathrm{mi}$ west of Santa Rosa, then crosses Route 54 about $7 \mathrm{mi}$ southwest of Pastura and Route 219 about $6 \mathrm{mi}$ south of Pastura. Besides Santa Rosa, the tract includes the small ranching settlements of Pastura, Pintada, and San Ignacio. About onehalf of tract III overtlaps tract IV, and a very small amount of tract III overlaps tract Va.

Tract III has potential for the occurrence of sedimenthosted copper deposits. The criteria for outlining the tract are the exposures of the Grayburg and Queen Formations and the Santa Rosa Sandstone, which host deposits of this type at the Pintada and Stauber mines, and which contain copper and uranium minerals in measured sections of the Santa Rosa. Geochemical anomalies and karst topography in the tract favor formation of sediment-hosted copper deposits. The circular outline of tract III is the maximum radius from the Stauber mine at which the team would estimate the probability of a sediment-hosted copper deposit being discovered. The present subeconomic status of the Pintada deposit, and the relatively high amount of past exploration in the tract that apparently did not find additional deposits, suggest only a 10 percent probability of one or more undiscovered sediment-hosted copper deposits in tract III (table 9).

\section{TRACT IV}

Tract IV extends from the southern boundary of the study area in Chaves and Lincoln Counties and from the White Sands Missile Range in far western Lincoln County to the Mescalero pediment east of the Pecos River in Chaves and De Baca Counties (pl. 14). The area of the tract is approximately $8,766 \mathrm{mi}^{2}$, excluding the area of the Lincoln County porphyry belt (tract Ia). The area surrounds 12 known gypsum deposits (Weber and Kottlowski, 1959), but does not take into consideration the vast deposits in the subsurface outside the tract in the eastern part of the study area due to insufficient subsurface information on gypsum grade and extent in these areas.

Tract IV has potential for the occurrence of gypsum in Permian formations less than $200 \mathrm{ft}$ from the surface. The gypsum resources of the study area are compared to the marine bedded gypsum deposit model (Kirkham, 1984; Raup, 1991) and to known gypsum occurrences. Our quantitative estimate of marine bedded gypsum resources is based, in part, on a grade and tonnage model under development (G.J. Orris, oral commun., 1991). The mineral resource assessment team did not estimate the probability of undiscovered marine bedded gypsum deposits in the study area because the deposit model was not available at the time of the assessment meeting and there are no recent, published figures of mined gypsum or resource estimates for gypsum from these deposits. Estimates herein are based mainly on descriptions and locations of deposits by Weber and Kottlowski (1959) and by Darton (1920). 
Gypsum deposits of commercial grade are known at 12 locations within the study area (Weber and Kottlowski, 1959) (fig. 17). The largest of these deposits underlies an area of about $1,200 \mathrm{mi}^{2}$ in the Pecos River valley. Some of the other large deposits within the study area underlie 150 $\mathrm{mi}^{2}$ in the Vaughn area, $103 \mathrm{mi}^{2}$ in the Rio Hondo and Rio Ruidoso valleys, and $14 \mathrm{mi}^{2}$ in the Phillips Hills. The combined area underlain by gypsum deposits is about $1,730 \mathrm{mi}^{2}$.

Tract IV encompasses all of the gypsum occurrences as well as the space between them. It was chosen as the part of the study area most likely to contain undiscovered gypsum resources. If it were underlain by $3 \mathrm{ft}$ of material containing 90 percent gypsum, the total contained amount of that commodity would be about 57 billion short tons. In comparison, the world's largest gypsum deposits, such as those in the Paris Basin, France, cover an approximate area of over 3,100 $\mathrm{mi}^{2}$ at a thickness of as much as $180 \mathrm{ft}$, and the Permian deposits of Oklahoma and Texas cover an area of about $1,000 \mathrm{mi}^{2}$ at a maximum thickness of $20 \mathrm{ft}$ (Pressler, 1985).

The grade and tonnage model for marine bedded gypsum deposits (G.J. Oris, oral commun., 1991) consists of 12 world-wide deposits ranging in size from 1.1 million to 17 billion metric tons (1.2 million to 19 billion short tons), and the median size is 158 million metric tons ( 174 milliion short tons). Of the deposits in the model, four are in Canada and there are three each in Oklahoma and France. The OkJahoma deposits are the largest, ranging from 1.2 billion to 17 billion metric tons ( 1.3 billion to 19 billion short tons). Grades of the gypsum deposits range from 75 to 97.5 percent, and the median grade is 94.1 percent. One of the deposits in the grade and tonnage model is located in New Mexico, north of the study area at White Mesa (Sandoval County). At White Mesa, according to Weber and Kottlowski (1959), the gently dipping gypsum member of the Middle Jurassic Todilto Limestone Member of the Wanakah Formation (Condon and Huffman, 1988) is 50-100 ft thick and forms an arcuate band that is $0.2-0.75 \mathrm{mi}$ wide and $3 \mathrm{mi}$ long. In 1959, an area of 1,180 acres was thought to contain 222 million short tons of material containing 95 percent gypsum under relatively thin overburden.

Because a large part of the study area is underlain by marine bedded gypsum and because 12 potentially economic deposits are already known in the study area (Weber and Kottlowski, 1959), a 90 percent probability is estimated for two or more undiscovered marine bedded gypsum deposits in tract IV (table 9). There is a 50 percent probability for three or more undiscovered deposits in the tract, and a 10 percent probability for four or more deposits (table 9). The predicted median tonnage of gypsum in the tract is 1.77 billion metric tons ( 1.95 billion short tons). There is, however, a 10 percent probability that there is as little as 114 million metric tons (126 million short tons) in the tract of the grade and tonnage described by the model. There is also a 10 percent probability that the tract contains more than 23.5 billion metric tons ( 25.9 billion short tons) of gypsum.
Table 10. Estimated pre-mining tonnages of commoditics contained in undiscovered deposits in tracts J-IV of the Roswcll Resource Area, New Mexico

[Values in metric tons: 1 metric ton=1, 102 short tons]

\begin{tabular}{|c|c|c|c|}
\hline \multirow[t]{2}{*}{ Commodity } & \multirow{2}{*}{$\begin{array}{c}\text { Median tonnage } \\
50 \text { th }\end{array}$} & \multicolumn{2}{|c|}{ Tonnage by probability range } \\
\hline & & 90th & 10th \\
\hline \multicolumn{4}{|c|}{ Tract I } \\
\hline Gold & 263 & 20.9 & 1,510 \\
\hline Silver & 236 & 30.1 & 1.020 \\
\hline Iron & $46,600,000$ & $3,120,000$ & $477,000,000$ \\
\hline Thoria & 171 & 0 & 7,980 \\
\hline Rare-earth oxides & 0 & 0 & 780 \\
\hline Molyt & 49,900 & 0 & 502,000 \\
\hline Mang & 773 & 0 & 147,000 \\
\hline Copper & 7.55 & 0 & 302 \\
\hline Lead & 4,030 & 52.7 & 48,100 \\
\hline Zinc & 1,230 & 0 & 36,000 \\
\hline Bari & 127,000 & 473 & $1,720,000$ \\
\hline Phos & 0 & 0 & \\
\hline \multicolumn{4}{|c|}{ Tract II } \\
\hline Silver & 0 & 0 & 3,930 \\
\hline Copper & 244,000 & 0 & $8,070,000$ \\
\hline Lead & 0 & 0 & 656,000 \\
\hline Zinc & 0 & 0 & $3,810,000$ \\
\hline Cobalt & 0 & 0 & 82,000 \\
\hline \multicolumn{4}{|c|}{ Tract III } \\
\hline Silver & 0 & 0 & $v$ \\
\hline Copper & 0 & 0 & $1,240,000$ \\
\hline Cobalt & 0 & 0 & \\
\hline \multicolumn{4}{|c|}{ Tract IV } \\
\hline Gypsum & $1,770,000,000$ & $14,000,000$ & $23,500,000,000$ \\
\hline
\end{tabular}

\section{ESTIMATES OF TONNAGES OF METALLIC COMMODITIES AND GYPSUM IN UNDISCOVERED DEPOSITS}

The estimates of the number of undiscovered deposits were used by the MARK-3 computer program to generate estimates of the tonnages of the undiscovered mineral resources in tracts I-IV (tables 10-12). The undiscovered resources are expressed as the median (50th percentile) of the distribution for each of the commodities associated with the deposit types considered. The range of probability for the amount of each commodity is expressed by the 90th and the 10 th percentiles of its distribution.

The median, rather than the mean, of the distribution was chosen as the primary measure of central tendency of each commodity distribution because the median is less sensitive to extreme values that arise during the simulation runs due to the highly positively skewed nature of most grade and tonnage distributions.

An example from table 11 serves to illustrate interpretation of the estimates. The median estimate of gold contained in undiscovered alkaline-associated gold-silvertellurium deposits is 262 metric tons ( 289 short tons). That is, if there were many regions of the same size and having the same geological, geochemical, and geophysical characteristics as the study area, one would expect that 50 percent of the regions would contain more than 262 metric tons ( 289 short 
Table 11. Estimated mean number of undiscovered deposits and pre-mining tonnages of commodities contained in undiscovered deposits in tracts I-IV, listed by deposit type, of the Roswell Resourcc Area, New Mexico

[Values are in metric tons and have been rounded: 1 metric ton=1.102 short tons]

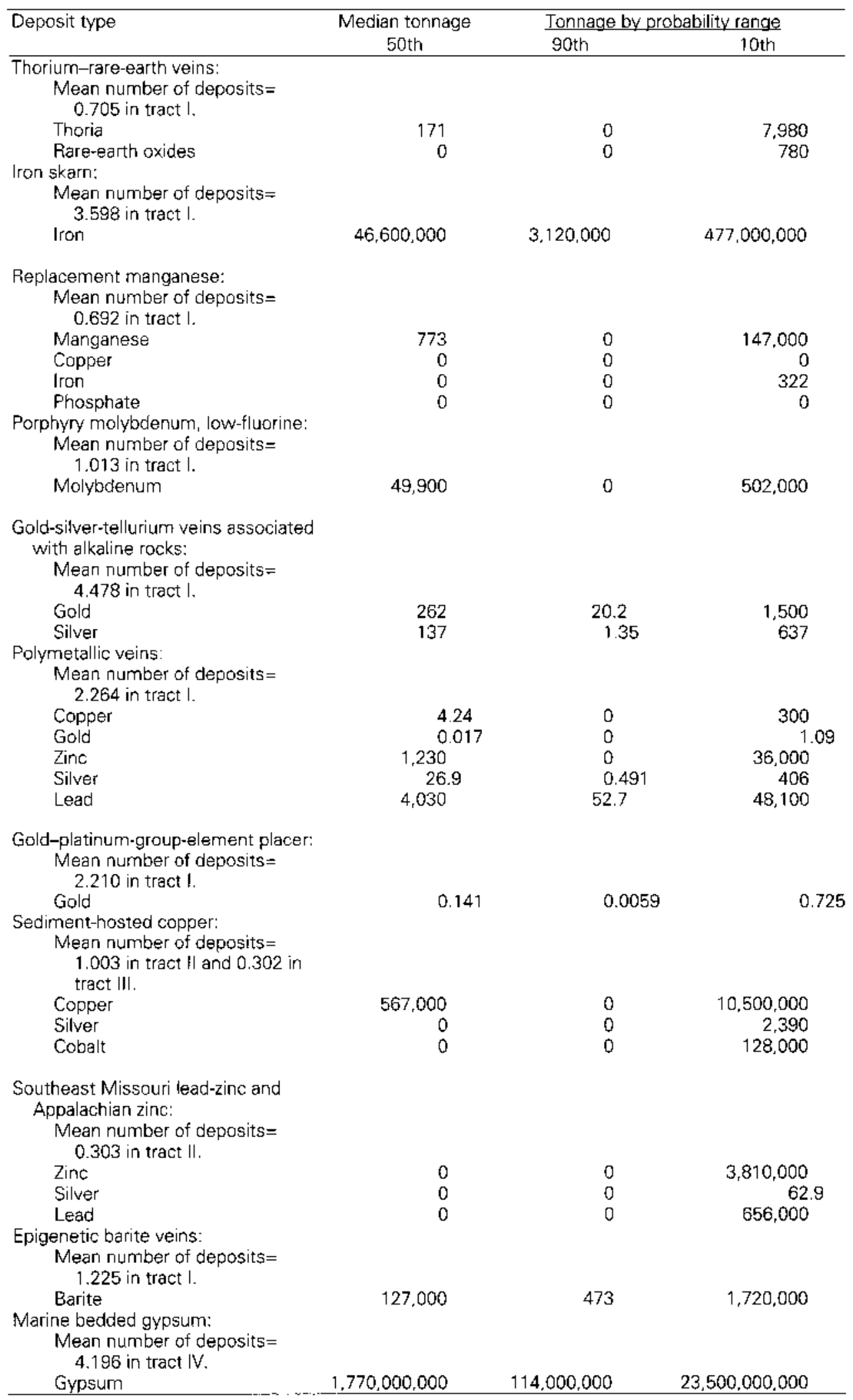


Table 12. Estimated pre-mining tonnages of commodities contained in undiscovered deposits in tracts I-IV of the Roswell Resource Area, New Mexico

[Values in metric tons; 1 metric ton=1.102 short tons]

\begin{tabular}{|c|c|c|c|c|}
\hline \multirow[t]{2}{*}{ Commodity } & \multirow{2}{*}{$\begin{array}{l}\text { Median tonnage } \\
50 \text { th }\end{array}$} & \multicolumn{2}{|c|}{ Tonnage by probability range } & \multirow{2}{*}{$\begin{array}{c}\mathrm{E} / \mathrm{C} \\
\text { index }\end{array}$} \\
\hline & & 90th & 10th & \\
\hline Gold & 263 & 20.9 & 1.510 & 2.6 \\
\hline Silver & 412 & 53.3 & 7,710 & 0.1 \\
\hline Copper & 516,000 & 4.56 & $11,000.000$ & 0.2 \\
\hline Lead & 9.110 & 113 & 795,000 & 0.01 \\
\hline Zinc & 5,950 & 3.98 & $4,450,000$ & 0.005 \\
\hline |ron & $46,600,000$ & $3,120,000$ & $477,000,000$ & 1.0 \\
\hline Cobalt & 0 & 0 & 129,000 & \\
\hline Manganese & 773 & 0 & 147,000 & 0.001 \\
\hline Molybdenum & 49,900 & 0 & 502,000 & 2.9 \\
\hline Rare-earth oxides & 0 & 0 & 780 & 0 \\
\hline Thoria $\left(\mathrm{ThO}_{2}\right)$ & 171 & 0 & 7,980 & 3 \\
\hline Bạite & 127,000 & 473 & $1,720,000$ & 0.09 \\
\hline Gypsum & $1,770,000,000$ & $114,000,000$ & $23,500,000,000$ & 73 \\
\hline
\end{tabular}

tons) of gold in this deposit type and 50 percent would contain less. Ninety percent of the regions would contain more than 20.2 metric tons (22.3 short tons) of gold in this deposit type and 10 percent would contain more than 1,500 metric tons (1,650 short tons) of gold. It follows that for 80 percent of the regions, the gold contained in this deposit type would be between 20.2 and 1,500 metric tons ( 22.3 and 1,650 short tons). The wide range in the estimates for this example is due to the wide range (2-8) in the number of undiscovered deposits estimated (table 9) and the large skewness of the distribution of gold grade for this type of deposit.

For tables 10-12, the parameters include the 50th (median), 90th, and 10th percentiles of each of the distributions. It should be noted that in summing probability distributions, neither the median nor the other percentiles are additive. For example, the median estimates of total contained commodities in tables 10-12 are not simply the sum of medians of the commodities in the tracts. Moreover, the median estimates of the total contained commodities are larger than one's intuition might first suggest. The reason the estimates of the total contained commodities are larger than expected is because for each of the tracts there is a probability that no deposits will occur. In summing the probability distributions, the probability that all of the tracts, for either a given deposit type or for a given commodity, will contain no deposits is naturally smaller, and this in turn gives rise to probability distributions having considerably greater medians.

Comparing the median tonnages estimated for each commodity in the study area (table 12) with the median tonnages for tracts I, II, and III (table 10) shows that tract I contains the majority of the metals in undiscovered deposits. Tract I contains 100 percent of the gold, iron, manganese, molybdenum, and thorium, 57 percent of the silver, 44 percent of the lead, and 21 percent of the zinc. An almost negligible proportion of the copper is contained in tract $I$. Tract II is estimated to contain about 47 percent of the copper in undiscovered deposits. Estimated median values for the other metals-silver, cobalt, lead, and zinc-in tract II are zero as are the median estimates for copper, silver, and cobalt in tract III.

The $\mathrm{E} / \mathrm{C}$ index, given for comparison (table 10), is defined as the median endowment to consumption index (Drew and others, 1986), where median endowment is divided by annual apparent consumption for each commodity. The $\mathrm{E} / \mathrm{C}$ index is the number of years at the 1990 level of United States consumption that the commodities in undiscovered deposits represents. Gypsum, for example, represents about 73 years of consumption at the 1990 level, whereas the base metals (copper, lead, and zinc) represent fractions of a percent. The $\mathrm{E} / \mathrm{C}$ index should only be taken as a qualitative reference.

Resource estimates presented here for a particular commodity are point estimates (medians) that are subject to several variabilities, such as the contribution of a particular commodity from several deposit models, and the variances of the grade and tonnage distributions for the deposit models.

\section{REFERENCES CITED}

Bachman, G.O., 1968, Geology of the Mockingbird Gap quadrangle, Lincoln and Socorro Counties, New Mexico: U.S. Geological Survey Professional Paper 594-J, 43 p.

Bliss, J.D., 1992, Grade and tonnage model of thorium-rare-earth veins, in Bliss, J.D., ed., Developments in mineral deposit modeling: U.S. Geological Survey Bulletin 2004, p. 16-18.

Bliss, J.D., Sutphin, D.M., Mosier, D.L., and Allen, M., 1992, Grade-tonnage and target-area models of $\mathrm{Au}-\mathrm{Ag}$ - $\mathrm{Te}$ veins 
associated with alkalic rocks: U.S. Geological Survey OpenFile Report 92-208, 15 p.

Condon, S.A., and Huffman, A.C., Jr., 1988, Revisions in nomenclature of the Middle Jurassic Wanakah Formation, northwestem New Mexico and northeastern Arizona: U.S. Geological Survey Bulletin 1633-A, 12 p.

Cox, D.P., and Singer, D.A., eds., 1986, Mineral deposit models: U.S. Geological Survey Bulletin 1693, 379 p.

Darton, N.H., 1920, New Mexico, in Stone, R.W., and others, Gypsum deposits of the United States: U.S. Geological Survey Bulletin 697, p. 161-186.

Drew, L.J., Bliss, J.D., Bowen, R.W., Bridges, N.J., Cox, D.P., DeYoung, J.H., Jr., Houghton, J.C., Ludington, S., Menzie, W.D., Page, N.J., Root, D.H., and Singer, D.A., 1986, Quantitative estimation of undiscovered mineral resources - A case study of U.S. Forest Service wildemess tracts in the Pacific Mountain System: Economic Geology, v. 81, no. 1, p. 80-88.

Kirkham, R.V., 1984, Evaporites and brines, in Eckstrand, O.R., ed., Canadian mineral deposit types-A geological synopsis: Geological Survey of Canada Economic Geology Report 36, p. 13-15.

Orris, G.J., and Bliss, J.D., eds., 1991, Some industrial mineral deposit models-Descriptive deposit models: U.S. Geological Survey Open-File Report 91-11-A, 73 p.

Pressler, J.W., 1985, Gypsum, in Knoerr, A.W., ed., Mineral facts and problems, 1985 edition: U.S. Bureau of Mines Bulletin 675 , p. 349-356.

Raup, O.B., 1991, Descriptive model of bedded salt; Deposit subtype-Marine evaporite salt model 35ac, in Orris, G.J., and Bliss, J.D., eds., Some industrial mineral deposit models-Descriptive deposit models: U.S. Geological Survey Open-File Report 91-11-A, p. 29-30.

Root, D.H., and Scott, W.A., 1988, User manual for mineral simulation program: U.S. Geological Survey Open-File Report 88-15, 64 p.

Segerstrom, Kenneth, Stotelmeyer, R.B., and Williams, F.E., 1979, Mineral resources of the White Mountain Wildemess and adjacent areas, Lincoln County, New Mexico: U.S. Geological Survey Bulletin 1453, $135 \mathrm{p}$.

Singer, D.A., and Ovenshine, A.T., 1979, Assessing metallic resources in Alaska: American Scientist, v. 67, no. 5, p. 582-589.

U.S. Bureau of Mines, 1991, Mineral commodity summaries, 1991: Washington, D.C., Government Printing Office, 196 p.

Weber, R.H., and Kottlowski, F.E., 1959, Gypsum resources of New Mexico: New Mexico Bureat of Mines and Mineral Resources Bulletin 68, 68 p.

\section{URANIUM AND VANADIUM}

\section{URANIUM DEPOSITS AND OCCURRENCES}

By Warren I. Finch, James K. Otion, and Charles T. Pierson

\section{SANDSTONE URANIUM DEPOSITS}

Sandstone uranium deposits have been discovered in the Roswell Resource Area in Chaves, De Baca, Guadalupe, Lincoln, and Quay Counties (Finch, 1972a, b) (pl. 13;
Appendix); the largest deposits occur in Guadalupe and Quay Counties. Host rocks include the Santa Rosa Sandstone and Chinle Formation of the Upper Triassic Dockum Group, the Upper Triassic Redonda Formation, and the Upper Jurassic Morrison Formation, which crop out principally in Guadalupe and Quay Counties. Although sandstone ore bodies may be either tabular or roll-front in form, most of those in the study area are tabular. Although their origin is controversial, tabular ore bodies were most likely formed during diagenesis under reducing conditions, whereas rollfront ores were formed by oxidation solution fronts advancing downdip in the host sandstone (Ruzicka and Bell, 1984; Turner-Peterson and Hodges, 1986). Vanadium minerals commonly occur together with uranium minerals, and in some deposits vanadium is more abundant than uranium. Uranium minerals are commonly associated with pyrite and (or) marcasite and with organic matter of plant origin. The vanadium occurs mainly in clay and oxide minerals that impregnate the sandstone.

In Guadalupe County near Santa Rosa, anomalous radioactivity related to uranium has been detected in the upper sandstone member of the Santa Rosa Sandstone (Finch, 1988) at three sites. In the Pastura district, at the American Uranium prospect, yellowish-gray limonitic calcareous sandstone about 6 in. thick contains 0.045 percent uranium oxide $\left(\mathrm{U}_{3} \mathrm{O}_{8}\right)$. Exploratory drilling has identified other thin uraniferous zones at depths of 10,65 , and $85 \mathrm{ft}$. At the Porcupine prospect about $5 \mathrm{mi}$ northwest of the American Uranium prospect, anomalous radioactivity is identified by a light-olive-gray sandy claystone near the base of the upper sandstone member. At a railroad cut northwest of Santa Rosa, anomalous radioactivity has been identified in an irregular claystone lens as thick as $3 \mathrm{ft}$ and as long as $400 \mathrm{ft}$ near the base of the upper sandstone member (Finch, 1988).

In northeastern Guadalupe County, the Branch Ranch and Neafus Ranch deposits occur in the middle sandstone member (Cuervo Member) of the Chinle Formation. This member consists of interbedded fluvial sandstone, limestone-pebble conglomerate, and shale. Carbonized wood fragments occur in light-brown sandstone and in the limestone-pebble zone in the lower part of the member. Uranium, although sparse, is associated with the carbonaceous zones in the minerals tyuyamunite and metatyuyamunite. At Branch Ranch, uranophane and unohoite have been identified. The primary uranium material in both deposits was probably uraninite associated with pyrite.

In Quay County, several uranium occurrences have been identified in the Chinle, Redonda, and Morrison Formations. From the middle sandstone member of the Chinle Formation, the Good Luck No. 3 mine yielded 8.43 short tons of ore averaging 0.22 percent $\mathrm{U}_{3} \mathrm{O}_{8}$. Another 80 short tons of trial material was shipped from the Good Luck No. 1, Little Rattler, and Windy No. 9 mines. At Troutman Ranch, a 1-ft-thick, 250-ft-long tabular body of disseminated 
uranium minerals in the middle sandstone member is reported to contain 0.06 percent $\mathrm{U}_{3} \mathrm{O}_{8}$. At Wallace Ranch, the upper shale member of the Chinle Formation (Finch, 1988) contains uranium in thick, predominantly dark- to orange-red shale that overlies the middle sandstone member at the Red Peak prospect. Chert nodules containing malachite and azurite were found to contain 0.12 percent $\mathrm{U}_{3} \mathrm{O}_{8}$, over 10 percent copper, 0.70 percent vanadium, 0.003 percent silver, 1.5 percent arsenic, and 0.003 percent selenium (Finch, 1972a, b). At the Fife prospects, uranium is found in an 8-in.-thick, pale-yellowish-green, calcareous, noncarbonaceous, laminated sandstone of the Redonda Formation. Finch (1972a, b) noted that in Quay County most of the uranium occurrences in the Morrison Formation occur in a small area west of Tucumcari. These deposits are associated with silicified wood, bone, and carbonaceous wood. Most of the silicified materials contain a few tenths of a percent $\mathrm{U}_{3} \mathrm{O}_{8}$, whereas sandstone and shale associated with this organic material contain a few thousandths of a percent $\mathrm{U}_{3} \mathrm{O}_{8}$. The Breen prospect in this area consists of a 1-ft-thick roll-front containing limonite and gray organic(?) material found to contain 0.004 percent $\mathrm{U}_{3} \mathrm{O}_{8}$. In westem Quay County, small amounts of uranium occur also at the contact between the Dakota(?) Sandstone and Mancos Shale.

\section{URANIUM IN VEINS IN TERTIARY IGNEOUS ROCKS}

In Lincoln County, veins that contain thorium, rareearth-elements, and uranium, and skam deposits that contain uranium are known in three localities where large-displacement faults cut the Tertiary intrusives and adjacent units shown on the geologic map (pl. 1). Uranium occurs in ironrich veins cutting Tertiary alaskite at the Bear Canyon mine in the Capitan Mountains area (pl. 13). Uranium also occurs in veins filling fractures and breccia in the Yeso Formation and Tertiary trachyte porphyry (McLemore and Chenoweth, 1989). Lastly, uranium occurs in iron veins at the Prince mine on Lone Mountain. Tertiary intrusives are exposed in eight igneous centers in the southwestem part of the study area (pl. 1); three of the centers have faults associated with them and two of them have uranium-bearing veins. The grade of these deposits is below 0.03 percent $\mathrm{U}_{3} \mathrm{O}_{8}$, which is the present-day lowest mining cutoff. No data are available for tonnage, but the deposits are assumed to be very small. In western Lincoln County, a small occurrence in trachyte in the Little Black Peak Lava Flow Wilderness Study Area shows no evidence of production (Griswold, 1964; Stoeser and others, 1989; Berry and others, 1982).

\section{UNDISCOVERED URANIUM RESOURCES}

The study area has a small potential for undiscovered uranium resources in three types of uranium deposits: tabular sandstone, surficial, and vein. Northwest of the study area, tabular sandstone deposits occur in the Permian part of the sequence of Permian and Pennsylvanian rocks, but none are known in the study area. Small tabular sandstone-type deposits may be discovered in the Triassic Dockum Group and in Jurassic sedimentary rocks mainly in the northern part of the study area in Guadalupe and Quay Counties (Appendix). Although several very small occurrences of uranium occur in the Upper Jurassic Morrison Formation just north of Tucumcari, the potential for uranium in the Morrison in the study area is too small to consider further. Arid-land surficial uranium deposits occur in Tertiary sedimentary rocks adjacent to the study area in Texas and such deposits may remain undiscovered, mostly east of the Pecos River, in the study area. In the southwestern part of the study area, uranium is associated with iron skarn deposits and thorium veins in Tertiary intrusive rocks (see "Metal resources" section). The undiscovered endowment in these Tertiary igneous rocks is insignificant.

\section{SANDSTONE URANIUM DEPOSITS}

\section{PERMIAN AND UPPER PENNSYLVANIAN ROCKS}

Permian and Upper Pennsylvanian rocks are present in the subsurface in Tucumcari Basin in Guadalupe and Quay Counties and northem Roosevelt, De Baca, and Curry Counties, but are absent in the study area immediately to the south. In the National Uranium Resource Evaluation (NURE) program, a speculative uranium endowment ${ }^{1}$ was calculated for the Middle Pennsylvanian to Lower Permian Sangre de Cristo Formation north of the study area (U.S. Department of Energy, 1980). This endowment estimate resulted from the southeastward projection of a favorable area that contains occurrences of small tabular uranium and copper deposits in the Coyote Creek district, Mora County, N. Mex. (Tschanz and others, 1958), and from knowledge of the uranium in the Sangre de Cristo in the isolated deep Conoco Leatherwood-Reed No. 1 well in sec. 15, T. $16 \mathrm{~N}$., R. 17 E., San Miguel County, N. Mex. (Finch, 1972b). In the study area, the favorable part of the Sangre de Cristo equivalent probably includes the Lower Permian San Andres and Abo Formations. Small tabular uranium deposits are known in the Abo Formation in the southeasternmost Colorado Plateau uranium province (Finch, 1991). In the NURE program, the use of a roll-front model for large and relatively high grade deposits in Tertiary formations in the Shirley Basin district, Wyoming, to estimate uranium resources for the Sangre de Cristo causes one to question the validity of the estimate, particularly the grade and tonnage. The NURE

\footnotetext{
'Speculative resources: undiscovered uranium resources that may $\alpha$ cur either as known types of deposits in favorable areas in which no discoveries have been made or in new lypes of deposits not yet recognized for their economic potential.

Uranium endowment: the uranium that is estimated to occur in rock having a grade of at least 0.01 percent $\mathrm{U}_{3} \mathrm{O}_{8}$. Unconditional endowment is based on the assumption that one or more deposits exist in the favorable area.
} 
Table 13. National Uranium Resource Evaluation program estimates of unconditional mean uranium endowment of formations in the Roswell Resource Area, New Mexico (modified from U.S. Department of Energy, 1980)

\begin{tabular}{|c|c|c|c|}
\hline $\begin{array}{l}1^{\circ} \times 2^{\circ} \\
\text { quadrangle }\end{array}$ & Locality ${ }^{1}$ & $\begin{array}{c}\text { Favorable area } \\
\qquad\left\{\mathrm{mi}^{2}\right\}\end{array}$ & $\begin{array}{c}\mathrm{U}_{3} \mathrm{O}_{8} \\
\text { (short tons) }\end{array}$ \\
\hline \multicolumn{4}{|c|}{ Sangre de Cristo Formation } \\
\hline Tucumcari & Tucumcari & 1,570 & 921 \\
\hline Clovis & $\begin{array}{l}\text { Clovis-Sangre } \\
\text { de Cristo. }\end{array}$ & 470 & 275 \\
\hline Santa $\mathrm{Fe}$ & Undefined & 750 & 11,077 \\
\hline Fort Sumner & Undefined & 1.520 & 433 \\
\hline Total & & 4,310 & 12,706 \\
\hline \multicolumn{4}{|c|}{ Dockum Group (including Chinle Formation) } \\
\hline Tucumcari & San Jon-T & 280 & 920 \\
\hline Clovis & San Jon-C & $\underline{128}$ & 420 \\
\hline Total & & 408 & 1,340 \\
\hline
\end{tabular}

${ }^{\text {l}}$ Locality name used in tables in source report.

estimate of 12,706 short tons of $\mathrm{U}_{3} \mathrm{O}_{8}$ for the Sangre de Cristo Formation (table 13) is here judged much too high. The San Andres and Abo Formations in the southem part of the study area are not favorable for uranium deposits.

\section{DOCKUM GROUP}

In order to evaluate the favorability of the Late Triassic Dockum Group for uranium, one needs to compare the Dockum Group to units of similar age and lithology on the Colorado Plateau uranium province. Major deposits of uranium occur in Triassic rocks in southeastern Utah and northeastern Arizona (Finch, 1991). Organic humic matter was a major factor in the formation of these deposits, but the source of uranium for these deposits was most likely volcanic ash in mudstone units overlying the host sandstone beds. This ash apparently came from volcanic centers adjacent to the western and southern edges of the Colorado Plateau (Granger and Finch, 1988; Stewart and others, 1986).

The amount of volcanic detritus in the Dockum Group is much less than in the Late Triassic Chinle Formation of the Colorado Plateau, so that a volcanic ash source for uranium in the depositional basin of the Dockum was probably insufficient to form extensive uranium districts and very large deposits. Ash from the volcanic centers west of the Colorado Plateau was probably not deposited in the Dockum's depositional basin because the basin is too distant. The Dockum's depositional basin is separated from the Colorado Plateau Triassic depositional basin by the Ancestral Rocky Mountain highland and its southern extension, as evidenced by abundant thick coarse polymictic conglomerate at the base of the Dockum in central New Mexico. Thus, surface transport of ash by streams from the Colorado Plateau would also have been unlikely. The source for Dockum sediments was most likely the southern Ancestral Rocky Mountain highland in central New Mexico and other highlands to the south and east (Stewart and others, 1986; McGowen and others, 1979).
Certain features of the stratigraphy and paleohydrology of the Dockum Group also may have played a role in limiting formation of uranium deposits there. Favorable host rocks for uranium in the Dockum, such as organic-rich fluvial sandstone and limestone-pebble conglomerate, lie above, rather than below, the only known ash-bearing strata. The underlying Permian nonorganic marine sandstone beds would have been unfavorable for uranium deposition. Finally, the paleohydrology of the depositional basin of the Dockum was much different than that of the Colorado Plateau (Sanford, 1990) and probably did not yield saline-freshwater interfaces thought to be critical for the formation of tabular sandstone uranium deposits (Sanford, 1990; Granger and Finch, 1988). Uplift of the Matador arch influenced sedimentation of the basal units of the Dockum Group. For example, the mudstone of the Dockum (a potential uranium source) in the basal Tecovas Formation thins over the arch, and the Santa Rosa Sandstone (a potential uranium host) does not exist in Texas on the arch. The Santa Rosa Sandstone probably did not extend south of the crest of the arch in New Mexico. Therefore, the area south of the arch in New Mexico is judged to be less favorable for the existence of uranium deposits than the area to the north.

Known deposits of Dockum sandstone in the study area and adjacent areas to the north are small, particularly in the Sabinoso and San Jon areas where the productive deposits have yielded a total of about 100 short tons of rock at an average grade of less than 0.10 percent $\mathrm{U}_{3} \mathrm{O}_{8}$. The main host for the more productive deposits is a dense limestone-pellet conglomerate having a black carbonaceous coating. Uranium within the sandstone is limited primarily to the carbonized wood fragments; only small amounts of disseminated uranium occur in the sandstone. Host rock is lenticular, fluvial, channel-fill sandstone. Limestone-pebble conglomerate lenses are rarely greater than $5 \mathrm{ft}$ thick and $50 \mathrm{ft}$ long, and have little likelihood for hosting large uranium concentrations.

Estimates of speculative uranium endowment made for the NURE program (U.S. Department of Energy, 1980) for the San Jon favorable area, herein termed the Dockum Group (including Chinle Formation) NURE favorable area (pl. 14), total 1,340 short tons $\mathrm{U}_{3} \mathrm{O}_{8}$ (table 13). The NURE estimate is based on the Cameron, Ariz., control area, where the productive deposits are very large (Finch, 1991) and have higher average grade than those in the study area and adjacent areas. Thus, the NURE estimate for uranium endowment in the study area is probably much too large.

For the study area, new estimates of the undiscovered uranium endowment in the Dockum Group were made using the deposit-size-frequency (DSF) method (Finch and McCammon, 1987). This method was used because no grade and tonnage models are available for the use of the MARK3 method, which is used in this report for metals and certain industrial minerals. The entire area underlain by the Dockum is considered to be favorable for the occurrence of uranium 
Table 14. Estimated grade distribution and size-frequency distribution for urasium in the Dockum Group and Ogallala Formation, Roswell Resource Area, New Mexico

\begin{tabular}{|c|c|c|c|c|c|c|c|c|}
\hline $\mathrm{G}$ & ade distribut & $n$ & & & ze-frequ & distrib & & \\
\hline Percent & $\mathrm{J}_{3} \mathrm{O}_{8}$ at 0.01 & cutoff & $\begin{array}{l}\text { ishort } \\
\text { above }\end{array}$ & $\begin{array}{l}\text {-class inter } \\
\text { sof minera } \\
\text { toff of } 0.01\end{array}$ & $\begin{array}{l}\text { ed rock } \\
\left.\mathrm{U}_{3} \mathrm{O}_{8}\right)\end{array}$ & & aber of depo & \\
\hline $\begin{array}{l}\text { Lower } \\
\text { (5th) }\end{array}$ & $\begin{array}{c}\text { Most likely } \\
\text { value }\end{array}$ & $\begin{array}{l}\text { Upper } \\
\text { (95th) }\end{array}$ & $\begin{array}{c}\text { Lower } \\
\text { (5th) }\end{array}$ & Midpoint ${ }^{2}$ & $\begin{array}{l}\text { Upper } \\
\text { (95th) }\end{array}$ & $\begin{array}{c}\text { Lower } \\
\text { (5th) }\end{array}$ & $\begin{array}{c}\text { Most likely } \\
\text { value }\end{array}$ & $\begin{array}{l}\text { Upper } \\
\text { (95th) }\end{array}$ \\
\hline & & & & cklım Grou & & & & \\
\hline Tract Ve & $4,276-m i^{2} a$ & & & & & & & \\
\hline 0.03 & 0.05 & 0.08 & $\begin{array}{r}1 \\
10 \\
100 \\
1,000\end{array}$ & $\begin{array}{r}3.2 \\
32 \\
320 \\
3,200\end{array}$ & $\begin{array}{r}9.9 \\
99 \\
999 \\
9,999\end{array}$ & $\begin{array}{r}10 \\
5 \\
1 \\
0 \\
16\end{array}$ & $\begin{array}{r}20 \\
10 \\
1 \\
0 \\
31\end{array}$ & $\begin{array}{r}30 \\
20 \\
1 \\
1 \\
52\end{array}$ \\
\hline
\end{tabular}

Tract Vb $\left(5,687-\mathrm{mi}^{2}\right.$ area $)$

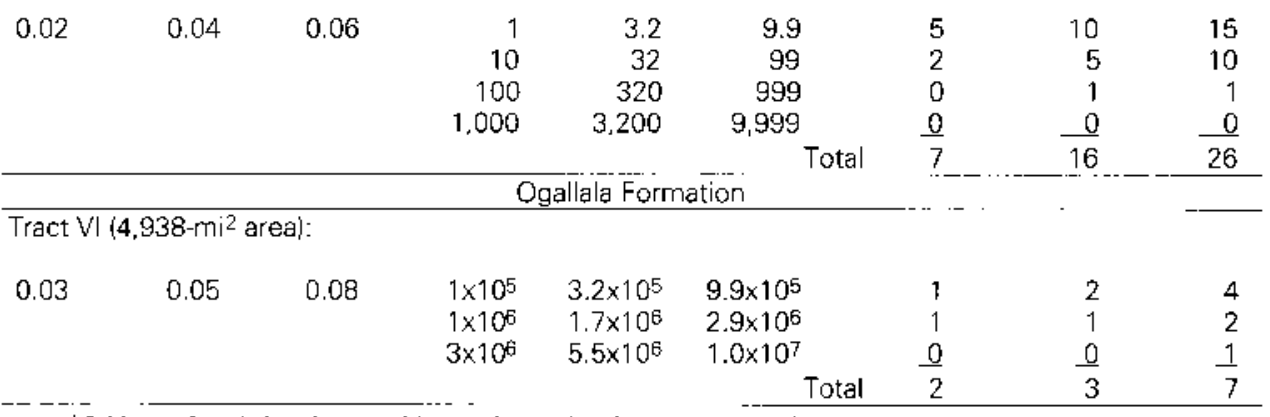

IOdds are 9 to 1 that the stated interval contains the true mean value.

-Midpoinls of size-class inlervals are represented by the geometric mean of the upper and lower limits.

deposits and is divided into two parts: tract $\mathrm{Va}$ and tract $\mathrm{Vb}$ (pl. 14). The division of the two tracts is based on the character of the Dockum. North of the Matador arch (tract Va), the Dockum is more favorable for uranium because it is light colored and locally contains abundant carbonaceous matter. South of the Matador arch (tract Vb), the Dockum is less favorable because it is essentially mostly dark red and contains very little carbonaceous matter. However, a few occurrences are known south of the arch, and there are strong geochemical uranium anomalies in the area (pl. 4, maps $A$ and $B$ ).

Size classes and grade ranges were established on the basis of the sizes of known deposits in the Sabinosa (about $40 \mathrm{mi}$ northwest of Tucumcari) and San Jon areas (east of Tucumcari). The number of deposits in the four size classes (ranging from 1 to 9,999 short tons of mineralized rock) were estimated for both tracts $\mathrm{Va}$ and $\mathrm{Vb}$ (table 14). Using these data, the undiscovered uranium endowments in the Dockum Group for both tracts were calculated in probability distributions (table 15) using the TENDOWG program (McCammon and others, 1988). The values of the undiscovered uranium endowment are less than 1 short ton of $\mathrm{U}_{3} \mathrm{O}_{8}$. Thus, the potential for large uranium deposits in the Dockum
Table 15. Probability distribution of estimated uranium endowment in the Dockum Group, tracts Va and Vb, Roswell Resourcc Area, New Mexico

\begin{tabular}{|c|c|c|c|}
\hline $\begin{array}{c}\cup_{3} \mathrm{O}_{8} \\
\text { (short tons) }\end{array}$ & $\begin{array}{l}\text { Probability } \\
\text { unconditional } \\
\text { (in percent) }\end{array}$ & $\begin{array}{c}\mathrm{U}_{3} \overline{\mathrm{O}}_{8} \\
\text { (short tons) }\end{array}$ & $\begin{array}{l}\text { Probability } \\
\text { unconditiona } \\
\text { (in percent) }\end{array}$ \\
\hline \multicolumn{4}{|c|}{ Tract $V a$ (mean $=0.34$ short tons } \\
\hline 0.19 & 0.05 & 0.35 & 0.55 \\
\hline .22 & .10 & 36 & .60 \\
\hline .24 & .15 & 37 & 65 \\
\hline .26 & .20 & 39 & .70 \\
\hline .27 & .25 & 40 & .75 \\
\hline .28 & .30 & 42 & .80 \\
\hline .30 & .35 & .44 & .85 \\
\hline .31 & .40 & .47 & .90 \\
\hline .32 & .45 & .51 & 95 \\
\hline .33 & .50 & & \\
\hline \multicolumn{4}{|c|}{ Tract $V b$ (mean $=0.28$ short tons) } \\
\hline 0.12 & 0.05 & 0.28 & 0.55 \\
\hline .15 & .10 & .30 & .60 \\
\hline .16 & 15 & .31 & .65 \\
\hline .18 & 20 & .32 & .70 \\
\hline 20 & 25 & .35 & .70 \\
\hline .21 & 30 & .37 & .80 \\
\hline .23 & 35 & 40 & 85 \\
\hline 24 & 40 & .43 & .90 \\
\hline .25 & .45 & .49 & .95 \\
\hline .26 & 50 & & \\
\hline
\end{tabular}


is extremely small. The expected undiscovered deposits, buried by more than $1,000 \mathrm{ft}$ of overburden, would not be economically recoverable by either conventional mining or in-situ leach methods. Mining ceased in the Sabinosa area in 1956 , because the deposits were small and low grade, inaccessible, and too costly to mine and explore (McLemore and Menzie, 1983). Exploration costs for small deposits would be even more prohibitive in the 1990's.

\section{SURFICIAL URANIUM DEPOSITS}

The area underlain by the Tertiary Ogallala Formation in eastern New Mexico is shown to be favorable for surficial uranium deposits on the map by McLemore and Chenoweth (1989). Fairly large uranium deposits of this type are known in the area east of the study area in West Texas (Otton, 1984). These deposits were not known during the NURE program.

Although uranium has not been reported in the Ogallala Formation of eastern New Mexico, it has been found in outcrops and in the subsurface in scattered localities along the Ogallala outcrop at the southern and eastem edge of the Llano Estacado in the Texas Panhandle. The area of uranium occurrence extends from the Seminole Draw area northwest of Midland, Texas, northward to the Tule Draw area northeast of Lubbock, Texas. Deposits closest to the study area lie $30-60 \mathrm{mi}$ to the east and southeast. Exploration drilling for uranium has been conducted by FRAMCO and Union Carbide in the Tule Draw area, by Kerr-McGee in the Sulphur Springs Draw area (north of Midland), and by Energy Reserves Group in the Seminole Draw area (Otton, 1984; Steve Schurman, consultant, Denver, Colo, written commun., 1990). Although information on grade and tonnage is very limited, deposits of uranium apparently range in size from a few hundred thousand to several million pounds of contained uranium. Grades are probably less than 0.1 percent $\mathrm{U}_{3} \mathrm{O}_{8}$.

Little information is available on the nature of the uranium host rocks in the Ogallala Formation. Our examination of outcrop and available company data (Steve Schurman, written commun., 1990) suggests that three types of uranium hosts may be present: (1) silcrete, (2) lacustrine calcrete, and (3) sandstone; however, the available data are so limited that no specific deposit models may be developed.

Uraniferous silcrete occurs in scattered localities in the Amarillo $1^{\circ} \times 2^{\circ}$ quadrangle (Seni and others, 1980), the Lubbock $1^{\circ} \times 2^{\circ}$ quadrangle (McGowen and others, 1981; J.K. Otton, unpublished data, 1985), and the Plainview $1^{\circ} \times 2^{\circ}$ quadrangle (Amaral, 1979). However, these occurrences are of very low grade (a few tens of ppm uranium), small size, and of limited uranium resource potential (Seni and others, 1980, p. 16). Lacustrine calcrete appears to be the host rock at the Sulphur Springs Draw deposit north of Midland, Texas. There, carnotite occurs in calcrete beds associated with fine-grained, greenish-gray mudstone beds of probable
Table 16. Probability distribution of estimated uranium endowment in the Ogallala Formation in tract VI, Roswell Resource Area, New Mexico

\begin{tabular}{cccc}
$\begin{array}{c}\mathrm{U}_{3} \mathrm{O}_{8} \\
\text { (short tons) }\end{array}$ & $\begin{array}{c}\text { Probability } \\
\text { unconditional } \\
\text { (in percent) }\end{array}$ & $\begin{array}{c}\mathrm{U}_{3} \mathrm{O}_{8} \\
\text { (short tons) }\end{array}$ & $\begin{array}{c}\text { Probability } \\
\text { unconditional } \\
\text { (in percent) }\end{array}$ \\
\cline { 2 - 4 } 726 & 0.05 & 1.315 & 0.55 \\
832 & .10 & 1.363 & .63 \\
908 & .15 & 1.414 & .65 \\
971 & .20 & 1.468 & .70 \\
1.027 & .25 & 1.527 & .75 \\
1.079 & .30 & 1.593 & .80 \\
1.128 & .35 & 1.670 & .85 \\
1.175 & .40 & 1.768 & .90 \\
1.222 & .45 & 1.914 & .95 \\
1.268 & .50 & &
\end{tabular}

lacustrine origin (fig. 41). These beds may be similar to lacustrine (playa) beds that host the Lake Austin and Lake Maitland calcrete uranium deposits in western Australia (Heath and others, 1984; Cavaney, 1984). In the Seminole Draw area, the host rocks are fine-grained sandstone beds that are probably in the middle of the Ogallala.

Away from the outcrop belt of the Ogallala in Texas and New Mexico, the subsurface distribution of uranium in the unit is little known. However, extensive sampling of Ogallala water wells was conducted during the NURE program both within the study area (Erdman, this report) and in Texas. Scattered high values ranging from 100 to $200 \mathrm{ppb}$ uranium occur in the study area and in the Lubbock, Texas, area. Values as high as $40 \mathrm{ppb}$ uranium occur in the Amarillo, Texas, area. Such elevated uranium concentrations in waters were probably derived from leaching of uranium accumulations within the aquifer.

In the study area, the size, grade, and location of such accumulations cannot be estimated directly, but they may be comparable to known uranium occurrences and deposits to the east in Texas. Thus, the Ogallala Formation seems a likely host to uranium deposits in tract VI in the study area (pl. 14). Tonnage size classes and grade distributions were established for tract VI on the basis of deposits in the Texas area, and the number of deposits in each size class was estimated (table 14). Endowment calculations for the Ogallala Formation using the deposit-size-frequency (DSF) method and the TENDOWG program show a mean uranium endowment of 1,287 shont tons of $\mathrm{U}_{3} \mathrm{O}_{8}$ for the study area (table 16).

\section{VANADIUM}

By George N. Breit

\section{PRODUCTION}

Eighty-four pounds of vanadium pentoxide $\left(\mathrm{V}_{2} \mathrm{O}_{5}\right)$ have been produced from deposits within the study area as a byproduct of uranium production (table 17), and of 

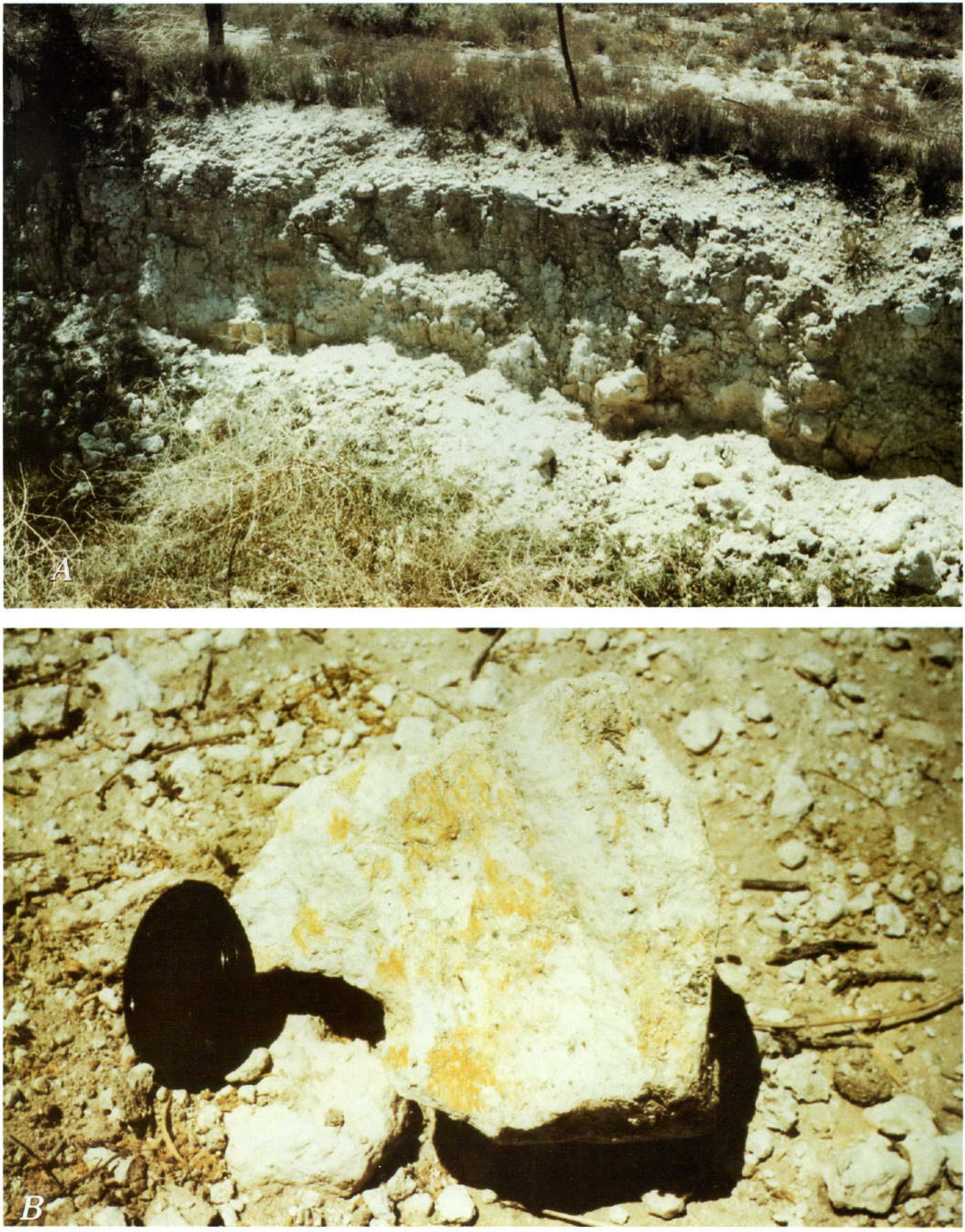

Figure 41. A, uraniferous calcrete exposed in a trench on the Beam Ranch along Sulphur Springs Draw north of Midland, Texas.B, uranium concentrated along fractures in calcrete at Bean Ranch. 
Table 17. Vanadium production from deposits within the Roswell Resource Area, New Mexico

[All production was during 1954-1957 (from McLemore, 1983)]

\begin{tabular}{|c|c|c|c|c|c|}
\hline Mine name & $\begin{array}{c}\text { Location } \\
\text { (sec., T., R.) }\end{array}$ & $\begin{array}{l}\mathrm{V}_{2} \mathrm{O}_{5} \\
(\mathrm{bb})\end{array}$ & $\begin{array}{c}\text { Ore } \\
\text { (short tons? }\end{array}$ & Host rock & Deposit type \\
\hline Good Luck & $6,7 \mathrm{~N} .3 \mathrm{E}$ & 38 & 24 & Chinle Formation & $\begin{array}{l}\text { Sandstone vanadium- } \\
\text { uranium. }\end{array}$ \\
\hline Little Rattler & $11,11 \mathrm{~N} ., 33 \mathrm{E}$. & 44 & 59 & Chinle Formation & $\begin{array}{l}\text { Sandstone vanadium- } \\
\text { uranium. }\end{array}$ \\
\hline $\begin{array}{l}\text { Bear Canyon } \\
\text { Group. }\end{array}$ & $9.8 \mathrm{~S} ., 17 \mathrm{E}$. & 2 & 3 & Magnetite vein & $\begin{array}{l}\text { Uraniferous vein } \\
\text { intruding alaskite. }\end{array}$ \\
\hline
\end{tabular}

this production $82 \mathrm{lb}$ came from two small vanadiumuranium deposits hosted by the middle sandstone member (Cuervo Member) of the Chinle Formation in Quay County (McLemore and North, 1985). Small amounts of vanadium also have been recovered from similar sandstone vanadium-uranium deposits $30 \mathrm{mi}$ north of the study area. This production includes $174 \mathrm{lb}$ of $\mathrm{V}_{2} \mathrm{O}_{5}$ that was extracted from the Chinle Formation in the Sabinoso district (McLemore and Menzie, 1983) and less than a short ton of silicified wood containing 0.31 percent $\mathrm{V}_{2} \mathrm{O}_{5}$ that was mined from the Morrison Formation in Harding County, N. Mex. (Finch, 1972a, b).

Two pounds of $\mathrm{V}_{2} \mathrm{O}_{5}$ were produced from a uraniferous magnetite vein at the Bear Canyon Group mine in Lincoln County (table 17; pl. 13). The vanadium content of this magnetite is only 0.04 weight percent (McLemore, 1983), which is consistent with the low grade of most hydrothermal magnetite. On the basis of the low grade compared to most vanadium deposits, the iron deposits of Lincoln County are not considered a vanadium resource.

Base-metal vanadate deposits have produced vanadium within New Mexico, but not within the study area (Fischer, 1975). Vanadate minerals are reported to occur in metal deposits within and adjacent to the study area (DeMark, 1980; Jerome and others, 1965). The size of the deposits and the abundance of vanadates within the deposits are both small.

\section{UNDISCOVERED VANADIUM RESOURCES}

Vanadium-uranium ore deposits are distinguished from other sandstone-hosted uranium deposits by their large vanadium concentrations ( $\left(1.0-2.5\right.$ percent $\mathrm{V}_{2} \mathrm{O}_{5}$ ) and their $\mathrm{V}_{2} \mathrm{O}_{5}$ ' $\mathrm{U}_{3} \mathrm{O}_{8}$ ratios, which commonly range from $10: 1$ to $3: 1$. Samples analyzed for vanadium from exposed deposits in eastern New Mexico (Finch, 1972b; Leibold and others, 1987; McLemore, 1983; McLemore and Menzie, 1983; McLemore and North, 1985) were examined for high vanadium values and vanadium/uranium ratios. Of samples that contain greater than 0.005 weight percent uranium, only a few have vanadium contents greater than 1 weight percent; most contain $0.5-0.01$ weight percent $\mathrm{V}_{2} \mathrm{O}_{5}$. The $\mathrm{V}_{2} \mathrm{O}_{5} / \mathrm{U}_{3} \mathrm{O}_{8}$ ratio in these samples ranges from 0.3 to 50 , and the median is 5 . The median value is within the range of other sandstone vanadium-uranium deposits, but the grade of both $\mathrm{V}_{2} \mathrm{O}_{5}$ and $\mathrm{U}_{3} \mathrm{O}_{8}$ are lower.
Host rocks for major vanadium-uranium deposits located in Arizona, Colorado, and Utah include the Triassic Chinle Formation, the Jurassic Entrada Sandstone, and the Salt Wash Member of the Jurassic Morrison Formation (Finch, 1991). All three formations or their equivalents are present in the study area; both the Chinle and Morrison Formations contain small deposits in the study area. The greatest potential vanadium resource within the study area is the vanadium-uranium deposits hosted by the Chinle Formation of the Dockum Group.

Although deposits in the Chinle Formation are considered to have the greatest potential to produce vanadium within the study area, the potential for large deposits containing greater than 1 weight percent $\mathrm{V}_{2} \mathrm{O}_{5}$ is small. Vanadiumproducing sandstone-hosted deposits typically contain ore layers that are suspended in the sandstone over relatively large areas. Deposits described within and near the study area are small and hosted by carbonaceous matter, calcareous clay lenses, or limestone-pebble conglomerate; rarely is the ore disseminated within the host sandstone. Sandstone beds within the study area are generally thinner and contain less carbonaceous matter than rock units that contain the large deposits in Utah, Colorado, and Arizona (Finch, 1972a, b; McLemore, 1983). Extensive exploration of the Chinle Formation in the study area during the uranium boom of the 1970's failed to yield any large discoveries. A numerical estimate of the vanadium resources within the study area was calculated by multiplying the $\mathrm{V}_{2} \mathrm{O}_{5} / \mathrm{U}_{3} \mathrm{O}_{8}$ ratio by the uranium resource estimate (table 15). The estimates of the uranium endowment for tracts $\mathrm{Va}$ and $\mathrm{Vb}(\mathrm{pl} .13$ ) is less than 1 short ton of $\mathrm{U}_{3} \mathrm{O}_{8}$, and ore grades are $0.03-0.08$ weight percent $\mathrm{U}_{3} \mathrm{O}_{8}$. Considering the $\mathrm{V}_{2} \mathrm{O}_{5} / \mathrm{U}_{3} \mathrm{O}_{8}$ ratio of 5 , this would suggest that only 5 short tons of recoverable $\mathrm{V}_{2} \mathrm{O}_{5}$ is present in the study area. The predicted tonnage is very small relative to areas elsewhere that contain producing sandstone-hosted vanadium-uranium deposits.

\section{REFERENCES CITED}

Amaral, E.J., 1979, National uranium resource evaluation, Plainview quadrangle. Texas: U.S. Department of Energy Open-file Report GJQ-001(79), 34 p. [Available from U.S. Geological Survey Books and Open-File Reports Section, P.O. Box 25425, Denver, CO 80225.] 
Berry, V.P., Nagy, P.A., Spreng, W.C., Barnes, C.W., and Smouse, D., 1982, Uranium resource evaluation, Tularosa quadrangle, New Mexico: U.S. Department of Energy Open-file Report GJQ-014(82), 22 p. [Available from U.S. Geological Survey Books and Open-File Reports Section, P.O. Box 25425, Denver, CO 80225.]

Cavaney, R.J., 1984, Lake Maitland uranium deposit, in Toens, D., project leader, Surficial uranium deposits: Vienna, Austria, Intemational Atomic Energy Agency, TECDOC 322, p. $137-140$.

DeMark, R.S., 1980, The Red Cloud mines, Gallinas Mountains, New Mexico: Mineralogical Record, March-April 1980. p. 69-72.

Finch, W.I., 1972a, Uranium in eastern New Mexico, in Kelley. V.C., and Trauger, F.D., eds., Guidebook of east-central New Mexico: New Mexico Geological Society, Twenty-third Field Conference Guidebook, p. 171-175.

1972b, Uranium in eastem New Mexico: U.S. Geological Survey Open-File Report 72-117, 19 p.

1988, The principal reference section for the Santa Rosa Formation, in Finch, W.I., ed., Principal reference section for the Santa Rosa Formation of Middle and Late Triassic age, Guadalupe County, New Mexico: U.S. Geological Survey Bulletin 1804-A, p. 1-10.

1991, Maps showing the distribution of uranium deposit clusters in the Colorado Plateau Uranium Province: U.S. Geological Survey Miscellaneous Field Studies Map MF-2080, scale $1: 2,500,000$.

Finch, W.I., and McCammon, R.B., 1987, Uranium resource assessment by the Geological Survey-Methodology and plan to update the national resource base: U.S. Geological Survey Circular 994, 31 p.

Fischer, R.P., 1975, Geology and resources of base-metal vanadate deposits: U.S. Geological Survey Professional Paper 926-A, p. Al-A14.

Granger, H.C., and Finch, W.I., 1988, The Colorado Plateau Uranium Province, U.S.A., in Proceedings of a Technical Committee Meeting on Recognition of Uranium Provinces, London, England, 18-20 September, 1985: Vienna, Austria, Intemational Atomic Energy Agency, p. 157-193.

Griswold, G.B., 1964, Mineral resources of Lincoln County, in Ash, S.R., and Davis, L.V., eds., Guidebook of Ruidoso Country: New Mexico Geological Society, Fifteenth Field Conference Guidebook, p. 148-151.

Heath, A.G., Deutscher, R.L., and Butt, C.R.M., 1984, Lake Austin uranium deposit, western Australia, in Toens, D., project leader, Surficial uranium deposits: Vienna, Austria, International Atomic Energy Agency, TECDOC 322, p. 129-132.

Jerome, S.E., Campbell, D.D., Wright, J.S., and Vitz, H.E., 1965, Geology and ore deposits of the Sacramento (High Rolls) mining district, Otero County, New Mexico: New Mexico Bureau of Mines and Mineral Resources Bulletin 86, $30 \mathrm{p}$.

Leibold, A.M., Saltus, E.W., Grauch, V.J.S., Lindsey, D.A., and Almquist, C.L., 1987, Mineral resources of the Sabinoso Wildemess Study Area, San Miguel County, New Mexico: U.S. Geological Survey Bulletin 1733-A, p. Al-A12.

McCammon, R.B., Finch, W.I., Pierson, C.T., and Bridges, N.J., 1988, The micro-computer program TENDOWG for estimating undiscovered uranium endowment: U.S. Geological Survey Open-File Report 88-653, 11 p., 1 diskette.

McGowen, J.H., Granata, G.E., and Seni, S.J., 1979, Depositional framework of the lower Dockum Group (Triassic), Texas panhandle: Austin, Texas, University of Texas Bureau of Economic Geology, Report of Investigations No. 97-1979, 60 p.

McGowen, J.H., Seni, S.J., Andersen, R.L., and Thurwachter, J.E., 1981, National uranium resource evaluation, Lubbock quadrangle, Texas: U.S. Department of Energy, Open-file Report GJQ-012(81), 48 p. [Available from U.S. Geological Survey Books and Open-File Reports Section, P.O. Box 25425, Denver, CO 80225.]

McLemore, V.T., 1983, Uranium and thorium occurrences in New Mexico-Distribution, geology, production, and resources, with selected bibliography: New Mexico Bureau of Mines and Mineral Resources Open-file report OF-183, $180 \mathrm{p}$.

McLemore, V.T, and Chenoweth, W.L., 1989, Uranium resources in New Mexico: New Mexico Bureau of Mines and Mineral Resources Resource Map 18, scale 1:1,000,000, 36-p. pamphlet.

McLemore, V.T., and Menzie, D., 1983, Geology and uranium potential of Sabinoso district. San Miguel County, New Mexico: New Mexico Geology, v. 5, p. 35-38, 40.

McLemore, V.T., and North, R.M., 1985, Copper and uranium mineralization in east-central New Mexico, in Lucas, S.G., ed., Santa Rosa-Tucumcari region: New Mexico Geological Society, 36th Field Conference Guidebook, p. 289-299.

Otton, J.K., 1984, Surficial uranium deposits in the United States of America, in Toens, D., project leader, Surficial uranium deposits: Vienna, Austria, International Atomic Energy Association, TECDOC 322, p. 237-242.

Ruzicka, V., and Bell, R.T., 1984, Sandstone uranium, in Eckstrand, O.R., ed., Canadian mineral deposit types - A general synopsis: Geological Survey of Canada Repon 36, p. 28.

Sanford, R.F., 1990, Paleohydrology of the Colorado Plateau-Background and conceptual models, in Fluid-mineral interactions-A tribute to H.P. Eugster: The Geochemical Society Special Publication No. 2, p. 285-311.

Seni, S.J., McGowen, J.H., and Risner, R.S., 1980, National uranium resource evaluation, Amarillo quadrangle, Texas: U.S. Department of Energy, Open-file Report GJQ-013(81), 24 p. [Available from U.S. Geological Survey Books and Open-File Reports Section, P.O. Box 25425, Denver, CO 80225.]

Stewart, J.H., Anderson, T.H., Haxel, G.B., Silver, L.T., and Wright, J.E., 1986, Late Triassic paleogeography of the southem Cordillera-The problem of a source for voluminous volcanic detritus in the Chinle Fomation of the Colorado Plateau: Geology, v, 14, p. 567-570.

Stoeser, D.B., Senterfit, M.K., and Zeiten, J.E., 1989, Mineral resources of the Little Black Peak and Carrizozo Lava Flow Wildemess Study Areas, Lincoln County, New Mexico: U.S. Geological Survey Bulletin 1734-E, 17 p.

Tschanz, C.M., Laub, D.C., and Fuller, G.W., 1958, Copper and uranium deposits of the Coyote district, Mora County, New Mexico: U.S. Geological Survey Bulletin 1031-L, p. 343-397.

Turner-Peterson, C.E., and Hodges, C.A., 1986, Descriptive model of sandstone U, in Cox, D.P., and Singer, D.A., eds., Minemal deposit models: U.S. Geological Survey Bulletin 1693, p. 209-210.

U.S. Department of Energy, 1980, An assessment report on uranium in the United States of Amcrica: U.S. Department of Energy Open-file Report GJO-111(80), 150 p.. 6 microfiche. [Available from U.S. Gcological Survey Books and Open-File Reports Section, P.O. Box 25425. Denver, CO 80225.] 


\section{ENERGY RESOURCES OF THE ROSWELL RESOURCE AREA}

The Permian Basin, one of the largest oil- and gasproducing basins in the United States, extends from West Texas into southeastem New Mexico (inset, pl. 3). Oil and gas has been discovered in this basin in 4,400 oil pools and 900 gas pools, and totals more than 90 billion barrels of oilin-place and 106 trillion $\mathrm{ft}^{3}$ of gas-in-place (Dolton and others, 1979; Ward and others, 1986). Part of the Northwestem Shelf of the Permian Basin is included within the Roswell Resource Area.

Oil-bearing horizons in the Permian Basin of southeastern New Mexico include rocks of the Ordovician, Silurian, Devonian, Pennsylvanian, and Permian Systems. Stratigraphic and (or) structural traps form oil pools in Permian strata in much of the Northwestem Shelf where it encompasses the southern part of the study area, and shelf or backreef facies are the predominant site for oil, especially in Permian dolomitized limestone. On the Northwestern Shelf, hydrocarbons are recovered from Cambrian to Cretaceous rocks, but most production is from Permian units.

On the Northwestem Shelf, deposits of the San Andres Formation and Artesia Group grade updip into siltstone, evaporite, and dolomite, which have higher average porosities than the nearby reef or fore-reef deposits. Back-reef environments in these units provide the primary reservoirs for much of the Permian Basin, especially at the updip contact of lagoonal dolomite and clastics with coastal evaporite. Most of the explored producing areas are in New Mexico, south and southeast of the study area. Exploration targets, however, include numerous structural and (or) stratigraphic traps in the study area, including Tucumcari Basin and the northern parts of the Northwestern Shelf. Two principal oiland-gas plays within the study area are described in a following section.

In southem New Mexico, oil and gas activity is complicated by potash mining and reserves (Cheeseman, 1978). Oil and gas production in the Carlsbad potash district of the Delaware Basin south of the study area is from the Yates and Queen Formations of the Artesia Group and from Pennsylvanian formations, all of which lie below the potash deposits (Cheeseman, 1978). Oil and gas exploration is restricted to potash-barren areas or areas that will not interfere with potash mining activities (Cheeseman, 1978).

In addition to oil and gas, other gases such as carbon dioxide are recovered during petroleum recovery or have been discovered during petroleum exploration. The potential for these associated gases in the study area is assessed in the "Nonhydrocarbon gas" section of this report.

A brief discussion of the coal resources in the study area is presented in the "Coal production and estimated resources" section of this report. In the Sierra Blanca Basin in the Lincoln County porphyry belt, coal has been mined from several horizons in the Mesaverde Formation. Most of the major coal mining ceased early in the twentieth century due, in part, to the lateral restriction of the coal beds by faulting.

\section{PETROLEUM GEOLOGY}

By Mahlon M.Balt, Gordon L. Dolton, Richard F. Mast,

Ronald R. Charpentier, Mitchell E. Henry, Keith Robinson, Craig J. Wandrey, Robert A. Crovelli.

Charles W. Spencer, and William C. Butler

\section{INTRODUCTION}

This discussion presents an analysis of the petroleum geology of the Roswell Resource Area. The initial section describes the geologic structure, including regional tectonic setting and local structural styles that determine configurations of hydrocarbon traps. The second section covers reservoirs and seals in the context of the area's stratigraphy. The third section treats source, maturation, and migration of petroleum. The fourth section deals with exploration and production history, including brief descriptions of typical, significant oil and gas fields and references to depositional environments, sediment body geometry, and composition, texture, diagenesis, porosity, and permeability of host rocks as they relate to hydrocarbon accumulation. Finally, we describe and analyze the study area's oil and gas plays, and estimate the quantity of undiscovered recoverable hydrocarbons.

\section{STRUCTURAL CONTROLS OF HYDROCARBON TRAPS}

The residual Bouguer gravity anomaly map of eastern New Mexico and West Texas (Keller and Hills, 1988) (fig. 42) shows a correlation of uplifts with positive residual anomalies, and a strong correlation of basins with negative residual anomalies for major structural elements of the study area (pl. 8). Positive anomalies running northward from central Lincoln County correlate with the Pedernal uplift. This positive trend branches at the northwest corner of Guadalupe 


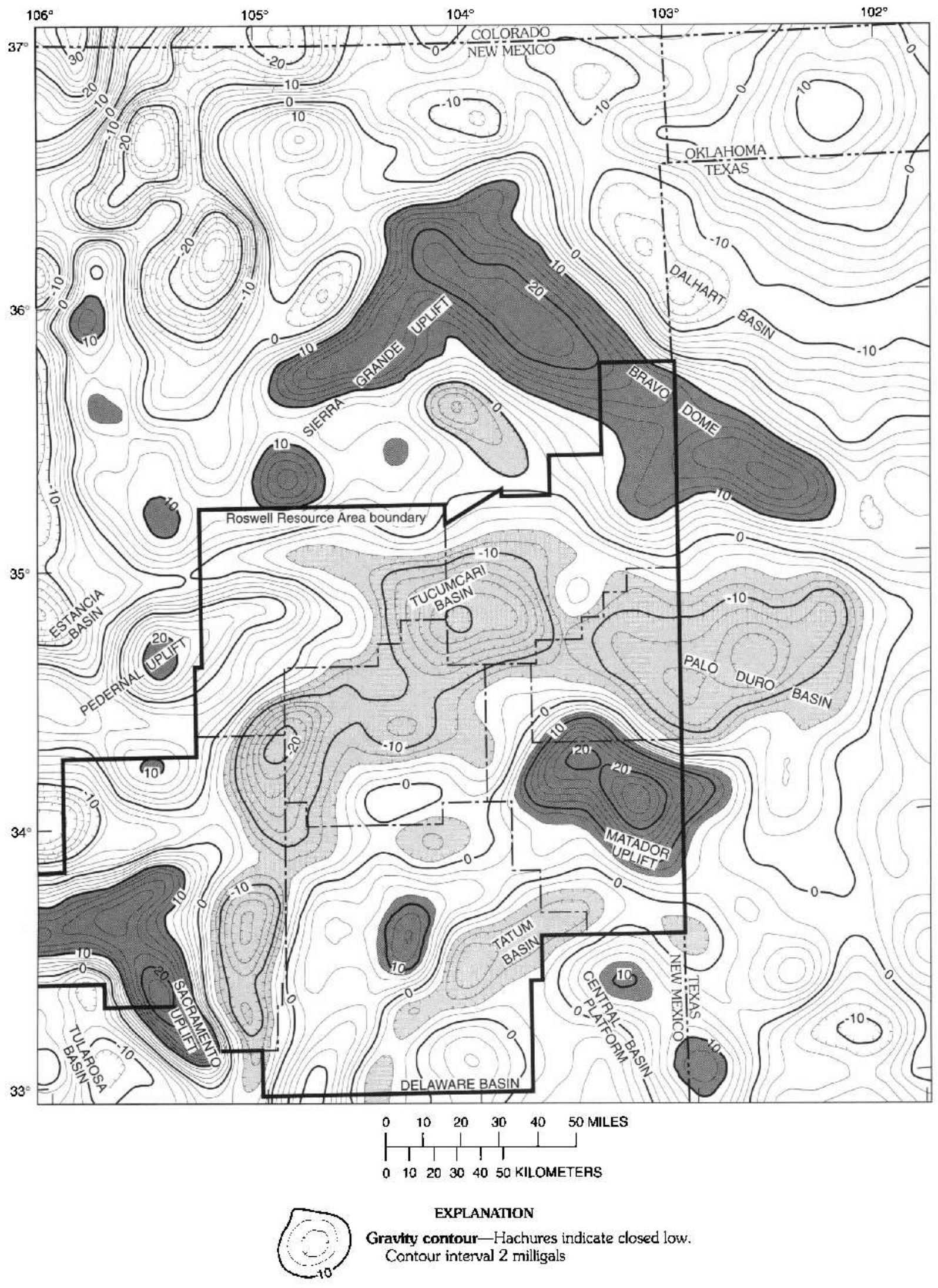

Figure 42. Residual Bouguer gravity anomaly map of eastern New Mexico and West Texas. Selected gravity highs and lows are shaded dark gray and light gray, respectively. This map was produced from 50,000 gravity readings, afler removal of a fifthorder polynomial suface. 
County. The northeastern branch follows the Sierra Grande uplift. At the juncture of the Sierra Grande uplift and the Bravo dome, the positive anomaly turns to the southeast and marks the dome's axial trend toward the northem tip of Quay County. A well-defined chain of negative anomalies curves westward from the Palo Duro Basin of Texas into the Tucumcari Basin of New Mexico, and bends southward through De Baca County into Lincoln County. A large positive anomaly centered in Roosevelt County includes the Roosevelt positive, which appears to be a westward continuation of the Matador uplift from Texas. Another trend of lows curves westward through the Tatum Basin and extends toward the southwest and south in Chaves County.

The magnitude of residual gravity anomalies is measured in tens of milligals. This exceeds, in most cases, the amount of anomaly that could reasonably be attributed to relief on basement rocks. It follows that the anomalies also reflect intrabasement density contrasts. High-density, moremafic, basement rock areas are associated with uplifts, and lower density basement materials underlie basins; therefore density contrasts that stem from lithology variations probably are attended by basement elevation differences due to a combination of differential erosion and faulting of the basement surface.

The main regional structural feature that essentially bounds the study area on the west and north is the Pedemal uplift and its northeastward and eastward continuations, the Sierra Grande uplift and Bravo dome. The history of this feature is complex. Thinning of lower Paleozoic strata toward its axis (pl. 2) indicates that the Pedernal uplift was a broad positive area or highland landmass of Precambrian rocks throughout early Paleozoic time. Major movement of the Pedernal uplift occurred during the late Paleozoic Ouachita orogeny, when it was part of the southern end of the Ancestral Rocky Mountain range. Major unconformities, known from surface and subsurface studies, provide evidence for episodic uplift and erosion of the Pedernal from Pennsylvanian through Early Permian time (pl. 2). Middle Permian strata continue across the uplift with only minor folding.

The history of the Pedernal uplift influenced the entire study area. The region was part of a broad shelf area during pre-Pennsylvanian time; pre-Mississippian strata were limited by erosion and nondeposition to southern De Baca, Roosevelt, and Chaves Counties. During late Paleozoic tectonic activity, the various uplifts and basins in the area acquired their present shapes, and the region was exposed from Late Permian to Cretaceous time. The late Cenozoic was a time of renewed uplift, when the region bounded by the Pedernal uplift-Sierra Grande uplift-Bravo dome system was tilted east (the present-day Pecos Slope). Regional tilting combines with stratigraphic configurations of depositional sequences in the study area to produce abundant stratigraphic traps for oil and gas. Uplift and tilting were accompanied by igneous activity, which was concentrated in southwestem Lincoln County during late Cenozoic time (the
Lincoln County porphyry belt). Although regional southward and eastward dips are the primary trapping control for the study area, some local structures also influence trapping. For instance, folding associated with the buckle zone of strike-slip faulting plays a role in formation of combination traps in Chaves County, and fault-bounded horst blocks may prove to be important in forming structural traps in Tucumcari Basin in Guadalupe and Quay Counties.

\section{RESERVOIRS AND SEAIS}

This section contains a description and discussion of important reservoirs and seals in the context of the regional stratigraphy of southeastern New Mexico. Paleozoic rocks in this region consist of four major stratigraphic intervals: prePennsylvanian, Pennsylvanian, Permian, and post-Permian units.

\section{PRE-PENNSYLVANIAN UNITS}

Relatively thin $(0-2,500 \mathrm{ft})$ pre-Pennsylvanian units are composed primarily of dolomite (pl. 2). Facies pattems within these rocks are indicative of deposition in a broad carbonate shelf environment. Rocks of the lower Paleozoic onlap toward the north. In the subsurface of central Chaves County, the updip limits of the Lower Ordovician Ellenburger Group, the Middle Ordovician Simpson Group, and the Upper Ordovician Montoya Dolomite are found, whereas Silurian and Devonian formations pinch out farther north near the Chaves County-De Baca County line. Lower and Upper Mississippian rocks continue into the Tucumcari Basin as the Arroyo Peñasco Group.

Dolomite units (Silurian Fusselman Dolomite and Wristen Formation) provide the only significant reservoirs [cumulative production exceeding 1 million barrels of oil equivalent (MMBOE)] within the pre-Pennsylvanian section of the study area (pl. 2). Accumulations of oil and gas from these reservoirs typically occur on the flanks of Precambrian basement highs and are sealed by Pennsylvanian shale beds.

\section{PENNSYLVANIAN UNITS}

Pennsylvanian limestone units thin updip onto the Pedemal uplift. In southem Chaves County, these beds have a combined thickness of approximately $2,000 \mathrm{ft}$ (pl. 2). Pennsylvanian rocks show early indications of the existence of a platform edge near the Chaves County-Eddy County line, where shelf limestone to the north grades into the basinal shale to the south.

Within the Pennsylvanian section, three series are significant producers. Updip Morrowan and Atokan quartz sandstone units produce gas from stratigraphic traps sealed by shale beds. Virgilian (lower part, Cisco Group) limestone units are important oil producers with lesser amounts of gas. These fields owe their trapping configurations to combinations of updip stratigraphic pinchouts and drape-overbasement structures. 


\section{PERMIAN UNITS}

The massive Permian section, changing in thickness from $10,000 \mathrm{ft}$ near the prograding platform edge in central Eddy County to $5,500 \mathrm{ft}$ in central De Baca County (the northern end of the regional section, pl. 2), contains a great variety of depositional facies. In all Pemnian stratigraphic divisions, the predominantly limestone platform-edge facies separates downdip (southem) basinal quartz clastic, carbonate, and evaporite beds from updip (northem) shelf dolomite beds, which contain more terrigenous sand, shale, and evaporite deposits.

Three Permian series contain reservoirs whose cumulative production exceeds $1 \mathrm{MMBOE}$. Wolfcampian limestone units produce gas and minor liquids from stratigraphic traps sealed by interbedded shale units. Sandstone units in the Leonardian part of the Abo Formation are important gas producers within the study area. Shale within this series provides adequate seals for both stratigraphic and combination structural and stratigraphic traps. Dolomite beds of Guadalupian age in the San Andres Formation constitute the most prolific oil producers of this region, and also produce significant quantities of gas. The extremely effective anhydrite seals within the San Andres Formation are major factors in the importance of this unit as a reservoir rock. Trap configuration in the San Andres is a combination of stratigraphic and drape-over-basement structures. Quartz sandstone beds in the Guadalupian Queen Formation are the youngest significant Permian reservoirs of the study area. Both anhydrite and salt serve to seal the predominantly stratigraphic traps characteristic of hydrocarbon accumulations in the Queen Formation. Oil is much more important than gas in these reservoirs.

\section{POST-PERMIAN UNITS}

The Triassic Santa Rosa Sandstone, a quartzose sandstone in the basal part of the Dockum Group, is another potential reservoir rock of the study area. This formation has a role in a speculative play in the Tucumcari Basin and has large resources of heavy oils and tar sands.

\section{HYDROCARBON SOURCE, MATURATION, AND MIGRATION}

Few published studies deal with hydrocarbon source, maturation, and migration in the Permian Basin, but lack of exploration success in the distal limits of the Northwestern Shelf of the Permian Basin makes understanding source a necessity. An early and useful analysis of oils in Lower Ordovician Ellenburger Group reservoirs (Kvenvolden, 1966) identified five families of hydrocarbons whose sources were judged to range in age from Ordovician to
Permian. Parke (1974) concluded that the distribution of condensate versus dry gas in the Ellenburger was consistent with the accepted roles of temperature and time in the maturation of hydrocarbons. Stahl and Carey (1975) concluded that the Upper Devonian and Lower Mississippian Woodford Shale was the source for Ellenburger hydrocarbons and that Permian shale beds were the source of hydrocarbons in Atokan sandstone reservoirs updip. In both cases, younger source rocks in downdip basinal settings were deemed to charge older reservoirs in updip settings with oil and gas. Although there are few published studies relating reservoir oil and gas to source beds in the Permian Basin, geochemical typing makes it seem likely that organic-carbon-rich formations in basinal settings, like the Woodford Shale and various shale beds of Pennsylvanian and Permian age, are the sources for the huge accumulations of oil and gas in the basins, platform edges, and shelves of the Permian Basin region.

Broadhead and King (1988) and Broadhead (1990a) documented the occurrence of mature source rocks in Pennsylvanian shale in the Tucumcari Basin in the northern part of the study area. These studies suggest that the Pennsylvanian shale beds have supplied the Triassic Santa Rosa Sandstone in Guadalupe County with 90 million barrels (MMB) of tar-in-place at Santa Rosa and 60 MMB of heavy oil-in-place at Newkirk. Such conclusions provide positive evidence that the Tucumcari Basin is a viable exploration setting.

Migration paths require permeable beds extending updip, or nonsealing faults connecting permeable strata at different structural levels. The time of migration or remigration of hydrocarbons clearly cannot predate the ages of the reservoirs and seals that hold and trap them. The youngest reservoir charged with petroleum is the Triassic quartz-rich Santa Rosa Sandstone. This reservoir is imperfectly sealed and hydrocarbons in it near Santa Rosa are exposed on the surface as tar sand.

The tilt responsible for the Pecos Slope, which dips eastward on the eastem flank of the Pedemal uplift (pl. 2), occurred during late Cenozoic tectonism, and, thus, hydrocarbons trapped in updip pinchouts on this slope necessarily migrated or remigrated to their present positions at that time.

\section{EXPLORATION AND PRODUCTION HISTORY}

Twenty oil fields and 12 gas fields in the study area (pl. 15) each have a cumulative production, through 1988, exceeding $1 \mathrm{MMBOE}$ [ 6 billion feet $^{3}$ (BCF) of gas equals 1 MMB of oil] (tables 18, 19). Total liquids (oil plus natural gas liquids) recovered from these fields are $225 \mathrm{MMB}$. Total gas amounts to $830 \mathrm{BCF}$ (Roswell Geological Society, 1988; New Mexico Department of Energy, Minerals and Natural Resources, 1990; Hill, 1988; NRG Associates, Inc., 1990). 
Table 18. Geologic, engineering, and production parameters of oil fields exceeding cumulative production of I million barrels of oil equivalency through 1988, in the Roswell Resource Area, New Mexico

|Trap type: Strat, stratigraphic; comb, structural/stratigraphic. kmd, permeabilily in milliłarcies; $\mathrm{H}$, horizontal; $\mathrm{V}$, vertical. NGL, natural gas liquids. Miscellaneous: >N2, high nitrogen (>55\%); sour, high sulfur content; swect, low sulfur content; To bottom hole temperature in degrees Fahrenheit; GOR, gas to oil ratio in cubic feet per barrel. Leaders (--), not teported]

\begin{tabular}{|c|c|c|c|c|c|c|c|c|c|c|c|c|c|c|}
\hline Field name & County & Reservoir & $\begin{array}{l}\text { Discovery } \\
\text { date }\end{array}$ & $\begin{array}{l}\text { Depth to } \\
\text { top (ft) }\end{array}$ & $\begin{array}{l}\text { Trap } \\
\text { type }\end{array}$ & $\begin{array}{l}\text { Net pay } \\
\text { thickness } \\
\text { (ft) }\end{array}$ & $\begin{array}{c}\text { Porosity } \\
(\%)\end{array}$ & kmd & $\begin{array}{c}\text { API } \\
\text { gravity } \\
\text { (degrees) }\end{array}$ & Drive & $\begin{array}{c}\text { Initial } \\
\text { pressure } \\
\text { (psi) }\end{array}$ & $\begin{array}{l}\text { Oil and NGL } \\
\text { cumulative } \\
\text { production } \\
\text { (MMBOE) }\end{array}$ & $\begin{array}{c}\text { Gas } \\
(\mathrm{BCF})\end{array}$ & Miscellaneous \\
\hline Caprock & Chaves & $\begin{array}{l}\text { Queen Formation } \\
\text { sandstone. }\end{array}$ & 1940 & 2,971 & Strat & 10 & 21 & $\begin{array}{l}250 \mathrm{H} \\
150 \mathrm{~V}\end{array}$ & 38 & $\begin{array}{l}\text { Solution } \\
\text { gas. }\end{array}$ & 900 & 74 & - & $\begin{array}{l}\mathrm{S}=1.07 \%,>\mathrm{N}_{2} . \\
\mathrm{TO}=154 .\end{array}$ \\
\hline Allison & Roosevelt & $\begin{array}{l}\text { Virgilian limestone } \\
\text { Cisco Group. }\end{array}$ & 1954 & 9,490 & Comb & 11 & 7 & 200 & 48 & Water & - & 26 & 51 & Sweet. \\
\hline Chaveroo & Roosevelt & $\begin{array}{l}\text { San Andres } \\
\text { Formation dolomite. }\end{array}$ & 1965 & 4.184 & Comb & 40 & 6 & 0.7 & 26 & $\begin{array}{l}\text { Solution } \\
\text { gas. }\end{array}$ & 1,340 & 26.2 & 31.4 & $\begin{array}{l}\text { Sour, GOR }=810 \\
T O=110\end{array}$ \\
\hline Cato & Chaves & $\begin{array}{l}\text { San Andres } \\
\text { Formation dolomite. }\end{array}$ & 1966 & 3.496 & Comb & 33 & 8 & 1.0 & 26 & $\begin{array}{l}\text { Solution } \\
\text { gas, water. }\end{array}$ & 1.116 & 17.4 & 30 & Sour, $T O=100$. \\
\hline Miłnesand & Roosevelt & $\begin{array}{l}\text { San Andres } \\
\text { Formation dolomite. }\end{array}$ & 1958 & 4,534 & Strat & 40 & $B$ & 1.0 & 29 & $\begin{array}{l}\text { Solution } \\
\text { gas, water. }\end{array}$ & 1,100 & 14.5 & 14.7 & Sour, $T 0=90$. \\
\hline Tobac & Chaves & $\begin{array}{l}\text { Virgilian limestone } \\
\text { Cisco Group. }\end{array}$ & 1964 & 9,058 & Comb & 10 & 7 & 100 & 44 & $\begin{array}{l}\text { Solution } \\
\text { gas, water. }\end{array}$ & 3.083 & 10.1 & 12.4 & Sweet. \\
\hline Vada & Roosevelt & $\begin{array}{l}\text { Virgilian limestone } \\
\text { Cisco Group. }\end{array}$ & 1966 & 9,792 & Strat & 10 & 8 & 150 & 47 & $\begin{array}{l}\text { Solution } \\
\text { gas. water. }\end{array}$ & 2.800 & 9.4 & 26.6 & Sweet, $T^{0}=145$. \\
\hline Todd & Roosevelt & $\begin{array}{l}\text { San Andres } \\
\text { Formation dolomite. }\end{array}$ & 1963 & 4,202 & Comb & 40 & 4 & - & 24 & $\begin{array}{l}\text { Solution } \\
\text { gas. }\end{array}$ & 1,339 & 4.0 & 19.2 & Sour, $T^{0}=102$ \\
\hline Twin Lakes & Chaves & $\begin{array}{l}\text { San Andres } \\
\text { Formation dolomite. }\end{array}$ & 1950 & 4,266 & Comb & - & 7 & - & 24 & $\begin{array}{l}\text { Solution } \\
\text { gas. }\end{array}$ & 700 & 4.8 & 5.4 & Sour, $T^{O=100}$ \\
\hline $\begin{array}{l}\text { Peterson } \\
\text { South. }\end{array}$ & Roosevelt & $\begin{array}{l}\text { Silurian dolomite, } \\
\text { Virgilian limestone. }\end{array}$ & 1978 & 7,808 & Comb & 10 & 8 & 20 & 46 & $\begin{array}{l}\text { Sölution } \\
\text { gas. }\end{array}$ & 2,634 & 4.3 & 15.3 & Sweet. $T O=152$. \\
\hline $\begin{array}{l}\text { Prairie } \\
\text { South. }\end{array}$ & Roosevelt & Virgilian limestone & 1960 & 9.651 & Comb & 24 & 6 & 90 & 49 & Water & 3,159 & 4.0 & 6.9 & Sweet, $T^{0 \pm} 186$. \\
\hline Bluitt & Roosevelt & $\begin{array}{l}\text { San Andres } \\
\text { Formation dolomite. }\end{array}$ & 1951 & 4,500 & Comb & 30 & 8 & 5 & 27 & $\begin{array}{l}\text { Solution } \\
\text { gas. }\end{array}$ & 1.515 & 4.0 & 14.7 & Sour, $T^{O=}=105$. \\
\hline Double L & Chaves & $\begin{array}{l}\text { Queen Formation } \\
\text { sandstone. }\end{array}$ & 1969 & 1.920 & Strat & 6 & 22 & 40 & 35 & $\begin{array}{l}\text { Gas cap. } \\
\text { solution gas. }\end{array}$ & 743 & 3.9 & 5.8 & $>\mathrm{N}_{2}, \mathrm{~T}^{\mathrm{O}}=84$. \\
\hline Tom Tom & Chaves & $\begin{array}{l}\text { San Andres } \\
\text { Formation dolomite. }\end{array}$ & 1967 & 3,914 & Comb & 20 & 7 & 2 & 25 & $\begin{array}{l}\text { Solution } \\
\text { gas. }\end{array}$ & 1,192 & 3.2 & 2.0 & Sour, $\mathrm{T}^{\mathrm{O}}=100$ \\
\hline Peterson & Roosevelt & Virgilian limestone & 1971 & 7,542 & Comb & - & - & - & 35 & - & - & 1.6 & 5.7 & - \\
\hline Tomahawk & Chaves & $\begin{array}{l}\text { San Andres } \\
\text { Formation dolomite. }\end{array}$ & 1967 & 3,914 & Comb & 22 & 7 & - & 26 & $\begin{array}{l}\text { Solution } \\
\text { gas. }\end{array}$ & 1,302 & 2.2 & 1.9 & Sour, $\mathrm{T}^{\mathrm{O}}=102$. \\
\hline Sulimar & Chaves & $\begin{array}{l}\text { Queen Formation } \\
\text { sandstone. }\end{array}$ & 1968 & 2,028 & Strat & 6 & 20 & 150 & 35 & $\begin{array}{l}\text { Solution } \\
\text { gas. }\end{array}$ & - & 2.3 & 0.8 & $>\mathrm{N}_{2}$. \\
\hline Milnesand & Roosevelt & Virgilian limestone & 1956 & 9,125 & Comb & - & 3.6 & 1.4 & 44 & $\begin{array}{l}\text { Solution } \\
\text { gas. }\end{array}$ & - & 1.0 & 1.7 & Sweet. \\
\hline Diablo & Chaves & $\begin{array}{l}\text { San Andres } \\
\text { Formation dolomite. }\end{array}$ & 1962 & 2,060 & - & - & - & - & 30 & - & - & 1.0 & - & - \\
\hline Bluitt & Roosevelt & Silurian-Devonian & 1987 & 8,845 & - & - & - & - & - & - & - & 1.0 & - & - \\
\hline
\end{tabular}


Table 19. Geologic, engineering, and production parameters of gas fields exceeding cumulative production of 1 million barrels of oil equivalency (6 BCF=1 MMBOE) through 1988, in the Roswell Resource Area, New Mexico

[Trap type: Strat, stratigraphic; struct, struetural; comb, structural/stratigraphic. kmd, permeability in millidarcies. NGL, natural gas liquids. Miscellaneous: T $T^{b}$, bottom hole temperature in degrees Fahrenheit. Leaders (--), not reported]

\begin{tabular}{|c|c|c|c|c|c|c|c|c|c|c|c|c|c|c|}
\hline Field name & County & Reservoir & $\begin{array}{l}\text { Discovery } \\
\text { date }\end{array}$ & $\begin{array}{c}\text { Depth to } \\
\text { top (ft) }\end{array}$ & $\begin{array}{l}\text { Trap } \\
\text { type }\end{array}$ & $\begin{array}{c}\text { Net pay } \\
\text { thickness } \\
\text { (ft) }\end{array}$ & $\begin{array}{c}\text { Porosity } \\
(\%)\end{array}$ & $\mathrm{km}$ & $\begin{array}{c}\text { API } \\
\text { gravity } \\
\text { (degrees) }\end{array}$ & Drive & $\begin{array}{c}\text { Initial } \\
\text { pressure } \\
\text { (psi) }\end{array}$ & $\begin{array}{l}\text { Oil and NGL } \\
\text { cumulative } \\
\text { production } \\
\text { (MMBOE) }\end{array}$ & $\begin{array}{c}\text { Gas } \\
\text { (BCF) }\end{array}$ & Miscellaneous \\
\hline Pecos Slope & Chaves & $\begin{array}{l}\text { Abo Formation } \\
\text { sandstone. }\end{array}$ & 1977 & 4,406 & Strat & 30 & 13 & $\begin{array}{l}0.03- \\
0.05\end{array}$ & 54 & $\begin{array}{l}\text { Solution } \\
\text { gas. }\end{array}$ & 1,125 & 4.0 & 261 & Tight gas. \\
\hline $\begin{array}{l}\text { Buffalo } \\
\text { Valley. }\end{array}$ & Chaves & Atokan sandstone & 1959 & 8.181 & Strat & 22 & 12 & High & 61.5 & $\begin{array}{l}\text { Solution } \\
\text { gas. }\end{array}$ & 3.282 & 0.9 & 132 & $T^{\circ}=135$ \\
\hline $\begin{array}{l}\text { Bluitt } \\
\text { (Wolfcamp). }\end{array}$ & $\begin{array}{l}\text { Roosevelt } \\
\text { limestone. }\end{array}$ & Wolfcampian & 1959 & 8,022 & Strat & 36 & 13 & 80 & 50 & $\begin{array}{l}\text { Solution } \\
\text { gas. }\end{array}$ & - & 0.5 & 36 & - \\
\hline Foor Ranch & Chaves & $\begin{array}{l}\text { Silurian Fusselman } \\
\text { Dolomite. }\end{array}$ & 1981 & 6,154 & Struct & 10 & 13 & - & - & Water & 2,377 & 0.1 & 36 & $T^{\circ}=120$. \\
\hline $\begin{array}{l}\text { Pecos Slope } \\
\text { West. }\end{array}$ & Chaves & $\begin{array}{l}\text { Abo Formation } \\
\text { sandstone. }\end{array}$ & 1980 & 2.923 & Strat & 20 & 14 & 0.3 & - & $\begin{array}{l}\text { Solution } \\
\text { gas. }\end{array}$ & - & 0.5 & 30 & - \\
\hline $\begin{array}{l}\text { Pecos Slope } \\
\text { South. }\end{array}$ & Chaves & $\begin{array}{l}\text { Abo Formation } \\
\text { sandstone. }\end{array}$ & 1979 & - & Strat & - & 14 & 0.3 & - & $\begin{array}{l}\text { Solution } \\
\text { gas. }\end{array}$ & - & 0.5 & 25.5 & - \\
\hline $\begin{array}{l}\text { Little Lucky } \\
\text { Lake. }\end{array}$ & Chaves & $\begin{array}{l}\text { Silurian and Devonian } \\
\text { dolomite. }\end{array}$ & 1958 & 11,050 & Comb & 84 & 6 & 55 & - & - & - & 2.1 & 13.2 & - \\
\hline $\begin{array}{l}\text { Diamond } \\
\text { Mound. }\end{array}$ & Chaves & $\begin{array}{l}\text { Atokan-Morrowan } \\
\text { sandstone. }\end{array}$ & - & - & - & - & - & - & - & - & - & 0.4 & 23.3 & - \\
\hline Tule & Roosevelt & $\begin{array}{l}\text { Pennsylvanian } \\
\text { limestone. }\end{array}$ & 1986 & 6,759 & Comb & 10 & - & - & 62 & - & - & 0.1 & 9.0 & - \\
\hline $\begin{array}{l}\text { Springer } \\
\text { Basin. }\end{array}$ & Chaves & $\begin{array}{l}\text { Atokan-Morrowan } \\
\text { sandstone. }\end{array}$ & 1979 & 8,050 & Strat & 8 & 13 & - & 62.5 & $\begin{array}{l}\text { Solution } \\
\text { gas. }\end{array}$ & 3,000 & 0 & 7.8 & $T^{\circ}=145$. \\
\hline Haystack & Chaves & $\begin{array}{l}\text { Virgilian limestone } \\
\text { [Cisco Group]. }\end{array}$ & 1970 & 5,832 & Comb & 11 & 7 & 13 & 56.5 & $\begin{array}{l}\text { Solution } \\
\text { gas, water. }\end{array}$ & 2,421 & 0.1 & 6.3 & $\mathrm{~T}^{\circ}=112$ \\
\hline Vest Ranch & Chaves & $\begin{array}{l}\text { Queen Formation } \\
\text { sandstone. }\end{array}$ & 1971 & 5,999 & - & 2 & - & - & - & - & - & 0.3 & 4.1 & - \\
\hline
\end{tabular}


Almost all of this oil and gas production has occurred in Chaves and Roosevelt Counties, the two southeasternmost counties of the study area; Chaves County contained 57 percent of the liquids and 72 percent of the gas. A significant amount of the total gas ( $245.9 \mathrm{BCF}, 30$ percent) is associated with oil fields, whereas only $9.5 \mathrm{MMBOE}$ ( 4 percent) of total liquids come from the gas fields. Caprock field, discovered in 1940, has produced 33 percent of the oil in the study area. Fields discovered in the 1950's have produced 24 percent of the regions oil. The 1960's was the decade of discovery for most of the oil produced to date, at a total of 88.6 MMB, constituting 39 percent of the total for the area. Only 3 percent of the oil produced is from fields found in the 1970's, and only 1 percent is from fields discovered in the 1980's. This history of oil production indicates that oil exploration activity in the study area is in a mature stage, which is characteristic of the entire Permian Basin (Robinson, 1988).

The Pecos Slope gas fields (Pecos Slope, Pecos Slope West, and Pecos Slope South), discovered from 1977 to 1980 , have produced $317 \mathrm{BCF}$ of gas (38 percent of the area's total), and most (261 BCF) occurred in Pecos Slope field proper. Other fields having produced 33 percent of the area's total gas were discovered in the 1950's. Sixteen percent of the area's gas was discovered during the 1960's, 39 percent during the 1970 's, and 12 percent during the 1980's.

Production figures for the major stratigraphic intervals are as follows: 6.2 million barrels of oil (MMBO) (3 percent) and 51.2 BCF ( 6 percent) from pre-Pennsylvanian (SilurianDevonian) dolomite reservoirs; 55.9 MMBO (25 percent) and 296.3 BCF (36 percent) from Pennsylvanian quartz sandstone and limestone reservoirs; and 163 MMBO (72 percent) and 482.5 BCF ( 58 percent) from Permian quartz sandstone and dolomite reservoirs. Permian oil production is more or less evenly divided among nine dolomite reservoir fields in the San Andres Formation and the single quartz sandstone reservoir in the Queen Formation at the Caprock field. Most Permian gas is associated with the nine San Andres fields. There are essentially no records of gas production from the Queen Formation sandstone at Caprock, although this field is reported to have solution gas drive. Production breakdown by reservoir lithology is $83.5 \mathrm{MMBO}$ (37 percent) and $170.5 \mathrm{BCF}$ (21 percent) in dolomite reservoirs, 86.8 MMBO (39 percent) and 490.2 BCF ( 59 percent) in quartz sandstone reservoirs, and $55.1 \mathrm{MMBO}$ (24 percent) and 169.3 BCF (20 percent) in limestone reservoirs.

Perhaps the most meaningful statistic available from our study of oil and gas fields in the study area involves initial reservoir pressures versus depth. A normal hydrostatic pressure gradient ranges from 0.43 to $0.47 \mathrm{psi} / \mathrm{ft}$ depth, depending on salinity. It is clear that all of the study area's oil and gas fields are underpressured. This observation is typical of shallow, uplifted, cooled hydrocarbon reservoirs (Spencer, 1988). As pointed out by Spencer (1988), lowpressured reservoirs can cause exploration and production problems. Deep mud and filtrate invasion can make log identification of hydrocarbons difficult. Underpressured gas

\author{
EXPLANATION \\ Oil and gas fields \\ Penn $V$ Distribution of oil fields producing from Virgilian (or \\ lower part of Cisco Groupl limestone \\ SA Distribution of oil fields producing from Guadalupian \\ dolomite in the San Andres formation \\ Q Distribution of oil fields producing from Guadalupian \\ quartz sandstone in the Queen Formation \\ Penn MA Distribution of gas fields producing from Pennsylva- \\ nian Morrowan and Atokan quartz sandstone \\ A Distribution of gas fields producing from Leonardian \\ quartz sandstone in the Abo Formation
}

Figure 43 (above and facing page). Plan distribution of Pennsylvanian and Permian oil and gas fields of the Roswell Resource Area and vicinity, New Mexico-Texas (modified from Roswell Geological Society, 1988).

reservoirs often yield poor or no shows, even when mudlogging equipment is used, and drill-stem tests can be inconclusive.

The plan distribution of Pennsylvanian and Permian oil and gas fields reveals broad groupings that appear to be related to regional structure (fig. 43). Oil fields producing from the Virgilian (or lower Cisco) limestone trend east-west in southernmost Roosevelt County (labeled Penn V, fig. 43) and bend to a north-south trend in Lea County. This bend marks a change in regional strike from east-west in the north along the southem flank of the Roosevelt positive (northern flank of Tatum Basin, pl. 3) to the north-northeast strike of the Pecos Slope. Oil fields producing from the Guadalupian dolomite in the San Andres Formation (labeled SA, fig. 43), north of the Virgilian limestone, have east-west alignments in the east, reflecting strike along the Roosevelt positive, but give way to north-south orientations in the west, reflecting strike of the Pecos Slope. The isolated cluster of oil fields in San Andres dolomite in central Chaves County (also labeled SA, fig. 43) extends east-west, but individual fields in this cluster trend north-south in response to the strike of the Pecos Slope. Oil fields producing from the Guadalupian quartz sandstone in the Queen Formation in southeasternmost Chaves County (labeled Q, fig. 43) are aligned along the Pecos Slope strike. This trend is also apparent in the Pennsylvanian Morrowan and Atokan quartz sandstone gas reservoirs (labeled Penn MA, fig. 43), including Buffalo Valley field located just west of the accumulations in the Queen Formation on the southem Chaves County line. The quartz sandstone gas fields of northwestern Chaves County in the Leonardian part of the Abo Formation (labeled A, fig. 43) are also aligned north-south along the Pecos Slope strike. Gas accumulations generally occupy updip positions relative to oil. 


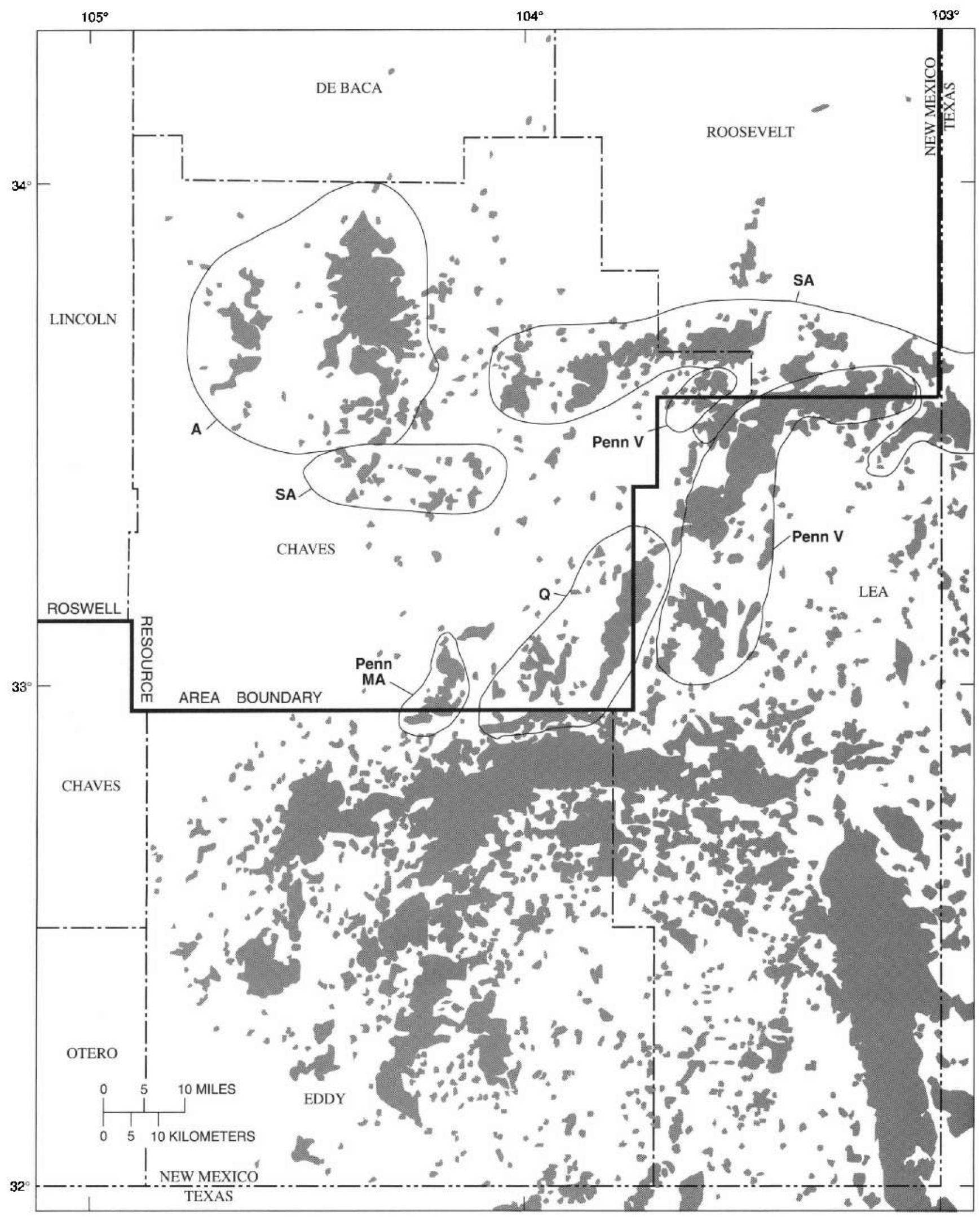




\section{A SYNOPSIS OF TYPICAL FIELDS}

This section presents brief descriptions of four fields that typify stratigraphic units and production groupings within the study area.

\section{PETERSON AND PETERSON SOUTH FIELDS}

The Peterson and Peterson South fields (pl. 15) are typical of pre-Pennsylvanian oil and gas accumulations of the study area in that they do not occur in any production grouping and instead appear to be randomly distributed. This may be a result of the low drilling density of pre-Pennsylvanian prospects.

The Peterson and Peterson South fields were discovered in the 1970's and have produced relatively minor gas and oil from limestone beds of the Upper Pennsylvanian or Missourian and Virgilian Series (Canyon and Cisco Groups). The fields occur above more important oil production in the Silurian Fusselman Dolomite. Field extensions have merged these fields into a producing area, extending 5 mi north-south and 2 mi east-west.

Trap configuration is controlled by a local structure consisting of a faulted basement high (Green and Schlueter, 1989) that was uplifted and eroded during Early Pennsylvanian time. Upper Pennsylvanian Series (Canyon and Cisco Groups) sediments were draped over this Precambrian basement on the structures crest, and truncated pre-Pennsylvanian rocks are located on the structure's flanks. There is some indication that this structure existed as early as the time of deposition of the lower part of the Fusselman, because the upper part of the Fusselman is only present on the downthrown side of the western boundary fault. Thickness variations in the Lower Pennsylvanian section on the structure confirm post-Mississippian and Early Pennsylvanian tectonic activity. Maximum structural closure on Upper Pennsylvanian beds is $170 \mathrm{ft}$; throw on the western boundary fault is approximately $100 \mathrm{ft}$.

The Pennsylvanian reservoir consists of shelf limestone units that contain collapse breccias sealed by Wolfcampian shale beds. Gross reservoir thickness is about $100 \mathrm{ft}$, and the average pay thickness is $30 \mathrm{ft}$. Porosity averages 12 percent and permeabilities are measured in a few hundred millidarcies. The Virgilian carbonate reservoir has a combined structural and stratigraphic trap configuration that is typical of other Pennsylvanian reservoirs in the study area, with the exception that at Peterson it is an isolated outlier, whereas most other Pennsylvanian limestone reservoirs are grouped in southern Roosevelt County (fig. 43).

The Fusselman Dolomite reservoir is a coarsely crystalline dolomitized shelf carbonate mudstone having a gross thickness of $100 \mathrm{ft}$ and a pay thickness of $40 \mathrm{ft}$. The pay zone lies in the lower part of the Fusselman Dolomite (Green and Schlueter, 1989) (pl. 2). The Devonian and Mississippian Woodford Shale overlies the Wristen Formation on the flank of the structure. The Woodford Shale could provide the source for the hydrocarbons in both Peterson fields. The truncated updip end of the Fusselman Dolomite reservoir is sealed by Upper Pennsylvanian shale beds.

\section{PECOS SLOPE FIELDS}

The complex of Pecos Slope fields (A, fig. 43) was discovered in 1977 as a result of reworking and relogging an exploration well originally abandoned in 1951 (Bentz, 1988). The field's dimensions are large. The combined Pecos Slope and Pecos Slope South fields extend $36 \mathrm{mi}$ north-south and $15 \mathrm{mi}$ east-west. Included are $215 \mathrm{mi}^{2}$ of producing acreage. Depth of production is $3,500 \mathrm{ft}$. The traps are westerly directed porosity pinchouts of very fine grained sandstone and siltstone beds encased in shale beds of the Leonardian part of the Abo Formation.

Regional east dip of the Pecos Slope in the field area varies from 50 to $100 \mathrm{ft} / \mathrm{mi}$ (slope of $0.5^{\circ}-1.0^{\circ}$ ). A rightlateral buckle zone (pl. 3) passes through the field area, but does not appear to influence hydrocarbon accumulation. The net reservoir interval varies from $500 \mathrm{ft}$ in the east to a wedge edge on the Precambrian basement in the west.

Reservoir lithology consists of quartzose red-bed sandstone beds inferred to have been deposited in a distal-fluvial environment (Bentz, 1988), although this environmental interpretation is controversial. Anastomosing "channels" traverse almost the entire 35-mi north-south dimension of the field. The "channels" are about $1 \mathrm{mi}$ wide and tens of feet thick, have concave-downward cross sections, and are composed of numerous branches inferred to have been deposited by north-flowing streams. The very fine grained sandstone and siltstone beds are the pay zones in the field, but spaces between the grains may be plugged with anhydrite, dolomite, clay, and (or) calcite cement. Porosity averages 13 percent and permeability ranges from 0.3 to 0.03 millidarcies.

Both the pressure and compositional characteristics of the gas in the Pecos Slope field indicate connected migration of the gas throughout the field complex. However, the westem part of the Pecos Slope field (Pecos Slope West field) is separated from the main field complex by a nonproducing zone.

Because of the very low permeabilities in the Pecos Slope fields, the hydrocarbons present qualify as "tight gas" under the Natural Gas Policy Act of 1978; under this legislation, production qualified for a subsidized price of $\$ 5.00 /$ $1,000 \mathrm{ft}^{3}$. This preferential treatment of tight gas was responsible for the rapid expansion in development of the Pecos Slope region. In 1985, deregulation and an end to subsidization of tight gas resulted in considerable cutback in development.

The hydrocarbons have an API gravity of $54^{\circ}$ and gas expansion drive, and are dry, with a gas/liquid ratio of 2.5 million $\mathrm{ft}^{3} /$ barrel. The Leonardian Bone Spring Limestone in the Delaware Basin and Pennsylvanian shale in closer proximity to the Pecos Slope fields have been postulated as sources for these dry gas accumulations. 


\section{CHAVEROO FIELD}

The Chaveroo field, discovered in 1966, is representative of dolomite production in the Leonardian and Guadalupian San Andres Formation (pl. 15). The field trends eastwest in southem Roosevelt County, extends into Chaves County (SA, fig. 43), and is about $12 \mathrm{mi}$ wide and $5 \mathrm{mi}$ long. Producing acreage exceeds $30 \mathrm{mi}^{2}$. The average depth of producing zones is about $4,200 \mathrm{ft}$.

Trap configuration is the result of the interplay of stratigraphic, structural, and hydrodynamic conditions (Gratton and LeMay, 1969). Depositional dip was toward the south and resulted in pinchouts to the north of porous, dolomitized, platform-interior carbonate beds between salt-bearing anhydrite beds. Subsequent eastward tilting superimposed an eastward dip of about $50 \mathrm{ft} / \mathrm{mi}$ on the dolomite of the San Andres Formation; the tilted zone most critical to production extends from the Pecos River in central Chaves County to the Texas line. The eastward dip, in combination with northward pinchout of reservoir facies and north dip off the Roosevelt positive into the Tatum Basin, constitute two critical elements of trap formation at Chaveroo. The third element is hydrodynamic flushing through San Andres Formation reservoir intervals. This eastward water movement resulted in tilt to the east of oil-water contacts in excess of $30 \mathrm{ft} / \mathrm{mi}$ (Gratton and LeMay, 1969). The net result is that the water contact is the basal seal on the westward updip margin of the hydrocarbon accumulations at Chaveroo. In light of the influence of hydrodynamic flushing in this trend, it is possible that San Andres oil first accumulated in northbound, updip porous pinchouts in post-Guadalupian time. The introduction of eastward tilt in the Cenozoic must have resulted in westward remigration into stratigraphic traps on the Pecos Slope adjacent to the Pedernal uplift (pl. 2). This is consistent with the plan configuration of east-west-aligned fields to the east and north-south-aligned fields to the west that is apparent in the San Andres trend of southern Roosevelt and Chaves Counties (fig. 43).

The reservoir consists of porous dolomite originally deposited in shallow-marine to transitional-evaporitic environments. Interfingering of lagoonal, tidal-flat, and openmarine limestone, dolomite, anhydrite, and salt occurs throughout the section. Pay sections are measured in tens of feet. Porosities average 6 percent and permeabilities average 1 millidarcy. Hydrocarbons of this field have API gravities in the low $20^{\circ} \mathrm{s}$ and are soured by considerable hydrogen sulfide (typical of all of the San Andres fields).

\section{CAPROCK FIELD}

The Caprock field, discovered in 1940, occurs in southeastern Chaves County and northwestern Lea County $(Q$, fig. 43). The reservoir is at a depth of about $2,870 \mathrm{ft}$, and the field occupies an area of approximately $47 \mathrm{mi}^{2}$ and is about $20 \mathrm{mi}$ long. This reservoir is the most important oil accumulation in the study area, having produced $74 \mathrm{MMBO}$.
Trap configuration is essentially stratigraphic and consists of westward porosity pinchouts in sandstone in the middle Guadalupian Queen Formation that occur on the eastern flank of the Pedemal uplift. The reservoir consists of gray and red quartz sandstone averaging $20 \mathrm{ft}$ thick; a typical pay section is $10 \mathrm{ft}$ thick. Porosity is around 20 percent, and permeabilities are a few hundred (100-200) millidarcies. The top and basal seals are anhydrite and salt beds. Anhydrite tends to plug porosity in west-northwestward-trending embayments along the strike of the field (Dunn, 1956).

Hydrocarbons at Caprock have API gravities ranging from $36^{\circ}$ to $40^{\circ}$ (Dunn, 1956) and are high in sulfur (greater than 1.0 percent, typical of accumulations sealed by anhydrite) and nitrogen. Although gas production of only 10 million $\mathrm{ft}^{3}$ (MMCF) is recorded at Caprock, solution gas is deemed to be the driving mechanism for the oil in this field.

Smaller fields in the sandstone beds of the Queen Formation, such as Double $\mathrm{L}$ and Sulimar which were discovered in the late 1960's and 1970's, are located $10 \mathrm{mi}$ west and updip from Caprock at depths of around 2,000 ft. These small fields are very similar to Caprock in the nature of their traps and hydrocarbon character. According to Lampert (1977), these fields are potentially part of a regional oil and gas accumulation that is hydrocarbon bearing, tight, and anhydrite and salt plugged, having nonproducing sandstone beds that separate producing field areas.

\section{PLAY ANALYSIS AND HYDROCARBON ASSESSMENT}

The oil and gas assessments presented herein were derived from the national assessment of 1988 (U.S. Geological Survey and Minerals Management Service, 1988; Mast and others, 1989) and are based on hydrocarbon play analysis.

A hydrocarbon play is a group of actual or potential oil and gas accumulations that share certain geologic attributes. Some of the geologic attributes included in the hydrocarbon play analysis in this report are regional structural setting, reservoir type and configuration, sealing mechanisms, reservoir age, characteristics of the hydrocarbon source rocks, timing of hydrocarbon maturation and migration, and fluid types associated with the reservoir.

Two hydrocarbon plays that extend into the study area have undiscovered, recoverable, conventional accumulations of oil and gas estimated to exceed 1 MMBOE. They are (1) the Northwestern Shelf of the Permian Basin, Pennsylvanian and Permian play and (2) the Northwestern Shelf of the Permian Basin, pre-Pennsylvanian play (pl. 15; fig. 44). Additionally, four other plays in two provinces (parts of the Permian and Palo Duro Basins that occur within the study area) have expected oil and gas accumulations of less than 1 MMBOE. Estimates of undiscovered recoverable hydrocarbons for these six plays and for Federal lands within these plays are presented here. The Tucumcari Basin play, although not quantitatively assessed herein, could prove to be of future importance and is described and discussed at the conclusion of this section. 


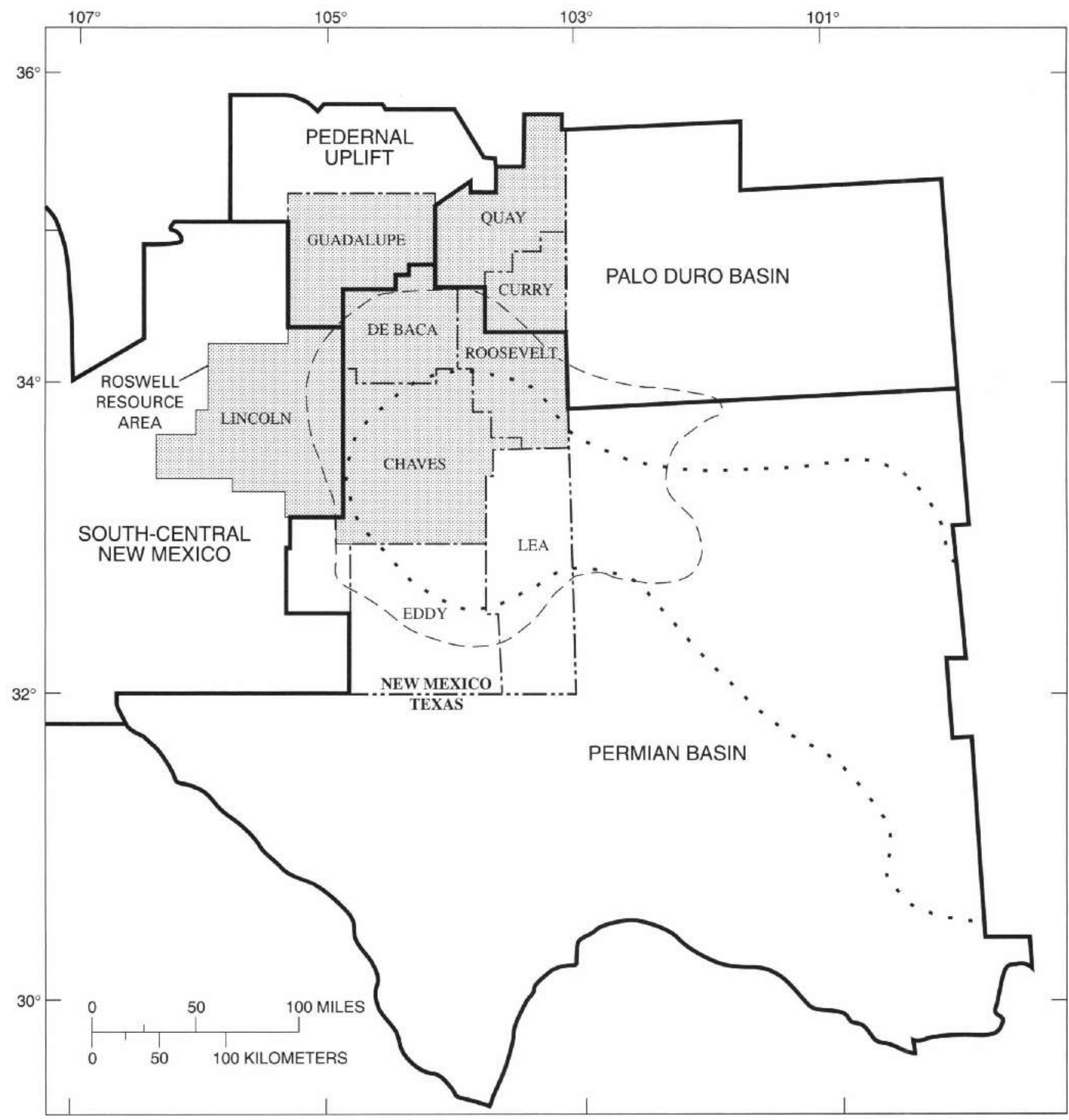

Figure 44. Regional oil and gas provinces of southeastem New Mexico and West Texas (from Mast and others, 1989). Heavy solid lines indicate boundaries of the four provinces. Dashed line indicates Northwestern Shelf of Permian Basin, Pennsylvanian and Permian play; dotled line indicates Northwestern Shelf of Permian Basin, pre-Pennsylvanian play.

NORTHWESTERN SHELF OF THE PERMIAN BASIN, PENNSYLVANIAN AND PERMIAN PLAY

The Northwestern Shelf, Pennsylvanian and Permian oil and subordinate gas play is a combination of stratigraphic, stratigraphic and structural, and structural traps, in shelf margin and interior facies carbonate and (to a lesser extent) terrigenous clastic reservoirs of Pennsylvanian to middle Permian age. The play area covers the whole of the 
Northwestern Shelf of West Texas and New Mexico south of the Tucumcari Basin and east of the Pedernal uplift (pls. 3 and 15; fig. 44). Maximum thickness of Pennsylvanian and Permian sedimentary rocks in the area of this play is about $15,000 \mathrm{ft}$.

Reservoir rocks consist of porous limestone, dolomite, dolomitized mudstone and wackestone, and lesser amounts of fine-grained clastic rocks frequently associated with evaporite beds, red beds, and sabkha facies. The reservoir rocks appear to have been deposited in strandline, intertidal to supratidal, and restricted shelf environments. The reservoirs are contained in the Pennsylvanian Morrow, Atoka, Strawn, and Cisco rocks, the Wolfcampian and Leonardian Abo Formation, the Leonardian Bone Spring Limestone and Clear Fork Group, the Leonardian and Guadalupian San Andres Formation, and the Guadalupian Grayburg, Queen, Seven Rivers, and Yates Formations (pl. 2). Gross reservoir thicknesses are as much as $1,000 \mathrm{ft}$, porosities average 10 percent, and permeabilities average 6 millidarcies.

Source rocks are considered to be indigenous organic-rich calcareous shale and shaly limestone of Pennsylvanian and Permian age. It is inferred that Lower Permian sedimentary rocks are the primary source beds. Deposited under restricted shelf, intertidal, and lagoonal environments, the source beds are extremely rich in organic material. Hydrocarbon generation from adjacent organic-rich source rocks probably occurred during middle to Late Permian time. Hydrocarbon fluids migrated laterally and upward into the reservoir rocks simultaneously with generation. Stratigraphic traps in the shelf sequence are formed by lateral facies changes into nonporous and impermeable strata. Structural traps are generally simple anticlinal closures that had topographic relief during the Permian. Buried-reef traps are also present. Seals consist of anhydrite, salt beds, nonporous dolomites, and red beds. Stratigraphically and structurally entrapped hydrocarbons occur at depths of $1,000-11,000 \mathrm{ft}$, and an average of $5,100 \mathrm{ft}$.

The first exploration discovery of this play was made in Texas in 1923, but most discoveries were made during the 1950's and 1960's. Approximately 55 fields (46 oil fields and 9 gas fields) larger than $1 \mathrm{MMBO}$ and 6 BCF gas have been discovered in the overall play since 1961. These post-1961 fields have combined known recoveries of only $225 \mathrm{MMBO}, 627 \mathrm{BCF}$ gas, and 11 MMBOE of natural gas liquids. This oil play may contain more than 12 billion barrels of oil (BBO)-in-place. One of the largest oil fields discovered is Wasson, Texas, at approximately 2 BBO recoverable. The largest gas field discovered in the study area is Pecos Slope, located in Chavez County, which contains 1.25 trillion $\mathrm{ft}^{3}$ (TCF) recoverable gas. Future resource potential is estimated as relatively good for the discovery of many additional small fields and possibly one or more medium-size fields.

\section{NORTHWESTERN SHELF OF THE PERMIAN BASIN, PRE-PENNSYLVANIAN PLAY}

The Northwestem Shelf, pre-Pennsylvanian oil and associated gas play is a combination of structural and stratigraphic, structural, and (to a lesser extent) stratigraphic traps in carbonate and subordinate clastic reservoirs of Early Mississippian through Cambrian age (pl. 15; fig. 44). The play area encompasses the northem part of the Eastern Shelf east of the Midland Basin, the northern part of the Midland Basin, and a large part of the Northwestem Shelf (inset, pl. 3). The thickness of lower Paleozoic sedimentary rocks is less than $5,000 \mathrm{ft}$.

Reservoir rocks consist of Ordovician to Mississippian limestone and dolomite, and minor Cambrian sandstone. The interbedded limestone and dolomite were deposited in the ancestral Tobosa Basin in environments that range from platform and strandline to deeper environments associated with evaporitic tidal flat and sabkha facies, and include mudstone, algal boundstone, wackestone, and oolitic grainstone. Significant reservoirs are in the Lower Ordovician Ellenburger Group, Middle and Upper Ordovician Simpson Group, Upper Ordovician Montoya Dolomite, Lower Silurian Fusselman Dolomite, Middle and Upper Silurian Wristen Formation, and Devonian and Mississippian carbonate rocks. Individual reservoir thicknesses are generally less than 100 $\mathrm{ft}$, porosities average 8 percent, and permeabilities (extremely variable) average 60 millidarcies.

Source rocks in the lower Paleozoic rocks are considered to be indigenous and proximal organic-rich shale, argillaceous limestone, and mudstone. However, a substantial part of the hydrocarbons in the play could have migrated long distances along extensive fault and fracture systems from overlying and underlying source beds. Source rocks for Cambrian reservoirs are thought to be in shale beds of the Simpson Group. For Ordovician and Mississippian reservoirs, source rocks are considered to be primarily the Upper Devonian and Lower Mississippian Woodford Shale and Middle and Upper Ordovician Simpson Group. Hydrocarbon generation in these Paleozoic source rocks probably occurred during Permian time. Generated hydrocarbons readily migrated into adjacent reservoirs. Trapping mechanisms are a combination of structural and stratigraphic features. Simple and faulted anticlines exist, together with stratigraphic updip pinchouts, reservoir rock truncations, porosity barriers, and lateral facies changes. Interbedded shale, source shale, and impervious crystalline and argillaceous carbonate rocks, updip pinchouts, truncations, facies changes, and permeability barriers act as effective seals. Depths to entrapped hydrocarbons are extremely variable and range from 5,000 to $13,000 \mathrm{ft}$, depending on the location within the play.

The first exploration discovery was in 1927, but most discoveries were made during the 1950's and 1960's. Since 1961,23 fields have been discovered, 20 of which are oil and 
3 are gas. These contain more than $103 \mathrm{MMBO}, 82 \mathrm{BCF}$ of gas, and 3.5 MMBOE of natural gas liquids. The average size of oil fields is $5.1 \mathrm{MMBO}$, and the average size of gas fields (discovered since 1961) is 9.7 BCF. The future resource potential of the play is probably fair to good, but limited to small-size fields.

\section{SMALL FIELD PLAYS}

Although small fields (less than 1 MMBOE or $6 \mathrm{BCF}$ of gas) are abundant, data for these fields tend to be incomplete and inaccurate. Full play analysis of these accumulations is impractical. Instead, an alternative, statistically based approach is used by the U.S. Geological Survey to estimate remaining undiscovered recoverable oil and gas resources in smaller fields (Root and Attanasi, 1988).

The small fields are grouped for the whole province, and separated according to fluid content into simplified oil and gas plays. Frequency and size of accumulations, discovered and undiscovered, that are larger than the MMBOE cutoff for full play analysis are used to construct log geometric curves that are then projected into the smaller field size classes. This method enables prediction of recoverable oil and gas still to be discovered in the smaller fields (Mast and others, 1989).

Small fields in two provinces, the Permian Basin and the Palo Duro Basin, were deemed relevant to oil and gas assessment of the study area (fig. 44). Province-wide variation in geologic factors such as quality and quantity of structures, reservoirs, seals, hydrocarbons, areas, and drilling densities were used to arrive at percentages of oil and gas field resources for each province within the study area for the area-wide resource assessment. A second iteration of this approach was used to estimate amount of small-field oil and gas resources on Federal lands within the study area.

\section{RESOURCE ESTIMATES}

Although the resource estimates reported herein were derived from the 1988 national assessment, some changes were made in the hydrocarbon play definitions to take into account new data unavailable at the time of that assessment. Play boundaries were extended farther to the north to expand play areas in which accumulations exceeding 1 MMBOE are deemed likely. Some lower Pennsylvanian production originally allocated to a Delaware Basin play was reallocated to the Northwestern Shelf of the Permian Basin, Pennsylvanian and Permian play, because this change facilitates description of oil and gas resources of the study area. In the national assessment, a single percentage of undiscovered oil and gas was used to allocate resources to Federal Lands within a given play (Dolton and others, 1990). This approach did not, in our opinion, adequately describe all of the undiscovered resources of the study area and of Federal lands within this area. Therefore, for this study, we used separate percentages for oil and gas to make these allocations. In general, this approach tended to increase the amount of gas resources inferred to be present in the study area. The resources within the study area and included Federal lands were determined on the basis of areas within the plays and variation of attributes affecting the probability of oil and gas accumulations, such as drilling density and quality of structures, reservoirs, seals, source, maturation, and migration paths.

Table 20 presents quantitative estimates of undiscovered, conventionally recoverable oil and gas within the study area. By conventionally recoverable, we mean that these estimates do not incorporate the less commonly exploited deposits, including intractable heavy oil deposits, tar sands, oil shales, gas from fractured shales or "tight gas" reservoirs with in-situ permeabilities of less than 0.1 millidarcy, coalbed methane, or gas from geopressured shale or brine. Some of these unconventional hydrocarbon types may be important future sources of oil and gas in this area, but they are not incorporated in table 20.

\section{ROSWELL RESOURCE AREA}

The assessments are presented in two categories: (1) the study area as a whole and (2) Federal lands within the study area (table 20). Each category is subdivided into the same six plays. Estimates are presented as means in ranges between F95 (percentile representing a 19 out of 20 chance of occurrence) and F5 (percentile representing a 1 in 20 chance of occurrence). For the entire study area, our estimates indicate undiscovered conventionally recoverable oil and gas resources of about 54-140 MMBO (and a mean of $87 \mathrm{MMBO}$ ), 260-555 BCF of gas (and a mean of $375 \mathrm{BCF}$ ), and 6-13 MMBOE of natural gas liquids (and a mean of 8 MMBOE). For Federal lands within the study area, we estimate undiscovered conventionally recoverable oil and gas resources of about 15-31 MMBO (and a mean of 21 $\mathrm{MMBO}$ ), 112-245 BCF of gas (and a mean of $165 \mathrm{BCF}$ ), and 2.5-5.5 MMBOE of natural gas liquids (and a mean of $3.5 \mathrm{MMBOE})$.

\section{TUCUMCARI BASIN}

Petroleum resources in Tucumcari Basin in the northem part of the study area (pl. 3) were considered too speculative to quantitatively assess. Broadhead (1989, 1990a) and Broadhead and King (1988) synthesized available subsurface information with gravity and magnetic data of Keller and Cordell (1983) and Cordell (1983), and with limited seismic reflection data. They arrived at a version of the nature of basement structure (pl. 3) that differs significantly from that of Keller and Hills (1988). Their interpretation 
Table 20. Quantitative estimates of undiscovered, conventionally recoverable oil and gas in the Roswell Resource Area, New Mexico, and for Federal lands therein

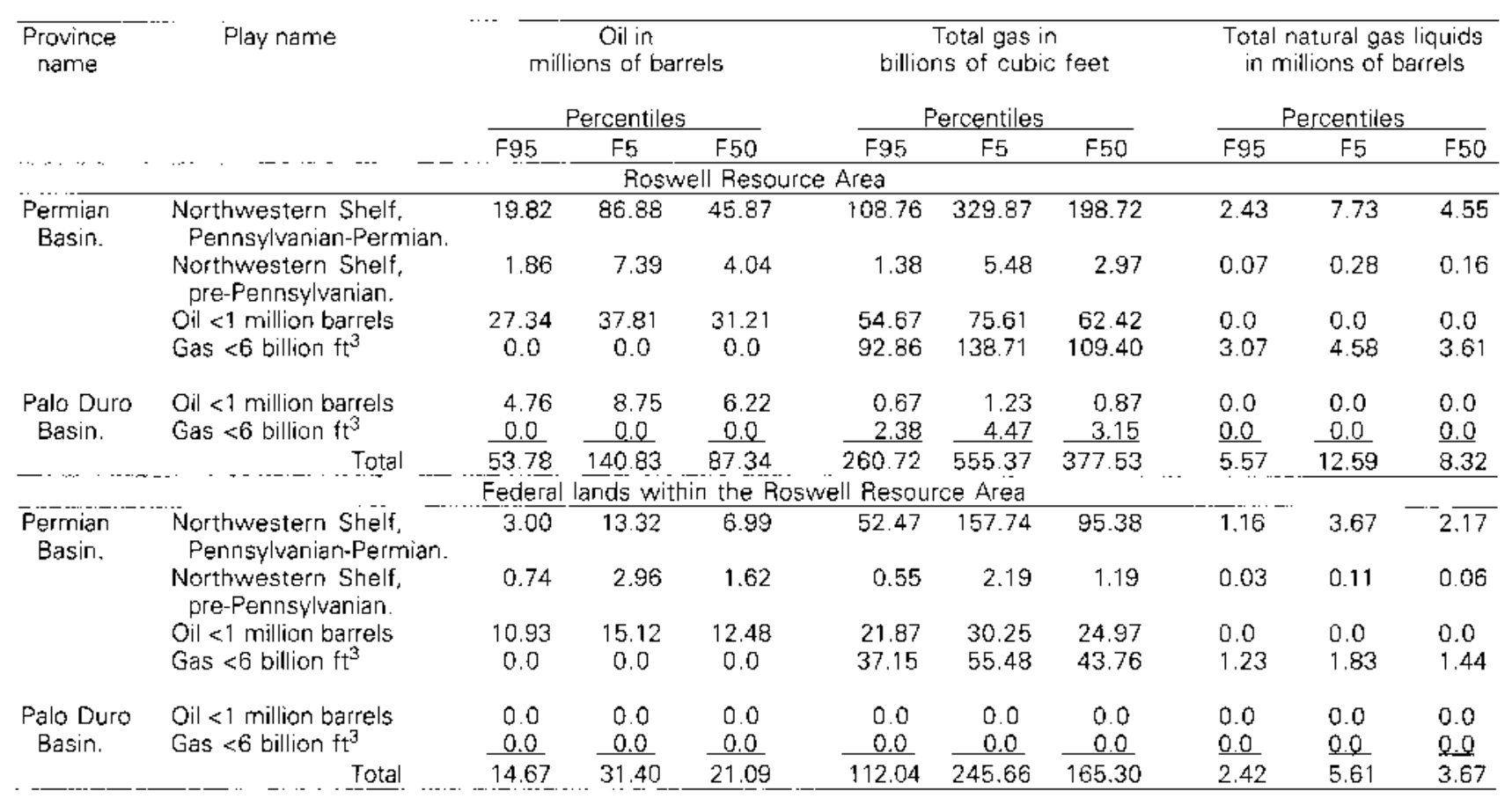

depicts a complicated system of basement horsts and grabens bounded by high-angle faults whose throws exceed $2,000 \mathrm{ft}$. This structural style offers possibilities of numerous stratigraphic as well as structural traps throughout the $70-\mathrm{mi}$ east-west and 50-mi north-south extent of the basin.

Residual gravity data suggest the possibility of a continuation of the Palo Duro Basin-Tucumcari Basin chain southward into two additional basins beneath eastern Lincoln County (Keller and Hills, 1988) (fig. 42). Thickness and facies variations indicate that faulting in Tucumcari Basin was active during Pennsylvanian and Wolfcampian time (Broadhead and King, 1988).

Potential reservoirs include Upper Pennsylvanian limestone, sandstone, and dolomite of the Permian Wolfcampian and Leonardian Series and sandstone of the Triassic Santa Rosa Sandstone (pl. 2). Seals include Pennsylvanian shale and anhydrite and Permian shale. Hydrocarbon shows occur in units ranging from Mississippian limestone to Upper Triassic sandstone of the Chinle Formation. The two most impressive deposits (discussed in greater detail in following section of this report) are the 90 MMBO-in-place as tar sands in the Santa Rosa Sandstone located 7 mi north of Santa Rosa in Guadalupe County and the $60 \mathrm{MMBO}$-in-place at Newkirk field in northeasternmost Guadalupe County (pl. 15). Pennsylvanian shale is the probable source of these major shows (Broadhead and King, 1988). Lack of an effective seal for the Santa Rosa Sandstone appears to detract from the oil and gas potential of Tucumcari Basin.

\section{OTHER RESOURCES ASSOCIATED WITH CONVENTIONAL OIL AND GAS}

\section{TAR SAND AT SANTA ROSA}

The tar sand reservoir at Santa Rosa is a hydrocarbon accumulation that has migrated to the surface through porous and permeable strata and along faults and fractures, some of which are the result of collapse brecciation accompanying dissolution of evaporite beds. At the surface, these hydrocarbons lost their lighter components, due to biodegradation and dissolution, to become tars. These tars have, in essence, sealed themselves in the Santa Rosa Sandstone reservoir.

The reservoir is a stratigraphic trap, having an average thickness of $40 \mathrm{ft}$ over an area of $5 \mathrm{mi}^{2}$. Reservoir porosity is about 10 percent and permeabilities range from 100 to 200 millidarcies. API gravity of the hydrocarbons ranges between $5^{\circ}$ and $13^{\circ}$. In addition to being biodegraded, the source may have been marginally mature, which means that they initially contained larger percentages of heavier and more complex hydrocarbon molecules. Broadhead (1990a) favored Pennsylvanian shale beds as the source for these deposits and ruled out San Andres shale as a source based on its observed immaturity in proximity to the tar deposits. Time-and-temperature studies indicate that the source shale beds probably began delivering hydrocarbons to migration routes no earlier than Late Cretaceous.

Volume of the tar is estimated to be about 90 MMBOEin-place. The tars were mined in the 1930's for use as paving 
material. The exposures of the tar sand are currently flooded by the Santa Rosa Reservoir (Broadhead and King, 1988). However, future economic conditions could revive commercial interest in these deposits.

\section{HEAVY OIL AT NEWKIRK}

The heavy oil near Newkirk is trapped at shallow depths of 400-800 ft in a drape of Triassic Santa Rosa Sandstone over a large basement structure in northeastem Guadalupe County. The trap has a stratigraphic component, as a facies change to mudstone in the Santa Rosa serves to limit the accumulation. The structure was formed in Pennsylvanian through Wolfcampian time (Broadhead and King, 1988), and the trap was completed by deposition of shale seals in the Upper Triassic Chinle Formation. The reservoir porosity is 20 percent, and permeabilities are around 200 millidarcies.

Volume of hydrocarbons is $60 \mathrm{MMBOE}$-in-place. API gravity is $15^{\circ}-17^{\circ}$. The Pennsylvanian shale beds are the most likely source of these hydrocarbons. Two attempts at steam flooding to recover oil at this location were made in the 1980 's. Both failed, largely because injection pressures exceeded the low pressures in the shallow reservoir to the extent that excessive fracturing and steam loss precluded flooding.

In addition to the heavy oil deposits at Newkirk field, Crysdale and Schenk (1990) listed three small accumulations having API gravities of $19^{\circ}-20^{\circ}$ in stratigraphically trapped dolomite reservoirs (San Andres Formation) in Chaves County. Depths for these occurrences in Chisum, Leslie Springs, and Tower fields are 2,000, 1,500, and 4,100 $\mathrm{ft}$, respectively. Reservoir porosities are less than 10 percent, and permeabilities are measured in single digits. The largest volume produced is 56,000 barrels of heavy oil through 1984 at Chisum field.

\section{NONHYDROCARBON GAS}

\author{
By Susan Bartsch-Winkler and Mahlon M. Ball
}

Naturally occurring carbon dioxide gas is produced in northern New Mexico from the Bueyeros and Bravo dome fields (pl. 15), and the Des Moines field, all of which are north of the study area principally in Union and Harding Counties, and from the Estancia field (pl. 15), which is west of the study area in northwestem Torrance County. Gas-field limits have not yet been defined by drilling (Broadhead, $1990 \mathrm{~b}$ ), but the major producing fields are located on the Bravo dome (projecting into the northeastem part of the study area in Quay County) and the Sierra Grande uplift (northwest of the study area, the southern part of which is in San Miguel County). Nitrogen gas is produced from the Queen Formation (Artesia Group) east of Roswell and
Hagerman (Grant and Foster, 1989). Small quantities of hydrogen and helium gas were detected in wells drilled in 1985 in east-central Guadalupe County (Latigo Ranch, pl. 15) (Setter and Adams, 1985). Hydrogen sulfide gas is encountered in San Andres Formation dolomite reservoirs.

\section{CARBON DIOXIDE}

Carbon dioxide may accumulate as a gas in petroleum reservoirs. The most important use of carbon dioxide is in oil-recovery-enhancement techniques like those used in West Texas oil fields. Because carbon dioxide is miscible with oil, it acts as a solvent, displacing enough water to mobilize oil in water-invaded reservoirs that would otherwise be unrecoverable. Carbon dioxide dissolves in crude oil easily, and it both lightens the oil and decreases its viscosity to make it more easily recoverable.

A major accumulation of carbon dioxide occurs on the crest of the Bravo dome in Harding and Union Counties just north of the study area. The Bravo dome field, an eastern extension of the Bueyeros field that extends into the northeastern part of the study area in Quay County, was developed in the 1980's. In 1985, as many as 258 active carbon dioxide wells produced 101,227 MMCF (Broadhead, 1987). The gas is 98.6-99.8 mole percent carbon dioxide and contains minor amounts of nitrogen and trace amounts of noble gases (Johnson, 1983). The Bueyeros field was discovered in 1916 at a depth of $2,000 \mathrm{ft}$, but was not produced until about 1930 due to the lack of demand for carbon dioxide. The discovery well, an unsuccessful oil test, flowed at a rate of 25 MMCF per day and blew out for a year before being capped and abandoned due to the lack of a market for carbon dioxide (Broadhead, 1987). According to the New Mexico Department of Energy, Minerals and Natural Resources (1990), the Bueyeros field has estimated reserves of $16 \mathrm{TCF}$ of carbon dioxide, and is projected to be the largest carbon dioxide field in the United States, encompassing $1,875 \mathrm{mi}^{2}$ or 1.2 million acres. The Des Moines field was discovered in 1935; the discovery well had a reported potential of 6 MMCF per day (Anderson, 1959).

Estimated joint recoverable reserves for the Bravo dome and Bueyeros fields range from 5.3 to 9.8 TCF of gas (Johnson, 1983). In 1989, a total of 279 producing wells were located in the Bravo dome field (New Mexico Department of Energy, Minerals and Natural Resources, 1990). The future looks promising for continued growth of the industry-prior to 1984 , only $\$ 20,000$ worth of carbon dioxide was produced, but this value jumped to $\$ 7$ million in 1987 and \$4.5 million in 1989 (New Mexico Department of Energy, Minerals and Natural Resources, 1990).

Carbon dioxide reservoirs in Permian and (or) Pennsylvanian rocks have also been exploited in the western Estancia Basin at the Estancia field (Beaumont, 1961). Gases in these wells are 67-99 percent carbon dioxide, but may also contain small amounts of nitrogen, oxygen, helium, and 
hydrocarbons. Wells produce from 1 to several MMCF of gas per day.

The main carbon dioxide reservoir in the Bravo dome field is the quartz-rich Tubb sandstone at the base of the Leonardian Yeso Formation (pl. 2) at depths of 2,000-2,500 $\mathrm{ft}$. In the Tubb, the sandstone reservoirs are interbedded with beds of mudstone, dolomite, and anhydrite. According to Broadhead (1987), producing zones may be porous, sandrich zones that have been acidified, perforated, and probably fractured. Productive sandstone beds range in thickness from 5 to $20 \mathrm{ft}$, and have a porosity of $10-20$ percent and permeabilities of a few tens of millidarcies. Other reservoirs include arkosic sandstone and conglomerate beds in the Abo Formation at depths of $2,500-3,000 \mathrm{ft}$ and the quartzose Triassic Santa Rosa Sandstone at depths of less than $1,000 \mathrm{ft}$ (Broadhead, 1987). Small shows of the gas have been encountered in the Yeso Formation, Glorieta Sandstone, and Chinle Formation. These formations rest on Precambrian granite and (or) metasedimentary basement rocks (Broadhead, 1990b), depending on the locality.

The source of the carbon dioxide is problematic and controversial. Some of the gas may be of juvenile magmatic origin, some may originate from chemical breakdown of carbonate rocks by igneous intrusions, or it may result during solution of carbonate rocks by groundwater and thermal or bacterial decomposition of organic matter. Intrusion of magma into limestone beds in northwestern Harding and northern Union Counties north of Quay County, and subsequent migration of the carbon dioxide into the trap on Bravo dome, is another process by which carbon dioxide may have formed.

Prospective areas for carbon dioxide in the study area may include traps updip from Tertiary intrusions north and east of the porphyry belt of southwestern Lincoln County. Permian limestone and sandstone and the Upper Triassic Santa Rosa Sandstone and Chinle Formation occur in the region northeast of the porphyry belt, where they rest on Precambrian basement (Pedernal uplift). In this area, the rocks may have formed stratigraphic or structural features that are amenable to carbon dioxide entrapment. However, thick sandstone units, like the Tubb sandstone, do not occur in the region and the Triassic rocks are breached.

\section{NITROGEN}

Nitrogen is the dominant element in the Earth's atmosphere. When nitrogen occurs together with hydrocarbon gases, it is often considered to be derived from surfacerecharged groundwater that subsequently came in contact with oil and gas accumulations. Some nitrogen is also produced as a byproduct of thermal maturation of hydrocarbon source materials. Nitrogen is used in production of fertilizers and explosives.

Anomalously high nitrogen contents occur in associated gases of the oil fields producing from the Queen
Formation of southeastern Chaves County. The nitrogen content of gas at the Double $\mathrm{L}$ field is 63 percent, at Sulimar it is $\mathbf{5 5}$ percent, and at Caprock it is $\mathbf{4 4}$ percent. Nitrogen is slow to react chemically (inert) and, therefore, has a tendency to be concentrated in gas-phase migration over long distances. The concentration of nitrogen in Queen Formation reservoirs may also reflect interaction with an eastward flux of groundwater on the Pecos Slope. Moderate amounts of nitrogen may occur in natural gases in the study area.

\section{HYDROGEN SULFIDE}

Hydrogen sulfide gas occurs where oil and gas accumulations are sealed by anhydrite, such as in the sour gas of San Andres Formation dolomite reservoirs. Hydrogen sulfide gas is formed by bacteria-catalyzed sulfate reduction when oil or gas is in contact with anhydrite. Spirakis (this volume) discusses this process in detail. Moderate amounts of hydrogen sulfide gas occur along with natural gases in the study area.

\section{HELIUM}

Helium, a unique elemental gas, is chemically inert and has a simple chemical structure, a very low specific gravity, and a low density. Helium is thought to be formed during radioactive decay in igneous basement rocks. Being inert, this elemental gas is capable of Jong-range migration into traps. This capability may explain the lack of discernible correlation of helium occurrence and level of local basement rock radioactivity (Tiratsoo, 1979).

Helium is much more common in gases contained in rocks of Paleozoic age and near Precambrian basement. The highest helium content known in gases of the study area ( 0.3 percent) occurs at Peterson field. Here, helium occurs in Cisco Group limestone rocks directly overlying a Precambrian basement high.

\section{COAL PRODUCTION AND ESTIMATED RESOURCES}

\author{
By Gary D. Stricker
}

About 1880 , coal was mined in the Sierra Blanca or Capitan field near Capitan, Fort Stanton, White Oaks, and Carrizozo, in Lincoln County, for local mining operations and for fuel in Fort Stanton (Griswold, 1959). Additional coal was mined south of Carrizozo in the Willow Hill district (Griswold, 1959).

Until 1906, Lincoln County was the third-largest producer of coal in the State (Griswold, 1959), but about that time competition from other coal fields, where faults were fewer and coal-bed extent was greater, ended large-scale coal mining in the Capitan field (Bodine, 1956). Most mining was abandoned about 1910 (U.S. Geological Survey, 
Table 21. Analyses of coals in the Sierra Blanca field, Lincoln County, N. Mex. (from Campbell and others, 1991)

\begin{tabular}{|c|c|}
\hline \multicolumn{2}{|c|}{$\begin{array}{c}\text { Proximate analyses } \\
\text { (14 samples; data in percent, except Btu/b) }\end{array}$} \\
\hline Moisture & $5.53 \pm 4.51$ \\
\hline Ash & $13.51 \pm 5.32$ \\
\hline Volatile matter & $31.46 \pm 7.91$ \\
\hline Fixed carbon & $47.24 \pm 5.93$ \\
\hline $\mathrm{Btw} / \mathrm{b}$ : & \\
\hline As received & $11,175 \pm 1,787$ \\
\hline Mineral-matter free & $12,983 \pm 2,047$ \\
\hline \multicolumn{2}{|c|}{$\begin{array}{c}\text { Ultimate analyses } \\
\text { (12 samples; data in percent) }\end{array}$} \\
\hline Carbon & $61.33 \pm 7.74$ \\
\hline Hydrogen & $4.58 \pm 0.49$ \\
\hline Nitrogen & $1.17 \pm 0.16$ \\
\hline Oxygen & $13.37 \pm 5.78$ \\
\hline Sulfur & $0.75 \pm 0.16$ \\
\hline \multicolumn{2}{|c|}{$\begin{array}{c}\text { Major oxides } \\
\text { (4 samples; data in percent on an ash basis) }\end{array}$} \\
\hline $\mathrm{SiO}_{2}$ & $60.19 \pm 6.42$ \\
\hline $\mathrm{Al}_{2} \mathrm{O}_{3}$ & $15.78 \pm 1.26$ \\
\hline $\mathrm{Fe}_{2} \mathrm{O}_{3}$ & $2.60 \pm 0.29$ \\
\hline $\mathrm{TiO}_{2}$ & $1.25 \pm 0.10$ \\
\hline $\mathrm{CaO}$ & $4.41 \pm 0.48$ \\
\hline $\mathrm{MgO}$ & $0.88 \pm 0.11$ \\
\hline $\mathrm{K}_{2} \mathrm{O}$ & $0.32 \pm 0.03$ \\
\hline $\mathrm{Na}_{2} \mathrm{O}$ & $0.65 \pm 0.14$ \\
\hline \multicolumn{2}{|c|}{$\begin{array}{c}\text { Trace elements } \\
\text { (4 samples; data in parts per million on an ash basis }\end{array}$} \\
\hline As & $8.13 \pm 0.25$ \\
\hline $\mathrm{Cu}$ & $14.04 \pm 6.33$ \\
\hline $\mathrm{Hg}$ & $0.10 \pm 0.05$ \\
\hline $\mathrm{Li}$ & $8.52 \pm 1.10$ \\
\hline$M n$ & $32.73 \pm 30.17$ \\
\hline $\mathrm{Ni}$ & $4.38 \pm 2.13$ \\
\hline $\mathrm{Pb}$ & $7.97 \pm 3.26$ \\
\hline $\mathrm{Sb}$ & $1.60 \pm 0.77$ \\
\hline Se & $2.81 \pm 0.78$ \\
\hline Th & $5.10 \pm 2.21$ \\
\hline$U$ & $2.85 \pm 0.96$ \\
\hline $\mathrm{Zn}$ & $8.49 \pm 7.42$ \\
\hline
\end{tabular}

1965), but coal from the Capitan field was used to generate power for the town of Carrizozo until 1939 (Griswold, 1959). As of 1964 , total cumulative production was at least 600,000 short tons in Lincoln County (Bodine, 1956).

In the Capitan coal field, several coal horizons are present in the middle part of the Mesaverde Formation, which crops out around the Sierra Blanca Basin in Lincoln County (Bodine, 1956), a north-plunging synclinal depression covering approximately $435 \mathrm{mi}^{2}$ (Read and others, 1950). The Mesaverde is composed of intertonguing fossiliferous sandstone and shale of both marine and nonmarine origins. Coal occurs in the middle shale unit, is variable in thickness, and has internal unconformities. Coal beds, which are commonly eroded beneath sandstone channels, are, in places, broadly folded into east-trending flexures. The middle coal-bearing shale is overlain by white sandstone that is as much as $60 \mathrm{ft}$ thick. Numerous dikes and sills intrude the coal-bearing rocks (Wegemann, 1914; Bodine, 1956). Near Capitan, White Oaks, and the Willow Hill district, coal beds are disrupted by many faults having vertical displacements of as much as $300 \mathrm{ft}$. Faults having displacements of 5-10 ft are common. The coal beds have well-developed cleating and variable thickness (generally less than 30 in. thick, averaging $2.3 \mathrm{ft}$, and as thick as $7 \mathrm{ft}$ ) (Bodine, 1956). The coal beds have an apparent rank of high-volatile $C$ and $B$ bituminous (Campbell and others, 1991), and coals near igneous intrusions are commonly of coking quality (table 21).

According to Read and others (1950), the estimated original coal resources of Lincoln County in the Sierra Blanca (Capitan) field are as follows: measured, 3.3 million short tons; indicated, 8.0 million short tons; and inferred, 1,400 million short tons. Measured resources are those within a $1 / 4$-mi radius of the point where a coal bed's thickness was measured; indicated resources are within a $1 / 4$ - to 3/4-mi radius; and inferred resources are within a $3 / 4$ - to 3 -mi radius (Wood and others, 1983). Total original coal resources for Lincoln County are about 1,410 million short tons.

\section{REFERENCES CITED}

Anderson, E.C., 1959, Carbon dioxide in New Mexico (1959): New Mexico Bureau of Mines and Mineral Resources Cincular $43,13 \mathrm{p}$.

Beaumont, E.C., 1961, Petroleum exploration in a part of northcentral New Mexico, in Northrop, S.A., ed., Guidebook of the Albuquerque country: New Mexico Geological Society, 12th Field Conference Guidebook, p. 175-185.

Bentz, L.M., 1988, Pecos Slope Abo, Chaves County, New Mexi$\mathrm{CO}$, in A symposium on oil and gas fields of southeastern New Mexico: Roswell Geological Society, 1988 Supplement, 337 p.

Bodine, M.C., 1956, Geology of Capitan coal field, Lincoln County, New Mexico: New Mexico Bureau of Mines and Mineral Resources Circular 35, 27 p.

Broadhead, R.F., 1987, Carbon dioxide in Union and Harding Counties, in Northeastern New Mexico: New Mexico Geological Society, 38th Field Conference Guidebook, p. 339-349.

1989 , Petroleum potential of Tucumcari Basin, east-central New Mexico, in Grant, P.R., Jr., and Foster, R.W., eds., Future petroleum provinces in New Mexico-Discovering new reserves: New Mexico Bureau of Mines and Mineral Resources Atlas, p. 39-48.

1990a, Petroleum source rocks in the Tucumcari Basin, east-central New Mexico: West Texas Geological Society Bulletin, v. 29, p. 5-16.

1990b, Bravo Dome carbon dioxide gas field, in Beaumont, E.C., and Foster, N.H., eds., Treatise of petroleum geology, Atlas of oil and gas fields; Structural traps I, tectonic fold traps: Tulsa, Okla., The American Association of Petroleum Geologists, p. 213-232.

Broadhead, R.F., and King, W.E., 1988, Petroleum geology of Pennsylvanian and Lower Permian strata, Tucumcari Basin, 
east-central New Mexico: New Mexico Bureau of Mines and Mineral Resources Bulletin 119, 51 p.

Campbell, F.W., Hoffman, G.K., Kottlowski, F.E., and Arkell, B.W., 1991, Geology and coal resources of New Mexico's small coal fields, in Molnia, C.L., Jobin, D.A., O'Connor, J.T., and Kottlowski, F.E., eds., Coal fields of New Mexico-Geology and resources: U.S. Geological Survey Bulletin 1972, p. 71-77.

Cheeseman, R.J., 1978, Geology and oil/potash resources of Delaware Basin, Eddy and Lea Counties, New Mexico, in Austin, G.S., compiler, Geology and mineral deposits of Ochoan rocks in Delaware Basin and adjacent areas: New Mexico Bureau of Mines and Mineral Resources Circular 159, p. 7-14.

Cordell, Lindreth, 1983, Composite residual total intensity aeromagnetic map of New Mexico: National Geophysical Data Center, National Oceanic and Atmospheric Administration, scale 1:500,000.

Crysdale, B.L., and Schenk, C.J., 1990, Heavy oil resources of the United States: U.S. Geological Survey Bulletin 1885, 127 p.

Dolton, G.L., Coury, A.B., Frezon, S.E., Robinson, Keith, Varnes, K.L., Wunder, J.M., and Allen, R.W., 1979, Estimates of undiscovered oil and gas, Permian Basin, West Texas and southeast New Mexico: U.S. Geological Survey Open-File Report 79-838, p. 1-72.

Dolton, G.L., Mast, R.F., and Crovelli, R.A., 1990, Estimates of undiscovered resources of oil and gas for Federal lands and for Indian and Native lands of the continental United States: U.S. Geological Survey Open-File Report 90-705, 64 p.

Dunn, D.A., 1956, Caprock (Queen), in Stipp, T.F., ed., Oil and gas fields of southeastem New Mexico: Roswell Geological Society, Symposium Supplement, p. 91.

Grant, P.R., Jr., and Foster, R.W., 1989, Future petroleum provinces in New Mexico-Discovering new reserves: Socorro, $\mathbf{N}$. Mex., Atlas prepared for the New Mexico Research and Development Institute by the New Mexico Bureau of Mines and Mineral Resources, 94 p.

Gratton, P.J.F., and LeMay, W.J., 1969, San Andres oil east of the Pecos, in Summers, W.K., and Kottlowski, F.E., eds., The San Andres Limestone-A reservoir for oil and water in New Mexico: New Mexico Geological Society Special Publication 3, p. $37-43$.

Green, W.R., and Schlueter, J.C., 1989, Peterson and South Peterson Fields, Roosevelt Positive, Roosevelt County, New Mexico, in Flis, J.E., Price, R.C., and Sarg, J.F., eds., Search for the subtle trap hydrocarbon exploration in mature basins: West Texas Geological Society Symposium, Publication No. 89-75, p. 53-58.

Griswold, G.B., 1959, Mineral deposits of Lincoln County, New Mexico: New Mexico Bureau of Mines Bulletin 67, 117 p.

Hill, James, 1988, Annual resources report: New Mexico Energy, Minerals, and Natural Resources Department, p. 3-16.

Johnson, R.E., 1983, Bravo Dome carbon dioxide area, northeast New Mexico, in Fassett, J.E., ed., Oil and gas fields of the Four Corners area, v. 3: Four Corners Geological Society, p. 745-748.

Keller, G.R., and Cordell, Lindreth, 1983, Bouguer gravity anomaly map of New Mexico; Geothermal resources of New Mexico: New Mexico State University Energy Institute, Scientific Map Series, scale 1:500,000.
Keller, G.R., and Hills, J.M., 1988, Basement structures and geophysical anomalies in southeastern New Mexico, in Bowsher, A.L., ed., Oil and gas fields of southeastem New Mexico: Roswell Geological Society, Symposium Supplement. p. 82-89.

Kvenvolden, K.H., 1966, Carbon isotope compositions of Ellenburger crude oils [abs.]: Geological Society of America Special Paper 101, p. 117.

Lampert, L.M., 1977, Queen sand in the Double L and Sulimar Fields, in Havenor, K.C., ed., Oil and gas fields of southeastem New Mexico: Roswell Geological Society, Symposium Supplement, p. 29-37.

Mast, R.F., Dolton, G.L., Crovelli, R.A., Root, D.H., Attanasi, E.D., Martin, P.E., Cooke, L.W., Carpenter, G.B., Pecora, W.C., and Rose, M.B., 1989, Estimates of undiscovered conventional oil and gas resources in the United States-A part of the Nation's energy endowment: U.S. Geological Survey and Minerals Management Service Special Publication, 44 p.

New Mexico Department of Energy. Minerals and Natural Resources, 1990, Annual resources report: Santa Fe, N. Mex., Energy, Minerals and Natural Resources Department, $106 \mathrm{p}$.

NRG Associates, Inc., 1990, The significant oil and gas ficlds of the United States (through December 31, 1989): 1 diskette. [Available from Nehring Associates, Inc., P.O. Box 1655, Colorado Springs, CO 80901.]

Parke, R.P., 1974, Occurrence of deep gas in the Delaware Basin of West Texas: Houston Geological Society Bulletin, v. 16, p. 2-3.

Read, C.B., Duffner, R.T., Wood, G.H., Jr., and Zapp, A.D., 1950, Coal resources of New Mexico: U.S. Geological Survey Cincu$\operatorname{lar} 89,24$ p.

Robinson, Keith, 1988, Petroleum geology and hydrocarbon plays of the Permian basin petroleum province, West Texas and southeast New Mexico: U.S. Geological Survey Open-File Report 88-450-Z, 53 p.

Root, D.H., and Attanasi, E.D., 1988, Small field assessment, in National assessment of undiscovered conventional oil and gas resources; U.S. Geological Survey and Minerals Management Service working paper: U.S. Geological Survey Open-File Report 88-373, p. 87-99.

Roswell Geological Society, 1988, A symposium on oil and gas fields of southeastem New Mexico: Roswell Geological Society, 1988 Supplement, $337 \mathrm{p}$.

Setter, J.R.D., and Adams, J.A.S., 1985, Geochronology of basement and Recent intrusive rocks from the Cuervo area, eastcentral New Mexico, in Lucas, S.G., ed., Santa Rosa-Tucumcari Region: New Mexico Geological Society, Thirty-sixth Field Conference Guidebook, p. 147-149.

Spencer, C.W, 1988, Underpressured reservoir-The other part of the story: American Association of Petroleum Geologists Bulletin, v. 72, p. 882.

Stahl, W.J., and Carey, B.D., 1975, Source-rock identification by isotope analyses of natural gases in the Val Verde and Delaware Basins, West Texas: Chemical Geology, v. 16, p. 257-267.

Tiratsoo, E.N., 1979, Natural gas: Houston, Texas, Gulf Publishing Company, $360 \mathrm{p}$.

U.S. Geological Survey, 1965, Mineral and water resources of New Mexico: Washington. D.C., U.S. Government Printing Office, 
Report to the Committee on Interior and Insular Affairs, U.S. Senate, $437 \mathrm{p}$.

U.S. Geological Survey and Minerals Management Service, 1988, National assessment of undiscovered conventional oil and gas resources; U.S. Geological Survey and Minerals Management Service working paper: U.S. Geological Survey Open-File Report 88-373, 511 p.

Ward, R.E., Kendall, C.G., and Harris, P.M., 1986, Upper Permian (Guadalupian) facies and their association with hydro-
carbons-Permian Basin, West Texas and New Mexico: American Association of Petroleum Geologists Bulletin, v. 70, no. 3, p. 239-262.

Wegemann, C.H., 1914, Geology and coal resounces of the Sierra Blanca coal field, Lincoln and Otero Counties, New Mexico: U.S. Geological Survey Bulletin 541, p. 419-452.

Wood, G.H.. Jr., 1983, Coal resource classification system of the U.S. Geological Survey: U.S. Geological Survey Circular 891. $65 \mathrm{p}$.

Manuscript approved for publication July 2, 1993

Published in the Central Region, Denver, Colorado

Photocomposition by Shelly A. Fields

Drafting of figures by Susan Bartsch-Winkler and Norma J. Maes

Color design of plates by Virginia D. Scott

Graphic design of plates by Patricia L. Wilber

Drafting of plates by Michael Kirtley

Cover design by Arthur $L$. Isom 


\section{APPENDIX}


APPENDIX. GEOLOGIC AND MINERAL RESOURCES INFORMATION FOR THE ROSWELL RESOURCE AREA, NEW MEXICO, by David M. Sutphin

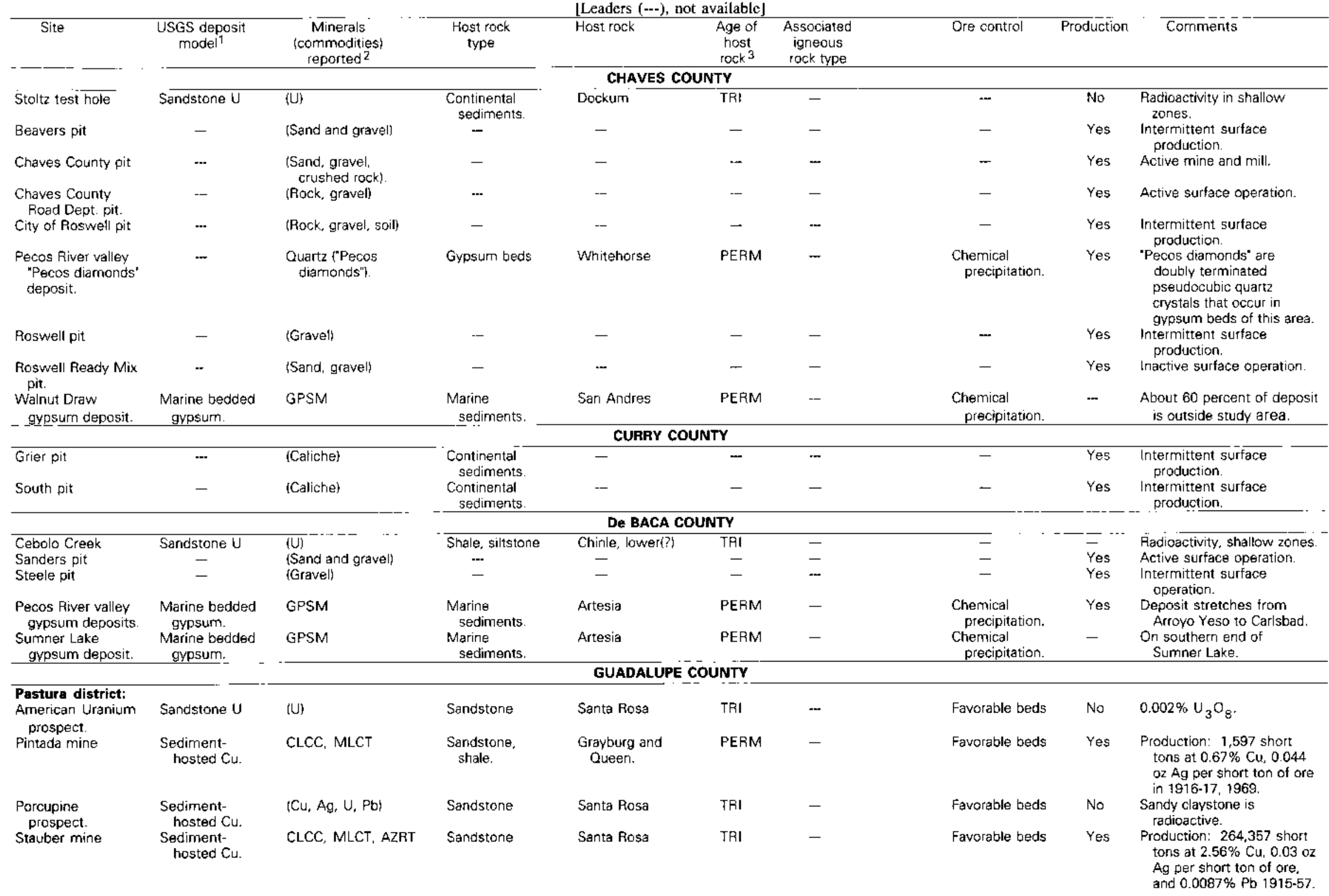




\begin{tabular}{|c|c|c|c|c|c|c|c|c|c|}
\hline \multicolumn{10}{|l|}{ Other deposits: } \\
\hline $\begin{array}{l}\text { Branch Ranch } \\
\text { prospect. }\end{array}$ & Sandstone U & $(U, V)$ & $\begin{array}{l}\text { Shale, } \\
\text { sandstone. }\end{array}$ & Chinle & TRI & - & \multirow{2}{*}{$\begin{array}{l}\text { Carbonized wood } \\
\text { fragments. } \\
-\end{array}$} & No & $\begin{array}{l}\text { Uranium associated with } \\
\text { carbonized wood. }\end{array}$ \\
\hline $\begin{array}{l}\text { Neafus Fanch } \\
\text { prospect. }\end{array}$ & Sandstone $U$ & $(U, V)$ & $\begin{array}{l}\text { Shale, } \\
\text { sandstone. }\end{array}$ & Chinle & TRI & - & & No & $\begin{array}{l}\text { Carbonaceous lavers a fow } \\
\text { inches thick. }\end{array}$ \\
\hline $\begin{array}{l}\text { Santa Rosa } \\
\text { jet deposit. }\end{array}$ & - & Coal (jet) & Coal beds & - & - & - & $\begin{array}{l}\text { Deposition of } \\
\text { coal. }\end{array}$ & Yes & A little developed producer. \\
\hline $\begin{array}{l}\text { Santa Rosa } \\
\text { railroad cut. }\end{array}$ & Sandstone U & (U) & $\begin{array}{l}\text { Shale, } \\
\text { sandstone. }\end{array}$ & Chinle & TRI & - & $\begin{array}{l}\text { Carbonaceous } \\
\text { material. }\end{array}$ & No & $\begin{array}{l}\text { Radioactivity in a clavstone } \\
\text { lens } 3 \mathrm{ft} \text { thick and } 400 \mathrm{ft} \\
\text { long. }\end{array}$ \\
\hline $\begin{array}{l}\text { Santa Rosa } \\
\text { tar sands. }\end{array}$ & - & $\{U$, tar sand $\}$ & Sandstone & Santa Rosa & TR: & - & $\begin{array}{l}\text { Carbonaceous } \\
\text { material. }\end{array}$ & Yes & $\begin{array}{l}\text { Production: } 153,000 \text { short } \\
\text { tons of tar sand } 1930-39 .\end{array}$ \\
\hline $\begin{array}{l}\text { Santa Rosa } \\
\text { gypsum deposit. }\end{array}$ & $\begin{array}{l}\text { Marine bedded } \\
\text { gypsum. }\end{array}$ & GPSM & $\begin{array}{l}\text { Marine } \\
\text { sediments. }\end{array}$ & Artesia & PERM & - & $\begin{array}{l}\text { Chemical } \\
\text { precipitation. }\end{array}$ & No & $\begin{array}{l}\text { Located south and west of } \\
\text { Santa Rosa. }\end{array}$ \\
\hline $\begin{array}{l}\text { Vaughn region } \\
\text { gypsum deposit. }\end{array}$ & $\begin{array}{l}\text { Marine bedded } \\
\text { gypsum. }\end{array}$ & GPSM & $\begin{array}{l}\text { Marine } \\
\text { sediments. }\end{array}$ & San Andres & PERM & - & $\begin{array}{l}\text { Chemical } \\
\text { precipitation. }\end{array}$ & No & $\begin{array}{l}\text { Deposit covers a } 22 \times 11-\mathrm{mi} \\
\text { teardrop-shaped area. }\end{array}$ \\
\hline & & & & LINCOLN COUI & STY & & & & \\
\hline Capitan Mountain & district: & & & & & & & & \\
\hline $\begin{array}{l}\text { Arabela Mines } \\
\text { Mn mine. }\end{array}$ & $\begin{array}{l}\text { Replacement } \\
\text { Mn. }\end{array}$ & PSLM, KLNT & Limestone & San Andres & PERM & Alaskite & Intrusive contact & Yes & Post-1959 production. \\
\hline $\begin{array}{r}\text { Barlejon \#2 } \\
\text { prospect. }\end{array}$ & Th-REE veins & - & Alaskite & $\begin{array}{l}\text { Capitan Mountains } \\
\text { alaskite. }\end{array}$ & TERT & Alaskite & Breccia zone & No & $0.03-0.39 \% \mathrm{U}_{3} \mathrm{O}_{8}$ \\
\hline Barry prospects & Th-REE veins & $\begin{array}{l}\text { ALNT, QRTZ, FLRT, } \\
\text { TRML, Fe oxides. }\end{array}$ & Alaskite & $\begin{array}{l}\text { Capitan Mountains } \\
\text { alaskite. }\end{array}$ & TERT & Alaskite & $\begin{array}{l}\text { Fractures or } \\
\text { shears. }\end{array}$ & No & $1.7 \%$ Th in biased samples. \\
\hline $\begin{array}{l}\text { Bear Canyon } \\
\text { Group. }\end{array}$ & Th-REE veins & (U) & Alaskite & $\begin{array}{l}\text { Capitan Mountains } \\
\text { alaskite. }\end{array}$ & TERT & Alaskite & $\begin{array}{l}\text { Fractures or } \\
\text { shears. }\end{array}$ & Yes & $\begin{array}{l}\text { Production: } 3 \text { short tons } \\
\text { at } 0.02 \% \cup_{3} \mathrm{O}_{\mathrm{B}} \text { between } \\
1948 \text { and } 1970 \text {. }\end{array}$ \\
\hline $\begin{array}{l}\text { Capitan iron } \\
\text { deposit. }\end{array}$ & Fe skarn & $\begin{array}{l}\text { MGNT, HMT, GTHT, } \\
\text { EPDT, PLGP. }\end{array}$ & Limestone & San Andres & PERM & $\begin{array}{l}\text { Aplite and } \\
\text { alaskite. }\end{array}$ & $\begin{array}{l}\text { Karst topography, } \\
\text { sinkhole. }\end{array}$ & Yes & $\begin{array}{l}\text { Resources: } 3,000,000 \text { short } \\
\text { tons at } 45.6 \% \mathrm{Fe} \text { in } 1949 .\end{array}$ \\
\hline $\begin{array}{l}\text { Capitan Uranium } \\
\text { Co. prospect. }\end{array}$ & Th-REE veins & - & Alaskite & $\begin{array}{l}\text { Capitan Mountains } \\
\text { alaskite. }\end{array}$ & TERT & Alaskite & Fractures & No & $\begin{array}{l}0.06-0.18 \% \mathrm{U}_{2} \mathrm{O}_{\mathrm{O}} \\
0.35-1.00 \% \mathrm{P}_{2}\end{array}$ \\
\hline $\begin{array}{l}\text { Copeland Canyon } \\
\text { prospect. }\end{array}$ & Th-REE veins & MGNT & Alaskite & $\begin{array}{l}\text { Capitan Mountains } \\
\text { alaskite. }\end{array}$ & TERT & Alaskite & Fractures & No & $\begin{array}{l}\text { Twice background } \\
\text { radioactivity. }\end{array}$ \\
\hline Drunzer prospect & Th-REE veins & $\begin{array}{l}\text { ALNT, QRTZ, FLRT, } \\
\text { TRML, Fe oxides. }\end{array}$ & Alaskite & $\begin{array}{l}\text { Capitan Mountains } \\
\text { alasskite. }\end{array}$ & TERT & Alaskite & $\begin{array}{l}\text { Fractures or } \\
\text { shears. }\end{array}$ & No & $\begin{array}{l}\text { 3-in.-wide breccia vein } \\
\text { exposed in trench. }\end{array}$ \\
\hline El Tigré prospect & Th-FEE veins & ALNT? & Alaskite & $\begin{array}{l}\text { Capitan Mountains } \\
\text { alaskite. }\end{array}$ & TERT & Alaskite & $\begin{array}{l}\text { Fractures or } \\
\text { shears. }\end{array}$ & No & Radioactive vein in alaskite. \\
\hline $\begin{array}{l}\text { Fuzzy Nut 1-18 } \\
\text { claims. }\end{array}$ & Th-REE veins & ALNT? & Alaskite & $\begin{array}{l}\text { Capitan Mountains } \\
\text { alaskite. }\end{array}$ & TERT & Alaskite & Fractures & No & Radioactive vein in alaskite. \\
\hline Hopeful claims & Th-REE veins & FLRT & Alaskite & $\begin{array}{l}\text { Capitan Mountains } \\
\text { alaskite. }\end{array}$ & TERT & Alaskite & Breccia vein & No & $\begin{array}{l}\text { Radioactive breccia vein in } \\
\text { alaskite. }\end{array}$ \\
\hline King prospect & Th-PEE veins & $\begin{array}{l}\text { ALNT, ORTZ, FLRT, } \\
\text { TRML, Fe oxides. }\end{array}$ & Alaskite & $\begin{array}{l}\text { Capitan Mountains } \\
\text { alaskite. }\end{array}$ & TERT & Alaskite & $\begin{array}{l}\text { Fractures or } \\
\text { shears. }\end{array}$ & No & $\begin{array}{l}\text { Several small radicactive } \\
\text { anomalies noted. }\end{array}$ \\
\hline Koprian Springs & Th-REE veins & - & Alaskite & $\begin{array}{l}\text { Capitan Mountains } \\
\text { alaskite. }\end{array}$ & TERT & Alaskite & $\begin{array}{l}\text { Fractures or } \\
\text { shears. }\end{array}$ & No & $\begin{array}{c}0.002-0.051 \% \mathrm{U}_{3} \mathrm{O}_{8} \\
0.34 \% \mathrm{ThO}_{2}\end{array}$ \\
\hline Major prospect & Fe skarn & $\begin{array}{l}\text { MGNT, CLRT, ACNL, } \\
\text { TMLT. }\end{array}$ & Limestone & San Andres & PERM & Alaskite & Fault zone & No & $\begin{array}{l}\text { Resources: } 20,000 \text { short } \\
\text { tons Fe material in } 1944 \\
\text { for Major, Red Wing. Ajax. } \\
\text { and Oslo prospects. }\end{array}$ \\
\hline McCory prospects & Th-REE veins & $\begin{array}{l}\text { ALNT, ORTZ, FLRT, } \\
\text { TAML, Fe-oxides. }\end{array}$ & Alaskite & $\begin{array}{l}\text { Capitan Mountains } \\
\text { alaskite. }\end{array}$ & TERT & Alaskite & $\begin{array}{l}\text { Fractures or } \\
\text { shears. }\end{array}$ & No & $\begin{array}{l}\text { As much as } 64 \text { times } \\
\text { background radioactivity. }\end{array}$ \\
\hline Mina Tiro Estrella & Th-REE veins & ALNT, TTNT & Alaskite & $\begin{array}{l}\text { Capitan Mountains } \\
\text { alaskite. }\end{array}$ & TERT & Alaskite & $\begin{array}{l}\text { Fractures or } \\
\text { shears. }\end{array}$ & No & $\begin{array}{l}\text { Three to four times } \\
\text { background radioactivity. }\end{array}$ \\
\hline Monzo group & Th-REE veins & ALNT & Alaskite & $\begin{array}{l}\text { Capitan Mountains } \\
\text { alaskite. }\end{array}$ & TERT & Alaskite & $\begin{array}{l}\text { Fractures, } \\
\text { brecciation. }\end{array}$ & No & $\begin{array}{l}0.003-0.01 \% \mathrm{U}_{3} \mathrm{O}_{\mathrm{\theta}} \\
3.57 \% \mathrm{ThO}_{2}\end{array}$ \\
\hline $\begin{array}{l}\text { Pine Lodge } \\
\text { deposits. }\end{array}$ & Th-REE veins & ALNT & Alaskite & $\begin{array}{l}\text { Capitan Mountains } \\
\text { alaskite. }\end{array}$ & TERT & Alaskite & $\begin{array}{l}\text { Fractures, } \\
\text { brecciation. }\end{array}$ & No & $\begin{array}{l}\text { As much as } 20 \text { times } \\
\text { background radioactivity. }\end{array}$ \\
\hline
\end{tabular}


APPENDIX. GEOLOGIC AND MINERAL RESOURCES INFORMATION FOR THE ROSWELL RESOURCE AREA, NEW MEXICO-Continued

\begin{tabular}{|c|c|c|c|c|c|c|c|c|c|}
\hline Site & $\begin{array}{l}\text { USGS deposit } \\
\text { model }^{1}\end{array}$ & $\begin{array}{l}\text { Minerals } \\
\text { (commodities\}) } \\
\text { reported }^{2}\end{array}$ & $\begin{array}{l}\text { Host rock } \\
\text { type }\end{array}$ & Host rock & $\begin{array}{l}\text { Age of } \\
\text { host } \\
\text { rock } 3\end{array}$ & $\begin{array}{l}\text { Associated } \\
\text { igneous } \\
\text { rock type }\end{array}$ & Ore control & Production & Comments \\
\hline $\begin{array}{l}\text { San Pedro-Link- } \\
\text { Nob Hill. }\end{array}$ & Th-REE veins & ALNT & Alaskite & $\begin{array}{l}\text { Capitan Mountains } \\
\text { alaskite. }\end{array}$ & TERT & Alaskite & Fractures & No & $\begin{array}{l}\text { Twice background } \\
\text { radioactivity. }\end{array}$ \\
\hline Silvertone claim & Th-REE veins & - & - & $\begin{array}{l}\text { Capitan Mountains } \\
\text { alaskite. }\end{array}$ & TERT & - & Brecciation & No & $\begin{array}{l}0.01 \% \mathrm{U}_{3} \mathrm{O}_{8} \\
0.04 \% \mathrm{~V}_{2} \mathrm{O}_{5}\end{array}$ \\
\hline Tide iron deposit & Fe skarn & MGNT, HMTT & Alaskite & $\begin{array}{l}\text { Capitan Mountains } \\
\text { alaskite. }\end{array}$ & TERT & Alaskite & $\begin{array}{l}\text { East-west- } \\
\text { trending fault. }\end{array}$ & No & $\begin{array}{l}\text { Early development did not } \\
\text { determine size of deposit. }\end{array}$ \\
\hline Wee-Three 1-3 & Th-REE veins & ALNT & Alaskite & $\begin{array}{l}\text { Capitan Mountains } \\
\text { alaskite. }\end{array}$ & TERT & Alaskite & Fractures & No & $\begin{array}{l}0.001-0.002 \% \mathrm{U}_{3} \mathrm{O}_{8} \\
0.17 \% \mathrm{ThO}_{2} .\end{array}$ \\
\hline Whettige deposits & Fe skarn & MGNT & Limestone & San Andres & PERM & - & $\begin{array}{l}\text { Favorable host } \\
\text { rock. }\end{array}$ & No & $\begin{array}{l}\text { Two small undeveloped } \\
\text { prospects. }\end{array}$ \\
\hline $\begin{array}{l}\text { Gallinas district: } \\
\text { All American mine }\end{array}$ & Fluorite veins & $\begin{array}{l}\text { FLRT, BRIT, BSNS, } \\
\text { Cu oxides. }\end{array}$ & $\begin{array}{l}\text { Quartzitic } \\
\text { sandstone. }\end{array}$ & Yeso & PERM & $\begin{array}{l}\text { Ouartz monzonite } \\
\text { porphyry: syenite }\end{array}$ & Brecciated fault & Yes & $\begin{array}{l}\text { Production: } 129 \text { short tons } \\
\text { fluorspar in 1949-51. }\end{array}$ \\
\hline $\begin{array}{l}\text { American iron } \\
\text { mine. }\end{array}$ & Fe skarn & MGNT, HMTT & Limestone & Yeso & PERM & $\begin{array}{l}\text { Porphyritic trachyte } \\
\text { and syenite. }\end{array}$ & $\begin{array}{l}\text { Limestone } \\
\text { xenolith. }\end{array}$ & Yes & $\begin{array}{l}\text { Production: } 3.944 \text { short tons } \\
\text { ore at } 55.7 \% \mathrm{Fe} 1942-43 .\end{array}$ \\
\hline $\begin{array}{l}\text { Big Ben (Sky High) } \\
\text { prospect. }\end{array}$ & Fluorite veins & FLRT, BRIT & $\begin{array}{l}\text { Quartzitic } \\
\text { sandstone. }\end{array}$ & Yeso & PERM & $\begin{array}{l}\text { Quartz monzonite } \\
\text { porphyry; syenite } \\
\text { porphyry sill. }\end{array}$ & Brecciated fault & No & $\begin{array}{l}\text { Deposits of irregular- } \\
\text { shaped pods and lenses. }\end{array}$ \\
\hline $\begin{array}{l}\text { Bottleneck } \\
\text { prospect. }\end{array}$ & Fluorite veins & FLRT, BAIT & $\begin{array}{l}\text { Sandstone, } \\
\text { limestone. }\end{array}$ & Yeso & PERM & $\begin{array}{l}\text { Syenite porphyry; } \\
\text { quartz monzonite. }\end{array}$ & Brecciated fault & No & $\begin{array}{l}\text { Composite sample: } \\
47.94 \% \mathrm{CaF}_{2}, 21.12 \% \\
\mathrm{BaSO}_{4} \text { and } 25.2 \% \mathrm{SiO}_{2} \text {. }\end{array}$ \\
\hline $\begin{array}{l}\text { Buckhorn } \\
\text { prospect. }\end{array}$ & Fluorite veins & $\begin{array}{l}\text { Cu minerals, FLRT, } \\
\text { BRIT. }\end{array}$ & Sandstone & Yeso & PERM & $\begin{array}{l}\text { Quartz monzonite } \\
\text { porphyry: syenite } \\
\text { porphyry sill. }\end{array}$ & Brecciated fault & No & $\begin{array}{l}\text { Small vein exposed at } \\
\text { surface. }\end{array}$ \\
\hline Congress prospect & Fluorite veins & FLRT, BRIT & $\begin{array}{l}\text { Sandstone, } \\
\text { limestone. }\end{array}$ & Yeso & PERM & - & Brecciated fault & No & $\begin{array}{l}\text { Fluorspar occurs in irregular- } \\
\text { shaped pockets along a } \\
\text { brecciated fault. }\end{array}$ \\
\hline Conqueror mine & Fluorite veins & $\begin{array}{l}\text { FLRT, GLEN, BRIT, } \\
\text { CRST, ANGS. }\end{array}$ & Sandstone & Yeso & PERM & $\begin{array}{l}\text { Quartz monzonite } \\
\text { porphyry; syenite } \\
\text { porphyry sill. }\end{array}$ & Brecciated fault & Yes & $\begin{array}{l}\text { Production: } 300 \text { short tons } \\
\text { of F-Pb-Cu ore in } 1956 \text {. }\end{array}$ \\
\hline $\begin{array}{l}\text { Conqueror No. } 4 \\
\text { and Hilltop } \\
\text { prospect. }\end{array}$ & Fluorite veins & FLRT, BRIT & $\begin{array}{l}\text { Quartzitic } \\
\text { sandstone. }\end{array}$ & Yeso & PERM & $\begin{array}{l}\text { Quartz monzonite } \\
\text { porphyry: syenite } \\
\text { porphyry sill. }\end{array}$ & Brecciated fault & Yes & $\begin{array}{l}\text { Composite sample: } 57.4 \% \\
\mathrm{CaF}_{2}, 21.2 \% \mathrm{BaSO}_{4} \text {. } \\
\text { and } 20.8 \% \mathrm{SiO}_{2} \text {. }\end{array}$ \\
\hline $\begin{array}{l}\text { Deadwood } \\
\text { prospect. }\end{array}$ & Fluorite veins & $\begin{array}{l}\text { Cu minerals, FLRT, } \\
\text { BRIT. }\end{array}$ & $\begin{array}{l}\text { Syenite } \\
\text { porphyry. }\end{array}$ & - & TERT & $\begin{array}{l}\text { Quartz monzonite } \\
\text { porphyry syenite } \\
\text { porphyry sill. }\end{array}$ & Brecciated fault & Yes & $\begin{array}{l}\text { A western extension of } \\
\text { Red Cloud deposit. }\end{array}$ \\
\hline $\begin{array}{l}\text { Eagle Nest } \\
\text { prospect. }\end{array}$ & Fluorite veins & FLFT, BRIT, BSNS & Sandstone & Yeso & PERM & $\begin{array}{l}\text { Quartz monzonite } \\
\text { porphyry; syenite } \\
\text { porphyry sill. }\end{array}$ & Brecciated fault & No & $\begin{array}{l}\text { Ore is a dense aggregate of } \\
\text { fluorite, barite, quartz, and } \\
\text { calcite. }\end{array}$ \\
\hline Eureka prospect & Fluorite veins & $\begin{array}{l}\text { FLRT, BRIT, CHRY, } \\
\text { GLEN. }\end{array}$ & $\begin{array}{l}\text { Sandstone, } \\
\text { limestone. }\end{array}$ & Yeso & PERM & $\begin{array}{l}\text { Quartz monzonite } \\
\text { porphyry; syenite } \\
\text { porphyry sill. }\end{array}$ & Brecciated fault & No & $\begin{array}{l}\text { Composite sample: } 43.8 \% \\
\mathrm{CaF}_{2}, 25.5 \% \mathrm{BaSO}_{4} \\
10.8 \% \mathrm{SiO}_{2} \text {, and } \\
5.5 \% \mathrm{CaO}^{2}\end{array}$ \\
\hline Gallinas iron mine & Fe skarn & MGNT, HMTT & Limestone & Yeso & PERM & $\begin{array}{l}\text { Porphyritic trachyte } \\
\text { and syenite. }\end{array}$ & $\begin{array}{l}\text { Favorable host } \\
\text { rock. }\end{array}$ & Yes & $\begin{array}{l}\text { Production: } 6,410 \text { short } \\
\text { tons ore at } 48.7 \% \mathrm{Fe} \text { in } \\
1942 \text {. }\end{array}$ \\
\hline Helen S prospect & Fluorite veins & FLRT & Sandstone & Yeso & PERM & $\begin{array}{l}\text { Quartz monzonite } \\
\text { porphyry; syenite } \\
\text { porphyry sill. }\end{array}$ & Brecciated fault & No & $\begin{array}{l}\text { Inactive undeveloped } \\
\text { occurrence. }\end{array}$ \\
\hline
\end{tabular}




\begin{tabular}{|c|c|c|c|c|c|c|c|c|c|}
\hline $\begin{array}{l}\text { Hoosier Girl } \\
\text { prospect. }\end{array}$ & Fluorite veins & FLRT, BRIT, BSNS & Sandstone & Yeso & PERM & $\begin{array}{l}\text { Quartz monzonite } \\
\text { porphyry: syenite } \\
\text { porphyry sill. }\end{array}$ & Brecciated faults & No & $\begin{array}{l}\text { Composite sample: } 54.2 \% \\
\mathrm{CaF}_{2}, 15.0 \% \mathrm{BaSO} \\
8.2 \% \mathrm{SiO}_{2}, \text { and } 4.5 \% \mathrm{CaO} \text {. }\end{array}$ \\
\hline Iron Box prospect & Fe skarn & MGNT & $\begin{array}{l}\text { Limestone, } \\
\text { sandstone. }\end{array}$ & Yesot?? & PERM & $\begin{array}{l}\text { Monzonite porphyry } \\
\text { sill. }\end{array}$ & Intrusive contact & No & Only 4-6 tt thick, low grade. \\
\hline $\begin{array}{l}\text { Last Chance } \\
\text { prospect. }\end{array}$ & Fluorite veins & FLRT, BSNS, BRIT & Sandstone & Yeso & PERM & $\begin{array}{l}\text { Quartz monzonite } \\
\text { porphyry; syenite } \\
\text { porphyry sill. }\end{array}$ & Brecciated fault & No & $\begin{array}{l}\text { Fluorite vein in Permian } \\
\text { sandstone. }\end{array}$ \\
\hline Old Hickory mine & Fluorite veins & $\begin{array}{l}\text { FLRT, BRIT, GLEN, } \\
\text { MLCT. BSNS, AZRT. }\end{array}$ & $\begin{array}{l}\text { Quartzitic } \\
\text { sandstone. }\end{array}$ & Yeso & PERM & $\begin{array}{l}\text { Quartz monzonite } \\
\text { porphyry; syenite } \\
\text { porphyry sill. }\end{array}$ & Brecciated fault & Yes & $\begin{array}{l}\text { Mineralization in a breccia } \\
\text { vein adjacent to a trachyte } \\
\text { dike. }\end{array}$ \\
\hline $\begin{array}{l}\text { Pride } 2 \text { and } E \text { and } \\
M 13 \text { prospects. }\end{array}$ & Fluorite veins & BSNS & $\begin{array}{l}\text { Limestone, } \\
\text { sandstone. }\end{array}$ & Yeso & PERM & - & - & No & $\begin{array}{l}\text { Bastnaesite veins in Yeso } \\
\text { Formation. }\end{array}$ \\
\hline $\begin{array}{l}\text { Rare Metals } \\
\text { prospect. }\end{array}$ & Fe skarn & $\begin{array}{l}\text { MGNT, HMTT, GLEN, } \\
\text { FLRT, skarn minerals. }\end{array}$ & Limestone & Yeso & PERM & Syenite porphyry & Intrusive contact & No & $\begin{array}{l}\text { A few tens of thousands } \\
\text { short tons at } 40-50 \% \text { Fe. }\end{array}$ \\
\hline Red Cloud mine & Fluorite veins & $\begin{array}{l}\text { FLRT, BSNS, BRIT, } \\
\text { GLEN, SPLR. }\end{array}$ & $\begin{array}{l}\text { Quartzitic } \\
\text { sandstone } \\
\text { and siltstone. }\end{array}$ & Yeso & PERM & $\begin{array}{l}\text { Quartz monzonite } \\
\text { porphyry: syenite } \\
\text { porphyry sill. }\end{array}$ & Brecciated fault & Yes & $\begin{array}{l}\text { Production: } 1.000 \text { short tons } \\
\text { fluorspar concentrates and } \\
60 \text { short tons REE } \\
\text { concentrates early } 1950 \text { 's. }\end{array}$ \\
\hline Summit prospect & Fluorite veins & FLRT, BFiT & $\begin{array}{l}\text { Quartzitic } \\
\text { sandstone. }\end{array}$ & $Y_{\theta S O}$ & PERM & $\begin{array}{l}\text { Quartz monzonite } \\
\text { porphyry; syenite } \\
\text { porphyry sill. }\end{array}$ & Brecciated fault & No & $\begin{array}{l}\text { Mineralization is in a } 4 \text {-ft- } \\
\text { wide brecciated fault zone. }\end{array}$ \\
\hline $\begin{array}{l}\text { Jicarille dis } \\
\text { Apex claims }\end{array}$ & $\begin{array}{l}\text { Au-Ag-Te veins } \\
\text { associated with } \\
\text { alkaline rocks. }\end{array}$ & GOLD & - & - & - & - & - & - & $\begin{array}{l}\text { About } 0.25 \mathrm{mi} \mathrm{SE} \text { of } S p r i n g \\
\text { mine. }\end{array}$ \\
\hline Black Gold mine & - & GOLD, MGNT, PYRT & $\begin{array}{l}\text { Granodiorite and } \\
\text { monzonite } \\
\text { porphyry. }\end{array}$ & - & - & $\begin{array}{l}\text { Granodiorite and } \\
\text { monzonite } \\
\text { porphyry. }\end{array}$ & - & No & $\begin{array}{l}\text { About } 700 \mathrm{ft} \text { of workings } \\
\text { show sparse } \\
\text { mineralization. }\end{array}$ \\
\hline Hoecradle deposit & Fe skarn & MGNT & - & - & - & - & - & Yes & $\begin{array}{l}\text { Production: } 590 \text { short tons } \\
\text { at } 60.1 \% \mathrm{Fe} 1942-43 \text {. }\end{array}$ \\
\hline Jack iron mines & Fe skarn & MGNT, HMTT & Limestone & San Andres & PERM & Monzonite porphyry & $\begin{array}{l}\text { Favorable host } \\
\text { rock. }\end{array}$ & Yes & $\begin{array}{l}\text { Production: } 3,736 \text { short tons } \\
\text { at } 55-65 \% \mathrm{Fe} 1918-21,43\end{array}$ \\
\hline Jicarilla placers & AL-PGE placer & GOLD, ELCM, SLVR & $\begin{array}{l}\text { Fanglomerate, } \\
\text { alluvium. }\end{array}$ & Ogallalat? & TERT & Granodiorite & $\begin{array}{l}\text { Hydrodynamic } \\
\text { sorting. }\end{array}$ & Yes & $\begin{array}{l}\text { Production: } 1,814.32 \text { oz } \\
\text { Au, } 143 \text { oz Ag in } 1933-42 \text {. }\end{array}$ \\
\hline Lane deposit & Fe skarn & MGNT & Limestone & San Andres & PERM & Monzonite dike & $\begin{array}{l}\text { Favorable host } \\
\text { rock. }\end{array}$ & Yes & $\begin{array}{l}\text { Production: } 70 \text { short tons } \\
\text { at } 60.0 \% \mathrm{~F} \theta \text { in } 1943 \text {. }\end{array}$ \\
\hline Lobner mine & Fe skarn & MGNT & Limestone & San Andres & PERM & Monzonite & $\begin{array}{l}\text { Favorable host } \\
\text { rock. }\end{array}$ & No & An undeveloped prospect. \\
\hline Lucky Strike area & $\begin{array}{l}\text { Au-Ag-Te veins } \\
\text { associated with } \\
\text { alkaline rocks. }\end{array}$ & GOLD & Limestone & San Andres & PERM & Monzonite & Intrusive contact & Yes & $\begin{array}{l}\text { Production: } 82.62 \text { oz Au in } \\
1933 \text {. }\end{array}$ \\
\hline Magnetite mine & Fe skarn & MGNT, HMTT. KLNT & $\begin{array}{l}\text { Monzonite, } \\
\text { limestone. }\end{array}$ & San Andres(?) & PERM & Monzonite & $\begin{array}{l}\text { Limestone inclu- } \\
\text { sion in monzonite. }\end{array}$ & Yes & $\begin{array}{l}\text { Production: } 2,514 \text { short tons } \\
\text { at } 57.2 \% \mathrm{Fe} 1942-43 \text {. }\end{array}$ \\
\hline Norma deposit & Fe skarn & MGNT & Limestone & San Andres & PERM & Monzonite sill & Intrusive contact & Yes & $\begin{array}{l}\text { Production: } 75 \text { short tons } \\
\text { Fe ore in } 1942 \text {. }\end{array}$ \\
\hline Sally mine & $\begin{array}{l}\text { Au-Ag-Te veins } \\
\text { associated with } \\
\text { alkaline rocks. }\end{array}$ & GOLD, AU-PYRT & $\begin{array}{l}\text { Monzonite } \\
\text { porphyry. }\end{array}$ & - & TERT & Monzonite porphyry & Intrusive contact & Yes & $\begin{array}{l}\text { Deposit consists of } \\
\text { numerous quartz-pyrite } \\
\text { veinlets. }\end{array}$ \\
\hline $\begin{array}{l}\text { Spring \{Gold Stain\} } \\
\text { mine. }\end{array}$ & $\begin{array}{l}\text { Au-Ag-Te veins } \\
\text { associated with } \\
\text { alkaline rocks. }\end{array}$ & GOLD, PYRT & Monzonite sill & - & TERT & Monzonite sill & - & No & $\begin{array}{l}\text { About } 0.25 \mathrm{mi} \mathrm{NW} \text { of } \\
\text { Apex mine. }\end{array}$ \\
\hline Zuni mines & Fe skarn & MGNT & Limestone & San Andres & PERM & Monzonite porphyry & Intrusive contact & Yes & $\begin{array}{l}\text { Production: } 829 \text { short tons } \\
\text { Fe ore in } 1943 \text {. }\end{array}$ \\
\hline & $\begin{array}{l}\text { Polymetallic } \\
\text { veins. }\end{array}$ & $\begin{array}{l}\text { GOLD, SLVR, SPLR, } \\
\text { GLEN. }\end{array}$ & $\begin{array}{l}\text { Monzonite and } \\
\text { andesite. }\end{array}$ & $\begin{array}{l}\text { Sierra Blanca } \\
\text { Igneous Complex. }\end{array}$ & TERT & Monzonite & Fault-fracture & Yes & $\begin{array}{l}\text { Best mineralization was at } \\
\text { intersection of main and } \\
\text { minor veins. }\end{array}$ \\
\hline
\end{tabular}


APPENDIX. GEOLOGIC AND MINERAL RESOURCES NNFORMATION FOR THE ROSWELL RESOURCE AREA, NEW MEXICO-Continued

\begin{tabular}{|c|c|c|c|c|c|c|c|c|c|}
\hline Site & $\begin{array}{l}\text { USGS deposit } \\
\text { model }^{1}\end{array}$ & $\begin{array}{l}\text { Minerals } \\
\text { (commodities) } \\
\text { reported }^{2}\end{array}$ & $\begin{array}{l}\text { Host rock } \\
\text { type }\end{array}$ & Host rock & $\begin{array}{c}\text { Age of } \\
\text { host } \\
\text { rock }\end{array}$ & $\begin{array}{l}\text { Associated } \\
\text { igneous } \\
\text { rock type }\end{array}$ & Ore control & Production & Comments \\
\hline $\begin{array}{l}\text { Bon group molv } \\
\text { prospect. }\end{array}$ & $\begin{array}{l}\text { Porphyry Mo, } \\
\text { low F. }\end{array}$ & MLDB & Syenite & Three Rivers stock & TERT & Syenite & - & No & \\
\hline Bonita claims & $\begin{array}{l}\text { Polymetallic } \\
\text { veins. }\end{array}$ & QRTZ, SLPD, CLCP & Andesite & $\begin{array}{l}\text { Sierra Blanca } \\
\text { Igneous Complex. }\end{array}$ & TERT & Andesite & Fault-fracture & No & $\begin{array}{l}\text { As much as } 20 \text { times } \\
\text { background radioactivity. }\end{array}$ \\
\hline Bonito property & $\begin{array}{l}\text { Alu-Ag-Te veins } \\
\text { associated with } \\
\text { alkakine rocks. }\end{array}$ & Oxides and sulfides & $\begin{array}{l}\text { Altered } \\
\text { monzonite. }\end{array}$ & - & TERT & Altered monzonite & $\begin{array}{l}\text { Brecciation, } \\
\text { faulting. } \\
\text { alteration. }\end{array}$ & No & $\begin{array}{l}\text { Resources estimated at } \\
3,603,000 \text { short tons at } \\
0.053 \text { oz Au per short ton } \\
\text { of ore. }\end{array}$ \\
\hline Commercial mine & $\begin{array}{l}\text { Polymetallic } \\
\text { veins. }\end{array}$ & CLCP, BRNT, GLEN & Andesite & $\begin{array}{l}\text { Sierra Blanca } \\
\text { Igneous Complex. }\end{array}$ & TERT & Andesite & Fault-fracture & Yes & $\begin{array}{l}\text { Deposit intensely altered } \\
\text { and sheared. }\end{array}$ \\
\hline Crow mine & $\begin{array}{l}\text { Polymetallic } \\
\text { veins. }\end{array}$ & $\begin{array}{l}\text { GOLO, SLVA, SPLR, } \\
\text { GLEN. }\end{array}$ & Andesite & $\begin{array}{l}\text { Sierra Blanca } \\
\text { Igneous Complex. }\end{array}$ & TERT & $\begin{array}{l}\text { Andesite and } \\
\text { monzonite. }\end{array}$ & Fault-fracture & Yes & $\begin{array}{c}\text { Grades } 0.03 \text { oz Au per short } \\
\text { ton of ore, } 64.64 \mathrm{Oz} \mathrm{Ag} \mathrm{per} \\
\text { short ton of ore, } 1.13 \% \mathrm{~Pb} \text {, } \\
0.1 \% \mathrm{Cu}, 3.4 \% \mathrm{Zn} 1962 .\end{array}$ \\
\hline Helen Rae mine & $\begin{array}{l}\text { Polymetallic } \\
\text { veins. }\end{array}$ & CLCP, GLEN, SFLR & $\begin{array}{l}\text { Monzonite and } \\
\text { andesite. }\end{array}$ & $\begin{array}{l}\text { Sierra Blanca } \\
\text { Igneous Complex. }\end{array}$ & TERT & $\begin{array}{l}\text { Monzonite and } \\
\text { andesite. }\end{array}$ & Fault-fracture & Yes & $\begin{array}{l}\text { Produced from same vein } \\
\text { as American mine. }\end{array}$ \\
\hline Homestake group & $\begin{array}{l}\text { Polymetallic } \\
\text { veins. }\end{array}$ & GLEN，SLVR，GOLD & $\begin{array}{l}\text { Andesite and } \\
\text { diorite. }\end{array}$ & $\begin{array}{l}\text { Sierra Blanca } \\
\text { Igneous Complex. }\end{array}$ & TERT & $\begin{array}{l}\text { Andesite and diorite } \\
\text { porphyry dikes. }\end{array}$ & Fault-fracture & Yes & $\begin{array}{l}\text { In a brecciated zone adjacent } \\
\text { to east-trending dikes. }\end{array}$ \\
\hline Maud mine & $\begin{array}{l}\text { Polvmetallic } \\
\text { veins. }\end{array}$ & GOLD, ELCM, MLBD & Andesite & $\begin{array}{l}\text { Sierra Blanca } \\
\text { Igneous Complex. }\end{array}$ & TERT & Andesite & Fault-fracture & Yes & $\begin{array}{l}\text { Composite sample } \\
\text { contained } 7.10 \% \mathrm{~Pb}, \\
0.39 \% \mathrm{Zn}, 0.17 \% \mathrm{Mo}, 0.32 \\
\text { oz Au per short ton of ore, } \\
\text { and } 1.28 \text { oz } \mathrm{Ag} \text { per short } \\
\text { ton of ore. }\end{array}$ \\
\hline $\begin{array}{l}\text { Mudpuppy- } \\
\text { Waterdog } \\
\text { prospect. }\end{array}$ & $\begin{array}{l}\text { Au-Ag-Te veins } \\
\text { associated with } \\
\text { alkaline rocks. }\end{array}$ & $\begin{array}{l}\text { CU-SLPD, PYRT, } \\
\text { LMON, MLBD. }\end{array}$ & $\begin{array}{l}\text { Syenite to } \\
\text { monzonite. }\end{array}$ & Bonito Lake ștock & OLFGO & $\begin{array}{l}\text { Syenite to } \\
\text { monzonite. }\end{array}$ & $\begin{array}{l}\text { Brecciation, } \\
\text { faulting, } \\
\text { alteration. }\end{array}$ & No & $\begin{array}{l}\text { Mapping has identified } \\
\text { concentric zones of } \\
\text { alteration in a } \\
\text { hydrothermal system. }\end{array}$ \\
\hline Parsons mine & $\begin{array}{l}\text { Au-Ag-Te veins } \\
\text { associated with } \\
\text { alkaline rocks. }\end{array}$ & $\begin{array}{l}\text { GLEN, Ag-GLEN, } \\
\text { SPLR. }\end{array}$ & Monzonite & $\begin{array}{l}\text { Sierra Blanca } \\
\text { Igneous Complex. }\end{array}$ & TERT & Monzonite & Breccia & Yes & $\begin{array}{l}70,000-85,000 \text { short tons } \\
\text { of Au ore were mined } \\
\text { from } 1900 \text { to } 1920 \text { 's. }\end{array}$ \\
\hline $\begin{array}{l}\text { Renowned OK } \\
\text { mine. }\end{array}$ & $\begin{array}{l}\text { Polymetallic } \\
\text { veins. }\end{array}$ & MLBD. CLCC, BFNT & Andesite & $\begin{array}{l}\text { Sierra Blanca } \\
\text { Igneous Complex. }\end{array}$ & TERT & $\begin{array}{l}\text { Andesite and } \\
\text { monzonite. }\end{array}$ & Fault-fracture & Yes & $\begin{array}{l}\text { Produced about } 25 \text { short } \\
\text { tons of } \mathrm{Pb}-\mathrm{Ag} \text { ore in } 1957 .\end{array}$ \\
\hline $\begin{array}{l}\text { Rialto moly } \\
\text { prospect. }\end{array}$ & $\begin{array}{l}\text { Poiphyry Mo, } \\
\text { low F. }\end{array}$ & SLVR, GOLD, GLEN & Monzonite & $\begin{array}{l}\text { Sierra Blanca } \\
\text { Igneous Complex. }\end{array}$ & TERT & Monzonite & Breccia & No & $\begin{array}{l}\text { Resources about } 30,000,000 \\
\text { short tons of Mo ore. }\end{array}$ \\
\hline Richardson claims & $\begin{array}{l}\text { Polymetallic } \\
\text { veins. }\end{array}$ & - & Andesite & $\begin{array}{l}\text { Sierra Blanca } \\
\text { Igneous Complex. }\end{array}$ & TERT & Andesite & Fault-fracture & No & $\begin{array}{l}\text { A. radioactive vein in } \\
\text { volcanic rocks. }\end{array}$ \\
\hline $\begin{array}{l}\text { Silver contact } \\
\text { claims. }\end{array}$ & $\begin{array}{l}\text { Polymetallic } \\
\text { veins. }\end{array}$ & GOLD, SLVR, GLEN & Andesite & $\begin{array}{l}\text { Sierra Blanca } \\
\text { Igneous Complex. }\end{array}$ & TERT & Andesite & Fault-fracture & Yes & $\begin{array}{l}\text { Being prospected as late } \\
\text { as } 1982 \text {. }\end{array}$ \\
\hline Spur adit & $\begin{array}{l}\text { Polymetallic } \\
\text { veins. }\end{array}$ & - & Andesite & $\begin{array}{l}\text { Sierra Blanca } \\
\text { Igneous Complex. }\end{array}$ & TERT & Andesite & Fault-fracture & No & $\begin{array}{l}\text { Three times background } \\
\text { radioactivity. }\end{array}$ \\
\hline Suprise prospect & $\begin{array}{l}\text { Polymetallic } \\
\text { veins. }\end{array}$ & CLCC, MLCT, AZRT & Andesite & $\begin{array}{l}\text { Sierra Blanca } \\
\text { Igneous Compiex. }\end{array}$ & TERT & $\begin{array}{l}\text { Andesite and } \\
\text { syenite. }\end{array}$ & Fault-fracture & No & $\begin{array}{l}\text { Principal vein is } 5,000 \mathrm{ft} \\
\text { long. }\end{array}$ \\
\hline $\begin{array}{l}\text { Tortolita Canyon } \\
\text { vein. }\end{array}$ & $\begin{array}{l}\text { Polymetallic } \\
\text { veins. }\end{array}$ & QRTZ. PYRT & - & $\begin{array}{l}\text { Sierra Blanca } \\
\text { Igneous Complex. }\end{array}$ & TERT & $\begin{array}{l}\text { Fadioactive vein } \\
\text { in andesite. }\end{array}$ & Fault-fracture & No & $\begin{array}{l}\text { Twice background } \\
\text { radioactivity. }\end{array}$ \\
\hline Turkey group & - & GOLD, SLVR, CLCC & Andesite & $\begin{array}{l}\text { Sierra Blanca } \\
\text { Igneous Complex. }\end{array}$ & TERT & $\begin{array}{l}\text { Andesite and } \\
\text { monzonite. }\end{array}$ & Fault-fracture & Yes & $\begin{array}{l}\text { Samples contained } 0.02- \\
0.08 \text { oz Au per short ton } \\
\text { of ore and } 0.08-0.56 \mathrm{oz} \mathrm{Ag} \\
\text { per short ton of ore. }\end{array}$ \\
\hline Vera Cruz mine & $\begin{array}{l}\text { Au-Ag-Te veins } \\
\text { associated with }\end{array}$ & GOLD, ELCM & $\begin{array}{l}\text { Sandstone and } \\
\text { shale. }\end{array}$ & Mesaverde & CRET & Alaskite & Brecciá & Yes & $\begin{array}{l}\text { Average grade about } 0.1 \mathrm{oz} \\
\text { Au per short ton of ore. }\end{array}$ \\
\hline
\end{tabular}


Oscura (Estey) district:

Estey City copper

hosted $C_{\text {- }}$

Copper prospect 1 -

Copper prospect 3

Schelerville subdistrict:

Idaho mine

Junction mine

\section{Tecolote district:}

Betty prospect Fe skarn

Bond prospect

Fe skarn

Consolidated

prospect.
Elcta iron mine

Fe skarn

Fe skarn

Iron City prospect Fe skarn

White Oaks district:

Fe skarn

Goodnight and Fe skarn

Black Knight.

Fe skarn

ouse mines

Lady Godiva mine

Au-Ag-Te vein associated with

$\begin{array}{cc}\text { Little Mack and } & \text { alkaline rocks. } \\ \text { Henry Clay mines. } & \text { asg-Te veins } \\ \text { associated with }\end{array}$

Henry Clay mines. $\begin{aligned} & \text { associated with } \\ & \text { alkaline rocks. }\end{aligned}$

Lone Mountain Polymetallic

Au-Ag-Te veins

prospect.

North and South
Homestake

associated with

alkaline rocks.

Au-Ag-Te veins
associated with associated with

Old Abe mine

alkaline rocks.

associated with

alkaline rocks.

Section 2

occurrence.

Au-Ag-Te veins associated with alkaline rocks.

White Oaks Draw Au-PGE placer

and Baxter Gulch

placers.

Fellow Jacket $\quad$ Fern

LMON, PRLS.
HMT, MGNT,

MLCT, AZRT, CLCC, Arkose Abo

AZRT, MLCT

AZRT, MLCT
AZRT, MLCT

Granite

AZRT, MLCT

Sandstone

SLPD, CU-SLPD

Dolomite

SLP, CU-SLPD

Andesite flows

BRIT.

and breccias.

and

MGNT
MGNT

MGNT, HMTT

Limestone

Limestone and

shale.

MGNT, HMTT

Sediments

MGNT, skarn-type

silicates.

MGNT. HMTT, PYRT

MGNT

Limestone

MGNT, metatorbern-

ite, GPSM.

Limestone

Monzonitel?!

GOLD, AU-PYRT

Monzonite

Limestone

OLD, AU-PYRT,

ELCM. HBNR,

Shale and

monzonite.

Shale and

monzonite.

Monzonite

Shale

GOLD

GOLD

Monzonite

Stream gravels

Limestone

San Andres
Bliss

Mancos

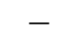

PERM

PREC Granite

CAM, Granite

El Paso

Igneous Complex

tgneous Complex.

Yeso
Yeso

Yeso

Yeso

Yeso

San Andres

San Andres

Yeso

-

$-$

Yeso

Mancos

Mancos

$-$

-

TERT

CRET

TERT
Carbonaceous

debris.

Faulting

Faulting

Faulting

Syenite dike

Andesite and basal-

tic andesite flows.

tic andesite flows.

E-W dikes

Intrusive contact

Intrusive contact

Intrusive contact

Replacement

PERM Monzonite dike

PERM Monzonite

PERM Monzonite

PERM Lone Mountain

PERM Lone Mountain

PERM Lone Mount

TERT Monzonitel?

TERT Monzonite

PERM Quartz monzonite

CRET Morphyry.

CRET Mọzonite

Monzonite

Rhyolite dike

TERT Monzonite

Monzonite

PERM

Monzonite
Intrusive contact

Intrusive contact

Intrusive contact

Intrusive contact

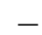

Fault-fracture

Fault-fracture

Fault-fracture

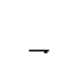

$-$

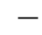

Hydrodynarmic
sorting.

Replacement of

hast.
Yes Only a few carloads of ore ever shipped.

No

sandstone.
Mineralized fault in dolomite.

160 short tons of $\mathrm{Cu}-\mathrm{Ag}$

ore shipped.

35 production unk 1934

Very small deposit.

Magnetite zones 3.30 th thick.

Production: 50 short tons of Fe ore in 1942.

Production: 14,343 short tons of ore at $54.5 \% \mathrm{Fe}$ in 1915-19.

Deposit is $200 \mathrm{ft}$ long and

$2-6 \mathrm{ft}$ thick.

Production: 4,116 short tons of Fe ore in 1952-53. Black Knight assayed 43.4\%

$\mathrm{Fe}_{\text {, Goodnight }} 45.1 \% \mathrm{Fe}$. Contains very

Connected to Rita mine at 425-ft level.

2,579 oz Au

Chip sample contained 35.5 percent $\mathrm{CaF}_{2}$.

Production: 50,039 oz Au in 1879-1951.

Production: 45.745 oz Als in 1879-1951.

Hoisted ore after Homestake's shaft had burned.

No $\quad 0.01 \% \mathrm{U}_{3} \mathrm{O}_{8}$

Yes Production: $279 \mathrm{oz} \mathrm{Au}$ in 1935.

From 1933 to 1941 some
placer mining was done.

Production: 20,008 shor tons of $58.2 \%$ Fe ore in 1913-15, 1942 
APPENDIX. GEOLOGIC AND MINERAL RESOURCES INFORMATION FOR THE ROSWELL RESOURCE AREA, NEW MEXICO—Continued

\begin{tabular}{|c|c|c|c|c|c|c|c|c|c|}
\hline Site & $\begin{array}{l}\text { USGS deposit } \\
\text { model }^{1}\end{array}$ & $\begin{array}{c}\text { Minerals } \\
\text { (commodities) } \\
\text { reported }{ }^{2}\end{array}$ & $\begin{array}{l}\text { Host rock } \\
\text { type }\end{array}$ & Host rock & $\begin{array}{l}\text { Age of } \\
\text { host } \\
\text { rock }\end{array}$ & $\begin{array}{l}\text { Associated } \\
\text { igneous } \\
\text { rock type }\end{array}$ & Ore control & Production & Comments \\
\hline $\begin{array}{l}\text { Other deposits: } \\
\text { Ancho fire clay } \\
\text { deposit. }\end{array}$ & - & Clay & $\begin{array}{l}\text { Sedimentary clay. } \\
\text { clayey shale, } \\
\text { and sandy clay } \\
\text { interbedded } \\
\text { with sandstone. }\end{array}$ & Dakota & CRET & - & Sedimentation & Yes & $\begin{array}{l}\text { Supplied clay for bricks } \\
\text { from } 1902 \text { to } 1922 \text {. }\end{array}$ \\
\hline Fox lode prospect & $\begin{array}{l}\text { Epigenetic barite } \\
\text { veins. }\end{array}$ & BRIT, Cu oxides & Limestone & Yesor?\} & PERM? & - & Fault-fracture & No & $\begin{array}{l}\text { Sample contained } 89.7 \\
\text { percent } \mathrm{BaSO}_{4}, 2.4 \\
\text { percent } \mathrm{CaCO}_{3}, 4.2 \\
\text { specific gravity. }\end{array}$ \\
\hline $\begin{array}{l}\text { Hall \{Macho\} } \\
\text { deposit. }\end{array}$ & Fe skarn & MGNT & Limestone & San Andres & PEFM & Monzonite & $\begin{array}{l}\text { Replacement of } \\
\text { host. }\end{array}$ & Yes & $\begin{array}{l}\text { Produced several thousand } \\
\text { short tons of } \mathrm{Fe} \text { ore in } \\
1951-53 \text {. }\end{array}$ \\
\hline $\begin{array}{l}\text { Valley of Fire } \\
\text { road cut. }\end{array}$ & - & - & Shale & Mancos & CRET & Syenite dike & - & No & $\begin{array}{l}\text { Twenty four times } \\
\text { background radioactivity, } \\
207 \mathrm{ppm} \mathrm{U} \text {. }\end{array}$ \\
\hline $\begin{array}{l}\text { Bonnell sand and } \\
\text { gravel pit. }\end{array}$ & - & (Sand and gravel\} & Sediments & - & - & - & - & Yes & Active surface operation. \\
\hline Lietzman pit & - & (Gravel) & - & - & - & - & - & Yes & Intermittent producer. \\
\hline Mac rock quarry & - & $\begin{array}{l}\text { (Stone, railroad } \\
\text { ballast). }\end{array}$ & - & - & - & - & - & Yes & Active surface operation. \\
\hline Pit BP2 & - & (Gravel) & - & - & - & - & - & - & Inactive surface mine. \\
\hline $\begin{array}{l}\text { Tom's gravel pit } \\
\text { Ancho gypsum }\end{array}$ & Marine bedded & $\begin{array}{l}\text { \{Gravel, base coarse\} } \\
\text { GPSM }\end{array}$ & Marine & San Andres & $\overline{P E R M}$ & Monzonite porphyry & $\begin{array}{l}- \\
-\end{array}$ & $\begin{array}{l}\text { Yes } \\
\text { Yes }\end{array}$ & $\begin{array}{l}\text { Active surface operation. } \\
\text { Ouarried in early } 1900 \text { 's. }\end{array}$ \\
\hline $\begin{array}{l}\text { deposits. } \\
\text { Cowboy Mesa } \\
\text { gypsum deposit. }\end{array}$ & $\begin{array}{l}\text { gypsum. } \\
\text { Marine bedded } \\
\text { gypsum. }\end{array}$ & GPSM & $\begin{array}{l}\text { sediments. } \\
\text { Marine } \\
\text { sediments. }\end{array}$ & San Andres, Yeso & PEAM & - & - & - & $\begin{array}{l}\text { Thin gypsum beds are } \\
\text { poorly exposed. }\end{array}$ \\
\hline $\begin{array}{l}\text { Hasparos Canyon } \\
\text { gypsum deposit. }\end{array}$ & $\begin{array}{l}\text { Märine bedded } \\
\text { gypsum. }\end{array}$ & GPSM & $\begin{array}{l}\text { Marine } \\
\text { sediments. }\end{array}$ & San Andres, Yeso & PERM & - & - & - & $\begin{array}{l}\text { Thin gypsum beds are } \\
\text { poorly exposed. }\end{array}$ \\
\hline $\begin{array}{l}\text { Mescalero gypsum } \\
\text { deposit. }\end{array}$ & $\begin{array}{l}\text { Marine bedded } \\
\text { gypsum. }\end{array}$ & GPSM & $\begin{array}{l}\text { Marine } \\
\text { sediments. }\end{array}$ & Yeso & PERM & - & - & - & $\begin{array}{l}\text { Most of deposit is outside } \\
\text { study area. }\end{array}$ \\
\hline $\begin{array}{l}\text { Phillips Hills } \\
\text { gypsum deposit. }\end{array}$ & $\begin{array}{l}\text { Marine bedded } \\
\text { gypsum. }\end{array}$ & GPSM & $\begin{array}{l}\text { Marine } \\
\text { sediments. }\end{array}$ & Yeso, San Andres & PERM & - & - & - & $\begin{array}{l}\text { Reports of white gypsum } \\
50-100 \mathrm{ft} \text { thick. }\end{array}$ \\
\hline $\begin{array}{l}\text { Rio Hondo and Rio } \\
\text { Ruidoso valley } \\
\text { gypsum. }\end{array}$ & $\begin{array}{l}\text { Marine bedded } \\
\text { gypsum. }\end{array}$ & GPSM & $\begin{array}{l}\text { Marine } \\
\text { sediments. }\end{array}$ & San Andres, Yeso & PEFM & - & - & - & $\begin{array}{l}\text { Large production would } \\
\text { require underground } \\
\text { mining. }\end{array}$ \\
\hline $\begin{array}{l}\text { Wagon Canyon } \\
\text { gypsum deposit. }\end{array}$ & $\begin{array}{l}\text { Marine bedded } \\
\text { gypsum. }\end{array}$ & GPSM & $\begin{array}{l}\text { Marine } \\
\text { sediments. }\end{array}$ & San Andres, Yeso & PEFM & - & - & - & $\begin{array}{l}\text { Nearby sample was } 98.6 \\
\text { percent } \mathrm{gypsum}^{1} 1 \\
\text { percent } \mathrm{SiO}_{2} \text {. }\end{array}$ \\
\hline \multicolumn{10}{|c|}{ QUAY COUNTY } \\
\hline $\begin{array}{l}\text { Beasley Brothers } 4 \\
\text { prospect. }\end{array}$ & Sandstone U & (U) & Sandstone & Chinle & TRI & - & - & No & \\
\hline Bel Aro mine & Sandston $\theta U$ & (U) & Sediments & Morrison, basal(?) & JUA & - & Silicified wood & Yes & $\begin{array}{l}\text { Production: } 30 \text { short tons } \\
\text { of silicified uraniferous } \\
\text { wood in } 1950 \text { 's. }\end{array}$ \\
\hline Breen prospect & Sandstone U & (U) & Sandstone & Morrison, middle & JUR & - & $\begin{array}{l}\text { Carbonaceous } \\
\text { material. }\end{array}$ & No & $\begin{array}{l}\text { Limonite and organict?) } \\
\text { material in a } 1-\text { tt-thick roll. }\end{array}$ \\
\hline Eight point claims & Sandstone $U$ & (U) & Sediments & Morrison, basal(?) & JUR & - & $\begin{array}{l}\text { Silicified or } \\
\text { carbonaceous } \\
\text { wood. }\end{array}$ & No & \\
\hline
\end{tabular}




\begin{tabular}{|c|c|c|c|c|c|c|c|c|c|}
\hline Fife prospects & Sandstone U & (U) & Claystone & $\begin{array}{l}\text { Redonda, lower } \\
\text { part. }\end{array}$ & TR & - & - & No & $\begin{array}{l}\text { 8-in.-thick radioactive } \\
\text { claystone. }\end{array}$ \\
\hline $\begin{array}{l}\text { Gilstrip and Trusde: } \\
\text { property. }\end{array}$ & Sandstone U & (U) & Sandstone & Chinle, middle & $T R \mid$ & - & $\begin{array}{l}\text { Carbonized wood } \\
\text { fragments. }\end{array}$ & No & $\begin{array}{l}\text { Sandstone and limestone- } \\
\text { pebble zones contain } \mathrm{U} \text {. }\end{array}$ \\
\hline Good Luck group & Sandstone $U$ & $(U, V)$ & Sandstone & Chinle, middle & TRI & - & $\begin{array}{l}\text { Carbonized wood } \\
\text { fragments. }\end{array}$ & Yes & $\begin{array}{l}\text { Production: } 24 \text { short tons } \\
\text { of ore at } 0.10 \% \cup_{3} O_{8} \\
\text { and } 0.12 \% \vee \text { in } 1955-57 \text {. }\end{array}$ \\
\hline Ima prospect & Sandstone U & $\{\mathrm{U}\}$ & Sediments & Chinle & TRI & - & - & No & Small radioactive anomaly. \\
\hline Little Rattler mine & Sandstone $U$ & $\{\mathrm{U}, \mathrm{Cu}, \mathrm{Ag}\}$ & Sediments & Chirle, middle & TRI & - & - & Yes & $\begin{array}{l}\text { Production: } 59 \text { short tons } \\
\text { of ore at } 0.03 \% \cup_{3} O_{g}\end{array}$ \\
\hline Logan prospects & Sandstone U & $(\mathrm{Cu}, U, \mathrm{Ag}, \mathrm{Au})$ & Sediments & Chinle & TRI & - & - & No & Large area of radioactive \\
\hline $\begin{array}{l}\text { Lucky Find } 15 \\
\text { prospect. }\end{array}$ & Sandstone U & (U\} & Sediments & Chinle, middle(?) & TR! & - & - & No & \\
\hline $\begin{array}{l}\text { Red Peak area } \\
\text { prospects. }\end{array}$ & Sandstone U & (U) & Shale & Chinle (Cuervo\} & TRI & - & - & No & $\begin{array}{l}\text { Uranium is in a thick red } \\
\text { shale. }\end{array}$ \\
\hline $\begin{array}{l}\text { Richardson Ranch } \\
\text { prospects. }\end{array}$ & Sandstone U & (U) & Sediments & Morrison, middle & JUR & -.. & $\begin{array}{l}\text { Silicified or } \\
\text { carbonaceous } \\
\text { wopd. }\end{array}$ & No & $\begin{array}{l}\text { Associated with silicified } \\
\text { wood, bone, or } \\
\text { carbonaceous wood. }\end{array}$ \\
\hline San Jon area & Sandstone U & (U, Cu, Ag) & Sediments & Chinle & TRI & - & - & - & $\begin{array}{l}\text { Large area of radioactive } \\
\text { anomalies. }\end{array}$ \\
\hline $\begin{array}{l}\text { Smith Ranch } \\
\text { prospect. }\end{array}$ & Sandstone U & (U) & Sediments & Chinle, minddie & TRI & - & - & No & \\
\hline Strawn prospect & Sandstone $U$ & (U) & Sediments & Morrison, middle & JUR & - & - & No & $\begin{array}{l}\text { Associated with silicified } \\
\text { wood or bone. }\end{array}$ \\
\hline Troutman Ranch & Sandstone U & (U) & Sandstone & Chinle, middle & TRI & - & - & No & $0.06 \% \cup_{3} \mathrm{O}_{8}$ in sample. \\
\hline $\begin{array}{l}\text { Ute Creek copper } \\
\text { deposits. }\end{array}$ & $\begin{array}{l}\text { Sediment- } \\
\text { hosted Cu. }\end{array}$ & MLCT, AZRT, CLCC & Shaly sandstone & Dockum & TRI & - & - & Yes & $\begin{array}{l}\text { Several low-grade deposits } \\
\text { in area. }\end{array}$ \\
\hline $\begin{array}{l}\text { Wallace Ranch } \\
\text { prospect. } \\
\text { Other deposits: }\end{array}$ & Sandstone U & $(U)$ & Sediments & Chinle, middle & TRI & - & - & Yes & \\
\hline Bruhn gravel pit & - & (Sand and gravel) & Sediments & - & - & - & - & Yes & Active surface operation. \\
\hline Caprock pit & - & (Caliche) & Sediments & - & - & - & - & Yes & Intermittent surface mining. \\
\hline Duke pit & - & (Caliche) & Sediments & - & - & - & - & Yes & Intermittent surface mining. \\
\hline Ragland pit & - & (Caliche) & Sediments & - & - & - & - & Yes & Intermittent surface mining. \\
\hline & & & & ROOSEVELT C & JNTY & & & & \\
\hline $\begin{array}{l}\text { Blackwater Draw } \\
\text { diatomaceous } \\
\text { earth deposit. }\end{array}$ & - & (Diatomaceous earth) & $\begin{array}{l}\text { Sedimentary } \\
\text { sand and clay. }\end{array}$ & - & QUAT & - & $\begin{array}{l}\text { Fresh-water } \\
\text { sedimentation. }\end{array}$ & No & $\begin{array}{l}67 \text { of the } 88 \text { species of } \\
\text { diatams identified are } \\
\text { living today. }\end{array}$ \\
\hline Nunn pit & - & (Caliche) & Sediments & - & - & - & - & Yes & Intermittent surface mining. \\
\hline Sadler pit & - & (Gravel) & Sediments & - & - & - & - & Yes & Intermittent surface mining. \\
\hline $\begin{array}{l}\text { Valley Tolar pit } \\
\text { No. } \uparrow \text {. }\end{array}$ & - & $\begin{array}{l}\text { Trushed rock, sand, } \\
\text { gravell. }\end{array}$ & Sediments & - & - & - & - & Yes & Active surface operation. \\
\hline
\end{tabular}

1Descriptive USGS deposit models are as follows: thorium-rare-earth veins, Staatz (1992): iron skarn, Cox (1986c); replacement manganese, Mosier (1986); porphyry molybdenum, low-fluorine, Theodore (1986); gold-silver-tellurium veins associated with alkaline rocks. Cox and Bagby (1986); polymetallic veins, Cox (1986b); epigenetic barite veins, Clark and Orris \$1991\}; bedded gypsum, Raup \{1991);

2Mineral abbreviations lafter Longe and others, 1978): actinolite, ACNL; allanite, ALNT: anglesite. ANGS; azurite, AZRT; barite, BRIT; bastnaesite, BSNS: bornite, BRNT; cerussite, CRST; chalcocite, CLCC; chalcopyrite, CLCP; chlorite, CLRT; chrysocolla, CHRY; clay, CLAY; electrum, ELCM; epidote, EPDT; fluorite, FLRT; galena, GLEN; goethite, GTHT; gold. GOLD: gypsum, GPSM; hematite, sMT: hubnerite, HBNR; kaolinite, KLNT; limonite, LMON; magnetite, MGNT; malachite, MLCT; molybdenite, MLBD; phlogopite, PLGP; psilomene, PSLM; pyrite, PYRT; Pyrolusite, PRLS; quartz, OATZ;

${ }^{3}$ Age abbreviations: Quaternary, QUAT; Tertiary, TERT: Cretaceous, CRET; Jurassic, JUR; Triassic, TRI; Permian, PERM: Ordovician, ORD; Cambrian, CAM; Precambrian, PREC. 




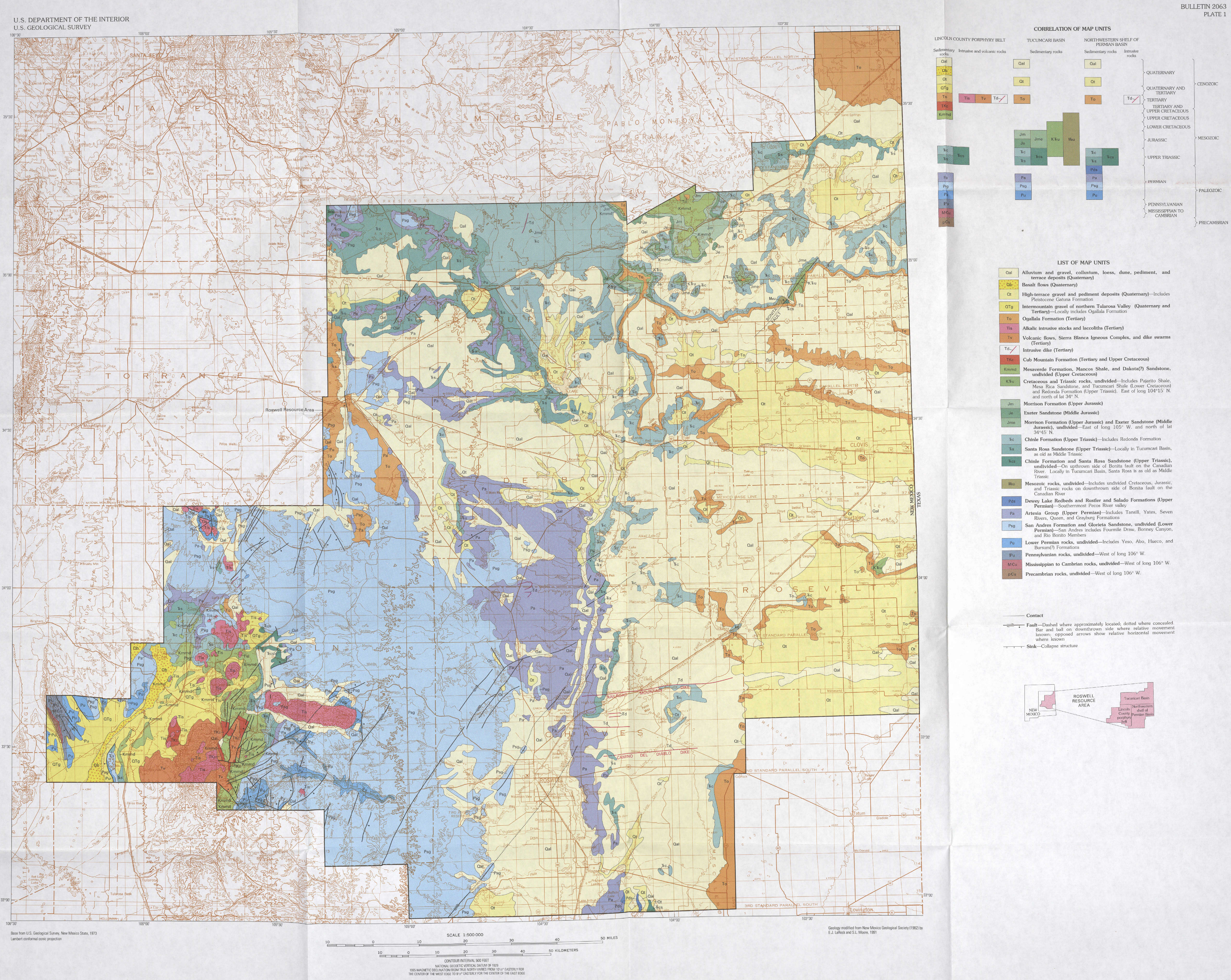

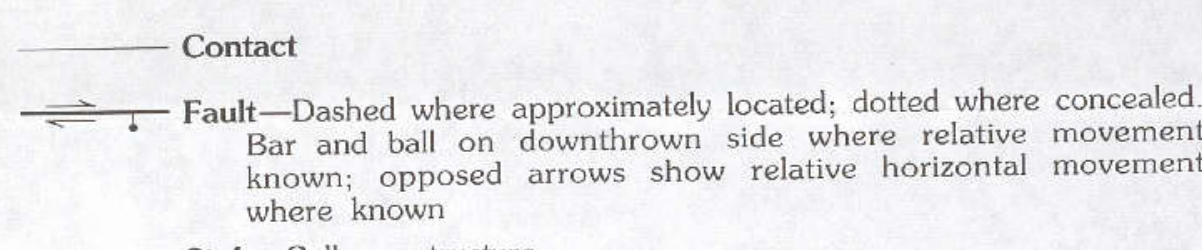

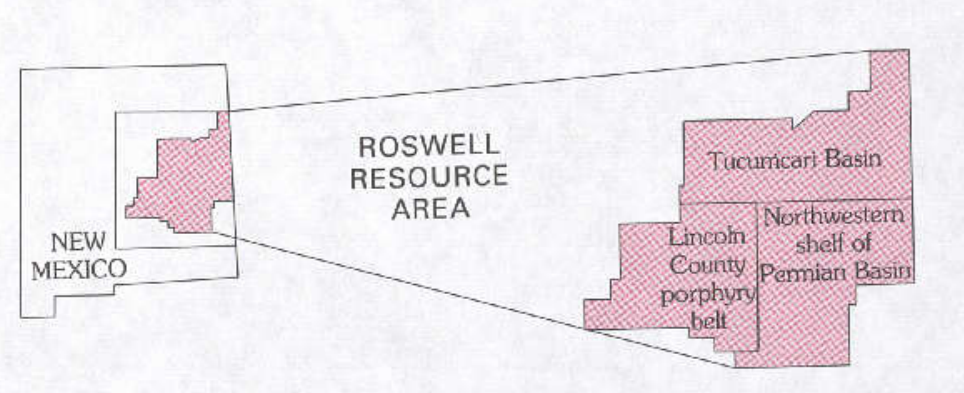

GEOLOGIC MAP OF THE ROSWELL RESOURCE AREA, NEW MEXICO 


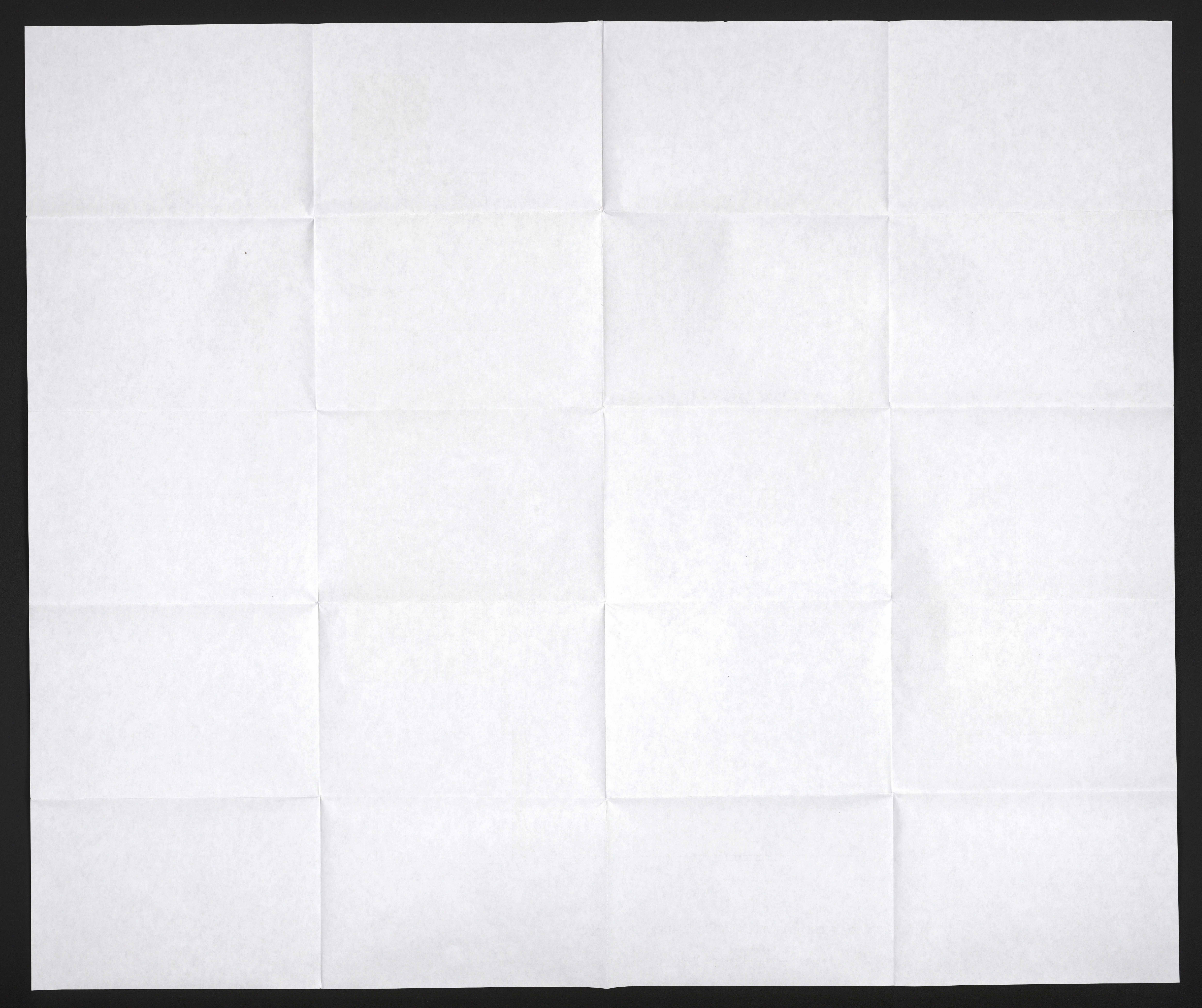




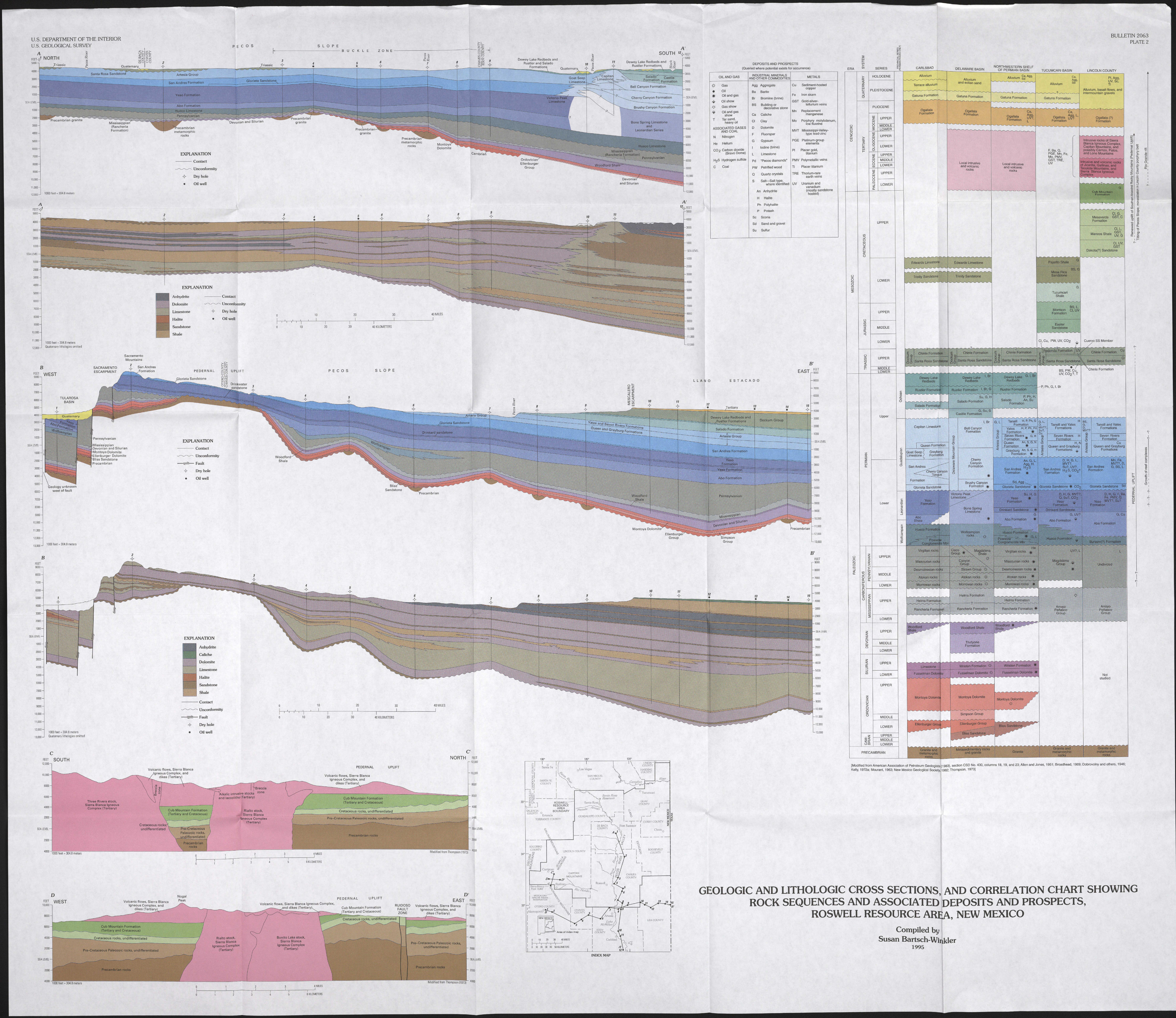




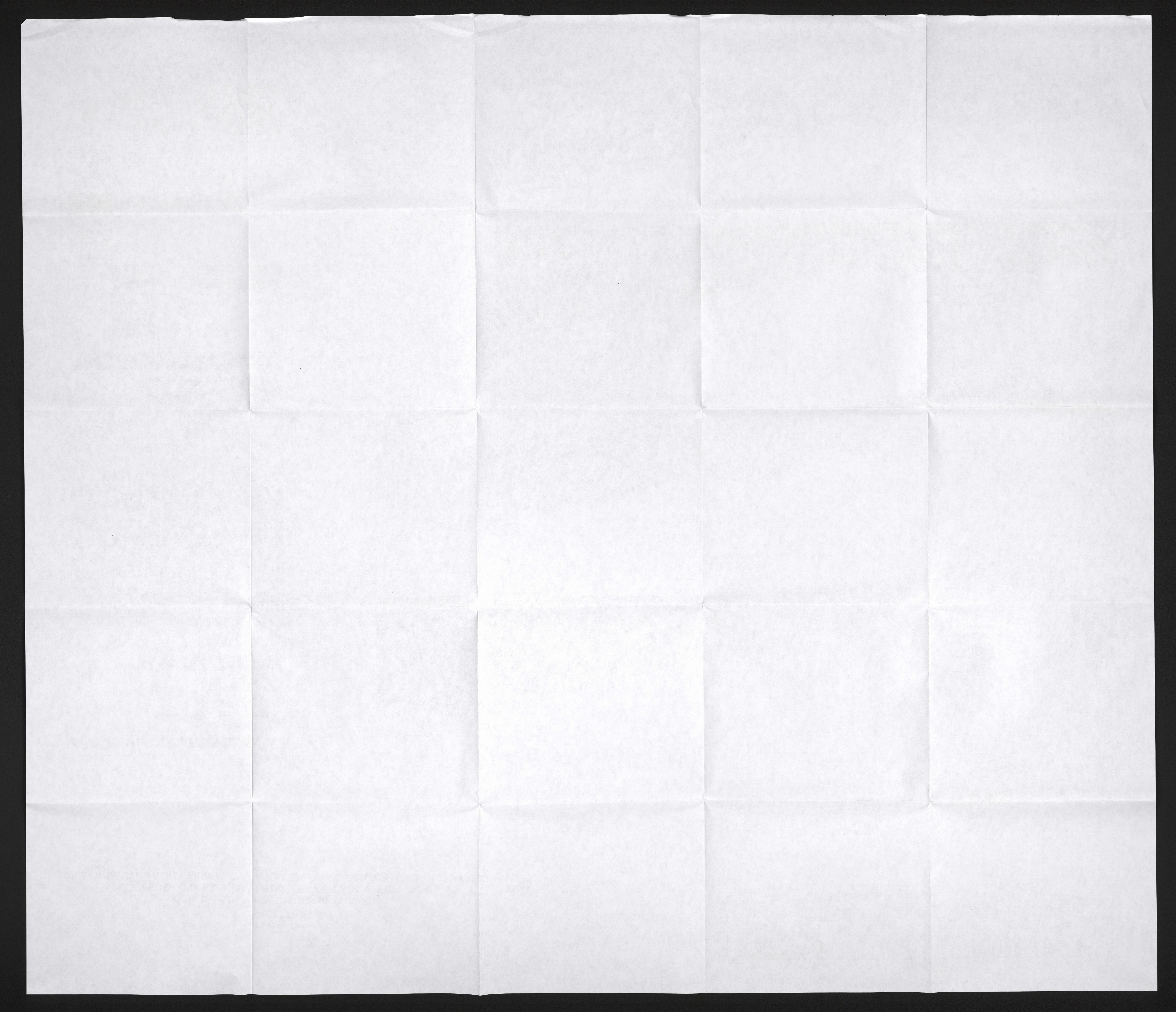



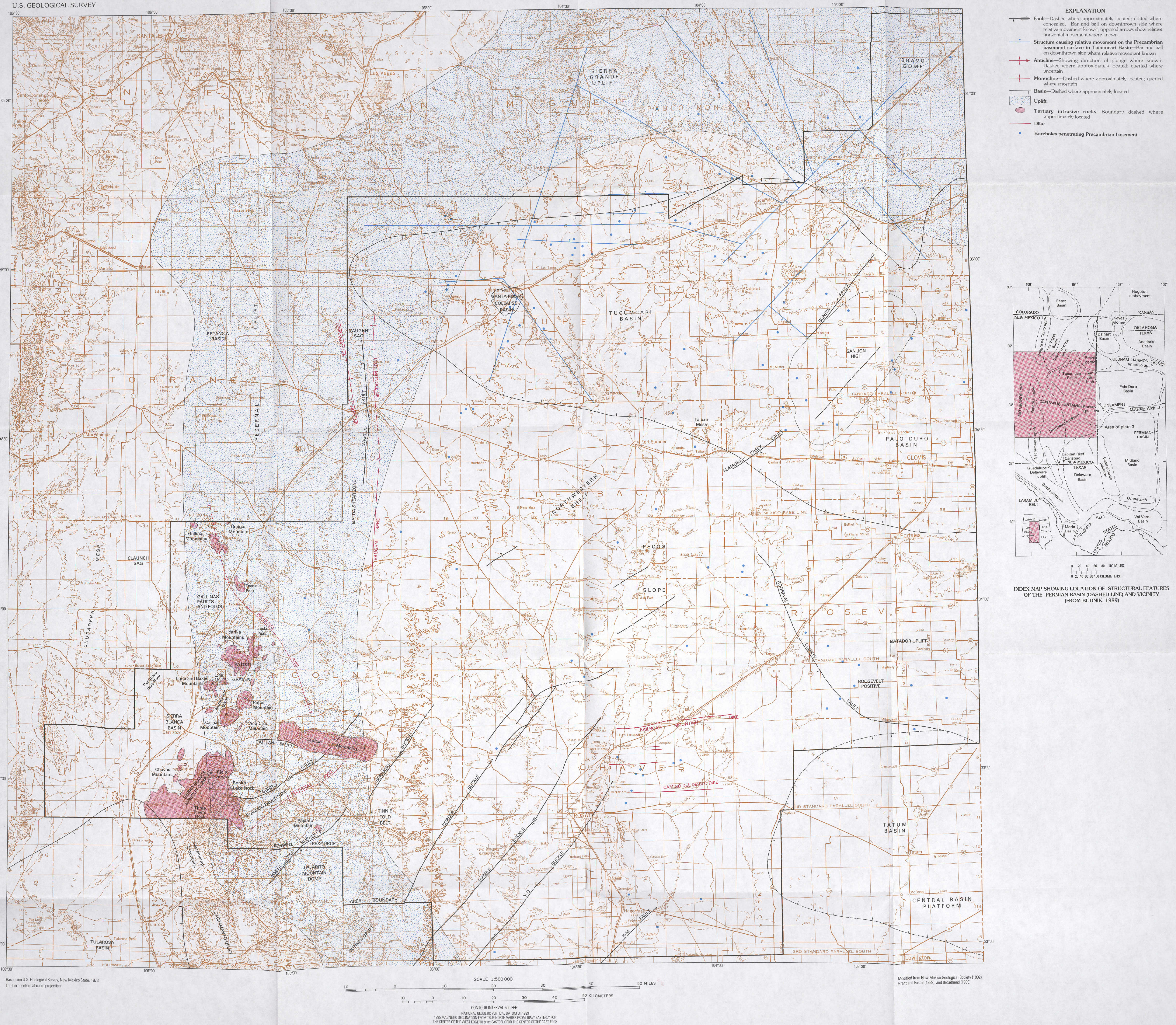

MAP SHOWING TECTONIC FEATURES OF THE ROSWELL RESOURCE AREA AND VICINITY, NEW MEXICO 


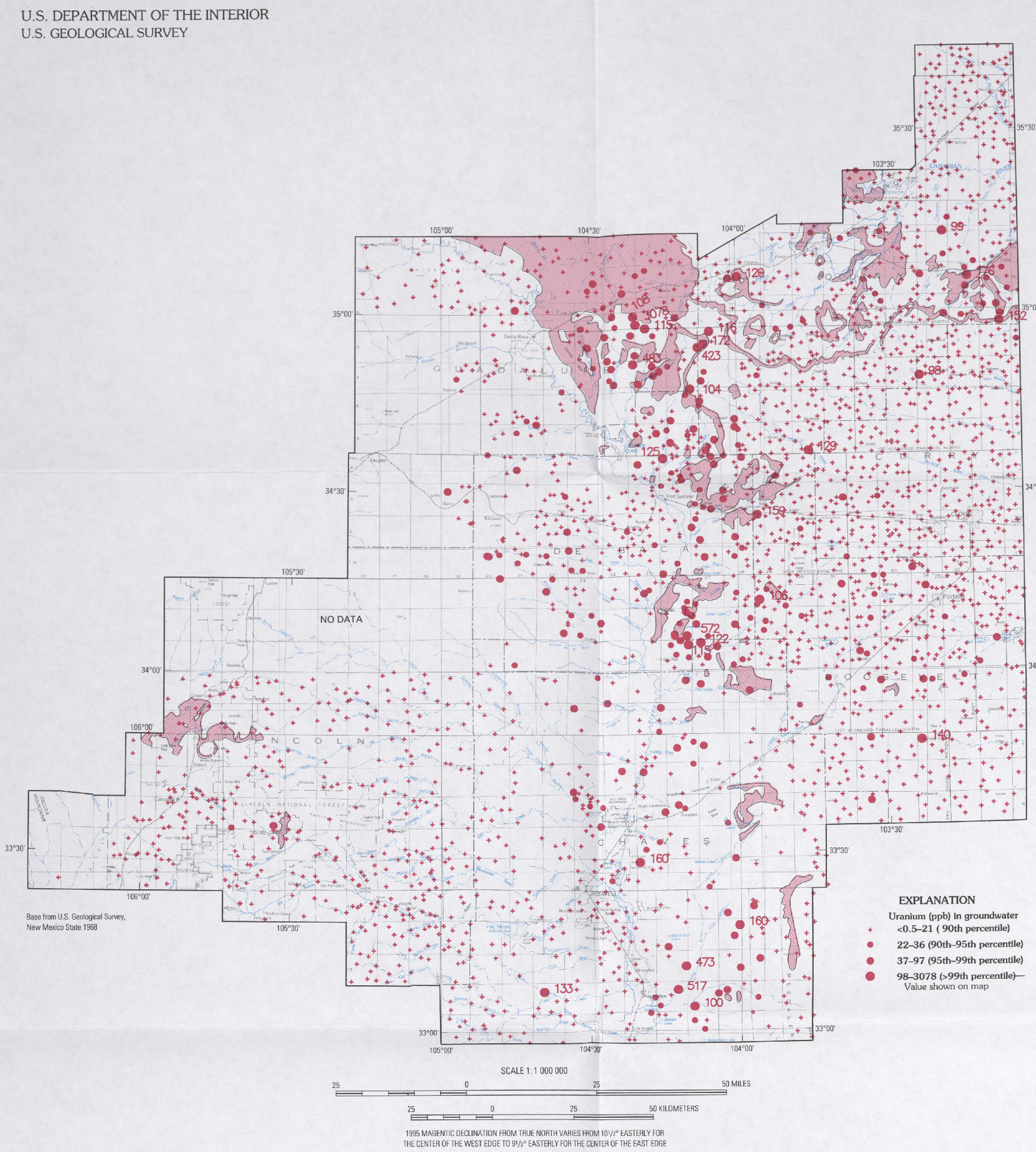

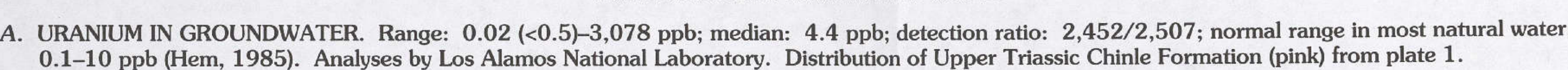

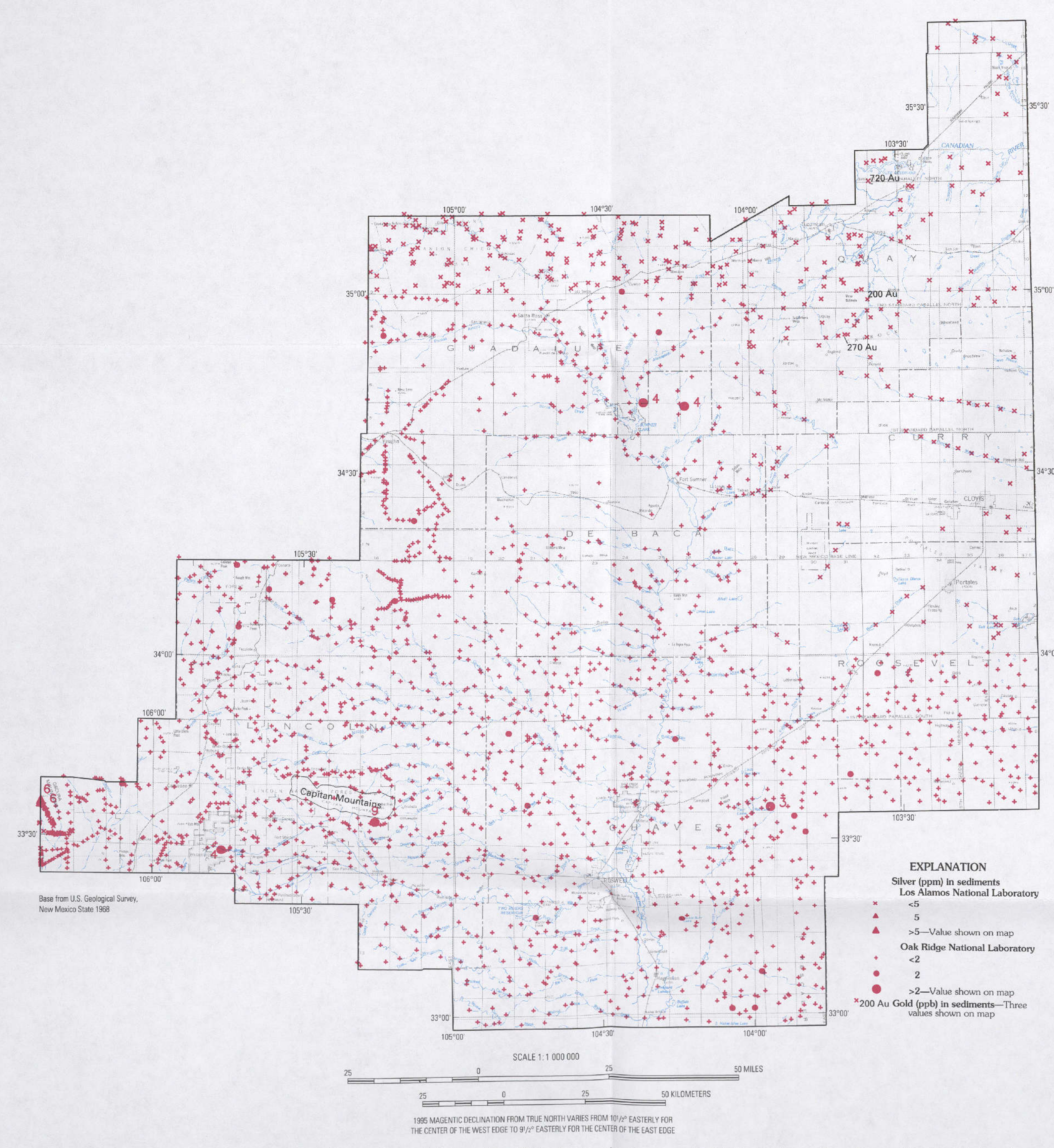

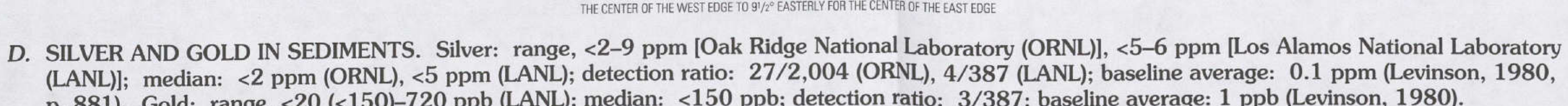

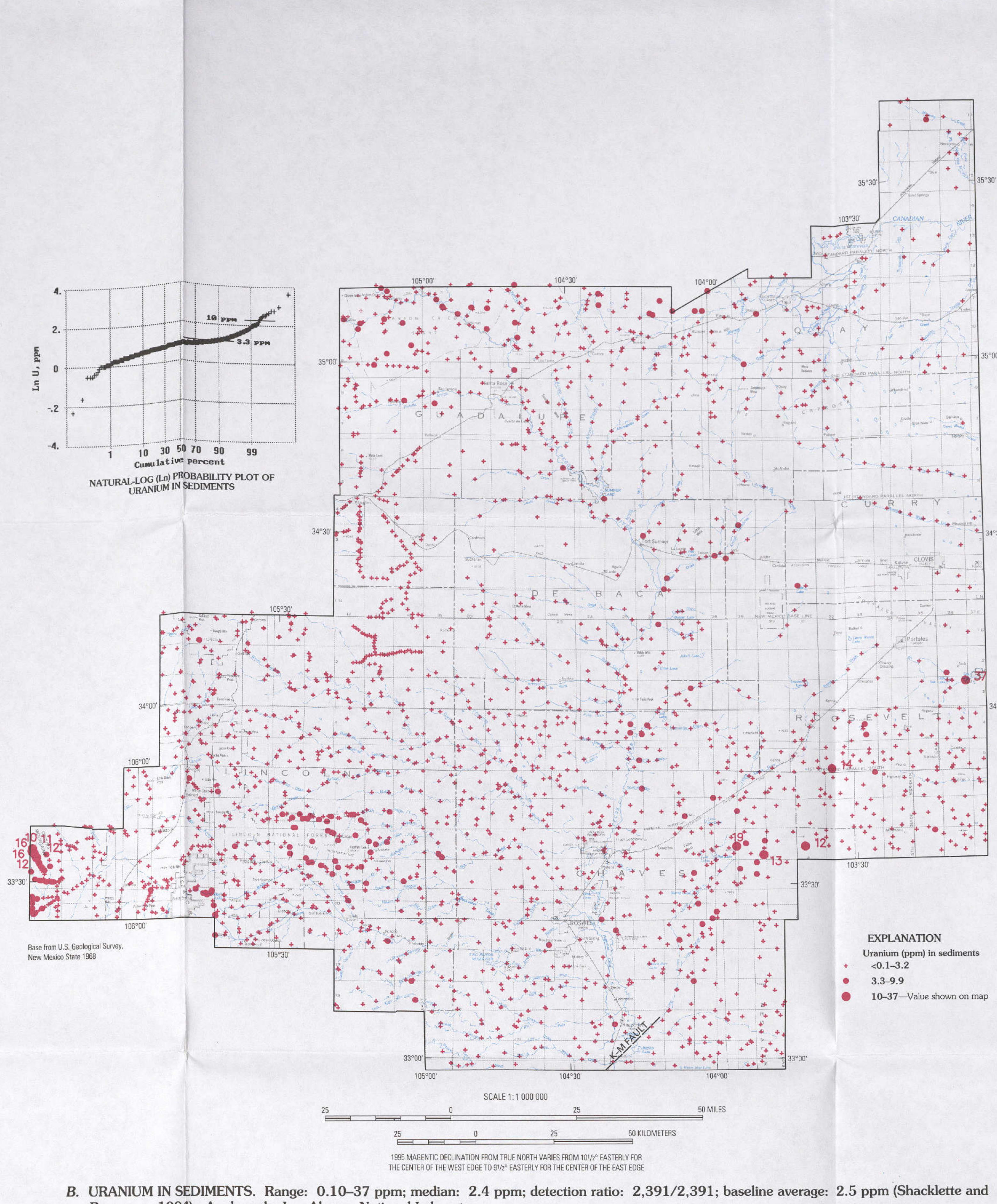

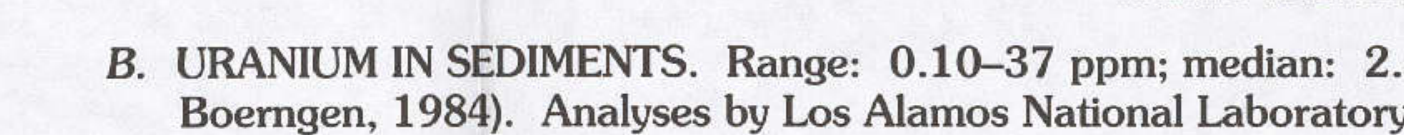

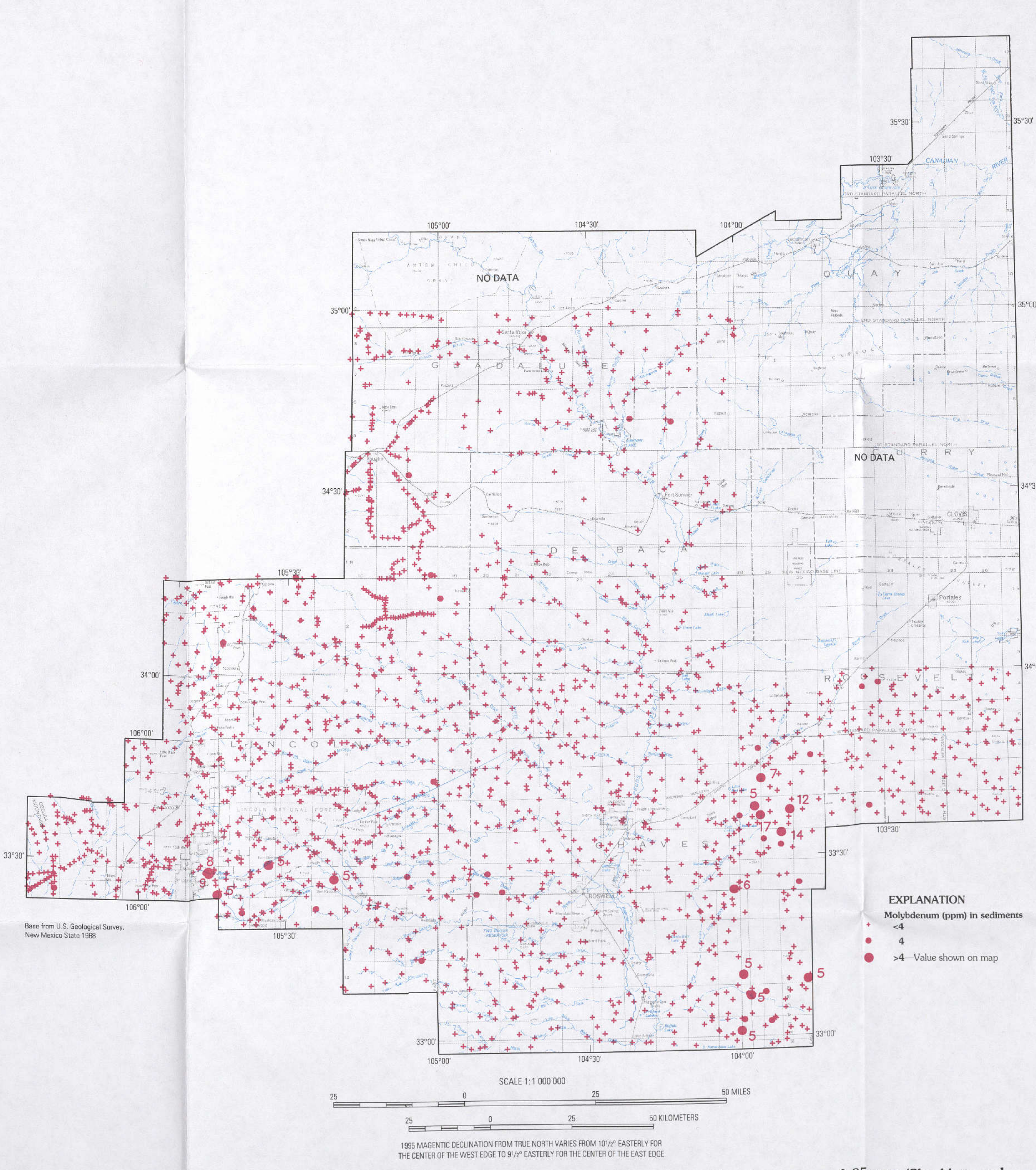

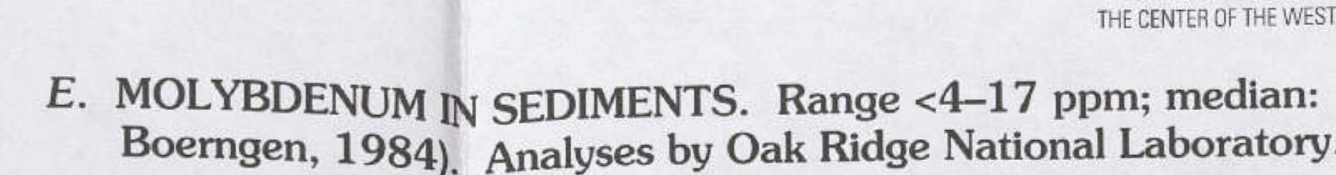

\section{1.}
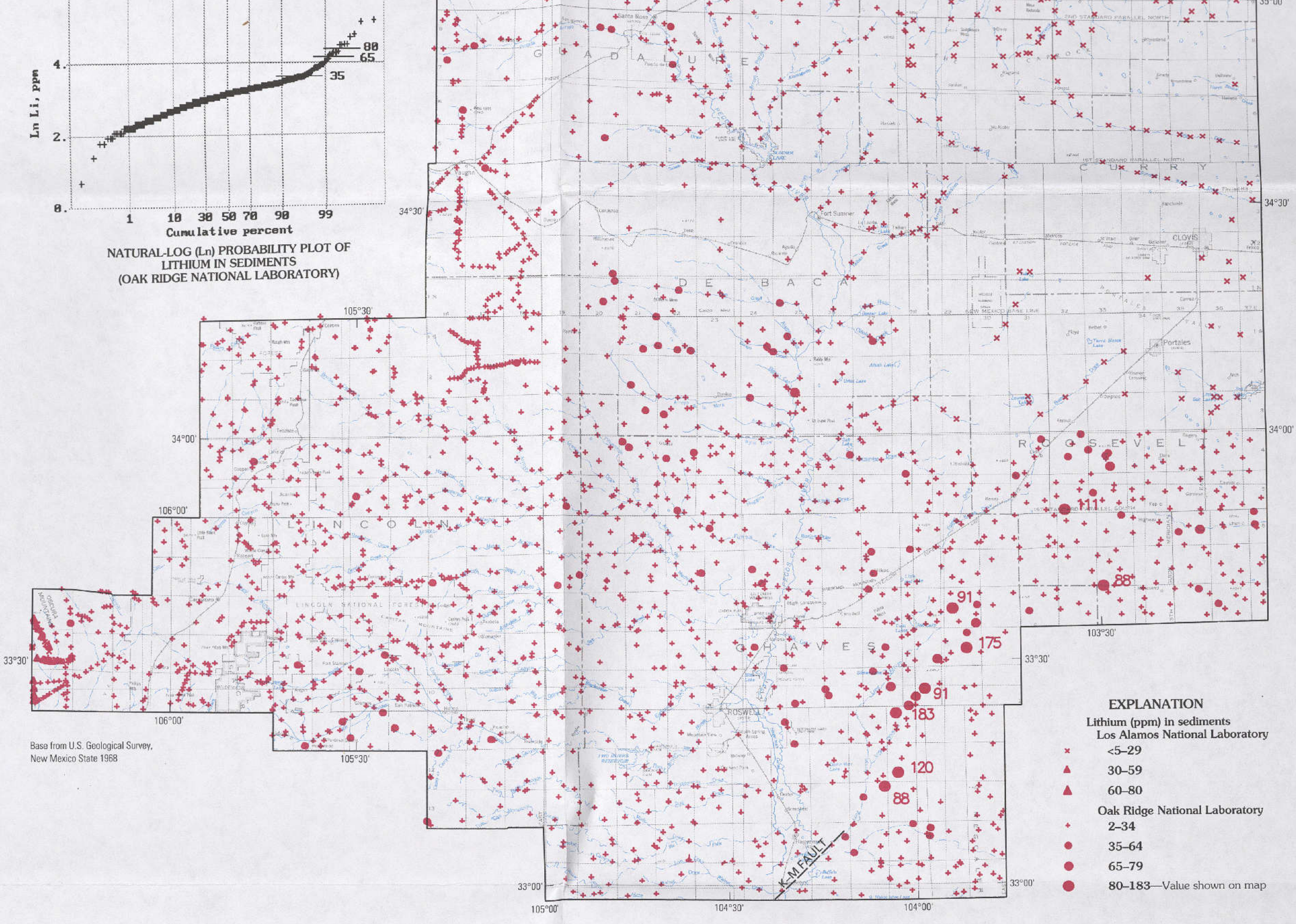

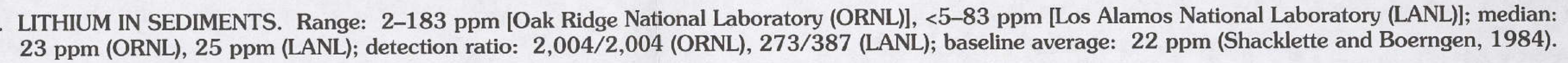

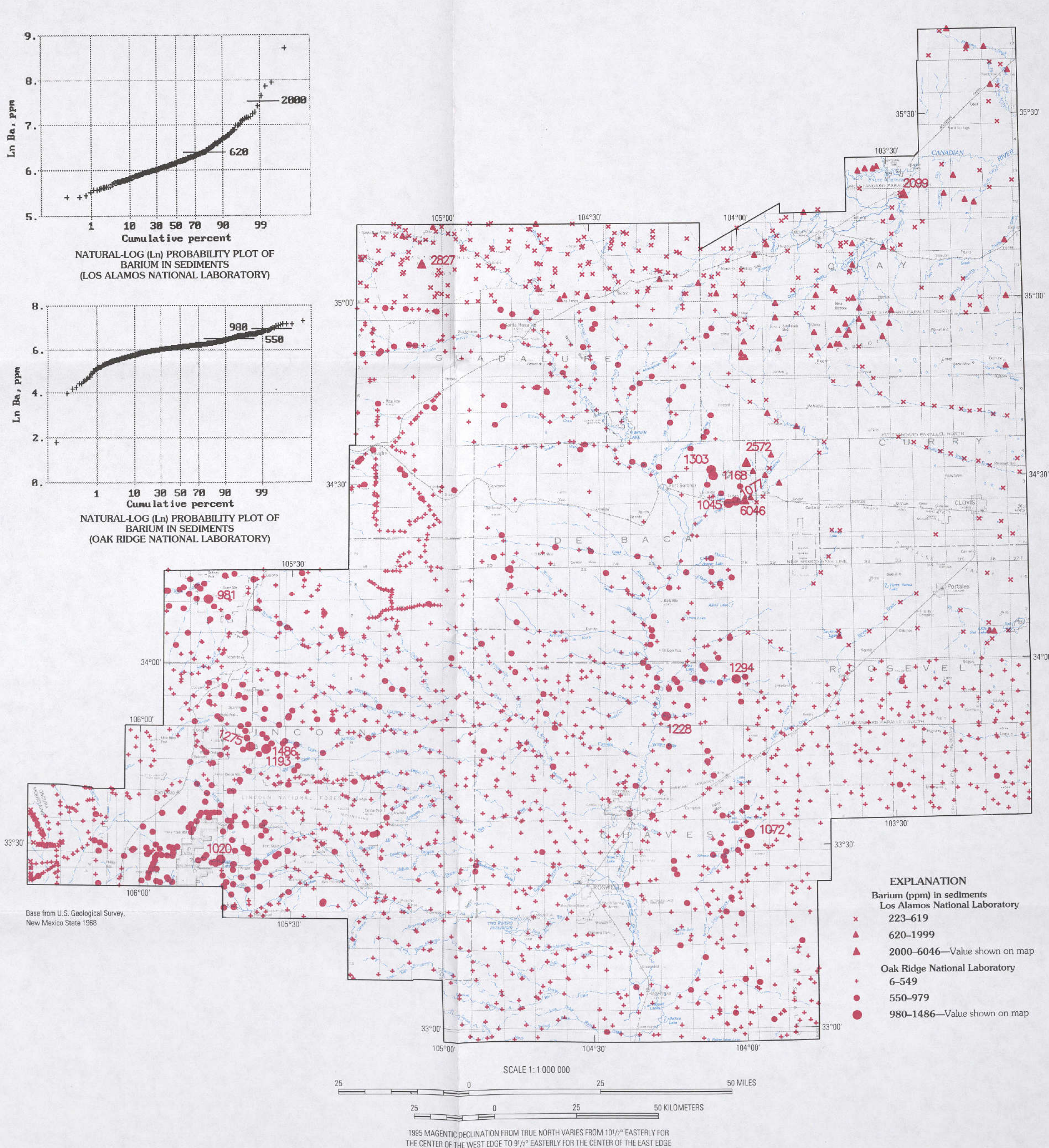

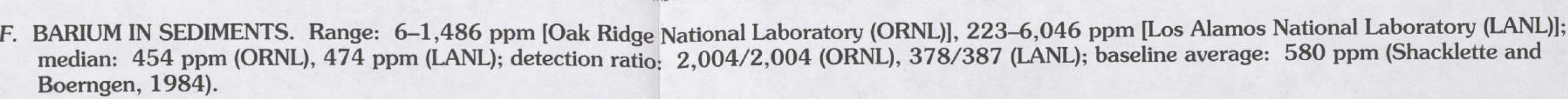

MAPS SHOWING DISTRIBUTION OF URANIUM IN GROUNDWATER AND OF SELECTED ELEMENTS IN SEDIMENTS, ROSWELL RESOURCE AREA, NEW MEXICO

By
James A. Erdman, Ronald R. Tidball, and Richard B. Tripp
1995 


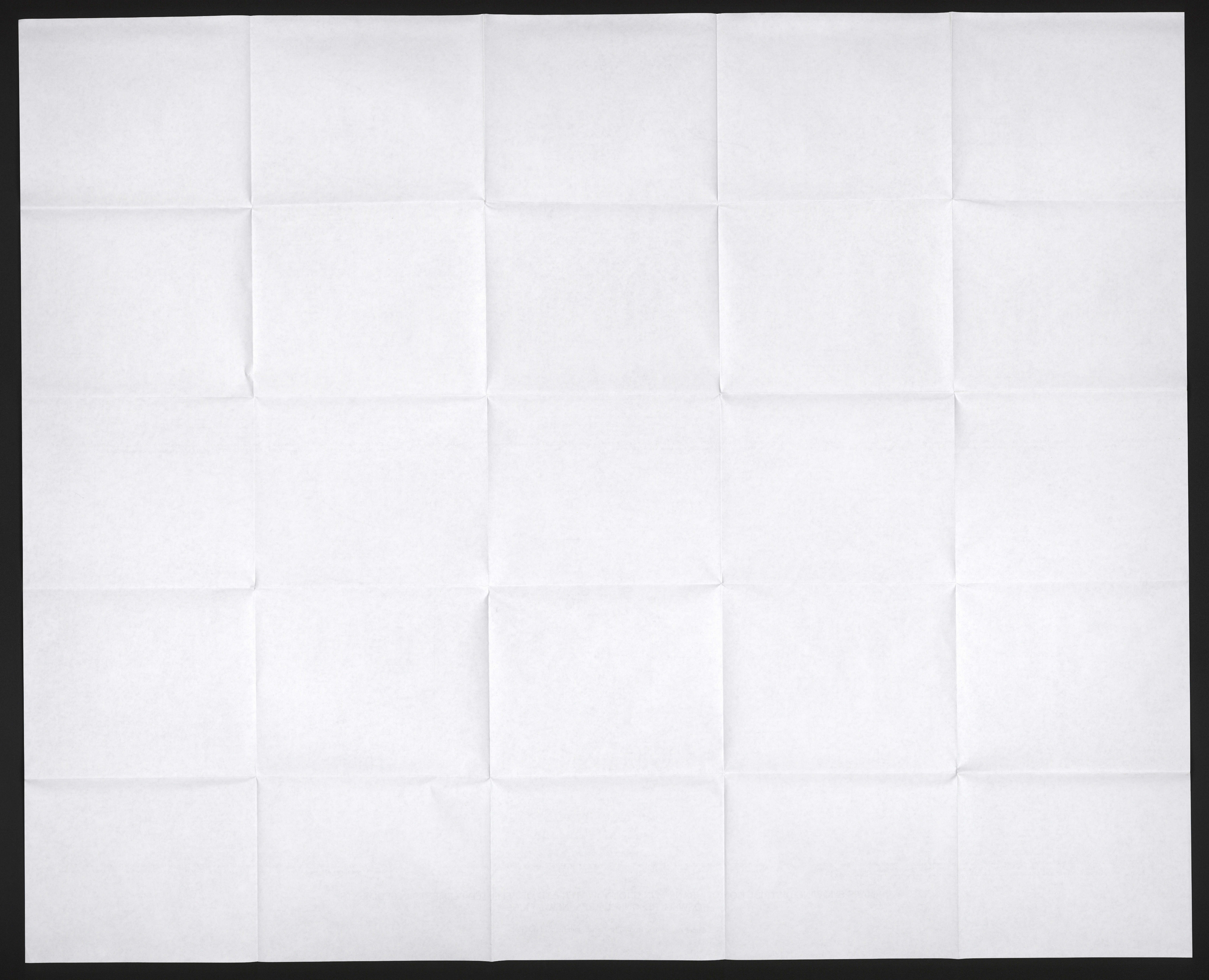



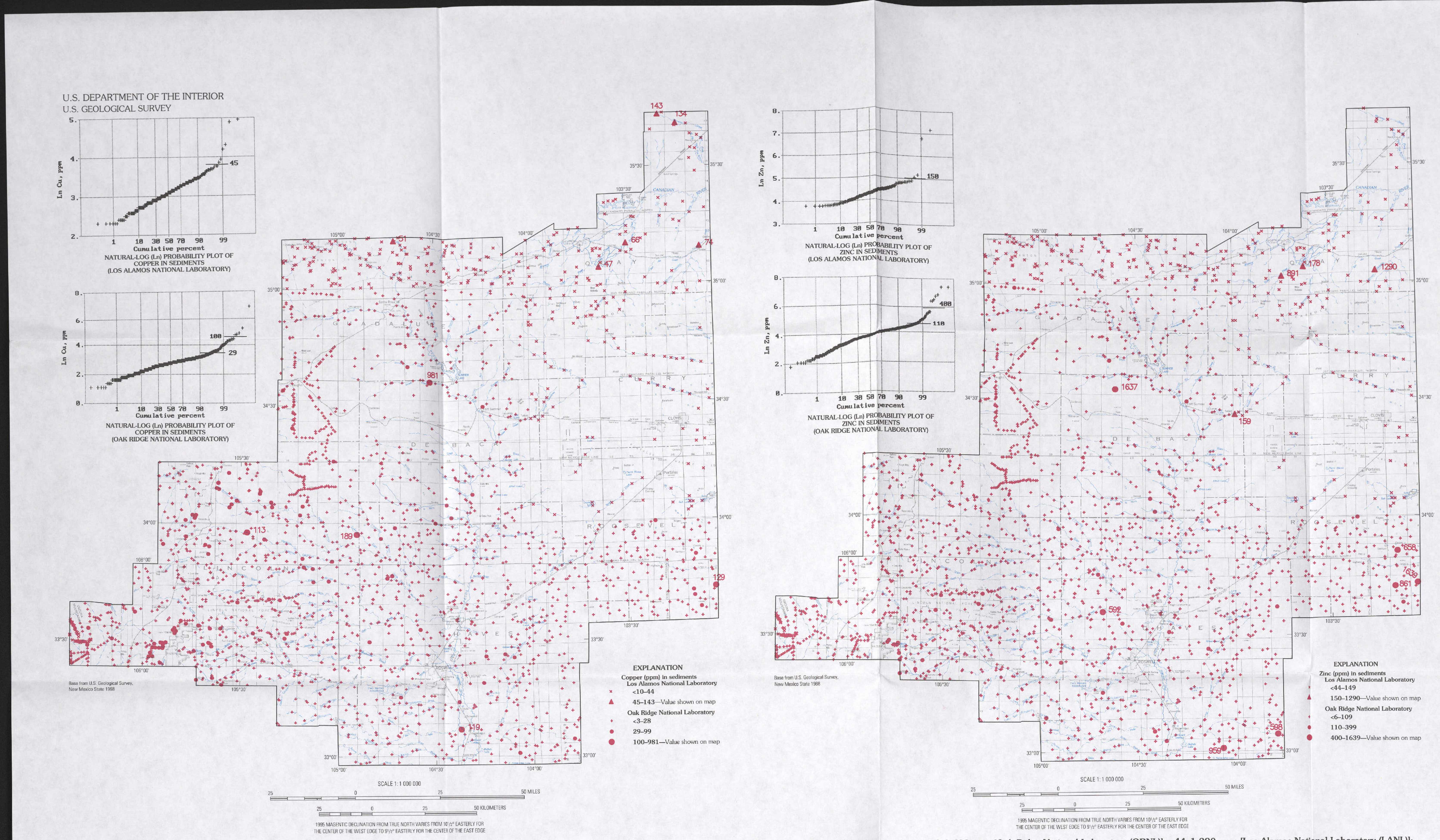

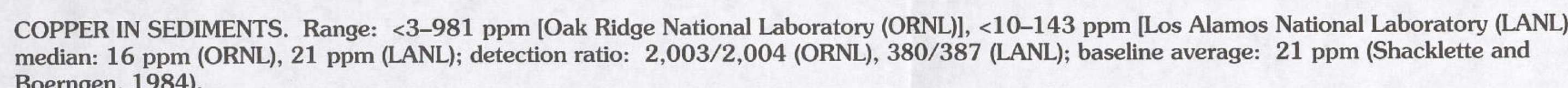
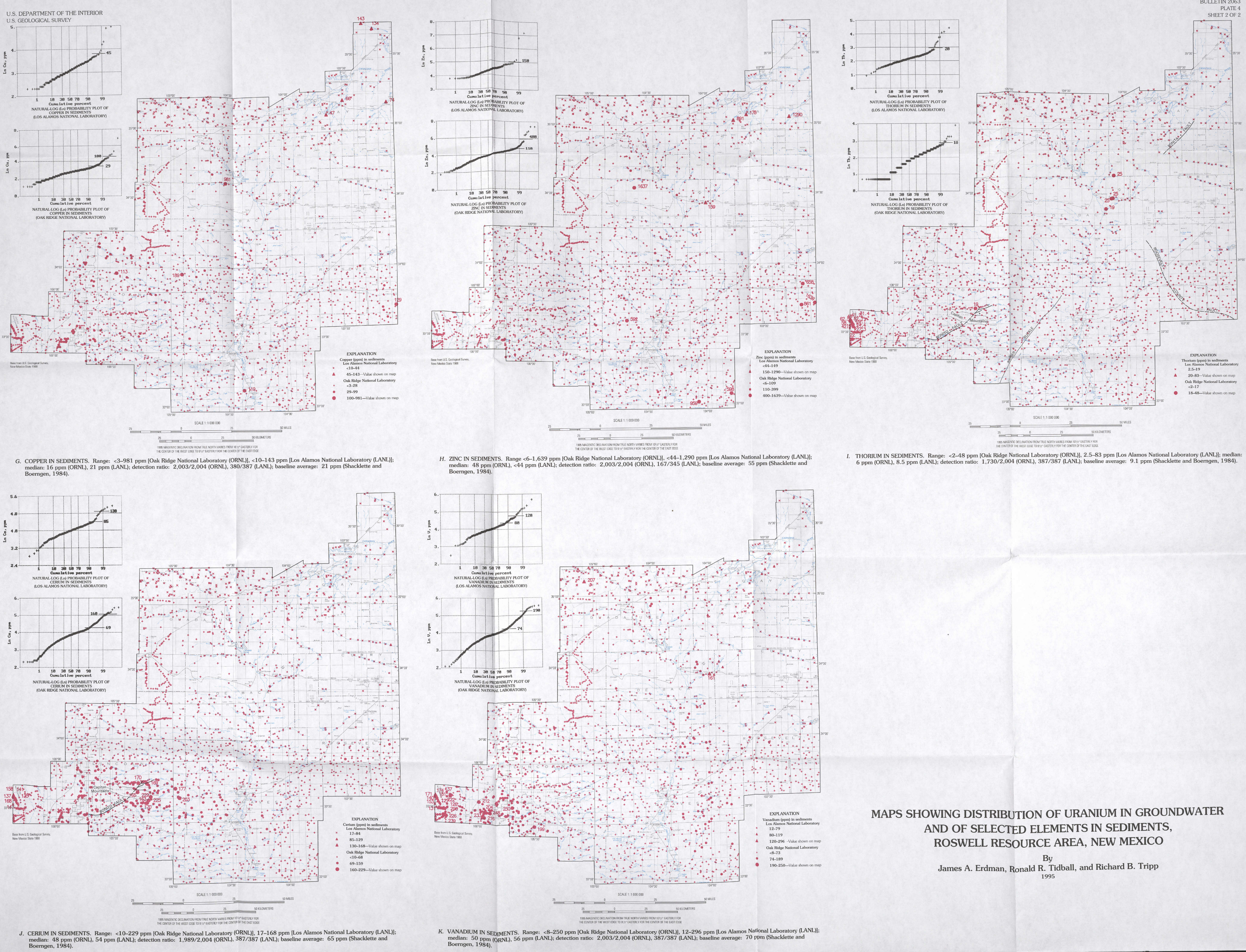

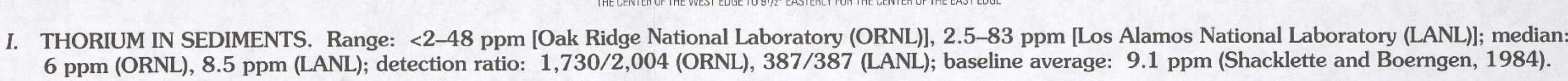

MAPS SHOWING DISTRIBUTION OF URANIUM IN GROUNDWATER AND OF SELECTED ELEMENTS IN SEDIMENTS, ROSWELL RESOURCE AREA, NEW MEXICO

James A. Erdman, Ronald R. T. Tidball, and Richard B. Tripp 


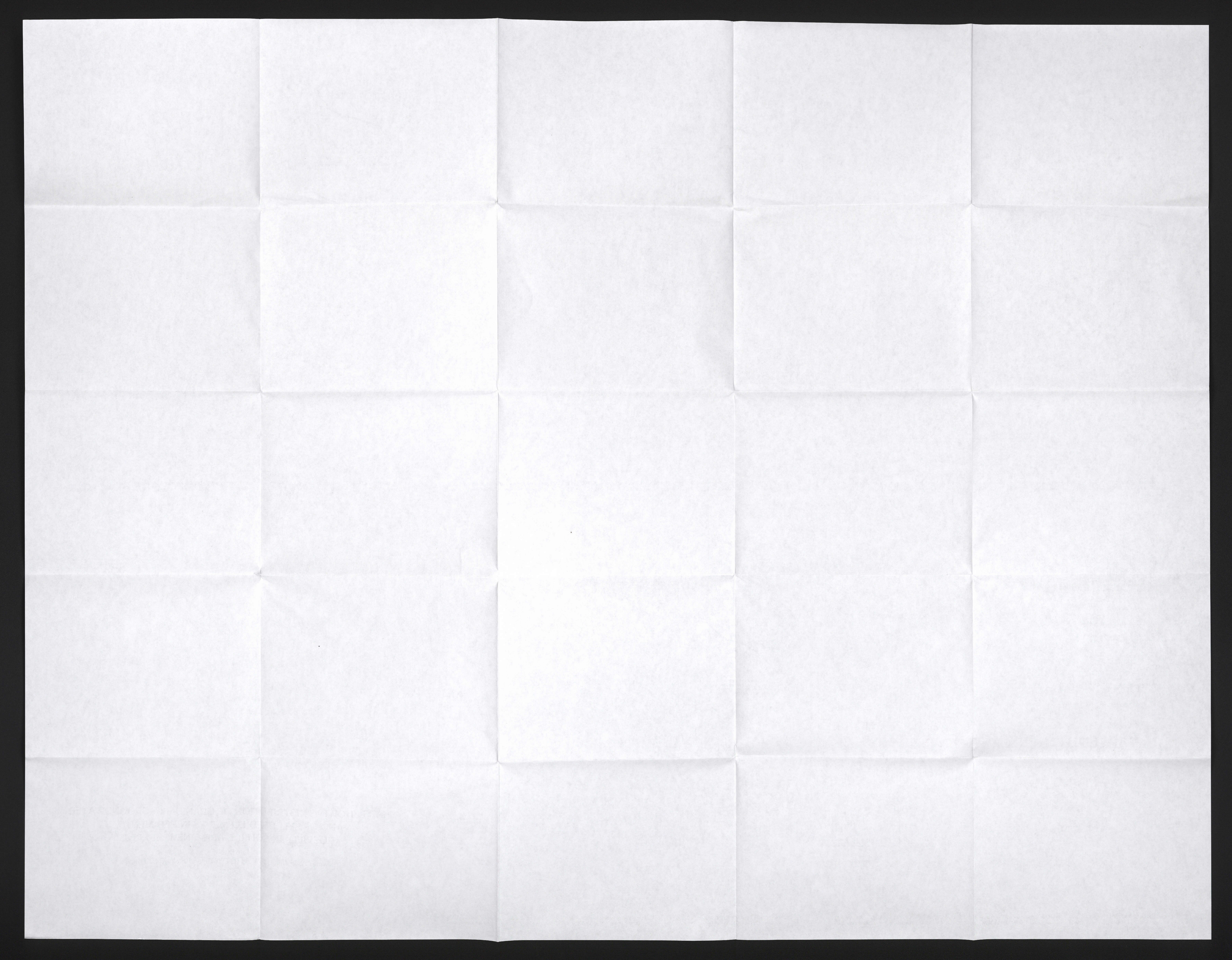




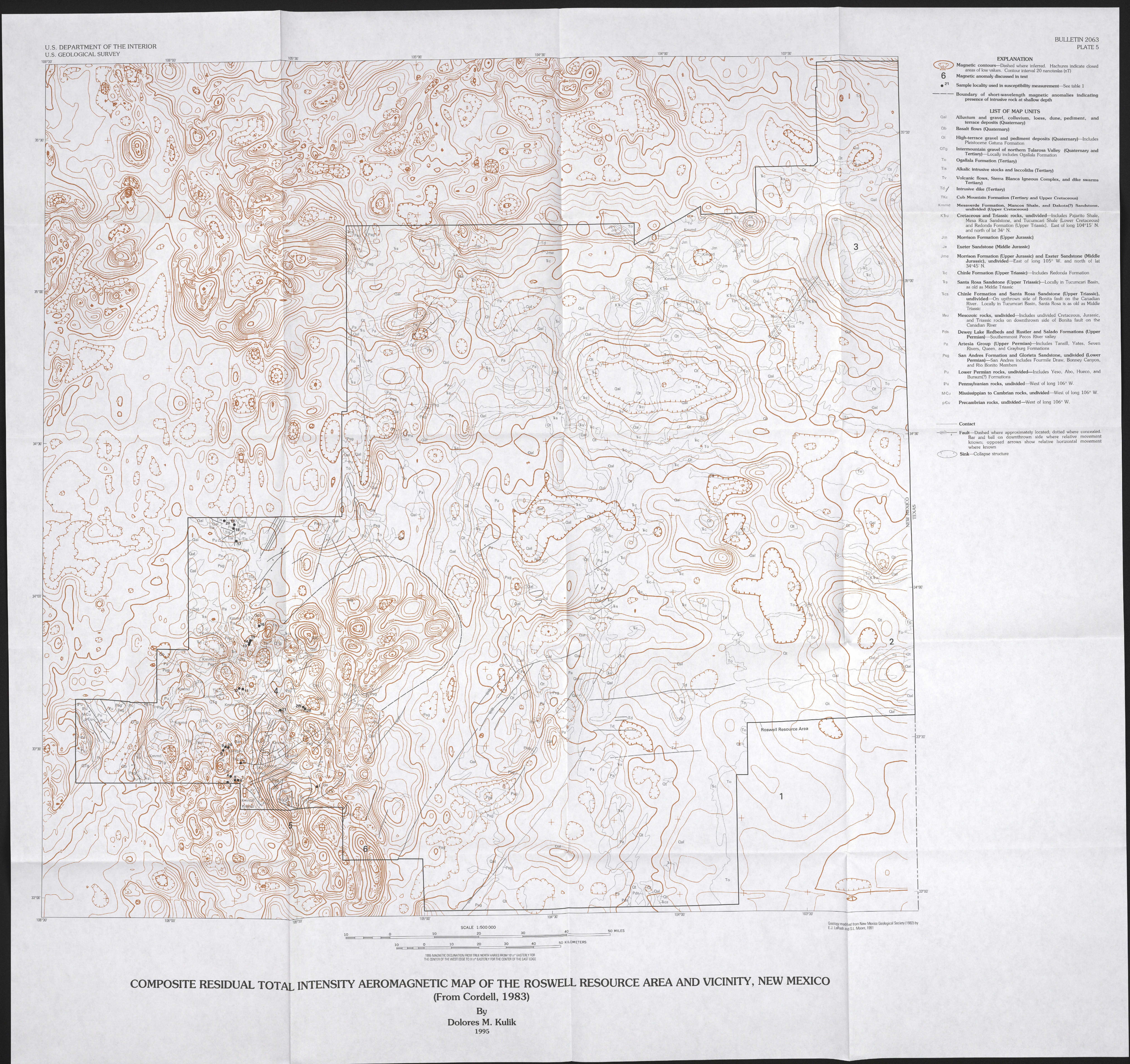




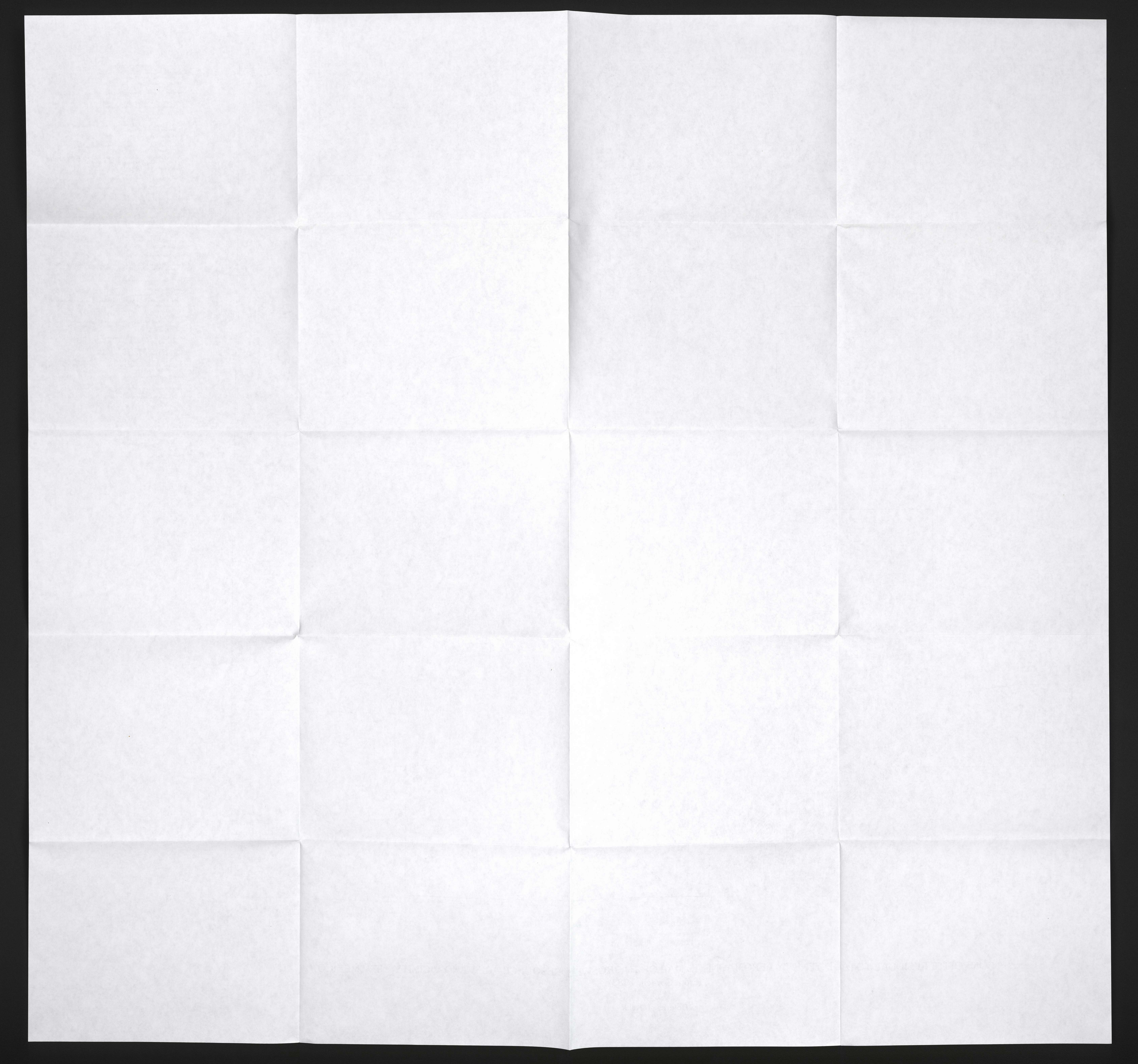




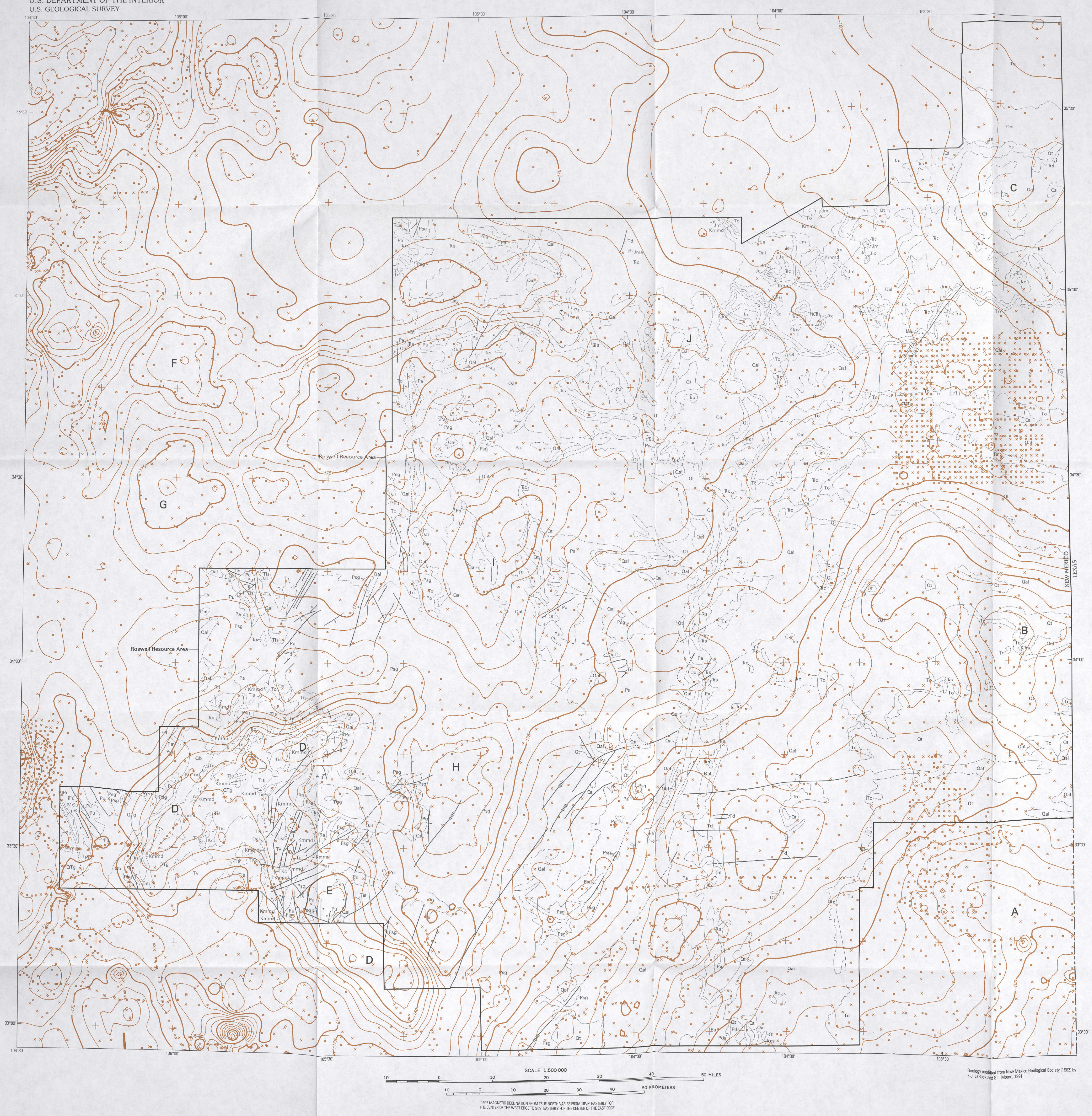

(T)

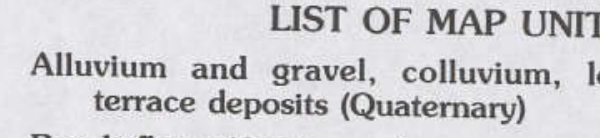

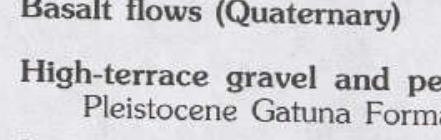

t deposits (Quatemany)-ncludes

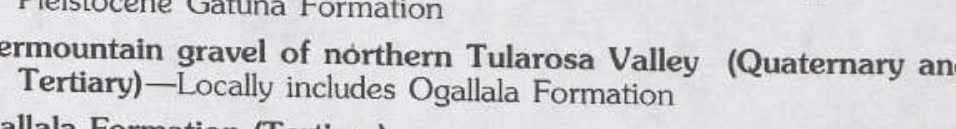

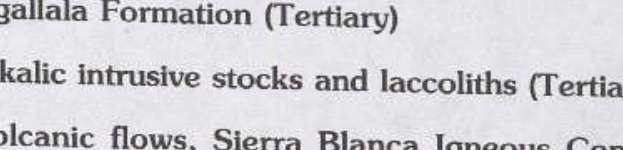

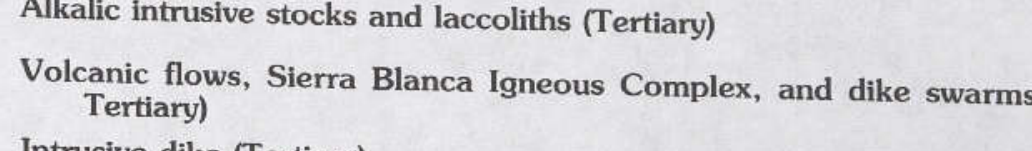

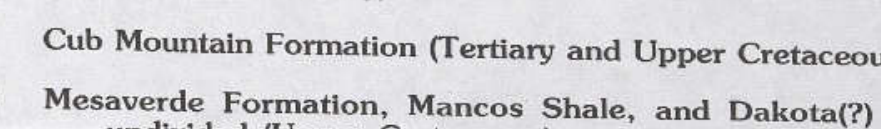

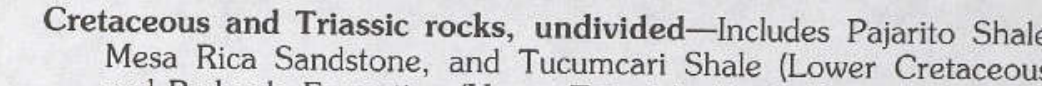

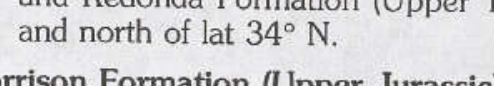

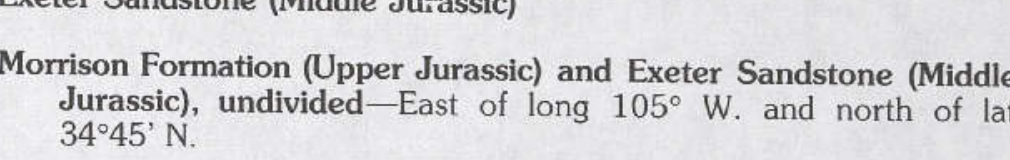

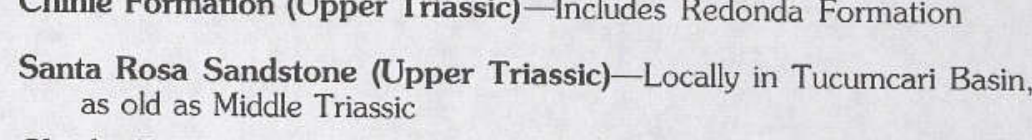

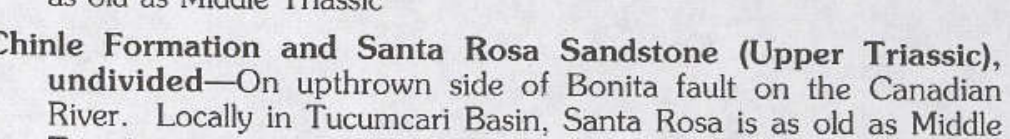

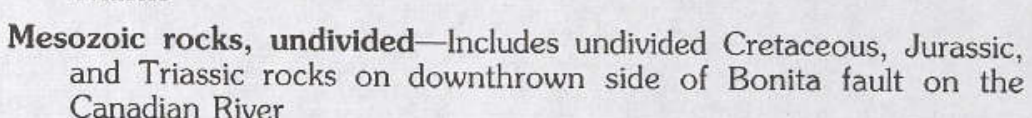

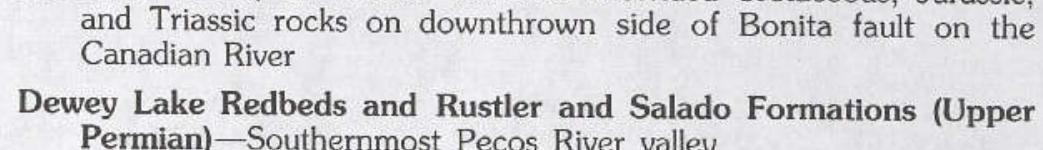

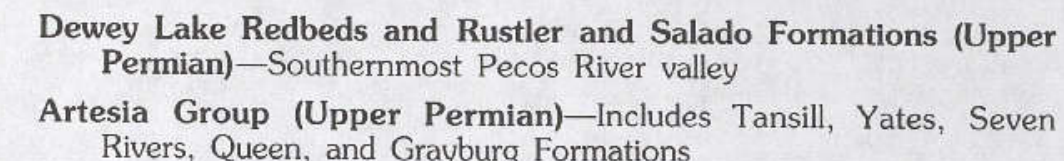

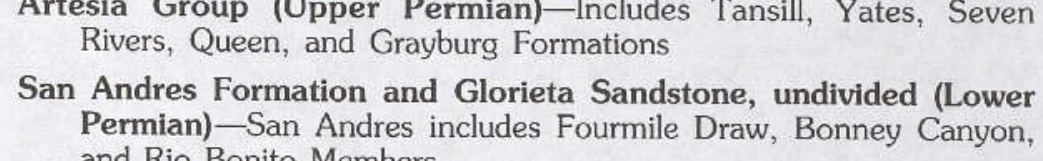

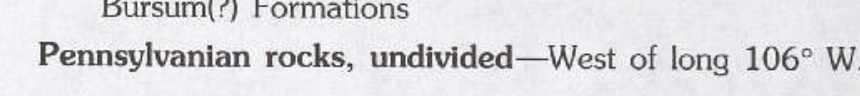

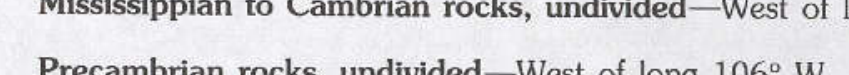

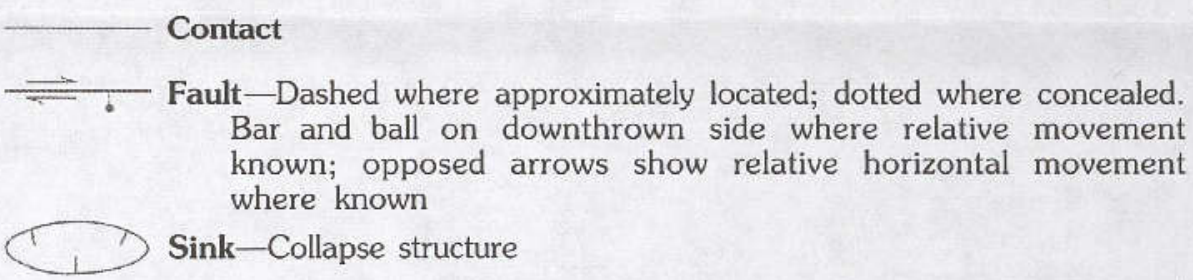

COMPLETE BOUGUER GRAVITY ANOMALY MAP OF THE ROSWELL RESOURCE AREA AND VICINITY, NEW MEXICO By
Dolores M. Kulik
1995 


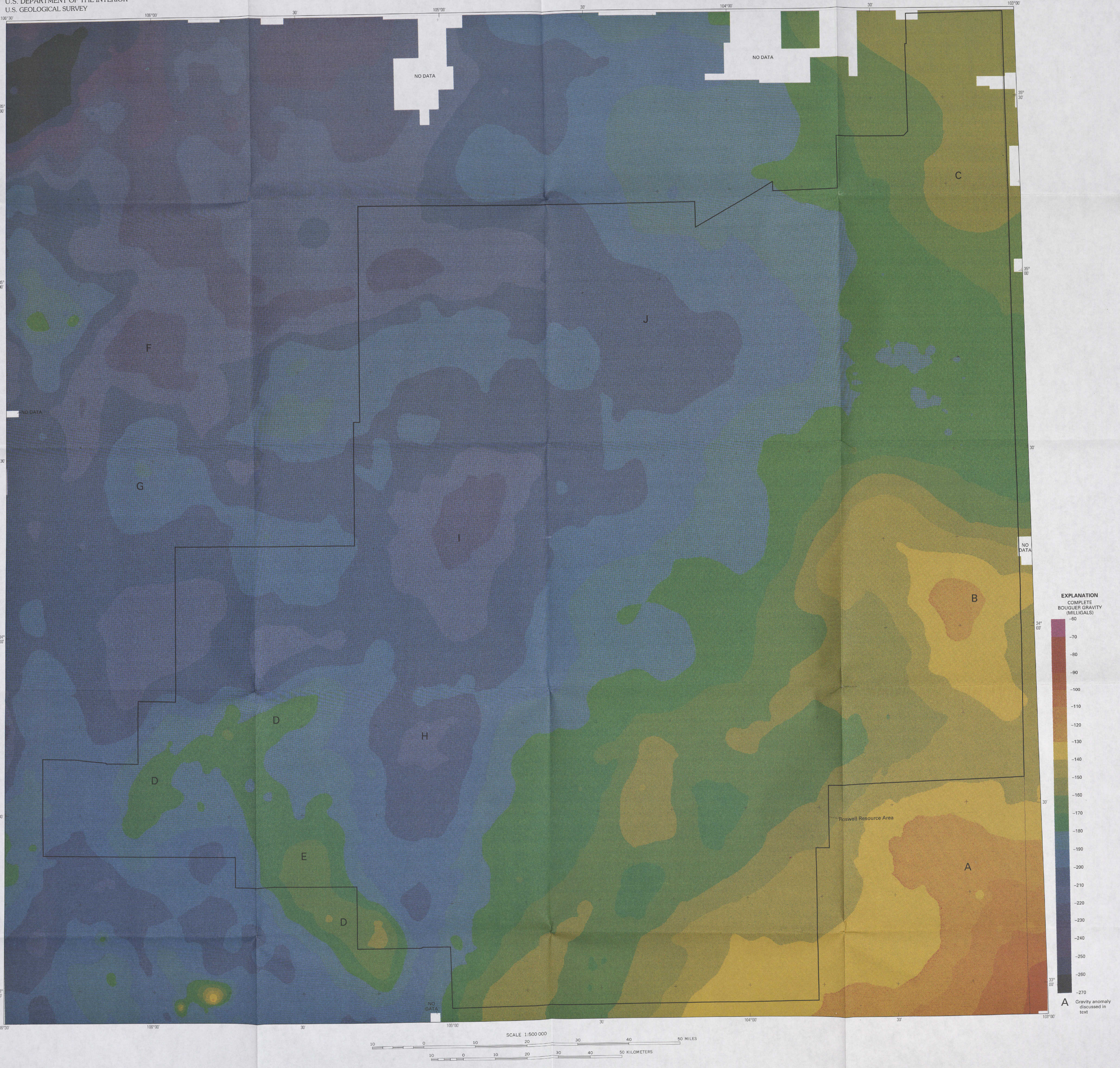

COLOR REPRESENTATION OF COMPLETE BOUGUER GRAVITY ANOMALY MAP OF THE ROSWELL RESOURCE AREA AND VICINITY, NEW MEXICO 


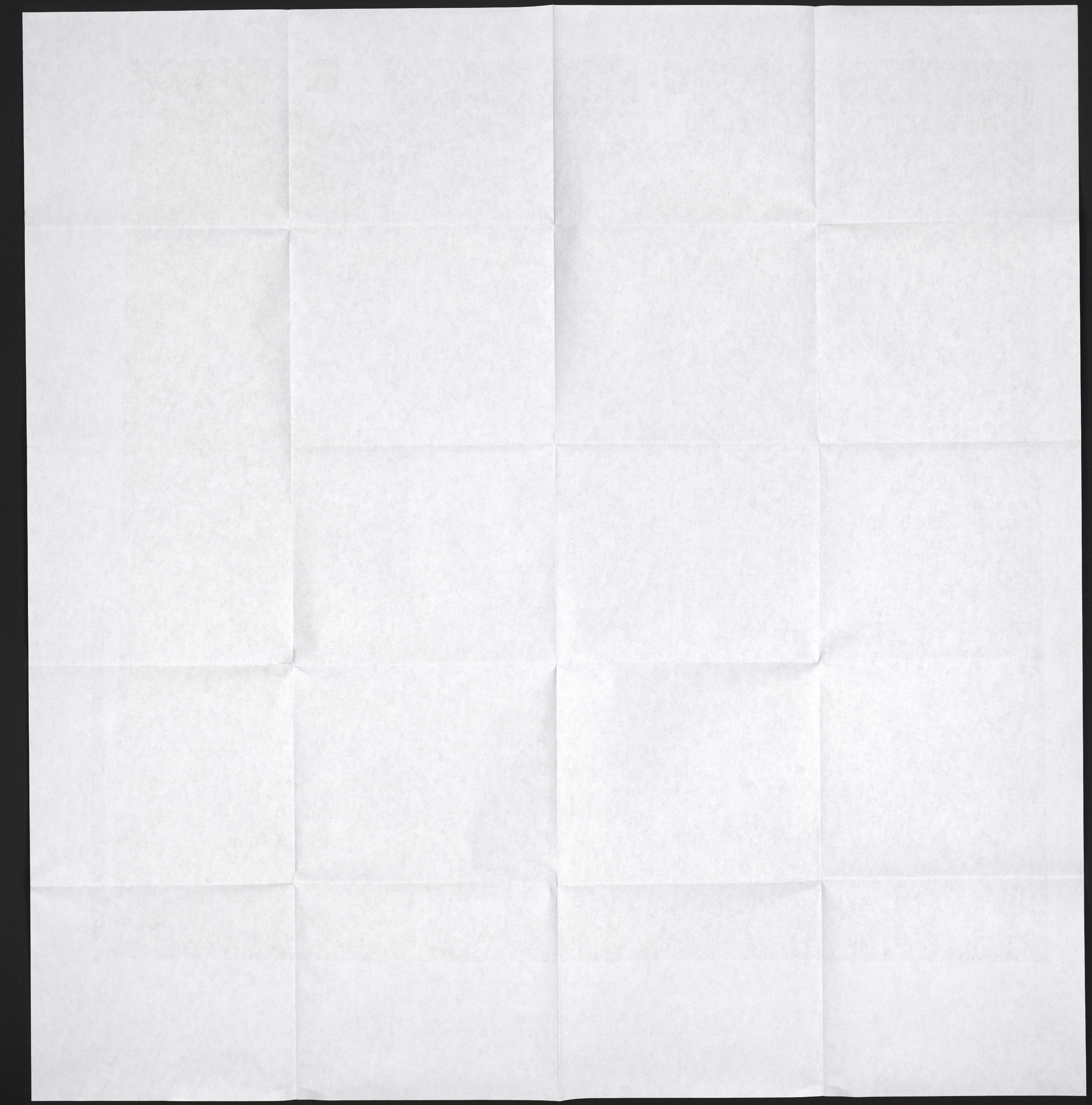




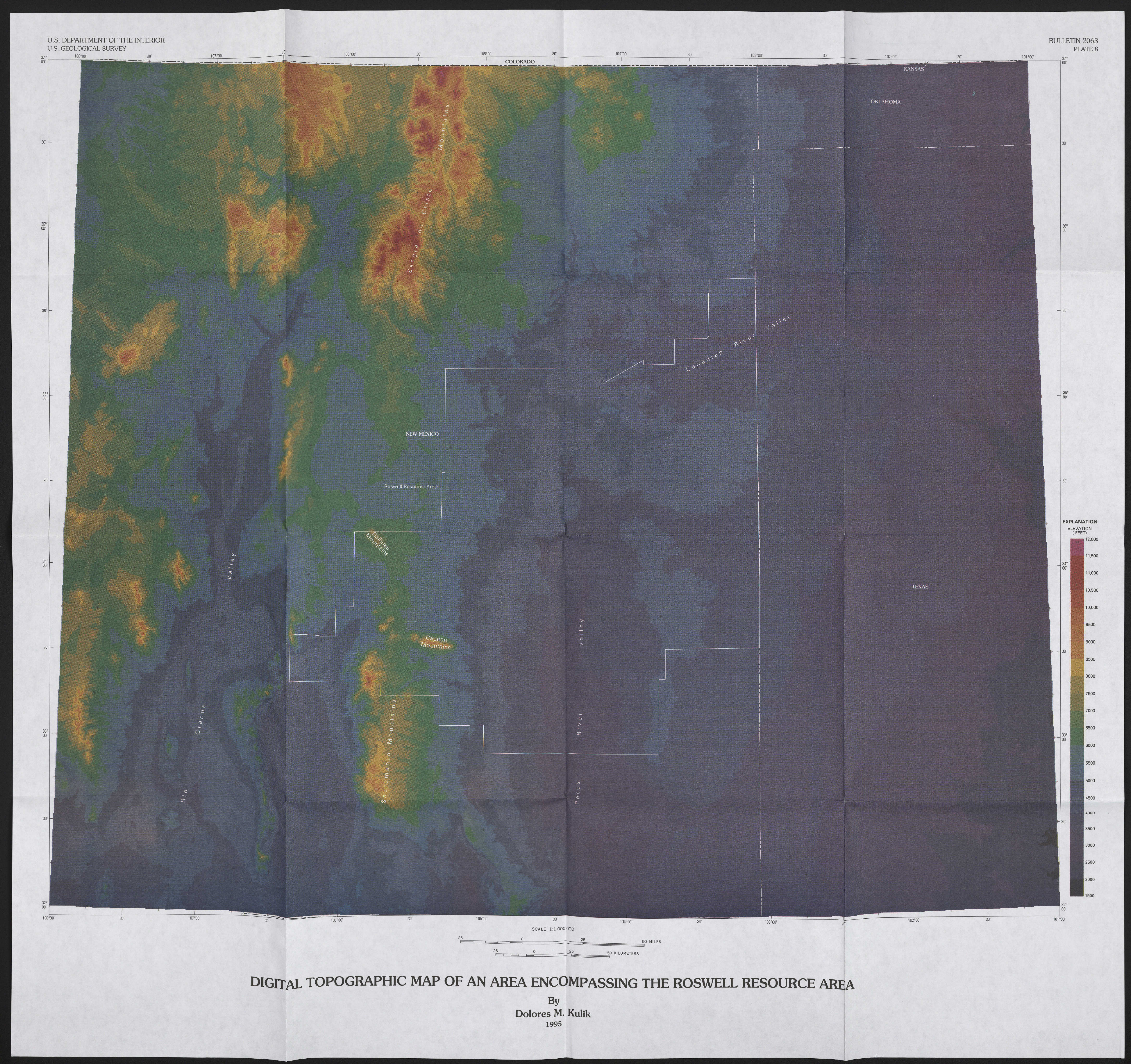




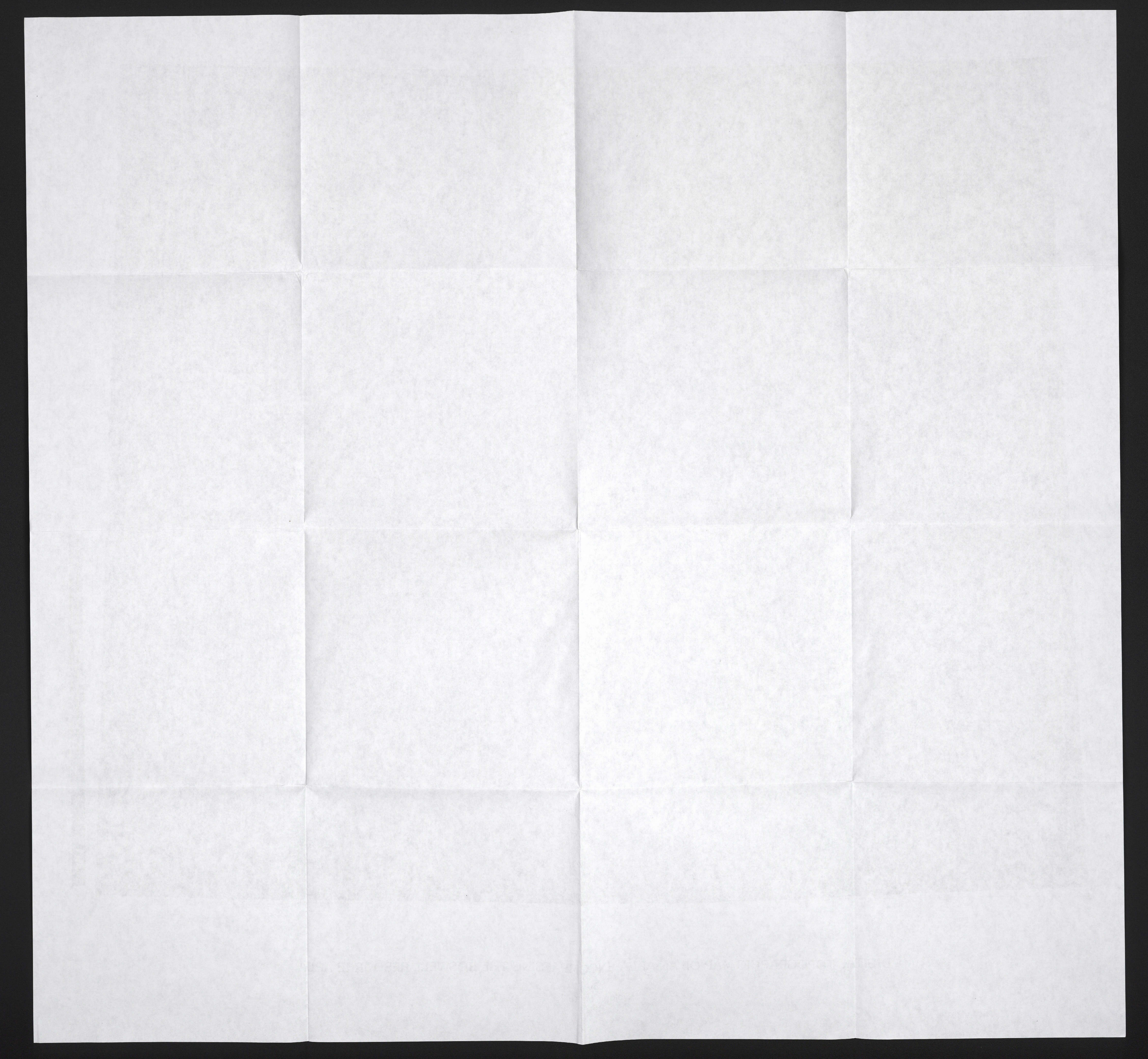




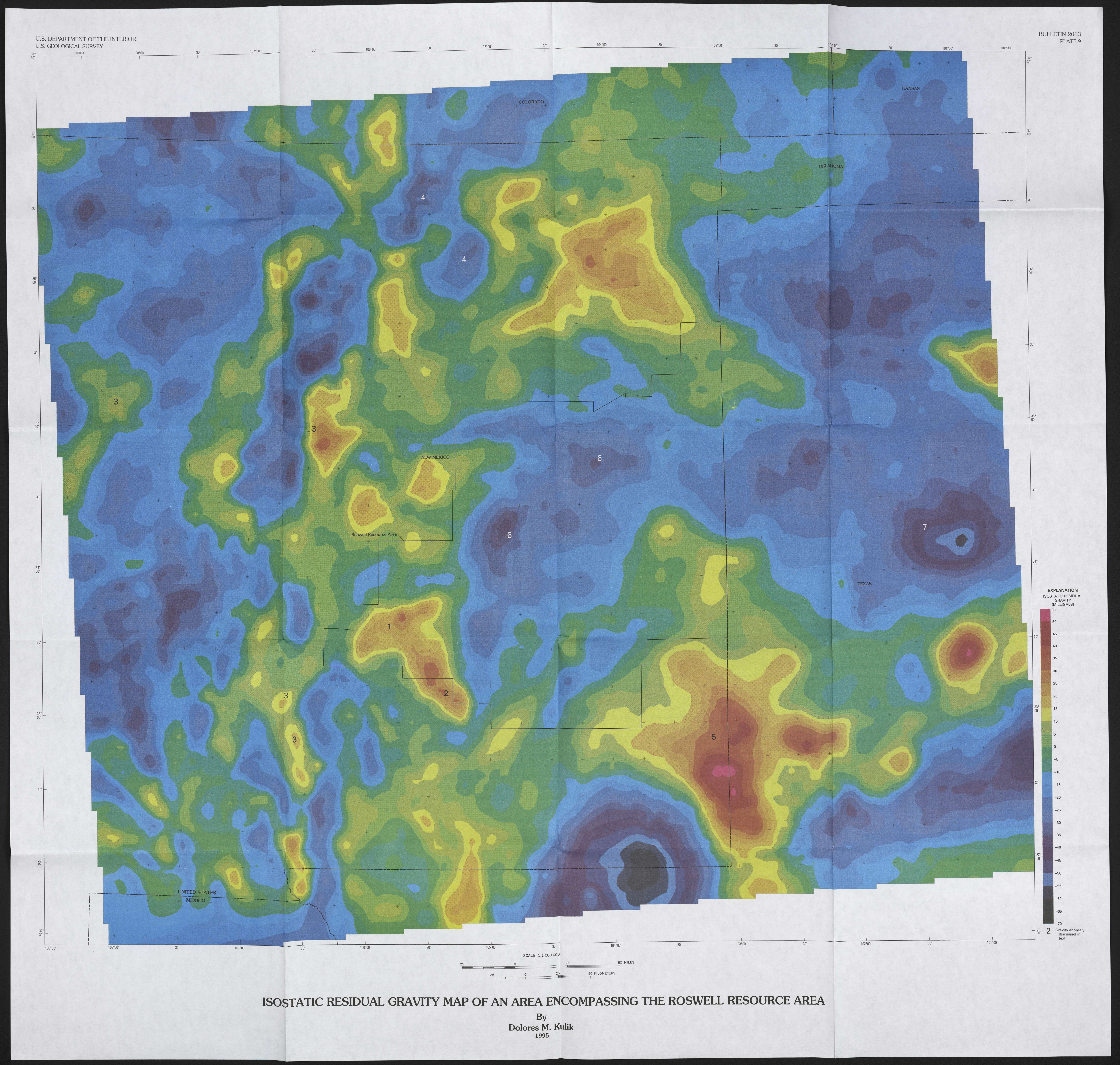




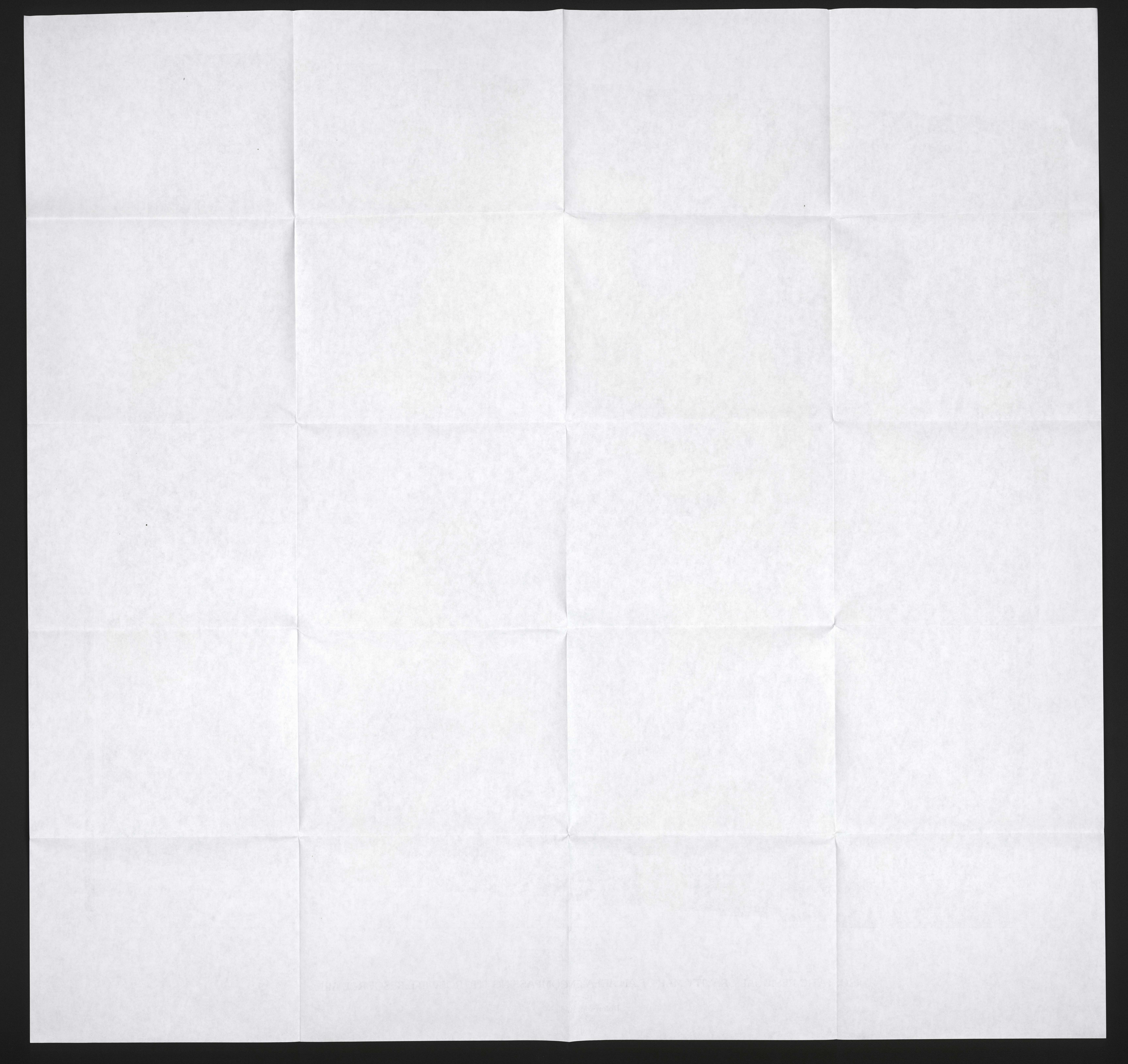




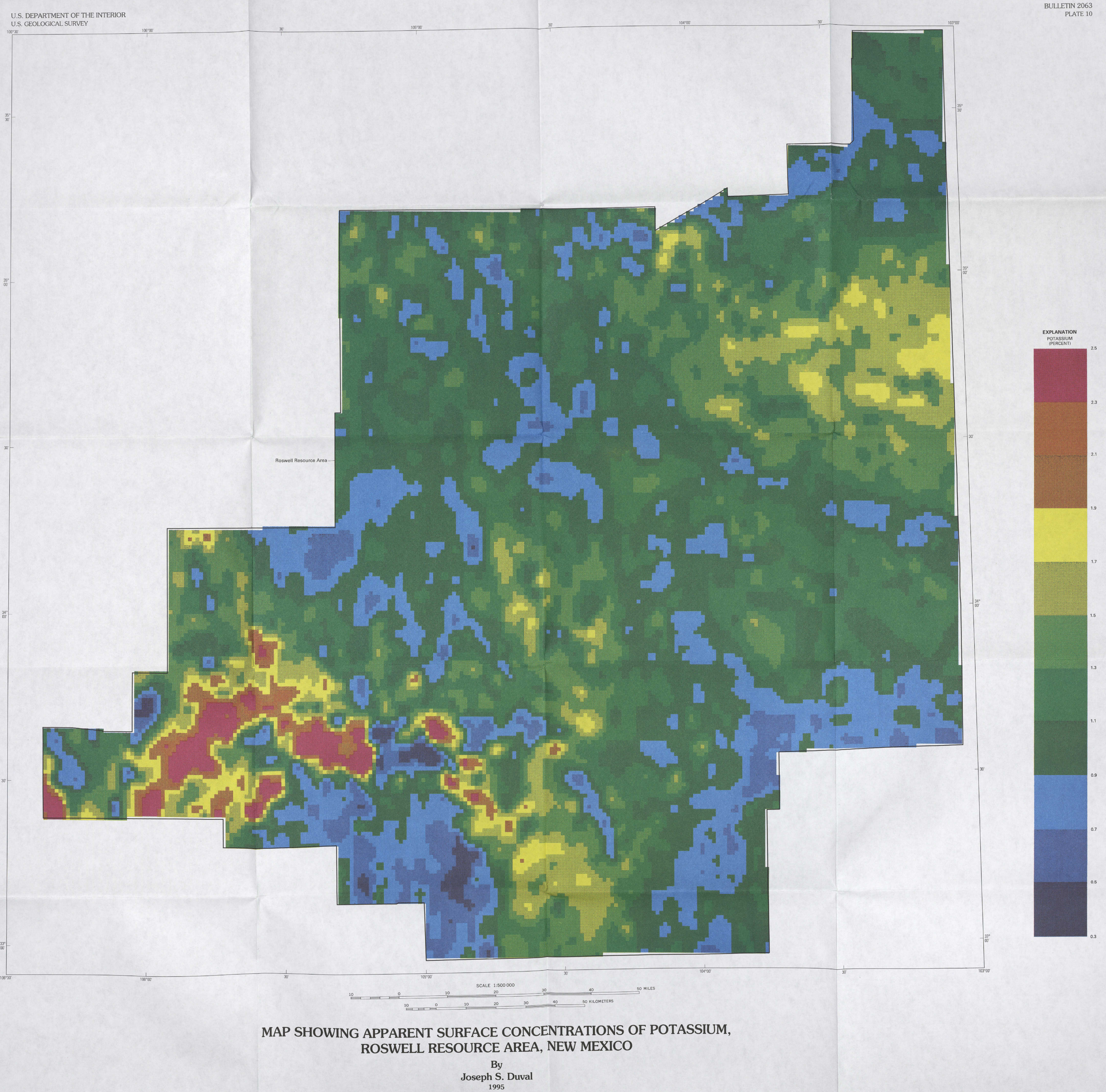




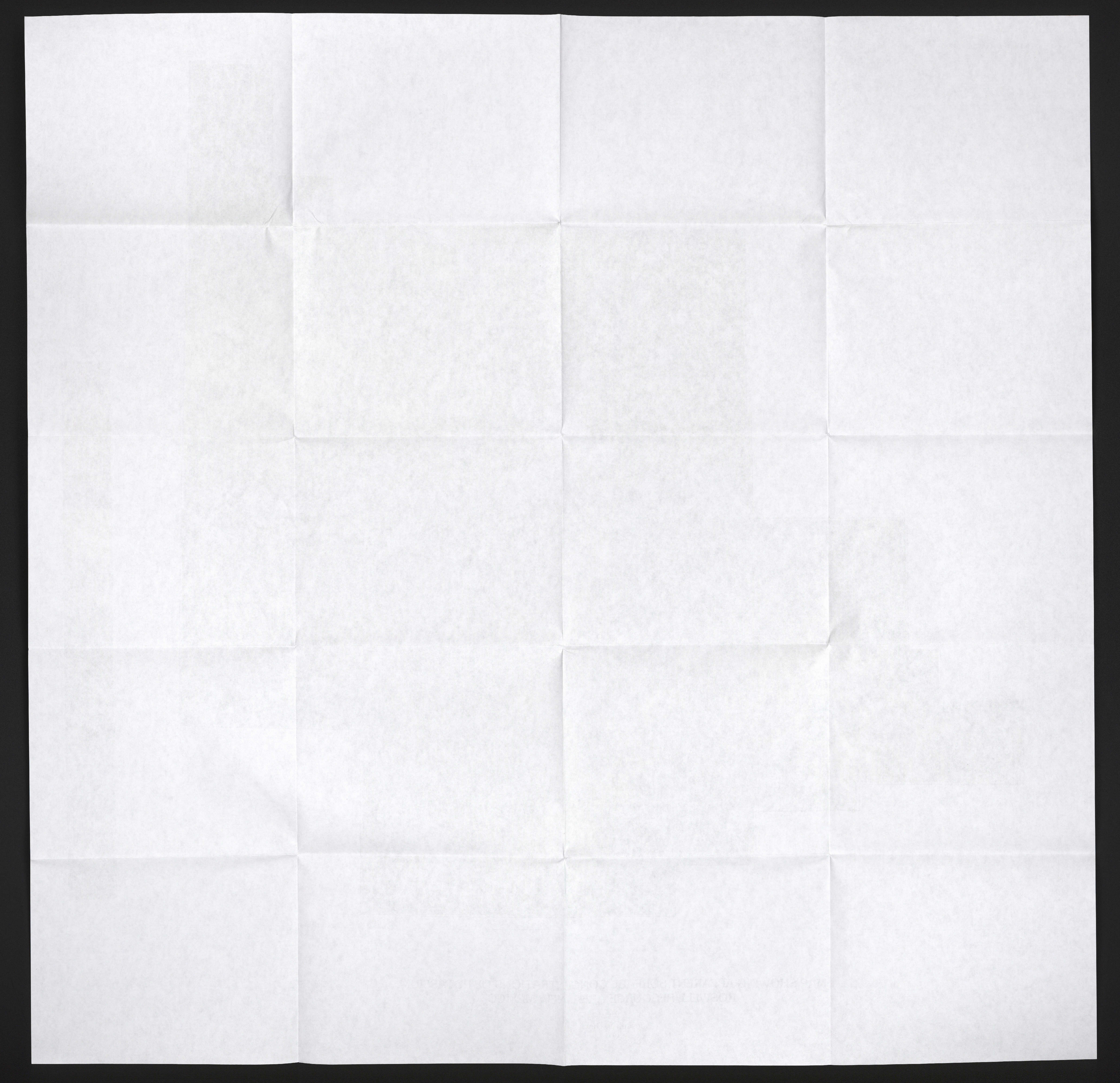



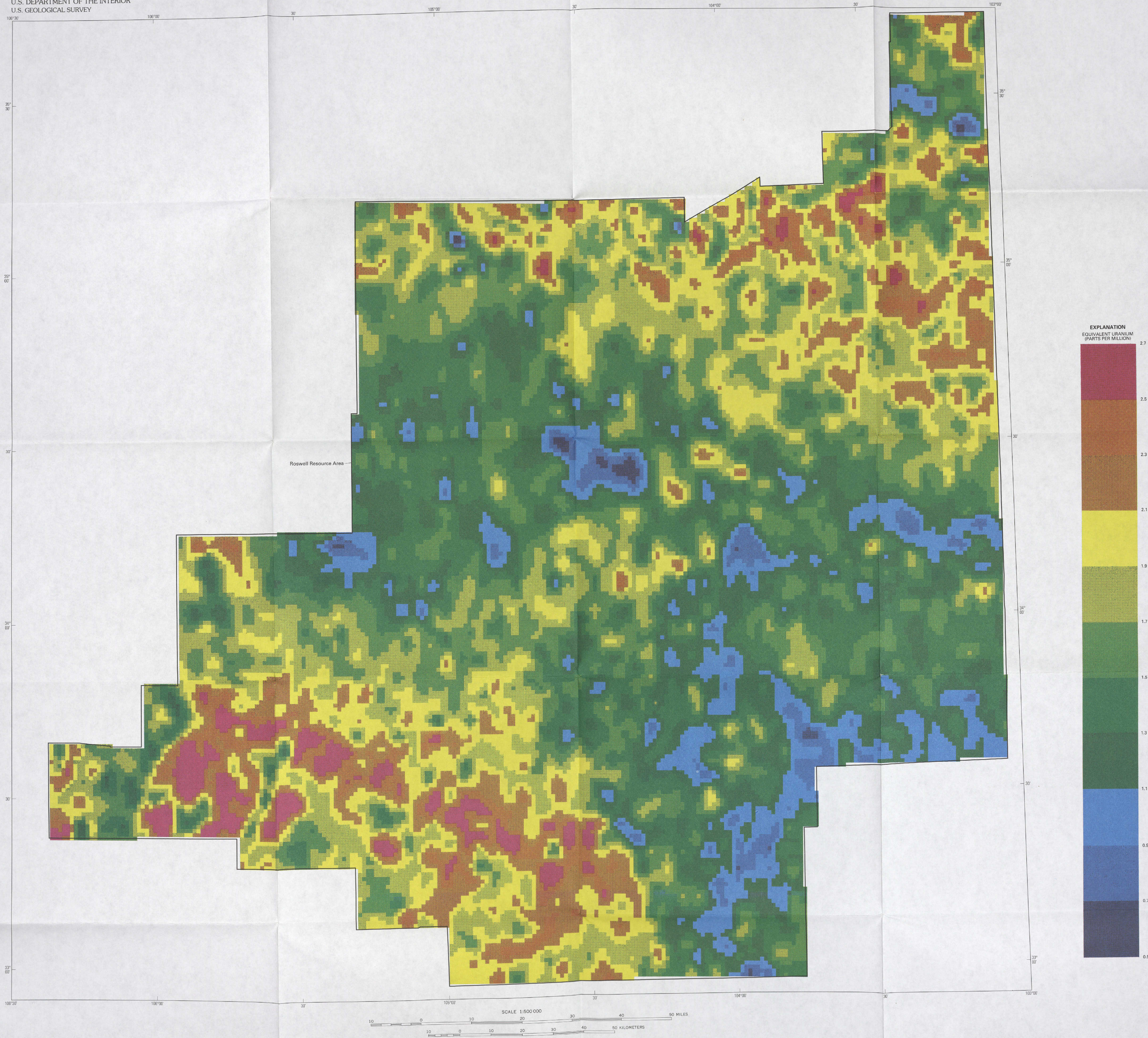

MAP SHOWING APPARENT SURFACE CONCENTRATIONS OF EQUIVALENT URANIUM, ROSWELL RESOURCE AREA, NEW MEXICO 


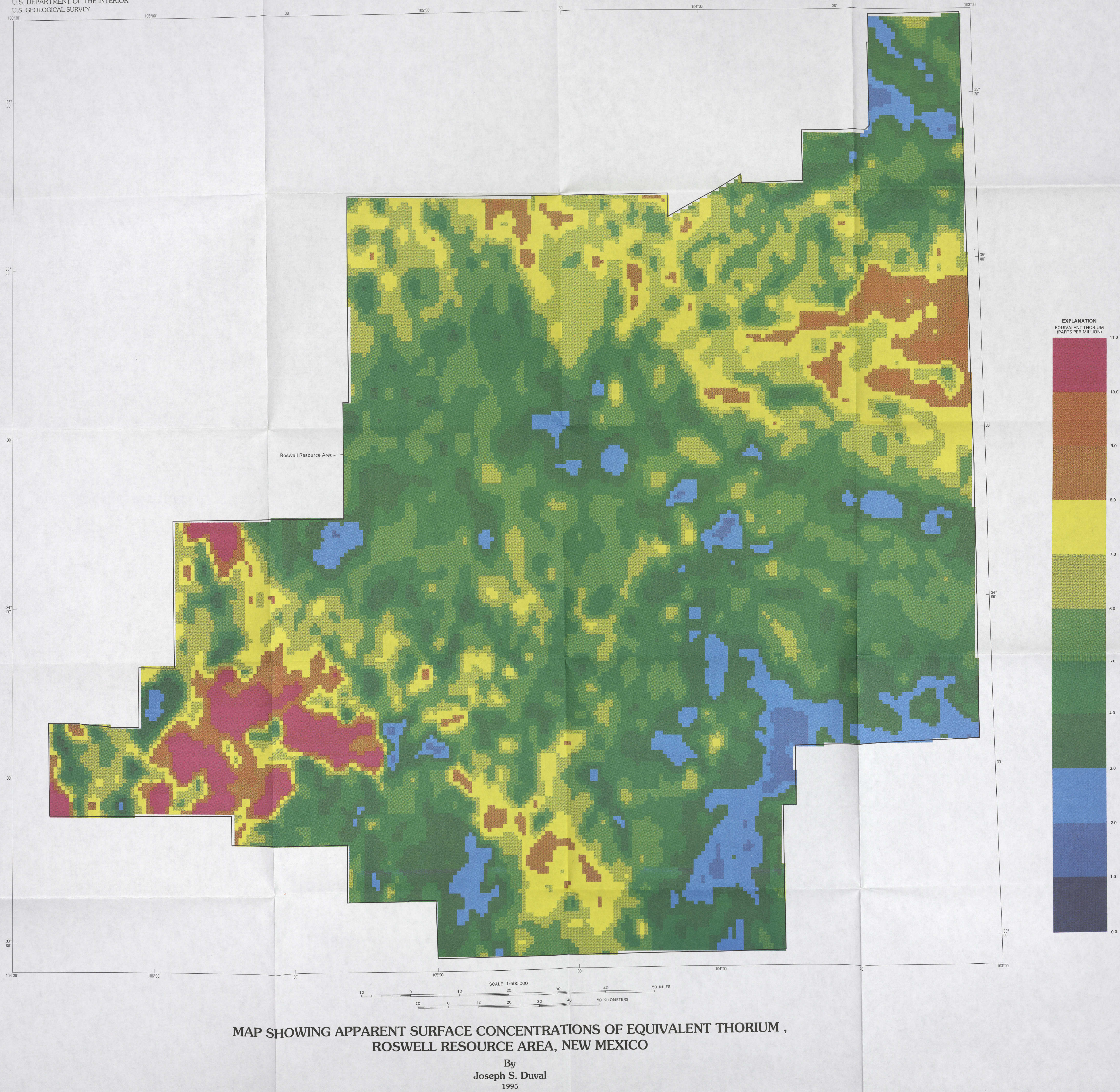




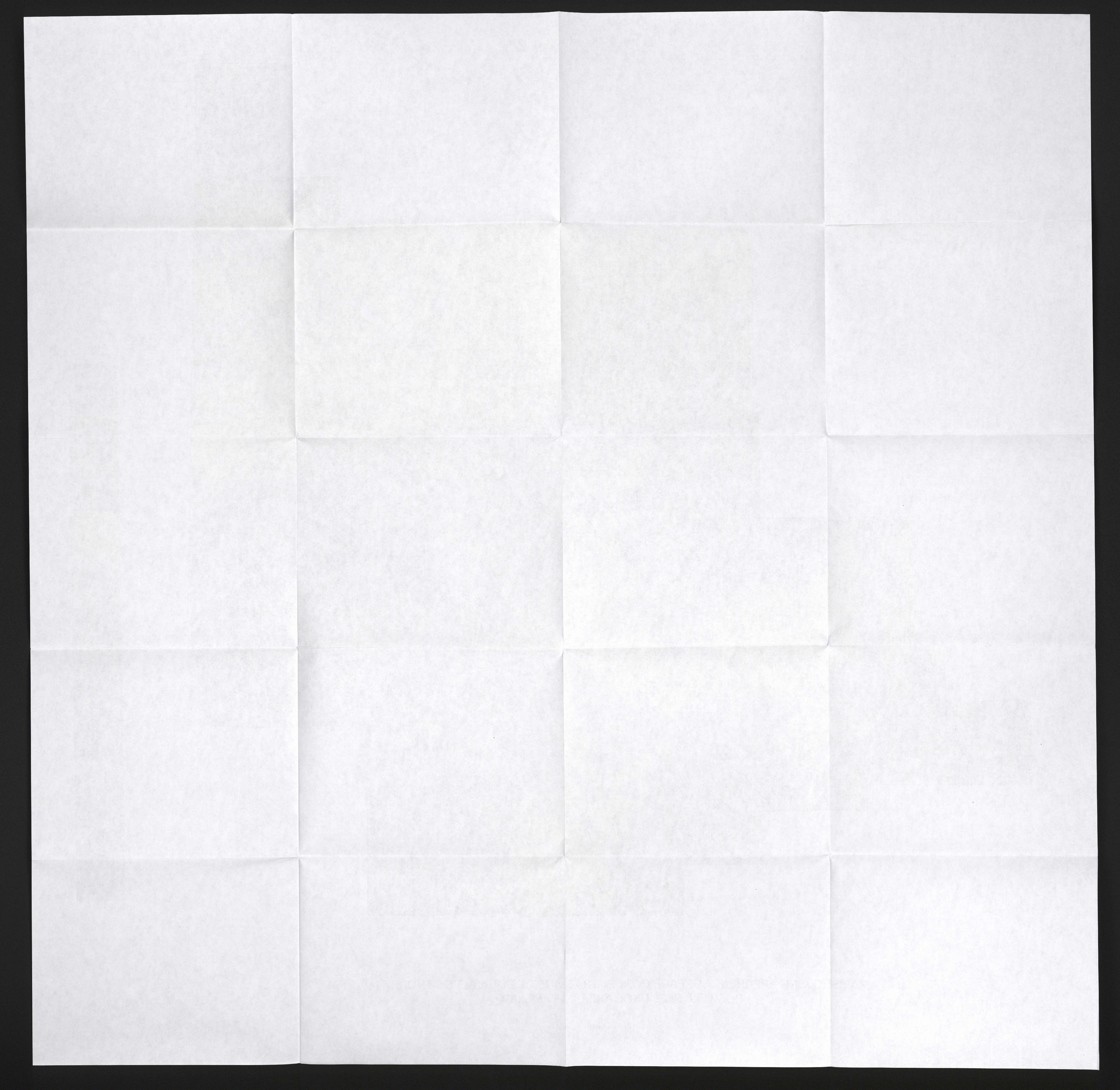




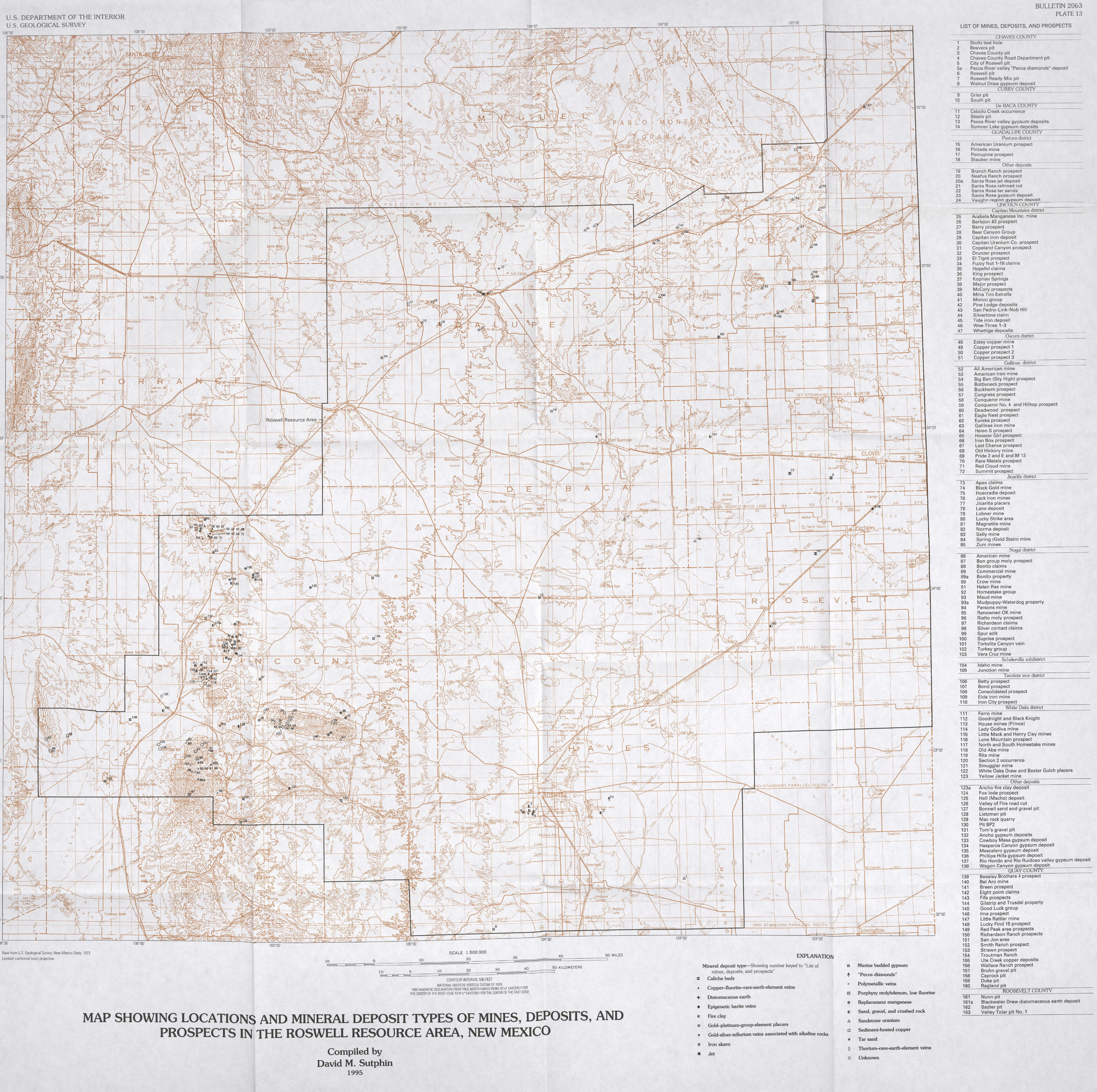




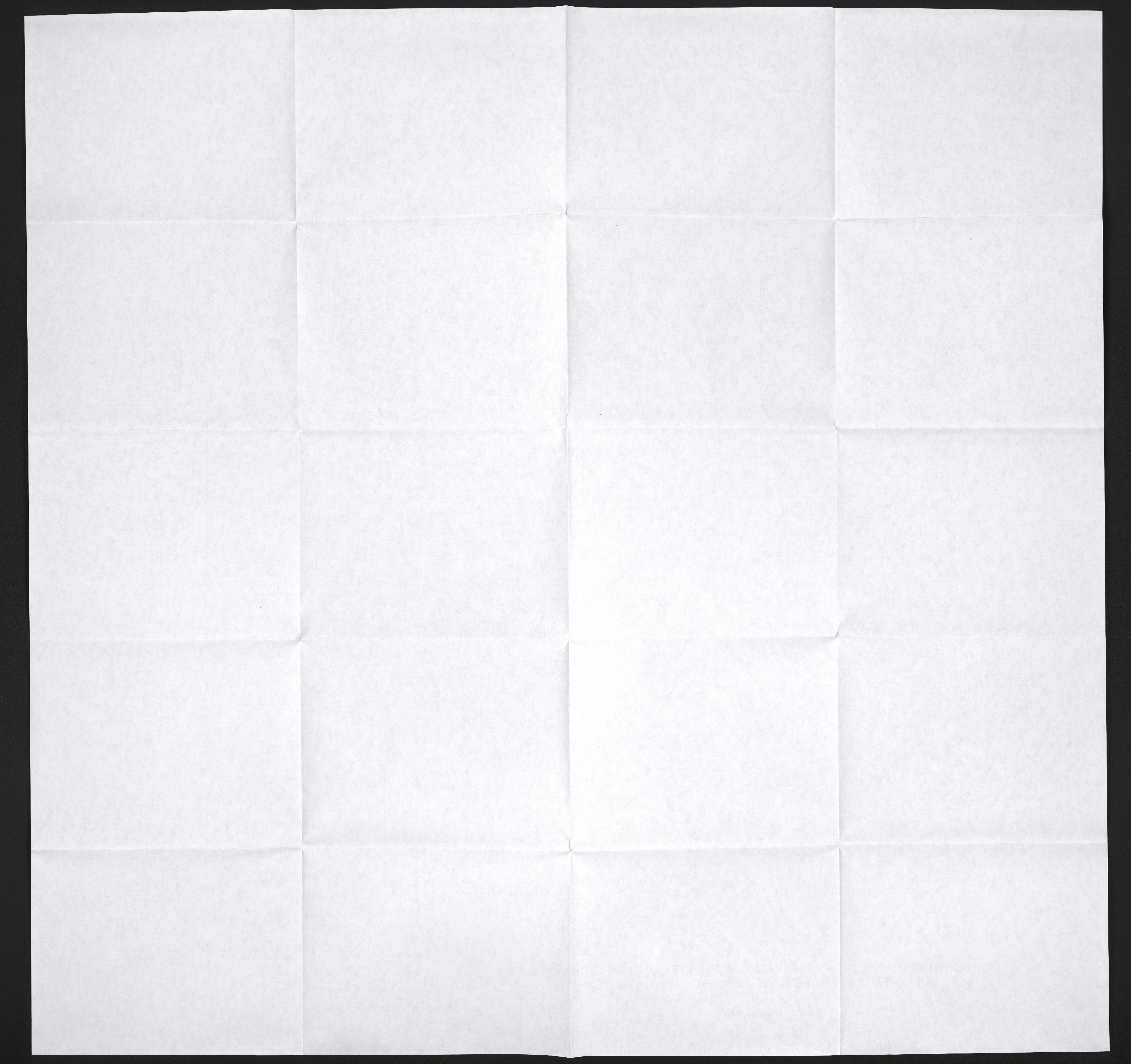




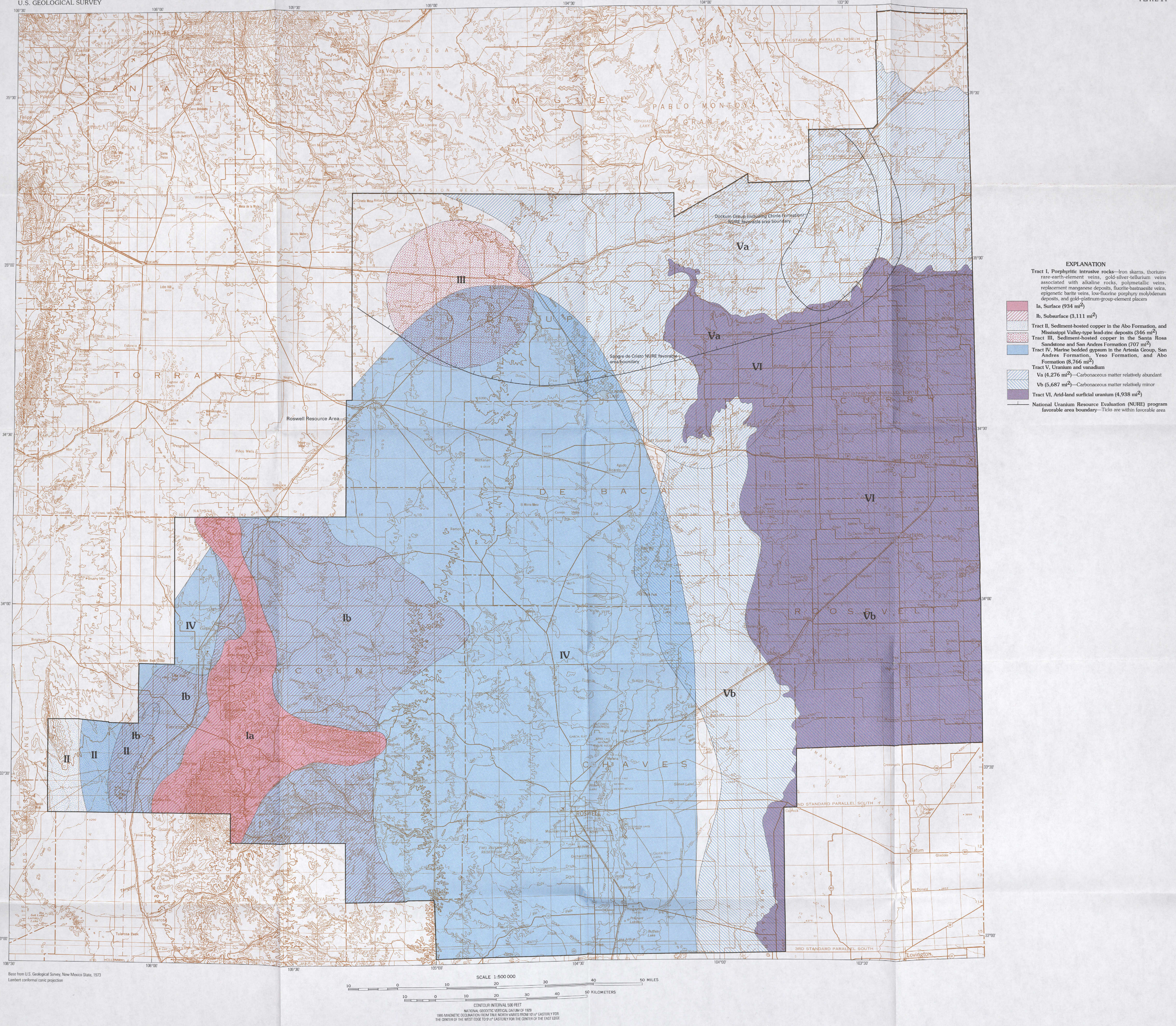

MAP SHOWING MINERAL RESOURCE TRACTS OF UNDISCOVERED COMMODITIES IN THE ROSWELL RESOURCE AREA, NEW MEXICO

Compiled by 


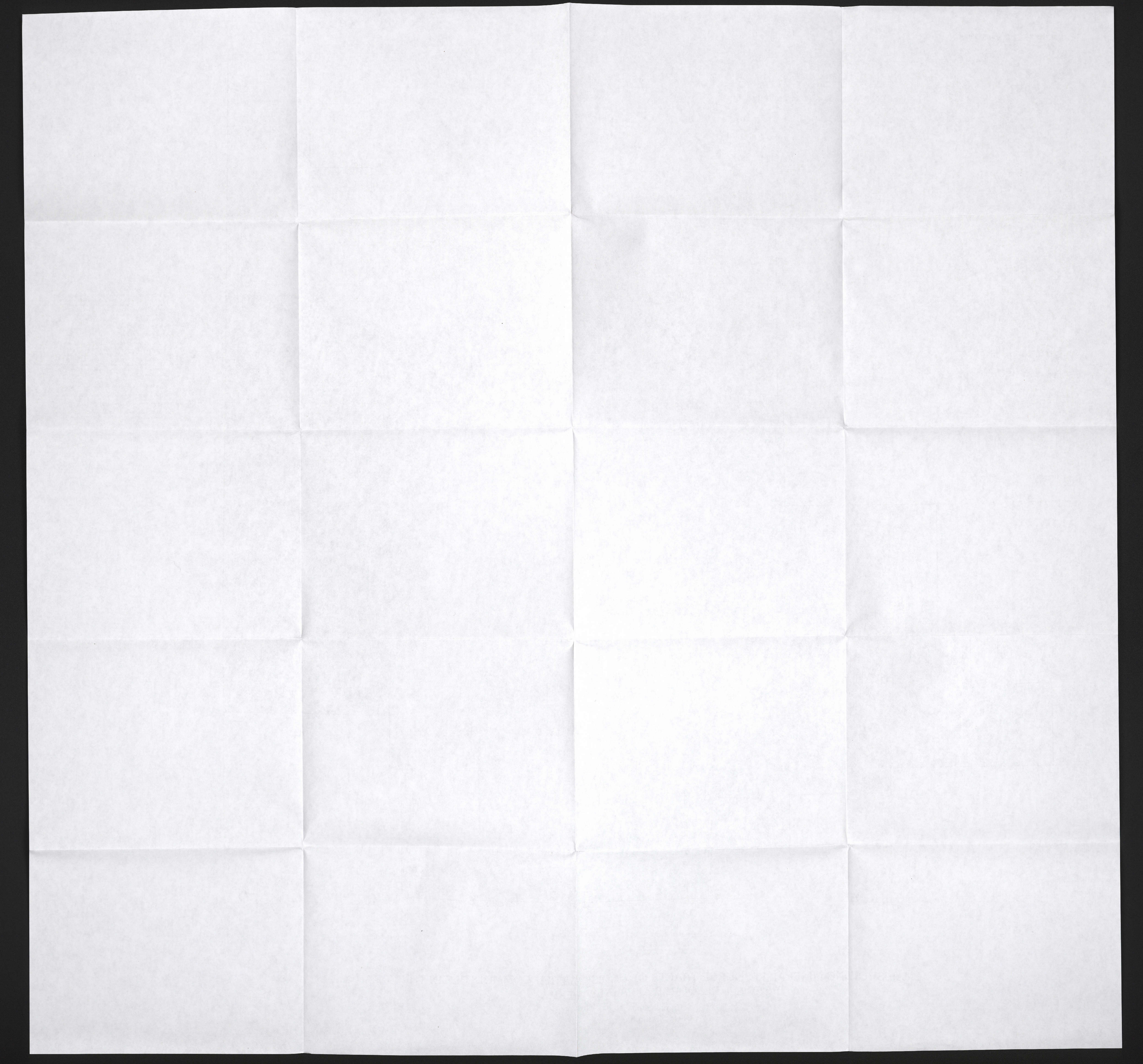




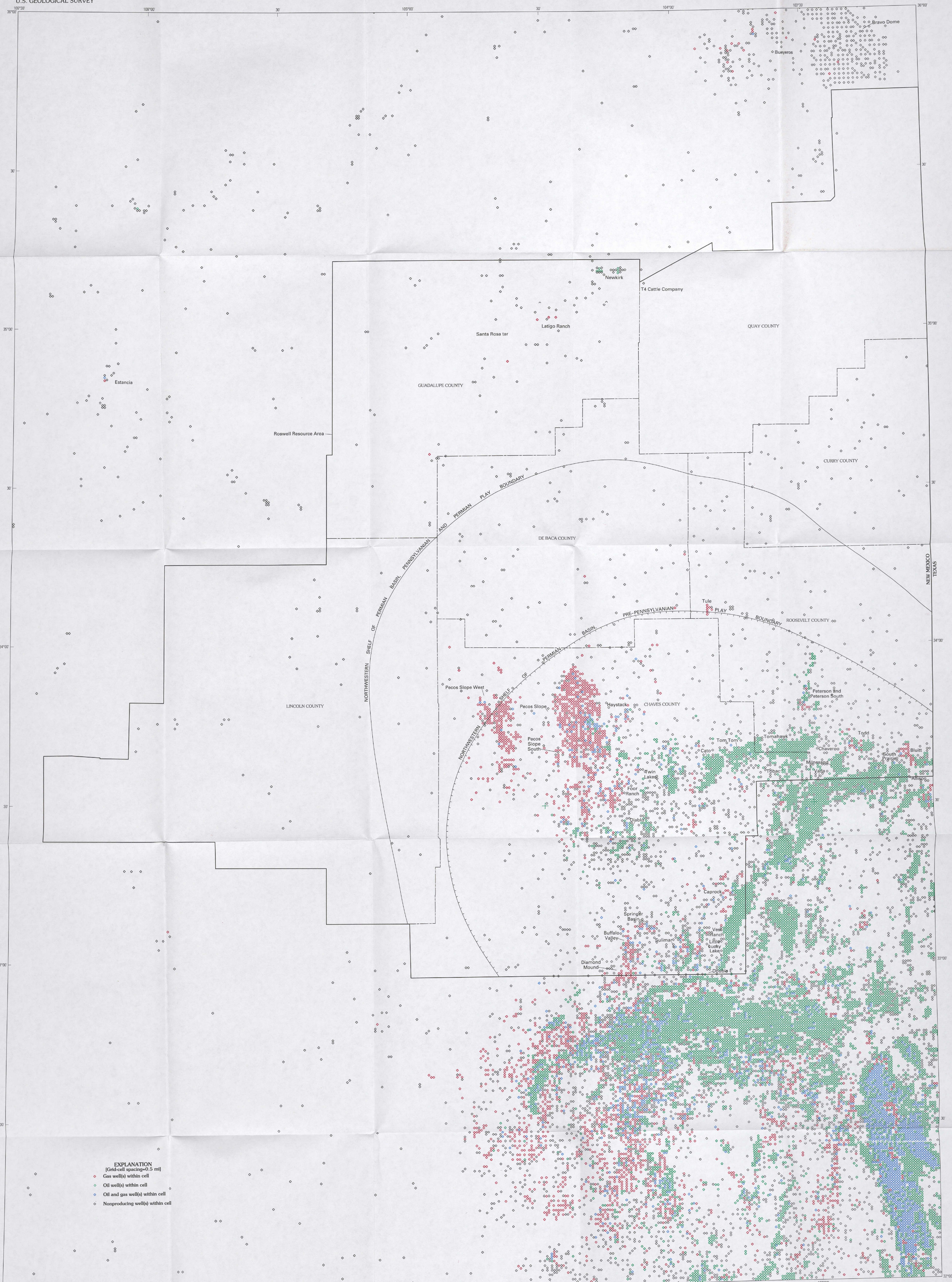






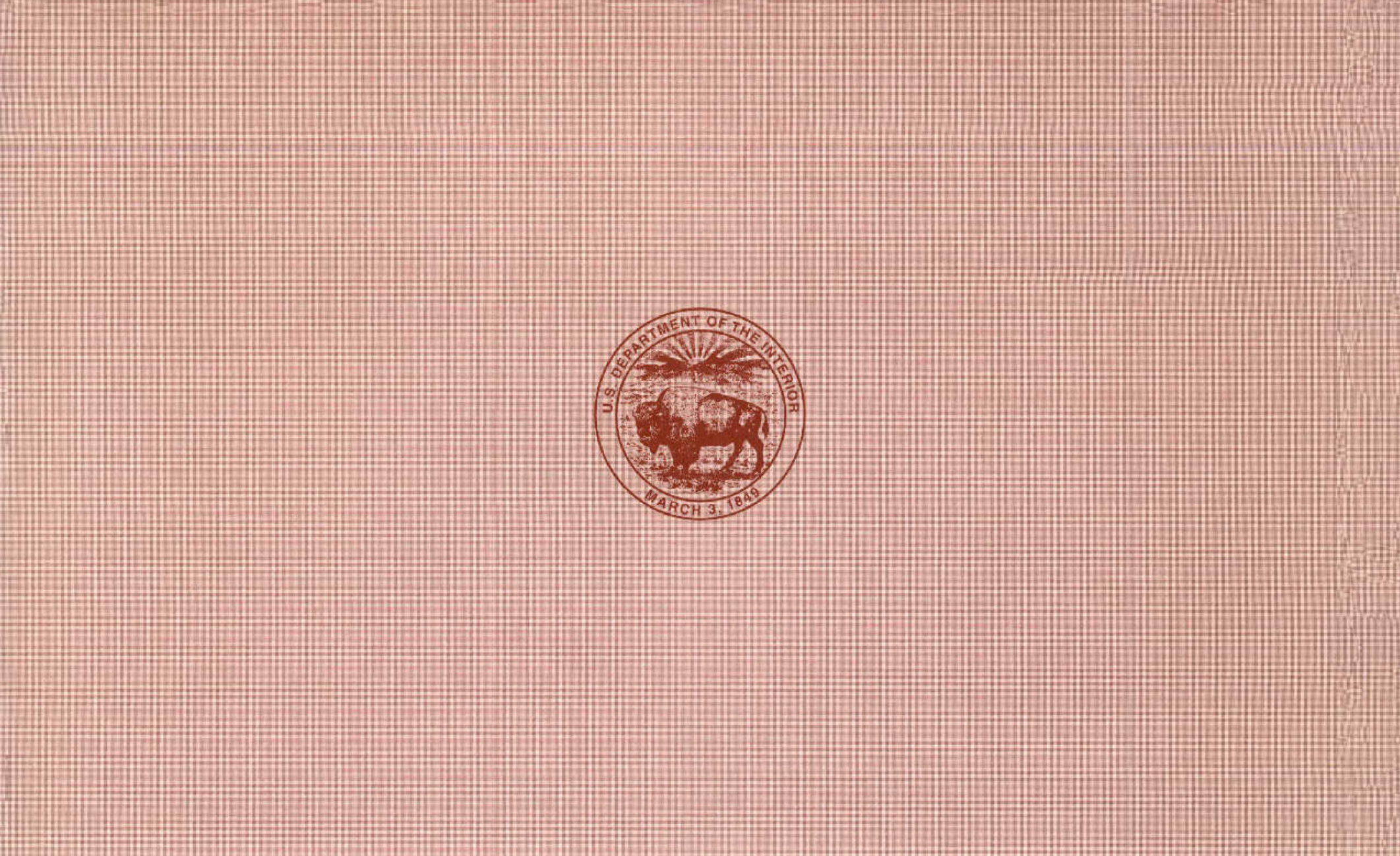

